\title{
Particulate Matter in Swine Barns: A Comprehensive Review
}

\author{
Xufei Yang ${ }^{1, *}$, Noor Haleem ${ }^{1}$, Augustina Osabutey ${ }^{1}$, Zhisheng Cen ${ }^{1}$, Karlee L. Albert ${ }^{2}$ \\ ${ }^{1}$ Department of Agricultural and Biosystems Engineering, South Dakota State University, Brookings, SD \\ 57007, USA \\ ${ }^{2}$ Department of Biology and Microbiology, South Dakota State University, Brookings, SD 57007, USA \\ * Corresponding to xufei.yang@sdstate.edu or yanglinyangyang@gmail.com
}

The authors acclaim that the paper is a non-peer-reviewed preprint submitted to preprints.org. It has not been submitted to or published in any journals.

\begin{abstract}
Particulate matter (PM) represents an air quality management challenge for confined swine production systems. Because of the limited space and ventilation rate, PM can reach relatively high concentrations in swine barns. PM in swine barns possesses different physical, chemical, and biological characteristics than that in the atmosphere and other indoor environments. As a result, it exerts different environmental and health effects and creates some unique challenges regarding PM measurement and mitigation. Numerous research efforts have been made, generating massive data and information. However, relevant review reports are sporadic. This study aims to provide an updated comprehensive review of swine barn PM, focusing on publications since 1990. It covers various topics, including PM characteristics, sources, measurement methods, and in-barn mitigation technologies. Since PM in swine barns is of primarily biological origins, bioaerosols are reviewed in great detail. Relevant topics include bacterial/fungal counts, viruses, microbial community composition, antibiotic-resistant bacteria, antibiotic resistance genes, endotoxins, and $(1 \rightarrow 3)-\beta$-D-glucans. For each topic, existing knowledge is summarized and discussed and knowledge gaps are identified. Overall, PM in swine barns is complicated in chemical and biological composition and highly variable in mass concentrations, size, and microbial abundance. Feed, feces, and skins constitute the major PM sources. Regarding in-barn PM mitigation, four technologies (oil/water sprinkling, ionization, alternation of feed and feeders, and recirculating air filtration) are dominant. However, none of them have been widely used in commercial barns. A collective discussion of major knowledge gaps and future research needs is offered at the end of the report.
\end{abstract}

\section{Keywords}

Swine barn, particulate matter, characteristics, bioaerosols, mitigation, measurement

\section{Table of Contents}

Abstract

Keywords

1 Introduction...

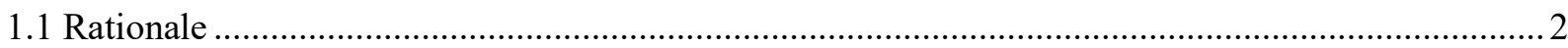

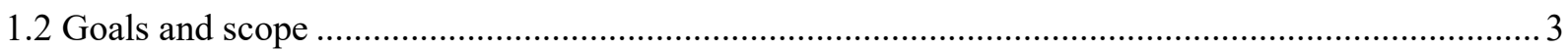

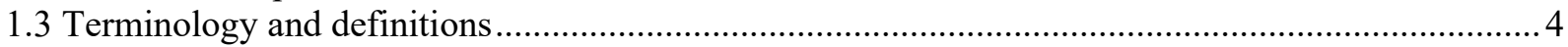

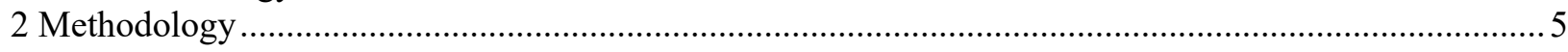

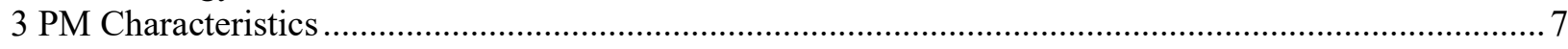

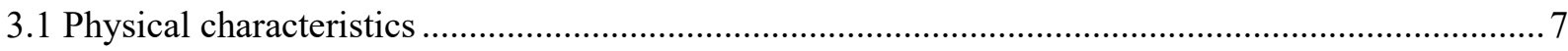

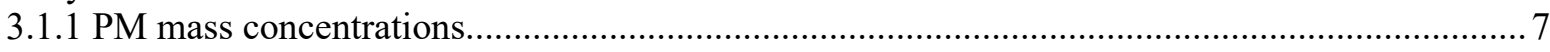

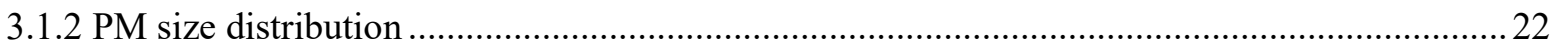

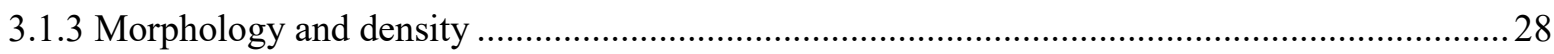

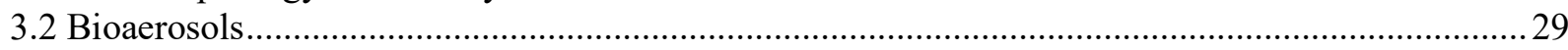

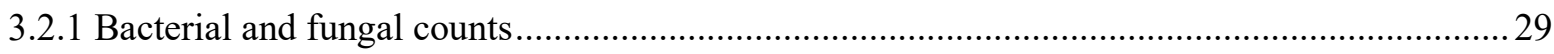

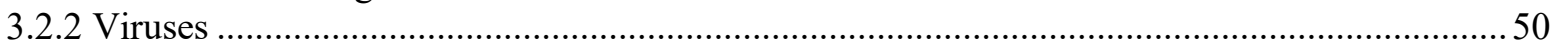




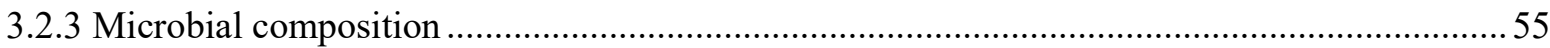

3.2.4 Antibiotic resistant bacteria (ARB) and antibiotic resistance genes (ARGs) ..........................6 68

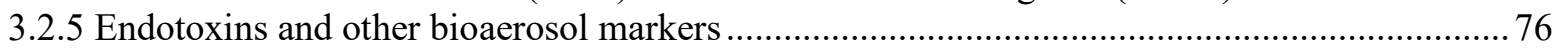

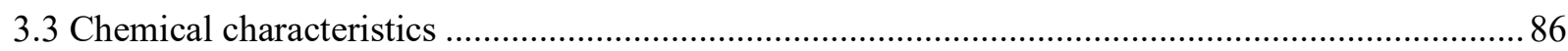

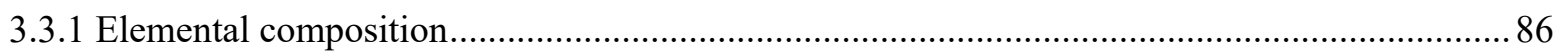

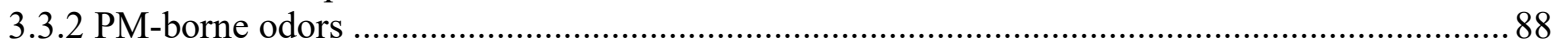

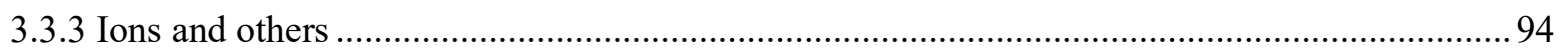

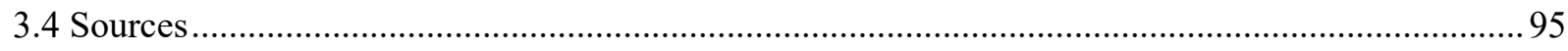

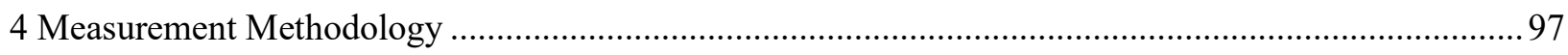

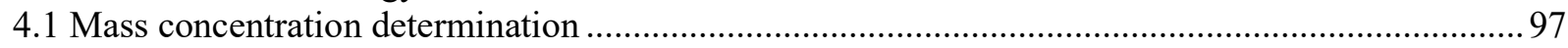

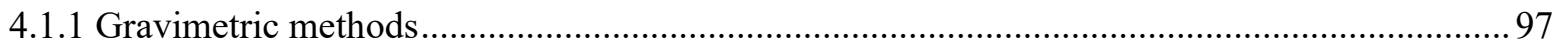

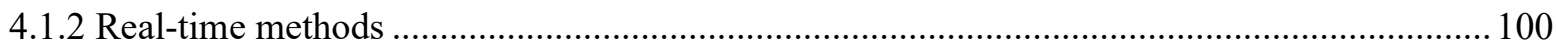

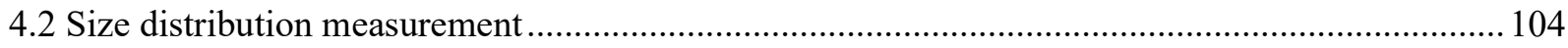

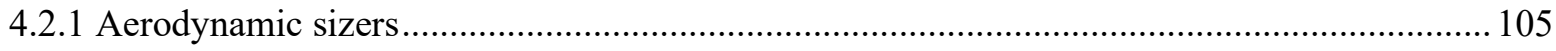

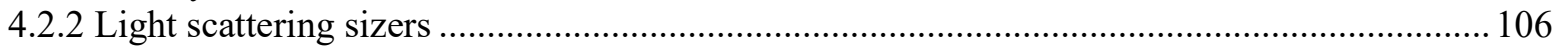

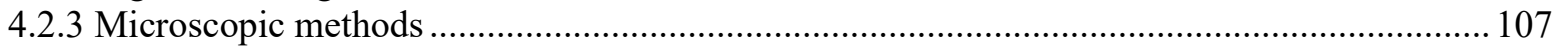

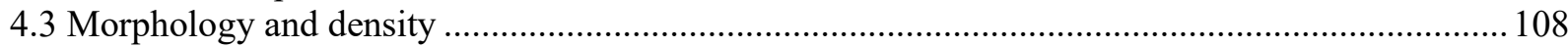

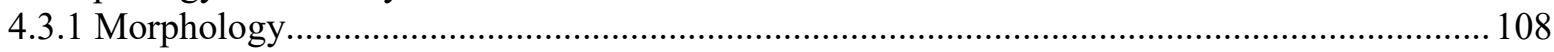

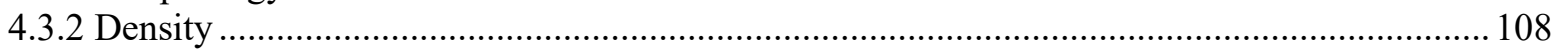

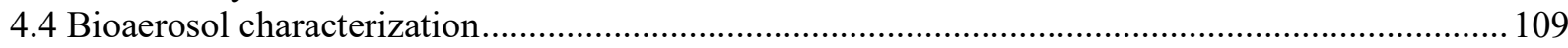

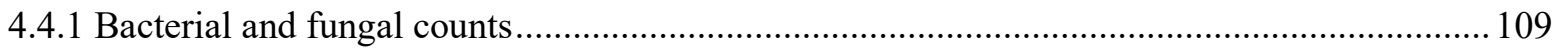

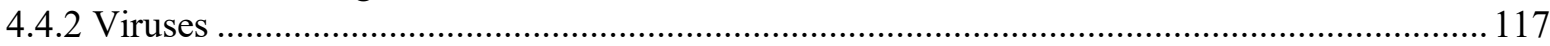

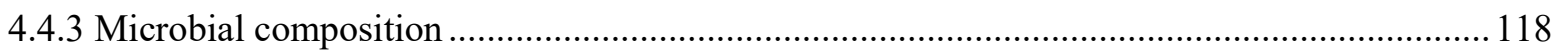

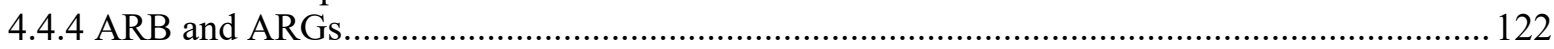

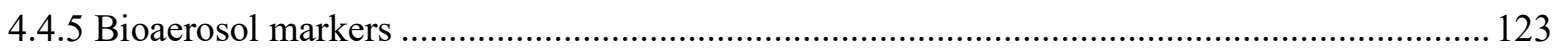

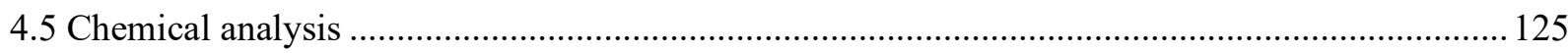

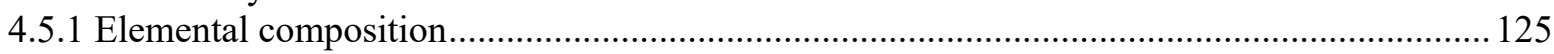

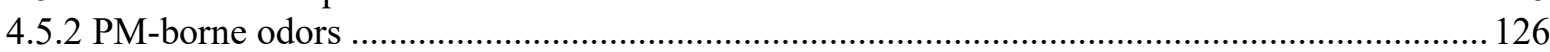

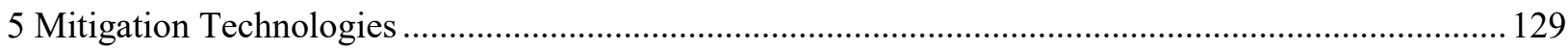

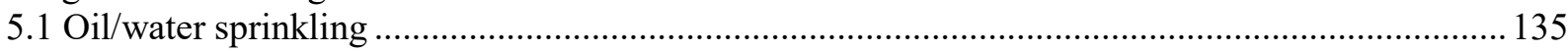

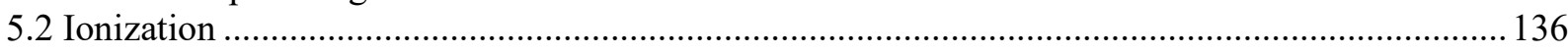

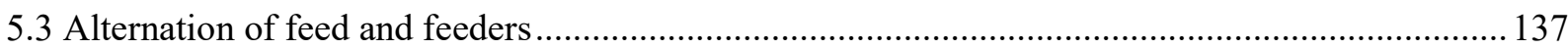

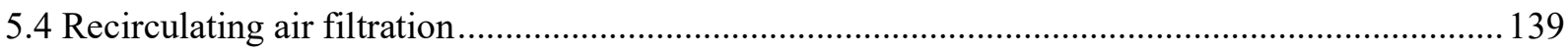

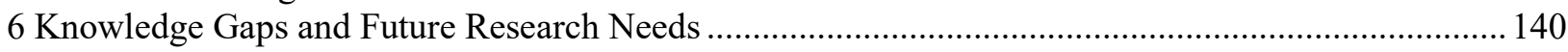

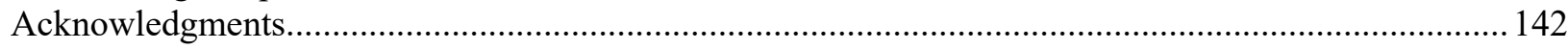

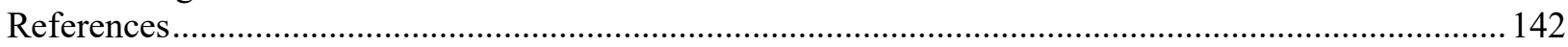

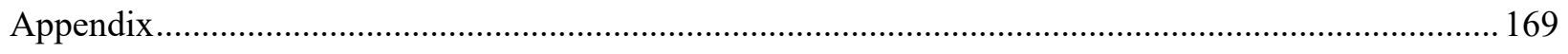

\section{Introduction}

\subsection{Rationale}

The production of pork, as a major source of proteins in many countries, cannot be overemphasized given the growing global population and the pursuit of improved nutrition (McGlone, 2013). The U.S. is the second-largest pork producing country in the world, with 74.8 million pigs in inventory as of March 1, 2021 (NASS, 2021); and exported pork and pork products at a value of $\$ 7.7$ billion in 2020 (Welshans, 2021). The vast majority of pigs are kept in confined swine barns, also known as confinement buildings or indoor systems. Swine barns not only protect pigs from harsh environments but also improve the management of pigs on the aspects of monitoring, feeding, vaccination, waste management, etc.

However, confinement swine production receives public scrutiny especially when it comes to animal welfare and environmental stewardship (McGlone, 2013; Lai et al., 2018). Both animal welfare and 
environmental stewardship are tied to air pollutants generated inside swine barns, such as ammonia, hydrogen sulfide, odors, and particulate matter (PM).

PM refers to a collection of solid particles and liquid droplets suspended in an air environment. PM in the ambient air, also known as atmospheric PM, is one of six criteria air pollutants regulated by the National Ambient Air Quality Standards (NAAQS) (USEPA, 2021) because of its adverse impacts on human health and welfare. PM has been known to compromise the human respiratory, cardiovascular, and even reproduction systems (Davidson et al., 2005; Kim et al., 2015). The welfare effects of atmospheric PM include impaired visibility, reduced photosynthesis, and the acidification and eutrophication of ecosystems caused by PM deposition (Grantz et al., 2003). It is important to note that PM in swine barns is different from atmospheric PM in terms of sources, sizes, constituents, etc. As a result, it has certain unique health and welfare implications that justify associated assessment and mitigation efforts. For example, swine barn PM carries a considerable number of microorganisms, and some of them can be pathogenic and responsible for the airborne transmissions of diseases (Anderson et al., 2017). Another example is that swine barn PM can concentrate and transport odorous chemicals downwind, causing a greater or more persistent odor nuisance (Bottcher, 2001).

Numerous studies have been done on PM in swine barns. They cover a broad range of research topics, including PM sources, characterization, emissions, measurement methods, mitigation technologies, health impacts (on humans and animals), exposure thresholds, etc. A few review efforts were made (Pedersen et al., 2000; Cambra-López et al., 2010). In a mini-review paper entitled "Dust in Pig Buildings", Pedersen et al. (2000) summarized the sources, characteristics, measurement methods, dose-response and control standards, impacts on animals, concentration modeling, and mitigation technologies for PM in swine barns. Cambra-López et al. (2010) offered a comprehensive review about PM from livestock production systems, covering various livestock environments besides swine barns. Both papers were published over ten years ago. Since then, numerous publications have become available regarding PM in swine barns. In summary, an updated review specifically of PM in swine barns is needed given the importance of this topic and the lack of similar efforts in recent years. The target readers include environmental engineers, veterinarians, animal scientists, industrial hygienists, agricultural engineers, and government agencies.

\subsection{Goals and scope}

Numerous publications are available regarding PM in swine barns. A preliminary literature search has identified $>600$ relevant publications, covering a broad range of topics. To make the report manageable, the scope of the review effort is defined as below:

- It focuses on PM inside swine barns. The emissions of PM from swine barns and the transport and fate of PM in the environment are excluded.

- It consists of three major parts: PM characteristics, measurement methodology, and mitigation technologies. For mitigation technologies, only those for in-barn PM mitigation are reviewed.

- It focuses on publications since 1990. Earlier publications are included when necessary (e.g., when discussing technology development).

- No detailed review is included about the health effects of PM in swine barns. Since the health effects are closely related to PM components, a brief discussion is sometimes given when reviewing a specific component. For detailed health effect information, several review papers are available (Donham, 1990; Kirkhorn and Garry, 2000; Schenker et al., 1998; Iversen et al., 2000; Heederik et al., 2007; May et al., 2012).

- The PM characteristics reviewed include physical characteristics, chemical composition, bioaerosols, and PM sources. The review of bioaerosols covers bacteria, fungi, viruses, antibiotic resistant bacteria, antibiotic resistance genes, and bioaerosol markers in swine barns. 
Swine barns by no means are significant PM emitters or contributors to atmospheric PM. In 2005, approximately 2.2 million tons of $\mathrm{PM}_{10}$ in the U.S. were emitted from anthropogenic sources (USEPA, 2018). Assuming an aggressive $\mathrm{PM}_{10}$ emission factor for pigs ( $3 \mathrm{~g} \mathrm{PM} 10$ per animal unit per day; compiled from multiple sources), the total $\mathrm{PM}_{10}$ emission from the U.S. swine barns would be $<10,000$ tons in the same year (Yang, 2010). PM in swine barns is primarily an indoor or local air quality issue.

\subsection{Terminology and definitions}

PM in swine barns has attracted researchers from various disciplines, backgrounds, or regions. They occasionally use different terms to describe the same entity. To ease the reading experience, standardized terminology is used throughout the report, as clarified below:

- "PM" replaces the following terms: "dust", "airborne particles" (or "airborne particulates"), "suspended particulate matter", and "aerosols." These terms carry slightly different meanings but were interchangeably used with PM in most of the previous studies. "A particle" and "particles" are used in the review when singular and plural expressions are necessary.

- “Total suspended particles (TSP)" replace "total particles." Although both terms refer to particles of all sizes, many of the previous studies did not use standard TSP samplers to collect total particles. A thorough discussion about the samplers' efficiency is impossible given the lack of details in the literature. For simplicity, TSP and total particles are treated as the same entity.

- "Bioaerosols" replace "biological aerosols", "biological particles", and "biological aerosol particles." In a broad sense, bioaerosols refer to any PM of biological origins, including bacteria, fungal spores, viruses, pollen grains, insect fragments, and plant detritus (Douwes et al., 2003). However, this broad-sense definition can hardly apply to PM in swine barns because most in-barn particles are suspended from biomaterials (e.g., feed and feces). To address the dilemma, bioaerosols are defined in this review as PM of microbiological origins.

PM concentrations and properties are reported and discussed based on particle size. The following size fractions were often studied in swine barns:

- Inhalable PM refers to the particles that can enter the human respiratory tract through the nose or mouth during normal breathing.

- Respirable PM refers to the particles that can penetrate the human respiratory tract and reach air exchange regions, e.g., alveoli in the lung.

- TSP refers to particles of all sizes.

- $\mathrm{PM}_{10}$ refers to particles with aerodynamic diameters less than 10 microns $(\mu \mathrm{m})$.

- $\mathrm{PM}_{2.5}$, also known as fine PM, refers to particles with aerodynamic diameters less than $2.5 \mu \mathrm{m}$.

- $\mathrm{PM}_{2.5-10}$, also known as coarse PM, refers to particles with aerodynamic diameters greater than 2.5 $\mu \mathrm{m}$ but less than $10 \mu \mathrm{m}$.

Among these size fractions, inhalable PM and respirable PM are defined by the American Conference of Governmental Industrial Hygienists (ACGIH) for PM exposure assessment in occupational environments (ACGIH, 1985), based on the compartments where these particles can reach in the human respiratory system. Another ACGIH-defined size fraction is thoracic PM and it refers to a sub-fraction of inhalable PM that can pass the upper respiratory tract and reach the lower respiratory tract (i.e., thoracic airways). Thoracic PM was rarely measured in swine barns because its similarity to $\mathrm{PM}_{10}$ (Figure 1). Other size fractions that were occasionally studied include $\mathrm{PM}_{1}, \mathrm{PM}_{5}$, and $\mathrm{PM}_{7}$, where $\mathrm{PM}_{x}$ refers to particles with aerodynamic diameters less than $x \mu \mathrm{m}$. 


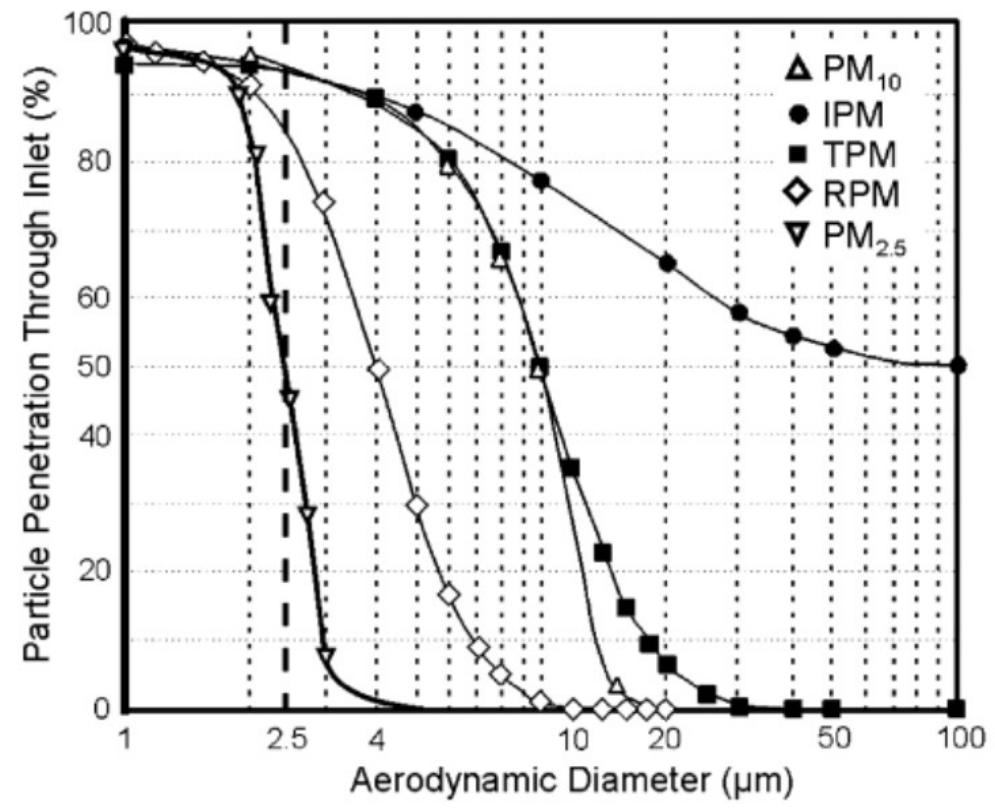

Figure 1. Sampling curves of the EPA defined reference $P M_{10}$ and $P M_{2.5}$ samplers, as well as the ACGIH defined inhalable, thoracic, and respirable samplers. [Adapted from Wilson et al. (2002)]

It is noteworthy that the definitions given above are scientific definitions. In reality, PM size fractions are defined by reference sampling methods. Under this definition framework, $\mathrm{PM}_{10}$ refers to particles collected with a reference $\mathrm{PM}_{10}$ sampler or any samplers with an equivalent sampling curve (Figure 1). The rationale of the operational definition lies in the fact that no samplers can remove all particles larger than a target size (e.g., $10 \mu \mathrm{m}$ for $\mathrm{PM}_{10}$ samplers) while retaining all particles smaller than that size. A key parameter of a sampling curve is $50 \%$ cut size $\left(D_{50}\right)$ - the diameter of particles with $50 \%$ sampling efficiency. $\mathrm{D}_{50}$ is $100 \mu \mathrm{m}$ for inhalable PM, $4 \mu \mathrm{m}$ for respirable PM, $10 \mu \mathrm{m}$ for $\mathrm{PM}_{10}$ and thoracic PM, and $2.5 \mu \mathrm{m}$ for $\mathrm{PM}_{2.5}$.

\section{Methodology}

Both peer-reviewed and non-peer-reviewed articles were included. For peer-reviewed articles, six databases (CAB International, AGEICOLA, MEDLINE, EBSCO, Scopus, and Web of Science) were selected as the primary sources. For non-peer-reviewed articles, only scholarly ones (e.g., conference papers, extension factsheets, and thesis) were included. Many of them were indexed by the six aforementioned databases. For articles unindexed by any database, the Google search engine was used to search for their records on the websites of universities (e.g., ".edu" and "ac.uk") and governmental agencies (e.g., ".gov"). Attempts were also made to include non-scholarly articles (e.g., trade magazine articles and newspaper articles); however, no solid or original data were found.

To further increase the number of search records, the references of each identified article were checked to see if any of them would be relevant. The articles citing those identified from the previous steps were searched with Google Scholar. Relevant records were also included. For the broad scope of this study, each section or subsection used a different set of keywords (Table 1). The generic keywords for "overallswine barn PM" were used in all search efforts. For a specific subject, additional keywords were used to further refine the search results.

Table 1. A list of keywords (search terms) in this review project.

\begin{tabular}{|l|l|}
\hline Topics & Keywords (search terms) \\
\hline Overall-swine barn PM & $\begin{array}{c}\text { (Swine } \mid \text { pig } \mid \text { hog) \& (barn } \mid \text { house } \mid \text { building } \mid \text { farm) \& (airborne particle } \mid \\
\text { particulate matter } \mid \text { PM } \mid \text { dust } \mid \text { particulate) }\end{array}$ \\
\hline
\end{tabular}




\begin{tabular}{|c|c|}
\hline PM characteristics & \\
\hline -concentration & Concentration | level | count \\
\hline- size & Size distribution $|\mathrm{PSD}| \mathrm{PM}_{10}\left|\mathrm{PM}_{2.5}\right| \mathrm{TSP} \mid$ inhalable $\mid$ respirable \\
\hline -sources & Source | origin | apportionment \\
\hline -chemical composition & $\begin{array}{l}\text { Composition | elements } \mid \text { ions } \mid \text { odorants } \mid \text { volatile organic compounds } \mid \text { protein } \mid \\
\quad \text { lipid } \mid \text { fatty acid } \mid \text { ash }\end{array}$ \\
\hline -bioaerosol & $\begin{array}{l}\text { (Bioaerosol } \mid \text { biological particles | biological aerosol) \& (bacteria } \mid \text { fungi } \mid \text { virus } \mid \\
\text { endotoxin } \mid \text { glucan } \mid \text { antibiotic } \mid \text { DNA } \mid \text { RNA } \mid \text { PCR } \mid \text { sequencing } \mid \text { biomarker) }\end{array}$ \\
\hline Measurement methodology & $\begin{array}{l}\text { Measurement } \mid \text { sampling } \mid \text { monitoring } \mid \text { sampler } \mid \text { analyzer } \mid \text { monitor } \mid \text { instrument } \mid \\
\text { instrumentation } \mid \text { calibration }\end{array}$ \\
\hline Mitigation technologies & Mitigation $\mid$ abatement $\mid$ reduction $\mid$ dedusting $\mid$ removal \\
\hline
\end{tabular}

The acquired search records were imported into Zetero (a reference management program), including the title and abstract of each record. With Zetero, the search records were screened based on the following exclusion criteria: (1) Uniqueness. Duplicate records were removed; (2) Relevance. Irrelevant records were removed based on the information in the abstract; (3) Originality. Only original studies were included. The articles citing an original study but providing no further findings were removed; (4) Language. Only articles in English were included. Articles with an English abstract but a non-English full text were removed; (5) Scientific soundness. Articles with no supporting evidence (observational, experimental, and/or simulative) were removed.

The full texts of the remaining search records were downloaded to further assess their eligibility. Around $6 \%$ of the search records had no full texts accessible and were excluded from the review effort. The downloaded full-text articles were read to assess the articles' uniqueness, relevance, originality, and scientific soundness. Articles failing to meet the criteria were removed. Finally, the remaining full-text articles were sorted based on their topics. A total of 380 articles were compiled for review (Figure 2). Additional 94 articles were referenced to support the analysis and discussion of individual topics.

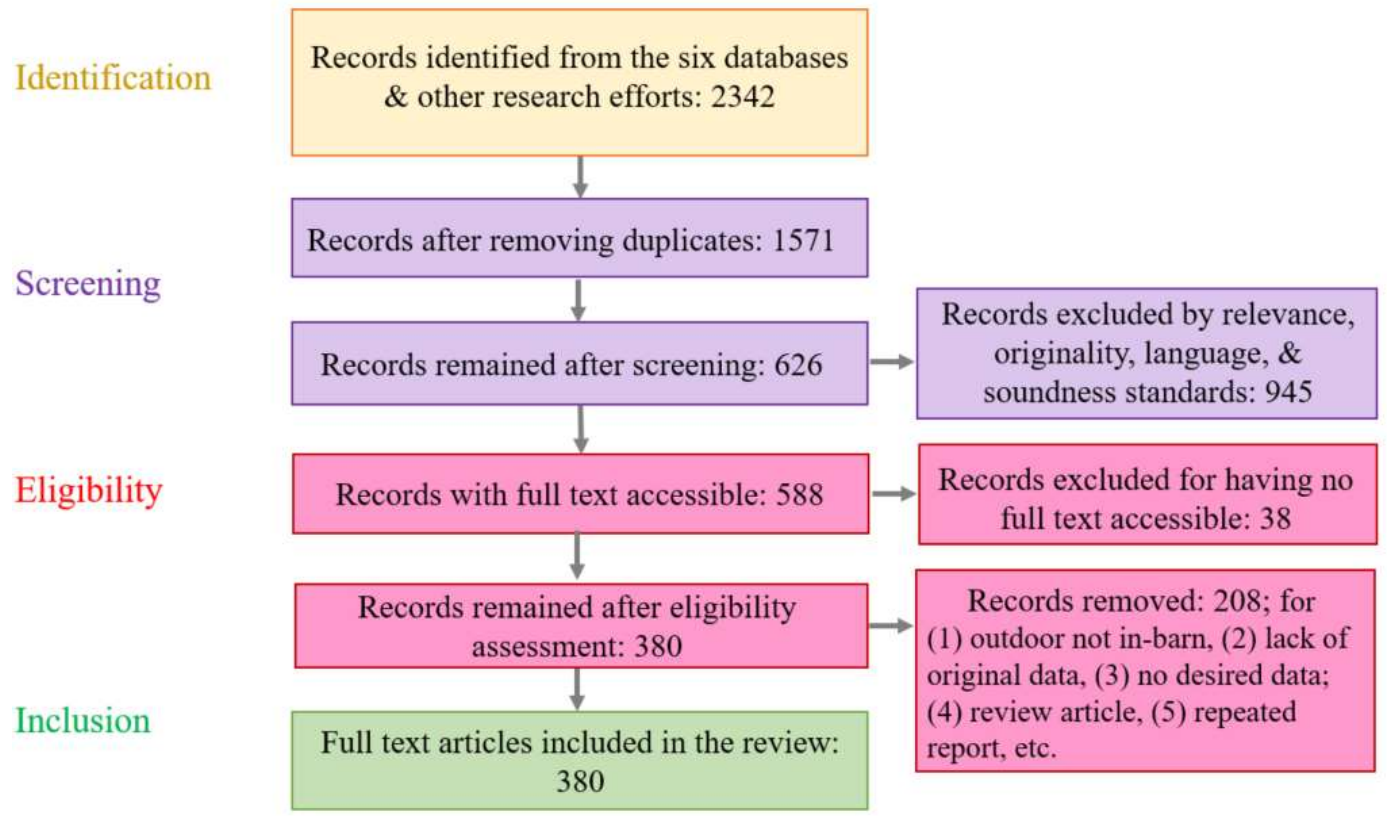

Figure 2. A flowchart diagram of the literature search procedure. 


\section{PM Characteristics}

\subsection{Physical characteristics}

\subsubsection{PM mass concentrations}

PM can be characterized by several concentration measures, including number concentrations, surface area concentrations, and mass concentrations (Zhang, 2005). Among them, PM mass concentrations are most frequently measured because PM regulations are predominantly mass-based. Examples of PM regulations include the NAAQS for $\mathrm{PM}_{10}$ (daily average concentrations $\leq 150 \mu \mathrm{g} \mathrm{m}^{-3}$ ) and $\mathrm{PM}_{2.5}$ (daily average concentrations $\leq 35 \mu \mathrm{g} \mathrm{m}^{-3}$ ) (USEPA, 2021), and the Occupational Safety and Health Administration (OSHA) Permissible Exposure Limits (PEL) for respirable PM $\left(5.0 \mathrm{mg} \mathrm{m}^{-3}\right)$ (NIOSH, 2021). In swine barns, Donham et al. (2000) recommended an exposure limit of $2.4 \mathrm{mg} \mathrm{m}^{-3}$ for total dust (TSP) and $0.23 \mathrm{mg} \mathrm{m}^{-3}$ for respirable PM - both were mass-based. Thus, only PM mass concentrations are reviewed here.

Although PM has been a farm hygiene consideration for over a century (Shirley, 1905; Lillie, 1949), the first measurement of PM concentrations in swine barns, to our knowledge, was done in the 1970s (Bundy, 1974; Bundy and Hazen, 1975; Curtis et al., 1975a, b). These early investigations were largely stimulated by the findings that PM, along with noxious gases (e.g., ammonia), could impact pig health (Doig and Willoughby, 1971; Martin and Willoughby, 1972). In the 1980s, an increasing number of studies were published about PM concentrations in swine barns (Clark et al., 1983; Donham et al., 1986; Heber et al., 1988; Donham et al., 1989). The research focus, however, shifted to occupational exposure assessment. Also in the 1970s and 1980s, various in-barn PM mitigation technologies, such as ionization, oil sprinkling, and feed additives, were initially developed and/or tested. These early measurement and mitigation efforts coincided with the consolidation and concentration of swine production facilities. With a larger number of pigs per barn and a greater stock density than before, swine barns faced a growing challenge regarding indoor air quality management, including PM management.

Moving into the 1990s, the enactment of $\mathrm{PM}_{2.5}$ standards spurred another round of research interest in swine barn PM. Meanwhile, public awareness of air quality (including $\mathrm{PM}_{10}$ and $\mathrm{PM}_{2.5}$ ) continued to grow. Table 2 summarizes the monitoring efforts since 1990. It can be seen that $\mathrm{PM}_{10}$ and $\mathrm{PM}_{2.5}$ have gradually outpaced inhalable PM and respirable PM as the measurement focus, especially in recent years. Also during this period, several major monitoring campaigns were conducted to determine the baseline emission of air pollutants from animal facilities, e.g., the Four Country study in Northern Europe (Takai et al., 1998), the Aerial Pollutant Emissions from Confined Animal Buildings (APECAB) study in the U.S. Midwest (Jacobson et al., 2006), and the National Air Emissions Monitoring Study (NAEMS) across the U.S. (Jin et al., 2012). These campaigns have greatly facilitated the use of highly accurate, real-time instruments and the development of standard operating procedures (SOPs) for PM concentration measurement in swine barns.

Table 2. PM mass concentrations in swine barns - A summary of studies since 1990.

\begin{tabular}{|l|l|l|l|l|c|}
\hline Reference & PM concentration $\left(\mathrm{mg} \mathrm{m}^{-3}\right)^{1}$ & $\begin{array}{l}\text { Barn \& } \\
\text { ventilation } \\
\text { type }\end{array}$ & Location & Season & $\begin{array}{l}\text { Major findings or } \\
\text { notes }\end{array}$ \\
\hline $\begin{array}{l}\text { Christensen et } \\
\text { al. (1992) }\end{array}$ & $\begin{array}{l}\text { Mean TSP: 4.13 } \\
\text { Mean respirable: } 0.48\end{array}$ & Denmark & n/a & - \\
\cline { 1 - 4 } $\begin{array}{l}\text { Dutkiewicz et } \\
\text { al. (1994) }\end{array}$ & Mean TSP: 3.03-14.05 & $\begin{array}{l}\text { Farrowing; } \\
\text { n/a }\end{array}$ & Poland & n/a & \\
\cline { 2 - 3 } \cline { 2 - 3 } & Mean TSP:4.10-6.25 & $\begin{array}{l}\text { Finisher; } \\
\text { n/a }\end{array}$ & n/a & \\
\hline
\end{tabular}




\begin{tabular}{|c|c|c|c|c|c|}
\hline \multirow[t]{3}{*}{$\begin{array}{l}\text { Takai et al. } \\
\text { (1995) }\end{array}$} & $\begin{array}{l}\text { Control - } \\
\text { Mean TSP: } 2.1\end{array}$ & \multirow[t]{3}{*}{$\begin{array}{l}\text { Nursery, } \\
\text { finisher; } \mathrm{n} / \mathrm{a}\end{array}$} & \multirow[t]{3}{*}{ Denmark } & $\mathrm{n} / \mathrm{a}$ & \multirow[t]{3}{*}{-} \\
\hline & $\begin{array}{l}\text { Sprinkling an oil-water mixture } \\
\left(3 \mathrm{~mL} \text { oil } \text { pig }^{-1} \mathrm{~d}^{-1}\right)- \\
\text { Mean TSP: } 1.6\end{array}$ & & & $\mathrm{n} / \mathrm{a}$ & \\
\hline & $\begin{array}{l}\text { Sprinkling an oil-water mixture } \\
\left(11 \mathrm{~mL} \text { oil pig } \mathrm{pi}^{-1} \mathrm{~d}^{-1}\right)- \\
\text { Mean TSP: } 0.4\end{array}$ & & & $\mathrm{n} / \mathrm{a}$ & \\
\hline $\begin{array}{l}\text { Douwes et al. } \\
(1996)^{3}\end{array}$ & Geomean inhalable: 2.1 & $\mathrm{n} / \mathrm{a} ; \mathrm{n} / \mathrm{a}$ & $\begin{array}{l}\text { The } \\
\text { Netherlands }\end{array}$ & \begin{tabular}{|l|} 
All \\
seasons \\
\end{tabular} & - \\
\hline \multirow[t]{2}{*}{$\begin{array}{l}\text { Reynolds et al. } \\
(1996)^{3}\end{array}$} & $\begin{array}{l}\text { Time } 1- \\
\text { Geomean TSP: } 4.55 ; 2.62 \\
\text { (GSD) } \\
\text { Geomean respirable: } 0.23 ; 2.90 \\
\text { (GSD) }\end{array}$ & $\mathrm{n} / \mathrm{a} ; \mathrm{n} / \mathrm{a}$ & \multirow[t]{2}{*}{ Iowa } & \multirow[t]{2}{*}{$\begin{array}{l}\text { Spring, } \\
\text { fall, } \\
\text { winter }\end{array}$} & \multirow[t]{2}{*}{-} \\
\hline & $\begin{array}{l}\text { Time } 2 \text { - } \\
\text { Geomean TSP: } 3.45 ; 2.39 \\
\text { (GSD) } \\
\text { Geomean respirable: } 0.26 ; 2.24 \\
\text { (GSD) }\end{array}$ & $\mathrm{n} / \mathrm{a} ; \mathrm{n} / \mathrm{a}$ & & & \\
\hline \multirow[t]{4}{*}{$\begin{array}{l}\text { Takai et al. } \\
\text { (1996) }\end{array}$} & $\begin{array}{l}\text { Control- } \\
\text { Mean TSP: } 3.59 \\
\text { Mean respirable: } 0.27\end{array}$ & \multirow[t]{2}{*}{$\begin{array}{l}\text { Nursery; } \\
\text { MV }\end{array}$} & \multirow[t]{4}{*}{ Denmark } & $n / a$ & \multirow[t]{4}{*}{-} \\
\hline & $\begin{array}{l}\text { Adding 4\% fat in feed-- } \\
\text { Mean TSP: } 2.26 \\
\text { Mean respirable: } 0.122\end{array}$ & & & $\mathrm{n} / \mathrm{a}$ & \\
\hline & \begin{tabular}{|l|} 
Control - \\
Mean TSP: 1.99 \\
Mean respirable: 0.124
\end{tabular} & \multirow[t]{2}{*}{$\begin{array}{l}\text { Finisher; } \\
\text { MV }\end{array}$} & & $\mathrm{n} / \mathrm{a}$ & \\
\hline & $\begin{array}{l}\text { Adding } 4 \% \text { fat in feed }- \\
\text { Mean TSP: } 1.16 \\
\text { Mean respirable: } 0.075\end{array}$ & & & $\mathrm{n} / \mathrm{a}$ & \\
\hline $\begin{array}{l}\text { Maghirang et } \\
\text { al. (1997) }\end{array}$ & $\begin{array}{l}\text { Mean TSP: } 0.72(0.12-1.4) \\
\text { Mean respirable: } 0.07(0.01- \\
0.17)\end{array}$ & $\begin{array}{l}\text { Nursery; } \\
\text { MV }\end{array}$ & Kansas & $\begin{array}{l}\text { Warm } \\
\text { season } \\
(25- \\
\left.34^{\circ} \mathrm{C}\right)\end{array}$ & $\begin{array}{l}\text { Particle size } \\
\text { distribution and } \\
\text { concentration } \\
\text { varied greatly with } \\
\text { time. }\end{array}$ \\
\hline \multirow[t]{2}{*}{$\begin{array}{l}\text { Senthilselvan et } \\
\text { al. }(1997)^{3}\end{array}$} & \begin{tabular}{|l|} 
Control - \\
TSP: $3.8 \pm 0.2$
\end{tabular} & \multirow[t]{2}{*}{$\begin{array}{l}\text { Grower- } \\
\text { finisher; } \\
\text { MV }\end{array}$} & \multirow[t]{2}{*}{$\begin{array}{l}\text { Saskatchewa } \\
\text { n, Canada }\end{array}$} & $\begin{array}{l}\text { Warm } \\
\text { season }\end{array}$ & \multirow[t]{2}{*}{-} \\
\hline & $\begin{array}{l}\text { Oil Sprinkling - } \\
\text { TSP: } 0.6 \pm 0.3\end{array}$ & & & Winter & \\
\hline $\begin{array}{l}\text { Hinz et al. } \\
\text { (1998) }\end{array}$ & TSP: $1.0-5.0$ & $\begin{array}{l}\text { Finisher; } \\
\text { MV }\end{array}$ & Germany & $\mathrm{n} / \mathrm{a}$ & - \\
\hline
\end{tabular}




\begin{tabular}{|c|c|c|c|c|c|}
\hline $\begin{array}{l}\text { Mackiewicz } \\
(1998)\end{array}$ & Mean TSP: 8.76 (3.03-14.05) & $\mathrm{n} / \mathrm{a} ; \mathrm{n} / \mathrm{a}$ & Poland & $\mathrm{n} / \mathrm{a}$ & - \\
\hline \multirow[t]{4}{*}{$\begin{array}{l}\text { Takai et al. } \\
\text { (1998) }\end{array}$} & $\begin{array}{l}\text { Mean inhalable: } 1.87 \\
\text { Mean respirable: } 0.24\end{array}$ & $\begin{array}{l}\text { Sow, } \\
\text { nursery, } \\
\text { finisher; n/a }\end{array}$ & England & $\begin{array}{l}\text { Winter, } \\
\text { summer }\end{array}$ & \multirow{4}{*}{$\begin{array}{l}\text { Swine barns had } \\
\text { higher PM } \\
\text { concentrations } \\
\text { during the day } \\
\text { than at night. }\end{array}$} \\
\hline & $\begin{array}{l}\text { Mean inhalable: } 2.43 \\
\text { Mean respirable: } 0.25\end{array}$ & $\begin{array}{l}\text { Sow, } \\
\text { nursery, } \\
\text { finisher; n/a }\end{array}$ & $\begin{array}{l}\text { The } \\
\text { Netherlands }\end{array}$ & $\begin{array}{l}\text { Winter, } \\
\text { summer }\end{array}$ & \\
\hline & $\begin{array}{l}\text { Mean inhalable: } 2.76 \\
\text { Mean respirable: } 0.26\end{array}$ & $\begin{array}{l}\text { Sow, } \\
\text { nursery, } \\
\text { finisher; n/a }\end{array}$ & Denmark & $\begin{array}{l}\text { Winter, } \\
\text { summer }\end{array}$ & \\
\hline & $\begin{array}{l}\text { Mean inhalable: } 1.95 \\
\text { Mean respirable: } 0.18\end{array}$ & $\begin{array}{l}\text { Sow, } \\
\text { nursery, } \\
\text { finisher; n/a }\end{array}$ & Germany & $\begin{array}{l}\text { Winter, } \\
\text { summer }\end{array}$ & \\
\hline \multirow[t]{2}{*}{$\begin{array}{l}\text { Gustafsson } \\
\text { (1999) }\end{array}$} & $\begin{array}{l}\text { A barn with high-speed air inlet } \\
\text { and high exhaust - } \\
\text { TSP: } 1.29 \pm 0.57 \\
\text { Respirable: } 0.26 \pm 0.095\end{array}$ & $\begin{array}{l}\text { Grower- } \\
\text { finisher; } \\
\text { MV }\end{array}$ & \multirow[t]{2}{*}{ Sweden } & $\mathrm{n} / \mathrm{a}$ & \multirow{2}{*}{$\begin{array}{l}\text { Spraying a } \\
\text { rapeseed oil-water } \\
\text { mixture } \\
\text { effectively } \\
\text { suppressed PM } \\
\text { generation; both } \\
\text { automatic } \\
\text { spraying and } \\
\text { manual spraying } \\
\text { were effective. }\end{array}$} \\
\hline & $\begin{array}{l}\text { A barn with a breathing ceiling } \\
\text { and low exhaust - } \\
\text { TSP: } 1.14 \pm 0.32 \\
\text { Respirable: } 0.15 \pm 0.061\end{array}$ & $\begin{array}{l}\text { Grower- } \\
\text { finisher; } \\
\text { MV }\end{array}$ & & $\mathrm{n} / \mathrm{a}$ & \\
\hline $\begin{array}{l}\text { Simpson et al. } \\
(1999)^{3}\end{array}$ & Median TSP: 6.71 (0.76-19.09) & $\mathrm{n} / \mathrm{a} ; \mathrm{n} / \mathrm{a}$ & $\begin{array}{l}\text { United } \\
\text { Kingdom }\end{array}$ & $\begin{array}{l}\text { All } \\
\text { seasons }\end{array}$ & - \\
\hline $\begin{array}{l}\text { Duchaine et al. } \\
\text { (2000) }\end{array}$ & Mean TSP: $3.54(2.15-5.60)$ & Finisher; $\mathrm{n} / \mathrm{a}$ & $\begin{array}{l}\text { Quebec, } \\
\text { Canada }\end{array}$ & $\begin{array}{l}\text { Winter, } \\
\text { summer }\end{array}$ & - \\
\hline \multirow[t]{5}{*}{$\begin{array}{l}\text { Chang et al. } \\
\text { (2001a) }\end{array}$} & $\begin{array}{l}\text { TSP: } 0.15 \pm 0.04 \\
\text { Respirable: } 0.12 \pm 13\end{array}$ & $\begin{array}{l}\text { Breeding; } \\
\text { NV (open } \\
\text { air) }\end{array}$ & \multirow[t]{5}{*}{ Taiwan } & \multirow[t]{5}{*}{ Summer } & \multirow{5}{*}{$\begin{array}{l}\text { Finisher barns had } \\
\text { the highest } \\
\text { respirable PM } \\
\text { concentration } \\
\text { levels. }\end{array}$} \\
\hline & $\begin{array}{l}\text { TSP: } 0.23 \pm 0.12 \\
\text { Respirable: } 0.08 \pm 0.05\end{array}$ & $\begin{array}{l}\text { Farrowing; } \\
\text { NV (open } \\
\text { air) }\end{array}$ & & & \\
\hline & $\begin{array}{l}\text { TSP: } 0.34 \pm 0.13 \\
\text { Respirable: } 0.13 \pm 0.15\end{array}$ & $\begin{array}{l}\text { Nursery; } \\
\text { NV (open } \\
\text { air) }\end{array}$ & & & \\
\hline & $\begin{array}{l}\text { TSP: } 0.28 \pm 0.28 \\
\text { Respirable: } 0.15 \pm 0.18\end{array}$ & $\begin{array}{l}\text { Grower; } \\
\text { NV (open } \\
\text { air) }\end{array}$ & & & \\
\hline & $\begin{array}{l}\text { TSP: } 0.21 \pm 0.07 \\
\text { Respirable: } 0.24 \pm 0.46\end{array}$ & $\begin{array}{l}\text { Finisher; } \\
\text { NV (open } \\
\text { air) }\end{array}$ & & & \\
\hline \multirow[t]{3}{*}{$\begin{array}{l}\text { Liao et al. } \\
(2001)\end{array}$} & $\begin{array}{l}1^{\text {st }} \text { feeding period }(6-7 \mathrm{am})- \\
\text { TSP: } 20.47 \pm 8.23\end{array}$ & \multirow[t]{3}{*}{$\begin{array}{l}\text { Grower; } \\
\text { MV }\end{array}$} & \multirow[t]{3}{*}{ Taiwan } & $\mathrm{n} / \mathrm{a}$ & \multirow[t]{3}{*}{$\begin{array}{l}\text { Feeding caused a } \\
\text { surge in PM } \\
\text { concentrations. }\end{array}$} \\
\hline & $\begin{array}{l}2^{\text {nd }} \text { feeding period }(6-7 \mathrm{pm})- \\
\text { TSP: } 20.47 \pm 8.14\end{array}$ & & & $\mathrm{n} / \mathrm{a}$ & \\
\hline & $\begin{array}{l}\text { Non-feeding periods - } \\
\text { TSP: } 2.32 \pm 0.45\end{array}$ & & & $\mathrm{n} / \mathrm{a}$ & \\
\hline
\end{tabular}




\begin{tabular}{|c|c|c|c|c|c|}
\hline \multirow[t]{2}{*}{$\begin{array}{l}\text { Predicala et al. } \\
\text { (2001) }\end{array}$} & $\begin{array}{l}\text { Inhalable: } 2.13 \pm 0.52 \\
\text { Respirable: } 0.11 \pm 0.02\end{array}$ & $\begin{array}{l}\text { Finisher; } \\
\text { MV }\end{array}$ & Kansas & \begin{tabular}{|l|l} 
All \\
seasons
\end{tabular} & \multirow{2}{*}{$\begin{array}{l}\text { PM concentrations } \\
\text { were significantly } \\
\text { affected by } \\
\text { outdoor air } \\
\text { temperature and } \\
\text { pig weight; no } \\
\text { significant } \\
\text { difference in PM } \\
\text { concentrations } \\
\text { was noted betweer } \\
\text { mechanical and } \\
\text { natural ventilation } \\
\text { barns. }\end{array}$} \\
\hline & $\begin{array}{l}\text { Inhalable: } 2.19 \pm 0.61 \\
\text { Respirable: } 0.10 \pm 0.02\end{array}$ & $\begin{array}{l}\text { Finisher; } \\
\text { NV }\end{array}$ & & \begin{tabular}{|l} 
All \\
seasons
\end{tabular} & \\
\hline \multirow[t]{2}{*}{$\begin{array}{l}\text { Gallmann et al. } \\
\text { (2002) }\end{array}$} & $\begin{array}{l}\mathrm{PM}_{10}: 0.46(0.17-0.91) \\
\mathrm{PM}_{2.5}: 0.12(0.08-0.13)\end{array}$ & $\begin{array}{l}\text { Finisher; } \\
\text { MV }\end{array}$ & Germany & \begin{tabular}{|l} 
Fall, \\
winter, \\
spring
\end{tabular} & \multirow{2}{*}{$\begin{array}{l}\text { The two barns } \\
\text { were under the } \\
\text { same roof and had } \\
\text { the same stock } \\
\text { density. Higher } \\
\text { ventilation rates } \\
\text { were noted for the } \\
\text { naturally } \\
\text { ventilated barn } \\
\text { during the } \\
\text { monitoring period. }\end{array}$} \\
\hline & $\begin{array}{l}\mathrm{PM}_{10}: 0.17(0.12-0.25) \\
\mathrm{PM}_{2.5}: 0.06(0.05-0.07)\end{array}$ & $\begin{array}{l}\text { Finisher; } \\
\text { NV }\end{array}$ & & $\begin{array}{l}\text { Fall, } \\
\text { winter, } \\
\text { spring }\end{array}$ & \\
\hline \multirow{2}{*}{$\begin{array}{l}\text { Radon et al. } \\
(2002)^{3}\end{array}$} & Median TSP: 3.95 (1.11-13.75) & $\mathrm{n} / \mathrm{a} ; \mathrm{n} / \mathrm{a}$ & Denmark & $\mathrm{n} / \mathrm{a}$ & \multirow[t]{2}{*}{-} \\
\hline & Median TSP: 5.00 (BDL-76.7) & $\mathrm{n} / \mathrm{a} ; \mathrm{n} / \mathrm{a}$ & Germany & $\mathrm{n} / \mathrm{a}$ & \\
\hline \multirow[t]{2}{*}{$\begin{array}{l}\text { Schmidt et al. } \\
\text { (2002) }\end{array}$} & $\begin{array}{l}\text { TSP: } 6.86 \pm 1.30 \\
\text { PM } 10: 1.63 \pm 0.16 \\
\text { Inhalable: } 4.56 \pm 2.74 \\
\text { Respirable: } 0.44 \pm 0.15\end{array}$ & \multirow[t]{2}{*}{$\begin{array}{l}\text { Finisher; } \\
\text { MV }\end{array}$} & \multirow[t]{2}{*}{ Minnesota } & Winter & \multirow[t]{2}{*}{-} \\
\hline & $\begin{array}{l}\text { TSP: } 0.42 \pm 0.26 \\
\text { PM } 10: 0.24 \pm 0.14 \\
\text { Inhalable: } 0.64 \pm 0.07 \\
\text { Respirable: } 0.04 \pm 0.02\end{array}$ & & & Summer & \\
\hline \multirow[t]{6}{*}{$\begin{array}{l}\text { Wang et al. } \\
(2002)\end{array}$} & $\begin{array}{l}\text { Control room - } \\
\text { TSP: } 5.02 \pm 0.03\end{array}$ & \multirow[t]{6}{*}{$\begin{array}{l}\text { Finisher; } \\
\text { MV }\end{array}$} & \multirow[t]{6}{*}{ Illinois } & \multirow[t]{6}{*}{$\mathrm{n} / \mathrm{a}$} & \multirow{6}{*}{$\begin{array}{l}\text { A significant } \\
\text { diurnal variation } \\
\text { in TSP } \\
\text { concentrations } \\
\text { was noted; oil } \\
\text { sprinkling was } \\
\text { effective in } \\
\text { reducing in-barn } \\
\text { dust levels (by } \\
70 \% \text { ). }\end{array}$} \\
\hline & $\begin{array}{l}\text { Low ventilation-- } \\
\text { TSP: } 4.56 \pm 0.02\end{array}$ & & & & \\
\hline & $\begin{array}{l}\text { Middle rate ventilation - } \\
\text { TSP: } 4.05 \pm 0.02\end{array}$ & & & & \\
\hline & $\begin{array}{l}\text { High ventilation }- \\
\text { TSP: } 2.86 \pm 0.02\end{array}$ & & & & \\
\hline & $\begin{array}{l}\text { Nighttime - } \\
\text { TSP: } 4.23 \pm 0.02\end{array}$ & & & & \\
\hline & $\begin{array}{l}\text { Daytime - } \\
\text { TSP: } 7.14 \pm 0.04\end{array}$ & & & & \\
\hline
\end{tabular}




\begin{tabular}{|c|c|c|c|c|c|}
\hline & $\begin{array}{l}\text { Air cleaning with dedusters - } \\
\text { TSP: } 3.82 \pm 0.02\end{array}$ & & & & \\
\hline & $\begin{array}{l}\text { Oil sprinkling - } \\
\text { TSP: } 0.82 \pm 0.01\end{array}$ & & & & \\
\hline \multirow[t]{3}{*}{$\begin{array}{l}\text { Nonnenmann et } \\
\text { al. (2004) }\end{array}$} & $\begin{array}{l}\text { Control - } \\
\text { Mean respirable: } 1.33\end{array}$ & Finisher; n/a & \multirow[t]{3}{*}{ Iowa } & $\begin{array}{l}\text { Winter, } \\
\text { Spring }\end{array}$ & \multirow[t]{3}{*}{-} \\
\hline & $\begin{array}{l}\text { Sprinkling soybean oil - } \\
\text { Mean respirable: } 0.69\end{array}$ & Finisher; n/a & & $\begin{array}{l}\text { Winter, } \\
\text { Spring }\end{array}$ & \\
\hline & $\begin{array}{l}\text { Sprinkling canola oil - } \\
\text { Mean respirable: } 0.60\end{array}$ & Finisher; n/a & & $\begin{array}{l}\text { Winter, } \\
\text { Spring }\end{array}$ & \\
\hline $\begin{array}{l}\text { Godbout et al. } \\
(2005)\end{array}$ & $\begin{array}{l}\text { 1) Control - } \\
\text { TSP: } 1.02 \pm 0.21 \\
\text { 2) Conventional scrapper - } \\
\text { TSP: } 1.25 \pm 0.31 \\
\text { 3) V-shaped scraper - } \\
\text { TSP: } 1.12 \pm 0.25 \\
\text { 4) Daily V-shape scraper - } \\
\text { TSP: } 0.95 \pm 0.26 \\
\text { 5) Van Kempen belt - } \\
\text { TSP: } 1.16 \pm 0.24 \\
\text { 6) Cemagref net - } \\
\text { TSP: } 1.03 \pm 0.22\end{array}$ & $\begin{array}{l}\text { Grower- } \\
\text { finisher; n/a }\end{array}$ & $\begin{array}{l}\text { Quebec, } \\
\text { Canada }\end{array}$ & Summer & $\begin{array}{l}\text { Data were } \\
\text { acquired from } \\
\text { experimental } \\
\text { rooms and might } \\
\text { not represent the } \\
\text { real-world } \\
\text { situation. }\end{array}$ \\
\hline $\begin{array}{l}\text { Kim et al. } \\
(2005)\end{array}$ & $\begin{array}{l}\text { 8:00 to 9:00 am - } \\
\text { Mean TSP: } 1.04 \\
\text { 2:00 to 3:00 } \mathrm{pm}- \\
\text { Mean TSP: } 2.53 \\
\text { 8:00 to 9:00 pm - } \\
\text { Mean TSP: } 1.83\end{array}$ & $\begin{array}{l}\text { Grower- } \\
\text { finisher; } \\
\text { MV }\end{array}$ & South Korea & Winter & $\begin{array}{l}\text { The level of aerial } \\
\text { environment risk } \\
\text { factors in the } \\
\text { building was the } \\
\text { highest at } 2: 00 \text { to } \\
\text { 3:00 pm, followed } \\
\text { by 8:00 to } 9: 00 \text { pm } \\
\text { and 8:00 to } 9: 00 \\
\text { am. }\end{array}$ \\
\hline $\begin{array}{l}\text { Rule et al. } \\
(2005)\end{array}$ & $\begin{array}{l}\text { Control (On the first day)- } \\
\text { Mean TSP: } 1.576(1.571-1.580) \\
\text { Mean PM } 10: 0.848(0.752- \\
1.010) \\
\text { Mean PM } 2.5: 0.294(0.189- \\
0.439) \\
\text { Control (On the second day)- } \\
\text { Mean TSP: } 1.446(1.431-1.461) \\
\text { Mean PM } 10: 0.911(0.855- \\
1.005)\end{array}$ & $\begin{array}{l}\text { Finisher; } \\
\text { MV }\end{array}$ & $\begin{array}{l}\text { Mid-Atlantic } \\
\text { region, USA }\end{array}$ & Winter & - \\
\hline
\end{tabular}




\begin{tabular}{|c|c|c|c|c|c|}
\hline & $\begin{array}{l}\text { Mean } \mathrm{PM}_{2.5}: 0.262(0.136- \\
0.385)\end{array}$ & & & & \\
\hline & 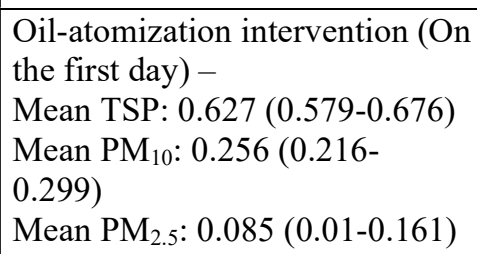 & & & & \\
\hline & 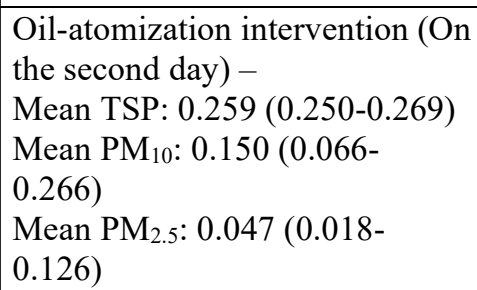 & & & & \\
\hline $\begin{array}{l}\text { Spaan et al. } \\
(2005)^{3}\end{array}$ & $\begin{array}{l}\text { Geomean Inhalable: } 2.6 \text { (1.6- } \\
5.4) ; 1.6 \text { (GSD) }\end{array}$ & $\mathrm{n} / \mathrm{a} ; \mathrm{n} / \mathrm{a}$ & $\begin{array}{l}\text { The } \\
\text { Netherlands }\end{array}$ & $\begin{array}{l}\text { All } \\
\text { seasons }\end{array}$ & - \\
\hline $\begin{array}{l}\text { Zhu et al. } \\
(2005)\end{array}$ & Mean TSP: 4.70 (1.58-17.00) & $\begin{array}{l}\text { Gestation; } \\
\text { MV }\end{array}$ & China & $\begin{array}{l}\text { Winter } \\
(\text { Jan })\end{array}$ & $\begin{array}{l}\text { Feeding resulted } \\
\text { in high TSP }\end{array}$ \\
\hline & Mean TSP: $4.24(0.00-17.75)$ & & & $\begin{array}{l}\text { Spring } \\
\text { (Mar) }\end{array}$ & concentrations. \\
\hline & $\begin{array}{l}\text { Mean TSP: } 2.20(0.00-15.25) \\
\text { 1) With water spray }- \\
\text { Mean TSP: } 1.98 \\
\text { 2) Without water spray - } \\
\text { Mean TSP: } 7.94\end{array}$ & & & $\begin{array}{l}\text { Summer } \\
\text { (Jul) }\end{array}$ & \\
\hline & $\begin{array}{l}\text { Mean TSP: } 2.18(0.00-8.00) \\
\text { 1) With water spray - } \\
\text { Mean TSP: } 3.98 \\
\text { 2) Without water spray - } \\
\text { Mean TSP: } 3.73\end{array}$ & & & $\begin{array}{l}\text { Summer } \\
\text { (Aug) }\end{array}$ & \\
\hline $\begin{array}{l}\text { Heber et al. } \\
(2006)\end{array}$ & $\begin{array}{l}\text { Control - } \\
\text { TSP: } 1.143 \pm 0.619\end{array}$ & $\begin{array}{l}\text { Finisher; } \\
\text { MV }\end{array}$ & US Midwest & Winter & $\begin{array}{l}\text { PM concentrations } \\
\text { in swine barns }\end{array}$ \\
\hline & $\begin{array}{l}\text { Sprinkling soybean oil - } \\
\text { TSP: } 0.375 \pm 0.185\end{array}$ & & & & $\begin{array}{l}\text { with animal } \\
\text { activity. }\end{array}$ \\
\hline $\begin{array}{l}\text { Jacobson et al. } \\
(2006)\end{array}$ & $\mathrm{PM}_{10}: 0.545 \pm 0.240$ & $\begin{array}{l}\text { Gestation; } \\
\text { MV }\end{array}$ & US Midwest & $\begin{array}{l}\text { All } \\
\text { seasons }\end{array}$ & - \\
\hline & $\mathrm{PM}_{10}: 0.267 \pm 0.179$ & $\begin{array}{l}\text { Farrowing; } \\
\text { MV }\end{array}$ & & $\begin{array}{l}\text { All } \\
\text { seasons }\end{array}$ & \\
\hline & $\mathrm{PM}_{10}: 0.158 \pm 0.102$ & $\begin{array}{l}\text { Finisher; } \\
\text { MV }\end{array}$ & & $\begin{array}{l}\text { All } \\
\text { seasons }\end{array}$ & \\
\hline $\begin{array}{l}\text { Kim et al. } \\
(2007)\end{array}$ & $\begin{array}{l}\text { TSP: } 3.18 \pm 1.46 \\
\text { Respirable: } 0.92 \pm 0.81\end{array}$ & $\mathrm{n} / \mathrm{a} ; \mathrm{n} / \mathrm{a}$ & South Korea & Summer & $\begin{array}{l}\text { A significant } \\
\text { difference in }\end{array}$ \\
\hline & $\begin{array}{l}\text { TSP: } 2.93 \pm 0.81 \\
\text { Respirable: } 1.87 \pm 0.62\end{array}$ & $\mathrm{n} / \mathrm{a} ; \mathrm{n} / \mathrm{a}$ & & Winter & $\begin{array}{l}\text { levels was noted } \\
\text { between summer } \\
\text { and winter. }\end{array}$ \\
\hline
\end{tabular}




\begin{tabular}{|c|c|c|c|c|c|}
\hline \multirow[t]{4}{*}{$\begin{array}{l}\text { Haeussermann } \\
\text { et al. (2008) }\end{array}$} & Mean $\mathrm{PM}_{10}: 0.31$ & Sow; MV & Italy & $\begin{array}{l}\text { All } \\
\text { seasons }\end{array}$ & \multirow[t]{4}{*}{-} \\
\hline & Mean $\mathrm{PM}_{10}: 0.11-0.40$ & $\begin{array}{l}\text { Nursery; } \\
\text { MV }\end{array}$ & Italy & $\begin{array}{l}\text { All } \\
\text { seasons }\end{array}$ & \\
\hline & Mean $\mathrm{PM}_{10}: 0.47$ & $\begin{array}{l}\text { Grower- } \\
\text { finisher; } \\
\text { MV }\end{array}$ & Italy & \begin{tabular}{|l|} 
All \\
seasons
\end{tabular} & \\
\hline & Mean $\mathrm{PM}_{10}: 0.73$ & $\begin{array}{l}\text { Grower- } \\
\text { finisher; } \\
\text { MV }\end{array}$ & Germany & \begin{tabular}{|l|} 
All \\
seasons
\end{tabular} & \\
\hline \multirow[t]{5}{*}{$\begin{array}{l}\text { Mc Donnell et } \\
\text { al. }(2008)^{3}\end{array}$} & $\begin{array}{l}\text { Median inhalable: } 4.69(0.25- \\
\text { 7.6); } 2.3(\mathrm{SD}) \\
\text { Median respirable: } 0.19(0.03- \\
0.63) ; 0.19(\mathrm{SD})\end{array}$ & $\begin{array}{l}\text { Nursery; } \\
\text { NV, MV }\end{array}$ & \multirow[t]{5}{*}{ Ireland } & $\begin{array}{l}\text { Spring, } \\
\text { summer }\end{array}$ & \multirow[t]{5}{*}{-} \\
\hline & $\begin{array}{l}\text { Median inhalable: } 2.31(1.9- \\
5.0) ; 1.16(\mathrm{SD}) \\
\text { Median respirable: } 0.17(0.01- \\
0.3) ; 0.09 \text { (SD) }\end{array}$ & $\begin{array}{l}\text { Finisher; } \\
\text { MV }\end{array}$ & & $\begin{array}{l}\text { Spring, } \\
\text { summer }\end{array}$ & \\
\hline & $\begin{array}{l}\text { Median inhalable: } 1.49(0.29- \\
4.4) ; 1.51(\mathrm{SD}) \\
\text { Median respirable: } 0.09(0.01- \\
3.4) ; 0.95(\mathrm{SD})\end{array}$ & $\begin{array}{l}\text { Farrowing; } \\
\text { NV }\end{array}$ & & $\begin{array}{l}\text { Spring, } \\
\text { summer }\end{array}$ & \\
\hline & $\begin{array}{l}\text { Median inhalable: } 1.1(0.25- \\
3.5) ; 0.79(\mathrm{SD}) \\
\text { Median respirable: } 0.06(0.01- \\
0.31) ; 0.11(\mathrm{SD})\end{array}$ & Sow; NV & & $\begin{array}{l}\text { Spring, } \\
\text { summer }\end{array}$ & \\
\hline & $\begin{array}{l}\text { Median inhalable: } 2.99(1.1- \\
5.6) ; 1.49(\mathrm{SD}) \\
\text { Median respirable: } 0.19(0.03 \text { - } \\
0.63) ; 0.24(\mathrm{SD})\end{array}$ & $\begin{array}{l}\text { General } \\
\text { farm; MV }\end{array}$ & & $\begin{array}{l}\text { Spring, } \\
\text { summer }\end{array}$ & \\
\hline \multirow[t]{5}{*}{$\begin{array}{l}\text { Kim et al. } \\
(2008)\end{array}$} & $\begin{array}{l}\text { Deep-pit manure storage - } \\
\text { Mean TSP: } 0.83 \\
\text { Mean respirable: } 0.24\end{array}$ & n/a; NV & \multirow[t]{5}{*}{ South Korea } & $\begin{array}{l}\text { Spring, } \\
\text { Fall }\end{array}$ & \multirow[t]{5}{*}{-} \\
\hline & $\begin{array}{l}\text { Deep-pit manure storage - } \\
\text { Mean TSP: } 1.52 \\
\text { Mean respirable: } 0.51\end{array}$ & $\mathrm{n} / \mathrm{a} ; \mathrm{MV}$ & & $\begin{array}{l}\text { Spring, } \\
\text { Fall }\end{array}$ & \\
\hline & $\begin{array}{l}\text { Manure removal by scrapers - } \\
\text { Mean TSP: } 1.67 \\
\text { Mean respirable: } 0.48\end{array}$ & n/a; NV & & \begin{tabular}{|l} 
Spring, \\
Fall
\end{tabular} & \\
\hline & $\begin{array}{l}\text { Manure removal by scrapers - } \\
\text { Mean TSP: } 2.42 \\
\text { Mean respirable: } 0.83\end{array}$ & n/a; MV & & \begin{tabular}{|l} 
Spring, \\
Fall
\end{tabular} & \\
\hline & $\begin{array}{l}\text { Deep-litter bed system- } \\
\text { Mean TSP: } 2.94 \\
\text { Mean respirable: } 1.14\end{array}$ & $\mathrm{n} / \mathrm{a} ; \mathrm{NV}$ & & \begin{tabular}{|l} 
Spring, \\
Fall
\end{tabular} & \\
\hline
\end{tabular}




\begin{tabular}{|c|c|c|c|c|c|}
\hline $\begin{array}{l}\text { Costa et al. } \\
(2009)\end{array}$ & $\mathrm{PM}_{10}: 0.316-0.624$ & $\begin{array}{l}\text { Finisher; } \\
\text { MV }\end{array}$ & Italy & April & $\begin{array}{l}\text { The highest } \mathrm{PM}_{10} \\
\text { concentration } \\
\text { occurred during } \\
\text { feeding. }\end{array}$ \\
\hline \multirow{2}{*}{$\begin{array}{l}\text { Jerez et al. } \\
(2009)\end{array}$} & Mean TSP: $0.24-1.68$ & \multirow{2}{*}{$\begin{array}{l}\text { Wean-to- } \\
\text { finish; MV }\end{array}$} & \multirow[t]{2}{*}{ Illinois } & Summer & \multirow[t]{2}{*}{-} \\
\hline & Mean TSP: $0.85-3.81$ & & & Winter & \\
\hline \multirow[t]{6}{*}{$\begin{array}{l}\text { Lavoie et al. } \\
\text { (2009) }\end{array}$} & $\begin{array}{l}\text { Control- } \\
\text { Geomean TSP: } 1.03\end{array}$ & \multirow{6}{*}{$\begin{array}{l}\text { Grower- } \\
\text { finisher (lab } \\
\text { chambers); } \\
\text { MV }\end{array}$} & \multirow[t]{6}{*}{$\begin{array}{l}\text { Quebec, } \\
\text { Canada }\end{array}$} & \multirow[t]{6}{*}{$\begin{array}{l}\text { Winter, } \\
\text { Spring, } \\
\text { Summer }\end{array}$} & \multirow{6}{*}{$\begin{array}{l}\text { Data were } \\
\text { acquired from } \\
\text { experimental } \\
\text { rooms and might } \\
\text { not represent the } \\
\text { real-world } \\
\text { situation. }\end{array}$} \\
\hline & $\begin{array}{l}\text { V-shaped system with the } \\
\text { manure scraped daily - } \\
\text { Geomean TSP: } 0.95\end{array}$ & & & & \\
\hline & $\begin{array}{l}\text { V-shaped scraper with V-shaped } \\
\text { concrete gutter - } \\
\text { Geomean TSP: } 1.12\end{array}$ & & & & \\
\hline & $\begin{array}{l}\text { A net underneath the floor for } \\
\text { urine-feces separation - } \\
\text { Geomean TSP: } 1.03\end{array}$ & & & & \\
\hline & $\begin{array}{l}\text { Conventional flat scraper and } \\
\text { stainless gutter - } \\
\text { Geomean TSP: } 1.25\end{array}$ & & & & \\
\hline & $\begin{array}{l}\text { Feces stayed on an inclined } \\
\text { stable rubber belt - } \\
\text { Geomean TSP: } 1.16\end{array}$ & & & & \\
\hline \multirow[t]{3}{*}{$\begin{array}{l}\text { Létourneau et } \\
\text { al. (2009) }\end{array}$} & $\begin{array}{l}\text { Conventional - } \\
\text { TSP: } 1.77 \pm 0.72(0.62-2.83)\end{array}$ & \multirow[t]{3}{*}{$\begin{array}{l}\text { Finisher; } \\
\text { MV }\end{array}$} & \multirow[t]{3}{*}{$\begin{array}{l}\text { Quebec, } \\
\text { Canada }\end{array}$} & \multirow[t]{3}{*}{ Winter } & \multirow[t]{3}{*}{-} \\
\hline & $\begin{array}{l}\text { Sawdust bedding- } \\
\text { TSP: } 1.24 \pm 0.94(0.49-2.49)\end{array}$ & & & & \\
\hline & $\begin{array}{l}\text { Source separation system - } \\
\text { Mean TSP: } 1.02-1.59\end{array}$ & & & & \\
\hline \multirow[t]{3}{*}{$\begin{array}{l}\text { O'Shaughnessy } \\
\text { et al. }(2009)^{3}\end{array}$} & $\begin{array}{l}\text { Geomean Inhalable: } 0.83(0.50- \\
2.28) ; 2.34 \text { (GSD) }\end{array}$ & \multirow{3}{*}{$\begin{array}{l}\text { Gestation, } \\
\text { farrowing; } \\
\mathrm{n} / \mathrm{a}\end{array}$} & \multirow[t]{3}{*}{ US Midwest } & Summer & \multirow[t]{3}{*}{-} \\
\hline & $\begin{array}{l}\text { Geomean Inhalable: } 2.53 \text { (1.37- } \\
4.11) ; 1.56 \text { (GSD) }\end{array}$ & & & Spring & \\
\hline & $\begin{array}{l}\text { Geomean Inhalable: } 3.76 \text { (2.19- } \\
\text { 7.20); } 1.91 \text { (GSD) }\end{array}$ & & & Winter & \\
\hline $\begin{array}{l}\text { Thorne et } \\
\text { al. }(2009)^{3}\end{array}$ & $\begin{array}{l}\text { Geomean Inhalable: } 1.4 ; 0.0059 \\
\text { (GSD) }\end{array}$ & $\begin{array}{l}\text { Grower- } \\
\text { finisher, NV } \\
\text { (hoop barns) }\end{array}$ & Iowa & \begin{tabular}{|l|} 
All \\
seasons
\end{tabular} & - \\
\hline
\end{tabular}




\begin{tabular}{|c|c|c|c|c|c|}
\hline & $\begin{array}{l}\text { Geomean Inhalable: 1.91; } \\
0.0021 \text { (GSD) }\end{array}$ & $\begin{array}{l}\text { Grower- } \\
\text { finisher; } \\
\text { MV }\end{array}$ & & & \\
\hline \multirow[t]{4}{*}{$\begin{array}{l}\text { Yao et al. } \\
(2010)\end{array}$} & $\begin{array}{l}\text { TSP: } 0.455 \pm 0.205 \\
\mathrm{PM}_{10}: 0.0997 \pm 0.0705 \\
\mathrm{PM}_{7}: 0.0726 \pm 0.0269 \\
\mathrm{PM}_{2.5}: 0.0207 \pm 0.0273 \\
\mathrm{PM}_{1}: 0.0160 \pm 0.0163\end{array}$ & \multirow[t]{4}{*}{$\begin{array}{l}\text { Nursery; } \\
\text { MV }\end{array}$} & \multirow[t]{4}{*}{ South Korea } & Spring & \multirow[t]{4}{*}{$\begin{array}{l}\text { A negative } \\
\text { correlation was } \\
\text { found between } \\
\text { temperature and } \\
\text { PM. }\end{array}$} \\
\hline & $\begin{array}{l}\text { TSP: } 0.204 \pm 0.169 \\
\mathrm{PM}_{10}: 0.0335 \pm 0.0306 \\
\mathrm{PM}_{7}: 0.0353 \pm 0.0294 \\
\mathrm{PM}_{2.5}: 0.0112 \pm 0.0146 \\
\mathrm{PM}_{1}: 0.0107 \pm 0.0115\end{array}$ & & & Summer & \\
\hline & $\begin{array}{l}\text { TSP: } 0.607 \pm 0.304 \\
\mathrm{PM}_{10}: 0.122 \pm 0.0946 \\
\mathrm{PM}_{7}: 0.104 \pm 0.0570 \\
\mathrm{PM}_{2.5}: 0.0179 \pm 0.0172 \\
\mathrm{PM}_{1}: 0.0147 \pm 0.0196\end{array}$ & & & Fall & \\
\hline & $\begin{array}{l}\text { TSP: } 0.462 \pm 0.200 \\
\mathrm{PM}_{10}: 0.0922 \pm 0.0474 \\
\mathrm{PM}_{7}: 0.0744 \pm 0.0235 \\
\mathrm{PM}_{2.5}: 0.0149 \pm 0.0100 \\
\mathrm{PM}_{1}: 0.0157 \pm 0.0123\end{array}$ & & & Winter & \\
\hline \multirow[t]{3}{*}{$\begin{array}{l}\text { Cambra-López } \\
\text { et al. (2011a) }\end{array}$} & Mean $\mathrm{PM}_{10}: 1.44$ & $\begin{array}{l}\text { Nursery; } \\
\text { MV }\end{array}$ & \multirow[t]{3}{*}{$\begin{array}{l}\text { The } \\
\text { Netherlands }\end{array}$} & Winter & \multirow[t]{3}{*}{-} \\
\hline & Mean $\mathrm{PM}_{10}: 1.27$ & $\begin{array}{l}\text { Grower- } \\
\text { finisher; } \\
\text { MV }\end{array}$ & & Winter & \\
\hline & Mean $\mathrm{PM}_{10}: 0.39$ & $\begin{array}{l}\text { Farrowing; } \\
\text { MV }\end{array}$ & & Winter & \\
\hline \multirow[t]{4}{*}{$\begin{array}{l}\text { Huaitalla et al. } \\
\text { (2011) }\end{array}$} & $\begin{array}{l}\text { Mean } \mathrm{PM}_{10}: 0.29 \\
\text { Mean } \mathrm{PM}_{2.5}: 0.21 \\
\text { Mean } \mathrm{PM}_{1}: 0.25\end{array}$ & $\begin{array}{l}\text { Gestation; } \\
\text { MV }\end{array}$ & \multirow[t]{4}{*}{ China } & Summer & \multirow[t]{4}{*}{-} \\
\hline & $\begin{array}{l}\text { Mean } \mathrm{PM}_{10}: 0.46 \\
\text { Mean } \mathrm{PM}_{2.5}: 0.45 \\
\text { Mean } \mathrm{PM}_{1}: 0.15\end{array}$ & $\begin{array}{l}\text { Farrowing; } \\
\text { MV }\end{array}$ & & Summer & \\
\hline & $\begin{array}{l}\text { Mean } \mathrm{PM}_{10}: 0.83 \\
\text { Mean } \mathrm{PM}_{2.5}: 0.29 \\
\text { Mean } \mathrm{PM}_{1}: 0.35\end{array}$ & $\begin{array}{l}\text { Nursery; } \\
\text { MV }\end{array}$ & & Summer & \\
\hline & $\begin{array}{l}\text { Mean } \mathrm{PM}_{10}: 0.98 \\
\text { Mean } \mathrm{PM}_{2.5}: 0.22 \\
\text { Mean } \mathrm{PM}_{1}: 0.36\end{array}$ & $\begin{array}{l}\text { Finisher; } \\
\text { MV }\end{array}$ & & Summer & \\
\hline $\begin{array}{l}\text { Jerez et al. } \\
(2011 \mathrm{a})\end{array}$ & $\mathrm{PM}_{10}: 0.014-0.125$ & $\begin{array}{l}\text { Grower- } \\
\text { finisher; } \\
\text { MV }\end{array}$ & Illinois & $\begin{array}{l}\text { Winter, } \\
\text { Spring, } \\
\text { Summer }\end{array}$ & - \\
\hline $\begin{array}{l}\text { Siggers et al. } \\
(2011)\end{array}$ & $\begin{array}{l}\text { Control - } \\
\text { Mean TSP: } 1.77\end{array}$ & & $\begin{array}{l}\text { Saskatchewa } \\
\text { n, Canada }\end{array}$ & Winter & - \\
\hline
\end{tabular}




\begin{tabular}{|c|c|c|c|c|c|}
\hline & $\begin{array}{l}\text { Oil sprinkling - } \\
\text { Mean TSP: } 0.25\end{array}$ & $\begin{array}{l}\text { Grower- } \\
\text { finisher; } \\
\text { MV }\end{array}$ & & & \\
\hline $\begin{array}{l}\text { Traversi et al. } \\
(2011)\end{array}$ & Mean $\mathrm{PM}_{10}: 0.17$ & $\mathrm{n} / \mathrm{a} ; \mathrm{MV}$ & Italy & Summer & - \\
\hline \multirow[t]{4}{*}{$\begin{array}{l}\text { Yang et al. } \\
(2011)\end{array}$} & $\begin{array}{l}\mathrm{PM}_{10}: 0.421 \pm 0.265 \\
\mathrm{PM}_{2.5}: 0.156 \pm 0.096\end{array}$ & $\begin{array}{l}\text { Gestation; } \\
\text { MV }\end{array}$ & \multirow[t]{4}{*}{ Illinois } & $\begin{array}{l}\text { All } \\
\text { seasons }\end{array}$ & \multirow{4}{*}{$\begin{array}{l}\text { Seasons had no } \\
\text { significant effect } \\
\text { on } \mathrm{PM}_{10} \text { and a } \\
\text { significant but } \\
\text { weak effect on } \\
\mathrm{PM}_{2.5} \text { inorganic } \\
\text { compositions. }\end{array}$} \\
\hline & $\begin{array}{l}\mathrm{PM}_{10}: 0.213 \pm 0.114 \\
\mathrm{PM}_{2.5}: 0.083 \pm 0.052\end{array}$ & $\begin{array}{l}\text { Farrowing; } \\
\text { MV }\end{array}$ & & $\begin{array}{l}\text { All } \\
\text { seasons }\end{array}$ & \\
\hline & $\begin{array}{l}\mathrm{PM}_{10}: 0.354 \pm 0.275 \\
\mathrm{PM}_{2.5}: 0.075 \pm 0.035\end{array}$ & $\begin{array}{l}\text { Nursery; } \\
\text { MV }\end{array}$ & & $\begin{array}{l}\text { All } \\
\text { seasons }\end{array}$ & \\
\hline & $\begin{array}{l}\mathrm{PM}_{10}: 0.390 \pm 0.303 \\
\mathrm{PM}_{2.5}: 0.177 \pm 0.203\end{array}$ & $\begin{array}{l}\text { Finisher; } \\
\text { MV }\end{array}$ & & $\begin{array}{l}\text { All } \\
\text { seasons }\end{array}$ & \\
\hline $\begin{array}{l}\text { Cyprowski et } \\
\text { al. (2012) }\end{array}$ & $\begin{array}{l}\text { Respirable: } 0.94 \pm 0.93(0.01- \\
\text { 4.69) } \\
\text { Inhalable: } 2.96 \pm 2.69(0.43-11.8)\end{array}$ & $\begin{array}{l}\text { Breeding; } \\
\text { n/a }\end{array}$ & Poland & $\mathrm{n} / \mathrm{a}$ & - \\
\hline $\begin{array}{l}\text { Kristiansen et } \\
\text { al. }(2012)\end{array}$ & TSP: $0.8 \pm 0.2$ & $\begin{array}{l}\text { Sows; MV } \\
\text { (chimney) }\end{array}$ & Denmark & $\begin{array}{l}\text { Spring, } \\
\text { summer }\end{array}$ & - \\
\hline $\begin{array}{l}\text { Van Ransbeeck } \\
\text { et al. (2012) }\end{array}$ & $\begin{array}{l}\mathrm{PM}_{10}: 0.617 \pm 0.433(0.035- \\
1.487) \\
\mathrm{PM}_{2.5}: 0.033 \pm 0.019(0.006- \\
0.071) \\
\mathrm{PM}_{1}: 0.011 \pm 0.007(0.002-0.03)\end{array}$ & $\begin{array}{l}\text { Finisher; } \\
\text { MV }\end{array}$ & Belgium & Summer & - \\
\hline \multirow[t]{2}{*}{$\begin{array}{l}\text { Basinas et al. } \\
(2013)\end{array}$} & $\begin{array}{l}\text { Mean inhalable: } 4.7 \\
\text { Geomean inhalable: } 3.4\end{array}$ & \multirow[t]{2}{*}{ n/a; MV } & \multirow[t]{2}{*}{ Denmark } & Summer & \multirow[t]{2}{*}{-} \\
\hline & $\begin{array}{l}\text { Mean inhalable: } 5.9 \\
\text { Geomean inhalable: } 4.8\end{array}$ & & & Winter & \\
\hline $\begin{array}{l}\text { Van Ransbeeck } \\
\text { et al. (2013) }\end{array}$ & $\begin{array}{l}\mathrm{PM}_{10}: 0.719 \pm 0.301 \\
\mathrm{PM}_{2.5}: 0.0389 \pm 0.0171 \\
\mathrm{PM}_{1}: 0.015 \pm 0.0049\end{array}$ & $\begin{array}{l}\text { Finisher; } \\
\text { MV }\end{array}$ & Belgium & $\begin{array}{l}\text { Summer } \\
\text { to winter }\end{array}$ & $\begin{array}{l}\text { Indoor } \mathrm{PM}_{1}, \\
\mathrm{PM}_{2.5} \text {, and } \mathrm{PM}_{10} \\
\text { concentrations } \\
\text { were significantly } \\
\text { correlated. }\end{array}$ \\
\hline $\begin{array}{l}\text { Viegas et al. } \\
(2013)\end{array}$ & $\begin{array}{l}\text { Mean } \mathrm{PM}_{10}: 2.212 \\
\text { Mean } \mathrm{PM}_{5}: 0.439 \\
\text { Mean } \mathrm{PM}_{2.5}: 0.046 \\
\text { Mean } \mathrm{PM}_{1}: 0.013 \\
\text { Mean } \mathrm{PM}_{0.5}: 0.008\end{array}$ & $\mathrm{n} / \mathrm{a} ; \mathrm{n} / \mathrm{a}$ & Portugal & $\mathrm{n} / \mathrm{a}$ & - \\
\hline \multirow[t]{3}{*}{$\begin{array}{l}\text { Yang et al. } \\
(2013)\end{array}$} & TSP: $0.95 \pm 0.66(0.24-2.27)$ & $\begin{array}{l}\text { Farrowing; } \\
\text { MV }\end{array}$ & \multirow[t]{3}{*}{ Illinois } & \multirow[t]{3}{*}{$\begin{array}{l}\text { All } \\
\text { seasons }\end{array}$} & \multirow[t]{3}{*}{-} \\
\hline & TSP: $0.76 \pm 0.37$ (0.30-1.39) & $\begin{array}{l}\text { Gestation; } \\
\text { MV }\end{array}$ & & & \\
\hline & TSP: $1.70 \pm 1.41(0.14-4.59)$ & $\begin{array}{l}\text { Nursery; } \\
\text { MV }\end{array}$ & & & \\
\hline
\end{tabular}




\begin{tabular}{|c|c|c|c|c|c|}
\hline & TSP: $1.76 \pm 1.10(0.32-3.50)$ & $\begin{array}{l}\text { Finisher; } \\
\text { MV }\end{array}$ & & & \\
\hline \multirow[t]{4}{*}{$\begin{array}{l}\text { Ulens et al. } \\
\text { (2014) }\end{array}$} & $\begin{array}{l}\text { Wet protocol- }- \\
\mathrm{PM}_{10}: 2.146 \pm 0.159 \\
\mathrm{PM}_{2.5}: 0.201 \pm 0.012 \\
\mathrm{PM}_{1}: 0.0287 \pm 0.0014\end{array}$ & \multirow[t]{4}{*}{$\begin{array}{l}\text { Finisher; } \\
\text { MV }\end{array}$} & \multirow[t]{4}{*}{ Belgium } & \multirow[t]{4}{*}{\begin{tabular}{|l|} 
All \\
seasons
\end{tabular}} & \multirow{4}{*}{$\begin{array}{l}\text { The study } \\
\text { compared } \\
\text { different pen } \\
\text { cleaning } \\
\text { techniques and } \\
\text { housing systems. }\end{array}$} \\
\hline & $\begin{array}{l}\text { Dry protocol - } \\
\mathrm{PM}_{10}: 2.215 \pm 0.159 \\
\mathrm{PM}_{2.5}: 0.208 \pm 0.012 \\
\mathrm{PM}_{1}: 0.0263 \pm 0.0014\end{array}$ & & & & \\
\hline & $\begin{array}{l}\text { Low-ammonia-emission - } \\
\mathrm{PM}_{10}: 2.393 \pm 0.159 \\
\mathrm{PM}_{2.5}: 0.219 \pm 0.012 \\
\mathrm{PM}_{1}: 0.0278 \pm 0.0014\end{array}$ & & & & \\
\hline & $\begin{array}{l}\text { Conventional- } \\
\mathrm{PM}_{10}: 1.968 \pm 0.159 \\
\mathrm{PM}_{2.5}: 0.19 \pm 0.012 \\
\mathrm{PM}_{1}: 0.0272 \pm 0.0014\end{array}$ & & & & \\
\hline $\begin{array}{l}\text { Anthony et al. } \\
\text { (2015) }\end{array}$ & $\begin{array}{l}\text { Respirable: } 0.005-0.31 \\
\text { Inhalable: } 0.17-2.09\end{array}$ & $\begin{array}{l}\text { Farrowing; } \\
\text { MV }\end{array}$ & Iowa & Winter & - \\
\hline $\begin{array}{l}\text { Cambra-López } \\
\text { et al. (2015) }\end{array}$ & Mean $\mathrm{PM}_{10}: 0.76$ & $\begin{array}{l}\text { Grower- } \\
\text { finisher, } \\
\text { gestation; } \\
\text { MV }\end{array}$ & $\begin{array}{l}\text { The } \\
\text { Netherlands }\end{array}$ & $\mathrm{n} / \mathrm{a}$ & - \\
\hline $\begin{array}{l}\text { Winkel et al. } \\
\text { (2015) }\end{array}$ & Mean $\mathrm{PM}_{10}: 0.511$ (0.159-1.402) & $\begin{array}{l}\text { Finisher; } \\
\text { MV }\end{array}$ & $\begin{array}{l}\text { The } \\
\text { Netherlands }\end{array}$ & $\begin{array}{l}\text { Fall \& } \\
\text { winter }\end{array}$ & - \\
\hline $\begin{array}{l}\text { Mostafa et al. } \\
(2016)\end{array}$ & Mean TSP: 1.28 & n/a; MV & Germany & $\mathrm{n} / \mathrm{a}$ & - \\
\hline $\begin{array}{l}\text { Kwon et al. } \\
\text { (2016) }\end{array}$ & $\begin{array}{l}\text { TSP: } 1.40 \pm 0.10 \\
\text { PM }_{10}: 0.78 \pm 0.04\end{array}$ & $\begin{array}{l}\text { Nursery; } \\
\text { MV }\end{array}$ & South Korea & $\begin{array}{l}\text { Spring, } \\
\text { Fall }\end{array}$ & - \\
\hline \multirow[t]{4}{*}{ Xu et al. (2016) } & Mean $\mathrm{PM}_{10}: 0.96$ & \multirow[t]{4}{*}{$\begin{array}{l}\text { Finisher; } \\
\text { NV }\end{array}$} & \multirow[t]{4}{*}{ China } & Spring & \multirow{4}{*}{$\begin{array}{l}\text { A significant } \\
\text { seasonality was } \\
\text { noted. }\end{array}$} \\
\hline & $\begin{array}{l}\text { Mean TSP: } 0.59 \\
\text { Mean } \text { PM }_{10}: 0.34\end{array}$ & & & Summer & \\
\hline & Mean TSP: 2.34 & & & Fall & \\
\hline & Mean TSP: 3.94 & & & Winter & \\
\hline \multirow[t]{2}{*}{$\begin{array}{l}\text { Mostafa et al. } \\
\text { (2017) }\end{array}$} & $\begin{array}{l}\text { Recirculated air scrubber system } \\
\text { (Control) - } \\
\text { Mean TSP: } 0.93-1.51 \\
\text { Mean PM }{ }_{10}: 0.37-0.65\end{array}$ & \multirow[t]{2}{*}{$\begin{array}{l}\text { Finisher; } \\
\text { MV }\end{array}$} & \multirow[t]{2}{*}{ Germany } & \multirow[t]{2}{*}{$\begin{array}{l}\text { Winter, } \\
\text { Spring }\end{array}$} & \multirow{2}{*}{$\begin{array}{l}\text { The main purpose } \\
\text { of the study was to } \\
\text { study the PM } \\
\text { reduction } \\
\text { performance of } \\
\text { two mitigation } \\
\text { technologies. }\end{array}$} \\
\hline & $\begin{array}{l}\text { Recirculated air scrubber system } \\
\text { (Water) - } \\
\text { Mean TSP: } 0.4 \\
\text { Mean PM } 10: 0.16\end{array}$ & & & & \\
\hline
\end{tabular}




\begin{tabular}{|c|c|c|c|c|c|}
\hline & $\begin{array}{l}\text { Recirculated air scrubber system } \\
\text { (Acid) - } \\
\text { Mean TSP: } 0.42-0.44 \\
\text { Mean PM }_{10}: 0.18-0.21\end{array}$ & & & & \\
\hline & $\begin{array}{l}\text { Water-oil mixture spraying } \\
\text { system (Control) - } \\
\text { Mean TSP: } 0.80-1.33 \\
\text { Mean PM } 10: 0.26-0.39\end{array}$ & & & & \\
\hline & $\begin{array}{l}\text { Water-oil mixture spraying } \\
\text { system (Small nozzle)- } \\
\text { Mean TSP: } 0.18-0.47 \\
\text { Mean PM } 10: 0.08-0.18\end{array}$ & & & & \\
\hline & $\begin{array}{l}\text { Water-oil mixture spraying } \\
\text { system (Large nozzle)- } \\
\text { Mean TSP: } 0.45-0.65 \\
\text { Mean PM } 10: 0.17-0.27\end{array}$ & & & & \\
\hline $\begin{array}{l}\text { Wenke et al. } \\
(2018)\end{array}$ & $\begin{array}{l}\text { Air filter modules - } \\
\text { Mean TSP: } 0.02-0.242 \\
\text { Air filter attic - } \\
\text { Mean TSP: } 0.003-0.643 \\
\text { Without air filtrations system - } \\
\text { Mean TSP: } 0.019-0.243 \\
\text { Recirculating air filtration } \\
\text { modules - } \\
\text { Mean TSP:0.041-0.280 }\end{array}$ & $\begin{array}{l}\text { Grower- } \\
\text { finisher; } \\
\text { MV }\end{array}$ & Germany & $\begin{array}{l}\text { All } \\
\text { seasons }\end{array}$ & - \\
\hline $\begin{array}{l}\text { Dai et al. } \\
(2019)\end{array}$ & $\begin{array}{l}\text { Mean TSP: } 0.2 \\
\text { Mean PM} 10: 0.091 \\
\text { Mean } \mathrm{PM}_{4}: 0.06 \\
\text { Mean } \mathrm{PM}_{2.5}: 0.056 \\
\text { Mean } \mathrm{PM}_{1}: 0.053\end{array}$ & $\begin{array}{l}\text { Finisher; } \\
\text { NV }\end{array}$ & China & $\begin{array}{l}\text { All } \\
\text { seasons }\end{array}$ & - \\
\hline $\begin{array}{l}\text { Pilote et al. } \\
(2019)\end{array}$ & TSP: $1.56 \pm 1.06(0.164-3.40)$ & $\begin{array}{l}\text { Finisher; } \\
\text { MV }\end{array}$ & $\begin{array}{l}\text { Quebec, } \\
\text { Canada }\end{array}$ & Winter & $\begin{array}{l}\text { DustTrak DRX } \\
\text { yielded much } \\
\text { smaller TSP } \\
\text { concentrations } \\
\text { than gravimetric } \\
\text { samplers. }\end{array}$ \\
\hline \multirow[t]{2}{*}{$\begin{array}{l}\text { Shen et al. } \\
(2019)\end{array}$} & $\begin{array}{l}\text { TSP: } 0.635 \pm 0.1(0.228-1.08) \\
\mathrm{PM}_{10}: 0.388 \pm 0.09(0.152-0.658) \\
\mathrm{PM}_{2.5}: 0.210 \pm 0.09(0.095-0.415)\end{array}$ & $\begin{array}{l}\text { Nursery; } \\
\text { MV }\end{array}$ & \multirow[t]{2}{*}{ China } & $\mathrm{n} / \mathrm{a}$ & \multirow{2}{*}{$\begin{array}{l}\text { Indoor air quality } \\
\text { in the rear of the } \\
\text { barn was better } \\
\text { than in other } \\
\text { areas; TSP } \\
\text { concentrations in } \\
\text { the finisher barn } \\
\text { were significantly } \\
\text { higher than the } \\
\text { nursery barn. }\end{array}$} \\
\hline & $\begin{array}{l}\text { TSP: } 0.777 \pm 0.2(0.307-2.18) \\
\mathrm{PM}_{10}: 0.338 \pm 0.1(0116-0.835) \\
\mathrm{PM}_{2.5}: 0.144 \pm 0.06(0.038-0.374)\end{array}$ & $\begin{array}{l}\text { Finisher; } \\
\mathrm{MV}\end{array}$ & & $\mathrm{n} / \mathrm{a}$ & \\
\hline
\end{tabular}




\begin{tabular}{|c|c|c|c|c|c|}
\hline $\begin{array}{l}\text { Shin et al. } \\
(2019)\end{array}$ & $\begin{array}{l}\text { Inhalable: } 0.5 \pm 0.35 \\
\text { Respirable: } 0.13 \pm 0.12\end{array}$ & $\mathrm{n} / \mathrm{a} ; \mathrm{n} / \mathrm{a}$ & South Korea & Summer & - \\
\hline \multirow[t]{4}{*}{$\begin{array}{l}\text { Shang et al. } \\
(2020)\end{array}$} & $\begin{array}{l}\text { Mean TSP: } 1.14-3.20 \\
\text { Mean } \mathrm{PM}_{10}: 0.24-1.01 \\
\text { Mean } \mathrm{PM}_{2.5}: 0.07-0.12\end{array}$ & \multirow[t]{4}{*}{$\begin{array}{l}\text { Grower- } \\
\text { finisher; } \\
\mathrm{MV}\end{array}$} & \multirow[t]{4}{*}{ China } & Spring & \multirow{4}{*}{$\begin{array}{l}\text { TSP } \\
\text { concentrations } \\
\text { were significantly } \\
\text { greater in winter } \\
\text { than summer. }\end{array}$} \\
\hline & $\begin{array}{l}\text { Mean TSP: } 0.34-0.48 \\
\text { Mean } \text { PM }_{10}: 0.15-0.21 \\
\text { Mean } \text { PM }_{2.5}: 0.06-0.10\end{array}$ & & & Summer & \\
\hline & $\begin{array}{l}\text { Mean TSP: } 1.29-1.81 \\
\text { Mean } \mathrm{PM}_{10}: 0.51-0.69 \\
\text { Mean } \mathrm{PM}_{2.5}: 0.09-0.11\end{array}$ & & & Fall & \\
\hline & $\begin{array}{l}\text { Mean TSP: } 2.22-4.96 \\
\text { Mean } \mathrm{PM}_{10}: 0.71-0.88 \\
\text { Mean } \mathrm{PM}_{2.5}: 0.09-0.20\end{array}$ & & & Winter & \\
\hline
\end{tabular}

Note:

${ }^{1}$ GSD - geometric standard deviation; SD - standard deviation; BDL - below the detection limit. The default format is "mean $\pm \mathrm{SD}$ " or range. A range of mean values is given when mean concentration data are available from multiple barns.

${ }^{2} \mathrm{MV}$ - mechanical ventilation; NV - natural ventilation.

${ }^{3}$ Personal exposure samples were collected for PM concentration measurement.

PM mass concentrations in swine barns are affected by many factors. A good understanding of these factors is essential for the development of cost-effective PM mitigation strategies. Heber et al. (1988b) reviewed early publications and identified seven factors affecting in-barn PM concentrations. These include: (1) Outside temperature - PM concentrations decrease as the outside temperature goes up. Because a ventilation rate increases with the outside temperature, PM in swine barns is diluted by an increased volume of fresh air; (2) Ventilation system - Natural ventilation systems are generally associated with higher in-barn PM concentrations because of their lower ventilation rates than those of mechanical ventilation systems; (3) Air velocity in a barn - An increased air velocity may enhance the suspension and re-suspension of particles, but meanwhile an increased amount of PM may be removed because of enhanced inertial impaction of PM on room surfaces and other objects; (4) Humidity - PM concentrations decrease with relative humidity $(\mathrm{RH})$. The sorption of water enlarges PM size, thereby suppressing PM suspension and re-suspension. However, the effect of moisture becomes significant only under very high $\mathrm{RH}$ conditions, e.g., $\mathrm{RH} \geq 85 \%$; (5) Animal activity - Increased animal activity leads to elevated PM concentrations. Animal activity is in turn affected by indoor temperature, feeding method, feed type, light, and human activity inside swine barns; (6) Quantity of feed per animal - Feed is a major source of PM. An excessive amount of feed may lead to high PM concentrations; and (7) Barn cleanliness - Dusty floors and wall surfaces are sources of PM and also raise the chance of PM re-suspension. Most of these generalizations still stand today. However, significant changes have occurred to pork production on aspects such as genetics, nutrition, and environmental management. New findings have been reported, including contradictory ones. For example, Gustafsson (1999) found that increasing ventilation rates had a limited effect on in-barn PM concentrations.

Upon the analysis of relevant publications since 1990, the following updates are made:

- While North America and Europe lead the effort of PM concentration measurement, a growing interest has been seen in Asian countries (with 12 out of 66 reports from South Korea, China, and Taiwan since 1990), especially in recent years (Table 2). TSP (or total particles) was most frequently measured (Table 3), followed by $\mathrm{PM}_{10}$ and respirable PM. Since 2010, a rapidly 
increasing number of reports have been available regarding $\mathrm{PM}_{10}$ and $\mathrm{PM}_{2.5}$ concentrations. Ten studies collected personal samples for PM exposure assessment, in which farm workers were asked to wear personal PM samplers during their work shifts. A few studies also used personal samplers but mounted the samplers at a fixed location - a setup known as fixed samplers. In principle, the PM concentrations derived from personal exposure samples cannot be directly compared with those from fixed samples.

Table 3. Numbers of measurement efforts for different PM size fractions.

\begin{tabular}{|l|l|l|l|l|l|l|}
\hline Years & TSP & $\mathrm{PM}_{10}$ & $\mathrm{PM}_{2.5}$ & Inhalable & Respirable & Others $^{1}$ \\
\hline $1990-1999$ & 7 & 0 & 0 & 2 & 6 & 0 \\
\hline $2000-2009$ & 16 & 5 & 1 & 6 & 7 & 0 \\
\hline $2010-$ Present & 12 & 17 & 9 & 4 & 3 & 6 \\
\hline Total & 35 & 22 & 10 & 12 & 16 & 6 \\
\hline
\end{tabular}

Note:

${ }^{1}$ Other size fractions include $\mathrm{PM}_{1}, \mathrm{PM}_{5}$, and $\mathrm{PM}_{7}$.

- PM concentrations varied greatly in the literature. With no PM mitigation measures implemented, the reported mean TSP concentrations (including algorithmic mean, geometric mean [geomean], and median) ranged from 0.15 (Chang et al., 2001a) to $>20 \mathrm{mg} \mathrm{m}^{-3}$ (Liao et al., 2001). Sampling or averaging time is highly influential on measurement results. Many studies collected 24-hr filter samples or ran PM monitors for 24 hours to address diurnal variability and determine daily average PM concentrations. However, a shorter or longer sampling time was occasionally seen. As for the aforementioned TSP concentration range, the lowest value was a daily average (Chang et al., 2001a) while the highest one was an hourly average (Liao et al., 2001). Strictly said, they cannot be directly compared. Such dilemma is further complicated by the lack of sampling or averaging time information in part of the publications. The reported mean concentrations ranged from 0.64 (Schmidt et al., 2002) to $5.9 \mathrm{mg} \mathrm{m}^{-3}$ (Basinas et al., 2013) for inhalable PM, from 0.04 (Schmidt et al., 2002) to $1.87 \mathrm{mg} \mathrm{m}^{-3}$ (Kim et al., 2007) for respirable PM, from 0.034 (Yao et al., 2010) to $1.63 \mathrm{mg} \mathrm{m}^{-3}$ (Schmidt et al., 2002) for $\mathrm{PM}_{10}$, and from 0.015 (Yao et al., 2010) to 0.45 $\mathrm{mg} \mathrm{m}^{-3}$ (Huaitalla et al., 2011) for $\mathrm{PM}_{2.5}$. A gradual decrease in TSP concentrations over the past 30 years is noted. The reasons are uncertain but likely related to the improved environmental management of swine barns.

- PM concentrations show significant seasonality (Predicala et al., 2001; Schmidt et al., 2002; Zhu et al., 2005; Jerez et al., 2009; Yao et al., 2010; Peters, et al., 2012; Basinas et al., 2013; Xu et al., 2016; Yang et al., 2015; Shang et al., 2020), with generally the highest concentrations occurring in winter and the lowest concentrations in summer. Such seasonality is believed to be related to ventilation rates (Predicala et al., 2001; Yang et al., 2015). Most modern swine barns use mechanical ventilation or mechanically assisted ventilation (with sidewall curtains dropped in hot weather conditions). In either case, a barn's ventilation rate is maximal in summer - to cool down the barn's temperature - and minimal in winter - to keep the barn warm. An elevated ventilation rate would enhance the dilution of PM by fresh air, thus decreasing in-barn PM concentrations. For a similar reason (i.e., changes in outdoor temperatures), PM concentrations also exhibit significant diurnal variability (Takai et al., 1998; Wang et al., 2002). However, such variability could be caused by a diurnal change in animal activity other than outdoor temperatures.

- No agreement has yet been reached regarding the effect of ventilation systems. Although several studies reported that naturally ventilated barns had higher PM concentrations than mechanically ventilated barns (Heber et al 1988; Kim et al. 2008), Predicala et al. (2001) found no significant difference in inhalable or respirable PM concentrations between naturally and mechanically ventilated finisher barns in Kansas. Another counter finding was reported by Gallmann et al. (2002) that $\mathrm{PM}_{2.5}$ and $\mathrm{PM}_{10}$ concentrations were lower in a naturally ventilated than a mechanically ventilated finisher barn in Germany. A comparison of different ventilation systems 
is challenging for several reasons. First, many previous publications provide no detailed description of a barn's ventilation system. Even for mechanical ventilation systems, there are various configurations such as tunnel ventilation, cross-flow ventilation, and chimney ventilation. Different configurations could result in different airflow patterns and dilution levels (by fresh air) at the monitoring point. Classifying ventilation systems into natural, mechanical, and mixed types could oversimplify a barn's ventilation conditions. Secondly, it is difficult to find swine barns only differing in ventilation systems. Other environmental and operating parameters (e.g., local climatic conditions and feed types) could substantially affect PM concentrations in swine barns. Thirdly, for naturally ventilation barns, their ventilation rates are highly variable and can be affected by wind speeds and directions, barn locations (e.g., valley or hilltop) and orientations, solar radiation, ground objects, etc.

- PM concentrations increase with animal activity (Heber et al., 1988b; Kim et al., 2005; Heber et al., 2006). Costa et al. (2009) found a significant correlation $(\mathrm{p}<0.001)$ between animal activity and $\mathrm{PM}_{10}$ concentrations inside a finisher barn in Italy. Animal activity was determined through image analysis. Takai et al. (1998) and Wang et al. (2002) observed higher PM concentrations during the day than the night and ascribed this to increased animal activity during the day. Kim et al. (2005) further compared TSP concentrations in three time slots: morning (8-9 am), afternoon (2-3 pm), and evening (8-9 pm), and found that the overall highest concentrations occurred in the afternoon when pigs were usually most active. Feeding is one of the parameters that regulate animal activity. Elevated in-barn PM concentrations were detected during feeding periods (Liao et al., 2001; Costa et al., 2009; Zhu et al., 2005; Shen et al., 2019), regardless of the feeding methods (hand or automated) (Attwood et al., 1987; Takai et al., 1998). However, feedingresulted high PM concentrations could be related to not only increased animal activity but also the suspension of feed particles by feed delivery systems.

- No agreement has yet been reached regarding the effect of barn types. Jacobson et al. (2006) and Yang et al. (2011) measured $\mathrm{PM}_{10}$ concentrations in various barns in the U.S. Midwest and found that the overall lowest concentrations occurred in gestation barns; whereas Huaitailla et al. (2011) reported that gestation barns had higher $\mathrm{PM}_{10}$ concentrations than other barn types in northern China. Another study in China compared PM concentrations in a finisher versus a nursery barn, with higher TSP concentrations detected in the finisher barn (Shen et al. 2019). A similar observation was made by Yang et al. (2013) from a field study in Illinois. However, this is contradictory to the findings of Chang et al. (2001a) who reported significantly higher TSP concentrations in nursery than finisher barns in Taiwan. Several studies found overall lower PM concentrations in farrowing barns than finisher or nursery barns (Chang et al., 2001a; CamraLópez et al., 2011a; Huaitailla et al., 2011; Yang et al., 2011; Yang et al., 2013); while higher $\mathrm{PM}_{10}$ concentrations in farrowing than finisher barns were reported by Jacobson et al. (2006). A conclusive comparison among different barn types may require extended monitoring periods and/or additional farm sites to address the uncertainties created by temporal and farm-to-farm variations.

- PM concentrations show a heterogeneous spatial distribution inside swine barns (Barber et al., 1991; Wang et al., 2000; Wang et al., 2002; Kim et al., 2005; Wang et al., 2005; Jerez et al., 2011b; Peters et al., 2012; Reeve et al., 2013). Barber et al. (1991) collected 24-hour TSP samples from 16 points inside a partially slatted grower-finisher barn. They found that the TSP mass concentrations ranged from 1.6 to $2.74 \mathrm{mg} \mathrm{m}^{-3}$, with the highest concentration at the floor level within non-slatted areas and the lowest concentration at pen divider height over slatted areas. Wang et al. (2002) measured the spatial distribution of TSP concentrations in a partially slatted grower-finisher barn with cross-flow ventilation. The distribution was found to be affected by ventilation rates, diurnal changes in outdoor weather, and dust mitigation efforts such as oil sprinkling. TSP concentrations at the exhaust were lower than the average indoor concentrations, 
under all tested ventilation rates and outdoor weather conditions. Jerez et al. (2011b) conducted a similar investigation in a tunnel-ventilated grower-finisher barn. They reported that in December (winter) while air velocities increased longitudinally from the barn's end-wall intake to tunnel fans (because of air intake from celling inlets), TSP concentrations gradually decreased at the heights of $1.6 \mathrm{~m}$ and $0.8 \mathrm{~m}$ above the floor. However, in June (summer) both TSP concentrations and air velocities increased longitudinally. Peters et al. (2012) mapped inhalable PM mass concentrations inside a tunnel-ventilated gestation barn. In winter, the highest concentrations occurred near the center of the barn; while in spring and summer, the highest concentrations were found close to the tunnel fans. Given the non-uniform spatial distribution of PM, it is important to find sampling/monitoring points representative of average in-barn PM concentrations. But in reality, it is difficult to do so because PM spatial distribution can be affected by various factors. Caution therefore must be taken when comparing PM concentration data from different studies.

- There has been no consistent conclusion regarding the effect of indoor air humidity. Gallmann et al. (2002) found that both $\mathrm{PM}_{10}$ and $\mathrm{PM}_{2.5}$ concentrations decreased with air humidity levels in two finisher barns in Germany. Kim et al. (2005) in Korea found that TSP concentrations in a grower-finisher barn significantly decreased with air humidity levels $(R=-0.52, p<0.05)$. Costa et al. (2009) measured $\mathrm{PM}_{10}$ concentrations in a chimney-ventilated finisher barn in Italy. The measured $\mathrm{PM}_{10}$ concentrations exhibited a significant but negative correlation with air humidity levels $(\mathrm{R}=-0.929$ and $\mathrm{p}<0.0001)$. However, counter findings were also reported. Maghirang et al. (1997) in Kansas found that in a nursery barn both TSP and respirable PM concentrations increased with air humidity levels and that no significant correlation existed between PM concentrations and air humidity levels. A similar observation was made for $\mathrm{PM}_{10}$ from a barn study in Czech (Kosová et al., 2009). In the same study, $\mathrm{PM}_{2.5}$ concentrations significantly increased with air humidity levels $(\mathrm{p}<0.001)$. Since no raw data are available, it remains uncertain whether the air humidity levels in Maghirang et al. (1997) and Kosová et al. (2009) exceeded the threshold of $\mathrm{RH} \geq 85 \%$ (Heber et al., 1988b) or 70\% (Takai et al., 1998) above which a significant effect of air humidity could be anticipated.

PM concentrations inside swine barns can additionally be affected by animal age (Li, 1997; Shin et al., 2019) and stock density (Yang, 2010). Because few relevant publications are available, no review is provided here. Other influential factors include feed diet and feeders, housekeeping, and mitigation technologies implemented. Detailed information about PM mitigation is available in Section 5.

\subsubsection{PM size distribution}

Size is one of the most important physical characteristics of PM. It significantly impacts the PM's health and environmental effects. The smaller a particle is, the more deeply it may penetrate the respiratory tract of humans and animals. Smaller particles can travel a longer distance in the air than larger ones (Wilson et al. 2002). Particle size is also a key parameter for the design and operation of PM mitigation systems. The PM reduction efficiency of these systems is usually size-dependent and increases with particle size (Cooper and Alley, 2010). Thus, from both environmental health and PM mitigation standpoints, the field measurement of PM size distribution in swine barns is of great importance.

For a spherical particle, the particle size is characterized by its geometric diameter. However, most particles collected in polluted environments (including swine barns) are non-spherical and irregular in shape. To apply the concept of particle size to non-spherical particles, several equivalent diameters were defined. Two commonly used equivalent diameters are (1) equivalent volume diameter, defined as the diameter of a sphere with the same volume as the real particle, and (2) aerodynamic diameter, defined as the diameter of a unit density $\left(\rho=1000 \mathrm{~kg} \mathrm{~m}^{-3}\right)$ sphere with the same aerodynamic behaviors (e.g., settling velocity) as the real particle (Hinds, 1999; Zhang, 2005).

Particles are heterogeneous in size (polydispersed). A particle size distribution (PSD) can be derived by classifying the particles into multiple size channels. The y-axis of a derived PSD graph represents the 
quantity or occurrence frequency of particles of a certain size and it can be particle number (count), surface area, volume, or mass, etc. The x-axis of the graph represents the size of particles (e.g., geometric diameter, or aerodynamic diameter). The central location of a PSD profile can be described by arithmetic mean, geometric mean, median, or mode diameters (Zhang, 2005). Among them, the mass median diameter (MMD) - defined as the diameter that splits the total PM mass by half - is most frequently used, primarily for two reasons. First, PM regulations are predominately mass-based. Secondly, most mass PSD profiles measured in swine barns are approximately lognormal (Predicala et al., 2001; Predicala and Maghirang, 2003; Yang et al., 2012). A measured PSD profile can therefore be approximated by a lognormal distribution model with MMD representing the central location represented and GSD characterizing the spread (width) of the PSD (Eq. 1):

$$
M(d)=\frac{1}{2} \operatorname{erfc}\left(-\frac{\log d-\log M M D}{\sqrt{2} \log G S D}\right)
$$

where, $\quad M(d)=$ cumulative particle mass fraction at the diameter of $d$, as predicted by the lognormal distribution equation $\operatorname{erfc}()=$ complementary error function

A measured PSD may consist of tens of size channels. The use of MMD and GSD, thus, greatly simplifies data reporting as well as discussions on size-dependent PM properties or impacts (Zhang, 2005). It is noteworthy that PSDs in livestock barns can be approximated by other statistical models (Chen et al., 1995; Yang et al., 2012). However, the lognormal distribution model has been most commonly used.

To our knowledge, the first PSD measurement in swine barns was reported by Dr. Bundy at Iowa State University (Bundy, 1974). An optical particle counter (OPC; Royco Model 215) was used in a farrowing barn to measure particle numbers in six size channels: $0.5,1,2,3,5$, and $10 \mu \mathrm{m}$. The highest particle number concentration was found for particles of $0.5 \mu \mathrm{m}$ and particle numbers decreased with increased diameters. Donham et al. (1986) measured the size of particles in 21 swine barns in Iowa, with a number median diameter (NMD; the diameter splitting the total PM count by half) of $2.2 \mu \mathrm{m}$ derived from an optical microscope and an MMD of $9.6 \mu \mathrm{m}$ determined by a cascade impactor. Heber et al. (1988a) collected PM samples from 11 finisher barns, measured the PSD of the collected samples using a Coulter counter, and reported an MMD of $18.5 \mu \mathrm{m}$ and a GSD of 2.54. Since 1990, additional efforts have been devoted to PSD measurement in swine barns, as summarized in Table 4.

Table 4. PM size distribution in swine barns - a summary of studies since 1990.

\begin{tabular}{|c|c|c|c|c|}
\hline Reference & $\begin{array}{l}\text { Size measurement } \\
\text { results } 1\end{array}$ & $\begin{array}{l}\text { Barn \& ventilation } \\
\text { type }^{1}\end{array}$ & Location & Major findings or notes \\
\hline $\begin{array}{l}\text { Barber et al. } \\
\text { (1991) }\end{array}$ & $\begin{array}{l}\text { Mass mean diameter: } 14 \\
\mu \mathrm{m}\end{array}$ & $\begin{array}{l}\text { Grower-finisher; } \\
\text { MV }\end{array}$ & $\begin{array}{l}\text { Saskatchewan, } \\
\text { Canada }\end{array}$ & - \\
\hline $\begin{array}{l}\text { Welford et al. } \\
\text { (1992) }\end{array}$ & NMD: $1.5 \mu \mathrm{m}$ & $\begin{array}{l}\text { Grower-finisher; } \\
\text { MV }\end{array}$ & $\begin{array}{l}\text { Saskatchewan, } \\
\text { Canada }\end{array}$ & - \\
\hline $\begin{array}{l}\text { Zhang et al. } \\
\text { (1994) }\end{array}$ & $\begin{array}{l}\text { Before oil sprinkling- } \\
\text { Number mode } \\
\text { diameter: }>5.0 \mu \mathrm{m} \\
\text { After oil sprinkling- } \\
\text { Number mode diameter: } \\
0.3-0.5 \mu \mathrm{m}\end{array}$ & $\begin{array}{l}\text { Grower-finisher; } \\
\text { MV }\end{array}$ & $\begin{array}{l}\text { Saskatchewan, } \\
\text { Canada }\end{array}$ & $\begin{array}{l}\text { After oil sprinkling, the } \\
\text { particle size distribution } \\
\text { inside the swine barn was } \\
\text { similar to that in an } \\
\text { office. }\end{array}$ \\
\hline $\begin{array}{l}\text { Maghirang et } \\
\text { al. (1997) }\end{array}$ & $\begin{array}{l}\text { MMD: } 13 \mu \mathrm{m}(10-19 \\
\mu \mathrm{m}) \\
\text { GSD: } 3(2-5)\end{array}$ & Nursey; MV & Kansas & - \\
\hline
\end{tabular}




\begin{tabular}{|c|c|c|c|c|}
\hline $\begin{array}{l}\text { Aarnink et al. } \\
\text { (1999) }\end{array}$ & $\begin{array}{l}\text { MMD: } 8.31 \mu \mathrm{m} \\
\text { GSD: } 1.60\end{array}$ & $\begin{array}{l}\text { Nursery, lab } \\
\text { chamber }\end{array}$ & $\begin{array}{l}\text { The } \\
\text { Netherlands }\end{array}$ & - \\
\hline \multirow[t]{2}{*}{$\begin{array}{l}\text { Predicala et al. } \\
(2001)\end{array}$} & $\begin{array}{l}\text { Range: } 14.0-22.9 \mu \mathrm{m} \\
\text { GMD: } 17.9 \mu \mathrm{m} \\
\text { GSD: } 2.2\end{array}$ & $\mathrm{n} / \mathrm{a} ; \mathrm{NV}$ & \multirow[t]{2}{*}{ Kansas } & $\begin{array}{l}79 \% \text { of particles by mass } \\
\text { were larger than } 10 \mu \mathrm{m} .\end{array}$ \\
\hline & $\begin{array}{l}\text { Range: } 12.1-21.2 \mu \mathrm{m} \\
\text { GMD: } 18.1 \mu \mathrm{m} \\
\text { GSD: } 2.1\end{array}$ & $\mathrm{n} / \mathrm{a} ; \mathrm{MV}$ & & $\begin{array}{l}80 \% \text { of particles by mass } \\
\text { were larger than } 10 \mu \mathrm{m} .\end{array}$ \\
\hline $\begin{array}{l}\text { Schneider et al. } \\
\text { (2001) }\end{array}$ & $\mathrm{n} / \mathrm{a}$ & $\mathrm{n} / \mathrm{a} ; \mathrm{n} / \mathrm{a}$ & Germany & $\begin{array}{l}\text { A bimodal distribution } \\
\text { was noted, with one peak } \\
\text { in the submicron range } \\
\text { and the other in the } \\
\text { micron range. }\end{array}$ \\
\hline $\begin{array}{l}\text { O'Shaughnessy } \\
\text { et al. (2002) }\end{array}$ & $\begin{array}{l}\text { MMD: } 11 \text { (winter) to } 14 \\
\mu \mathrm{m} \text { (fall) }\end{array}$ & Finisher; MV & Iowa & $\begin{array}{l}\text { Respirable particles } \\
\text { accounted for } 25 \% \text { of the } \\
\text { mass of total particles. }\end{array}$ \\
\hline $\begin{array}{l}\text { Wang et al. } \\
(2002)^{3}\end{array}$ & $\begin{array}{l}\text { Before oil sprinkling - } \\
\text { NMD: } 4.82 \mu \mathrm{m} \\
\text { GSD: } 1.38 \\
\text { After oil sprinkling - } \\
\text { NMD: } 1.76 \mu \mathrm{m} \\
\text { GSD: } 2.04\end{array}$ & Finisher; MV & Illinois & - \\
\hline \multirow[t]{3}{*}{$\begin{array}{l}\text { Predicala and } \\
\text { Maghirang } \\
\text { (2003) }\end{array}$} & $\begin{array}{l}\text { GMD: } 16.7 \mu \mathrm{m} \\
\text { GSD: } 2.3\end{array}$ & Nursery; MV & \multirow[t]{3}{*}{ Kansas } & \multirow[t]{3}{*}{$\begin{array}{l}\text { Different barns shared a } \\
\text { similar particle size } \\
\text { distribution. }\end{array}$} \\
\hline & $\begin{array}{l}\text { GMD: } 15.7 \mu \mathrm{m} \\
\text { GSD: } 2.2\end{array}$ & $\begin{array}{l}\text { Experimental } \\
\text { finisher; MV }\end{array}$ & & \\
\hline & $\begin{array}{l}\text { GMD: } 17.4 \mu \mathrm{m} \\
\text { GSD: } 2.1\end{array}$ & $\begin{array}{l}\text { Commerical } \\
\text { finisher; MV }\end{array}$ & & \\
\hline $\begin{array}{l}\text { Agranovski et } \\
\text { al. (2004) }\end{array}$ & $\begin{array}{l}\text { Total particles- } \\
\text { NMD: } 2.23 \mu \mathrm{m} \\
\text { Viable particles - } \\
\text { NMD: } 2.79 \mu \mathrm{m} \\
\text { Non-viable particles - } \\
\text { NMD: } 1.15 \mu \mathrm{m}\end{array}$ & Grower; NV & Australia & $\begin{array}{l}\text { Around } 95 \% \text { of particles } \\
\text { by number were smaller } \\
\text { than } 7 \mu \mathrm{m} ; \sim 60 \% \text { of } \\
\text { particles by number were } \\
\text { smaller than } 2.5 \mu \mathrm{m} \text {. }\end{array}$ \\
\hline $\begin{array}{l}\text { Predicala and } \\
\text { Maghirang } \\
\text { (2004) }\end{array}$ & $\begin{array}{l}\text { GMD: } 14.0-17.0 \mu \mathrm{m} \\
\text { GSD: } 2.0-2.6\end{array}$ & Finisher; MV & Kansas & - \\
\hline $\begin{array}{l}\text { Jerez et al. } \\
(2008)\end{array}$ & $\begin{array}{l}\text { Winter- } \\
\text { MMD: } 20.33-21.87 \mu \mathrm{m} \\
\text { GSD: } 1.46-1.52 \\
\text { Summer - } \\
\text { MMD: } 30.79-32.21 \mu \mathrm{m} \\
\text { GSD: } 1.83-1.89\end{array}$ & $\begin{array}{l}\text { Wean-to-finish; } \\
\text { MV }\end{array}$ & Illinois & - \\
\hline
\end{tabular}




\begin{tabular}{|c|c|c|c|c|}
\hline \multirow[t]{3}{*}{$\begin{array}{l}\text { Lee et al. } \\
\text { (2008) }\end{array}$} & $\begin{array}{l}\text { Horiba LA-300- } \\
\text { MMD: } 24.3-24.1 \mu \mathrm{m} \\
\text { GSD: } 2.8-3.4 \\
\text { Coulter counter - } \\
\text { MMD: } 9.8-10.1 \mu \mathrm{m} \\
\text { GSD: } 2.1-2.4 \\
\text { Malvern Mastersizer- } \\
\text { MMD: } 12.1-13.4 \mu \mathrm{m} \\
\text { GSD: } 2.6-3.1 \\
\text { DSP - } \\
\text { MMD: } 9.1-9.8 \mu \mathrm{m} \\
\text { GSD: } 1.8\end{array}$ & Farrowing; MV & Illinois & - \\
\hline & $\begin{array}{l}\text { Horiba LA-300- } \\
\text { MMD: } 22.2-24.5 \mu \mathrm{m} \\
\text { GSD: } 2.2-2.9 \\
\text { Coulter counter - } \\
\text { MMD: } 9.5-12.8 \mu \mathrm{m} \\
\text { GSD: } 2.2-2.3 \\
\text { Malvern Mastersizer- } \\
\text { MMD: } 11.2-17.3 \mu \mathrm{m} \\
\text { GSD: } 2.7-3.2 \\
\text { DSP - } \\
\text { MMD: } 8.5-12.1 \mu \mathrm{m} \\
\text { GSD: } 1.6-1.8\end{array}$ & Gestation; MV & & - \\
\hline & $\begin{array}{l}\text { Horiba LA-300- } \\
\text { MMD: } 19.2-20.7 \mu \mathrm{m} \\
\text { GSD: } 2.7-2.9 \\
\text { Coulter counter- } \\
\text { MMD: 16.1-16.5 } \mu \mathrm{m} \\
\text { GSD: } 1.7-1.8 \\
\text { Malvern Mastersizer-- } \\
\text { MMD: 18.4-19.6 } \mu \mathrm{m} \\
\text { GSD: } 2.3-2.4 \\
\text { DSP - } \\
\text { MMD: } 10.7-13.4 \mu \mathrm{m} \\
\text { GSD: } 1.4-1.6\end{array}$ & $\begin{array}{l}\text { Wean-to-finish; } \\
\text { MV }\end{array}$ & & - \\
\hline $\begin{array}{l}\text { Martin et al. } \\
(2008)\end{array}$ & $\begin{array}{l}\text { Mass mode } \\
\text { diameter: }>10 \mu \mathrm{m}\end{array}$ & Finisher; MV & Iowa & - \\
\hline $\begin{array}{l}\text { Jerez et al. } \\
\text { (2011a) }\end{array}$ & $\begin{array}{l}\text { Coulter Counter - } \\
\text { MMD: } 22.63 \mu \mathrm{m} \\
\text { GSD: } 1.58\end{array}$ & $\begin{array}{l}\text { Wean-to-finish; } \\
\text { MV }\end{array}$ & Illinois & $\begin{array}{l}>90 \% \text { of particles by } \\
\text { mass were larger than } 10 \\
\mu \mathrm{m} .\end{array}$ \\
\hline
\end{tabular}




\begin{tabular}{|c|c|c|c|c|}
\hline & $\begin{array}{l}\text { Horiba LA-300 (all size } \\
\text { channels) - } \\
\text { MMD: } 32.23 \mu \mathrm{m} \\
\text { GSD: } 1.89 \\
\text { Horiba LA-300 } \\
\text { (only } 3-60 \mu \mathrm{m} \\
\text { considered) - } \\
\text { MMD: } 27.31 \mu \mathrm{m} \\
\text { GSD: } 1.92\end{array}$ & & & \\
\hline $\begin{array}{l}\text { Siggers et al. } \\
\text { (2011) }\end{array}$ & $\begin{array}{l}\text { Before oil sprinkling- } \\
\text { Mass mode diameter: } \\
9.0-10 \mu \mathrm{m} \\
\text { After oil sprinkling-- } \\
\text { Mass mode diameter: } \\
9.0-10 \mu \mathrm{m}\end{array}$ & $\begin{array}{l}\text { Grower-finisher; } \\
\text { MV }\end{array}$ & $\begin{array}{l}\text { Saskatchewan, } \\
\text { Canada }\end{array}$ & - \\
\hline $\begin{array}{l}\text { O'Shaughnessy } \\
\text { et al. (2012) }\end{array}$ & $\begin{array}{l}\text { MMD: } 5.6 \mu \mathrm{m} \\
\text { GSD: } 2.2\end{array}$ & Finisher; MV & Iowa & $\begin{array}{l}\text { Particle size distributions } \\
\text { during load-out and } \\
\text { power washing were } \\
\text { measured. }\end{array}$ \\
\hline $\begin{array}{l}\text { Van Ransbeeck } \\
\text { et al. (2013) }\end{array}$ & $\begin{array}{l}\text { Mass mode diameter: } \\
5.0-6.5 \mu \mathrm{m}\end{array}$ & $\begin{array}{l}\text { Finisher, MV } \\
\text { (chimney) }\end{array}$ & Belgium & $\begin{array}{l}\text { A bimodal distribution } \\
\text { was noted, with a minor } \\
\text { peak in the submicron } \\
\text { range. }\end{array}$ \\
\hline $\begin{array}{l}\text { Viegas et al. } \\
(2013)\end{array}$ & $\begin{array}{l}\text { Mass mode diameter: } \\
2.5-5.0 \mu \mathrm{m}\end{array}$ & $\begin{array}{l}\text { Complex } \\
\text { (farrowing, } \\
\text { gestation, nursery, } \\
\text { finisher); n/a }\end{array}$ & Portugal & $\begin{array}{l}\text { Particle size was the } \\
\text { smallest in nursery barns. }\end{array}$ \\
\hline $\begin{array}{l}\text { De Jong et al. } \\
\text { (2014) }\end{array}$ & $\begin{array}{l}\text { Control - } \\
\text { Number mode diameter: } \\
0.3-0.5 \mu \mathrm{m} \\
\\
\text { Treatment (ionization } \\
\text { dedusting) - } \\
\text { Number mode diameter: } \\
0.3-0.5 \mu \mathrm{m}\end{array}$ & Nursery; n/a & Kansas & - \\
\hline \multirow[t]{3}{*}{ Lai et al. (2014) } & $\begin{array}{l}\text { MMD: } 10.67-10.86 \mu \mathrm{m} \\
\text { NMD: } 0.33-0.36 \mu \mathrm{m}\end{array}$ & $\begin{array}{l}\text { Sow; MV } \\
\text { (chimney) }\end{array}$ & \multirow[t]{3}{*}{$\begin{array}{l}\text { The } \\
\text { Netherlands }\end{array}$} & \multirow{3}{*}{$\begin{array}{l}\text { Particle size was } \\
\text { measured for } 60 \text { minutes } \\
\text { per barn; No GSD } \\
\text { calculation was } \\
\text { conducted. }\end{array}$} \\
\hline & $\begin{array}{l}\text { MMD: } 9.29 \mu \mathrm{m} \\
\text { NMD: } 0.49 \mu \mathrm{m}\end{array}$ & $\begin{array}{l}\text { Nursery; MV } \\
\text { (chimney) }\end{array}$ & & \\
\hline & $\begin{array}{l}\text { MMD: } 10.26-10.39 \mu \mathrm{m} \\
\text { NMD: } 0.38-0.43 \mu \mathrm{m}\end{array}$ & $\begin{array}{l}\text { Finisher; MV } \\
\text { (chimney) }\end{array}$ & & \\
\hline \multirow[t]{2}{*}{$\begin{array}{l}\text { Yang et al. } \\
(2015)\end{array}$} & $\begin{array}{l}\text { MMD: } 15.7 \pm 1.0 \mu \mathrm{m} \\
\text { GSD: } 2.32 \pm 0.34\end{array}$ & $\begin{array}{l}\text { Wean-to-finish; } \\
\text { MV }\end{array}$ & \multirow[t]{2}{*}{ Illinois } & \multirow{2}{*}{$\begin{array}{l}\mathrm{PM}_{10} \text { accounted for } 20- \\
21 \% \text { of total particles by } \\
\text { mass while } \mathrm{PM}_{2.5} \\
\text { accounted for } 5-6 \% \text {; } \\
\text { particle size was larger in } \\
\text { summer than winter; A }\end{array}$} \\
\hline & $\begin{array}{l}\text { MMD: } 18.0 \pm 1.1 \mu \mathrm{m} \\
\text { GSD: } 2.22 \pm 0.25\end{array}$ & Farrowing; MV & & \\
\hline
\end{tabular}




\begin{tabular}{|c|c|c|c|c|}
\hline & $\begin{array}{l}\text { MMD: } 19.3 \pm 2.7 \mu \mathrm{m} \\
\text { GSD: } 2.28 \pm 0.22\end{array}$ & Gestation; MV & & $\begin{array}{l}\text { bimodal distribution was } \\
\text { occasionally seen. }\end{array}$ \\
\hline $\begin{array}{l}\text { Ulens et al. } \\
(2016)\end{array}$ & $\begin{array}{l}\text { MMD: } 10.73-12.18 \mu \mathrm{m} \\
\text { GSD: }>1.22\end{array}$ & Finisher; MV & Belgium & $\begin{array}{l}\text { No differences were seen } \\
\text { between different housing } \\
\text { systems (conventional } \\
\text { versus low } \mathrm{NH}_{3} \text { emission) } \\
\text { and two cleaning } \\
\text { protocols (dry versus } \\
\text { wet). }\end{array}$ \\
\hline $\begin{array}{l}\text { Naide et al. } \\
(2018)\end{array}$ & $\begin{array}{l}\text { No size statistics } \\
\text { presented }\end{array}$ & $\begin{array}{l}\text { Nursery; MV \& } \\
\text { NV }\end{array}$ & Japan & $\begin{array}{l}\text { The highest particle } \\
\text { number occurred in the } \\
\text { size range of } 0.3-0.5 \mu \mathrm{m} \text {. }\end{array}$ \\
\hline Dai et al. (2019) & $\begin{array}{l}\text { No size statistics } \\
\text { presented. }\end{array}$ & Nursery; NV & China & $\begin{array}{l}>50 \% \text { of particles by } \\
\text { mass were larger than } 10 \\
\mu \mathrm{m} .\end{array}$ \\
\hline
\end{tabular}

Note:

${ }^{1} \mathrm{MV}$ - mechanical ventilation; NV - natural ventilation.

${ }^{2} \mathrm{MMD}$ - mass median diameter; GMD - geometric mean diameter; NMD - number median diameter ( $50 \%$ of particles by number have a diameter smaller than NMD).

${ }^{3}$ The value was calculated from the measurement data given in the publication.

Upon the analysis of existing publications, the following generalizations are made:

- A large portion of particles by mass have diameters larger than $10 \mu \mathrm{m}$ in swine barns. The reported MMD values ranged from 5.6 (O'Shaughnessy et al., 2002) to $32.23 \mu \mathrm{m}$ (Jerez et al., 2011a). Among twelve studies with MMD results available, nine of them reported an average MMD value greater than $10 \mu \mathrm{m}$. This indicates that $\mathrm{PM}_{10}$ accounts for only $<50 \%$ of total $\mathrm{PM}$ mass concentrations in many swine barns.

- Although their mass contribution is minor, small particles are predominant in terms of particle counts (numbers). The reported NMD values ranged from 0.33 (Lai et al., 2014) to $4.82 \mu \mathrm{m}$ (Wang et al., 2002), smaller than their corresponding MMD values. Particle counts tend to decrease with size, with the highest counts observed for submicron particles (Bundy, 1974; Zhang et al., 1994; Agranovski et al., 2004; Van Ransbeeck et al., 2013; Lai et al., 2014).

- Particle size tends to be overall smaller in winter than in warm seasons (O'Shaughnessy et al., 2002; Jerez et al., 2008; Yang et al., 2015). This is likely because swine barns run at a minimum ventilation rate in winter (Yang et al., 2015). The minimum ventilation rate results in calm air in barns, which encourages the gravitational settling of large particles. Conversely, an elevated ventilation rate results in a high air velocity, thereby enhancing the suspension and resuspension of large particles (Noble et al., 1963; Yang et al., 2015).

- Particle size tends to be greater in sow (e.g., farrowing and gestation) barns than other barn types. Viegas et al. (2013) surveyed four types of barns (farrowing, gestation, nursery, and finisher) and found that the smallest particle size occurred in nursery barns. A similar observation was reported by Lai et al. (2014). Both studies were done in Europe. A field campaign in Illinois revealed that particle size was smaller in wean-to-finish barns than farrowing and gestation barns (Lee et al., 2008; Yang et al., 2015). No dedicated nursery barns were visited in the campaign.

- The mass PSDs in swine barns occasionally show a bimodal distribution, i.e., with a major peak in the large size range $(5-20 \mu \mathrm{m})$ and a minor peak in the submicron range $(<0.5 \mu \mathrm{m})$ (Sheneider et al., 2001; Van Ransbeeck et al., 2013; Yang et al., 2015). The minor peak was considered to originate from the atmospheric PM that entered a barn through the barn's air inlet (Zhang et al., 1994; Van Ransbeeck et al., 2013). These ultrafine particles (with aerodynamic diameters $<0.5$ 
$\mu \mathrm{m})$ were designated as "diminutive dust" for air quality management in swine barns (Zhang et al., 1994; Tanaka and Zhang, 1996; Senthilselvan et al., 1997; Dosman et al., 2000).

Different PSD analyzers result in different measurement results. The measured MMD and GSD values differed with selected instruments even after a rigorous calibration and validation process (Lee et al., 2008; Jerez et al., 2011a; Yang et al., 2012). This is related to the detection principles, assumptions, and experimental procedures adopted by different PSD analyzers (Refer to Section 4.2). The qualitative conclusions however remained largely the same regardless of the selected instruments.

The acquired PSDs were primarily used to estimate the mass fractions or concentrations of PM within a certain size range (e.g., $\mathrm{PM}_{10}, \mathrm{PM}_{2.5}$, respirable, and inhalable). Further utilization of the PSD data may include the development and validation of PM mitigation technologies, respiratory health-exposure modeling for pigs and humans (Kelly et al., 2011), and source apportionment of PM in swine barns. PSDs have been used for source apportionment of atmospheric PM through receptor modeling (Yue et al., 2008; $\mathrm{Vu}$ et al., 2015). Since large and small particles in swine barns originate from different sources (Donham et al., 1986; Heber et al., 2008), the same methodology could apply to PM in swine barns as well.

\subsubsection{Morphology and density}

PM size fractions (e.g., $\mathrm{PM}_{10}$ and respirable $\mathrm{PM}$ ) are defined and regulated based on the aerodynamic diameter of particles. The aerodynamic diameter also dictates the removal of a particle in aerodynamic dedusters such as cyclones and impactors (Cooper and Alley, 2010). For a nonspherical particle in the environment (including swine barns), its aerodynamic diameter is related to not only the equivalent volume diameter but also the morphology and density of the particle (Eq. 2) (Zhang, 2005).

where, $\mathrm{d}_{\mathrm{a}}=$ aerodynamic diameter $(\mathrm{m})$

$$
d_{a}=d_{e}\left(\frac{C_{c e} \rho_{p}}{C_{c a} \rho_{0} \chi}\right)^{2}
$$

$\mathrm{d}_{\mathrm{e}}=$ equivalent volume diameter $(\mathrm{m})$

$\mathrm{C}_{\mathrm{ce}}=$ slip corrector factor for $\mathrm{d}_{\mathrm{e}}$ (dimensionless)

$\mathrm{C}_{\mathrm{ca}}=$ slip corrector factor for $\mathrm{d}_{\mathrm{a}}$ (dimensionless)

$\rho_{\mathrm{p}}=$ particle density $\left(\mathrm{kg} \mathrm{m}^{-3}\right)$

$\rho_{0}=$ unit density $\left(1000 \mathrm{~kg} \mathrm{~m}^{-3}\right)$

$\chi=$ shape factor (dimensionless), a measure of PM morphology

Morphology and density also affect the optical properties of particles and accordingly the response of optical PM monitors (Molenar, 2000), as well as the performance of non-aerodynamic dedusters such as baghouses and wet scrubbers (Cooper and Alley, 2010).

\section{Morphology}

Only a few studies examined the morphology of PM in swine barns. Heber et al. (1988a) measured the morphology of PM from 11 finisher barns using scanning electron microscopy (SEM). Starch granules, grain meal, and skin particles were identified based on their shape and size. The unidentified particles were classified into irregular, rounded, and cylindrical particles. Cambra-López et al. (2011a) used a highresolution SEM, in coupling with FETEX 2.0 image analysis software, to determine the morphology of PM in four types of swine barns in the Netherlands. They found large, fattened skin particles, and layered manure particles in nursery and grower-finisher barns, and large, folded skin particles in gilt and gestation barns. Mostafa et al. (2016) calculated the shape factors of PM in a swine production complex (housing sows, piglets, and grower-finishers) in Germany through optical microscope image analysis. The derived shape factors (1.28 \pm 0.23 ; range: 1.07-1.60) increased with particle size. Shen et al. (2019) analyzed the morphology of $\mathrm{PM}_{2.5}$ in a high-rise nursery barn and a high-rise finisher barn in China, using a field emission SEM. They reported a mixture of roughly spherical and irregularly shaped particles in the nursery barn; while in the finisher barn, $\mathrm{PM}_{2.5}$ was composed of strip-, rod-, and bar-shaped particles with 
loose, smooth surfaces. Several additional studies also used microscopes to image PM sampled from the inside of swine barns, e.g., Donham et al., (1986) and Schneider et al. (2001). However, no morphology analysis results were reported from the acquired PM images.

Density

PM density here refers to the true density of particle material, to distinguish it from the bulk of particles. Density is a key factor affecting the aerodynamic behavior of PM (Zhang, 2005). It is required for conversions between equivalent volume diameters and aerodynamic diameters and between number PSDs and mass PSDs (Almuhanna, 2007).

Only a few publications reported the density of PM in swine barns. All of them but one (Mostafa et al., 2016) used a gas pycnometry method. The method uses settled dust as a surrogate for PM for density determination. Puma et al. (1999) measured PM density in a simulated swine barn and reported an average PM density of $1,600 \mathrm{~kg} \mathrm{~m}^{-3}$. Almuhanna (2007) characterized PM sampled from a finisher barn in Kansas and found an average density of $1,840 \mathrm{~kg} \mathrm{~m}^{-3}$. Jerez (2007) measured the density of settled dust in a mechanically ventilated finisher barn in Illinois and reported an average density of $1,450 \mathrm{~kg} \mathrm{~m}^{-3}$. A slightly higher value $\left(1,580 \mathrm{~kg} \mathrm{~m}^{-3}\right)$ was reported by Lee and Zhang (2008) in efforts to characterize the $\mathrm{NH}_{3}$ emission potency of swine barn PM. Again in Illinois, a PM monitoring campaign was conducted in nine swine barns (Lee, 2009; Yang et al., 2015). The measured density values ranged from 1,460 to 2,000 $\mathrm{kg} \mathrm{m}^{-3}$ (average: $1,640 \mathrm{~kg} \mathrm{~m}^{-3}$ ), with the highest one $\left(1,750 \pm 150 \mathrm{~kg} \mathrm{~m}^{-3}\right)$ found in farrowing barns and the lowest $\left(1,580 \pm 100 \mathrm{~kg} \mathrm{~m}^{-3}\right)$ in gestation barns. The highest PM density in farrowing barns coincided with that farrowing barn PM had the greatest mineral contents (Yang et al., 2011). Significant seasonality was noted, with the highest PM density occurring in summer and the lowest in winter (Yang et al., 2015). Mostafa et al. (2016) collected PM samples from the inside of a swine production complex in Germany and measured PM density over six size channels (4.0-5.0, 5.0-7.5, 7.5-10, 10-15, 15-20, and >20 $\mu \mathrm{m})$ using an indirect method. A density value of $2,025 \pm 478 \mathrm{~kg} \mathrm{~m}^{-3}$ was reported.

Caution should be taken when interpreting the density data derived from gas pycnometry. The measurement assumes that PM and settled dust share the same density and that PM density remains constant regardless of particle size. However, compared to PM, settled dust contained more large particles because of their greater settling velocities (Barber et al., 1991). Large and small particles in swine barns originated from different sources (Heber et al., 1998; Cambra-López et al., 2011b) and, thus, could differ in density. Another counter evidence was given by Mostafa et al. (2016) who observed PM density to be size-dependent in swine barns; however, only a single data set (with no replicates) was taken in the study. Similar to pycnometry, the indirect method involves several major assumptions. As a result, the acquired size-segregated density data could carry large uncertainties.

The PM density values reported in the literature ranged from 1,400 to $2,100 \mathrm{~kg} \mathrm{~m}^{-3}$. In comparison, the densities of starch and proteins are $\sim 1,500$ and $\sim 1,350 \mathrm{~kg} \mathrm{~m}^{-3}$, respectively; and the density of limestone (a common mineral additive in swine feed) is $\sim 2,700 \mathrm{~kg} \mathrm{~m}^{-3}$. This suggests that PM in swine barns is chemically a blend of organics and minerals. For future studies, a PM density value of $1,650 \mathrm{~kg} \mathrm{~m}^{-3}$ is recommended when no field measurement data is available.

\subsection{Bioaerosols}

\subsubsection{Bacterial and fungal counts}

Bioaerosols in swine barns are highly complex in terms of composition, size, source, and health effect. As a result, no single universal measure of bioaerosols exists. Among various measures, airborne bacterial and fungal counts have been most widely used for assessing bioaerosol contamination levels. The counts can be selective of a specific microbial species (or group) or non-selective of general bacteria or fungi, depending on measurement methodology. Also depending on the methodology, the counts can be of viable, culturable, or total bacteria/fungi, with their definitions given below (Oliver, 2005): 
- Viable bacteria/fungi refer to living bacterial/fungal cells. These microbes are of particular interest because of their continued growth and reproduction in the environment;

- Culturable bacteria/fungi are a subset of viable bacteria/fungi that can be cultivated with certain growth media under certain environmental conditions;

- Total bacteria/fungi are a collection of viable and non-viable (i.e., dead) bacteria/fungi.

Although viable counts are desired, only a few publications reported true viable counts because they are difficult to measure. Interchangeable use of the terms 'viable counts' and 'culturable counts' is frequently seen in the literature, despite their different meanings. As of today, culturable/viable counts are the most prevalent bioaerosol concentration measure, followed by total counts.

It is noteworthy that viable microbes are not the sole contributor to bioaerosol-related environmental and health effects. Agents such as allergens, endotoxins, and $(1 \rightarrow 3)-\beta$-D-glucan from dead bacterial or fungal cells are also known for their health effect (Douwes, et al., 2003). Relevant information is available in Section 3.2.5.

\section{Culturable bacterial and fungal counts}

Culturable bacteria/fungi account for only a small portion of total populations (Vieira and Ely, 2005; Kristiansen et al., 2012; Salazar-Cerezo., 2018). However, their counts can still reach extremely high levels in swine barns (Table 5). This is anticipated because of high PM concentrations in swine barns and the PM's biological origins. Culturable counts are highly method dependent. Under the umbrella of culturable methods, various experimental protocols were adopted in the literature, differing in samplers, growth media, cultivation conditions, enumeration methods, etc. A protocol can significantly affect the measurement results and caution must be taken when comparing the results from different studies.

Table 5. Culturable bacterial and fungal counts in swine barns - a summary of studies since 1990.

\begin{tabular}{|c|c|c|c|c|}
\hline References & Culturable counts $\left(\mathrm{CFU} \mathrm{m} \mathrm{m}^{-3}\right)$ & $\begin{array}{l}\text { Barn \& } \\
\text { ventilation } \\
\text { type }^{1}\end{array}$ & Location & Season \\
\hline \multirow[t]{3}{*}{$\begin{array}{l}\text { Cormier et al. } \\
\text { (1990) }\end{array}$} & $\begin{array}{l}\text { Unit A - } \\
\text { Median bacteria: } 1.51 \times 10^{5} \\
\text { Median fungi: } 150 \\
\text { Median Gram-negative bacteria: } 80 \\
\text { Median Aspergillus sp.: } 0 \\
\text { Median respirable bacteria: } 8.1 \times 10^{4} \\
\text { Median respirable fungi: } 52 \\
\text { Median respirable Gram-negative bacteria: } 11 \\
\text { Median respirable Aspergillus sp.: } 2\end{array}$ & \multirow[t]{2}{*}{$\begin{array}{l}\text { Farrowing; } \\
\text { MV }\end{array}$} & \multirow[t]{3}{*}{$\begin{array}{l}\text { Quebec, } \\
\text { Canada }\end{array}$} & \multirow[t]{3}{*}{$\begin{array}{l}\text { Spring, } \\
\text { winter }\end{array}$} \\
\hline & $\begin{array}{l}\text { Unit } \mathrm{C}- \\
\text { Median bacteria: } 1.83 \times 10^{5} \\
\text { Median fungi: } 60 \\
\text { Median Gram-negative bacteria: } 80 \\
\text { Median Aspergillus sp.: } 0 \\
\text { Median respirable bacteria: } 8.63 \times 10^{4} \\
\text { Median respirable fungi: } 22 \\
\text { Median respirable Gram-negative bacteria: } 11 \\
\text { Median respirable Aspergillus sp.: } 2\end{array}$ & & & \\
\hline & $\begin{array}{l}\text { Unit B - } \\
\text { Median bacteria: } 4.92 \times 10^{5} \\
\text { Median fungi: } 190\end{array}$ & $\begin{array}{l}\text { Finisher; } \\
\text { MV }\end{array}$ & & \\
\hline
\end{tabular}




\begin{tabular}{|c|c|c|c|c|}
\hline & $\begin{array}{l}\text { Median Gram-negative bacteria: } 140 \\
\text { Median Aspergillus sp.: } 40 \\
\text { Median respirable bacteria: } 1.68 \times 10^{5} \\
\text { Median respirable fungi: } 34 \\
\text { Median respirable Gram-negative bacteria: } 25 \\
\text { Median respirable Aspergillus sp.: } 16\end{array}$ & & & \\
\hline & $\begin{array}{l}\text { Unit D - } \\
\text { Median bacteria: } 5.44 \times 10^{5} \\
\text { Median fungi: } 220 \\
\text { Median Gram-negative bacteria: } 180 \\
\text { Median Aspergillus sp.: } 10 \\
\text { Median respirable bacteria: } 2.05 \times 10^{5} \\
\text { Median respirable fungi: } 25 \\
\text { Median respirable Gram-negative bacteria: } 22 \\
\text { Median respirable Aspergillus } \mathrm{sp} .: 2\end{array}$ & & & \\
\hline $\begin{array}{l}\text { Butera et al. } \\
\text { (1991) }\end{array}$ & $\begin{array}{l}\text { Unit 1- } \\
\text { Bacteria: }(4.14 \pm 1.50) \times 10^{5} \\
\text { Fungi: }(1.53 \pm 2.02) \times 10^{5} \\
\text { Unit } 2 \text { - } \\
\text { Bacteria: }(5.10 \pm 1.60) \times 10^{5} \\
\text { Fungi: }(1.83 \pm 0.60) \times 10^{5}\end{array}$ & $\begin{array}{l}\text { Grower; } \\
\text { MV }\end{array}$ & $\begin{array}{l}\text { Ontario, } \\
\text { Canada }\end{array}$ & $\mathrm{n} / \mathrm{a}$ \\
\hline $\begin{array}{l}\text { Crook et al. } \\
(1991)\end{array}$ & $\begin{array}{l}\text { Mean microbes: } 2 \times 10^{5}-6 \times 10^{6} \\
\text { Mean fungi: } 2 \times 10^{3}-1 \times 10^{5}\end{array}$ & $\begin{array}{l}\text { Finisher; } \\
\text { n/a }\end{array}$ & Scotland & $\mathrm{n} / \mathrm{a}$ \\
\hline $\begin{array}{l}\text { Heederik et al. } \\
\text { (1991) }\end{array}$ & $\begin{array}{l}\text { Mean microbes: } 1.1 \times 10^{5} \\
\text { Mean Gram-negative bacteria: } 7.7 \times 10^{3}\end{array}$ & $\mathrm{n} / \mathrm{a}, \mathrm{n} / \mathrm{a}$ & $\begin{array}{l}\text { The } \\
\text { Netherlands }\end{array}$ & $\mathrm{n} / \mathrm{a}$ \\
\hline $\begin{array}{l}\text { Thorne et al. } \\
\text { (1992) }\end{array}$ & $\begin{array}{l}\text { Nuclepore filter }- \\
\text { Mean bacteria: } 7.78 \times 10^{4} \\
\text { Mean fungi: } 5.85 \times 10^{3} \\
\text { Anderson 6-stage viable cascade impactor - } \\
\text { Mean bacteria: } 7.32 \times 10^{4} \\
\text { Mean fungi: } 1.97 \times 10^{3} \\
\text { AGI impinger - } \\
\text { Mean bacteria: } 9.64 \times 10^{4} \\
\text { Mean fungi: } 5.38 \times 10^{3}\end{array}$ & $\begin{array}{l}\text { Farrowing, } \\
\text { nursery- } \\
\text { grower, } \\
\text { finisher; } \\
\text { n/a }\end{array}$ & $\begin{array}{l}\text { US } \\
\text { Midwest }\end{array}$ & $\begin{array}{l}\text { Fall, } \\
\text { winter }\end{array}$ \\
\hline \multirow[t]{2}{*}{$\begin{array}{l}\text { Dutkiewicz et al. } \\
\text { (1994) }\end{array}$} & $\begin{array}{l}\text { Mean fungi: } 1.3-7.4 \\
\text { Mean mesophilic bacteria: } 1.12 \times 10^{3}-1.24 \times 10^{3} \\
\text { Mean Gram-negative bacteria: } 10.0-36.1 \\
\text { Mean thermophilic Actinomycetes: } 0.4-7.3\end{array}$ & $\begin{array}{l}\text { Farrowing } \\
\text { (3 farms); } \\
\text { n/a }\end{array}$ & \multirow[t]{2}{*}{ Poland } & $\mathrm{n} / \mathrm{a}$ \\
\hline & $\begin{array}{l}\text { Mean fungi: } 1.7-31.2 \\
\text { Mean mesophilic bacteria: } 569-1481 \\
\text { Mean Gram-negative bacteria: } 13.4-35.8 \\
\text { Mean thermophilic Actinomycetes: } 0.2-1.4\end{array}$ & $\begin{array}{l}\text { Finisher (2 } \\
\text { farms); n/a }\end{array}$ & & $\mathrm{n} / \mathrm{a}$ \\
\hline
\end{tabular}




\begin{tabular}{|c|c|c|c|c|}
\hline \multirow[t]{2}{*}{ Lau et al. (1996) } & $\begin{array}{l}\text { Control - } \\
\text { Bacteria: } 1.3 \times 10^{5}-5.2 \times 10^{5} \\
\text { Recirculating fabric filter }- \\
\text { Bacteria: } 1.1 \times 10^{5}-2.7 \times 10^{5}\end{array}$ & $\begin{array}{l}\text { Grower; } \\
\text { MV }\end{array}$ & \multirow[t]{2}{*}{$\begin{array}{l}\text { British } \\
\text { Columbia, } \\
\text { Canada }\end{array}$} & \multirow[t]{2}{*}{$\begin{array}{l}\text { All } \\
\text { seasons }\end{array}$} \\
\hline & $\begin{array}{l}\text { Control - } \\
\text { Bacteria: } 1.4 \times 10^{5}-4.5 \times 10^{5} \\
\text { Recirculating electrostatic filter }- \\
\text { Bacteria: } 0.8 \times 10^{5}-3.2 \times 10^{5}\end{array}$ & $\begin{array}{l}\text { Finisher; } \\
\text { MV }\end{array}$ & & \\
\hline $\begin{array}{l}\text { Mackiewicz } \\
\text { (1998) }\end{array}$ & Mean microbes: $930.6 \times 10^{3}\left(613.7-1246.7 \times 10^{3}\right)$ & $\mathrm{n} / \mathrm{a} ; \mathrm{n} / \mathrm{a}$ & Poland & $\mathrm{n} / \mathrm{a}$ \\
\hline $\begin{array}{l}\text { Duchaine et al. } \\
(2000)\end{array}$ & $\begin{array}{l}\text { Mean molds: } 883\left(557-2.86 \times 10^{3}\right) \\
\text { Mean bacteria: } 4.25 \times 10^{5}\left(1.67 \times 10^{5}-9.30 \times 10^{5}\right) \\
\text { Mean thermophilic Actinomycetes: } 29(3-94)\end{array}$ & $\begin{array}{l}\text { Finisher; } \\
\text { n/a }\end{array}$ & $\begin{array}{l}\text { Quebec, } \\
\text { Canada }\end{array}$ & $\begin{array}{l}\text { Winter, } \\
\text { summer }\end{array}$ \\
\hline \multirow[t]{5}{*}{$\begin{array}{l}\text { Chang et al. } \\
(2001 b)\end{array}$} & $\begin{array}{l}\text { Bacteria: }(4.97 \pm 4.23) \times 10^{5} \\
\text { Gram-negative bacteria: } 50 \pm 93 \\
\text { Fungi: }(3.58 \pm 5.82) \times 10^{3}\end{array}$ & $\begin{array}{l}\text { Breeding; } \\
\text { NV (open } \\
\text { air) }\end{array}$ & \multirow[t]{5}{*}{ Taiwan } & \multirow[t]{5}{*}{ Spring } \\
\hline & $\begin{array}{l}\text { Bacteria: }(1.83 \pm 1.91) \times 10^{5} \\
\text { Gram-negative bacteria: } 42 \pm 37 \\
\text { Fungi: }(3.01 \pm 1.93) \times 10^{3}\end{array}$ & $\begin{array}{l}\text { Farrowing; } \\
\text { NV (open } \\
\text { air) }\end{array}$ & & \\
\hline & $\begin{array}{l}\text { Bacteria: }(1.03 \pm 1.16) \times 10^{5} \\
\text { Gram-negative bacteria: } 44 \pm 38 \\
\text { Fungi: }(2.30 \pm 1.34) \times 10^{3}\end{array}$ & $\begin{array}{l}\text { Nursery; } \\
\text { NV (open } \\
\text { air) }\end{array}$ & & \\
\hline & $\begin{array}{l}\text { Bacteria: }(1.27 \pm 1.47) \times 10^{5} \\
\text { Gram-negative bacteria: } 75 \pm 82 \\
\text { Fungi: }(2.47 \pm 2.04) \times 10^{3}\end{array}$ & $\begin{array}{l}\text { Grower; } \\
\text { NV (open } \\
\text { air) }\end{array}$ & & \\
\hline & $\begin{array}{l}\text { Bacteria: }(0.76 \pm 1.04) \times 10^{6} \\
\text { Gram-negative bacteria: } 452 \pm 690 \\
\text { Fungi: }(2.69 \pm 2.95) \times 10^{3}\end{array}$ & $\begin{array}{l}\text { Finisher; } \\
\text { NV (open } \\
\text { air) }\end{array}$ & & \\
\hline $\begin{array}{l}\text { Predicala et al. } \\
(2002)\end{array}$ & $\begin{array}{l}\text { Filtration - } \\
\text { Staphylococcus: }(5.6 \pm 3.4) \times 10^{4} \\
\text { Respirable staphylococcus: }(6.7 \pm 3.7) \times 10^{3} \\
\text { Pseudomonas: }(0.98 \pm 1.2) \times 10^{3} \\
\text { Respirable Pseudomonas: }(3.4 \pm 4.4) \times 10^{2} \\
\text { Bacillus: }(0.50 \pm 1.3) \times 10^{4} \\
\text { Respirable Bacillus: }(6.6 \pm 9.1) \times 10^{2} \\
\text { Listeria: }(6.3 \pm 5.4) \times 10^{2} \\
\text { Respirable Listeria: }(1.1 \pm 1.2) \times 10^{2} \\
\text { Enterococcus: }(2.7 \pm 2.3) \times 10^{2} \\
\text { Respirable Enterococcus: }(1.8 \pm 4.3) \times 10^{1} \\
\text { Nocardia: }(3.3 \pm 7.2) \times 10^{2} \\
\text { Respirable Nocardia: }(0.85 \pm 1.7) \times 10^{2}\end{array}$ & $\begin{array}{l}\text { Grower- } \\
\text { finisher; } \\
\text { NV }\end{array}$ & Kansas & $\begin{array}{l}\text { Winter, } \\
\text { spring, } \\
\text { summer }\end{array}$ \\
\hline
\end{tabular}




\begin{tabular}{|c|c|c|c|c|}
\hline & 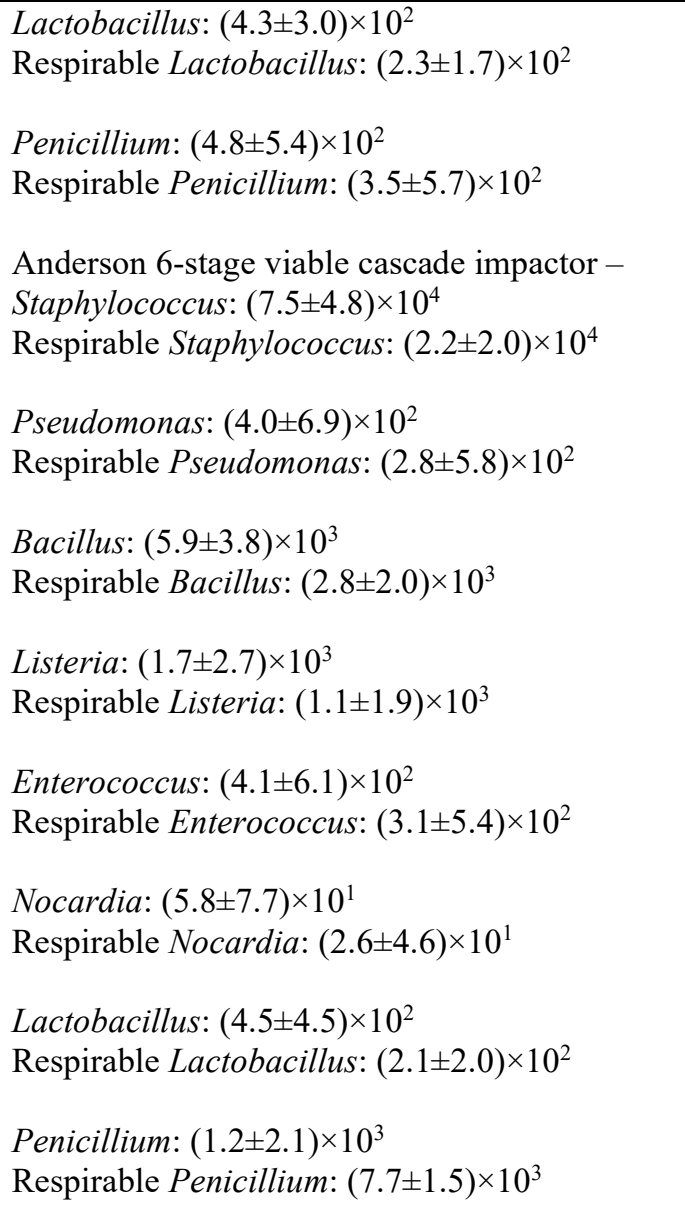 & & & \\
\hline $\begin{array}{l}\text { Radon et al. } \\
(2002)\end{array}$ & $\begin{array}{l}\text { Median fungi: } 3.8 \times 10^{5}\left(\mathrm{BDL}-4.3 \times 10^{6}\right) \\
\text { Median bacteria: } 5.8 \times 10^{6}\left(\mathrm{BDL}-1.6 \times 10^{8}\right)\end{array}$ & $\mathrm{n} / \mathrm{a} ; \mathrm{n} / \mathrm{a}$ & Denmark & $\mathrm{n} / \mathrm{a}$ \\
\hline $\begin{array}{l}\text { Agranovski et al. } \\
(2004)\end{array}$ & $\begin{array}{l}\text { AGI Impinger }- \\
\text { Bacteria: }(2.89 \pm 1.69) \times 10^{5}\left(1.12 \times 10^{5}-5.17 \times 10^{5}\right) \\
\text { Fungi: }(1.49 \pm 0.35) \times 10^{3}\left(9.83 \times 10^{2}-1.85 \times 10^{3}\right) \\
\text { Anderson 6-stage viable cascade impactor }- \\
\text { Fungi: }(18.2 \pm 6.18) \times 10^{2}\left(1.12 \times 10^{3}-2.79 \times 10^{3}\right)\end{array}$ & $\begin{array}{l}\text { Grower; } \\
\text { NV }\end{array}$ & Australia & $\mathrm{n} / \mathrm{a}$ \\
\hline $\begin{array}{l}\text { Gibbs et al. } \\
(2004)\end{array}$ & $\begin{array}{l}\text { Site A (tunnel ventilation) - } \\
\text { Respriable }(<0.8-8 \mu \mathrm{m}) \text { fungi: } 81 \pm 6.2 \\
\text { Nonrespirable }(>8 \mu \mathrm{m}) \text { fungi: } 640 \pm 320 \\
\text { Respriable bacteria: } 7,400 \pm 1,470 \\
\text { Nonrespirable bacteria: } 31,000 \pm 2,680 \\
\text { Site B (chimney ventilation) - } \\
\text { Respriable fungi: } 90 \pm 8.6 \\
\text { Nonrespirable fungi: } 160 \pm 29 \\
\text { Respriable bacteria: } 2,100 \pm 180 \\
\text { Nonrespirable bacteria: } 1,500 \pm 250\end{array}$ & $\begin{array}{l}\text { Grower- } \\
\text { finisher; } \\
\text { MV }\end{array}$ & $\begin{array}{l}\text { U.S. } \\
\text { Midwest }\end{array}$ & $\mathrm{n} / \mathrm{a}$ \\
\hline
\end{tabular}




\begin{tabular}{|c|c|c|c|c|}
\hline \multirow[t]{5}{*}{$\begin{array}{l}\text { Chi and Li } \\
(2005)\end{array}$} & $\begin{array}{l}\text { Mean bacteria: } 3.02 \times 10^{4}-2.58 \times 10^{5} \\
\text { Mean fungi: } 1.16 \times 10^{3}-1.31 \times 10^{3}\end{array}$ & $\begin{array}{l}\text { Gestation; } \\
\text { n/a }\end{array}$ & \multirow[t]{5}{*}{ Taiwan } & \multirow[t]{5}{*}{ Winter } \\
\hline & $\begin{array}{l}\text { Bacteria: }(5.38 \pm 0.65) \times 10^{4} \\
\text { Fungi: }(4.89 \pm 1.41) \times 10^{2}\end{array}$ & $\begin{array}{l}\text { Farrowing; } \\
\mathrm{n} / \mathrm{a}\end{array}$ & & \\
\hline & $\begin{array}{l}\text { Mean bacteria: } 5.95 \times 10^{4}-2.21 \times 10^{5} \\
\text { Mean fungi: } 1.21 \times 10^{3}-1.83 \times 10^{3}\end{array}$ & $\begin{array}{l}\text { Nursery; } \\
\text { n/a }\end{array}$ & & \\
\hline & $\begin{array}{l}\text { Mean bacteria: } 1.24 \times 10^{4}-3.45 \times 10^{4} \\
\text { Mean fungi: } 1.54 \times 10^{3}-1.83 \times 10^{3}\end{array}$ & $\begin{array}{l}\text { Grower; } \\
\text { n/a }\end{array}$ & & \\
\hline & $\begin{array}{l}\text { Mean bacteria: } 8.05 \times 10^{4}-1.76 \times 10^{5} \\
\text { Mean fungi: } 2.93 \times 10^{2}-1.76 \times 10^{3}\end{array}$ & $\begin{array}{l}\text { Finisher; } \\
\text { n/a }\end{array}$ & & \\
\hline $\begin{array}{l}\text { Chiivasagam and } \\
\text { Balckall (2005) }\end{array}$ & $\begin{array}{l}\text { Normal pig activity - } \\
\text { Geomean heterotrophic bacteria: } 2.2 \times 10^{5}\left(2.8 \times 10^{4}-\right. \\
\left.9.0 \times 10^{5}\right) \\
\text { Geomean } E \text {. coli: } 21(3-59) \\
\text { After flushing - } \\
\text { Geomean heterotrophic bacteria: } 2.2 \times 10^{5} \\
\text { Geomean } E \text {. coli: } 23\end{array}$ & $\begin{array}{l}\text { Grower; } \\
\text { NV }\end{array}$ & Austrilia & $\mathrm{n} / \mathrm{a}$ \\
\hline $\begin{array}{l}\text { Godbout et al. } \\
\text { (2005) }\end{array}$ & $\begin{array}{l}\text { Control - } \\
\text { Geomean bacteria: } 7.9 \times 10^{4} \\
\text { Geomean molds: } 930 \\
\text { Conventional scrapper - } \\
\text { Geomean bacteria: } 3.1 \times 10^{4} \\
\text { Geomean molds: } 950 \\
\text { V-shaped scraper - } \\
\text { Geomean bacteria: } 1.3 \times 10^{5} \\
\text { Geomean molds: } 1190 \\
\text { Daily V-shape scraper - } \\
\text { Geomean bacteria: } 5.9 \times 10^{4} \\
\text { Geomean molds: } 1070 \\
\text { Van Kempen belt - } \\
\text { Geomean bacteria: } 4.9 \times 10^{4} \\
\text { Geomean molds: } 1020 \\
\text { Cemagref net - } \\
\text { Geomean bacteria: } 4.3 \times 10^{4} \\
\text { Geomean molds: } 900\end{array}$ & $\begin{array}{l}\text { Grower- } \\
\text { finisher; } \\
\text { MV }\end{array}$ & $\begin{array}{l}\text { Quebec, } \\
\text { Canada }\end{array}$ & Summer \\
\hline $\begin{array}{l}\text { Gibbs et al. } \\
(2006)\end{array}$ & Mean bacteria: 18,132 & $\begin{array}{l}\text { Gestation; } \\
\text { MV } \\
\text { (chimney) }\end{array}$ & $\begin{array}{l}\text { U.S. } \\
\text { Midwest }\end{array}$ & Summer \\
\hline $\begin{array}{l}\text { Green et al. } \\
(2006)\end{array}$ & $\begin{array}{l}\text { Respriable }(<0.8-8 \mu \mathrm{m}) \text { bacteria: } 9,629 \pm 2,433 \\
\text { Nonrespirable }(>8 \mu \mathrm{m}) \text { bacteria: } 8,556 \pm 3,737 \\
\text { Staphylococcus aureus (S. aureus): }(1.40 \pm 0.89) \\
\times 10^{4}\end{array}$ & $\begin{array}{l}\text { Grower- } \\
\text { finisher; } \\
\text { MV }\end{array}$ & $\begin{array}{l}\text { U.S. } \\
\text { Midwest }\end{array}$ & Summer \\
\hline
\end{tabular}




\begin{tabular}{|c|c|c|c|c|}
\hline & Coliform: $(1.3 \pm 1.2) \times 10^{3}$ & & & \\
\hline Kim et al. (2006) & $\begin{array}{l}\text { Fungi: }(11.9 \pm 8.87) \times 10^{4} \\
\text { Bacteria: }(10.4 \pm 3.08) \times 10^{5}\end{array}$ & $\begin{array}{l}\text { Grower; } \\
\text { MV }\end{array}$ & $\begin{array}{l}\text { South } \\
\text { Korea }\end{array}$ & Summer \\
\hline \multirow[t]{2}{*}{$\begin{array}{l}\text { Banhazi et al. } \\
\text { (2007) }\end{array}$} & $\begin{array}{l}\text { Control - } \\
\text { Mean bacteria: } 6.7 \times 10^{4} \\
\text { Oil spraying system - } \\
\text { Mean bacteria: } 3.9 \times 10^{4}\end{array}$ & $\begin{array}{l}\text { Nursery; } \\
\text { MV }\end{array}$ & \multirow[t]{2}{*}{ Australia } & $\mathrm{n} / \mathrm{a}$ \\
\hline & $\begin{array}{l}\text { Control - } \\
\text { Mean bacteria: } 6.6 \times 10^{4} \\
\text { Oil spraying system - } \\
\text { Mean bacteria: } 1.12 \times 10^{5}\end{array}$ & $\begin{array}{l}\text { Grower; } \\
\text { NV }\end{array}$ & & $\mathrm{n} / \mathrm{a}$ \\
\hline \multirow[t]{2}{*}{ Kim et al. (2007) } & $\begin{array}{l}\text { Bacteria: } 10^{6.13 \pm 2.87} \\
\text { Fungi: } 10^{4.26 \pm 1.51} \\
\text { Gram-negative bacteria: } 10^{4.32 \pm 2.66}\end{array}$ & \multirow[t]{2}{*}{$\begin{array}{l}\text { Grower; } \\
\text { MV }\end{array}$} & \multirow[t]{2}{*}{$\begin{array}{l}\text { South } \\
\text { Korea }\end{array}$} & Summer \\
\hline & $\begin{array}{l}\text { Bacteria: } 10^{5.67 \pm 2.09} \\
\text { Fungi: } 10^{4.37 \pm 1.67} \\
\text { Gram-negative bacteria: } 10^{3.98 \pm 2.37}\end{array}$ & & & Winter \\
\hline \multirow[t]{2}{*}{ Kim et al. (2008) } & $\begin{array}{l}\text { Deep pits with slatted floor - } \\
\text { Bacteria: } 6.76 \times 10^{3}\left(17.4-6.76 \times 10^{4}\right) \\
\text { Fungi:56.2 }\left(11-7.08 \times 10^{3}\right) \\
\text { Manure scraper - } \\
\text { Bacteria: } 1.10 \times 10^{5}\left(135-2.34 \times 10^{8}\right) \\
\text { Fungi: } 1.38 \times 10^{3}\left(8.1-7.59 \times 10^{4}\right)\end{array}$ & $\begin{array}{l}\text { Grower- } \\
\text { finisher; } \\
\text { MV }\end{array}$ & \multirow[t]{2}{*}{$\begin{array}{l}\text { South } \\
\text { Korea }\end{array}$} & \multirow[t]{2}{*}{$\begin{array}{l}\text { Summer, } \\
\text { fall }\end{array}$} \\
\hline & $\begin{array}{l}\text { Deep pits with slatted floor }- \\
\text { Bacteria: } 3.31 \times 10^{2}\left(81-1.51 \times 10^{4}\right) \\
\text { Fungi: } 69.2(3.0-741) \\
\text { Manure scraper - } \\
\text { Bacteria: } 3.31 \times 10^{3}\left(14.5-2.24 \times 10^{5}\right) \\
\text { Fungi:676 }\left(17.4-4.37 \times 10^{4}\right) \\
\text { Deep litter bed system - } \\
\text { Bacteria: } 5.75 \times 10^{5}\left(372-1.81 \times 10^{10}\right) \\
\text { Fungi: } 1.38 \times 10^{5}\left(708-7.24 \times 10^{6}\right)\end{array}$ & $\begin{array}{l}\text { Grower- } \\
\text { finisher; } \\
\text { NV }\end{array}$ & & \\
\hline $\begin{array}{l}\text { Nehme et al. } \\
(2008)\end{array}$ & Mean bacteria: $1.26 \times 10^{5}$ & $\begin{array}{l}\text { Grower- } \\
\text { finisher; } \\
\text { n/a }\end{array}$ & $\begin{array}{l}\text { Quebec, } \\
\text { Canada }\end{array}$ & Winter \\
\hline $\begin{array}{l}\text { Vanhee et al. } \\
\text { (2008) }\end{array}$ & $\begin{array}{l}\text { Mean bacteria: } 4.0 \times 10^{4}-1.7 \times 10^{6} \\
\text { Mean fungi: } 5.3 \times 10^{2}-6.0 \times 10^{3}\end{array}$ & $\mathrm{n} / \mathrm{a} ; \mathrm{n} / \mathrm{a}$ & Belgium & $\mathrm{n} / \mathrm{a}$ \\
\hline Lee (2009) & Mean bacteria: $1.2 \times 10^{4}-1.6 \times 10^{4}$ & $\begin{array}{l}\text { Farrowing, } \\
\text { gestation, }\end{array}$ & Illinois & $\begin{array}{l}\text { All } \\
\text { seasons }\end{array}$ \\
\hline
\end{tabular}




\begin{tabular}{|c|c|c|c|c|}
\hline & & $\begin{array}{l}\text { Finisher; } \\
\mathrm{n} / \mathrm{a}\end{array}$ & & \\
\hline \multirow[t]{4}{*}{$\begin{array}{l}\text { Létourneau et } \\
\text { al. (2009) }\end{array}$} & $\begin{array}{l}\text { Conventional barns - } \\
\text { Mesophilic molds: }(8.65 \pm 9.36) \times 10^{2} \\
\text { Thermotolerant molds: } 24 \pm 37 \\
\text { Thermotolerant Actinomycetes: } 5 \pm 8\end{array}$ & \multirow[t]{4}{*}{$\begin{array}{l}\text { Finisher; } \\
\text { MV (17 } \\
\text { farms), NV } \\
(1 \text { farm })\end{array}$} & \multirow[t]{4}{*}{$\begin{array}{l}\text { Quebec, } \\
\text { Canada }\end{array}$} & \multirow[t]{4}{*}{ Winter } \\
\hline & $\begin{array}{l}\text { Barns with sawdust beddings - } \\
\text { Mesophilic molds: }(4.82 \pm 9.39) \times 10^{4} \\
\text { Thermotolerant molds: }(4.07 \pm 7.12) \times 10^{2} \\
\text { Mesophilic bacteria: }(1.54 \pm 0.88) \times 10^{6} \\
\text { Thermotolerant } \text { Actinomycetes: }(2.66 \pm 5.16) \times 10^{3}\end{array}$ & & & \\
\hline & $\begin{array}{l}\text { With slatted floors - } \\
\text { Mesophilic bacteria: }(1.98 \pm 2.44) \times 10^{5}\end{array}$ & & & \\
\hline & $\begin{array}{l}\text { With source separation - } \\
\text { Mesophilic bacteria: } 1.37 \times 10^{4}-1.44 \times 10^{4} \\
\text { Thermotolerant Actinomycetes: } 2 \pm 0\end{array}$ & & & \\
\hline \multirow[t]{2}{*}{$\begin{array}{l}\text { Thorne et al. } \\
\text { (2009) }\end{array}$} & $\begin{array}{l}\text { Geomean mesophilic bacteria - tryptic soy agar: } \\
1.57 \times 10^{6}\left(1.48 \times 10^{5}-1.8 \times 10^{7}\right) \\
\text { Reasoner's 2A agar: } 8.5 \times 10^{5}\left(4.18 \times 10^{4}-1.59 \times 10^{7}\right) \\
\text { Geomean fungi: } 2.83 \times 10^{4}\left(2.1 \times 10^{3}-4.28 \times 10^{5}\right)\end{array}$ & $\begin{array}{l}\text { Grower- } \\
\text { finisher; } \\
\text { NV (hoop } \\
\text { barns) }\end{array}$ & \multirow[t]{2}{*}{ Iowa } & $\begin{array}{l}\text { All } \\
\text { seasons }\end{array}$ \\
\hline & $\begin{array}{l}\text { Geomean mesophilic bacteria - Tryptic soy agar: } \\
6.31 \times 10^{4}\left(2.1 \times 10^{3}-8.24 \times 10^{5}\right) \\
\text { Reasoner's 2A agar: } 6.48 \times 10^{4}\left(2.1 \times 10^{3}-8.21 \times 10^{5}\right) \\
\text { Geomean fungi: } 2.05 \times 10^{4}\left(2.1 \times 10^{3}-2.09 \times 10^{5}\right)\end{array}$ & $\begin{array}{l}\text { Grower- } \\
\text { finisher, } \\
\text { MV }\end{array}$ & & $\begin{array}{l}\text { All } \\
\text { seasons }\end{array}$ \\
\hline Ko et al. (2010) & $\begin{array}{l}\text { Mean bacteria: } 34,399\left(161-29.4 \times 10^{5}\right) \\
\text { Mean fungi: } 1,882\left(136-5.06 \times 10^{3}\right)\end{array}$ & $\begin{array}{l}\text { Finisher, } \\
\text { farrowing, } \\
\text { nursery }(17 \\
\text { farms); } \mathrm{n} / \mathrm{a}\end{array}$ & $\begin{array}{l}\text { North } \\
\text { Carolina }\end{array}$ & $\mathrm{n} / \mathrm{a}$ \\
\hline $\begin{array}{l}\text { Létourneau et } \\
\text { al. }(2010)^{2}\end{array}$ & Enterococcus spp.: $(1.1 \pm 2.6) \times 10^{4}$ & $\begin{array}{l}\text { Grower- } \\
\text { finisher; } \\
\text { n/a }\end{array}$ & $\begin{array}{l}\text { Quebec, } \\
\text { Canada }\end{array}$ & Winter \\
\hline \multirow[t]{4}{*}{ Yao et al. (2010) } & $\begin{array}{l}\text { Bacteria: } 10^{4.15 \pm 0.31} \\
\text { Coliforms: } 10^{2.43 \pm 0.58} \\
\text { E.coli: } 10^{1.36 \pm 0.33}\end{array}$ & \multirow[t]{4}{*}{$\begin{array}{l}\text { Nursery; } \\
\text { HV }\end{array}$} & \multirow[t]{4}{*}{$\begin{array}{l}\text { South } \\
\text { Korea }\end{array}$} & Spring \\
\hline & $\begin{array}{l}\text { Bacteria: } 10^{4.30 \pm 0.35} \\
\text { Coliforms: } 10^{3.13 \pm 0.61} \\
\text { E.coli: } 10^{3.04 \pm 0.74}\end{array}$ & & & Summer \\
\hline & $\begin{array}{l}\text { Bacteria: } 10^{4.01 \pm 0.25} \\
\text { Coliforms: } 10^{2.08 \pm 0.90} \\
\text { E.coli: } 10^{1.78 \pm 0.87}\end{array}$ & & & Fall \\
\hline & $\begin{array}{l}\text { Bacteria: } 10^{2.13 \pm 0.35} \\
\text { Coliforms: } 10^{2.40 \pm 0.42} \\
\text { E.coli: } 10^{1.64 \pm 0.28}\end{array}$ & & & Winter \\
\hline
\end{tabular}




\begin{tabular}{|c|c|c|c|c|}
\hline \multirow[t]{2}{*}{$\begin{array}{l}\text { Yuan et al. } \\
\text { (2010) }\end{array}$} & $\begin{array}{l}\text { Farm A- } \\
\text { Median E.coli: } 35 \text { (13-76) }\end{array}$ & $\mathrm{n} / \mathrm{a}, \mathrm{NV}$ & \multirow[t]{2}{*}{ China } & \multirow[t]{2}{*}{$\begin{array}{l}\text { All } \\
\text { seasons }\end{array}$} \\
\hline & $\begin{array}{l}\text { Farm B - } \\
\text { Median E.coli: } 23 \text { (19-58) } \\
\text { Farm C - } \\
\text { Median E.coli: } 27 \text { (10-67) } \\
\text { Farm D - } \\
\text { Median E.coli: } 21 \text { (9-47) }\end{array}$ & $\mathrm{n} / \mathrm{a}, \mathrm{MV}$ & & \\
\hline $\begin{array}{l}\text { Keessen et al. } \\
(2011)\end{array}$ & $\begin{array}{l}\text { In all barns - } \\
\text { Clostridium difficile: } 2-625 \\
\text { In farrowing pen } 1- \\
\text { Clostridium difficile: } 135-575 \\
\text { In farrowing pen } 2 \& 3- \\
\text { Clostridium difficile: } 0-480\end{array}$ & $\begin{array}{l}\text { Farrowing, } \\
\text { gilt, boar; } \\
\text { n/a }\end{array}$ & $\begin{array}{l}\text { The } \\
\text { Netherlands }\end{array}$ & \\
\hline $\begin{array}{l}\text { Friese et al. } \\
(2012)\end{array}$ & $\begin{array}{l}\text { Impinger- } \\
\text { Geomean bacteria: } 3.1 \times 10^{5} \\
\text { Geomean MRSA }: 257 \\
\text { Geomean Staphylococcus spp: } 1.4 \times 10^{4} \\
\text { IOM dust sampler - } \\
\text { Geomean bacteria: } 2.4 \times 10^{5} \\
\text { Geomean MRSA: } 802 \\
\text { Geomean Staphylococcus spp: } 2.6 \times 10^{4}\end{array}$ & $\begin{array}{l}\text { Finisher, } \\
\text { gestation, } \\
\text { farrowing, } \\
\text { nursery; } \\
\text { n/a }\end{array}$ & Germany & $\mathrm{n} / \mathrm{a}$ \\
\hline $\begin{array}{l}\text { Schulz et al. } \\
(2012)\end{array}$ & Median MRSA: $151(6-3,619)$ & $\begin{array}{l}\text { Gestation, } \\
\text { finisher; } \\
\text { n/a }\end{array}$ & Germany & $\begin{array}{l}\text { All } \\
\text { seasons }\end{array}$ \\
\hline $\begin{array}{l}\text { Sowiak et al. } \\
\text { (2012) }\end{array}$ & $\begin{array}{l}\text { Bacteria: }(47.85 \pm 33.12) \times 10^{4} \\
\text { Fungi: }(1.55 \pm 3.03) \times 10^{4} \\
\text { Respirable bacteria: }(23.07 \pm 20.65) \times 10^{4} \\
\text { Respirable fungi: }(1.07 \pm 2.01) \times 10^{4}\end{array}$ & $\begin{array}{l}\text { Gestation, } \\
\text { finisher; } \\
\text { NV (6 } \\
\text { farms), } \\
\text { MV (7) }\end{array}$ & Poland & $\mathrm{n} / \mathrm{a}$ \\
\hline $\begin{array}{l}\text { Gongora et al. } \\
\text { (2013) }\end{array}$ & $\begin{array}{l}\text { Pretreatment - } \\
\text { MRSA: } 14 \text { (control) and } 23 \text { (treatment) } \\
\text { During treatment with Stalosan }{ }^{\circledR} \mathrm{F} \text { (a disinfectant) - } \\
\text { MRSA: } 32-274 \text { (control) and 0-215 (treatment) } \\
\text { Post-treatment - } \\
\text { MRSA: } 17-21 \text { (control) and 11-30 (treatment) }\end{array}$ & $\begin{array}{l}\text { Grower }{ }^{4} ; \\
\text { n/a }\end{array}$ & Denmark & $\mathrm{n} / \mathrm{a}$ \\
\hline $\begin{array}{l}\text { Masclaux et al. } \\
\text { (2013) }\end{array}$ & $\begin{array}{l}\text { Mean fungi: } 5.70 \times 10^{3}\left(20-5.26 \times 10^{4}\right) \\
\text { MSSA }^{5}: 1.56 \times 10^{3}\left(100-4 \times 10^{3}\right) \\
\text { Mean MRSA: } 300 \\
\text { Mean S. aureus: } 1.61 \times 10^{3}\left(100-4 \times 10^{3}\right)\end{array}$ & $\begin{array}{l}\text { Nursery, } \\
\text { farrowing, } \\
\text { finisher; } \\
\text { n/a }\end{array}$ & Switzerland & $\begin{array}{l}\text { Summer, } \\
\text { winter }\end{array}$ \\
\hline
\end{tabular}




\begin{tabular}{|c|c|c|c|c|}
\hline $\begin{array}{l}\text { Bonifait et al. } \\
(2014)\end{array}$ & Mean bacteria: $1 \times 10^{5}$ & $\begin{array}{l}\text { Grower- } \\
\text { finisher; } \\
\text { n/a }\end{array}$ & $\begin{array}{l}\text { Quebec, } \\
\text { Canada }\end{array}$ & $\mathrm{n} / \mathrm{a}$ \\
\hline $\begin{array}{l}\text { Lee and Liao } \\
(2014)\end{array}$ & $\begin{array}{l}\text { Mean fungi - } \\
>1.8 \mu \mathrm{m}: 3.0 \times 10^{3}\left(1.4 \times 10^{3}-9.0 \times 10^{3}\right) \\
1-1.8 \mu \mathrm{m}: 2.4 \times 10^{2}\left(\mathrm{BDL}-4.8 \times 10^{2}\right) \\
<1 \mu \mathrm{m}: \text { BDL }\left(\mathrm{BDL}-1.6 \times 10^{2}\right) \\
\text { total: } 3.1 \times 10^{3}\left(1.7 \times 10^{3}-9.5 \times 10^{3}\right)\end{array}$ & $\mathrm{n} / \mathrm{a} ; \mathrm{n} / \mathrm{a}$ & Taiwan & Summer \\
\hline \multirow[t]{4}{*}{$\begin{array}{l}\text { Popescu et al. } \\
\text { (2014) }\end{array}$} & $\begin{array}{l}\text { Farm A - } \\
\text { Mean mesophilic bacteria: } 5.21 \times 10^{4}-7.48 \times 10^{4} \\
\text { Mean fungi: } 0.21 \times 10^{4}-2.0 \times 10^{4} \\
\text { Mean Gram-negative bacteria: } 3.12 \times 10^{2}-3.75 \times 10^{3} \\
\text { Mean Staphylococci: } 3.36 \times 10^{3}-6.06 \times 10^{3} \\
\text { Mean Streptococci: } 3.93 \times 10^{4}-6.65 \times 10^{4}\end{array}$ & $\begin{array}{l}\text { Grower- } \\
\text { finisher; } \\
\text { HV }\end{array}$ & \multirow[t]{4}{*}{ Romania } & \multirow[t]{2}{*}{ Summer } \\
\hline & $\begin{array}{l}\text { Farm B - } \\
\text { Mean mesophilic bacteria: } 1.79 \times 10^{5}-1.86 \times 10^{5} \\
\text { Mean fungi: } 1.18 \times 10^{4}-1.53 \times 10^{4} \\
\text { Mean Gram-negative bacteria: } 2.62 \times 10^{2}-4.50 \times 10^{2} \\
\text { Mean Staphylococci: } 4.21 \times 10^{4}-5.03 \times 10^{4} \\
\text { Mean Streptococci: } 1.50 \times 10^{5}-1.60 \times 10^{5}\end{array}$ & $\begin{array}{l}\text { Grower- } \\
\text { finisher; } \\
\text { MV }\end{array}$ & & \\
\hline & $\begin{array}{l}\text { Farm A - } \\
\text { Mean mesophilic bacteria: } 3.51 \times 10^{5}-9.25 \times 10^{5} \\
\text { Mean fungi: } 0.85 \times 10^{4}-7.23 \times 10^{4} \\
\text { Mean Gram-negative bacteria: } 7.62 \times 10^{2}-8.12 \times 10^{2} \\
\text { Mean Staphylococci: } 4.43 \times 10^{4}-4.82 \times 10^{4} \\
\text { Mean Streptococci: } 1.91 \times 10^{5}-7.63 \times 10^{5}\end{array}$ & $\begin{array}{l}\text { Grower- } \\
\text { finisher; } \\
\mathrm{HV}\end{array}$ & & \multirow[t]{2}{*}{ Winter } \\
\hline & $\begin{array}{l}\text { Farm B - } \\
\text { Mean mesophilic bacteria: } 1.32 \times 10^{6}-1.56 \times 10^{6} \\
\text { Mean fungi: } 5.50 \times 10^{2}-7.12 \times 10^{2} \\
\text { Mean Gram-negative bacteria: } 7.50 \times 10^{2}-8.50 \times 10^{2} \\
\text { Mean Staphylococci: } 2.42 \times 10^{5}-2.92 \times 10^{5} \\
\text { Mean Streptococci: } 8.80 \times 10^{5}-9.18 \times 10^{5}\end{array}$ & $\begin{array}{l}\text { Grower- } \\
\text { finisher; } \\
\text { MV }\end{array}$ & & \\
\hline $\begin{array}{l}\text { Ferguson et al. } \\
(2016)^{6}\end{array}$ & $\begin{array}{l}\text { For particles }>5 \mu \mathrm{m}- \\
\text { Mean bacteria: } 363-2.32 \times 10^{4} \\
\text { Mean MRSA: } 0-825 \\
\text { For particles }<5 \mu \mathrm{m}- \\
\text { Mean bacteria: } 255-1.38 \times 10^{4} \\
\text { Mean MRSA: } 24-471\end{array}$ & $\begin{array}{l}\text { Nursery- } \\
\text { grower; n/a }\end{array}$ & $\begin{array}{l}\text { U.S. } \\
\text { Midwest }\end{array}$ & $\mathrm{n} / \mathrm{a}$ \\
\hline $\begin{array}{l}\text { Viegas et al. } \\
(2017)\end{array}$ & $\begin{array}{l}\text { Farm A: } \\
\text { Median bacteria: } 18,688 \\
\text { Mean Gram-negative bacteria: } 72 \\
\text { Median fungi: } 124 \text { (malt extract agar) } \\
\text { Median fungi: } 160 \text { (DG18 agar) } \\
\text { Farm B: } \\
\text { Median bacteria: } 13,660 \\
\text { Mean Gram-negative bacteria: } 72 \\
\text { Median fungi: } 140 \text { (malt extract agar) }\end{array}$ & $\begin{array}{l}\text { Complex } \\
\text { (gestation, } \\
\text { farrowing, } \\
\text { finisher); } \\
\text { HV }\end{array}$ & Portugal & Summer \\
\hline
\end{tabular}




\begin{tabular}{|c|c|c|c|c|}
\hline & $\begin{array}{l}\text { Median fungi: } 400 \text { (DG18 agar) } \\
\text { Farm C: } \\
\text { Median bacteria: 11,944 } \\
\text { Mean Gram-negative bacteria: } 4 \\
\text { Median fungi: } 604 \text { (malt extract agar) } \\
\text { Median fungi: } 604 \text { (DG18 agar) } \\
\text { Farm D: } \\
\text { Median bacteria: } 14,720 \\
\text { Mean Gram-negative bacteria: } 24 \\
\text { Median fungi: } 104 \text { (malt extract agar) } \\
\text { Median fungi: } 356 \text { (DG18 agar) } \\
\text { Farm E } \\
\text { Median bacteria: } 28,210 \\
\text { Mean Gram-negative bacteria: } 60 \\
\text { Median fungi: } 2500 \text { (malt extract agar) } \\
\text { Median fungi: } 2680 \text { (DG18 agar) }\end{array}$ & & & \\
\hline \multirow[t]{3}{*}{$\begin{array}{l}\text { Madsen et al. } \\
(2018)\end{array}$} & $\begin{array}{l}\text { Respicon }^{7}- \\
\text { Mean inhalable S.aureus: } 227 \\
\text { Mean thoracic S.aureus: } 113 \\
\text { Mean respirable S.aureus: } 91 \\
\text { Mean inhalable MRSA: } 219 \\
\text { Mean thoracic MRSA: } 95 \\
\text { Mean respirable MRSA: } 61 \\
\text { Anderson 6-stage viable cascade impactor - } \\
\text { Mean inhalable S.aureus: } 246 \\
\text { Mean respirable S.aureus: } 80 \\
\text { Mean inhalable MRSA: } 266 \\
\text { Mean respirable MRSA: } 88\end{array}$ & $\begin{array}{l}\text { Finisher; } \\
\text { n/a }\end{array}$ & \multirow[t]{3}{*}{ Denmark } & Fall \\
\hline & $\begin{array}{l}\text { Respicon- } \\
\text { Mean inhalable S.aureus: } 2.6 \times 10^{3} \\
\text { Mean thoracic S.aureus: } 850 \\
\text { Mean respirable S.aureus: } 732 \\
\text { Mean inhalable MRSA: } 100 \\
\text { Mean thoracic MRSA: } 34 \\
\text { Mean respirable MRSA: } 29 \\
\text { Anderson 6-stage viable cascade impactor - } \\
\text { Mean inhalable S.aureus: } 2.9 \times 10^{3} \\
\text { Mean respirable S.aureus: } 990\end{array}$ & $\begin{array}{l}\text { Farrowing; } \\
\text { n/a }\end{array}$ & & Winter \\
\hline & $\begin{array}{l}\text { Respicon - } \\
\text { Mean inhalable S.aureus: } 327 \\
\text { Mean thoracic S.aureus: } 194 \\
\text { Mean respirable S.aureus: } 138 \\
\text { Mean inhalable MRSA: } 202 \\
\text { Mean thoracic MRSA: } 113 \\
\text { Mean respirable MRSA: } 93 \\
\text { Anderson 6-stage viable cascade impactor- } \\
\text { Mean inhalable S.aureus: } 441\end{array}$ & $\begin{array}{l}\text { Nursery; } \\
\text { n/a }\end{array}$ & & Winter \\
\hline
\end{tabular}




\begin{tabular}{|c|c|c|c|c|}
\hline & $\begin{array}{l}\text { Mean respirable S.aureus: } 172 \\
\text { Mean inhalable MRSA: } 151 \\
\text { Mean respirable MRSA: } 85\end{array}$ & & & \\
\hline & $\begin{array}{l}\text { Respicon- } \\
\text { Mean inhalable S.aureus: } 211 \\
\text { Mean thoracic S.aureus: } 62 \\
\text { Mean respirable S.aureus: } 32 \\
\text { Mean inhalable MRSA: } 16 \\
\text { Mean thoracic MRSA: } 5.6 \\
\text { Mean respirable MRSA: } 3.6 \\
\text { Anderson 6-stage viable cascade impactor- } \\
\text { Mean inhalable S.aureus: } 188 \\
\text { Mean respirable S.aureus: } 43\end{array}$ & $\begin{array}{l}\text { Sick pigs; } \\
\text { n/a }\end{array}$ & & Winter \\
\hline $\begin{array}{l}\text { Naide et al. } \\
(2018)\end{array}$ & $\begin{array}{l}\text { Mena aerobic microbes: } 10^{4.50}-10^{5.42} \\
\text { Staphyloccoccus aureus: } 10^{3.90}-10^{5.06} \\
\text { E. coli: } 10^{0.91}-10^{2.97}\end{array}$ & $\begin{array}{l}\text { Nursery; } \\
\text { MV \& NV }\end{array}$ & Japan & Winter \\
\hline & $\begin{array}{l}\text { Mena aerobic microbes: } 10^{3.93}-10^{5.53} \\
\text { Staphyloccoccus aureus: } 10^{1.69}-10^{5.14} \\
\text { E. coli: BDL- } 10^{2.01}\end{array}$ & & & Summer \\
\hline $\begin{array}{l}\text { Wenke et al. } \\
(2018)\end{array}$ & $\begin{array}{l}\text { Barn } 1 \text { (supply air filter modules) }- \\
\text { Mean bacteria: } 1.78 \times 10^{2}-2.07 \times 10^{6} \\
\text { Mean MRSA: } 2-5.99 \times 10^{4} \\
\text { Coliforms: } 0-95 \\
\text { E.coli: } 0 \text {-34 } \\
\text { Barn } 2 \text { (supply air filter attic) - } \\
\text { Mean bacteria: } 2.07 \times 10^{2}-4.36 \times 10^{6} \\
\text { Mean MRSA: } 3-6.65 \times 10^{4} \\
\text { Mean Coliforms: } 0-47 \\
\text { Mean E.coli: } 0-125 \\
\text { Barn } 3 \text { (without air filtration system) - } \\
\text { Mean bacteria: } 1.36 \times 10^{3}-2.56 \times 10^{6} \\
\text { Mean MRSA: } 36-7.76 \times 10^{4} \\
\text { Mean Coliforms: } 0-45 \mu \\
\text { Mean E.coli: } 0-79 \\
\text { Barn } 4 \text { (recirculating air filtration) - } \\
\text { Mean bacteria: } 60-2.03 \times 10^{6} \\
\text { Mean MRSA: } 0-5.31 \times 10^{4} \\
\text { Mean Coliforms: } 0-292 \\
\text { Mean E.coli: } 0-361\end{array}$ & $\begin{array}{l}\text { Finisher; } \\
\text { MV }\end{array}$ & Germany & $\begin{array}{l}\text { All } \\
\text { seasons }\end{array}$ \\
\hline $\begin{array}{l}\text { Chen et al. } \\
(2019)\end{array}$ & $\begin{array}{l}\text { Geomean bacteria: } 21,777 \\
\text { Geomean tetracycline-resistant bacteria: } 2,011 \\
\text { Geomean erythromycin-resistant bacteria: } 5,876\end{array}$ & $\mathrm{n} / \mathrm{a} ; \mathrm{n} / \mathrm{a}$ & China & Fall \\
\hline $\begin{array}{l}\text { Eisenlöffe et al } \\
\text { (2019) }\end{array}$ & $\begin{array}{l}\text { UVC-recirculating air filtration }{ }^{8}- \\
\text { Mean bacteria: } 3.8 \times 10^{4}-1.3 \times 10^{6} \\
\text { No UVC-recirculating air filtration - }\end{array}$ & $\begin{array}{l}\text { Nursery; } \\
\text { MV }\end{array}$ & Germany & $\begin{array}{l}\text { All } \\
\text { seasons }\end{array}$ \\
\hline
\end{tabular}




\begin{tabular}{|c|c|c|c|c|}
\hline & Mean bacteria: $1.1 \times 10^{5}-1.07 \times 10^{6}$ & & & \\
\hline \multirow[t]{3}{*}{$\begin{array}{l}\text { Kim and Ko } \\
(2019)\end{array}$} & $\begin{array}{l}\text { Bacteria: } \\
3,428 \pm 1,244 \text { (spring) } \\
9,824 \pm 2,157 \text { (summer) } \\
1,707 \pm 957 \text { (fall) } \\
2,322 \pm 1,352 \text { (winter) }\end{array}$ & $\begin{array}{l}\text { Gestation- } \\
\text { farrowing; } \\
\text { MV }\end{array}$ & \multirow[t]{3}{*}{ Korea } & \multirow[t]{3}{*}{$\begin{array}{l}\text { All } \\
\text { seasons }\end{array}$} \\
\hline & $\begin{array}{l}\text { Bacteria: } \\
8,325 \pm 3,209 \text { (spring) } \\
18,254 \pm 5,166 \text { (summer) } \\
4,258 \pm 1,438 \text { (fall) } \\
6,124 \pm 1,527 \text { (winter) }\end{array}$ & $\begin{array}{l}\text { Nursery; } \\
\text { MV }\end{array}$ & & \\
\hline & $\begin{array}{l}\text { Bacteria: } \\
13,254 \pm 6,108 \text { (spring) } \\
24,088 \pm 9,274 \text { (summer) } \\
8,254 \pm 2,416 \text { (fall) } \\
12,470 \pm 4,869 \text { (winter) }\end{array}$ & $\begin{array}{l}\text { Grower- } \\
\text { finisher; } \\
\text { MV }\end{array}$ & & \\
\hline $\begin{array}{l}\text { Lühken et al. } \\
\text { (2019) }\end{array}$ & $\begin{array}{l}\text { Group housing system - } \\
\text { Bacteria: } 10^{4.22}-10^{5.67} \\
\text { Haemolytic streptococci: up to } 10^{4.78} \\
\text { Fungi: up to } 10^{3.43} \\
\text { Loose housing system - } \\
\text { Bacteria: } 10^{4.03}-10^{5.37} \\
\text { Haemolytic streptococci: up to } 10^{4.64} \\
\text { Fungi: up to } 10^{3.50} \\
\text { Farrowing crates - } \\
\text { Bacteria: } 10^{3.43}-10^{5.58} \\
\text { Haemolytic streptococci: up to } 10^{4.92} \\
\text { Fungi: up to } 10^{3.64}\end{array}$ & $\begin{array}{l}\text { Farrowing; } \\
\text { n/a }\end{array}$ & Germany & $\begin{array}{l}\text { All } \\
\text { seasons }\end{array}$ \\
\hline $\begin{array}{l}\text { Pilote et al. } \\
(2019)\end{array}$ & $\begin{array}{l}\text { Total bacteria: } 1.55 \times 10^{4}-1.55 \times 10^{6} \\
\text { Staphylococcus aureus: } 4.19 \times 10^{2}-9.05 \times 10^{4} \\
\text { MRSA: }<14-7.91 \times 10^{2} \\
\text { Salmonella } \text { spp.: }<14 \\
\text { Clostridium difficile: }<14-1.75 \times 10^{3} \\
\text { Mycobacterium avium: }<14-2.12 \times 10^{3} \\
\text { Listeria monocytogenes: }<14\end{array}$ & $\begin{array}{l}\text { Finisher; } \\
\text { MV }\end{array}$ & $\begin{array}{l}\text { Quebec, } \\
\text { Canada }\end{array}$ & Winter \\
\hline Tao et al. (2019) & $\begin{array}{l}\text { Bacteria: }(1.96 \pm 1.15) \times 10^{4}\left(5.37 \times 10^{3}-5.19 \times 10^{4}\right) \\
\text { E.coli: }(2.29 \pm 1.89) \times 10^{3}\left(1.41 \times 10^{2}-6.82 \times 10^{3}\right) \\
\text { Streptococcus aureus: }(1.44 \pm 0.59) \times 10^{4}\left(7.70 \times 10^{3}-\right. \\
\left.2.68 \times 10^{4}\right) \\
\text { Staphylococcus: }(9.16 \pm 4.15) \times 10^{3}\left(2.65 \times 10^{3}-\right. \\
\left.1.52 \times 10^{4}\right)\end{array}$ & $\begin{array}{l}\text { Grower; } \\
\text { MV }\end{array}$ & China & Fall \\
\hline $\begin{array}{l}\text { Watt et al. } \\
(2020)\end{array}$ & Actinobacillus pleuropneumoniae: BDL-1.26×10 & $\begin{array}{l}\text { Wean-to- } \\
\text { finish; MV }\end{array}$ & Australia & $\mathrm{n} / \mathrm{a}$ \\
\hline $\begin{array}{l}\text { White et al. } \\
(2020)\end{array}$ & Fungi: $1,281\left(377-2.17 \times 10^{3}\right)$ & $\begin{array}{l}\text { Finisher; } \\
\text { n/a }\end{array}$ & Denmark & $\begin{array}{l}\text { Summer, } \\
\text { winter }\end{array}$ \\
\hline
\end{tabular}




\begin{tabular}{|l|l|l|l|l|}
\hline $\begin{array}{l}\text { Haas et al. } \\
(2021)\end{array}$ & $\begin{array}{l}\text { Mean mesophilic bacteria: } 2.6 \times 10^{5}-7.3 \times 10^{5} \\
\text { Staphylococcus spp: } 9.4 \times 10^{3}-8.8 \times 10^{4} \\
\text { Aerococcus spp: } 4.1 \times 10^{4}-4.2 \times 10^{5}\end{array}$ & $\begin{array}{l}\text { Finisher; } \\
\text { n/a }\end{array}$ & Austria & Winter \\
\cline { 2 - 3 } & $\begin{array}{l}\text { Mean mesophilic bacteria: } 2.7 \times 10^{4}-1.1 \times 10^{5} \\
\text { Staphylococcus spp: } 1.2 \times 10^{3}-1.2 \times 10^{4} \\
\text { Aerococcus } \text { spp: } 9.3 \times 10^{3}-1.1 \times 10^{5}\end{array}$ & $\begin{array}{l}\text { Grower- } \\
\text { finisher; } \\
\text { n/a }\end{array}$ & Spring \\
\end{tabular}

Note:

${ }^{1} \mathrm{MV}$ - mechanical ventilation; NV - natural ventilation; HV - hybrid (mixed) ventilation (MV + NV).

${ }^{2}$ Clostridium perfringens, E. coli, and Yersinia enterocolitica were also quantified. However, no concentration numbers were available.

${ }^{3}$ MRSA - Methicillin-resistant Staphylococcus aureus (S. aureus).

${ }^{4}$ Experimental rooms, not real farms.

${ }^{5}$ MSSA - Methicillin-susceptible Staphylococcus aureus.

${ }^{6}$ Microbial counts were compiled from the supplementing materials of the paper.

${ }^{7}$ Respicon is a three-stage cascade impactor manufactured by TSI Inc. (Shoreview, MN) and it uses filters for bioaerosol collection.

${ }^{8}$ UVC-recirculating air filtration - two ultraviolet C light (UVC) tubes combined with air filters.

To our knowledge, the earliest study of culturable bacterial/fungal counts in swine barns was done by Dr. Fiser from the University of Veterinary Brno, Czech (Fiser 1969, 1970). In the U.S., the first of such efforts were made by Dr. Curtis and his colleagues from the University of Illinois at Urbana-Champaign (Curtis et al., 1975a, b). They collected bacterial-colony-forming particles (BCFP; i.e., particles carrying culturable bacteria) on tryptose agar using an Andersen viable cascade impactor and reported that culturable bacterial counts ranged from $2.1 \times 10^{4}$ to $1.5 \times 10^{5}$ colony forming units $(\mathrm{CFU}) \mathrm{m}^{-3}$. They further studied the size distribution of BCFPs in university research barns and commercial barns. These efforts advanced our understanding of the impact of swine barn aerial environments on pig performance (Curtis et al., 1975c) and occupational health (Holness et al., 1987) and, in turn, stimulated a growing interest in the measurement of culturable bacterial and fungal counts in swine barns in the 1970s and 1980s (Elliott et al., 1976; Curtis et al., 1978; Underdahl et al., 1982; Clark et al., 1983; Carpenter et al., 1986; Donham et al., 1986, 1989; Attwood et al., 1987; Chiba et al., 1987; Haglind and Rylander, 1987; Karlsson and Malmberg, 1989). From these early studies, a correlation was found of culturable bacterial/fungal counts with the incidence of respiratory diseases among farmers (Donham et al., 1989) and with reduced pig performance (Curtis et al. 1975c; Carpenter et al., 1986).

The interest in culturable bacterial and fungal counts continued into the 1990s and 2000s. Table 5 summarizes relevant publications since 1990. A few clarifications are provided below for readers with no relevant experience:

- Total culturable bacteria and fungi are abbreviated as bacteria and fungi, respectively, in the table. In the literature, "total" refers to the total culturable counts of all size stages since multiplestage cascade impactors are widely used for bioaerosol sampling. It should not be confused with total bacteria/fungi where "total" refer to a collection of viable and non-viable ones.

- Molds and yeasts are two subcategories of fungi. They form colonies differing in size, shape, and texture and they were counted separately in a few studies, e.g., Cormier et al. (1990). On a few occasions, molds and fungi were interchangeably used, e.g., Duchaine et al. (2000) and Godbout et al. (2005).

- Different publications could use different statistical measures to summarize counting results. The commonly used measures include mean, median, geometric mean (geomean), standard deviation, and range. A few studies use logarithmic numbers, e.g., Curtis et al. (1975a) and Kim et al. (2007). Caution must be taken when comparing the data from different publications. 
- No official occupational exposure limits exist for culturable airborne bacterial or fungal counts. Reponen et al. (1992) proposed a threshold limit value of 5,000 CFU m${ }^{-3}$ for culturable airborne bacteria and a more stringent value $\left(1,000 \mathrm{CFU} \mathrm{m}^{-3}\right)$ was later proposed by Wheeler et al. (2001). For culturable fungi, a concentration of $\leq 100 \mathrm{CFU} \mathrm{m}^{-3}$ could detriment immunosuppressed people (ACGIH, 1989). No threshold limits exist regarding pig exposure to culturable bacteria or fungi.

It is a daunting challenge to compile, compare, and analyze existing data in the literature because, as aforementioned, culturable bacterial/fungi counts vary with measurement methods and are presented in various forms. This challenge is further complicated by size-segregated sampling, i.e., many publications offered culturable counts in multiple size ranges. Upon the analysis of the publications since 1990, the following observations are made:

- Among the 53 publications compiled, 21 were done in Europe, followed by the U.S. (9), Canada (8), and South Korea (5). This is consistent with the geographical distribution of PM studies in Table 2. Thirty-three publications reported general bacterial counts and 21 presented general fungal/mold counts. The counts of a specific species (or group) were reported by 20 publications. The typical species (or group) of interest include Gram-negative bacteria, Staphylococcus, methicillin-resistant Staphylococcus aureus (MRSA), Actinomycetes, and E. coli. Many studies were limited to short-term farm surveys (Note: This is partly related to the methodology constraints). Only a few studies involved long-term monitoring efforts, e.g., Lau et al. (1996), Wenke et al. (2018), and Eisenlöffel et al. (2019).

- The total culturable bacterial count varied substantially in the literature, ranging from 14.5 (Kim et al., 2008) to $1.82 \times 10^{10} \mathrm{CFU} \mathrm{m}{ }^{-3}$ (Kim et al., 2008). Another high concentration $\left(1.6 \times 10^{8} \mathrm{CFU}\right.$ $\mathrm{m}^{-3}$ ) was reported by Radon et al. (2002). Caution should be taken when interpreting extremely high count values. Assuming that bacteria weigh at $1 \times 10^{-12} \mathrm{~g}$ per cell (Sender et al., 2016), the count of $1.82 \times 10^{10} \mathrm{CFU} \mathrm{m}^{-3}$ would indicate an airborne bacterial mass concentration of $18.2 \mathrm{mg}$ $\mathrm{m}^{-3}$, which is unlikely in reality. Excluding the extremes, most of the total culturable bacterial counts fall into the orders of magnitude of $10^{3}-10^{6} \mathrm{CPU} \mathrm{m}^{-3}$.

- The total culturable fungal count also varied greatly, ranging from 1.3 (Dutkiewicz et al., 1994) $\mathrm{CFU} \mathrm{m}{ }^{-3}$ in a farrowing barn in Poland to $7.24 \times 10^{6} \mathrm{CFU} \mathrm{m}^{-3}$ in a grower-finisher barn in South Korea (Kim et al., 2008). Another high concentration level $\left(4.3 \times 10^{6} \mathrm{CFU} \mathrm{m}^{-3}\right)$ was observed by Radon et al. (2002) in Denmark. Most of the total culturable fungal counts in the literature fall into the orders of magnitude of $10^{2}-10^{4} \mathrm{CPU} \mathrm{m} \mathrm{m}^{-3}$.

- Gram-negative bacteria accounted for only a small portion of culturable bacterial counts $(0.1 \%$ to $1 \%$ of the latter). This is consistent with the findings derived from the molecular biology analysis of airborne bacterial communities in swine barns (Nehme et al., 2008; Hong et al., 2012; White et al., 2019). However, molecular biology methods such as polymerase chain reaction (PCR) and DNA sequencing may detect both living and dead microorganisms (with DNA molecules yet to be degraded) (Hong et al., 2012). Gram-negative bacteria are of particular concern when it comes to human and animal health as they include pathogens such as coliforms (e.g., E. coli and Salmonella spp.). When dead, Gram-negative bacteria also release endotoxins, a cell wall component with well-established health implications (Milton et al., 1992).

- No consistent seasonality was observed. Duchaine et al. (2000) reported that culturable bacterial counts were significantly lower in summer than in winter. This contradicts an early finding by Kiekhaefer et al. (1995) that a significantly lower bacterial count occurred in winter/spring than in summer/fall. A significant seasonal variation was also noted by Thorne et al. (2009) and Lee (2009). Different microbial species or groups may exhibit different seasonality. In the same study by Duchaine et al. (2000), no significant difference was seen between summer and winter in terms of fungi, thermophilic actinomycetes, or Saccharopolyspora rectivirgula. The lack of significant seasonality was also reported by Kim et al. (2007) for fungi, bacteria, and Gram- 
negative bacteria. While there was no significant seasonality in bacteria, significant seasonable changes in coliforms and E. coli were reported by Yao et al. (2010). Similarly, Popescu et al. (2014) found a significant seasonality in mesophilic bacteria but no significant seasonal effect on fungi, Gram-negative bacteria, Streptococci, or Staphylococci.

- Limited information is known about the effect of barn types. Only a few studies compared culturable bacterial or fungal counts between different barn types - a sharp contrast to PM concentration assessment. Even worse, many of the existing studies (Dutkiewciz et al., 1994; Banhazi, 2007; Madsen et al., 2018) provided no conclusive comparison because of the lack of statistical analysis. Chang et al. (2001b) compared five types of swine barns in Taiwan: breeding, farrowing, nursery, grower, and finisher. A significantly higher bacterial count was detected in finisher barns than farrowing, nursery, and grower barns. No significant difference in culturable fungal counts was noted among these barns. Thorne et al. (2009) compared two types of growerfinisher barns: hoop barns (with natural ventilation) versus regular barns (with mechanical ventilation); and they found a significant effect of barn types on total microbes but no significant effect on mesophilic bacteria. Lee (2009) compared farrowing and finisher barns in Illinois and reported no significant difference in culturable bacterial counts between the two barn types.

- Limited information is known about the effect of waste management systems. Godbout et al. (2005) compared six manure separation systems and observed the highest bacterial and mold counts in the barn with V-shaped scrapers. However, no significant difference was found among different separation systems. The study by Thorne et al. (2009) also involved a comparison of waste management systems: deep manure pit in regular barns versus bedded floors in hoop barns. The overall higher bacterial and fungal counts in hoop barns could be related to manure build-up and microbial growth on bedding materials. In an extensive farm survey, Ko et al. (2010) compared 17 different manure treatment technologies and found a significant effect of the technologies on culturable bacterial counts.

- Culturable bacterial and fungal counts could be affected by animal (e.g., age/weight and the number of pigs) and environmental factors (e.g., air temperature, humidity, air speed). Duchaine et al. (2000) found that airborne culturable bacterial counts correlated negatively with barn dustiness and positively with the number of pigs; while culturable mold counts correlated positively with dustiness. Thorne et al. (2009) found significant effects on mesophilic bacteria by air temperature, humidity, wind speed, and the number of pigs, and significant effects on total microbes by air temperature and humidity. Yao et al. (2010) investigated the influence of barn microclimate on airborne bacteria and found a significant effect of air temperature and air speed on coliform and E. coli; however, no significant effect of air humidity was noted. Similar observations were made by Kim et al. (2007) and Sowiak et al. (2012). It is noteworthy that air temperature in swine barns varies with outdoor temperature and ventilation conditions. Thus, the effect of air temperature may confound with seasonality. Wenke et al. (2018) and Eisenlöffe et al (2019) measured culturable bacterial counts over multiple production cycles and noted that the bacterial counts generally increased with animal age/weight.

- The effectiveness of mitigation technologies remains uncertain for culturable bacteria/fungi. Banhazi et al. (2007) tested an oil sprinkling system for its effectiveness in dust, total bacteria, and ammonia removal and reported a $42 \%$ reduction in culturable bacterial counts in a nursery barn. However, in a grower barn, oil sprinkling increased culturable bacterial counts by $70 \%$. The reason remained unknown. Lau et al. (1996) tested two recirculating filtration technologies (fabric filters and electrostatic filters) and found culturable bacteria reduction efficiencies of 10$50 \%$ for the fabric filter in a grower barn and $20-52 \%$ for the electrostatic filter in a finisher barn. Wenke et al. (2018) compared four air filtration options (no filtration, supply air filter modules, supply air filter attic, and recirculating air filtration modules) in finisher barns. Pig performance was improved with recirculating air filtration modules. However, no significant reduction in 
culturable bacterial counts was observed. Eisenlöffe et al (2019) investigated the combination of ultraviolet $\mathrm{C}$ (UVC) light and air filtration for its mitigation of culturable bacteria and reported a reduction efficiency of $31.6 \%$ in trial 1 and $63 \%$ in trial 2 .

- Culturable bacteria and fungi show different size distribution patterns. Culturable bacterial counts tend to increase with particle size (Lee, 2009; Sowiak et al., 2012; Madsen et al., 2018; Kim and Ko, 2019). This, consistent with early findings (Carpenter, 1986), suggests that the bacteria may not exist as individual particles but bind to large particles in the air. Comparatively, culturable fungal counts peaked at approximately 2-5 $\mu \mathrm{m}$ (Sowiak et al., 2012; White et al. 2020), suggesting that airborne fungi in swine barns may exist as individual spores/particles. Different size distribution patterns suggest that airborne bacteria and fungi may undergo different aerodynamic transport and removal processes in swine barns (Zhang, 2005) and different strategies may be required for the mitigation of airborne bacteria than fungi.

- No agreement has been reached regarding the relationship between culturable bacterial counts and PM concentrations. A significant and positive correlation was observed by Duchaine et al. (2000) and Lee (2009). However, a later study by Yao et al. (2010) found no significant correlation of PM concentrations with culturable bacterial, coliform, or E. coli counts. The inconsistency in the literature might be caused by sampling duration. Because of the high bioaerosol concentrations inside swine barns, most bioaerosol samplers must be run for a short sampling duration (typically a few minutes) compared to PM samplers (typically 24 hours). Future research is needed to further investigate the relationship and alike. If a correlation exists, it will simplify the assessment and mitigation of airborne bacteria in swine barns.

Total bacterial and fungal counts

To our knowledge, the first measurement of total bacterial/fungal counts in swine barns was done by Palmgren et al. (1986a), immediately after the invention of the Nuclepore filter method (also known as CAMNEA method) by the same authors (Palmgren et al. 1986b). An average count of $2 \times 10^{9}$ cells m$^{-3}$ was reported for total microbes (fungi + bacteria). The method involved the use of acridine orange (AO) to stain PM collected on a Nuclepore (i.e., polycarbonate) filter and the identification and enumeration of microbes with epifluorescence microscopy (EPM). Using the same method, Donham et al. (1989) measured bioaerosol concentrations in 30 swine barns in Iowa and found an average count of $1.4 \times 10^{6}$ cells $\mathrm{m}^{-3}$ for bacteria, $2 \times 10^{4}$ cells $\mathrm{m}^{-3}$ for fungi, and $1.8 \times 10^{7}$ cells $\mathrm{m}^{-3}$ for total microbes. Additional measurement results have been available since 1990, as summarized in Table 6.

Table 6. Total bacterial and fungal counts in swine barns - a summary of studies since 1990.

\begin{tabular}{|l|l|l|l|l|l|}
\hline References & $\begin{array}{l}\text { Total counts }\left(\text { cell } \mathrm{m}^{-3} ; \text { unless }\right. \\
\text { otherwise noted)2, }\end{array}$ & $\begin{array}{l}\text { Building \& } \\
\text { ventilation } \\
\text { type }\end{array}$ & Location & Season & $\begin{array}{l}\text { Analytical } \\
\text { method }^{4}\end{array}$ \\
\hline $\begin{array}{l}\text { Lange et al. } \\
(1997)\end{array}$ & $\begin{array}{l}\text { Bacteria with AGI impingers }- \\
\text { Cytometry/DAPI: } \sim 3 \times 10^{7} \\
\text { EFM/DAPI: } \sim 1.5 \times 10^{7}\end{array}$ \\
$\begin{array}{l}\text { Bacteria with May impingers } \\
\text { Cytometry/DAPI: } \sim 1.3 \times 10^{7} \\
\text { EFM/DAPI: } 0.9 \times 10^{7} \\
(\text { Read from Figure } 4 \text { of the paper) }\end{array}$ & Iowa & n/a & $\begin{array}{l}\text { DAPI staining \& } \\
\text { flow cytometry; } \\
\text { DAPI staining \& } \\
\text { EPM; }\end{array}$ \\
\hline $\begin{array}{l}\text { Radon et al. } \\
(2002)\end{array}$ & $\begin{array}{l}\text { Mean bacteria: } 4.2 \times 10^{8} \text { (BDL- } \\
\left.1.6 \times 10^{10}\right) \\
\text { Mean fungi: } 3.8 \times 10^{5} \text { (BDL- } \\
\left.4.3 \times 10^{6}\right)\end{array}$ & $\mathrm{n} / \mathrm{a} ; \mathrm{n} / \mathrm{a}$ & Denmark & $\mathrm{n} / \mathrm{a}$ & $\begin{array}{l}\text { AO staining \& } \\
\text { EPM }\end{array}$ \\
\hline
\end{tabular}




\begin{tabular}{|c|c|c|c|c|c|}
\hline \multirow[t]{5}{*}{$\begin{array}{l}\text { Chi and Li } \\
(2005)\end{array}$} & $\begin{array}{l}\text { Mean total microbes }- \\
\text { EPM/AO: } 6.05 \times 10^{6}-6.63 \times 10^{6} \\
\text { EPM/DAPI: } 5.03 \times 10^{6}-5.82 \times 10^{6} \\
\text { FISH/DAPI: } 7.31 \times 10^{6}-1.05 \times 10^{7}\end{array}$ & Gestation; n/a & \multirow[t]{5}{*}{ Taiwan } & \multirow[t]{5}{*}{ Winter } & \multirow[t]{5}{*}{$\begin{array}{l}\text { AO or DAPI } \\
\text { staining \& EPM; } \\
\text { DAPI staining \& } \\
\text { FISH }\end{array}$} \\
\hline & $\begin{array}{l}\text { Total microbes }- \\
\text { EPM/AO: }(1.08 \pm 0.03) \times 10^{7} \\
\text { EPM/DAPI: }(9.43 \pm 0.25) \times 10^{6} \\
\text { FISH/DAPI: }(8.20 \pm 0.84) \times 10^{6}\end{array}$ & $\begin{array}{l}\text { Farrowing; } \\
\text { n/a }\end{array}$ & & & \\
\hline & $\begin{array}{l}\text { Mean total microbes }- \\
\text { EPM/AO: } 8.82 \times 10^{6}-2.18 \times 10^{7} \\
\text { EPM DAPI: } 5.69 \times 10^{6}-2.17 \times 10^{7} \\
\text { FISH/DAPI: } 9.87 \times 10^{6}-1.20 \times 10^{7}\end{array}$ & Nursery; n/a & & & \\
\hline & $\begin{array}{l}\text { Mean total microbes }- \\
\text { EPM/AO: } 5.48 \times 10^{6}-7.53 \times 10^{6} \\
\text { EPM/DAPI: } 5.39 \times 10^{6}-7.14 \times 10^{6} \\
\text { FISH/DAPI: } 5.66 \times 10^{6}-2.20 \times 10^{7}\end{array}$ & Grower; n/a & & & \\
\hline & $\begin{array}{l}\text { Mean total microbes }- \\
\text { EPM/AO: } 6.91 \times 10^{6}-1.12 \times 10^{7} \\
\text { EPM/DAPI: } 5.93 \times 10^{6}-1.07 \times 10^{7} \\
\text { FISH/DAPI: } 7.65 \times 10^{6}-1.32 \times 10^{7}\end{array}$ & Finisher; $\mathrm{n} / \mathrm{a}$ & & & \\
\hline $\begin{array}{l}\text { Vanhee et } \\
\text { al. (2008) }\end{array}$ & $\begin{array}{l}\text { Mean total microbes: } 7.9 \times 10^{4}- \\
9.4 \times 10^{5} \\
\text { Mean bacteria: } 7.5 \times 10^{4}-9.3 \times 10^{5} \\
\text { Mean fungi: } 1.01 \times 10^{3}-1.2 \times 10^{4}\end{array}$ & $\mathrm{n} / \mathrm{a} ; \mathrm{n} / \mathrm{a}$ & Belgium & $\mathrm{n} / \mathrm{a}$ & $\begin{array}{l}\text { Staining \& flow } \\
\text { cytometry: } \\
\text { ChemChrome } \\
\text { V6/ChemSol } \\
\text { B16 for total } \\
\text { microbes, and } \\
\text { ChemChrome } \\
\text { V6/ChemSol B2 } \\
\text { for fungi }\end{array}$ \\
\hline $\begin{array}{l}\text { Létourneau } \\
\text { et al. } \\
(2009)\end{array}$ & $\begin{array}{l}\text { Bacteria: } \sim 1 \times 10^{6}-1 \times 10^{8} \text { (read from } \\
\text { Figure } 2 \text { of the paper) }\end{array}$ & $\begin{array}{l}\text { Finisher; MV } \\
\text { (17 farms), } \\
\text { NV (1 farm) }\end{array}$ & $\begin{array}{l}\text { Quebec, } \\
\text { Canada }\end{array}$ & Winter & 16S rRNA qPCR \\
\hline \multirow[t]{2}{*}{$\begin{array}{l}\text { Thorne et } \\
\text { al. (2009) }\end{array}$} & $\begin{array}{l}\text { Geomean total microbes: } 3.01 \times 10^{6} \\
\left(2 \times 10^{4}-1.8 \times 10^{7}\right)\end{array}$ & $\begin{array}{l}\text { Grower- } \\
\text { finisher; NV } \\
\text { (hoop barns) }\end{array}$ & \multirow[t]{2}{*}{ Iowa } & $\begin{array}{l}\text { All } \\
\text { seasons }\end{array}$ & \multirow[t]{2}{*}{$\begin{array}{l}\text { AO staining \& } \\
\text { EPM }\end{array}$} \\
\hline & $\begin{array}{l}\text { Geomean total microbes: } 1.49 \times 10^{6} \\
\left(1.8 \times 10^{4}-1.22 \times 10^{7}\right)\end{array}$ & $\begin{array}{l}\text { Grower- } \\
\text { finisher; MV }\end{array}$ & & $\begin{array}{l}\text { All } \\
\text { seasons }\end{array}$ & \\
\hline $\begin{array}{l}\text { Verreault et } \\
\text { al }(2010)\end{array}$ & Bacteria: $5 \times 10^{6}-4 \times 10^{8}$ copies $\mathrm{m}^{-3}$ & $\begin{array}{l}\text { Farrowing, } \\
\text { nursery, } \\
\text { grower- } \\
\text { finisher; n/a }\end{array}$ & $\begin{array}{l}\text { Quebec, } \\
\text { Canada }\end{array}$ & $\begin{array}{l}\text { All } \\
\text { seasons }\end{array}$ & 16S rRNA qPCR \\
\hline $\begin{array}{l}\text { Kristiansen } \\
\text { et al. (2012) }\end{array}$ & $\begin{array}{l}\text { Total microbes: }(2.7 \pm 0.7) \times 10^{7} \\
\text { Fungi: }(1.2 \pm 0.3) \times 10^{6}\end{array}$ & $\begin{array}{l}\text { Sows; MV } \\
\text { (chimney) }\end{array}$ & Denmark & $\begin{array}{l}\text { Spring, } \\
\text { summer }\end{array}$ & $\begin{array}{l}\text { Staining \& EPM: } \\
\text { AO for total } \\
\text { microbes, and } \\
\text { PAS for fungi }\end{array}$ \\
\hline $\begin{array}{l}\text { Masclaux et } \\
\text { al. (2013) }\end{array}$ & $\begin{array}{l}\text { Mean bacteria: } 3.6 \times 10^{9} \text { copies } \mathrm{m}^{-3} \\
\left(1.6 \times 10^{5}-6.1 \times 10^{10}\right) \\
\text { Staphylococcus spp.: } 1.6 \times 10^{7} \\
\text { copies } \mathrm{m}^{-3}\left(2 \times 10^{3}-4 \times 10^{8}\right)\end{array}$ & $\begin{array}{l}\text { Nursery, } \\
\text { farrowing, } \\
\text { finisher; } \mathrm{n} / \mathrm{a}\end{array}$ & Switzerland & $\begin{array}{l}\text { Summer, } \\
\text { winter }\end{array}$ & $\begin{array}{l}\text { 16S rRNA qPCR } \\
\text { for bacteria; } \\
\text { qPCR with a } \\
\text { special primer }\end{array}$ \\
\hline
\end{tabular}




\begin{tabular}{|c|c|c|c|c|c|}
\hline & & & & & $\begin{array}{l}\text { pair for } \\
\text { Staphylococcus } \\
\text { spp. }\end{array}$ \\
\hline \multirow{3}{*}{$\begin{array}{l}\text { Rodríguez } \\
\text { de } \\
\text { Evgrafov et } \\
\text { al. (2013) }\end{array}$} & Mean total microbes: $1.1 \times 10^{6}$ & Nursery; n/a & \multirow[t]{3}{*}{ Colorado } & \multirow{3}{*}{$\begin{array}{l}\text { Summer, } \\
\text { fall }\end{array}$} & \multirow{3}{*}{$\begin{array}{l}\text { DAPI staining \& } \\
\text { EPM }\end{array}$} \\
\hline & Mean total microbes: $2 \times 10^{7}$ & Grower; n/a & & & \\
\hline & $\begin{array}{l}\text { Mean total microbes: } 1.1 \times 10^{6} \\
\text { (Read from Figure } 1 \text { of the paper) }\end{array}$ & Finisher; $\mathrm{n} / \mathrm{a}$ & & & \\
\hline $\begin{array}{l}\text { Bonifait et } \\
\text { al. (2014) }\end{array}$ & $\begin{array}{l}\text { Bacteria: } 1 \times 10^{8}-2 \times 10^{8} \\
\text { Streptococcus suis: } 4 \times 10^{5}-1 \times 10^{6} \\
\text { Streptococcus suis serotypes } 2 \text { and } \\
1 / 2: 1 \times 10^{3}-3 \times 10^{4}\end{array}$ & $\begin{array}{l}\text { Grower- } \\
\text { finisher; } \mathrm{n} / \mathrm{a}\end{array}$ & $\begin{array}{l}\text { Quebec, } \\
\text { Canada }\end{array}$ & $\mathrm{n} / \mathrm{a}$ & $\begin{array}{l}\text { 16S rRNA qPCR } \\
\text { for bacteria; } \\
\text { qPCR with a } \\
\text { special primer } \\
\text { pair for } S \text {. suis } \\
\text { and its serotypes. }\end{array}$ \\
\hline \multirow{2}{*}{$\begin{array}{l}\text { Kumari and } \\
\text { Choi (2014) }\end{array}$} & Mean bacteria: $1.4 \times 10^{8}$ copies $\mathrm{m}^{-3}$ & \multirow{2}{*}{$\begin{array}{l}\text { Grower- } \\
\text { finisher; } \mathrm{n} / \mathrm{a}\end{array}$} & \multirow{2}{*}{$\begin{array}{l}\text { South } \\
\text { Korean }\end{array}$} & Winter & \multirow[t]{2}{*}{ 16S rRNA qPCR } \\
\hline & Mean bacteria: $1.2 \times 10^{7}$ copies $\mathrm{m}^{-3}$ & & & Summer & \\
\hline $\begin{array}{l}\text { Lee and } \\
\text { Liao }(2014)\end{array}$ & $\begin{array}{l}\text { Mean fungi: } 4.1 \times 10^{5}\left(3.6 \times 10^{5}-\right. \\
\left.5.6 \times 10^{5}\right)\end{array}$ & $\mathrm{n} / \mathrm{a} ; \mathrm{n} / \mathrm{a}$ & Taiwan & Summer & $\begin{array}{l}\text { AO or PI } \\
\text { staining \& EPM }\end{array}$ \\
\hline $\begin{array}{l}\text { Kumari and } \\
\text { Choi (2015) }\end{array}$ & $\begin{array}{l}\text { Deep pit with slatted floor }- \\
\text { Mean bacteria: } \sim 10^{8.2} \text { copies } \mathrm{m}^{-3} \\
\text { Manure scraper }- \\
\text { Mean bacteria: } \sim 10^{7.6} \text { copies } \mathrm{m}^{-3} \\
\text { Litter bedding - } \\
\text { Mean bacteria: } \sim 10^{7.2} \text { copies } \mathrm{m}^{-3} \\
\text { (Read from Figure } 2 \text { of the paper) }\end{array}$ & $\begin{array}{l}\text { Grower- } \\
\text { finisher; } \mathrm{n} / \mathrm{a}\end{array}$ & $\begin{array}{l}\text { South } \\
\text { Korean }\end{array}$ & Winter & 16S rRNA qPCR \\
\hline \multirow{2}{*}{$\begin{array}{l}\text { Kumari et } \\
\text { al. (2016) }\end{array}$} & Mean fungi: $\sim 10^{5.3}-10^{5.8}$ copies $\mathrm{m}^{-3}$ & \multirow{2}{*}{$\begin{array}{l}\text { Grower- } \\
\text { finisher; n/a }\end{array}$} & \multirow{2}{*}{$\begin{array}{l}\text { South } \\
\text { Korean }\end{array}$} & Winter & \multirow[t]{2}{*}{ ITS qPCR } \\
\hline & $\begin{array}{l}\text { Mean fungi: } \sim 10^{4.5}-10^{5.7} \text { copies } \mathrm{m}^{-3} \\
\text { (Read from Figure } 2 \text { of the paper) }\end{array}$ & & & Summer & \\
\hline \multirow{4}{*}{$\begin{array}{l}\text { Kraemer et } \\
\text { al. }(2019)\end{array}$} & Mean bacteria: $\sim 10^{20}$ copies $\mathrm{m}^{-3}$ & \multirow[t]{4}{*}{$\mathrm{n} / \mathrm{a} ; \mathrm{n} / \mathrm{a}$} & \multirow[t]{4}{*}{ Switzerland } & Winter & \multirow[t]{4}{*}{ 16S rRNA qPCR } \\
\hline & Mean bacteria: $\sim 10^{16}$ copies $\mathrm{m}^{-3}$ & & & Spring & \\
\hline & Mean bacteria: $\sim 10^{10.5}$ copies $\mathrm{m}^{-3}$ & & & Summer & \\
\hline & $\begin{array}{l}\text { Mean bacteria: } \sim 10^{14} \text { copies } \mathrm{m}^{-3} \\
\text { (Read from Figure } 1 \text { of the paper) }\end{array}$ & & & Fall & \\
\hline $\begin{array}{l}\text { Pilote et al. } \\
\text { (2019) }\end{array}$ & $\begin{array}{l}\text { Bacteria: } 8.06 \times 10^{7}-3.34 \times 10^{9} \text { copies } \\
\mathrm{m}^{-3} \\
\text { Staphylococcus aureus: } 5.04 \times 10^{4}- \\
7.43 \times 10^{5} \text { copies } \mathrm{m}^{-3} \\
\text { MRSA: }<8-1.19 \times 10^{4} \text { copies } \mathrm{m}^{-3} \\
\text { Salmonella } \text { spp.: } 7.59 \times 10^{2}- \\
1.07 \times 10^{6} \text { copies } \mathrm{m}^{-3}\end{array}$ & $\begin{array}{l}\text { Finisher; } \\
\text { MV }\end{array}$ & $\begin{array}{l}\text { Quebec, } \\
\text { Canada }\end{array}$ & Winter & $\begin{array}{l}\text { 16S rRNA qPCR } \\
\text { for bacteria; } \\
\text { qPCR with } \\
\text { special primer } \\
\text { pairs for } \\
\text { individual } \\
\text { species }\end{array}$ \\
\hline
\end{tabular}




\begin{tabular}{|l|l|l|l|l|l|}
\hline & $\begin{array}{l}\text { Clostridium difficile: }<8-4.21 \times 10^{4} \\
\text { copies } \mathrm{m}^{-3} \\
\text { Mycobacterium avium: }<8 \text { copies } \\
\mathrm{m}^{-3} \\
\text { Listeria monocytogenes: }<8- \\
3.16 \times 10^{3} \text { copies } \mathrm{m}^{-3}\end{array}$ & & & & \\
& $\begin{array}{l}\text { Actinobacillus pleuropneumoniae: } \\
\text { Batt et al. } \\
(2020)\end{array}$ & $\begin{array}{l}\text { Wean-to- } \\
\text { finish; } \mathrm{MV}\end{array}$ & Australia & $\mathrm{n} / \mathrm{a}$ & apxIV qPCR \\
\hline $\begin{array}{l}\text { Luiken } \\
(2021)\end{array}$ & $\begin{array}{l}\text { Mean bacteria: } 10^{12} \text { copies } \mathrm{m}^{-3} \\
(\text { Read from Chap 5, Figure 1) }\end{array}$ & n/a; $\mathrm{n} / \mathrm{a}$ & $\begin{array}{l}\text { Nine } \\
\text { European } \\
\text { countries }\end{array}$ & $\mathrm{n} / \mathrm{a}$ & $16 \mathrm{~S} \mathrm{rRNA}$ qPCR \\
\hline
\end{tabular}

Note:

${ }^{1}$ Some studies did not distinguish bacteria from fungi. Instead, they presented the measurement results as the counts were for total microbes, i.e., fungi plus bacteria.

${ }^{2} \mathrm{AO}$ - acridine Orange; DAPI - 4',6-diamidino-2-phenylindole; EPM - epifluorescence microscope; FISH - fluorescence in situ hybridization; BDL - below the detection limit.

${ }^{3} \mathrm{MV}$ - mechanical ventilation; NV - natural ventilation.

${ }^{4}$ PAS - Periodic Acid-Schiff; PI - propidium iodide; ITS - internal transcribed spacer, an indicator gene for fungi; 16S rRNA - 16S ribosome RNA gene, an indicator gene for bacteria; apxIV - a speciesspecific gene for Actinobacillus pleuropneumoniae.

Besides AO, fluorochromes such as DAPI and PI were also used as staining agents for microscopic or cytometric counting of total bacteria and/or fungi. With technological advances in molecular biology, real-time quantitative polymerase chain reaction (qPCR) became a prevalent, alternative method in recent years. The results derived from qPCR were often presented in the number of gene copies per $\mathrm{m}^{3}$ of air $\left(\right.$ copies $\left.\mathrm{m}^{-3}\right)$. Here, the gene refers to an indicator gene selected for general bacteria, general fungi, or specific bacterial/fungal groups. A single microbial cell may have multiple copies of a target gene. Thus, the results from qPCR cannot be directly compared with those from fluorochrome-assisted counting. Moreover, different fluorochromes may result in different counting results (Chi and Li, 2005; Lee and Liao, 2014). In short, total bacterial/fungal counting is highly method dependent. Further information about measurement methodology can be found in Section 4.4.1.

Several publications also discussed the measurement of total bacterial/fungal counts in swine barns (Thorne et al., 1992; Eduard et al., 1990; Heldal et al., 1996; Clauß et al., 2011; Chang et al., 2017). However, they focused on methodology development with no measurement data provided. Upon the analysis of existing publications, the following observations are made:

- Among the 19 reports since 1990, six were from Europe, followed by Canada (four). Only three studies were done in the U.S., with all being over ten years ago. Eleven studies measured total bacterial counts, five monitored total fungal counts, five examined total microbial (bacterial + fungal) counts, and four reported the count of specific microbes. Among various barn types, finisher and grower-finisher barns were most studied.

- Total bacterial counts (in cells $\mathrm{m}^{-3}$ ) varied greatly in swine barns. Both the lowest (BDL) and the highest counts $\left(1.6 \times 10^{10}\right)$ were reported by Radon et al. (2002). Again, special attention should be paid to exceptionally high count values. The total bacterial counts typically fell into the range of $10^{6}-10^{8}$ cell $\mathrm{m}^{-3}$, two-to-three orders of magnitude greater than that for culturable bacteria $\left(10^{3}-10^{6}\right.$ CPU $\mathrm{m}^{-3}$ ). The total bacterial counts derived from $16 \mathrm{~S}$ rRNA qPCR exhibited even greater variability, ranging from $1.6 \times 10^{5}$ (Masclaux et al., 2013) to $\sim 10^{20}$ copies $\mathrm{m}^{-3}$ (Kraemer et al., 2019). A single bacterial cell can contain multiple copies of $16 \mathrm{~S}$ rRNA genes and the number of copies varies with bacterial species (Chapelle et al., 2002). Therefore, there is no well-established relationship that can readily translate bacterial counts from gene copies to cells. 
- Total fungal counts (in cells $\mathrm{m}^{-3}$ ) also varied substantially in the literature and typically stayed in the range of $10^{3}-10^{6}$ cells $\mathrm{m}^{-3}$. This is one-to-two orders of magnitude greater than that of culturable fungi $\left(10^{2}-10^{4} \mathrm{CPU} \mathrm{\textrm {m } ^ { - 3 }}\right)$. Only one study reported the fungal counts derived from ITS qPCR (Kumari and Choi, 2014), spanning from $\sim 10^{4}$ to $10^{7}$ copies $\mathrm{m}^{-3}$.

- A direct comparison of culturable versus total counts revealed that only a small portion of airborne bacteria/fungi in swine barns are culturable. Lange et al. (1997) reported that culturable bacterial counts were about two orders of magnitude lower than total bacterial counts derived from DAPI staining coupled with cytometric or EFM counting. Radon et al. (2002) found that culturable bacterial counts accounted for on average only $1.4 \%$ of total bacteria counts while culturable fungi counts were $4.4 \%$ of total fungal counts in the same barns. Chi and $\mathrm{Li}$ (2005) compared culturable bacterial counts versus total bacterial counts derived from three different methods (EFM/AO, EFM/DAPI, and FISH/DAPI) and found that regardless of the methods, culturable counts were one to three orders-of-magnitude lower than total counts. A similar observation was made by Vanhee et al. (2008), Létourneau et al. (2009), Thorne et al. (2009), Bonifait et al. (2014), and Lee and Liao (2014).

- Total bacterial/fungal counts showed significant seasonal variability. In nearly all reports, total bacterial/fungal counts were highest in winter and lowest in summer (Kumari and Choi, 2014, 2015; Kumari et al., 2016; Kraemer et al., 2019). The only exception is Thorne et al. (2009) in which the highest counts of total microbes occurred in summer in regular swine barns but fall in hoop barns. A significant seasonal effect was found through reduced ANOVA modeling. No winter samples were analyzed in the same study.

- Little is known about the effect of barn types or waste management systems. Only one study compared different barn types (Chi and Li, 2005), with no significant effect found. However, multiple types of barns are often collocated to form a farm complex in Taiwan, which is different from the setting in the U.S. Thus, it is uncertain whether the finding would apply to the U.S. pork production systems. Only one study compared different waste management systems (Kumari and Choi, 2005), with significantly greater total bacterial counts detected in barns with slatted floors and deep pits than those with beddings. No discussion about possible reasons was offered.

- Challenges remain regarding the interpretation of qPCR-derived total count data. As qPCR becomes increasingly accessible and affordable, numerous qPCR data were generated in the past decade. To date, the data (in copies $\mathrm{m}^{-3}$ ) have only been used to compare the relative abundance of bacteria/fungi in different environments or barn conditions. How to relate them to the health and welfare of pigs or farm workers remains a technical challenge.

$\underline{\text { Viable bacterial and fungal counts }}$

Viability is critical for assessing the health effects of airborne microbes. Despite the importance of viable bacteria and fungi, the direct measurement of their airborne counts is technically challenging. Only a few studies reported the measurement results from swine barns. The measurement usually involved various assumptions and combined use of multiple technologies. Since only a few reports are available, both the measurement results and methodology are summarized in this section.

Agranovski et al. (2004) measured the counts of viable particles in swine barns using an ultraviolet aerodynamic particle sizer (UVAPS). Viable particles refer to airborne particles carrying viable microbes. The detection of viable particles by UVAPS relies on the autofluorescence of nicotinamide adenine dinucleotide phosphate (NADPH), a fluorophore and an essential molecule for all living organisms (Pöhlker et al., 2012). An assumption behind the measurement is that only viable microbes contain NADPH and that no interference from other fluorophores occurs at the exciting light wavelength (335 $\mathrm{nm})$ in the UVAPS. An average concentration of $(10.71 \pm 4.41) \times 10^{6}$ particles $\mathrm{m}^{-3}$ was reported. 
Chi and Li (2005) studied the viability of airborne microbes in swine barns with three methods: (1) PI staining followed by EPM counting - since PI can stain completely damaged cells, viable counts can be acquired by subtracting damaged dead cells from total counts; (2) YOPRO-1 staining followed by EPM counting - YOPRO-1 can stain both partially and completely damaged cells so viable counts can be estimated by subtracting damaged cells from total counts; and (3) FISH coupled with EPM counting assuming that only viable cells have enough DNA to be hybridized with fl-Univ FISH probes, viable counts can be acquired from EPM counting of FISH-labeled cells. Approximately 55\% of total microbes were found to be viable with the PI method, $37 \%$ with the YOPRO- 1 method, and $66 \%$ with the FISH method. Li and Liao (2014) used a similar method (PI staining followed by EPM counting) to study the viability of swine barn aerosols. An average viable fungal count of $4.1 \times 10^{5}$ cells m$^{-3}$ (range: $3.6 \times 10^{5}$ $5.6 \times 10^{5}$ ) was reported, accounting for on average $27.9 \%$ (range: $22.2 \%-62.5 \%$ ) of total fungi.

Chang et al. (2017) used viable-qPCR (vPCR) to measure viable airborne bacteria in multiple indoor environments, including swine barns. The method combined propidium monoazide (a DNA stain) and 16S rRNA qPCR to construct a calibration curve (of 16rRNA gene copies versus viable cells) for viability assessment. However, no measurement data was given for swine barns.

\subsubsection{Viruses}

Airborne transmission has been long recognized as a pathway for the spread of infective zoonotic viruses, including porcine viruses (Sattar et al., 1987). For example, Donaldson and Ferris (1976) studied the survivability of airborne African swine fever viruses - which remain as one of the most critical swine pathogens today - at different relative humidity levels. Other investigated airborne porcine viruses include influenza A virus (IAV) and foot-and-mouth disease virus (FMDV), as summarized in Ijaz (1985). Early investigations focused on the survivability of porcine viruses in the air, a key factor for viral spread and infection; and they stimulated the development of relevant measurement technologies (Ijaz, 1987; Cox, 1989). Nearly all these investigations were done in the lab, likely because of biosecurity considerations and viral detection being then complicated and labor-intensive.

A milestone paper about airborne porcine viruses is Torremorell et al. (1997) and it provided the first experimental evidence for airborne viral transmission in swine barns. The experiment spatially separated healthy pigs from pigs inoculated with porcine reproductive and respiratory syndrome viruses (PRRSV) and the initially healthy group was found to be PRRSV-positive after 16 days. This artificial inoculation method was adopted by many follow-up studies. For example, Dee et al. (2009) reported the detection of PRRSV-positive bioaerosol samples $4.7 \mathrm{~km}$ away from artificially infected barns, backing a longstanding viewpoint that airborne transmission can attribute to a regional outbreak of porcine reproductive and respiratory syndromes (PRRS) (Albina, 1997). Despite intense interest in airborne porcine viruses, field measurement reports remain sporadic.

To our knowledge, the first field measurement of airborne viruses in swine barns was done by Verreault et al. (2010). Since then, 15 field studies have been reported (Table 7). A brief overview of part of these studies can be found in Anderson et al. (2017). This section summarizes each study in greater detail and includes the latest efforts (2017-present). Only the direct measurement of airborne viruses in production barns is reviewed here. Indirect measurement [e.g., using infected pigs as an indication of airborne transmission (Brokmeier and Lager, 2002; Otake et al., 2002)] or artificially infected barns [e.g., Torremorell et al. (1997), Dee et al. (2009), and Alonso et al. (2015)] is excluded. These studies are important in understanding the airborne transmission of pathogenic viruses in and around swine farms but do not represent actual barn conditions.

Table 7. Field measurement of airborne viruses in swine barns.

\begin{tabular}{|l|l|l|l|l|l|}
\hline Reference & $\begin{array}{l}\text { Barn \& } \\
\text { ventilation } \\
\text { type }^{1}\end{array}$ & Location & Season & $\begin{array}{l}\text { Analytical } \\
\text { method }^{2}\end{array}$ & Key findings and/or notes \\
\hline
\end{tabular}




\begin{tabular}{|c|c|c|c|c|c|}
\hline $\begin{array}{l}\text { Verreault et al. } \\
(2010)\end{array}$ & $\begin{array}{l}\text { Farrowing, } \\
\text { nursery, } \\
\text { grower- } \\
\text { finisher; n/a }\end{array}$ & $\begin{array}{l}\text { Quebec, } \\
\text { Canada }\end{array}$ & $\begin{array}{l}\text { All } \\
\text { seasons }\end{array}$ & qPCR & $\begin{array}{l}\text { Most TSP samples were PCV2 } \\
\text { positive. Airborne PCV2 } \\
\text { concentrations ranged from } 2 \times 10^{3} \text { to } \\
10^{7} \text { copies } \mathrm{m}^{-3} \text {. A significant but weak } \\
\text { correlation was found between } \\
\text { airborne PCV2 and PM } \\
\text { concentrations. }\end{array}$ \\
\hline $\begin{array}{l}\text { Corzo et al. } \\
(2013)\end{array}$ & $\begin{array}{l}\text { Nursery (1 } \\
\text { farm), wean- } \\
\text { to-finish (3 } \\
\text { farms) }\end{array}$ & $\begin{array}{l}\text { Iowa, } \\
\text { Minnesota }\end{array}$ & $\begin{array}{l}\text { Spring, } \\
\text { fall }\end{array}$ & $\begin{array}{l}\text { Real-time } \\
\text { RT-PCR }\end{array}$ & $\begin{array}{l}\text { Presumptively infected farms were } \\
\text { visited. All farms but one (wean-to- } \\
\text { finish) were found to be IAV positive } \\
\text { with collected bioaerosol samples. The } \\
\text { average IAV concentration was } \\
3.20 \pm 4.01 \times 10^{5} \text { copies } \mathrm{m}^{-3} \text {. The } \\
\text { detected IAV subtypes included } \\
\text { H1N2, H1N } 1 \text {, and H3N2. The air at } \\
\text { the exhaust and that downwind (up to } \\
1.9 \mathrm{~km} \text { ) from the infected barns also } \\
\text { contained IAV. }\end{array}$ \\
\hline $\begin{array}{l}\text { Rodríguez de } \\
\text { Evgrafov et al. } \\
(2013)\end{array}$ & $\begin{array}{l}\text { Nursery, } \\
\text { grower, } \\
\text { finisher, } \\
\text { Wean-to- } \\
\text { finish; n/a }\end{array}$ & Colorado & $\begin{array}{l}\text { Spring, } \\
\text { summer, } \\
\text { fall }\end{array}$ & qPCR & $\begin{array}{l}\text { PCV2 was detected in all but nursery } \\
\text { barns, with airborne concentrations } \\
\text { ranging from } 10^{3}-10^{5} \text { copies } \mathrm{m}^{-3} \text {. The } \\
\text { PCV2 genotypes identified through } \\
\text { DNA sequencing included PCV2, } \\
\text { PCV2a, PCV2b, PCV1/2a, and } \\
\text { PCV2e. }\end{array}$ \\
\hline $\begin{array}{l}\text { Brito et al. } \\
(2014)\end{array}$ & $\begin{array}{l}\text { Farrowing, } \\
\text { gestation, } \\
\text { gilts; n/a }\end{array}$ & $\begin{array}{l}\text { Iowa, } \\
\text { Minnesota, } \\
\text { South } \\
\text { Dakota }\end{array}$ & $\begin{array}{l}\text { Fall, } \\
\text { winter }\end{array}$ & $\begin{array}{l}\text { Real-time } \\
\text { RT-PCR }\end{array}$ & $\begin{array}{l}\text { Bioaerosol samples were collected } 30 \\
\text { m downwind from farms during an } \\
\text { outbreak, with } 37 \% \text { of the samples } \\
\text { being PRRSV positive. Phylogenetic } \\
\text { analysis was done through sequencing, } \\
\text { with } 19 \text { viral clades identified. Viral } \\
\text { concentrations were presented in } \\
\text { median tissue culture infectious dose } \\
\left.\text { per mL of sample (TCID } \mathrm{mL}_{50}^{-1}\right) \text {. }\end{array}$ \\
\hline $\begin{array}{l}\text { Priebe et al. } \\
(2015)\end{array}$ & $\begin{array}{l}\text { Wean-to- } \\
\text { finish; } \mathrm{n} / \mathrm{a}\end{array}$ & Demark & $\mathrm{n} / \mathrm{a}$ & $\begin{array}{l}\text { Real-time } \\
\text { RT-PCR }\end{array}$ & $\begin{array}{l}\text { Bioaerosol samples from four infected } \\
\text { herds were analyzed. The majority of } \\
\text { in-barn samples were PRRSV positive. } \\
\text { Outdoor samples ( } \sim 30 \text { m downwind) } \\
\text { were also tested, with four out of } 20 \\
\text { being positive. }\end{array}$ \\
\hline $\begin{array}{l}\text { Anderson et } \\
\text { al. }(2016)\end{array}$ & $\begin{array}{l}\text { Nursery, } \\
\text { grower, } \\
\text { finisher, } \\
\text { sow; n/a }\end{array}$ & China & $\begin{array}{l}\text { Summer, } \\
\text { fall, } \\
\text { winter }\end{array}$ & $\begin{array}{l}\text { Real-time } \\
\text { RT-PCR }\end{array}$ & $\begin{array}{l}\text { None of the summer bioaerosol } \\
\text { samples were IAV positive; while } 9 \\
\text { fall/winter bioaerosol samples (out of } \\
95 \text { ) were positive. The positive rate of } \\
\text { bioaerosol samples was lower than } \\
\text { that of pig oral secretion samples or } \\
\text { environmental swab samples. }\end{array}$ \\
\hline $\begin{array}{l}\text { Neira et al. } \\
(2016)\end{array}$ & $\mathrm{n} / \mathrm{a} ; \mathrm{n} / \mathrm{a}$ & $\begin{array}{l}\text { Iowa, } \\
\text { Minnesota }\end{array}$ & $\begin{array}{l}\text { Fall, } \\
\text { winter, } \\
\text { spring }\end{array}$ & $\begin{array}{l}\text { Real-time } \\
\text { RT-PCR }\end{array}$ & $\begin{array}{l}43 \% \text { of in-barn bioaerosol samples } \\
\text { were IAV positive, slightly lower than } \\
\text { the positive rate }(48 \%) \text { of pig oral }\end{array}$ \\
\hline
\end{tabular}




\begin{tabular}{|c|c|c|c|c|c|}
\hline & & & & & $\begin{array}{l}\text { secretion samples. Bioaerosol samples } \\
\text { were also collected } 25 \mathrm{~m} \text { upwind and } \\
\text { downwind from barns but none of } \\
\text { them was IAV positive. }\end{array}$ \\
\hline $\begin{array}{l}\text { O’Brien and } \\
\text { Nonnenmann } \\
(2016)\end{array}$ & $\mathrm{n} / \mathrm{a} ; \mathrm{n} / \mathrm{a}$ & Iowa & $\mathrm{n} / \mathrm{a}$ & $\begin{array}{l}\text { Real-time } \\
\text { RT-PCR }\end{array}$ & $\begin{array}{l}\text { Two samplers (NIOSH bioaerosol } \\
\text { sampler BC251 and PHISH) were } \\
\text { used for assessing the personal } \\
\text { exposure of veterinarians in infected } \\
\text { barns. The geometric mean IAV } \\
\text { concentration was } 2,094 \text { copies } \mathrm{m}^{-3} \\
\text { using the NIOSH sampler and } 545 \\
\text { copies } \mathrm{m}^{-3} \text { using the PHISH sampler. } \\
\text { Three IAV subtypes were identified: } \\
\text { H1N1, H3N2, and H1N2. }\end{array}$ \\
\hline $\begin{array}{l}\text { Alonso et al. } \\
(2017)\end{array}$ & Nursery; n/a & Minnesota & Spring & $\begin{array}{l}\text { Real-time } \\
\text { RT-PCR }\end{array}$ & $\begin{array}{l}\text { Presumptively infected farms were } \\
\text { visited to compare two bioaerosol } \\
\text { samplers (Andersen eight-stage non- } \\
\text { viable cascade impactor and Tisch } \\
\text { four-stage non-viable cascade } \\
\text { impactor) for their performance } \\
\text { regarding PRRSV and PEDV } \\
\text { sampling. Seven out of } 16 \text { samples } \\
\text { were PRRSV positive, and } 12 \text { out of } \\
12 \text { samples were PEDV positive. The } \\
\text { PRRSV positive rate derived from } \\
\text { Tisch was lower than that from } \\
\text { Andersen. The airborne virus } \\
\text { concentration was } 10^{6.04 \pm 0.72} \text { copies } \mathrm{m}^{-3} \\
\text { for PEDV and } 10^{3.79 \pm 1.35} \text { copies } \mathrm{m}^{-3} \text { for } \\
\text { PRRSV. Outdoor bioaerosol samples } \\
\text { were also tested. }\end{array}$ \\
\hline $\begin{array}{l}\text { Naide et al. } \\
(2018)\end{array}$ & $\begin{array}{l}\text { Nursery; } \\
\text { MV \& NV }\end{array}$ & Japan & $\begin{array}{l}\text { Winter, } \\
\text { summer }\end{array}$ & $\begin{array}{l}\text { Real-time } \\
\text { RT-PCR }\end{array}$ & $\begin{array}{l}\text { Barn-average airborne PSV } \\
\text { concentrations ranged from } 10^{3.57} \text { to } \\
10^{4.03} \text { copies } \mathrm{m}^{-3} \text { in summer and from } \\
10^{5.22} \text { to } 10^{5.85} \text { copies } \mathrm{m}^{-3} \text { in winter. No } \\
\text { correlation between airborne PSV and } \\
\text { PM concentrations was found. }\end{array}$ \\
\hline $\begin{array}{l}\text { Stein et al. } \\
(2018)\end{array}$ & $\begin{array}{l}\text { Nursery, } \\
\text { finisher; n/a }\end{array}$ & Germany & $\mathrm{n} / \mathrm{a}$ & $\begin{array}{l}\text { Real-time } \\
\text { RT-PCR }\end{array}$ & $\begin{array}{l}\text { The study collected bioaerosol } \\
\text { samples from three PRRSV-2 infected } \\
\text { barns with three different samplers } \\
\text { (Coriolis } \AA \mu, \text { MD8 Airscan, and IOM } \\
\text { Multidust). None of the field samples } \\
\text { were PRRSV-2 positive. }\end{array}$ \\
\hline $\begin{array}{l}\text { Wenke et al. } \\
(2018)\end{array}$ & $\begin{array}{l}\text { Finisher; } \\
\text { MV }\end{array}$ & Germany & $\begin{array}{l}\text { All } \\
\text { seasons }\end{array}$ & $\begin{array}{l}\text { Real-time } \\
\text { RT-PCR }\end{array}$ & $\begin{array}{l}\text { No PRRSV was detected in any barns. } \\
\text { The reason was ascribed to no } \\
\text { infection or blow the qPCR's detection } \\
\text { limit. }\end{array}$ \\
\hline $\begin{array}{l}\text { Vilata et al. } \\
(2019)\end{array}$ & $\begin{array}{l}\text { Farrowing- } \\
\text { to-wean; n/a }\end{array}$ & $\begin{array}{l}\text { U.S. } \\
\text { Midwest }\end{array}$ & $\mathrm{n} / \mathrm{a}$ & $\begin{array}{l}\text { Real-time } \\
\text { RT-PCR }\end{array}$ & $\begin{array}{l}\text { Deposition samples in an infected barn } \\
\text { were collected (until } 23 \text { weeks after an } \\
\text { outbreak) for PRRSV analysis. For }\end{array}$ \\
\hline
\end{tabular}




\begin{tabular}{|c|c|c|c|c|c|}
\hline & & & & & $\begin{array}{l}\text { newborns ( } 3-5 \text { days), } 24 \% \text { of aerosol } \\
\text { samples were PRRSV positive. For } \\
\text { piglets of } \sim 21 \text { days, } 33.3 \% \text { of aerosol } \\
\text { samples were positive. }\end{array}$ \\
\hline Bell (2020) & $\begin{array}{l}\text { Farrowing, } \\
\text { gestation; } \\
\text { MV }\end{array}$ & $\begin{array}{l}\text { Ontario, } \\
\text { Canada }\end{array}$ & $\begin{array}{l}\text { All } \\
\text { seasons }\end{array}$ & $\begin{array}{l}\text { Real-time } \\
\text { RT-PCR }\end{array}$ & $\begin{array}{l}\text { Four samplers were used: a PTFE } \\
\text { filter in an open cassette, a NIOSH } \\
\text { cyclone, a Coriolis }{ }^{\circledR} \mu \text { sampler, and a } \\
\text { SASS } 3100 \text { bioaerosol sampler. IAV- } \\
\text { positive samples accounted for } 28.9 \% \text {, } \\
30.3 \%, 11 \% \text {, and } 0 \% \text { of those from the } \\
\text { four samplers, respectively. Viral } \\
\text { phenotyping was done through high- } \\
\text { throughput sequencing. }\end{array}$ \\
\hline $\begin{array}{l}\text { López- } \\
\text { Lorenzo et al. } \\
(2021)\end{array}$ & $\begin{array}{l}\text { Wean-to- } \\
\text { finish; NV }\end{array}$ & Spain & $\mathrm{n} / \mathrm{a}$ & qPCR & $\begin{array}{l}\text { Three batches were monitored: one } \\
\text { unvaccinated and two vaccinated. } \\
\text { Bioaerosol samples from the } \\
\text { unvaccinated batch showed greater } \\
\text { PCV } 2 \text { concentrations }\left(1.19 \times 10^{3} \text { - }\right. \\
2.42 \times 10^{7} \text { copies } \mathrm{m}^{-3} \text {; Note: positive } \\
\text { samples only) than those from } \\
\text { vaccinated batches }\left(5.39 \times 10^{2}-\right. \\
\left.5.93 \times 10^{4} \text { copies } \mathrm{m}^{-3}\right) \text {. Positive } \\
\text { bioaerosol samples occurred earlier } \\
\text { than positive blood samples. }\end{array}$ \\
\hline
\end{tabular}

Note:

${ }^{1} \mathrm{MV}$ - mechanical ventilation; NV - natural ventilation.

${ }^{2}$ RT-PCR - reverse transcript polymerase chain reaction.

${ }^{3}$ PCV2 - porcine circovirus type 2; IAV - influenza A virus; PRRSV - porcine reproductive and respiratory syndrome virus; PEDV - porcine epidemic diarrhea virus; PSV - porcine sapelovirus; PHISH - personal high-flow inhalable sampler head.

Among the 15 field measurement reports, seven came from the U.S. (in particular Upper Midwest), four from Europe, and two each from Canada and Asia. Five common porcine viruses were studied: PCV2, IAV, PRRSV, PEDV, and PSV. PCV2 is a DNA virus. The rest are RNA viruses, demanding a different measurement method. IAV has been the most measured virus, followed by PRRSV. The presence of IAV, PCV2, and PSV is common in commercial production barns because they present relatively low hazards (except for high-risk subtypes); whereas PRRSV and PEDV are highly hazardous, with stringent surveillance and elimination programs implemented to prevent their presence. Accordingly, airborne PRRSV and PEDV measurement was primarily done in infected or presumptively infected swine barns (Brito et al., 2014; Priebe et al., 2015; Alonso et al., 2017; Vilata et al., 2019). Three studies further examined the subtypes of viruses through sequencing (Rodríguez de Evgrafov et al., 2013; Brito et al., 2014; Bell, 2020).

The measurement results affirmed the presence of IAV, PCV2, and PSV in the air of swine barns. For IAV, the occurrence frequency of positive samples ranged from $0 \%$ [summer samples in Anderson et al. (2016)] to $68 \%$ [calculated from Corzo et al. (2013)] and the measured airborne concentration was up to $1.25 \times 10^{6}$ copies $\mathrm{m}^{-3}$ (Neira et al., 2016). For PCV2, positive samples ranged from $25 \%$ (López-Lorenzo et al., 2021) to $91 \%$ (Verreault et al., 2010) in occurrence frequency and from $10^{3}$ (Rodríguez de Evgrafov et al., 2013) to $2.42 \times 10^{7}$ copies $\mathrm{m}^{-3}$ (López-Lorenzo et al., 2021) in airborne concentrations. For PSV, only one study was available (Naide et al., 2018) in which all bioaerosol samples were found PSV-

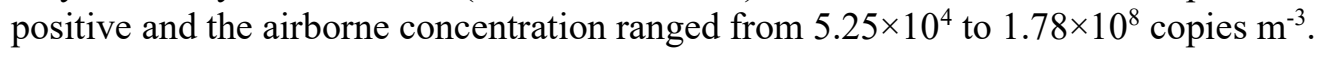


The measurement results affirmed the presence of PRRSV and PEDV in the air of swine barns during and after an outbreak. Wenke et al. (2018) reported the absence of airborne PRRSV in uninfected finisher barns. Comparatively, 24\% (Vilata et al., 2019) to 44\% (Alonso et al., 2017) of bioaerosol samples in infected barns were PRRSV-positive. Only one report is available about PEDV measurement (Alonso et al., 2017). All collected bioaerosol samples were found PEDV-positive. Airborne PRRSV and PEDV concentration data are sporadic, with a single report available (Alonso et al., 2017). Bioaerosol samples persisted to be PRRSV-positive 14 weeks after an outbreak (Vilata et al., 2019). No reference (threshold) concentration or dose values were available regarding inhalation exposure to the two viruses.

Six studies measured porcine viruses in outdoor bioaerosol samples. Five of them identified the presence of viruses but at lower concentrations or occurrence frequency than in-barn samples (Corzo et al., 2013; Brito et al., 2014; Brito et al., 2014; Priebe et al., 2015; Alonso et al., 2017). Only one study reported the absence of viruses (IAV) in outdoor samples (Neira et al., 2016). In particular, Corzo et al. (2013) reported an average IAV concentration of $6.83 \times 10^{3}$ copies $\mathrm{m}^{-3} 1.9 \mathrm{~km}$ downwind from an IAV-infected commercial farm. Positive outdoor samples suggest the possibility of farm-to-farm airborne viral transmission and the necessity of having filtered air inlets to protect high-value pig herds from airborne porcine viruses.

Little is known regarding the effect of barn types and seasons. Because of the limited data, no statistical analysis was done to compare different barn types or seasons. Verreault et al. (2010) noted a farrowing barn to be the only PCV2-negative barn during their field survey. Rodríguez de Evgrafov et al. (2013) reported that the highest airborne PCV2 concentrations occurred in a grower barn. Naide et al. (2018) compared airborne PSV concentrations between winter and summer samples and found an overall higher concentration in winter. However, Verreault et al. (2010) reported that no correlation existed between airborne PCV2 concentrations and outdoor temperatures.

Sampling methods affect measurement results. O'Brien and Nonnenmann (2016) reported that higher IAV concentrations were derived from a NIOSH BC251 bioaerosol sampler than from a PHISH sampler. Alonso et al. (2017) compared an Andersen eight-stage non-viable cascade impactor with a Tisch fourstage non-viable cascade impactor and found the Tisch yield higher airborne viral concentrations than the Andersen impactor. Bell (2020) compared four different bioaerosol samplers and found that the highest percent of IAV-positive samples was from a NIOSH cyclone sampler and the lowest percent $(0 \%)$ from a SASS 3100 dry bioaerosol sampler.

Limited information is available regarding the size distribution of airborne porcine viruses. Only two studies conducted size-segregated viral measurement (O'Brien and Nonnenmann, 2016; Alonso et al., 2017). Both studies reported that the majority of airborne viruses (IAV, PRRSV, and PEDV) were associated with coarse PM $(>4 \mu \mathrm{m})$. This suggests that these viruses tend not to exist as individual particles in the air but rather attach to large particles during airborne transmission. For IAV and PEDV, a minor size distribution peak occurred in the submicron range (i.e., $<1 \mu \mathrm{m}$ ), which may be attributed to individual viral particles.

Bioaerosol monitoring may serve as a useful tool for field surveillance of porcine viruses. In reality, many field studies took this (tool development) as a goal. In addition to bioaerosol samples, pig nasal swab, oral fluid, and environmental swab samples were often collected. Because of the small volume of bioaerosol samples (and accordingly fewer viral genomic materials), airborne viral detection was less sensitive and required a greater cycle threshold $(\mathrm{Ct})$ than the analysis of other samples (Refer to Section 4.4.2).

However, bioaerosol measurement still showed its great potential as it yielded only slightly lower positive counts than pig oral secretion or environmental swab samples (Anderson et al., 2016; Neira et al., 2016; López-Lorenzo et al., 2021), enabled earlier viral detection than blood sample analysis (López-Lorenzo et al., 2021), and was able to reflect the onset, peak, and disappearance of a viral infection episode (Vilata et al., 2019; López-Lorenzo et al., 2021). 
Extensive research has been done to mitigate airborne porcine viruses, including mitigation technology development and performance assessment. The former research was predominantly conducted in the lab with artificial viral suspensions or artificially inoculated pigs. For example, Naide et al. (2015) examined the effectiveness of spraying functional water in reducing airborne PSV, PEDV, and picornaviruses. The test was done in an experimental room using a nebulizer to aerosolize viral particles. Other mitigation technology development studies include Dee et al., (2005), La et al. (2019), Nayak et al. (2020), and Létourneau et al. (2020), to name a few; and none of them were done in actual production barns. The performance of viral mitigation technologies was assessed through lab experiments, epidemiological (cohort) studies (Alonso et al., 2013), and ventilation modeling (Janni et al., 2018). The latter two types of studies have been, to date, restricted to filtered air inlet systems (that are increasingly popular in Upper Midwest). No field measurement of airborne viruses has yet been done to validate the performance of viral mitigation technologies.

\subsubsection{Microbial composition}

Different from cell or viral counting, microbial composition (also known as microbial community composition) analysis focuses on the identification of microbial species in PM samples. Although counting can be selective of target microbial species (e.g., E. coli or Salmonella spp.), it lacks the capability of generating a taxonomic spectrum. Two types of methods are used in microbial composition analysis: culture-dependent and culture-independent methods. Correspondingly, this section is structured into two parts. A review of the relevant methods is available in Section 4.4.3. Culture-dependent methods were commonly used in early investigations. With the advances in molecular biology technologies, most of the recent studies selected culture-independent methods for composition analysis.

\section{Culture-dependent methods}

The interest in PM microbial composition is largely driven by health considerations. Pathogenic bacteria (e.g., E. coli and Salmonella) and fungi (e.g., mucormycetes [black fungus]) can be transmitted in the air and cause a variety of adverse health effects on humans and animals (Donham, 1990; Douwes et al., 2003). These pathogens can colonize and infect organs, produce toxins, reproduce, and hijack nutrients only when they are alive. Thus, it is important to identify viable microbes in swine barn PM. However, this is technically difficult and for decades, culturable microbes have been studied as an alternative.

The effort to identify microbial species in swine barn PM can date back to the 1970s. Elliott et al. (1976) measured culturable bacterial counts in a grower-finisher barn in Nebraska. They further identified Staphylococcus and Salmonella on formed bacterial colonies using selective agars and biochemical testing. In a follow-up study in Nebraska, Underdahl et al. (1982) found that culturable bacteria in the air of swine barns were primarily micrococci. Clark et al. (1983) identified 8 bacterial species or genera in the air of swine barns (Acinetobacter calcoacetucus, Alcaligenes odorans, Enterobacter agglomerans, Enterococcus, E. coli, Klebsiella, Pseudomonas, and Pseudomonas syringae) and found that a large percentage of bacterial colonies comprised of Gram-positive Enterococcus. A fungal species Aspergillus fumigatus was also identified using a selective agar. Donham et al. (1986) reported 6 predominant fungal genera (Penecillium, Alternaria, Aspergillus, Fucarium, Verticillium, and Scopulariopsis) detected in swine barns in Iowa and 6 predominant fungal genera (Penecillium, Alternaria, Aspergillus, Rhizopus, Cladosporium, and Homodendrum) in Swedish swine barns. Karlsson and Malmberg (1989) measured bacterial and fungal counts in 79 farms in Sweden including swine barns, and found Aspergillus and Penecillium to be the predominant fungal genera.

Additional bacterial and fungal species have been identified since 1990. To make a summary manageable, the identification results are organized based on barn types and classified into multiple taxonomic levels (Table 8). No references are given for each identified microbial species (because it would otherwise make the table too wordy). Instead, all the relevant references are listed below the table. Bacterial and fungal species were also detected in settled dust, e.g., Martin et al. (1996). However, it is uncertain whether 
settled dust and PM share a similar microbial composition because many factors can affect the viability of microbes. Thus, no relevant studies are included in this review effort.

Table 8. Microorganisms identified in swine barn PM using culture-dependent methods - A summary of studies since 1990.

\begin{tabular}{|c|c|}
\hline Barn type & Microorganisms identified $^{1,2}$ \\
\hline Farrowing & $\begin{array}{l}\text { Bacteria - } \\
\text { Phyla: Proteobacteria, Actinobacteria, Firmicutes } \\
\text { Classes: Gammaproteobacteria, Actinobacteria, Bacilli } \\
\text { Orders: Pseudomonadales, Enterobacterales, Pasteurellales, Micrococcales, Mycobacteriales, } \\
\text { Bacillales, Streptomycetales, Caryophanales, Pseudonocardiales, Streptosporangiales } \\
\text { Families: Moraxellaceae, Enterobacteriaceae, Pasteurellaceae, Micrococcaceae, } \\
\text { Corynebacteriaceae, Staphylococcaceae, Streptomycetaceae, Nocardiaceae, Erwiniaceae, } \\
\text { Thermoactinomycetaceae, Pseudonocardiaceae, Thermomonosporaceae, } \\
\text { Genera: Acinetobacter, Enterobacter, Escherichia, Moraxella, Pasteurella, Pseudomonas, } \\
\text { Arthrobacter, Corynebacterium, Staphylococcus, Streptomyces, Rhodococcus, } \\
\text { Klebsiella, Erwinia, Thermoactinomycetes, Saccharopolyspora, Saccharomonospora, } \\
\text { Thermomonospora } \\
\text { Species: Acinetobacter calcoaceticus, Enterobacter agglomerans, E. coli, Moraxella spp., } \\
\text { Pasteurella spp., Pseudomonas spp., Klebsiella pneumonia, Klebsiella oxytoca, Erwinia } \\
\text { herbicola, Enterobacter cloacae, Thermoactinomyces vulgaris, Thermoactinomyces } \\
\text { thalpophilus, Saccharopolyspora rectivirgula, Saccharomonospora viridis, } \\
\text { Thermomonospora fusca } \\
\text { Fungi- } \\
\text { Phyla: Ascomycota, Mucoromycota, Basidiomycota } \\
\text { Classes: Eurotiomycetes, Mucorales, Sordariomycetes, Saccharomycetes, Tremellomycetes, } \\
\text { Dothideomycetes } \\
\text { Orders: Eurotiales, Mucorales, Hypocreales, Saccharomycetales, Microascales, Tremellales, } \\
\text { Pleosporales } \\
\text { Families: Trichocomaceae, Syncephalastraceae, Dipodascaceae, Mucoraceae, Microascaceae, } \\
\text { Saccharomycetaceae, Trichosporonaceae, Pleosporaceae } \\
\text { Genera: Aspergillus, Circinella, Fusarium, Geotrichum, Mucor, Penicillium, Scopulariopsis, } \\
\text { Candida, Trichosporon, Eurotium, Alternaria, Monilinia } \\
\text { Species: Aspergillus spp., Circinella spp., Fusarium spp., Geotrichum spp., Mucor spp., } \\
\text { Penicillium spp., Scopulariopsis spp., Candida spp., Torulopsis candida, Trichosporon } \\
\text { beigelli, Aspergillus fumigatus, Eurotium repens, Alternaria alternata, Monilinia spp. }\end{array}$ \\
\hline Gestation & $\begin{array}{l}\text { Bacteria - } \\
\text { Phyla: Firmicutes, Actinobacteria, Proteobacteria } \\
\text { Classes: Bacilli, Actinobacteria, Gammaproteobacteria, } \\
\text { Orders: Bacillales, Micrococcales, Enterobacterales, Pseudomonadales } \\
\text { Families: Bacillaceae, Micrococcaceae, Erwiniaceae, Pseudomonadaceae, Moraxellaceae } \\
\text { Genera: Staphylococcus, Arthrobacter, Erwinia, Pseudomonas, Acinetobacter } \\
\text { Species: Staphylococcus equorum, Arthrobacter arilaitensis, Erwinia persicina, Pseudomonas } \\
\quad \text { poae, Acinetobacter lwoffii } \\
\text { Fungi - } \\
\text { Phyla: Ascomycota } \\
\text { Classes: Eurotiomycetes, Sordariomycetes } \\
\text { Orders: Eurotiales, Hypocreales, Onygenales } \\
\text { Families: Trichocomaceae, Stachybotryaceae, Onygenaceae } \\
\text { Genera: Penicillium, Stachybotrys, Chrysosporium } \\
\text { Species: Penicillium spp., Stachybotrys chartarum, Chrysosporium spp. }\end{array}$ \\
\hline Nursery & Bacteria - \\
\hline
\end{tabular}




\begin{tabular}{|c|c|}
\hline & $\begin{array}{l}\text { Phyla: Proteobacteria, Firmicutes } \\
\text { Classes: Gammaproteobacteria, Bacilli } \\
\text { Orders: Caryophanales, Pasteurellales } \\
\text { Families: Staphylococcaceae, Pasteurellaceae } \\
\text { Genera: Staphylococcus, Actinobacillus } \\
\text { Species: Staphylococcus aureus, Actinobacillus pleurophneumoniae }\end{array}$ \\
\hline Finisher $^{3}$ & 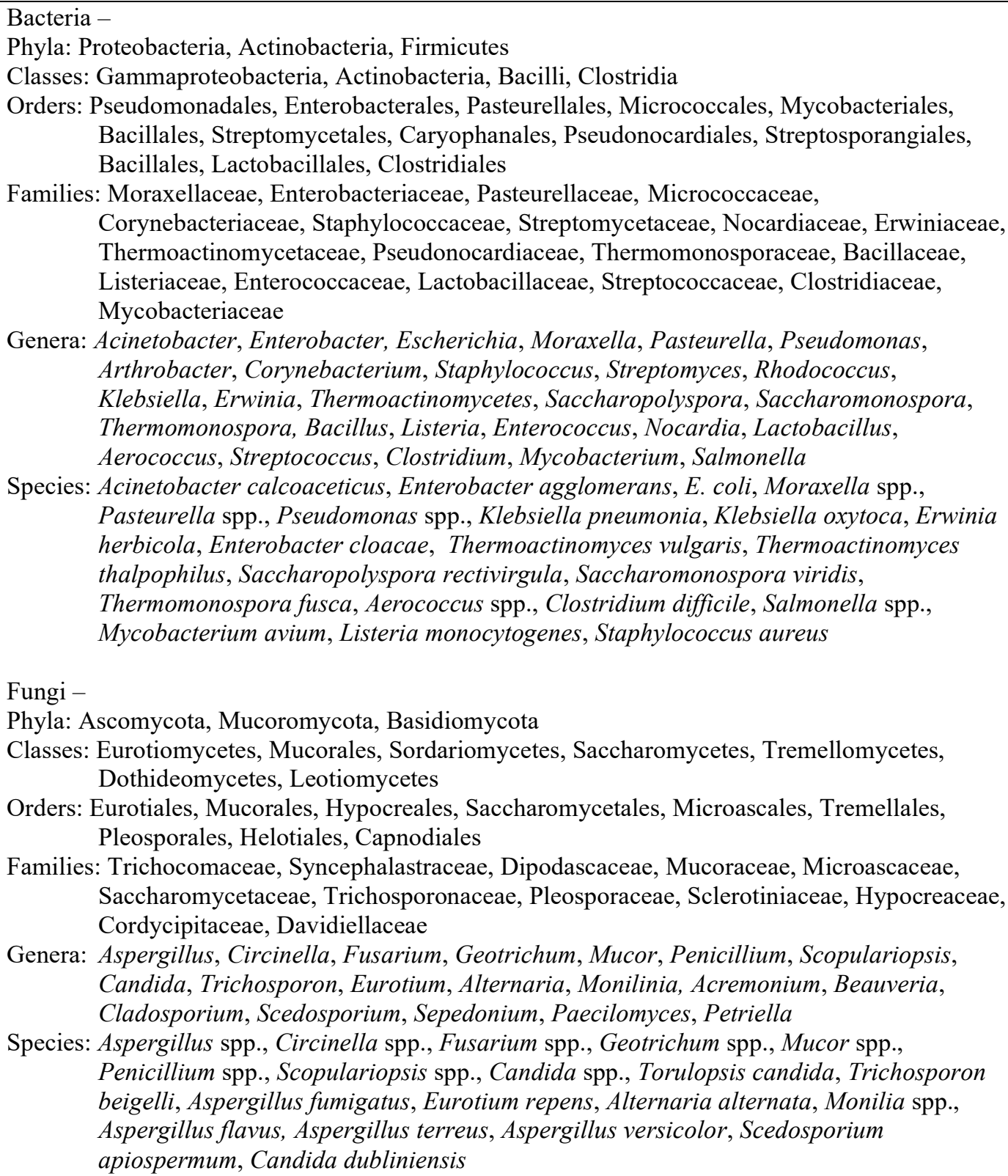 \\
\hline Unspecified $^{4}$ & $\begin{array}{l}\text { Bacteria - } \\
\text { Phyla: Proteobacteria, Actinobacteria, Firmicutes } \\
\text { Classes: Gammaproteobacteria, Actinobacteria, Bacilli } \\
\text { Orders: Pseudomonadales, Micrococcales, Mycobacteriales, Streptomycetales, Bacillales, } \\
\quad \text { Actinomycetales } \\
\text { Families: Moraxellaceae, Micrococcaceae, Corynebacteriaceae, Streptomycetaceae, Bacillaceae, } \\
\quad \text { Actinomycetaceae }\end{array}$ \\
\hline
\end{tabular}




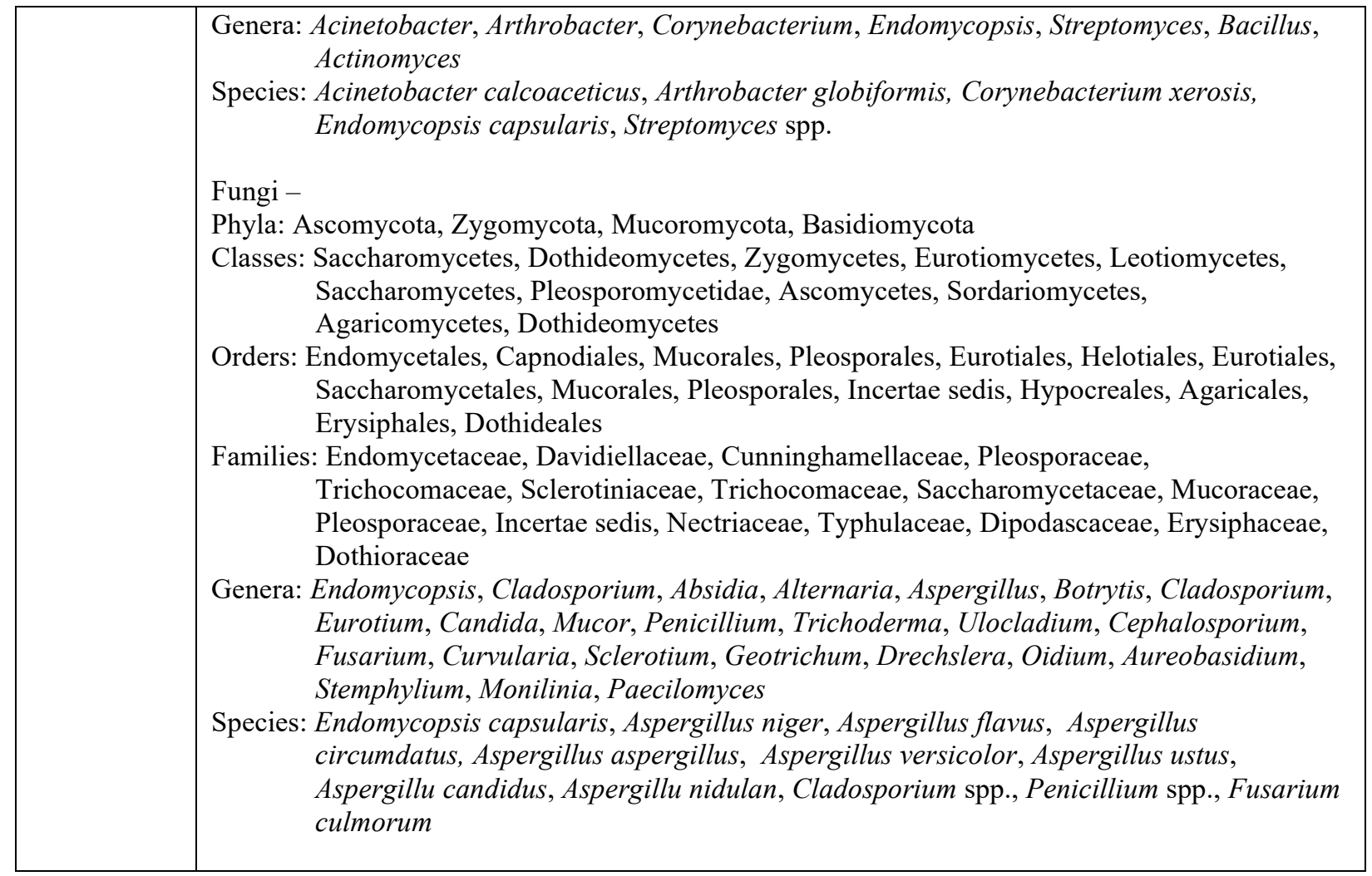

Note:

1 The lists of identified microorganisms were compiled primarily from the following studies: Cormier et al. (1990), Dutkiewicz et al. (1994), Mackiewicz (1998), Duchaine et al. (2000), Chang et al. (2001b), Predicala et al. (2002), Radon et al. (2002), Létourneau et al. (2009), Kristiansen et al. (2012), and Viegas et al. (2017). Several publications in Table 5 [e.g., Keessen et al. (2011) and Gongora et al. (2013)] used selective agar media to identify and quantify certain microorganisms. Although they were not truly microbial composition analyses, the identified microorganisms are also included in the table.

${ }^{2}$ A microorganism unreported in a barn type does not exclude the possibility of its existence. It could simply be because no relevant analysis was done in that barn type.

${ }^{3}$ For simplicity, finisher barns here include grower-finisher and wean-to-finish barns.

${ }^{4}$ The category also includes the studies with multiple barn types (including gestation barns) but providing no barn type-specific microbial composition information.

The following findings are made upon the analysis of the previous publications:

- Although most of the identified microorganisms are unharmful, pathogenic or potentially pathogenic bacteria and fungi were occasionally identified in swine barns. These include bacterial species Acinetobacter lwoffii, E. coli, Enterobacter cloacae, Klebsiella pneumonia, Klebsiella oxytoca, Listeria monocytogenes, Pseudomonas spp., Staphylococcus aureus, and Salmonella spp., bacterial genera Acinetobacter, Actinomyces, Aerococcus, Bacillus, Clostridium, Corynebacterium, Enterobacter, Enterococcus, Escherichia, Klebsiella, Listeria, Moraxella, Mycobacterium, Pasteurella, Pseudomonas, Staphylococcus, Streptococcus, and Salmonella, fungal species Aspergillus spp., Aspergillus niger, Aspergillus flavus, Aspergillus circumdatus, and Aspergillus versicolor, and fungal genera Aspergillus, Candida, and Trichosporon. The information of pathogens here is acquired from Hartmann Science Center, Pathogen Search A-toZ (https://www.bode-science-center.com/center/relevant-pathogens-from-a-z.html). 
- The majority of bacteria identified in swine barn PM are Gram-positive bacteria. The Gramnegative bacteria observed include genera Acinetobacter, Enterobacter, Escherichia, Erwinia, Klebsiella, Moraxella, Pasteurella, Pseudomonas, and Salmonella. Although Gram-negative bacteria account for only a small fraction of the bacterial community, they include many known pathogenic bacterial strains, such as Pseudomonas aeruginosa, E. coli, and Salmonella spp. Thus, they were often counted separately (Table 5) and identified at genus or species levels (Dutkiewicz et al., 1994).

- Quantitative analysis was occasionally done by counting the colonies assigned to be a specific species or group. Dutkiewicz et al. (1994) examined three farrowing and two finisher barns in Poland for the relative abundance of different mesophilic bacteria and found Corynebacteria to be the most abundant. A similar comparison was done for Gram-negative bacteria, thermophilic actinomycetes, and fungi. Mackiewicz (1998) compared the colony counts of six microbial groups among farms and found a significant effect of geographic locations. At two locations, the microbial community was dominated by Corynebacteria while at one location, Gram-positive micrococci were predominant. Gram-negative bacteria accounted for $<3 \%$ of culturable microbial counts. Chang et al. (2001b) studied airborne fungal composition in various swine barns in Taiwan and found the dominance of genus Cladosporium (>92\%) in all visited barn types. Predicala et al. (2002) reported higher counts of Staphylococcus than other identified bacterial genera (Pseudomonas, Bacillus, Listeria, Enterococcus, Nocardia, and Lactobacillus) in growerfinisher barns in Kansas. Kristiansen et al. (2012) reported the dominance of bacterial phylum Firmicutes and fungal phylum Ascomycota in the air of a Danish gestation barn. Again only a portion of viable microbes is culturable. Thus, the quantitative information derived from culturedependent methods may not represent the actual composition of viable microbes.

- Little is known regarding the effect of barn types. Only a few studies compared PM microbial composition in different types of barns, likely because microbial counting and identification require intensive time and labor input. Dutkiewicz et al. (1994) compared farrowing barns with finisher barns in Poland. While no considerable difference was seen in terms of mesophilic bacteria or thermophilic actinomycetes, a substantial difference in Gram-negative bacteria and fungi was observed between the two barn types. Specifically, the visited finisher barns had a lower abundance of Acinetobacter calcoaceticus, Erwinia Herbicols, E. coli, Klebsiella spp., and Pseudomonas spp. but a higher abundance of yeast than farrowing barns. Chang et al. (2001b) measured airborne fungal composition in five types of barns. The measured fungal composition differed with barn types. However, because of limited data points, it is uncertain whether the difference was statistically significant.

Although numerous efforts have been made to measure PM microbial composition with culturedependent methods, several questions remain unanswered. For example, no studies have been done regarding the effects of seasons, ventilation systems, and waste management systems even though their effects on PM microbial composition are anticipated. From a disease transmission standpoint, the PM size of bacterial or fungal pathogens is of critical importance. However, no size-segregated analysis of PM microbial composition (e.g., microflora within 1.1-2.1 $\mu \mathrm{m}$ ) has been conducted. Again, this is likely because of the intensive time and labor required for culture-dependent methods. Some of these questions have been addressed by studies using culture-independent methods.

\section{$\underline{\text { Culture-independent methods }}$}

Culture-independent methods can be classified into two categories: genomics and proteomics. The genomic methods derive microbial species information from the analysis of genetic materials extracted from swine barn PM samples; while the proteomic methods achieve it through fingerprinting proteins and peptides extracted from the PM samples. Most previous studies used genomic methods to analyze microbial composition in swine barn PM. Only a few recent studies used proteomic methods. Under the 
category of genomics methods, various technologies have been adopted, such as clone library and nextgeneration pyrosequencing (NGS). For simplicity, the findings acquired from different technologies are discussed collectively in this section.

It is a daunting challenge to summarize microbial composition analysis results from the previous studies because culture-independent methods often generate massive amounts of data. For example, Hong et al. (2012) - a study we participated in - used 16S rRNA NGS to analyze bacterial composition in TSP samples from 6 poultry barns and 14 swine barns. The study generated 214,795 sequences. Even after bioinformatics analysis, the amount of taxonomic data it created was still formidable. To make the review manageable, no exhaustive list of identified microbial species is provided. Instead, key findings from each study were summarized in Table 9. Following that, a summary and discussion of the existing findings are provided. Microbial species were also identified in settled dust using culture-independent methods, e.g., Boissy et al. (1994) (Note: The study is academically important as it was the first study using shotgun metagenomic pyrosequencing for the analysis of swine barn dust). However, for a potential difference in microbiota between PM and settled dust, no relevant studies are included. Quantitative information, often presented as relative abundance, was available in many publications. The relative abundance of a microbe was measured by the percentage of its counts, sequences, or clones in total identified bacteria or fungi.

Table 9. Microbial composition in swine barn PM - A summary of studies using cultureindependent methods.

\begin{tabular}{|c|c|c|c|c|}
\hline References & Barn type & Location & $\begin{array}{l}\text { Methods }{ }^{1} \& \text { target } \\
\text { microbes }\end{array}$ & Major findings and/or notes \\
\hline \multicolumn{5}{|c|}{ Proteomic methods } \\
\hline $\begin{array}{l}\text { Druckenmüller } \\
\text { et al. (2017) }\end{array}$ & Finisher & Germany & $\begin{array}{l}\text { MALDI-TOF MS } \\
\text { for bacteria }\end{array}$ & $\begin{array}{l}\text { A reference database was created by } \\
\text { comparing proteomics results against } 16 \mathrm{~S} \\
\text { rRNA sequencing results. Using the database, } \\
18 \text { bacterial species were identified, including } \\
5 \text { risk group } 2 \text { pathogens (Aerococcus } \\
\text { virdidans, Corynebacterium striatum, } \\
\text { Staphylococcus epdermidis, Staphylococcus } \\
\text { pasteuri, and Staphylococcus saprophyticus). } \\
\text { Two PM size fractions ( } \mathrm{PM}_{20} \text { and } \mathrm{PM}_{5} \text { ) were } \\
\text { examined. }\end{array}$ \\
\hline $\begin{array}{l}\text { White et al. } \\
(2019)^{2,3}\end{array}$ & $\begin{array}{l}\text { Farrowing, } \\
\text { nursing } \\
\text { nursery, } \\
\text { finisher }\end{array}$ & Denmark & $\begin{array}{l}\text { MALDI-TOF MS } \\
\text { for bacteria } \\
\text { (aerobes \& } \\
\text { anaerobes) and } \\
\text { fungi }\end{array}$ & $\begin{array}{l}\text { The study used MALDI-TOF MS to identify } \\
\text { colony isolates. With that, } 120(96+24) \\
\text { bacterial species and } 27 \text { fungal species were } \\
\text { identified. Many of them were classified into } \\
\text { species levels. The identified bacteria and } \\
\text { fungi included } 28 \text { risk group } 2 \text { pathogens. }\end{array}$ \\
\hline $\begin{array}{l}\text { White et al. } \\
(2020)^{3}\end{array}$ & Finisher & Denmark & $\begin{array}{l}\text { MALDI-TOF MS } \\
\text { for fungi }\end{array}$ & $\begin{array}{l}\text { The study used MALDI-TOF MS to identify } \\
\text { colony isolates. With that, } 40 \text { fungal species } \\
\text { were identified, including } 16 \text { allergens and } 5 \\
\text { risk group } 2 \text { pathogens. Size distribution of } \\
\text { these species was also available. The majority } \\
\text { of fungi occurred in the size range of } 1.1-3.3 \\
\mu \mathrm{m} \text {. However, it differed with species. }\end{array}$ \\
\hline \multicolumn{5}{|c|}{ Genomic methods } \\
\hline $\begin{array}{l}\text { Nehme et al. } \\
(2008)\end{array}$ & $\begin{array}{l}\text { Grower- } \\
\text { finisher }\end{array}$ & $\begin{array}{l}\text { Quebec, } \\
\text { Canada }\end{array}$ & $\begin{array}{l}\text { 16S rRNA DGGE } \\
\text { and clone library } \\
\text { for bacteria }\end{array}$ & $\begin{array}{l}\text { A total of } 245 \text { sequences (clones) were } \\
\text { generated from selected DGGE bands. They, } \\
\text { along with blast analysis of DGGE bands, } \\
\text { indicated the existence of Aerococcus spp., } \\
\text { Lacobacillus spp., Streptococcus spp., }\end{array}$ \\
\hline
\end{tabular}




\begin{tabular}{|c|c|c|c|c|}
\hline & & & & $\begin{array}{l}\text { Bacillus spp., Anaerococcus, spp., } \\
\text { Clostridium chauvoei, and Clostridium } \\
\text { litusburense, among many others. Bacterial } \\
\text { composition was dominated by three classes: } \\
\text { Clostridia, Bacteroidetes, and Lactobacillales. }\end{array}$ \\
\hline $\begin{array}{l}\text { Nehme et al. } \\
(2009)\end{array}$ & $\begin{array}{l}\text { Grower- } \\
\text { finisher }\end{array}$ & $\begin{array}{l}\text { Quebec, } \\
\text { Canada }\end{array}$ & $\begin{array}{l}\text { 16S rRNA DGGE } \\
\text { and clone library } \\
\text { for archaea }\end{array}$ & $\begin{array}{l}\text { A total of } 566 \text { sequences were generated from } \\
\text { selected DGGE bands. They suggested the } \\
\text { dominance }(>94.5 \%) \text { of Methanosphaera } \\
\text { stadimanea. Methanosarcina siciliae were } \\
\text { also detected. }\end{array}$ \\
\hline $\begin{array}{l}\text { Hong et al. } \\
(2012)^{5}\end{array}$ & $\begin{array}{l}\text { Farrowing, } \\
\text { gestation, } \\
\text { nursery, } \\
\text { finisher }\end{array}$ & Illinois & $\begin{array}{l}\text { 16S DGGE and } \\
\text { rRNA NGS for } \\
\text { bacteria }\end{array}$ & $\begin{array}{l}\text { Phylum Firmicutes were dominant, followed } \\
\text { by Bacteriodetes. Actinobacter were the third } \\
\text { most abundant phylum in farrowing and } \\
\text { gestation barns. PM samples from nursery } \\
\text { and finisher barns contained a significantly } \\
\text { higher abundance of Prevotella, Roseburia, } \\
\text { Faecalibacterium, Megaspaera, and } \\
\text { Subdoligranulum spp. than those from } \\
\text { farrowing and gestation barns. Twelve } \\
\text { identified genera were potentially associated } \\
\text { with pathogens. Swine barn PM samples } \\
\text { showed overall a significantly different } \\
\text { bacterial composition than those from poultry } \\
\text { barns and non-farm office environments. }\end{array}$ \\
\hline $\begin{array}{l}\text { Kristiansen et } \\
\text { al. }(2012)^{5}\end{array}$ & Gestation & Denmark & $\begin{array}{l}\text { 16S rRNA clone } \\
\text { library and FISH } \\
\text { for bacteria } \\
\text { 18S rRNA clone } \\
\text { library for fungi } \\
\text { FISH for archaea }\end{array}$ & $\begin{array}{l}\text { Archaea were identified by FISH but only } \\
\text { accounted for } 0.3 \% \text { of total microbial counts. } \\
\text { Sixty-two sequences were generated for } \\
\text { bacteria They were classified into } 15 \\
\text { operational taxonomic units (OTUs) and were } \\
\text { dominated by phylum Firmicutes and genus } \\
\text { Clostridium. The } 73 \text { fungal sequences } \\
\text { generated were grouped into } 6 \text { OTUs and } \\
\text { were dominated by genera Aspergillus and } \\
\text { Eurotium. }\end{array}$ \\
\hline $\begin{array}{l}\text { Rodríguez de } \\
\text { Evgrafov et al. } \\
(2013)^{5}\end{array}$ & $\begin{array}{l}\text { Nursery, } \\
\text { grower, } \\
\text { finisher, } \\
\text { Wean-to- } \\
\text { finish }\end{array}$ & Colorado & $\begin{array}{l}16 \mathrm{~S} \text { rRNA clone } \\
\text { library for } \\
\text { bacteria }\end{array}$ & $\begin{array}{l}\text { A total of } 810 \text { sequences were generated for } \\
\text { in-barn PM samples. Phylum Firmicutes were } \\
\text { predominant, followed by Bacteroidetes. In- } \\
\text { barn samples showed a significantly different } \\
\text { bacterial composition than outdoor samples. } \\
\text { Within Firmicutes, the dominant species } \\
\text { included Bacillus spp., Lachnospiraceae spp., } \\
\text { and Clostridium spp. Some identified species } \\
\text { were also found in pig gastrointestinal tracts. }\end{array}$ \\
\hline $\begin{array}{l}\text { Kumari and } \\
\text { Choi (2014) }\end{array}$ & $\begin{array}{l}\text { Grower- } \\
\text { finisher }\end{array}$ & $\begin{array}{l}\text { South } \\
\text { Korea }\end{array}$ & $\begin{array}{l}\text { 16S rRNA NGS } \\
\text { for bacteria }\end{array}$ & $\begin{array}{l}\text { A total of } 497,607 \text { sequences were generated, } \\
\text { classed into 13,597 OTUs. Firmicutes were } \\
\text { the most abundant phylum, followed by } \\
\text { Bacteroidetes and Proteobacteria. At the } \\
\text { genus level, Lactobacillus and Prevotella } \\
\text { were dominant. A significantly different } \\
\text { bacterial composition was found between } \\
\text { winter and summer samples, with winter }\end{array}$ \\
\hline
\end{tabular}




\begin{tabular}{|c|c|c|c|c|}
\hline & & & & $\begin{array}{l}\text { samples having more OTUs (i.e., greater } \\
\text { richness) and a higher abundance of } \\
\text { Prevotella. }\end{array}$ \\
\hline $\begin{array}{l}\text { Arfken et al. } \\
(2015)\end{array}$ & $\mathrm{n} / \mathrm{a}$ & $\begin{array}{l}\text { North } \\
\text { Carolina }\end{array}$ & $\begin{array}{l}16 \mathrm{~S} \text { rRNA NGS } \\
\text { for bacteria }\end{array}$ & $\begin{array}{l}\text { Note: PM samples were collected } 5 \mathrm{~m} \text { away } \\
\text { from a barn. The } 2,364 \text { sequences generated } \\
\text { were classified into } 441 \text { OTUs. Phylum } \\
\text { Proteobacteria were predominant, followed } \\
\text { by Actinobacteria and Bacteroidates. At the } \\
\text { genus level, Sphingomonas and } \\
\text { Hymenobacter were most abundant. }\end{array}$ \\
\hline $\begin{array}{l}\text { Kumari and } \\
\text { Choi (2015) }\end{array}$ & $\begin{array}{l}\text { Grower- } \\
\text { finisher }\end{array}$ & $\begin{array}{l}\text { South } \\
\text { Korea }\end{array}$ & $\begin{array}{l}\text { 16S rRNA NGS } \\
\text { for bacteria }\end{array}$ & $\begin{array}{l}\text { A total of 14,315 sequences were generated, } \\
\text { classified into } 976 \text { OTUs. Firmicutes were the } \\
\text { predominant phylum. The relative } \\
\text { abundances of Firmicutes, Actinobacteria and } \\
\text { Proteobacteria differed with waste } \\
\text { management systems (deep pits, beddings, } \\
\text { and scraper). Bedding systems showed a } \\
\text { significantly higher abundance of } \\
\text { Corynebacterium than other systems. Manure } \\
\text { scraper systems had over the lowest OTUs. }\end{array}$ \\
\hline $\begin{array}{l}\text { Kumari et al. } \\
(2016)\end{array}$ & $\begin{array}{l}\text { Grower- } \\
\text { finisher }\end{array}$ & $\begin{array}{l}\text { South } \\
\text { Korea }\end{array}$ & $\begin{array}{l}\text { ITS NGS for } \\
\text { fungi }\end{array}$ & $\begin{array}{l}\text { A total of 22,399 OTUs were identified. } \\
\text { Winter samples had different fungal } \\
\text { compositions and greater diversity than } \\
\text { summer samples. At the phylum level, } \\
\text { Ascomycota were the most abundant, } \\
\text { followed by Basidiomycota and Zygomycota. } \\
\text { The most abundant genera were Clavaria and } \\
\text { Fusarium. Twenty-nine potential pathogens } \\
\text { or allergens were found. Significant barn-to- } \\
\text { barn and within-barn variations were found in } \\
\text { fungal composition. }\end{array}$ \\
\hline $\begin{array}{l}\text { Druckenmüller } \\
\text { et al. (2017) }\end{array}$ & Finisher & Germany & $\begin{array}{l}16 \mathrm{~S} \text { rRNA clone } \\
\text { library for } \\
\text { bacteria }\end{array}$ & $\begin{array}{l}\text { The study used 16S rRNA clone library to } \\
\text { identify colony isolates. }^{2} \text { With that, } 65 \\
\text { sequences were generated and classified to } 21 \\
\text { bacterial OTUs. }\end{array}$ \\
\hline $\begin{array}{l}\text { Kraemer et al. } \\
(2018)\end{array}$ & $\mathrm{n} / \mathrm{a}$ & Switzerland & $\begin{array}{l}\text { 16S rRNA NGS } \\
\text { for bacteria }\end{array}$ & $\begin{array}{l}\text { The richness and diversity of bacteria in } \\
\text { swine barn PM were greater than those in } \\
\text { pigs' nasal swabs but lower than those in } \\
\text { farmer's nasal swabs. Regarding bacterial } \\
\text { composition, PM sat somewhere in-between } \\
\text { pigs' and pig farmers' nasal swabs. Farmers } \\
\text { from the same barn tended to share similar } \\
\text { nasal microbiota, suggesting a significant } \\
\text { influence of in-barn PM. }\end{array}$ \\
\hline $\begin{array}{l}\text { Vestergaard et } \\
\text { al. }(2018)\end{array}$ & $\mathrm{n} / \mathrm{a}$ & Denmark & $\begin{array}{l}16 \mathrm{~S} \text { rRNA NGS } \\
\text { for bacteria }\end{array}$ & $\begin{array}{l}\text { 16S rRNA genes in PM were more abundant } \\
\text { but less diverse in swine barns than farmer's } \\
\text { homes. Bacterial community was dominated } \\
\text { by phylum Firmicutes, followed by } \\
\text { Actinobacteria and Proteobacteria. The most } \\
\text { abundant bacteria were Clostridiales at the }\end{array}$ \\
\hline
\end{tabular}




\begin{tabular}{|c|c|c|c|c|}
\hline & & & & $\begin{array}{l}\text { order level and Cloristridiaceae and } \\
\text { Peptostreptococcaceae at the family level. No } \\
\text { significant seasonality was noted in bacterial } \\
\text { composition or diversity. }\end{array}$ \\
\hline $\begin{array}{l}\text { Kraemer et al. } \\
(2019)^{5}\end{array}$ & $\mathrm{n} / \mathrm{a}$ & Switzerland & $\begin{array}{l}16 \mathrm{~S} \text { rRNA NGS } \\
\text { for bacteria }\end{array}$ & $\begin{array}{l}\text { The richness and diversity of bacteria varied } \\
\text { significantly with seasons and they were } \\
\text { greater in winter. Phylum Firmicutes were } \\
\text { predominant, followed by Actinobacteria and } \\
\text { Proteobacteria. Dominant genera included } \\
\text { Veillonellaceae, Clostridiaceae, } \\
\text { Lactobacillaceae, and } \\
\text { Peptostreptococcaceae. About } 45-65 \% \text { of pig } \\
\text { farmers' nasal microbime was from PM and } \\
\text { the percentage was greater in winter and } \\
\text { lower in summer. }\end{array}$ \\
\hline $\begin{array}{l}\text { Mbareche et } \\
\text { al. (2019) }\end{array}$ & Finisher & $\begin{array}{l}\text { Quebec, } \\
\text { Canada }\end{array}$ & $\begin{array}{l}16 \mathrm{~S} \text { rRNA NGS } \\
\text { for bacteria }\end{array}$ & $\begin{array}{l}\text { Phylum Firmicutes were the most abundant } \\
\text { bacterial group, followed by Bacterodetes and } \\
\text { Actinobacteria. At the class level, Clostridia } \\
\text { Bacilli, and Bacteroidia were dorminant. } \\
\text { Microbial composition in PM samples } \\
\text { resembled that in farm workers' nasal swabs. }\end{array}$ \\
\hline $\begin{array}{l}\text { White et al. } \\
(2019)^{2}\end{array}$ & $\begin{array}{l}\text { Farrowing, } \\
\text { nursing }{ }^{4}, \\
\text { nursery, } \\
\text { finisher }\end{array}$ & Denmark & $\begin{array}{l}\text { 16S rRNA NGS } \\
\text { for bacteria } \\
\text { ITS NGS for } \\
\text { fungi }\end{array}$ & $\begin{array}{l}\text { A total of } 4.0 \times 10^{5} \text { bacterial } 1.5 \times 10^{5} \text { fungal } \\
\text { sequences were generated. The bacterial } \\
\text { community was dominated by genera } \\
\text { Clostridium sensu stricto, Lactobacillus, } \\
\text { Terrisporobacter, Turicibacter, Romboutisia, } \\
\text { Methanobrevibacter, Aerococcus, and } \\
\text { Weissella. Dominant fungal genera were } \\
\text { Filobasidum, Apiotrichum, Wallemia, and } \\
\text { Candida. A significant effect of barn type was } \\
\text { observed on fungal and bacterial } \\
\text { compositions. }\end{array}$ \\
\hline $\begin{array}{l}\text { Yan et al. } \\
(2019)^{5}\end{array}$ & $\begin{array}{l}\text { Farrowing, } \\
\text { gestation, } \\
\text { nursery, } \\
\text { grower- } \\
\text { finisher, } \\
\text { boar }\end{array}$ & China & $\begin{array}{l}\text { Shotgun } \\
\text { metagenomic } \\
\text { sequencing for } \\
\text { microbiota }\end{array}$ & $\begin{array}{l}\text { Most genes ( }>88.8 \%) \text { were assigned to } \\
\text { bacteria. Firmicutes were the most abundant } \\
\text { bacterial phylum, followed by Bacteroidetes, } \\
\text { Actinobacteria, and Proteobacteria. At the } \\
\text { genus level, Prevotella, Clostridium, } \\
\text { Corynebacterium, Bacteroides, and } \\
\text { Ruminococcus are abundant. Bacterial } \\
\text { composition differed with barn types. } \\
\text { Bacteria were also classified based on } \\
\text { functional characteristics (functional genes). } \\
\text { Archaea, viruses, and eukaryotes were } \\
\text { detected but not discussed. Only five } \\
\text { composite samples were analyzed. }\end{array}$ \\
\hline Liu (2020) & $\mathrm{n} / \mathrm{a}$ & $\begin{array}{l}\text { The } \\
\text { Netherlands }\end{array}$ & $\begin{array}{l}\text { 16S rRNA NGS } \\
\text { for bacteria } \\
\text { ITS NGS for } \\
\text { fungi }\end{array}$ & $\begin{array}{l}\mathrm{PM}_{2.5-10} \text { in two pig barns was sampled for } \\
\text { analysis. For bacteria, Lactobacillus and } \\
\text { Clostridium were the most abundant at the } \\
\text { genus level. For fungi, genus Emericella was } \\
\text { the most abundant, followed by genera } \\
\text { Penicillium and Candidia. Swine barns }\end{array}$ \\
\hline
\end{tabular}




\begin{tabular}{|c|c|c|c|c|}
\hline & & & & $\begin{array}{l}\text { showed significantly different PM bacterial or } \\
\text { fungal compositions than those chicken and } \\
\text { goat barns. }\end{array}$ \\
\hline $\begin{array}{l}\text { Luiken et al. } \\
(2020)^{6}\end{array}$ & $\mathrm{n} / \mathrm{a}$ & $\begin{array}{l}\text { Nine } \\
\text { European } \\
\text { countries }\end{array}$ & $\begin{array}{l}\text { Shotgun } \\
\text { metagenomic } \\
\text { sequencing for } \\
\text { bacteria }\end{array}$ & $\begin{array}{l}\text { At the class level, Clostridia were the most } \\
\text { abundant, followed by Bacilli, Bacteroidia, } \\
\text { Actinobacteria, Betaproterobacteria, and } \\
\text { Erysipelotrichia. }\end{array}$ \\
\hline $\begin{array}{l}\text { Tang et al. } \\
(2020)^{5}\end{array}$ & Nursery & China & $\begin{array}{l}\text { 16S rRNA NGS } \\
\text { for bacteria } \\
\text { ITS NGS for } \\
\text { fungi }\end{array}$ & $\begin{array}{l}\mathrm{PM}_{2.5} \text { was sampled for analysis. Thirty-three } \\
\text { bacterial phyla and } 460 \text { genera were } \\
\text { identified. At the phylum level, Firmicutes } \\
\text { were the most abundant, followed by } \\
\text { Bacteroidetes. At the genus level, } \\
\text { Lactobacillus } \text { was the most abundant. Eleven } \\
\text { fungal phyla and } 317 \text { genera were identified, } \\
\text { with Basidiomycota being the predominant } \\
\text { phylum. A significant seasonality was seen in } \\
\text { both bacterial and fungal compositions, as } \\
\text { well as microbial diversity. }\end{array}$ \\
\hline $\begin{array}{l}\text { White et al. } \\
(2020)\end{array}$ & Finisher & Denmark & $\begin{array}{l}\text { ITS NGS for } \\
\text { fungi }\end{array}$ & $\begin{array}{l}\text { A total of } 334,862 \text { fungal sequences were } \\
\text { generated. They were classified into } 59 \\
\text { genera (Note: Relevant information is } \\
\text { available in the supplementing document of } \\
\text { the paper). }\end{array}$ \\
\hline $\begin{array}{l}\text { Hong et al. } \\
(2021)\end{array}$ & $\begin{array}{l}\text { Nursery, } \\
\text { finisher }\end{array}$ & $\begin{array}{l}\text { South } \\
\text { Korea }\end{array}$ & $\begin{array}{l}\text { 16S rRNA NGS } \\
\text { for bacteria }\end{array}$ & $\begin{array}{l}\text { A total of } 351,016 \text { sequences were generated. } \\
\text { Firmicutes were the most abundant phylum, } \\
\text { followed by Proteobacteria and Bacteroidetes. } \\
\text { Clostridium was the most abundant genus, } \\
\text { followed by Terrisporobacter and } \\
\text { Turicibacter. Four genera (Curvibacter, } \\
\text { Sediminbacterium, Bradyrhizobium, and } \\
\text { Pelomonas) were associated with potential } \\
\text { pathogens. }\end{array}$ \\
\hline $\begin{array}{l}\text { Song et al. } \\
\text { (2021) }\end{array}$ & $\mathrm{n} / \mathrm{a}$ & China & $\begin{array}{l}\text { 16S rRNA NGS } \\
\text { for bacteria }\end{array}$ & $\begin{array}{l}\text { At the phylum level, Firmicutes were } \\
\text { predominant, followed by Bacteroidetes and } \\
\text { Proteobacteria. At the order level, Clostridia } \\
\text { was perdominant, followed by Lactobacillales } \\
\text { and Bacteriodales. At the genus level, } \\
\text { Clostridium and Streptococcus were the most } \\
\text { abundant. Summer samples contained a high } \\
\text { abundance of opportunistic pathogens. }\end{array}$ \\
\hline $\begin{array}{l}\text { Tang et al. } \\
(2021)\end{array}$ & Nursery & China & $\begin{array}{l}\text { 16S rRNA NGS } \\
\text { for bacteria }\end{array}$ & $\begin{array}{l}\text { A total of } 300 \text { bacterial genera were } \\
\text { identified. Bacterial composition differed } \\
\text { with size fractions (six fractions). The } \\
\text { dominant phylum was Bacteroidates in }>7 \\
\text { and } 4.7-7.0 \mu \mathrm{m} \text {, Firmicutes in } 3.3-4.7 \mu \mathrm{m} \text {, and } \\
\text { Fusobacteria in } 1.1-2.1 \text { and } 2.1-3.3 \mu \mathrm{m} \text {. Note: } \\
\text { Only one set of PM samples was sequenced. }\end{array}$ \\
\hline
\end{tabular}




\begin{tabular}{|l|l|l|l|l|}
\hline $\begin{array}{l}\text { Yan et al. } \\
(2021)^{5}\end{array}$ & $\begin{array}{l}\text { Farrowing, } \\
\text { gestation, } \\
\text { nursery, } \\
\text { grower- } \\
\text { finisher }\end{array}$ & $\begin{array}{l}\text { 16S rRNA NGS } \\
\text { for bacteria }\end{array}$ & $\begin{array}{l}\text { A total of 70,763 bacterial sequences were } \\
\text { generated, classified into 2643 OTUs. } \\
\text { Bacterial composition showed a significant } \\
\text { effect by barn types. Proteobacteria was the } \\
\text { most abundant phylum, followed by } \\
\text { Actinobacteria, Bacteroidetes, and Firmicutes. } \\
\text { Acinetobacter was the most abundant genus } \\
\text { in nursery and grower-finisher barns; while } \\
\text { Psychrobacter and } \text { Rothia } \text { were dominant } \\
\text { genera in farrowing and gestation barns. } \\
\text { Three potentially pathogenic genera were } \\
\text { detected. }\end{array}$ \\
\hline
\end{tabular}

Note:

${ }^{1}$ MALDI-TOF MS - matrix-assisted laser desorption/ionization time-of-flight mass spectrometry; DGGE - denaturing gradient gel electrophoresis.

${ }^{2}$ Although the title of the paper said settled dust, PM (dust) samples were collected using an electrostatic precipitator (ESP).

${ }^{3}$ Strictly speaking, the method was culture-dependent because microbial identification was done on colony isolates. Since the method generated substantially more information than traditional culturedependent identification methods (colony appearance-based identification, biochemical testing, and selective/differential media), the research results are included in the table for comparison.

${ }^{4}$ Nursing barns are a barn type in certain western European countries. The barns separate nursing from farrowing activity.

${ }^{5}$ Sequencing data were uploaded on Genbank, NCBI, and alike, allowing for post-hoc analysis by others. Other studies could also have archived microbial composition data online; however, no relevant information or data link was provided.

${ }^{6}$ Relevant information was retrieved from the publication's supplemental materials.

Upon the analysis of the above publications, the following summary and observations are made:

- Microbial composition analysis of swine barn PM with culture-independent methods has received increasing attention since the first report by Nehme et al. (2008). Out of the 24 papers compiled in the table, 14 were published in the past three years (2018 to present). This has not included non-English papers. Besides the pioneering work by Nehme et al. (2008), three milestone papers are worth mentioning from the methodology standpoint: (1) Hong et al. (2008), for the first report of using NGS to study microbial composition in swine barn PM; (2) Kumari et al. (2016), for the first use of ITS sequencing for fungal composition analysis in swine barns; and (3) Yan et al. (2019), for the first attempt of using shotgun metagenomic pyrosequencing for analysis of microbiota in swine barn PM (Note: Boissy et al. (2014) used the same technology to study settled dust in swine barns). A brief overview of these methods is available in Section 4.4.3.

- Regarding the geographic distribution of relevant studies, nine papers were from Asia (China and South Korea), nine from Europe, three from the U.S., and three from Canada. Twenty papers studied bacterial composition, six studied fungi, and one studied archaea. Seventeen papers used NGS for microbial identification, five used clone library, and three used MALDI-TOF MS. Nine studies each analyzed $\geq 20$ PM samples (Hong et al., 2012; Kumari et al., 2016; Kraemer et al., 2018, 2019; Vestergaard et al. 2018; White et al., 2019, 2020; Luiken et al., 2020; Yan et al., 2021). Others had relatively small sample sets. Finisher barns were most studied, followed by nursery barns. Regardless of barn types, identification methods, and farm locations, many studies reached similar observations about PM microbial composition in swine barns.

- Bacteria and fungi in swine barn PM are highly diverse. Numerous species have been identified, especially with NGS and shotgun metagenomic sequencing - both technologies generated a large 
number of reads. For bacteria, up to 13,597 OTUs (Kumari and Choi, 2014) and 460 genera (Tang et al., 2020) were identified; while for fungi, the identified OTUs and genera were up to 22,399 OTUs (Kumari et al., 2016) and 317 (Tang et al., 2020), respectively. An even larger number of OTUs or genera could exist in the literature but it requires a thorough inspection of raw data. It is noteworthy that many factors could affect the number of identified species, such as volume of PM samples, selection of primers, depth of sequencing, and classification criteria. Several studies used the number of OTUs predicted from rarefaction curves (OTUs versus sequences) to enable a reasonable comparison among samples (Hong et al., 2012; White et al., 2019, 2020).

- Firmicutes, the majority of which are Gram-positive, were reported by many to be the predominant (typically $\geq 60 \%$ ) bacterial phylum in swine barn PM. Other abundant bacterial phyla included Actinobacteria, Bacteroidetes, and Proteobacteria. One exception is Yan et al. (2021) in which Proteobacteria was found to be the most abundant. However, in an earlier report by the same authors, Firmicutes were dominant (Yan et al., 2019). At the genus level, Clostridium and Lactobacillus often accounted for significant fractions. Other abundant genera included Bacteroides, Corynebacterium, Peptostreptococcaceae, Prevotella, and Terrisporobacter; however, their abundance lacks the same degree of universality as that of Clostridium and Lactobacillus. This could be attributed to differences in factors such as geographical locations, barn types, waste management, and sampling seasons. It is noteworthy that Clostridium, a genus in phylum Firmicutes, contains several important pathogens. Clostridium, Lactobacillus, Prevotella, and Bacteroides were usually associated with pig gastrointestinal tracts and fecal microbiota, suggesting that a significant portion of airborne bacteria in swine barns are of fecal origins (Nehme et al., 2008; Hong et al., 2012; Humari and Choi, 2015; Yan et al., 2019; Tang et al., 2020).

- Many bacterial pathogens or potential pathogens were identified. A complete list was usually unavailable in the literature because of the large number of identified species. A partial list, including opportunistic and potential pathogens, is as follow: genera Aerococcus, Acinetobacteria, Arcobacter, Bacillus, Campylobacter, Clostridium, Erysipeiothrix, Escherichia, Fusobactgerium, Helicobacter, Leptotrichia, Moraxella, Pseudomonas, Salmonella, Staphylococcus, Streptococcus, and Treponema; and species Aerococcus viridans, Bacillus cereus, Clostridium perfringens, Clostridium bifermentans, Clostridium cadaveris, Clostridium baratii, Enterococcus avium, Enterococcus casseliflavus, Enterococcus durans, Enterococcus faecalis, Enterococcus villorum, Enterococcus gallinarum, Enterococcus hirae, Enterococcus faecium, Filobasidium untiguttulatum, Leuconostoc mesenteroides, Serratia marcescens, Staphylococcus aureus, Staphylococcus saprophyticus, Staphylococcus paseuri, Staphylococcus haemolyticus, Staphylococcus hominis, Staphylococcus hyicus, Staphylococcus pettenkoferi, Staphylococcus epidermidis, Streptococcus parauberis, Streptococcus lutetiensis, and Vagococcus fluvialis (Hong et al., 2012; Rodríguez de Evgrafov et al., 2013; Arfken et al., 2015; Druckenmüller et al., 2017; White et al., 2019; Tang et al., 2020; Song et al., 2021; Hong et al., 2021; Yan et al., 2021).

- Out of the six fungal studies, five reported Ascomycota and one found Basidiomycota to be the predominant phylum (division). The abundant fungal genera included Aspergillus, Eurotium, Clavaria, Fusarium, Filobasidum, Apiotrichum, Wallemia, and Candida; and their presence and/or relative abundance differed among publications. Several potential fungal pathogens or allergens were identified, including genera Fusarium, Aspergillus, Penicillium, Schizophyllum, Trichoderma, Wallemia, Humicola, and Sporobolomyces; and species Aspergillus fumigatus, Aspergillus niger, Aspergillus terreus, Trichosporon asahii, Trichosporon cutaneum, Alternaria alternata, Aureobasidium pullulans, Cladosporium cladosporoides, Cladosporium herbarum, and Schizophyllum commune (Kumari et al., 2016; White et al., 2019, 2020; Tang et al., 2020). 
- Barn types affect bacterial and fungal compositions. Hong et al. (2012) compared the bacterial composition of TSP sampled from four types of swine barns. Two clusters were identified: (1) farrowing and gestation and (2) nursery and finisher. The latter had higher abundances of Prevotella, Roseburia, Faecalibacterium, Megaspaera, and Subdoligranulum spp. than the former barns. White et al. (2019) found that both bacterial and fungal compositions varied with barn types; however, farm locations exhibited an even greater influence. For barns of different types but situated at the same farm sites, they shared a similar PM microbial composition. A significant influence of barn types on bacterial composition was reported by Yan et al. (2019, 2021). PM samples from finisher barns contained more Firmicutes but lesser Actinobacteria than those from farrowing and gestation barns. At the genus level, finisher barn samples had a higher abundance of Aerococcus but lower Kocuria than gestation barns. Within the same barn type, PM bacterial composition differed with selected waste management systems (Kumari and Choi, 2015).

- No agreement has yet been reached regarding the effect of seasons. A significant seasonal variation in bacterial or fungal composition was reported by four studies (Kumari and Choi, 2014; Kumari et al., 2016; Kraemer et al., 2019; Tang et al., 2020). However, Vestergraard et al. (2018) found no significant seasonality in PM bacterial composition. Temperature is a major shaping factor for airborne microbial communities (de Groot et al., 2021). As aforementioned, in-barn air temperature varies with seasons even with ventilation, heating, and/or cooling systems. Thus, a seasonal effect is not unexpected. However, the in-barn temperature variation is relatively minor as compared with outdoor environments. Moreover, other biotic and abiotic factors (e.g., air humidity and animal age) than temperature could affect microbial communities as well, causing uncertainties in observed seasonal patterns. Regarding the specific effects of seasons, Song et al. (2021) reported that bacterial phyla Proteobacteria and Actinobacteria were more abundant in winter than summer samples. Dr. Kumari and his colleagues (Kumari and Choi, 2014; Kumari et al., 2016) found that winter samples had a greater level of microbial richness (i.e., more OTUs) than summer samples. An opposite finding was reported by Tang et al. (2020) and Song et al. (2021). However, it should be noted that $\mathrm{PM}_{2.5}$ (rather than TSP) was sampled in Tang et al. (2020). A large portion of $\mathrm{PM}_{2.5}$ in swine barns could originate from ambient PM (Zhang, 2005), with different seasonal patterns than in-barn PM.

- Limited information is available regarding the size distribution of microbial communities. Only two recent studies analyzed the microbial composition of size-segregated PM samples. White et al. (2020) collected PM samples of different size ranges using Andersen multistage cascade impactors and examined the fungal composition of these samples. Most Wallemia spp. was found in PM of 0.65-2.1 $\mu \mathrm{m}$; while, the majority of Candida catenulate occurred in PM of 1.1-7 $\mu \mathrm{m}$. Fungal genera Cladosporium, Malassezia, and Kazachstania were detected in all size ranges. Tang et al. (2021) reported that genus Mycoides dominated the bacterial community in PM of $>7.0 \mu \mathrm{m}$ and 4.7-7.0 $\mu \mathrm{m}$ and genus Escherichia-Shigella was most abundant in PM of 1.1-2.1 and 2.1-3.3 $\mu \mathrm{m}$. In comparison, PM of 3.3-4.7 $\mu \mathrm{m}$ showed the greatest bacterial diversity, with four abundant bacterial genera in it: Burkholderia-Caballeronia-Paraburkholderia, Streptococcus, Actinobacillus, and Veillonella.

Culture-independent methods are becoming increasingly affordable and accessible. Ten years ago, the analysis of bacterial composition with NGS cost $\sim \$ 100$ per sample (Hong et al., 2012). Today it costs only $\sim \$ 18$ per sample, according to Illumina, Inc., an industrial leader of NGS technology (https://www.illumina.com/science/technology/next-generation-sequencing/beginners/ngs-cost.html). This has been less expensive than many regular physical and chemical tests of PM samples. In addition, many universities now offer low-cost or free bioinformatics services. Reduced cost, along with a growing interest in bioaerosols, leads to the booming of relevant publications in the past few years. Massive amounts of data have been generated (Table 9), which however raises a great challenge to data analysis 
and utilization (e.g., translating the data into the knowledge that average pork producers can utilize). Meanwhile, some research questions remain unanswered or unclarified, e.g., how PM microbial compositions vary before, during, and after a swine disease outbreak, and how pathogenic viruses correlate with bacterial and/or fungal linkages? Microbial composition could also be related to other air quality parameters. For example, our previous study found a significant correlation between PM-borne odorants and microbial composition (Unpublished data) (Hong et al., 2012; Yang et al., 2014). Additional efforts, thus, are needed to examine and interpret PM microbial composition in swine barns.

\subsubsection{Antibiotic resistant bacteria (ARB) and antibiotic resistance genes (ARGs)}

The use of antibiotics is critical for successful pork production. It also raises public concerns about the spread of ARB and ARGs from farms to the environment which could compromise the ability to curb bacterial illnesses. A renowned example of ARB is methicillin-resistant Staphylococcus aureus (MRSA), touted by some as "superbugs". It has been detected and quantified in the air of swine barns (Table 5). Antibiotic resistance can be acquired by other bacteria in the environment through horizontal gene transfer, a reason for the importance of ARG analysis (Aminov and Mackie, 2007). In the U.S., $~ 80 \%$ of antibiotics are used by animal agriculture, including swine barns (Martin et al., 2015). Although pork producers have made tremendous efforts to restrict the selection and dosage of swine antibiotics, public concerns and pressures are still lingering around. In the past 20 years, numerous studies have been done to examine ARB and ARGs in and around swine barns.

Swine manure is believed to be a main source for the propagation of ARB and ARGs in the environment. Their presence in swine manure, waste management systems, manure-fertilized soils, and downstream waters has been extensively studied (Zhu et al., 2013; He et al., 2020). Since PM in swine barns originates partially from manure, it can serve as a carrier of ARB and ARGs and disperse them into the environment via airborne transmission. It is important to recognize that airborne transmission is different from wateror soil-borne transmission in that it is not restricted by watersheds or manure sheds (defined as the land area where the manure is applied) and, thus, may disperse ARB and ARGs further away from farms. To our knowledge, the first observation of airborne ARB in swine barns was reported by Zahn et al. (2001). Since then, 24 publications have been available regarding ARB and ARGs in swine barn bioaerosols.

A relevant finding is the occurrence of PM-borne antibiotics in swine barns. In a 20-year study, fourteen antibiotics were detected in swine barn PM samples and six of them (tetracycline, oxytetracycline, chlortetracycline, tylosin, chloramphenicol, and sulfamethazine) were quantified using high-performance liquid chromatography (HPLC) (Hamscher et al., 2003, 2008). However, it remains unclear whether and how these PM-borne antibiotics would correlate with airborne ARB and ARGs.

\section{Antibiotic resistant bacteria}

ARB were usually measured with culture-dependent methods through the use of selective or differential cultivation media. Commercial selective or differential agars are available, e.g., a CHROMagar MRSA chromogenic agar for MRSA detection in swine barns (Ferguson et al., 2016; Wenke et al., 2018). Selfprepared cultivation media were used in four studies to examine bacterial colonies for their resistance to multiple antibiotics, following the minimal inhibitory concentration (MIC) agar dilution method (Chapin et al., 2005) or the Kirby-Bauer diffusion disk method (Gibbs et al., 2004, 2006; Wu et al., 2019). The measurement results include qualitative (presence or absence) and quantitative ones (CFU m${ }^{-3}$ ) (Table 10). Settled dust samples were also analyzed (Schulz et al., 2019; von Ah et al., 2019) but relevant studies were excluded for possible differences in microbiota between PM and settled dust.

Table 10. Airborne antibiotic resistant bacteria in swine barns.

\begin{tabular}{|l|l|l|l|l|}
\hline References & Barn type & Location & Target ARB & Major findings and/or notes \\
\hline $\begin{array}{l}\text { Zahn et al. } \\
(2001)\end{array}$ & Finisher & Iowa & Tylosin-resistant bacteria & $\begin{array}{l}\text { The average concentration ranged } \\
\text { from } 49,400 \text { to } 16,700 ~ C F U ~ \mathrm{~m}^{-3}, \\
\text { accounting for } \sim 80 \% \text { of culturable } \\
\text { bacterial counts. }\end{array}$ \\
\hline
\end{tabular}




\begin{tabular}{|c|c|c|c|c|}
\hline $\begin{array}{l}\text { Gibbs et al. } \\
(2004)^{1}\end{array}$ & $\begin{array}{l}\text { Grower- } \\
\text { finisher }\end{array}$ & $\begin{array}{l}\text { U.S. } \\
\text { Midwest }\end{array}$ & $\begin{array}{l}6 \text { antibiotics (ampicillin, } \\
\text { erythromycin, } \\
\text { oxytetracycline, penicillin, } \\
\text { tetracycline, tylosin) } \times 4 \\
\text { bacteria ( } S \text {. aureus, } \\
\text { Salmonella spp., fecal } \\
\text { coliforms, coliforms) }\end{array}$ & $\begin{array}{l}\text { The vast majority of bacterial isolates } \\
\text { showed resistance to the examined } \\
\text { antibiotics except for Penicillin. } \\
\text { While most } S \text {. aureus isolates were } \\
\text { Penicillin-resistant, only a small } \\
\text { portion of the other three bacteria } \\
\text { was resistant to Penicillin. Upwind } \\
\text { samples contained a much lower } \\
\text { percentage of ARBs than downwind } \\
\text { samples. }\end{array}$ \\
\hline $\begin{array}{l}\text { Chapin et } \\
\text { al. (2005) }\end{array}$ & Finisher & $\begin{array}{l}\text { U.S. Mid- } \\
\text { Atlantic }\end{array}$ & $\begin{array}{l}5 \text { antibiotics (clindamycin, } \\
\text { erythromycin, tetracycline, } \\
\text { vancomycin, } \\
\text { virginiamycin, }) \times 3 \text { genera } \\
\text { (Enterococcus, } \\
\text { Staphylococcus, } \\
\text { Streptococcus) and } 5 \\
\text { Enterococcus species (E. } \\
\text { dispar, E. Durans, E. } \\
\text { faecalis, E. faecium, E. } \\
\text { hirae) }\end{array}$ & $\begin{array}{l}\text { No vancomycin-resistant } \\
\text { Enterococcus was detected. The } \\
\text { percentage of antibiotic resistant } \\
\text { isolates differed with bacterial genera } \\
\text { or species, as well as antibiotics. } \\
98 \% \text { of isolates showed resistance to } \\
\geq 2 \text { antibiotics. }\end{array}$ \\
\hline $\begin{array}{l}\text { Gibbs et al. } \\
(2006)^{1}\end{array}$ & Gestation & $\begin{array}{l}\text { U.S. } \\
\text { Midwest }\end{array}$ & $\begin{array}{l}6 \text { antibiotics (ampicillin, } \\
\text { erythromycin, lincomycin, } \\
\text { oxytetracycline, penicillin, } \\
\text { tetracycline) } \times 4 \text { bacteria } \\
\text { (S. aureus, Streptococci., } \\
\text { fecal coliforms, coliforms) }\end{array}$ & $\begin{array}{l}\text { Among bacterial isolates from the } \\
\text { inside of the barns, } 45 \% \text { were } \\
\text { resistant to all six antibiotics and } \\
95 \% \text { were resistant to } \geq 2 \text { antibiotics. } \\
\text { These numbers were much greater } \\
\text { than those for upwind samples. The } \\
\text { percentage of ABR in culturable } \\
\text { bacteria gradually decreased } \\
\text { downwind away from the barn. }\end{array}$ \\
\hline $\begin{array}{l}\text { Friese et al. } \\
(2012)^{1}\end{array}$ & $\begin{array}{l}\text { Farrowing, } \\
\text { gestation, } \\
\text { nursery, } \\
\text { finisher }\end{array}$ & Germany & MRSA & $\begin{array}{l}\text { IOM dust samplers (a filter-based } \\
\text { method) yielded a lower MRSA } \\
\text { occurrence frequency and a lower } \\
\text { average airborne MRSA count than } \\
\text { impingers. The occurrence of MRSA } \\
\text { was confirmed through coagulase } \\
\text { reactions and real-time PCR. Settled } \\
\text { dust, pig nasal swab, boot swab, and } \\
\text { fecal samples from gestation and } \\
\text { finisher barns were also tested and } \\
\text { found positive for MRSA. }\end{array}$ \\
\hline $\begin{array}{l}\text { Schulz et } \\
\text { al. }(2012)^{1}\end{array}$ & $\begin{array}{l}\text { Gestation, } \\
\text { finisher }\end{array}$ & Germany & MRSA & $\begin{array}{l}\text { Quantitative information is available } \\
\text { in Table 5. MRSA was found on soil } \\
\text { surface downwind from barns. } \\
\text { Selected MRSA colonies were } \\
\text { cultivated with sheep blood agar and } \\
\text { confirmed for their existence via } \\
\text { coagulase reactions and real-time } \\
\text { PCR. }\end{array}$ \\
\hline $\begin{array}{l}\text { Gongora et } \\
\text { al. }(2013)^{1}\end{array}$ & Grower & Denmark & MRSA & $\begin{array}{l}\text { The study focused on the MRSA } \\
\text { mitigation performance of a }\end{array}$ \\
\hline
\end{tabular}




\begin{tabular}{|c|c|c|c|c|}
\hline & & & & $\begin{array}{l}\text { disinfectant. In addition to PM } \\
\text { samples, bedding and pig nasal swab } \\
\text { samples were also analyzed. The } \\
\text { disinfectant showed limited } \\
\text { effectiveness in MRSA reduction. }\end{array}$ \\
\hline $\begin{array}{l}\text { Masclaux } \\
\text { et al. } \\
(2013)^{1}\end{array}$ & $\begin{array}{l}\text { Nursery, } \\
\text { farrowing, } \\
\text { finisher }\end{array}$ & Switzerland & MRSA & $\begin{array}{l}\text { A genotype MRSA CC } 398 \text { was } \\
\text { targeted. MSSA was also measured. } \\
\text { The occurrence of MRSA was } \\
\text { confirmed through an agglutination } \\
\text { kit diagnostic test and molecular } \\
\text { identification. }\end{array}$ \\
\hline $\begin{array}{l}\text { Arfken et } \\
\text { al. (2015) }\end{array}$ & $\mathrm{n} / \mathrm{a}$ & $\begin{array}{l}\text { North } \\
\text { Carolina }\end{array}$ & $\begin{array}{l}\text { Kanamycin- and oxacillin- } \\
\text { resistant bacteria }\end{array}$ & $\begin{array}{l}\text { Sedimentation agar plates were used. } \\
\text { Both kanamycin and oxacillin plates } \\
\text { had over } 300 \text { colonies, among which } \\
37 \text { randomly selected colonies were } \\
\text { subjected to 16S rRNA sequencing } \\
\text { analysis. Results showed the } \\
\text { dominance of phyla Firmicutes, } \\
\text { Bacterioidetes, and Proteobacteria. } \\
\text { Multiple genera and species were } \\
\text { identified. }\end{array}$ \\
\hline $\begin{array}{l}\text { Ferguson et } \\
\text { al. }(2016)^{1}\end{array}$ & $\begin{array}{l}\text { Nursery- } \\
\text { grower }\end{array}$ & $\begin{array}{l}\text { U.S. } \\
\text { Midwest }\end{array}$ & MRSA & $\begin{array}{l}\text { In-barn samples were collected with } \\
\text { three different sampling durations. } \\
\text { Downwind samples were also } \\
\text { analyzed. Molecular typing of } \\
\text { suggestive MRSA isolates was done } \\
\text { through antimicrobial susceptibility } \\
\text { testing, mecA PCR, spa typing }{ }^{2} \text {, and } \\
\text { Panton-Valentine leucocidin PCR. } \\
\text { Several isolates were also resistant to } \\
\text { tetracycline, clindamycin, and } \\
\text { erythromycin. }\end{array}$ \\
\hline $\begin{array}{l}\text { Davis et al. } \\
(2018)\end{array}$ & $\mathrm{n} / \mathrm{a}$ & $\begin{array}{l}\text { North } \\
\text { Carolina }\end{array}$ & $\begin{array}{l}\text { MRSA and multi-drug } \\
\text { resistant } S . \text { aureus } \\
\text { (MDRSA) }\end{array}$ & $\begin{array}{l}\text { The study compared } 3 \text { industrial } \\
\text { swine barns versus an antibiotic-free } \\
\text { swine operation (open pasture). No } \\
\text { MRSA or MDRSA was detected at } \\
\text { the latter site. In swine barns, two } \\
\text { samples were positive for MDRSA } \\
\text { but at low concentrations ( } 7 \text { and } 9 \\
\text { CFU } \mathrm{m}^{-3} \text { ). }\end{array}$ \\
\hline $\begin{array}{l}\text { Madsen et } \\
\text { al. }(2018)^{1}\end{array}$ & $\begin{array}{l}\text { Farrowing, } \\
\text { nursery, } \\
\text { finisher, sick } \\
\text { pigs }\end{array}$ & Denmark & MRSA & $\begin{array}{l}\text { Two samplers (Andersen six-stage } \\
\text { viable cascade impactor and } \\
\text { Respicon) were used but showed no } \\
\text { significant differences. The highest } \\
\text { airborne MRSA counts were found in } \\
\text { nursery barns. The geometric mean } \\
\text { diameter of MRSA was } 7.2 \mu \mathrm{m} \\
\text { (slightly greater than that of } S \text {. } \\
\text { aureus) and it differed with sampling } \\
\text { locations. }\end{array}$ \\
\hline
\end{tabular}




\begin{tabular}{|c|c|c|c|c|}
\hline $\begin{array}{l}\text { Wenke et } \\
\text { al. }(2018)^{1}\end{array}$ & Finisher & Germany & MRSA & $\begin{array}{l}\text { The study compared four air } \\
\text { filtration systems regarding their } \\
\text { effectiveness in reducing MRSA and } \\
\text { other bioaerosols. Suggestive MRSA } \\
\text { isolates were further studied through } \\
\text { spa and mecA PCR. High MRSA } \\
\text { concentrations were ascribed to the } \\
\text { use of Coriolis }{ }^{\circledR} \mu \text { samplers (a wet } \\
\text { cyclone) for MRSA sampling. }\end{array}$ \\
\hline $\begin{array}{l}\text { Wu et al. } \\
\text { (2019) }\end{array}$ & $\mathrm{n} / \mathrm{a}$ & China & $\begin{array}{l}\text { Resistance of E. coli to } \\
\text { ampicillin, piperacillin, } \\
\text { amoxicillin/clavulanic } \\
\text { acid, ampicillin/sulbactam, } \\
\text { piperacillin/sulbactam, } \\
\text { piperacillin/sulbactam, } \\
\text { cephalothin, cefuroxime, } \\
\text { aztreonam, gentamicin, } \\
\text { kanamycin, streptomycin, } \\
\text { amikacin, tetracycline, } \\
\text { ciprofloxacin, ofloxacin, } \\
\text { nalidixicacid, } \\
\text { sulfamethoxazole, } \\
\text { chloramphenicol, and } \\
\text { nitrofurantoin }\end{array}$ & $\begin{array}{l}\text { Twenty-six E. coli isolates were } \\
\text { tested for antibiotic susceptibility. No } \\
\text { resistance to amoxicillin/clavulanic } \\
\text { acid, ampicillin/sulbactam, } \\
\text { piperacillin/sulbactam, or } \\
\text { nitrofurantoin was seen. Resistance } \\
\text { to other antibiotics was found in part } \\
\text { of } E \text {. coli isolates. }\end{array}$ \\
\hline $\begin{array}{l}\text { Chen et al. } \\
\text { (2019) }\end{array}$ & $\mathrm{n} / \mathrm{a}$ & China & $\begin{array}{l}\text { Tetracycline and } \\
\text { erythoromycin resistant } \\
\text { bacteria }\end{array}$ & $\begin{array}{l}\text { Self-prepared selective agar plates } \\
\text { were used to screen tetracycline and } \\
\text { erythromycin-resistant bacteria. } \\
\text { DNA was extracted from bacterial } \\
\text { isolates and subjected to } 16 \mathrm{~S} \text { rRNA } \\
\text { sequencing analysis. Genera } \\
\text { Staphylococcus and Rothia were } \\
\text { found to be abundant. The majority } \\
\text { of ARB species occurred } \\
\text { ubiquitously in both fine and coarse } \\
\text { PM fractions. Note: Cattle, broiler, } \\
\text { and layer barns were also studied and } \\
\text { discussed collectively. }\end{array}$ \\
\hline $\begin{array}{l}\text { Angen et } \\
\text { al. }(2021)\end{array}$ & Nursery & Denmark & MRSA & $\begin{array}{l}\text { In-barn airborne MRSA counts } \\
\text { ranged from } \sim 0.3 \text { to } 1.95 \text { CFU m }{ }^{-3} \\
\text { and reached the maximum in week } 2 \\
\text { of weaning and the minimum in } \\
\text { week } 6 . \text { A slight increase was noted } \\
\text { in weeks } 7 \text { and } 8 \text {. The concentrations } \\
\text { were much greater than those during } \\
\text { the finisher stage. A significant } \\
\text { correlation between in-barn and } \\
\text { outdoor MRSA counts was noted. }\end{array}$ \\
\hline
\end{tabular}

Note:

${ }^{1}$ The publication has been summarized in Table 5 for culturable microbial counts. It is listed here for the convenience of readers, with minimal repeated information.

${ }^{2}$ spa refers to Staphylococcal protein A, a critical factor affecting the virulence of S. aureus. spa typing is a method to distinguish $S$. aureus genotypes through PCR detection of spa genes. 
The existing publications were from the U.S. (7), Europe (7), and China (2). Nine of them focused on MRSA and seven tested bacteria other than $S$. aureus for antibiotic resistance. Methicillin resistance was most extensively investigated, followed by tetracycline and erythromycin resistance (Note: The resistance of MRSA to tetracycline and erythromycin was examined by several MRSA studies). Finisher barns were the most studied barn type, followed by nursery barns.

Airborne MRSA counts varied greatly in the literature, from undetected (zero) to $>10^{4} \mathrm{CFU} \mathrm{m} \mathrm{m}^{-3}$. Most of the reported MRSA counts fell into the range of 10 to $10^{3} \mathrm{CFU} \mathrm{\textrm {m } ^ { - 3 }}$. MRSA accounted for only a small portion of cultural bacteria (Friese et al., 2012; Ferguson et al. 2016; Wenke et al., 2018). Regarding the percentage of $S$. aureus being methicillin resistant, no agreement has been reached. Madsen et al. (2018) found that in finisher and nursey barns, the majority of airborne $S$. aureus strains were MRSA; while in farrowing and sick pig barns, the percentage was down to $<10 \%$. Comparatively, Masclaux et al. (2013) reported that $\sim 20 \%$ of $S$. aureus strains in visited nursery, finisher, and farrowing barns were MRSA.

Two studies measured the percentage of other ARBs in total culturable bacteria. Zahn et al. (2001) reported that $\sim 80 \%$ of airborne culturable bacteria in two finisher barns in Iowa were tylosin resistant. Chen et al. (2019) found that on average 9\% of airborne culturable bacteria in four swine barns in China were tetracycline resistant and $27 \%$ were erythromycin resistant. An overall higher percentage of ARB was found in broiler barns and a lower percentage in cattle barns in the same study.

PM samples in swine barns were frequently MRSA positive, especially those sampled from the inside of pig pens. The detected MRSA strains often carried resistance to other swine antibiotics (e.g., tetracycline) (Ferguson et al., 2016; Davis et al., 2018). Spa typing was performed to determine the genotype of MRSA isolates (Friese et al., 2012; Ferguson et al., 2016; Davis et al., 2018; Wenke et al., 2018; Angen et al., 2021). The identified spa genotypes include t011, t034, t108, and t337. Among them, t011 and t034 are known to be livestock associated (Ferguson et al., 2016).

The exhaust air from swine barns can be a major source of ARB in surrounding areas. Several studies analyzed downwind and/or upwind bioaerosol samples (Gibbs et al., 2004, 2006; Schulz et al., 2012; Ferguson et al., 2016; Angen et al., 2021). Results revealed a substantial increase in ARB counts or occurrence frequency downwind from swine barns. Another supporting evidence is a significant correlation between in-barn and outdoor airborne MRSA counts (Angen et al., 2021).

Two studies investigated the control of airborne ARB in swine barns. Gongora et al. (2013) tested a commercial disinfectant (Stalosan ${ }^{\circledR} F$ ) but did not see a significant reduction in MRSA counts after disinfection treatment. Wenke et al. (2018) compared four air filtration systems. However, no significant difference in in-barn airborne MRSA counts was reported. Madsen et al. (2018) examined the size distribution of MRSA and found its geometric mean diameter to be $7.2 \mu \mathrm{m}$, suggesting that the majority of MRSA could be attached to large particles. Although this is not an MRSA mitigation study, the size data derived is valuable for the development of MRSA mitigation technologies since many PM removal processes are size dependent (Refer to Section 5).

In summary, multiple studies detected the presence of airborne ARB (including MRSA) in swine barns. The emissions of ARB via the barns' exhaust were found to elevate downwind ARB concentrations in the air and soil. Although efforts were made, no effective mitigation technology has been identified. ARB mitigation, from source reduction to end-of-pipe abatement, should receive considerable attention in future research.

Antibiotic resistance genes (ARGs)

Bacteria including human pathogens can acquire antibiotic resistance from other bacterial cells through horizontal gene transfer. An investigation of ARGs in various media (e.g., air, water, food, and soil), therefore, enables an improved understanding of the dissemination of antibiotic resistance in the environment. Molecular biology technologies, such as PCR and qPCR, are extensively used for the detection of ARGs in swine barn bioaerosols. These technologies can be part of culture-dependent or 
culture-independent methods. Examples of culture-dependent applications include the confirmation of MRSA colonies through mecA PCR (Table 10) where mecA [also written as mec(A)] is a gene that grants methicillin resistance to bacteria. This subsection focuses on ARG analysis results derived from cultureindependent methods which constitute the vast majority of existing findings.

To our knowledge, the first analysis of ARGs in swine barn bioaerosols was reported by Sapkota et al. (2006), as an add-on effort to culture-dependent ARB monitoring in the same barns (Chapin et al., 2005). Both were done by Dr. Schwab and his colleagues at Johns Hopkins University. Table 11 summarizes ARG studies since then. From a methodology standpoint, the findings acquired from PCR/qPCR of ARGs cannot be directly compared with those from metagenomic sequencing. For simplicity, they are listed here in the same table; and a brief discussion of the methods is available in Section 4.4.4.

Table 11. Antibiotic resistance genes (ARGs) in swine barn PM - A summary of existing studies.

\begin{tabular}{|c|c|c|c|c|c|}
\hline References & Barn type & Location & Target ARGs $^{1}$ & $\begin{array}{l}\text { Analytical } \\
\text { method }\end{array}$ & Major findings and/or notes ${ }^{2}$ \\
\hline $\begin{array}{l}\text { Sapkota et } \\
\text { al. }(2006)^{3}\end{array}$ & Finisher & Iowa & $\begin{array}{l}\text { MLS resistance: } \\
\operatorname{erm}(\mathrm{A}), \operatorname{erm}(\mathrm{B}), \\
\operatorname{erm}(\mathrm{C}), \operatorname{erm}(\mathrm{F}), \\
\operatorname{mef}(\mathrm{A}) \\
\text { Tetracycline } \\
\text { resistance: } \operatorname{tet}(\mathrm{M}), \\
\operatorname{tet}(\mathrm{O}), \operatorname{tet}(\mathrm{S}), \operatorname{tet}(\mathrm{K}), \\
\operatorname{tet}(\mathrm{L})\end{array}$ & $\begin{array}{l}\text { DNA-DNA } \\
\text { hybridization, } \\
\text { PCR }\end{array}$ & $\begin{array}{l}\text { Sixteen Enterococcus spp. and } \\
16 \text { Streptococcus spp. isolates } \\
\text { selected from ARB screening } \\
\text { were subjected to ARG } \\
\text { analysis. All colonies carried } \\
\text { multiple MLS and tetracycline } \\
\text { resistance genes. }\end{array}$ \\
\hline $\begin{array}{l}\text { Létourneau } \\
\text { et al. } \\
(2010)\end{array}$ & $\begin{array}{l}\text { Grower- } \\
\text { finisher }\end{array}$ & $\begin{array}{l}\text { Quebec, } \\
\text { Canada }\end{array}$ & $\begin{array}{l}\text { Tetracycline } \\
\text { resistance: } \operatorname{tet}(\mathrm{A}), \\
\operatorname{tet}(\mathrm{C}), \operatorname{tet}(\mathrm{G}), \operatorname{tet}(\mathrm{M}), \\
\operatorname{tet}(\mathrm{O}), \operatorname{tet}(\mathrm{P}), \operatorname{tet}(\mathrm{Q}), \\
\operatorname{tet}(\mathrm{S}), \operatorname{tet}(\mathrm{T}), \operatorname{tet}(\mathrm{W})\end{array}$ & $\begin{array}{l}\text { qPCR for } \\
\text { tet }(G) \\
\text { PCR for others }\end{array}$ & $\begin{array}{l}\text { The concentration of } \operatorname{tet}(\mathrm{G}) \\
\text { was } 2.5 \pm 6.6 \times 10^{6} \text { copies } \mathrm{m}^{-3} \text {. } \\
\text { All the } 18 \text { visited barns were } \\
\text { positive for tetracycline } \\
\text { resistance genes analyzed. } \\
\text { Tetracycline resistance was } \\
\text { also found among culturable } \\
\text { pathogens at various } \\
\text { occurrence frequencies. }\end{array}$ \\
\hline $\begin{array}{l}\text { Hong et al. } \\
(2012)\end{array}$ & $\begin{array}{l}\text { Farrowing, } \\
\text { gestation, } \\
\text { nursery, } \\
\text { finisher }\end{array}$ & Illinois & $\begin{array}{l}\text { Tetracycline } \\
\text { resistance: } \operatorname{tet}(\mathrm{B}), \\
\operatorname{tet}(\mathrm{H}), \operatorname{tet}(\mathrm{Z}), \operatorname{tet}(\mathrm{O}), \\
\operatorname{tet}(\mathrm{Q}), \operatorname{tet}(\mathrm{W})\end{array}$ & qPCR & $\begin{array}{l}\text { These tetracycline resistance } \\
\text { genes were abundant in DNA } \\
\text { extracts from swine barn PM } \\
\left(9.55 \times 10^{2}-1.69 \times 10^{6} \text { copies ng }\right. \\
\left.{ }^{1}\right) \text {. tet }(\mathrm{O}) \text { and } \text { tet }(\mathrm{Q}) \text { were the } \\
\text { most abundant; while tet }(\mathrm{B}) \\
\text { was the least abundant. Swine } \\
\text { barn PM had much greater } \\
\text { tet }(\mathrm{H}) \text { and tet }(\mathrm{W}) \text { contents } \\
\text { than poultry barn PM but } \\
\text { lower tet }(\mathrm{Z}) \text { contents than } \\
\text { turkey barn PM. }\end{array}$ \\
\hline $\begin{array}{l}\text { Kumari } \\
\text { and Choi } \\
(2014)\end{array}$ & $\begin{array}{l}\text { Grower- } \\
\text { finisher }\end{array}$ & $\begin{array}{l}\text { South } \\
\text { Korea }\end{array}$ & $\begin{array}{l}\text { Tetracycline } \\
\text { resistance: } \operatorname{tet}(\mathrm{B}), \\
\operatorname{tet}(\mathrm{H}), \operatorname{tet}(\mathrm{Z}), \operatorname{tet}(\mathrm{O}), \\
\operatorname{tet}(\mathrm{Q}), \operatorname{tet}(\mathrm{W})\end{array}$ & qPCR & $\begin{array}{l}\text { tet }(\mathrm{Q}) \text { was the most abundant } \\
\left(8.89 \times 10^{5} \pm 1.45 \times 10^{6} \text { copies } \mathrm{m}-\right. \\
\left.{ }^{3}\right) \text { while } \operatorname{tet}(\mathrm{B}) \text { was the least } \\
\text { abundant. A significant } \\
\text { difference in } \mathrm{ABG} \text { abundance } \\
\text { was found for tet }(\mathrm{H}) \text {, tet }(\mathrm{O}) \text {, } \\
\text { tet }(\mathrm{Q}) \text {, and tet }(\mathrm{W}) \text { between } \\
\text { winter and summer samples. }\end{array}$ \\
\hline
\end{tabular}




\begin{tabular}{|c|c|c|c|c|c|}
\hline $\begin{array}{l}\text { Kumari } \\
\text { and Choi } \\
\text { (2015) }\end{array}$ & $\begin{array}{l}\text { Grower- } \\
\text { finisher }\end{array}$ & $\begin{array}{l}\text { South } \\
\text { Korea }\end{array}$ & $\begin{array}{l}\text { Tetracycline } \\
\text { resistance: } \operatorname{tet}(\mathrm{B}), \\
\operatorname{tet}(\mathrm{H}), \operatorname{tet}(\mathrm{Z}), \operatorname{tet}(\mathrm{O}), \\
\operatorname{tet}(\mathrm{Q}), \operatorname{tet}(\mathrm{W})\end{array}$ & qPCR & $\begin{array}{l}\text { All tested ARGs but tet(B) } \\
\text { were more abundant in barns } \\
\text { with deep manure pits. Barns } \\
\text { with bedded litter floors had } \\
\text { the lowest ARGs abundance } \\
\text { in the air. }\end{array}$ \\
\hline $\begin{array}{l}\text { Wu et al. } \\
(2019)^{3}\end{array}$ & $\mathrm{n} / \mathrm{a}$ & China & $\begin{array}{l}\text { Quinolone resistance } \\
\text { in } E . \operatorname{coli}: q n r(\mathrm{~A}), \\
q n r(\mathrm{~B}), q n r(\mathrm{~S}), \\
q n r(\mathrm{~S} 1), q n r(\mathrm{~S} 2), \\
q n r(\mathrm{~A}), \operatorname{aac}\left(6^{\prime}\right)-l b-c r, \\
\operatorname{aac}\left(6^{\prime}\right)-l b-c r, q e p(\mathrm{~A}), \\
\operatorname{oqx}(\mathrm{AB})\end{array}$ & PCR & $\begin{array}{l}\text { Twenty-six E. coli isolates } \\
\text { were analyzed. Among them, } \\
19 \text { carried at least one and } 4 \\
\text { carried two or more quinolone } \\
\text { resistance genes. The detected } \\
\text { subtypes included } q n r(\mathrm{~A}), \\
q n r(\mathrm{~S} 1), q n r(\mathrm{~S} 2), q n r(\mathrm{~B} 2), \\
\operatorname{acc}\left(6^{\prime}\right)-l b-c r, q e p(\mathrm{~A}), \text { and } \\
\text { oqx(AB). Other environmental } \\
\text { samples were also analyzed. }\end{array}$ \\
\hline $\begin{array}{l}\text { Pilote et al. } \\
(2019)\end{array}$ & Finisher & $\begin{array}{l}\text { Quebec, } \\
\text { Canada }\end{array}$ & $\begin{array}{l}\text { Zinc resistance: } \\
c z r(\mathrm{C}) \\
\text { Cephalosporin } \\
\text { resistance: bla } \\
\text { Colistin resistance: } \\
\text { mcr-1 }\end{array}$ & qPCR & $\begin{array}{l}\text { All PM samples carried } c z r(\mathrm{C}) \\
\text { and } 60 \% \text { of samples carried } \\
\text { blaCTX-M-1 and } m c r-1 \text {. Their } \\
\text { concentrations were } 1.73 \times 10^{2} \text { - } \\
1.78 \times 10^{5},<8-9.89 \times 10^{2} \text {, and } \\
<8-9.87 \times 10^{2} \text { copies } \mathrm{m}^{-3} \text {, } \\
\text { respectively. }\end{array}$ \\
\hline $\begin{array}{l}\text { Yan et al. } \\
\text { (2019) }\end{array}$ & $\begin{array}{l}\text { Farrowing, } \\
\text { gestation, } \\
\text { nursery, } \\
\text { grower- } \\
\text { finisher, } \\
\text { boar }\end{array}$ & China & Various resistance & $\begin{array}{l}\text { Shotgun } \\
\text { metagenomic } \\
\text { sequencing }\end{array}$ & $\begin{array}{l}\text { A total of } 304,300,300,277, \\
\text { and } 304 \text { ARG subtypes were } \\
\text { identified in boar, farrowing, } \\
\text { gestation, nursery, and finisher } \\
\text { barns, respectively. In terms } \\
\text { of ARG composition, two } \\
\text { clusters were found: (1) boar, } \\
\text { farrowing, and gestation, and } \\
\text { (2) nursery and finisher. The } \\
\text { top } 10 \text { ARG subtypes were } \\
\text { resistant to aminoglycosides, } \\
\text { aminocoumarin, mupirocin, } \\
\text { elfamycin, fluoroquinolone, } \\
\text { pleuromutilin, rifampin, and } \\
\text { lincosamide. Bacterial phyla } \\
\text { Firmicutes and Bacterioidetes } \\
\text { carried the majority of ARGs. }\end{array}$ \\
\hline $\begin{array}{l}\text { Luiken et } \\
\text { al. (2020) }\end{array}$ & $\mathrm{n} / \mathrm{a}$ & $\begin{array}{l}\text { Nine } \\
\text { European } \\
\text { countries }\end{array}$ & Various resistance & $\begin{array}{l}\text { Shotgun } \\
\text { metagenomic } \\
\text { sequencing }\end{array}$ & $\begin{array}{l}\text { The most abundant ARG was } \\
\text { tetracycline resistance genes, } \\
\text { followed by macrolide and } \\
\text { aminoglycoside. Nine other } \\
\text { major ARG types were } \\
\text { reported: beta-lactam, colistin, } \\
\text { nitroimidazole, oxazolidinone } \\
\text { phenicol, phenicol, quinolone, } \\
\text { sulphonamide, trimethoprim, } \\
\text { and vancomycin. }\end{array}$ \\
\hline
\end{tabular}




\begin{tabular}{|c|c|c|c|c|c|}
\hline $\begin{array}{l}\text { Song et al. } \\
\text { (2021) }\end{array}$ & $\mathrm{n} / \mathrm{a}$ & China & $\begin{array}{l}\text { Tetracycline } \\
\text { resistance: } \operatorname{tet}(\mathrm{M}) \text {, } \\
\text { tet }(\mathrm{G}), \operatorname{tet}(\mathrm{O}) \\
\text { Sulfonamide } \\
\text { resistance: } \operatorname{sul} 1, \text { sul2 } \\
\text { Quinolones } \\
\text { resistance: } q \operatorname{ta}(\mathrm{A}) \\
\text { Macrolides resistance: } \\
\operatorname{erm}(\mathrm{A}), \operatorname{erm}(\mathrm{B})\end{array}$ & qPCR & $\begin{array}{l}\text { ARGs were more abundant (in } \\
\text { copies } \mathrm{m}^{-3} \text { ) in winter than } \\
\text { summer samples. The most } \\
\text { dominant ARG was tet(M). } \\
\text { Mobile genetic elements } \\
\text { (MGEs), a carrier of ARGs in } \\
\text { bacteria, were also quantified. } \\
\text { Genera Lactobacillus, } \\
\text { Prevotella, Prevotellaceae, } \\
\text { Balutia, and Muribaculaceae } \\
\text { correlated significantly with } \\
\text { ARGs in winter. Genera } \\
\text { Prevotellaceae and } \\
\text { Ochrobactrum correlated } \\
\text { significantly with tetracycline } \\
\text { resistance genes. }\end{array}$ \\
\hline $\begin{array}{l}\text { Yan et al. } \\
(2021)^{4}\end{array}$ & $\begin{array}{l}\text { Farrowing, } \\
\text { gestation, } \\
\text { nursery, } \\
\text { grower- } \\
\text { finisher }\end{array}$ & China & Various resistance & $\begin{array}{l}\text { Metagenomic } \\
\text { sequencing } 5 \\
\text { for ARGs and } \\
\text { bacteria }\end{array}$ & $\begin{array}{l}\text { Twenty-two ARG types were } \\
\text { identified, with } 12 \text { shared by } \\
\text { all barn types. Nursery barns } \\
\text { had the fewest ARG types and } \\
\text { finisher barns had the lowest } \\
\text { abundance of ARGs. The top } \\
\text { three most abundant ARGs } \\
\text { were aph( } 3 \text { ',')-III, aad (E) and } \\
\text { tet(W). Genera Leadbetterella } \\
\text { and Methylobacterium were } \\
\text { hosts of most ARGs; while } 11 \\
\text { other genera carried } \geq 3 \text { ARGs. }\end{array}$ \\
\hline
\end{tabular}

Note:

${ }^{1}$ MLS - macrolide, lincosamide and streptogramin.

${ }^{2}$ Several papers presented qPCR quantitative results in figures only. It is difficult to derive accurate readings from those figures. Accordingly, no quantitative results were provided in this table.

${ }^{3}$ The study used PCR not to confirm the existence of ARB. Instead, it focused on the determination of ARG types and subtypes. Thus, it is also included in this table.

${ }^{4}$ The same paper used 16S rRNA NGS for bacterial taxonomic classification.

${ }^{5}$ Although no direct information was given, the selected technology appeared to be shotgun metagenomic sequencing based on method descriptions.

A rapidly growing interest in ARGs is witnessed. Out of the eleven publications in the table, six were published in the past two years. Regarding the geographic distribution of relevant studies, six were from Asia (China and South Korea) and only one from Europe. Although the U.S. pioneered in this subject, no relevant research has been reported since 2012.

Seven studies used qPCR for ARG detection and quantification. The abundance of ARGs was presented as the number of ARG copies per ng of DNA extracts (copies $\mathrm{ng}^{-1}$ ) or the number of ARG copies per $\mathrm{m}^{-3}$ of barn air (copies $\mathrm{m}^{-3}$ ). Three studies used PCR for qualitative (presence or absence of an ARG) or quantitative analysis (occurrence frequency of an ARG in bacterial colony isolates). Three studies used metagenomic analysis to survey the existence of various ARGs and to determine host bacterial groups.

Tetracycline resistance genes (TRGs) were the most studied ARGs (with eight publications) because of the extensive use of tetracycline for pork production (Dewey et al. 1999). Multiple TRG subtypes were investigated in the literature, including $\operatorname{tet}(\mathrm{A}), \operatorname{tet}(\mathrm{B}), \operatorname{tet}(\mathrm{C}), \operatorname{tet}(\mathrm{G}), \operatorname{tet}(\mathrm{H}), \operatorname{tet}(\mathrm{K}), \operatorname{tet}(\mathrm{L}), \operatorname{tet}(\mathrm{M}), \operatorname{tet}(\mathrm{O})$, $\operatorname{tet}(\mathrm{P}), \operatorname{tet}(\mathrm{Q}), \operatorname{tet}(\mathrm{S}), \operatorname{tet}(\mathrm{T}), \operatorname{tet}(\mathrm{W})$, and $\operatorname{tet}(\mathrm{Z})$. They confer tetracycline resistance to bacteria through 
several mechanisms including efflux pump, ribosomal protection, and enzymatic inactivation (van Hoek et al., 2011). TRGs encoding ribosomal protection proteins were commonly found in the gastrointestinal tracts of pigs (Aminov et al., 2001). Other ARGs that were reported by multiple publications include quinolones resistance genes and macrolides (or MLS) resistance genes.

Little information is known regarding the effect of seasons and barn types. Hong et al. (2012) compared four barn types but found no significant difference in TRG profiles. Kumari and Choi (2015) compared three waste management systems for finisher barns and revealed a significant effect of waste management on TRG concentrations. Song et al. (2021) examined four types of ARGs in winter and summer PM samples and found that ARGs were more abundant in winter. This is understandable since in-barn PM concentrations are typically the highest in winter.

Metagenomic analysis revealed that various airborne bacteria in swine barns could carry ARGs. The major ARG hosts identified include phyla Firmicutes and Bacterioidetes and genera Lactobacillus, Prevotella, Prevotellaceae, Balutia, Leadbetterella, and Methylobacterium. For TRGs, the major hosts include genera Prevotellaceae and Ochrobactrum. It is noteworthy that phyla Firmicutes and Bacterioidetes are two dominant bacterial groups in swine barn bioaerosols, as well as genera Lactobacillus and Prevotella (Refer to Section 3.2.3). However, it is uncertain whether other abundant bacterial groups in swine barn bioaerosols, such as genera Clostridium, Bacteroides, and Corynebacterium, are significant hosts of ARGs because of limited data in the literature.

Although significant progress has been made, several fundamental questions remain unanswered regarding ARGs in swine barn bioaerosols. For example, the air is an unideal environment for many gastrointestinal or fecal bacteria. Thus, it is uncertain how long airborne bacteria carrying ARGs can survive and whether they can propagate ARGs through horizontal or vertical gene transfer after a long travel in the air. No exposure model has been well established to describe the potential impact of airborne ARB and ARGs on animal and community health.

\subsubsection{Endotoxins and other bioaerosol markers}

Bioaerosols can be characterized by their fingerprint components or metabolites (Douwes et al., 2003). These components and metabolites are known as bioaerosols markers, or simply biomarkers. Some of them are etiological agents of diseases or disorders in animals and humans; while others have had no known health implications. In a previous review paper, etiological agents were listed as a separate category from markers (Ghosh et al. 2015). For simplicity, this review tags the agents in both categories (etiological and non-etiological) as bioaerosol markers.

Various markers have been used for bioaerosols assessment. In principle, any organism(s)-specific substance can potentially be selected as a bioaerosol marker. The specificity can be at the taxonomic level of domain, kingdom, phylum, etc., or even simply distinguish organisms from non-organisms. Table 12 lists several commonly selected markers. Among them, endotoxin is most frequently used for bioaerosols assessment in swine barns, followed by $(1 \rightarrow 3)-\beta$-D-glucan. Others are very occasionally measured. Accordingly, this section is structured into three subsections: endotoxin, $(1 \rightarrow 3)-\beta$-D-glucan, and other bioaerosol markers.

Table 12. Bioaerosol markers for different organisms.

\begin{tabular}{|l|l|l|}
\hline Organism & Marker & Reference \\
\hline General organisms & Total proteins & Poruthoor et al. (1998) \\
& ATP $^{1}$ & Crook and Sherwood-Higham (1997) \\
\hline Fungi & $(1 \rightarrow 3)-\beta$-D-glucan & Rylander et al. (1992) \\
& Ergosterol & Miller and Young (1997) \\
& EPS $^{2}$ & Douwes et al. (1999) \\
& Mannitol & Burshtein et al. (2011) \\
& Arabitol & Chow et al. (2015) \\
& Mycotoxins (e.g., aflatoxin B1) & Jargot and Melin (2013) \\
\hline
\end{tabular}




\begin{tabular}{|l|l|l|}
\hline Gram-negative bacteria & Endotoxin (3-hydroxy fatty acids) & Milton et al. (1990); Saraf et al. (1997) \\
\hline Gram-positive bacteria & Peptidoglycan (muramic acid) & Mielniczuk et al. (1995); Góra et al. (2009) \\
\hline
\end{tabular}

Note:

${ }^{1}$ ATP - Adenosine triphosphate

${ }^{2}$ EPS - Extracellular polysaccharides

\section{Endotoxin}

An endotoxin (lipopolysaccharide, LPS) is a cell envelop component of Gram-negative bacteria and is released when the bacteria are lysed or at the multiplication stage (Cox and Wathes, 1995). An LPS molecule consists of three parts: O-antigen, core polysaccharide, and lipid A. Among them, lipid A is believed to be responsible for the toxicity of endotoxins. Lipid A comprises two glucosamine groups with one phosphate and multiple acyl chains attached to each group. Different Gram-negative bacteria may differ in the number, length, and attachment site of acyl chains, resulting in different degrees of toxicity (Helander et al., 1982). Even for the same species, the structure of lipid A may change when the bacteria grow at different lifetime periods or under different environmental conditions (Milton et al., 1992).

Endotoxins are mildly toxic to mammals. Upon injection into the blood, endotoxins immediately trigger a series of immunoreactions, leading immune cells to release pro-inflammatory cytokines. For human, a dose of $2 \mathrm{ng}$ of Salmonella abortus-equi endotoxin per kg body weight could increase a body temperature by $1.9^{\circ} \mathrm{C}$ (Anderson et al., 2002). Symptoms such as "fever, change in white blood cell counts, disseminated intravascular coagulation, hypotension, shock, and death" can be observed (Todar, 2008). Inhalation of endotoxins is associated with various acute and chronic symptoms in humans, including fever, shivering, pulmonary inflammation, non-allergenic asthma, airway obstruction, and impaired lung functions (Kirkhorn and Garry, 2000). Acute lung function impairment and acute bronchial obstruction in swine farm workers were found to be highly dependent on endotoxin levels (Donham et al., 1984a; Donham et al., 1989; Donham, 1990). Chronic bronchial obstruction and hyperactive airways in swine farm workers could result from long-term exposure to airborne endotoxins (Donham et al., 1984b; Heederik et al., 1991). Efforts were made to develop endotoxin exposure limits through dose-response studies (Donham et al., 1989; Michel et al., 1997). Donham et al. (2000) recommended an exposure limit of 100 endotoxin units (EU) $\mathrm{m}^{-3}$ for swine barns. Inhalation of endotoxins could also compromise pig performance and health, causing decreased growth rates (Crowe et al., 1996), bronchial hyperreactivity, lung inflammation (Urbain et al., 1996), and even respiratory failure (Olson et al., 1985).

Endotoxins are extensively used as a marker of Gram-negative bacteria (Todar, 2008). Previous studies have revealed the ubiquitous occurrence of Gram-negative bacteria in swine barn PM samples (Refer to Sections 3.2.1 and 3.2.3). For example, Predicala et al. (2002) measured culturable bacterial counts in a finisher barn in Kansas and reported the presence of genera Pseudomonas, Vibro, and Gram-negative Bacilli. Similar findings were acquired using culture-independent methods. Nehme et al. (2008) examined the bacterial diversity of PM sampled from eight swine barns in Quebec, Canada, and found that most Gram-negative bacteria belonged to genera Moraxella, Bacteroides, and Pseudomonas. Using 16S rRNA NGS, Hong et al. (2012) found four Gram-negative bacterial phyla (Bacteroidetes, Proteobacteria, Fusobacteria, and Cyanobacteria) in TSP samples from 12 swine barns in Illinois. They further identified Gram-negative bacterial genera, such as Acinetobacter, Moraxella, and Fusobacterium.

To our knowledge, the first measurement of airborne endotoxins in swine barns was done by Dr. Terry Thedell and his colleagues at the National Institute of Occupational Safety and Health (NIOSH) (Thedell et al., 1980). Using a gel clot Limulus amebocyte lysate (LAL) assay, they reported the endotoxin levels of 4.77-47.74 $\mu \mathrm{g}$ per gram of PM in two swine barns in the U.S. Midwest. Following their work, multiple monitoring efforts were made in the 1980s (Clark et al., 1983; Donham et al., 1984a; 1984b; 1986; 1989; Attwood et al., 1986; 1987; Rylander et al., 1989). These early studies were often coupled with epidemiological surveys to further unravel or affirm the health effects of airborne endotoxins. Additional studies have been reported since 1990 (Table 13). However, the focus areas of the studies shifted to (1) 
comparing and further refining endotoxin sampling and testing protocols, and (2) determining baseline airborne endotoxin levels and their effects by environmental and operating parameters in swine barns.

Table 13. Airborne endotoxin concentrations in swine barns - a summary of studies since 1990.

\begin{tabular}{|c|c|c|c|c|c|}
\hline References & $\begin{array}{l}\text { Endotoxin concentration (EU } \\
\left.m^{-3}\right)^{1,2,3}\end{array}$ & $\begin{array}{l}\text { Barn \& } \\
\text { ventilation } \\
\text { type }^{4}\end{array}$ & Location & Season & $\begin{array}{l}\text { Analytical } \\
\text { method }\end{array}$ \\
\hline $\begin{array}{l}\text { Christensen et } \\
\text { al. }(1992)^{5}\end{array}$ & $\begin{array}{l}\text { TSP: } 64 \pm 34(9-120) \mathrm{ng} \mathrm{m}^{-3} \\
\text { Respirable: } 5 \pm 3(1-13) \mathrm{ng} \mathrm{m}^{-3}\end{array}$ & Breeding; $\mathrm{n} / \mathrm{a}$ & Denmark & $\mathrm{n} / \mathrm{a}$ & $\begin{array}{l}\text { Chromogenic } \\
\text { LAL assay }\end{array}$ \\
\hline \multirow[t]{2}{*}{$\begin{array}{l}\text { Larsson et al. } \\
(1992)^{5}\end{array}$} & $\begin{array}{l}\text { During tending - } \\
\text { TSP: } 37 \mathrm{ng} \mathrm{m}^{-3} \\
\text { Respirable: } 8 \mathrm{ng} \mathrm{m}^{-3}\end{array}$ & \multirow[t]{2}{*}{$\mathrm{n} / \mathrm{a} ; \mathrm{n} / \mathrm{a}$} & \multirow[t]{2}{*}{ Sweden } & \multirow[t]{2}{*}{$\mathrm{n} / \mathrm{a}$} & \multirow[t]{2}{*}{ LAL assay } \\
\hline & $\begin{array}{l}\text { During feeding - } \\
\text { TSP: } 315 \mathrm{ng} \mathrm{m}^{-3} \\
\text { Respirable: } 17 \mathrm{ng} \mathrm{m}^{-3}\end{array}$ & & & & \\
\hline $\begin{array}{l}\text { Vinzents and } \\
\text { Nielsen }(1992)^{5}\end{array}$ & TSP: 702 & Breeding; $\mathrm{n} / \mathrm{a}$ & Denmark & $\mathrm{n} / \mathrm{a}$ & LAL assay \\
\hline $\begin{array}{l}\text { Malmberg and } \\
\text { Larsson }(1993)^{5}\end{array}$ & TSP: $0.21-0.40 \mu \mathrm{g} \mathrm{m}^{-3}$ & $\mathrm{n} / \mathrm{a} ; \mathrm{n} / \mathrm{a}$ & Sweden & $\mathrm{n} / \mathrm{a}$ & $\begin{array}{l}\text { Chromogenic } \\
\text { LAL assay }\end{array}$ \\
\hline \multirow{2}{*}{$\begin{array}{l}\text { Dutkiewicz et } \\
\text { al. (1994) }\end{array}$} & TSP: $1.88-31.25 \mu \mathrm{g} \mathrm{m}^{-3}$ & Farrowing; $\mathrm{n} / \mathrm{a}$ & \multirow[t]{2}{*}{ Poland } & $\mathrm{n} / \mathrm{a}$ & \multirow{2}{*}{$\begin{array}{l}\text { Clot LAL } \\
\text { assay }\end{array}$} \\
\hline & TSP: $31.25-75.00 \mu \mathrm{g} \mathrm{m}^{-3}$ & Finisher; n/a & & $\mathrm{n} / \mathrm{a}$ & \\
\hline $\begin{array}{l}\text { Donham et al. } \\
(1995)^{5}\end{array}$ & $\begin{array}{l}\text { TSP: } 202.4 \\
\text { Respirable: } 16.59\end{array}$ & $\mathrm{n} / \mathrm{a} ; \mathrm{n} / \mathrm{a}$ & Iowa & $\begin{array}{l}\text { All } \\
\text { seasons }\end{array}$ & $\begin{array}{l}\text { Chromogenic } \\
\text { LAL assay }\end{array}$ \\
\hline \multirow[t]{2}{*}{$\begin{array}{l}\text { Preller et al. } \\
(1995)^{5}\end{array}$} & TSP: $111(5.6-825) \mathrm{ng} \mathrm{m}^{-3}$ & $\mathrm{n} / \mathrm{a} ; \mathrm{n} / \mathrm{a}$ & \multirow[t]{2}{*}{$\begin{array}{l}\text { The } \\
\text { Netherlands }\end{array}$} & Summer & \multirow[t]{2}{*}{$\begin{array}{l}\text { Kinetic LAL } \\
\text { assay }\end{array}$} \\
\hline & TSP: $150(10.6-1503) \mathrm{ng} \mathrm{m}^{-3}$ & $\mathrm{n} / \mathrm{a} ; \mathrm{n} / \mathrm{a}$ & & Winter & \\
\hline \multirow[t]{2}{*}{$\begin{array}{l}\text { Reynolds et al. } \\
(1996)^{5}\end{array}$} & $\begin{array}{l}\text { Time } 1- \\
\text { TSP: } 202.7 \mathrm{ng} \mathrm{m}^{-3}(\mathrm{GM}) \text {; } \\
4.33 \text { (GSD) } \\
\text { Respirable: } 17.0 \mathrm{ng} \mathrm{m}^{-3} \\
\text { (GM); } 2.30 \text { (GSD) }\end{array}$ & \multirow[t]{2}{*}{$\mathrm{n} / \mathrm{a} ; \mathrm{n} / \mathrm{a}$} & \multirow[t]{2}{*}{ Iowa } & \multirow[t]{2}{*}{$\begin{array}{l}\text { Spring, } \\
\text { fall, } \\
\text { winter }\end{array}$} & \multirow[t]{2}{*}{$\begin{array}{l}\text { Endpoint } \\
\text { chromogenic } \\
\text { LAL assay }\end{array}$} \\
\hline & $\begin{array}{l}\text { Time } 2- \\
\text { TSP: } 176.1 \mathrm{ng} \mathrm{m}^{-3}(\mathrm{GM}) \text {; } \\
3.16(\mathrm{GSD}) \\
\text { Respirable: } 11.9 \mathrm{ng} \mathrm{m}^{-3} \\
(\mathrm{GM}) ; 2.88 \text { (GSD) }\end{array}$ & & & & \\
\hline \multirow[t]{2}{*}{$\begin{array}{l}\text { Senthilselvan et } \\
\text { al. (1997) }\end{array}$} & $\begin{array}{l}\text { Area samples }- \\
\text { TSP: } 7.03 \times 10^{3} \text { without oil } \\
\text { sprinkling } \\
\text { TSP: } 566 \text { with oil sprinkling }\end{array}$ & \multirow[t]{2}{*}{$\begin{array}{l}\text { Grower- } \\
\text { finisher; MV }\end{array}$} & \multirow[t]{2}{*}{$\begin{array}{l}\text { Saskatchewan, } \\
\text { Canada }\end{array}$} & \multirow[t]{2}{*}{ Winter } & \multirow[t]{2}{*}{$\begin{array}{l}\text { Kinetic } \\
\text { chromogenic } \\
\text { LAL assay }\end{array}$} \\
\hline & $\begin{array}{l}\text { Personal sample }- \\
\text { TSP: } 1.60 \times 10^{3} \text { without oil } \\
\text { sprinkling } \\
\text { TSP: } 3.44 \times 10^{3} \text { with oil } \\
\text { sprinkling }\end{array}$ & & & & \\
\hline
\end{tabular}




\begin{tabular}{|c|c|c|c|c|c|}
\hline $\begin{array}{l}\text { Thorne et al. } \\
(1997)^{5}\end{array}$ & $\begin{array}{l}\text { TSP: } 2040-24,100 ; 8290 \\
\text { (GM) }\end{array}$ & $\mathrm{n} / \mathrm{a} ; \mathrm{n} / \mathrm{a}$ & Iowa & $\mathrm{n} / \mathrm{a}$ & $\begin{array}{l}\text { KLARE }^{6} \text {; } \\
\text { endpoint } \\
\text { chromogenic } \\
\text { LAL assay }\end{array}$ \\
\hline $\begin{array}{l}\text { Mackiewicz } \\
(1998)^{5}\end{array}$ & TSP: $22.8 \mu \mathrm{g} \mathrm{m}^{-3}$ & $\mathrm{n} / \mathrm{a} ; \mathrm{n} / \mathrm{a}$ & Poland & $\mathrm{n} / \mathrm{a}$ & LAL assay \\
\hline \multirow[t]{3}{*}{$\begin{array}{l}\text { Seedorf et al. } \\
\text { (1998) }\end{array}$} & $\begin{array}{l}\text { Daytime - } \\
\text { Inhalable: } 114.6 \mathrm{ng} \mathrm{m}^{-3} \\
\text { Respirable: } 8.3 \mathrm{ng} \mathrm{m}^{-3} \\
\text { Nighttime - } \\
\text { Inhalable: } 52.3 \mathrm{ng} \mathrm{m}^{-3} \\
\text { Respirable: } 7.4 \mathrm{ng} \mathrm{m}^{-3}\end{array}$ & Sow; n/a & \multirow[t]{3}{*}{$\begin{array}{l}\text { England, } \\
\text { The } \\
\text { Netherlands, } \\
\text { Denmark, } \\
\text { Germany }\end{array}$} & $\mathrm{n} / \mathrm{a}$ & \multirow[t]{3}{*}{$\begin{array}{l}\text { LAL clot } \\
\text { assay }\end{array}$} \\
\hline & $\begin{array}{l}\text { Daytime - } \\
\text { Inhalable: } 186.5 \mathrm{ng} \mathrm{m}^{-3} \\
\text { Respirable: } 17.7 \mathrm{ng} \mathrm{m}^{-3} \\
\text { Nighttime - } \\
\text { Inhalable: } 157.4 \mathrm{ng} \mathrm{m}^{-3} \\
\text { Respirable: } 18.9 \mathrm{ng} \mathrm{m}^{-3}\end{array}$ & Nursery; n/a & & $\mathrm{n} / \mathrm{a}$ & \\
\hline & $\begin{array}{l}\text { Daytime - } \\
\text { Inhalable: } 135.1 \mathrm{ng} \mathrm{m}^{-3} \\
\text { Respirable: } 13.0 \mathrm{ng} \mathrm{m}^{-3} \\
\text { Nighttime - } \\
\text { Inhalable: } 109.1 \mathrm{ng} \mathrm{m}^{-3} \\
\text { Respirable: } 11.4 \mathrm{ng} \mathrm{m}^{-3}\end{array}$ & Finisher; $\mathrm{n} / \mathrm{a}$ & & $\mathrm{n} / \mathrm{a}$ & \\
\hline \multirow[t]{2}{*}{$\begin{array}{l}\text { Zhang et al. } \\
(1998)^{5}\end{array}$} & $\begin{array}{l}\text { Control - } \\
\text { TSP: 3984; } 498 \text { (SE) }\end{array}$ & \multirow[t]{2}{*}{$\begin{array}{l}\text { Grower- } \\
\text { finisher; MV }\end{array}$} & \multirow[t]{2}{*}{$\begin{array}{l}\text { Saskatchewan, } \\
\text { Canada }\end{array}$} & $\mathrm{n} / \mathrm{a}$ & \multirow[t]{2}{*}{$\begin{array}{l}\text { Chromogenic } \\
\text { LAL assay }\end{array}$} \\
\hline & $\begin{array}{l}\text { Oil sprinkling - } \\
\text { TSP: } 452 ; 66 \text { (SE) }\end{array}$ & & & $\mathrm{n} / \mathrm{a}$ & \\
\hline $\begin{array}{l}\text { Simpson et al. } \\
(1999)^{5}\end{array}$ & $\begin{array}{l}\text { TSP: } 60-1.49 \times 10^{4} \mathrm{ng} \mathrm{m}^{-3} \text {; } \\
631 \mathrm{ng} \mathrm{m}^{-3} \text { (median); } 660 \mathrm{ng} \\
\mathrm{m}^{-3}(\mathrm{GM})\end{array}$ & $\mathrm{n} / \mathrm{a} ; \mathrm{n} / \mathrm{a}$ & $\begin{array}{l}\text { United } \\
\text { Kingdom }\end{array}$ & $\begin{array}{l}\text { All } \\
\text { seasons }\end{array}$ & $\begin{array}{l}\text { Kinetic } \\
\text { turbidimetric } \\
\text { LAL assay }\end{array}$ \\
\hline $\begin{array}{l}\text { Duchaine et al. } \\
(2000)^{5}\end{array}$ & TSP: $4.9 \times 10^{3}$ & Finisher; MV & $\begin{array}{l}\text { Quebec, } \\
\text { Canada }\end{array}$ & Winter & $\begin{array}{l}\text { Endpoint } \\
\text { chromogenic } \\
\text { LAL assay }\end{array}$ \\
\hline \multirow[t]{2}{*}{$\begin{array}{l}\text { Chang et al. } \\
\text { (2001a) }\end{array}$} & $\begin{array}{l}\text { TSP: } 36.8 \pm 18.1(15.8-73.2) \\
\text { Respirable: } 14.1 \pm 16.0(3.4- \\
56.6)\end{array}$ & $\begin{array}{l}\text { Breeding; NV } \\
\text { (open air) }\end{array}$ & \multirow[t]{2}{*}{ Taiwan } & Summer & \multirow[t]{2}{*}{$\begin{array}{l}\text { KLARE } \\
\text { assay }\end{array}$} \\
\hline & $\begin{array}{l}\text { TSP: } 82.1 \pm 85.0(14.4-277) \\
\text { Respirable: } 48.6 \pm 166(3.5- \\
837)\end{array}$ & $\begin{array}{l}\text { Farrowing; NV } \\
\text { (open air) }\end{array}$ & & Summer & \\
\hline
\end{tabular}




\begin{tabular}{|c|c|c|c|c|c|}
\hline & $\begin{array}{l}\text { TSP: } 298 \pm 249(32.0-818) \\
\text { Respirable: } 20.9 \pm 31.9(1.6- \\
\text { 155) }\end{array}$ & $\begin{array}{l}\text { Nursery; NV } \\
\text { (open air) }\end{array}$ & & Summer & \\
\hline & $\begin{array}{l}\text { TSP: } 145 \pm 81.4(40.1-298) \\
\text { Respirable: } 21.8 \pm 45.6(0.02- \\
\text { 217) }\end{array}$ & $\begin{array}{l}\text { Grower; NV } \\
\text { (open air) }\end{array}$ & & Summer & \\
\hline & $\begin{array}{l}\text { TSP: } 136 \pm 105(30.8-418) \\
\text { Respirable: } 129 \pm 396(5.6- \\
1643)\end{array}$ & $\begin{array}{l}\text { Finisher; NV } \\
\text { (open air) }\end{array}$ & & Summer & \\
\hline \multirow[t]{2}{*}{$\begin{array}{l}\text { Radon et al. } \\
(2002)^{5}\end{array}$} & $\begin{array}{l}\text { TSP: } 1.30-1101.7 \mathrm{ng} \mathrm{m}^{-3} \\
58.01 \mathrm{ng} \mathrm{m}^{-3} \text { (median) }\end{array}$ & $\mathrm{n} / \mathrm{a} ; \mathrm{n} / \mathrm{a}$ & Denmark & $\mathrm{n} / \mathrm{a}$ & \multirow[t]{2}{*}{$\begin{array}{l}\text { Kinetic } \\
\text { turbidimetric } \\
\text { LAL assay }\end{array}$} \\
\hline & $\begin{array}{l}\text { TSP: } 0.01-2090.1 \mathrm{ng} \mathrm{m}^{-3} \\
76.3 \mathrm{ng} \mathrm{m}^{-3} \text { (median) }\end{array}$ & $\mathrm{n} / \mathrm{a} ; \mathrm{n} / \mathrm{a}$ & Germany & $\mathrm{n} / \mathrm{a}$ & \\
\hline $\begin{array}{l}\text { Spaan et al. } \\
(2005)^{5}\end{array}$ & $\begin{array}{l}\text { TSP: 992-6970; } 1510 \text { (GM); } \\
2.1 \text { (GSD) }\end{array}$ & $\mathrm{n} / \mathrm{a} ; \mathrm{n} / \mathrm{a}$ & $\begin{array}{l}\text { The } \\
\text { Netherlands }\end{array}$ & $\begin{array}{l}\text { All } \\
\text { seasons }\end{array}$ & $\begin{array}{l}\text { Kinetic } \\
\text { chromogenic } \\
\text { LAL assay }\end{array}$ \\
\hline $\begin{array}{l}\text { Godbout et al. } \\
(2005)\end{array}$ & $\begin{array}{l}\text { Control - } \\
\text { TSP: } 1.72 \times 10^{3}(\mathrm{GM}) ; 1.5 \\
\text { (GSD) } \\
\text { Conventional scrapper - } \\
\text { TSP: } 1.85 \times 10^{3}(\mathrm{GM}) ; 2.0 \\
\text { (GSD) } \\
\text { V-shaped scraper - } \\
\text { TSP: } 2.14 \times 10^{3}(\mathrm{GM}) ; 2.3 \\
(\mathrm{GSD}) \\
\\
\text { Daily V-shape scraper - } \\
\text { TSP: } 1.53 \times 10^{3}(\mathrm{GM}) ; 2.1 \\
(\mathrm{GSD}) \\
\\
\text { Van Kempen belt - } \\
\text { TSP: } 1.85 \times 10^{3}(\mathrm{GM}) ; 2.5 \\
(\mathrm{GSD}) \\
\text { Cemagref net }- \\
\text { TSP: } 1.43 \times 10^{3}(\mathrm{GM}) ; 2.1 \\
(\mathrm{GSD})\end{array}$ & $\begin{array}{l}\text { Grower- } \\
\text { finisher; } \mathrm{n} / \mathrm{a}\end{array}$ & $\begin{array}{l}\text { Quebec, } \\
\text { Canada }\end{array}$ & Summer & LAL assay \\
\hline $\begin{array}{l}\text { Schierl et al. } \\
(2007)^{5}\end{array}$ & $\begin{array}{l}\text { Inhalable: } 43.2-7.47 \times 10^{3} ; \\
668.7 \text { (median) } \\
\text { Respirable: } 1.9-236 ; 23.1 \\
\text { (median) }\end{array}$ & Finisher; n/a & Germany & $\begin{array}{l}\text { All } \\
\text { seasons }\end{array}$ & $\begin{array}{l}\text { Kinetic } \\
\text { chromogenic } \\
\text { LAL assay }\end{array}$ \\
\hline $\begin{array}{l}\text { Mc Donnell et } \\
\text { al. }(2008)^{5}\end{array}$ & TSP: $1.67 \times 10^{5}$ (maximum) & $\begin{array}{l}\text { Nursery, } \\
\text { finisher; } \mathrm{n} / \mathrm{a}\end{array}$ & Ireland & $\begin{array}{l}\text { Spring, } \\
\text { summer }\end{array}$ & $\begin{array}{l}\text { Endpoint } \\
\text { LAL assay }\end{array}$ \\
\hline $\begin{array}{l}\text { Smit et al. } \\
(2008)^{5}\end{array}$ & $\begin{array}{l}\text { Inhalable: } 3400(\mathrm{GM}) ; 6.9 \\
\text { (GSD) }\end{array}$ & $\mathrm{n} / \mathrm{a} ; \mathrm{n} / \mathrm{a}$ & $\begin{array}{l}\text { The } \\
\text { Netherlands }\end{array}$ & Winter & $\begin{array}{l}\text { Kinetic } \\
\text { chromogenic } \\
\text { LAL assay }\end{array}$ \\
\hline
\end{tabular}




\begin{tabular}{|c|c|c|c|c|c|}
\hline \multirow[t]{2}{*}{$\begin{array}{l}\text { Bonlokke et al. } \\
(2009)^{5}\end{array}$} & $\begin{array}{l}\text { TSP: } 6.55 \times 10^{3}\left(2.22 \times 10^{3}-\right. \\
\left.2.59 \times 10^{4}\right)\end{array}$ & Finisher; n/a & \multirow[t]{2}{*}{$\begin{array}{l}\text { Quebec, } \\
\text { Canada }\end{array}$} & Summer & \multirow[t]{2}{*}{$\begin{array}{l}\text { Endpoint } \\
\text { chromogenic } \\
\text { LAL assay }\end{array}$} \\
\hline & $\begin{array}{l}\text { TSP: } 2.57 \times 10^{4}\left(1.80 \times 10^{3}-\right. \\
\left.6.91 \times 10^{4}\right)\end{array}$ & Finisher; $\mathrm{n} / \mathrm{a}$ & & Winter & \\
\hline \multirow{3}{*}{$\begin{array}{l}\text { O'Shaughnessy } \\
\text { et al. }(2009)^{5}\end{array}$} & Inhalable: $\sim 450$ & \multirow{3}{*}{$\begin{array}{l}\text { Gestation, } \\
\text { farrowing; n/a }\end{array}$} & \multirow[t]{3}{*}{ US Midwest } & Summer & \multirow{3}{*}{$\begin{array}{l}\text { Kinetic } \\
\text { chromogenic } \\
\text { LAL assay }\end{array}$} \\
\hline & Inhalable: $\sim 1400$ & & & Spring & \\
\hline & Inhalable: $\sim 2500$ & & & Winter & \\
\hline \multirow[t]{2}{*}{$\begin{array}{l}\text { Thorne et al. } \\
(2009)^{5}\end{array}$} & $\begin{array}{l}\text { Inhalable: } 48-3.77 \times 10^{4} \\
3.25 \times 10^{3}(\mathrm{GM}) ; 4.9(\mathrm{GSD})\end{array}$ & $\begin{array}{l}\text { Grower- } \\
\text { finisher; NV } \\
\text { (hoop barns) } \\
\end{array}$ & \multirow[t]{2}{*}{ Iowa } & $\begin{array}{l}\text { All } \\
\text { seasons }\end{array}$ & \multirow[t]{2}{*}{$\begin{array}{l}\text { Kinetic } \\
\text { chromogenic } \\
\text { LAL assay }\end{array}$} \\
\hline & $\begin{array}{l}\text { Inhalable: } 59-5.78 \times 10^{4} \\
3.10 \times 10^{3}(\mathrm{GM}) ; 5.8(\mathrm{GSD})\end{array}$ & $\begin{array}{l}\text { Grower- } \\
\text { finisher; MV }\end{array}$ & & $\begin{array}{l}\text { All } \\
\text { seasons }\end{array}$ & \\
\hline \multirow[t]{3}{*}{$\begin{array}{l}\text { Létourneau et } \\
\text { al. }(2009)^{5}\end{array}$} & $\begin{array}{l}\text { With slatted floors }- \\
\text { TSP: }(2.67 \pm 1.44) \times 10^{4}\end{array}$ & \multirow[t]{3}{*}{ Finisher; MV } & \multirow[t]{3}{*}{$\begin{array}{l}\text { Quebec, } \\
\text { Canada }\end{array}$} & \multirow[t]{3}{*}{ Winter } & \multirow[t]{3}{*}{$\begin{array}{l}\text { Endpoint } \\
\text { chromogenic } \\
\text { LAL assay }\end{array}$} \\
\hline & $\begin{array}{l}\text { With sawdust beddings - } \\
\text { TSP: }(5.19 \pm 3.04) \times 10^{4}\end{array}$ & & & & \\
\hline & $\begin{array}{l}\text { With source separation - } \\
\text { TSP: } 3.17 \times 10^{3}-7.25 \times 10^{3}\end{array}$ & & & & \\
\hline Ko et al. (2010) & $\begin{array}{l}\text { TSP: } 384.9\left(2.6-4.15 \times 10^{3}\right) \\
120 \text { (median); } 109.0(\mathrm{GM})\end{array}$ & $\begin{array}{l}\text { Finisher, } \\
\text { farrowing, } \\
\text { nursery; MV }\end{array}$ & North Carolina & $\mathrm{n} / \mathrm{a}$ & $\begin{array}{l}\text { Kinetic } \\
\text { chromogenic } \\
\text { LAL assay }\end{array}$ \\
\hline \multirow[t]{2}{*}{$\begin{array}{l}\text { Basinas et al. } \\
(2013)^{5}\end{array}$} & $\begin{array}{l}\text { Inhalable: } 5.2 \times 10^{3}(160- \\
\left.3.7 \times 10^{5}\right) ; 1.4 \times 10^{3}(\mathrm{GM}) ; 3.2 \\
(\mathrm{GSD})\end{array}$ & $\mathrm{n} / \mathrm{a} ; \mathrm{n} / \mathrm{a}$ & \multirow[t]{2}{*}{ Denmark } & Summer & \multirow[t]{2}{*}{$\begin{array}{l}\text { Chromogenic } \\
\text { kinetic LAL } \\
\text { assay }\end{array}$} \\
\hline & $\begin{array}{l}\text { Inhalable: } 5.3 \times 10^{3}(\mathrm{BDL}- \\
\left.1.10 \times 10^{5}\right) ; 2.4 \times 10^{3}(\mathrm{GM}) ; 3.1 \\
(\mathrm{GSD})\end{array}$ & $\mathrm{n} / \mathrm{a} ; \mathrm{n} / \mathrm{a}$ & & Winter & \\
\hline $\begin{array}{l}\text { Masclaux et al. } \\
(2013)\end{array}$ & $\begin{array}{l}\text { TSP: } 1.29 \times 10^{3}(17- \\
\left.6.15 \times 10^{3}\right) ; 636(\mathrm{GM})\end{array}$ & $\begin{array}{l}\text { Nursery, } \\
\text { farrowing, } \\
\text { finisher; } \mathrm{n} / \mathrm{a}\end{array}$ & Switzerland & $\begin{array}{l}\text { Winter, } \\
\text { summer }\end{array}$ & $\begin{array}{l}\text { Chromogenic } \\
\text { kinetic LAL } \\
\text { assay }\end{array}$ \\
\hline \multirow[t]{4}{*}{$\begin{array}{l}\text { Yang et al. } \\
(2013)\end{array}$} & $\begin{array}{l}\text { TSP: } 510 \pm 317 \text { (164-991); } \\
419 \text { (GM); } 1.98 \text { (GSD) }\end{array}$ & Gestation; MV & \multirow[t]{4}{*}{ Illinois } & \multirow[t]{4}{*}{$\begin{array}{l}\text { All } \\
\text { seasons }\end{array}$} & \multirow{4}{*}{$\begin{array}{l}\text { Chromogenic } \\
\text { kinetic LAL } \\
\text { assay }\end{array}$} \\
\hline & $\begin{array}{l}\text { TSP: } 508 \pm 617(98- \\
\left.2.10 \times 10^{3}\right) ; 334(\mathrm{GM}) ; 2.47 \\
(\mathrm{GSD})\end{array}$ & Farrowing; MV & & & \\
\hline & $\begin{array}{l}\text { TSP: } 1971 \pm 2816(217- \\
\left.8.7 \times 10^{3}\right) ; 1017(\mathrm{GM}) ; 3.30 \\
(\mathrm{GSD})\end{array}$ & Nursery; MV & & & \\
\hline & $\begin{array}{l}\text { TSP: } 1508 \pm 978,(693- \\
\left.3.59 \times 10^{3}\right) ; 1285(\mathrm{GM}) ; 1.51 \\
(\mathrm{GSD})\end{array}$ & Finisher; MV & & & \\
\hline
\end{tabular}




\begin{tabular}{|c|c|c|c|c|c|}
\hline \multirow[t]{4}{*}{$\begin{array}{l}\text { Yang et al. } \\
\text { (2014) }\end{array}$} & $\begin{array}{l}\mathrm{PM}_{10}: 74.7 \pm 54.2 ; 63.9(\mathrm{GM}) \\
1.72(\mathrm{GSD}) \\
\mathrm{PM}_{2.5}: 23.3 \pm 11.2 ; 20.5(\mathrm{GM}) \\
1.78(\mathrm{GSD})\end{array}$ & Gestation; MV & \multirow[t]{4}{*}{ Illinois } & \multirow[t]{4}{*}{$\begin{array}{l}\text { All } \\
\text { seasons }\end{array}$} & \multirow[t]{4}{*}{$\begin{array}{l}\text { Chromogenic } \\
\text { kinetic LAL } \\
\text { assay }\end{array}$} \\
\hline & $\begin{array}{l}\mathrm{PM}_{10}: 313 \pm 321 ; 201(\mathrm{GM}) \\
2.77(\mathrm{GSD}) \\
\mathrm{PM}_{2.5}: 66.1 \pm 56.4 ; 46.8(\mathrm{GM}) \\
2.52(\mathrm{GSD})\end{array}$ & Farrowing; MV & & & \\
\hline & $\begin{array}{l}\mathrm{PM}_{10}: 173 \pm 104 ; 148(\mathrm{GM}) \\
1.82(\mathrm{GSD}) \\
\mathrm{PM}_{2.5}: 26.2 \pm 14.0 ; 22.8(\mathrm{GM}) \\
1.79(\mathrm{GSD})\end{array}$ & Nursery; MV & & & \\
\hline & $\begin{array}{l}\mathrm{PM}_{10}: 198 \pm 164 ; 163(\mathrm{GM}) \\
1.83(\mathrm{GSD}) \\
\mathrm{PM}_{2.5}: 84.2 \pm 97.0 ; 64.1(\mathrm{GM}) \\
2.50(\mathrm{GSD})\end{array}$ & Finisher; MV & & & \\
\hline $\begin{array}{l}\text { Pilote et al. } \\
\text { (2019) }\end{array}$ & $\begin{array}{l}\text { TSP: }(9.03 \pm 9.52) \times 10^{3} \\
\left(6.02 \times 10^{2}-3.40 \times 10^{4}\right)\end{array}$ & Finisher; MV & $\begin{array}{l}\text { Quebec, } \\
\text { Canada }\end{array}$ & Winter & $\begin{array}{l}\text { Chromogenic } \\
\text { kinetic LAL } \\
\text { assay }\end{array}$ \\
\hline $\begin{array}{l}\text { Sauvé et al. } \\
(2020)^{5}\end{array}$ & $\begin{array}{l}\text { Inhalable: } \\
2026 \text { (GM); } 5.3 \text { (GSD) }\end{array}$ & $\mathrm{n} / \mathrm{a} ; \mathrm{n} / \mathrm{a}$ & Iowa & $\begin{array}{l}\text { Spring, } \\
\text { fall }\end{array}$ & $\begin{array}{l}\text { Chromogenic } \\
\text { kinetic LAL } \\
\text { assay }\end{array}$ \\
\hline
\end{tabular}

Note:

${ }^{1} \mathrm{~A}$ unit of $\mathrm{EU} \mathrm{m}^{-3}$ is used unless otherwise stated.

${ }^{2}$ Airborne endotoxins are measured as a component of particles (e.g., TSP, $\mathrm{PM}_{10}$, and $\mathrm{PM}_{2.5}$ ).

${ }^{3}$ Concentrations are expressed in the default forms of arithmetic mean, arithmetic mean \pm standard deviation, or concentration range. Other statistics, including median, geometric mean (GM), GSD, and standard error (SE), are reported when relevant data are available. A note in the parenthesis specifies the type of reported data.

${ }^{4} \mathrm{MV}$ - mechanical ventilation; NV - natural ventilation.

${ }^{5}$ Personal exposure samples were collected and analyzed for endotoxins.

${ }^{6}$ KLARE -Kinetic Limulus assay with resistant-parallel-line estimation

It is noteworthy that in some previous studies (especially those before 2000), airborne endotoxin concentrations were presented in the unit of $\mathrm{ng} \mathrm{m}^{-3}$ or $\mu \mathrm{g} \mathrm{m}^{-3}$. This is primarily because of the concentration unit of available endotoxin standards. These standards are extracted from pure Gramnegative bacterial strains (e.g., E. coli O55:B85). They can be quantitated by mass (e.g., ng of endotoxins) or endotoxin potency (i.e. endotoxin unit [EU]). As aforementioned, different bacterial strains, or the same strain but different batches, could possess different endotoxin potency (toxicity). In recent years, nearly all endotoxin standards come with a predetermined potency value (e.g., $1 \mathrm{ng}$ E. coli O55:B85 endotoxin $=12 \mathrm{EU}$ ). For studies with no potency information available, an approximate relationship of 1 ng endotoxin = 10 EU may be used (Schwartz et al., 1995; Thorne et al., 1997).

Taking the conversion factor $(1 \mathrm{ng}=10 \mathrm{EU})$, the following observations were derived from the analysis of existing publications:

- All but one endotoxin study was done in North America and Europe. In major pork-producing Asian countries like South Korea and China, no endotoxin measurement has been reported - a sharp contrast to a growing interest in in-barn bioaerosol composition in these countries. The 
majority of existing studies measured the endotoxin concentrations associated with large particles (TSP and inhalable). Only a few studies ( 7 out of 32 since 1990) measured the endotoxin concentrations associated with small particles (e.g., $\mathrm{PM}_{2.5}$ and respirable). Many studies used personal PM samplers for endotoxin exposure assessment. Since personal samplers are carried around by farm workers during their work shifts, the measured concentrations cannot be directly compared with those derived from fixed samplers, e.g., area samples (Donham et al., 1989).

- Airborne endotoxin concentrations varied greatly in the literature. For endotoxins associated with TSP and inhalable particles, their concentrations ranged from tens (Thorne et al., 2009; Chang et al., 2011a) to hundreds of thousands EU m ${ }^{-3}$ (Dutkiewicz et al., 1994; Basinas et al., 2013). Such variability (over four orders of magnitude) is more pronounced than that in TSP or inhalable PM concentrations in swine barns. However, the majority of measured concentrations associated with TSP or inhalable PM fell into the range of $10^{2}-10^{4} \mathrm{EU} \mathrm{m}^{-3}$. In comparison, the endotoxin concentrations associated with respirable $\mathrm{PM}$ were much smaller, with a typical range of a few to hundreds of $\mathrm{EU} \mathrm{m}^{-3}$. Only one study measured the endotoxin concentrations associated with $\mathrm{PM}_{10}$ and $\mathrm{PM}_{2.5}$ (Yang et al., 2014). No conclusion is drawn due to limited data.

- Airborne endotoxin concentrations differed with barn types. For endotoxins associated with large particles (inhalable and TSP), the overall highest concentrations were found in nursery barns, followed by grower or finisher barns; while the lowest concentrations occurred in sow (farrowing and gestation) barns (Seedorf et al., 1998; Chang et al., 2001a; Yang et al., 2013). It is noteworthy that the three studies on the effects of barn types were each conducted in Asia, North America, and Europe, respectively. Thus, the observed variability could be representative. For endotoxins associated with small particles, no agreement was reached. Seedorf et al. (1998) reported that for respirable PM, the overall highest endotoxin concentrations occurred in nursery barns. However, in a later study, Chang et al. (2001a) found that the highest respirable endotoxin concentrations occurred in finisher barns; and nursery barns had even lower respirable endotoxin concentrations than farrowing barns. A similar observation was reported by Yang et al. (2014) from the endotoxin measurement of $\mathrm{PM}_{2.5}$ samples.

- Airborne endotoxin concentrations were overall higher in winter than in summer (Preller et al., 1995; Bonlokke et al., 2009; O'Shaughnessy et al., 2009; Basinas et al., 2013; Yang et al., 2013; 2014). This is consistent with seasonality in in-barn PM concentrations. Elevated ventilation rates in summer enhance the dilution of endotoxin-laden PM by fresh air, thereby resulting in lower airborne endotoxin concentrations. However, it is noteworthy that the in-barn thermal environment, including temperature and humidity, could affect endotoxin loadings in PM samples. The loading is normally measured as the number of endotoxin units per mass of PM (e.g., EU mg ${ }^{-1}$ PM). O'Shaughnessy et al. (2009) found that winter inhalable particle samples had overall higher endotoxin loadings (on average $713 \mathrm{EU} \mathrm{mg}^{-1}$ ) than summer samples (on average $550 \mathrm{EU} \mathrm{mg}^{-1}$ ). This contradicts the study by Yang et al. (2013) in which endotoxin loadings in TSP increased with outdoor temperatures. They ascribed the higher endotoxin loadings in summer (on average $1308 \mathrm{EU} \mathrm{mg}^{-1}$; versus on average $484 \mathrm{EU} \mathrm{mg}^{-1}$ in winter) to enhanced bacterial growth as a result of elevated temperatures in swine barns and feed storages.

- Airborne endotoxin concentrations varied with manure collection systems. Godbout et al. (2005) compared six different manure collection systems in experimental swine barns and found that the barns with $\mathrm{V}$-shaped manure scrapers had the highest endotoxin concentrations. However, no significant difference was noted. Létourneau et al. (2009) observed overall higher endotoxin concentrations in swine barns with sawdust beddings than those with slatted floors. They further reported that by implementing a source separation (i.e., solid-liquid separation) system, the airborne endotoxin concentrations were reduced by nearly an order of magnitude. Thorne et al. (2009) compared inhalable endotoxin concentrations in hoop barns (with beddings and natural ventilation) versus regular barns (with slatted floors, manure pits, and mechanical ventilation). 
Slightly higher endotoxin concentrations were found in hoop barns. However, no significant difference was noted.

- Airborne endotoxin concentrations were affected by animal activity. Seedorf et al. (1998) found that airborne endotoxin concentrations were higher during the day than the night. Pigs are usually more active during the daytime, with their activity peaked in the afternoon (Pedersen et al, 2015). Animal activity is related to feeding. Larsson et al. (1992) reported significantly higher airborne endotoxin concentrations during feeding than tending. In addition to its regulation of animal activity, feeding could directly result in the suspension of endotoxin-laden feed particles, thereby raising airborne endotoxin concentrations.

- Airborne endotoxin concentrations could be reduced by oil sprinkling (Senthilselvan et al., 1997; Zhang et al., 1998). However, both previous studies targeted TSP-associated endotoxins. It remains unknown whether oil sprinkling would be similarly effective in reducing airborne endotoxins associated with small particles (respirable, $\mathrm{PM}_{10}$, or $\mathrm{PM}_{2.5}$ ) and whether other in-barn PM mitigation technologies (Refer to Section 5) would be effective. It is important to note that endotoxins are released from lysed Gram-negative bacteria. In-barn PM mitigation technologies that kill bacteria could elevate free endotoxin loadings in PM samples.

$(1 \rightarrow 3)-\beta$-D-glucan

$(1 \rightarrow 3)-\beta$-D-glucan is a fungal cell wall component and it also occurs in the cell wall of certain bacteria and high plants (Rylander, 1999). ( $1 \rightarrow 3)-\beta$-D-glucan is a water insoluble D-glucose polysaccharide linked by $\beta(1 \rightarrow 3)$ glycosidic bonds. In fungal cell walls, a $(1 \rightarrow 3)-\beta$-D-glucan molecule comprises of a $(1 \rightarrow 3) \beta$-D-glucose backbone and numerous branches attached to the backbone at $(1 \rightarrow 6)$ positions. For its ubiquitous existence in fungi, $(1 \rightarrow 3)-\beta$-D-glucan is selected as an indicator of mold contamination since direct, accurate mold measurement can be difficult (Iossifova, 2006).

The health implications of $(1 \rightarrow 3)-\beta$-D-glucans vary with molecular weight, shape, structure, and source; and are not always detrimental. Because they can activate immune systems, $(1 \rightarrow 3)-\beta$-D-glucans were occasionally used as medicines or supplements for cancer therapy and infection prevention (Rylander, 1999). Inhalation of $(1 \rightarrow 3)$ - $\beta$-D-glucans, however, is believed to exert adverse human health effects (Douwes et al., 2003). Similar to endotoxins, $(1 \rightarrow 3)-\beta$-D-glucans are non-allergenic but strongly inflammatory (Sigsgaard et al., 1994). Airborne $(1 \rightarrow 3)-\beta$-D-glucans have been associated with atopy and respiratory symptoms in humans, including non-allergic asthma, airway inflammation, and deteriorated pulmonary functions (Thorn et al., 1998; Wan and $\mathrm{Li}, 1999)$. ( $1 \rightarrow 3)-\beta$-D-glucans and endotoxins may have synergistic health effects, e.g., promoting the secretion of cytokines (Engstad et al., 2002). No $(1 \rightarrow 3)$ - $\beta$-D-glucan exposure limits have been available for the lack of essential dose-response data.

Airborne $(1 \rightarrow 3)-\beta$-D-glucans primarily originate from fungi. Relatively high temperature and humidity levels in swine barns are suitable for the growth of many fungal species. Fungal genera Aspergillus, Penicillium, and Mucor were observed by Seedorf et al. (1998) in the air of swine barns in four European countries. Predicala et al. (2002) reported fungal genus Penicillium in PM sampled from a finisher barn in Kansas. Both studies measured culturable fungi only. The majority of airborne fungal spores can be nonculturable (Rylander and Etzel, 1999). Using 18S rRNA clone library technology, Kristansen et al. (2012) found the dominance of fungal genera Aspergillus and Eurotium in TSP sampled from a gestation barn in Denmark. Kumari et al. (2016) studied airborne fungal composition in eight barns in South Korea with ITS NGS and found that phyla Ascomycota, Basidiomycota, Zygomycota, and Glomeromycota were dominant. They further identified the top 20 most abundant fungal genera.

Only six existing studies measured airborne $(1 \rightarrow 3)$ - $\beta$-D-glucans concentrations in swine barns (Table 14$)$. Because of limited data availability, it remains uncertain whether the findings derived from these studies are representative of average barns. The measured concentrations associated with large particles (inhalable and TSP) ranged from 0.5 (Lee and Liao, 2014) to 38,490 $\mathrm{ng} \mathrm{m}^{-3}$ (Douwes et al., 1996; Lee and 
Liao, 2014) and tended to decrease in recent publications. Cyprowski et al. (2012) analyzed inhalable and respirable $(1 \rightarrow 3)$ - $\beta$-D-glucan samples from 30 swine farms in Poland. Through the statistical analysis, they found that inhalable and respirable $(1 \rightarrow 3)$ - $\beta$-D-glucan concentrations were significantly affected by manure disposal, feeding method, and flooring type (with versus without beddings). Beddings, hand feeding, and manure scraping were found to significantly increase the concentrations of both inhalable and respirable $(1 \rightarrow 3)-\beta$-D-glucans. The use of manure pits and slatted floors significantly reduced airborne $(1 \rightarrow 3)$ - $\beta$-D-glucan concentrations. Yang et al., (2013) collected TSP samples from 12 swine barns in Illinois. The overall highest $(1 \rightarrow 3)-\beta$-D-glucan concentrations occurred in finisher barns while the lowest concentrations occurred in farrowing barns. Similar to endotoxins, $(1 \rightarrow 3)-\beta$-D-glucans had higher airborne concentrations in winter than summer. $(1 \rightarrow 3)-\beta$-D-glucan loadings in TSP $\left(\mathrm{ng} \mathrm{mg}^{-1}\right)$ were lower in winter possibly because fungal growth was suppressed by cold temperatures.

Table 14. Airborne $(1 \rightarrow 3)$ - $\beta$-D-glucan concentrations in swine barns - a summary of relevant studies since 1990.

\begin{tabular}{|c|c|c|c|c|c|}
\hline Reference & $\begin{array}{l}(1 \rightarrow 3) \text { - } \beta \text {-D-glucan concentration (ng } \\
\left.m^{-3}\right)^{1,2}\end{array}$ & $\begin{array}{l}\text { Barn \& } \\
\text { ventilation } \\
\text { type }\end{array}$ & Location & Season & $\begin{array}{l}\text { Analytical } \\
\text { method }\end{array}$ \\
\hline $\begin{array}{l}\text { Douwes et } \\
\text { al. }(1996)^{3}\end{array}$ & $\begin{array}{l}\text { Inhalable: BDL-38,490; } 4340 \text { (GM); } \\
3.4 \text { (GSD) }\end{array}$ & $\mathrm{n} / \mathrm{a} ; \mathrm{n} / \mathrm{a}$ & $\begin{array}{l}\text { The } \\
\text { Netherlands }\end{array}$ & $\begin{array}{l}\text { All } \\
\text { seasons }\end{array}$ & $\begin{array}{l}\text { Inhibition } \\
\text { enzyme } \\
\text { immunoassay }\end{array}$ \\
\hline $\begin{array}{l}\text { Sander et al. } \\
(2008)\end{array}$ & Inhalable: $33-410$ & $\mathrm{n} / \mathrm{a} ; \mathrm{n} / \mathrm{a}$ & Germany & $\mathrm{n} / \mathrm{a}$ & $\begin{array}{l}\text { Monoclonal } \\
\text { antibody-based } \\
\text { two-site enzyme } \\
\text { immunoassay }\end{array}$ \\
\hline $\begin{array}{l}\text { Cyprowski } \\
\text { et al. (2012) }\end{array}$ & $\begin{array}{l}\text { Inhalable: } 446 \pm 724 \text { (14-3594); } 190 \\
\text { (GM); } 3.90 \text { (GSD) } \\
\text { Respirable: } 124 \pm 183 \text { (1-703); } 37.0 \\
(\mathrm{GM}) ; 6.80 \text { (GSD) }\end{array}$ & $\begin{array}{l}\text { n/a; MV \& } \\
\text { NV }\end{array}$ & Poland & $\mathrm{n} / \mathrm{a}$ & $\begin{array}{l}\text { Chromogenic } \\
\text { kinetic LAL } \\
\text { assay }\end{array}$ \\
\hline \multirow[t]{4}{*}{$\begin{array}{l}\text { Yang et al. } \\
\text { (2013) }\end{array}$} & $\begin{array}{l}\text { TSP: } 25.2 \pm 20.2(3.7-50.8) ; 17.2 \\
\text { (GM); } 2.71 \text { (GSD) }\end{array}$ & $\begin{array}{l}\text { Gestation; } \\
\text { MV }\end{array}$ & \multirow[t]{4}{*}{ Illinois } & $\begin{array}{l}\text { All } \\
\text { seasons }\end{array}$ & \multirow[t]{4}{*}{$\begin{array}{l}\text { Chromogenic } \\
\text { kinetic LAL } \\
\text { assay }\end{array}$} \\
\hline & $\begin{array}{l}\text { TSP: } 21.2 \pm 20.2(2.4-50.7) ; 12.5 \\
\text { (GM); } 3.50 \text { (GSD) }\end{array}$ & $\begin{array}{l}\text { Farrowing; } \\
\text { MV }\end{array}$ & & $\begin{array}{l}\text { All } \\
\text { seasons }\end{array}$ & \\
\hline & $\begin{array}{l}\text { TSP: } 34.9 \pm 48.4(3.8-140.1) ; 16.3 \\
(\mathrm{GM}) ; 3.58(\mathrm{GSD})\end{array}$ & $\begin{array}{l}\text { Nursery; } \\
\text { MV }\end{array}$ & & $\begin{array}{l}\text { All } \\
\text { seasons }\end{array}$ & \\
\hline & $\begin{array}{l}\text { TSP: } 32.7 \pm 22.0(3.9-65.0) ; 24.3 \\
\text { (GM); } 2.62 \text { (GSD) }\end{array}$ & $\begin{array}{l}\text { Finisher; } \\
\text { MV }\end{array}$ & & $\begin{array}{l}\text { All } \\
\text { seasons }\end{array}$ & \\
\hline $\begin{array}{l}\text { Lee and } \\
\text { Liao }(2014)\end{array}$ & $\begin{array}{l}>1.8 \mu \mathrm{m}: 9.5(3.6-14) \\
1-1.8 \mu \mathrm{m}: 3.0(0.5-53) \\
<1 \mu \mathrm{m}: 2(8.0-9.0) \\
\text { Total: } 12(10-71)\end{array}$ & $\mathrm{n} / \mathrm{a}, \mathrm{n} / \mathrm{a}$ & Taiwan & Summer & $\begin{array}{l}\text { Chromogenic } \\
\text { kinetic LAL } \\
\text { assay }\end{array}$ \\
\hline $\begin{array}{l}\text { Sauvé et al. } \\
(2020)^{3}\end{array}$ & Inhalable: 33.5 (GM); 11.0 (GSD) & $\mathrm{n} / \mathrm{a}, \mathrm{n} / \mathrm{a}$ & Iowa & $\begin{array}{l}\text { Spring, } \\
\text { fall }\end{array}$ & $\begin{array}{l}\text { Chromogenic } \\
\text { kinetic LAL } \\
\text { assay }\end{array}$ \\
\hline
\end{tabular}

Note:

${ }^{1}$ Airborne $(1 \rightarrow 3)-\beta-$-D-glucan endotoxins are measured as a component of particles (e.g., inhalable and respirable). 
${ }^{2}$ Concentrations are expressed in the default forms of arithmetic mean, arithmetic mean \pm standard deviation, or concentration range. Other statistics, including GM and GSD, are given when relevant data are available. A note in the parenthesis specifies the type of reported data.

${ }^{3}$ Personal exposure samples.

Other bioaerosol markers

Proteins are essential constituents of organisms and, thus, are occasionally selected as a general marker for bioaerosols (Menetrez et al., 2007). Curtis et al. (1975a) measured crude-protein contents in finisher barn PM samples and reported an average content of $28.7 \pm 2.7 \%$. Donham et al. (1986) collected TSP samples from 21 swine barns in Iowa and found that total proteins accounted for $23 \%$ of dry mass in collected TSP samples. However, because of the high protein contents in the feed, it remains questionable whether total proteins are a valid bioaerosol marker. Total proteins were also used as a measure of organics during swine barn organic dust extract (ODE) preparation (Poole et al., 2009; Harting et al., 2012). A swine barn ODE was prepared primarily for toxicity research (through cell or tissue experiments). In addition to total proteins, markers in Table 12, such as peptidoglycan, muramic acids, 3hydroxy fatty acids, and ergosterol, were also analyzed for their presence and concentrations in swine barn ODEs (Poole et al., 2010). However, no translation of the analysis results to airborne bioaerosol concentrations was reported. Wang et al. (1996) analyzed muramic acid in swine barn PM samples with gas chromatograph-mass spectrometry (GC-MS) to estimate the concentration of peptidoglycans. An average airborne peptidoglycan concentration of $6.5 \mu \mathrm{g} \mathrm{m}^{-3}$ (range: $2.7-13 \mu \mathrm{g} \mathrm{m}^{-3}$ ) was reported.

\subsection{Chemical characteristics}

\subsubsection{Elemental composition}

Elemental composition analysis is extensively being done for ambient PM. Examples of such efforts in the U.S. include Chemical Speciation Network (CSN) and Interagency Monitoring of Protected Visual Environments (IMPROVE), each with hundreds of monitoring stations. Elemental composition analysis has also been done for various PM sources and the acquired source chemical profiles are included in SPECIATE, a USEPA's database of source profiles.

The effort to analyze chemical elements in swine barn PM can date back to Day et al. (1965) in Illinois. PM samples were collected on a glass fiber filter for spectrometric analysis. Nine elements were identified and quantified: $\mathrm{Ca}, \mathrm{Mg}, \mathrm{P}, \mathrm{Al}, \mathrm{Cu}, \mathrm{Na}, \mathrm{Fe}, \mathrm{Si}$, and $\mathrm{B}$, with $\mathrm{Ca}$ being the most abundant. For swine barn PM, the analysis of elemental composition can serve multiple purposes. First, it improves our understanding of PM's health and environmental implications. Secondly, elemental composition can be used as the fingerprint of swine barn PM, thereby facilitating PM source apportionment in areas with intensive pork production. Thirdly, elemental composition, along with other physical and chemical information, enables the identification of PM origins in swine barns (Refer to Section 3-4), thereby promoting in-barn PM management. Despite its scientific importance, only a few studies analyzed the elemental composition of PM in swine barns (Table 15). Differing in measurement methods, they are summarized into two categories: (1) elemental composition of individual particles and (2) elemental composition of bulk PM. Other than the listed, two studies also examined the elemental composition of swine barn PM (Lammel et al., 2004; Martin et al., 2008). However, both collected PM samples from the outside of barns (upwind and downwind) and, thus, are excluded in the table.

Table 15. Elemental composition of swine barn PM - a summary of studies since 1990.

\begin{tabular}{|c|c|c|c|c|}
\hline Reference & Elements detected or quantitated & $\begin{array}{l}\text { Barn \& } \\
\text { ventilation type }\end{array}$ & Location & Major findings or notes \\
\hline \multicolumn{5}{|c|}{ Composition of individual particles } \\
\hline $\begin{array}{l}\text { Schneider } \\
\text { et al. } \\
\text { (2001) }\end{array}$ & $\begin{array}{l}\mathrm{PM}_{0.18-0.35}, \mathrm{PM}_{0.35-0.65}, \mathrm{PM}_{0.65-1.2} \\
\mathrm{PM}_{1.2-3.5} \& \mathrm{PM}_{3.5-10}: \mathrm{C}, \mathrm{O}, \mathrm{Al}, \mathrm{S} \\
\mathrm{N}, \mathrm{Na}, \mathrm{Mg}, \mathrm{P}, \mathrm{K}, \mathrm{Ca}\end{array}$ & $\mathrm{n} / \mathrm{a} ; \mathrm{n} / \mathrm{a}$ & Germany & - \\
\hline
\end{tabular}




\begin{tabular}{|c|c|c|c|c|}
\hline $\begin{array}{l}\text { Cambra- } \\
\text { López et al. } \\
\text { (2011a) }\end{array}$ & $\begin{array}{l}\mathrm{PM}_{2.5-10} \& \mathrm{PM}_{2.5}: \mathrm{N}, \mathrm{Na}, \mathrm{Mg}, \mathrm{Al}, \\
\mathrm{Si}, \mathrm{P}, \mathrm{S}, \mathrm{Cl}, \mathrm{K}, \mathrm{Ca}, \mathrm{Fe}, \mathrm{Ni}, \mathrm{Cu}, \\
\mathrm{Zn}, \mathrm{Ag}, \mathrm{Pb}, \mathrm{Sn}, \mathrm{Cr}, \mathrm{Co}, \mathrm{Ba}, \mathrm{Br} \\
\mathrm{Ti}, \mathrm{V}, \mathrm{Sb}, \mathrm{Au}\end{array}$ & $\begin{array}{l}\text { Nursery, } \\
\text { grower-finisher, } \\
\text { gestation; MV }\end{array}$ & $\begin{array}{l}\text { The } \\
\text { Netherlands }\end{array}$ & $\begin{array}{l}\text { The study focused on } \\
\text { source apportionment; PM } \\
\text { was not the true in-barn PM } \\
\text { but suspended from in-barn } \\
\text { materials. }\end{array}$ \\
\hline $\begin{array}{l}\text { Cambra- } \\
\text { López et al. } \\
\text { (2011b) }\end{array}$ & $\begin{array}{l}\mathrm{PM}_{2.5-10}: \mathrm{P}, \mathrm{N}, \mathrm{K}, \mathrm{S}, \mathrm{Cl}, \mathrm{Al}, \mathrm{Ca} \\
\mathrm{Cr}, \mathrm{Na}, \mathrm{Mg}, \mathrm{Ba}, \mathrm{Fe} \\
\mathrm{PM}_{2.5}: \mathrm{P}, \mathrm{N}, \mathrm{Cl}, \mathrm{S}, \mathrm{K}, \mathrm{Si}, \mathrm{Na}, \mathrm{Al} \\
\mathrm{Ca}, \mathrm{Mg}, \mathrm{Sn}\end{array}$ & $\begin{array}{l}\text { Nursery, } \\
\text { grower-finisher, } \\
\text { farrowing, } \\
\text { gestation; MV }\end{array}$ & $\begin{array}{l}\text { The } \\
\text { Netherlands }\end{array}$ & $\begin{array}{l}\text { PM sources varied in } \\
\text { elemental composition; PM } \\
\text { was not the true in-barn PM } \\
\text { but suspended from in-barn } \\
\text { materials }\end{array}$ \\
\hline $\begin{array}{l}\text { Shen et al. } \\
(2019)\end{array}$ & $\begin{array}{l}\mathrm{PM}_{2.5}: \mathrm{C}, \mathrm{N}, \mathrm{O}, \mathrm{Na}, \mathrm{Mg}, \mathrm{Si}, \mathrm{P}, \mathrm{K} \\
\mathrm{Ca}, \mathrm{Fe}, \mathrm{Zn}\end{array}$ & $\begin{array}{l}\text { Nursery, } \\
\text { finisher; MV }\end{array}$ & China & $\begin{array}{l}\text { Only four scans were } \\
\text { conducted. }\end{array}$ \\
\hline \multicolumn{5}{|c|}{ Composition of bulk PM } \\
\hline $\begin{array}{l}\text { Aarnink et } \\
\text { al. (1999) }\end{array}$ & TSP: N, P, K, Cl, Na & $\begin{array}{l}\text { Grower- } \\
\text { finisher; MV }\end{array}$ & $\begin{array}{l}\text { The } \\
\text { Netherlands }\end{array}$ & $\begin{array}{l}\text { The elemental composition } \\
\text { of PM was close to that of } \\
\text { settled dust; PM was not the } \\
\text { true in-barn PM but } \\
\text { suspended from in-barn } \\
\text { materials. }\end{array}$ \\
\hline \multirow[t]{4}{*}{$\begin{array}{l}\text { Yang et al. } \\
(2011)\end{array}$} & $\begin{array}{l}\mathrm{PM}_{10}: \mathrm{Al}, \mathrm{B}, \mathrm{Ba}, \mathrm{Ca}, \mathrm{Cr}, \mathrm{Cu}, \mathrm{Fe} \\
\mathrm{K}, \mathrm{Mg}, \mathrm{Mn}, \mathrm{Na}, \mathrm{Ni}, \mathrm{P}, \mathrm{S}, \mathrm{Si}, \mathrm{Sr} \\
\mathrm{Ti}, \mathrm{Zn} \\
\mathrm{PM}_{2.5}: \mathrm{Al}, \mathrm{B}, \mathrm{Ba}, \mathrm{Ca}, \mathrm{Co}, \mathrm{Cr}, \mathrm{Cu}, \\
\mathrm{Fe}, \mathrm{K}, \mathrm{Mg}, \mathrm{Mn}, \mathrm{Na}, \mathrm{P}, \mathrm{S}, \mathrm{Si}, \mathrm{Sr} \\
\mathrm{Ti}, \mathrm{Zn}\end{array}$ & $\begin{array}{l}\text { Farrowing; } \\
\text { MV }\end{array}$ & \multirow[t]{4}{*}{ Illinois } & $\begin{array}{l}\text { The elements accounted for } \\
\text { on average } 13.0 \% \text { in } \mathrm{PM}_{10} \\
\text { and } 10.3 \% \text { in } \mathrm{PM}_{2.5} \text { by } \\
\text { mass. }\end{array}$ \\
\hline & $\begin{array}{l}\mathrm{PM}_{10}: \mathrm{Al}, \mathrm{B}, \mathrm{Ba}, \mathrm{Ca}, \mathrm{Co}, \mathrm{Cr}, \mathrm{Cu}, \\
\mathrm{Fe}, \mathrm{K}, \mathrm{Mg}, \mathrm{Mn}, \mathrm{Na}, \mathrm{P}, \mathrm{S}, \mathrm{Si}, \mathrm{Sr} \\
\mathrm{Ti}, \mathrm{Zn} \\
\mathrm{PM}_{2.5}: \mathrm{Al}, \mathrm{B}, \mathrm{Ba}, \mathrm{Ca}, \mathrm{Co}, \mathrm{Cr}, \mathrm{Cu}, \\
\mathrm{Fe}, \mathrm{K}, \mathrm{Mg}, \mathrm{Mn}, \mathrm{Na}, \mathrm{P}, \mathrm{S}, \mathrm{Si}, \mathrm{Sr}, \\
\mathrm{Ti}, \mathrm{Zn}\end{array}$ & Gestation; MV & & $\begin{array}{l}\text { The elements accounted for } \\
\text { on average } 9.98 \% \text { in } \mathrm{PM}_{10} \\
\text { and } 8.92 \% \text { in } \mathrm{PM}_{2.5} \text { by mass }\end{array}$ \\
\hline & $\begin{array}{l}\mathrm{PM}_{10}: \mathrm{Al}, \mathrm{B}, \mathrm{Ba}, \mathrm{Ca}, \mathrm{Cr}, \mathrm{Cu}, \mathrm{Fe}, \\
\mathrm{K}, \mathrm{Mg}, \mathrm{Mn}, \mathrm{Na}, \mathrm{P}, \mathrm{S}, \mathrm{Si}, \mathrm{Sr}, \mathrm{Ti}, \\
\mathrm{Zn} \\
\mathrm{PM}_{2.5}: \mathrm{Al}, \mathrm{B}, \mathrm{Ba}, \mathrm{Ca}, \mathrm{Co}, \mathrm{Cr}, \mathrm{Cu}, \\
\mathrm{Fe}, \mathrm{K}, \mathrm{Mg}, \mathrm{Mn}, \mathrm{Na}, \mathrm{P}, \mathrm{S}, \mathrm{Si}, \mathrm{Sr}, \\
\mathrm{Ti}, \mathrm{Zn}\end{array}$ & Nursery; MV & & $\begin{array}{l}\text { The elements accounted for } \\
\text { on average } 7.83 \% \text { in } \mathrm{PM}_{10} \\
\text { and } 7.81 \% \text { in } \mathrm{PM}_{2.5} \text { by } \\
\text { mass. }\end{array}$ \\
\hline & $\begin{array}{l}\mathrm{PM}_{10}: \mathrm{Al}, \mathrm{B}, \mathrm{Ba}, \mathrm{Ca}, \mathrm{Co}, \mathrm{Cr}, \mathrm{Cu}, \\
\mathrm{Fe}, \mathrm{K}, \mathrm{Mg}, \mathrm{Mn}, \mathrm{Na}, \mathrm{Ni}, \mathrm{P}, \mathrm{S}, \mathrm{Si} \\
\mathrm{Sr}, \mathrm{Ti}, \mathrm{Zn} \\
\mathrm{PM}_{2.5}: \mathrm{Al}, \mathrm{B}, \mathrm{Ba}, \mathrm{Ca}, \mathrm{Cr}, \mathrm{Cu}, \mathrm{Fe}, \\
\mathrm{K}, \mathrm{Mg}, \mathrm{Mn}, \mathrm{Na}, \mathrm{Ni}, \mathrm{P}, \mathrm{S}, \mathrm{Si}, \mathrm{Sr} \\
\mathrm{Ti}, \mathrm{Zn}\end{array}$ & Finisher; MV & & $\begin{array}{l}\text { The elements accounted for } \\
\text { on average } 8.09 \% \text { in } \mathrm{PM}_{10} \\
\text { and } 7.84 \% \text { in } \mathrm{PM}_{2.5} \text { by } \\
\text { mass; barn type showed a } \\
\text { significant impact on PM } \\
\text { elemental composition. }\end{array}$ \\
\hline
\end{tabular}

It is hard to generalize the findings from the previous studies because of differences in barn conditions, sampling setup, and analytical methods. They are individually discussed, as follow:

- Schneider et al. (2001) was largely an exploratory study, with the purpose to test and showcase two PM characterization technologies [electron probe X-ray microanalysis (EPXMA) and laser ablation microprobe mass analysis (LAMMA)] for their applicability to swine barn PM. Both technologies target single individual particles. No quantitative results were presented.

- Cambra-López et al. (2011a, 2011b) focused on the development of source profiles for several major PM sources (e.g., feed, skin, and feces) in swine barns, with a combination of size, shape, and elemental composition information derived from scanning electron microscope-energy 
dispersive X-ray spectroscopy (SEM-EDX) analysis. The developed source profiles were then used to determine the contribution of different sources (Cambra-López et al., 2011a).

- Shen et al. (2019) used PM elemental composition, along with morphology information acquired from SEM-EDX, to assign individual particles to different origins. Carbon (C) and oxygen (O) were found to be the most abundant elements, indicating the PM's organic origins.

- Aarnink et al. (1999) compared the element composition of PM with those of settle dust, feed, skins, and feces, with aims to identify the major sources of PM in swine barns. The average $\mathrm{N}$, phosphorus (P), and potassium (K) content in PM were $6.703 \%, 1.47 \%$, and $2.78 \%$, respectively. No information about analytical methods was presented.

- Yang et al. (2011) examined the elemental composition of multi-season PM samples from 12 swine barns using inductively coupled plasma-atomic emission spectroscopy (ICP-AES; also known as ICP-OES). The objectives were to study the effect of barn types and seasons on PM elemental composition and to develop PM source chemical profiles for typical barn types in the U.S. Midwest. While no significant seasonality was noted, $\mathrm{PM}_{10} / \mathrm{PM}_{2.5}$ compositions differed significantly with barn types. The lower mineral (inorganic) content in $\mathrm{PM}_{2.5}$ than $\mathrm{PM}_{10}$ samples suggests that $\mathrm{PM}_{2.5}$ in swine barns was of more organic origins than $\mathrm{PM}_{10}$. No toxic heavy metals (e.g., lead, cadmium, or arsenic) were detected. Among all the elements quantified, Ca was the most abundant. This is consistent with the early finding by Day et al. (1965).

It is noteworthy that several studies did not analyze true PM samples (Aarnink et al., 1999; CambraLópez et al., 2011a, 2011b). Instead, the samples analyzed were suspended from pre-collected in-barn dust or powder materials (e.g., feed, feces, and skin). It remains uncertain whether and to what degree this indirect method would affect the analysis results. Also, an SEM requires a high vacuum in its testing chamber unless it is an environmental SEM (Note: No previous studies appear to it). A high vacuum environment would result in the volatilization loss of volatiles and semivolatiles in PM (McDonald and Biswas, 2004), creating a measurement bias.

It is important to note that swine barn PM holds unique physical and chemical properties. Thus, the sampling and analysis protocol for ambient PM may not necessarily apply (Yang et al., 2011). Future efforts should be made to develop a SOP for swine barn PM, produce more and complete data sets, and interface the acquired measurement data with the databases for ambient PM and other PM sources.

\subsubsection{PM-borne odors}

PM is considered to play a critical role in the propagation of odors from animal barns (Bottcher, 2001). Because particles (e.g., $\mathrm{PM}_{10}$ and $\left.\mathrm{PM}_{2.5}\right)$ are much larger than gas molecules $\left(\sim 10^{-4} \mu \mathrm{m}\right)$, their generation, transport, and transformation inside and outside of swine barns are substantially different. For example, PM may deposit on hairs, clothes, tools, and vehicles, be carried around by these objects, and create persistent odor nuisance (Bottcher, 2001). When reaching human and animal receptors, PM and gases also behave differently regarding their transport and fate in respiratory systems (Levy and Wilmott, 1993). As a result, the management and mitigation of PM-borne odors demand different strategies.

The first study of PM-borne odorants in swine barns was done by Dr. Day and his colleagues at the University of Illinois at Urbana-Champaign (Day et al., 1965). Besides air samples, they also collected PM samples on glass fiber filters for odor assessment. Although the further chemical analysis was unsuccessful due to then methodology constraints, they found a strong odor from heated PM samples and PM extracts in methanol. This pioneering work spurred several follow-up studies in the 1970s and 1980s (Hammond et al., 1979, 1981; Louis and Licht, 1979; Hurtung, 1985, 1986; Donham et al., 1986).

Hammond et al. (1979) extracted settled dust from swine barns in water, concentrated the extract through distillation, and analyzed the dust's odorant composition using thin-layer chromatography and gas-liquid chromatography. A total of 19 odorous compounds were identified, including acids, phenols, aldehydes, 
and ketones. In their later study (Hammond et al., 1981), two swine barn PM samples were collected using an electrostatic precipitator (ESP) and extracted in diethyl ether. The extracts were further derivated, purified, and then analyzed using gas chromatography (GC). Thirty-four odorants were identified and quantified, including 15 acids, 16 carbonyls (ketones and aldehydes), and three phenols. Licht and Miner (1979) tested a wet scrubber for its performance of odor reduction in a finisher barn and found that odor reduction highly correlated with PM removal. Hartung (1985) collected settled dust from a finisher barn in Germany and extracted the dust in ethanol. The extract was alkalized with $\mathrm{NaOH}$ for volatile fatty acid (VFA) separation and then acidified to recover phenols. Using GC, six VFAs and five phenolic/indolic compounds were identified and quantified. Donham et al. (1986) reported that settled dust from swine barns in Iowa contained $3.9 \mathrm{mg} \mathrm{NH}$ per gram of dust. Hartung (1986) summarized past publications and concluded that $>60$ odorants could exist in livestock barn PM samples.

Additional measurement efforts have been reported since 1990, as summarized in Table 16. Besides field monitoring, modeling of odors carried by swine barn PM was also attempted, including odor adsorption dynamics, PM deposition, and inhalation dose simulation (Liao and Singh, 1998a, 1998b; Liao et al., 2001; Yeh et al., 2001). All of the modeling work was done by Dr. Liao and his group at the National Taiwan University in Taiwan. However, no model calibration or validation has been done likely due to the lack of essential experimental data.

Table 16. Measurement of PM-borne odors in swine barns since 1990.

\begin{tabular}{|c|c|c|c|c|c|}
\hline Reference & $\begin{array}{l}\text { Odorant(s) identified } \\
\text { and/or qualified }\end{array}$ & $\begin{array}{l}\text { Analytical } \\
\text { method }^{1}\end{array}$ & $\begin{array}{l}\text { Barn \& } \\
\text { ventilation } \\
\text { type }\end{array}$ & Location & $\begin{array}{l}\text { Major findings and/or } \\
\text { notes }\end{array}$ \\
\hline $\begin{array}{l}\text { Wang et } \\
\text { al. (1998) }\end{array}$ & Settled dust: $>100$ VOCs & $\begin{array}{l}\text { Solvent } \\
\text { extraction } \\
\text { followed by } \\
\text { GC-FID }\end{array}$ & $\begin{array}{l}\text { Finisher; } \\
\text { MV }\end{array}$ & Illinois & $\begin{array}{l}\text { No compound } \\
\text { identification was done. } \\
\text { VOC diversity was } \\
\text { estimated from the } \\
\text { number of peaks. }\end{array}$ \\
\hline $\begin{array}{l}\text { Oehrl et } \\
\text { al. }(2001)^{2}\end{array}$ & $\begin{array}{l}\text { Settled dust: } 10 \text { acids, } 2 \\
\text { phenols, indole \& skatole }\end{array}$ & $\begin{array}{l}\text { Solvent } \\
\text { extraction } \\
\text { followed by } \\
\text { GC-FID }\end{array}$ & $\mathrm{n} / \mathrm{a} ; \mathrm{n} / \mathrm{a}$ & $\begin{array}{l}\text { North } \\
\text { Carolina }\end{array}$ & $\begin{array}{l}\text { Ozonation and manure pit } \\
\text { additives significantly } \\
\text { reduced the concentrations } \\
\text { of many odorants. }\end{array}$ \\
\hline $\begin{array}{l}\text { Das et al. } \\
(2004)^{2}\end{array}$ & $\begin{array}{l}\text { Settled dust: } 5 \text { aldehydes, } \\
\text { 1-octane \& } \mathrm{H}_{2} \mathrm{~S}\end{array}$ & $\begin{array}{l}\text { Solvent } \\
\text { extraction } \\
\text { followed by } \\
\text { GC-MS }\end{array}$ & $\mathrm{n} / \mathrm{a} ; \mathrm{n} / \mathrm{a}$ & Georgia & $\begin{array}{l}\text { Settled dust was separated } \\
\text { into several size ranges } \\
\text { before analysis. }\end{array}$ \\
\hline $\begin{array}{l}\text { Razote et } \\
\text { al. } \\
(2004)^{2,3}\end{array}$ & $\begin{array}{l}\text { TSP (qualitative): } 13 \\
\text { acids, } 11 \text { ketones, } 16 \\
\text { aldehydes, } 9 \text { esters, } 3 \\
\text { phenols, } 5 \text { nitrogen- } \\
\text { containing compounds, } \\
13 \text { hydrocarbons, } 3 \\
\text { ethers, methylene } \\
\text { chloride, dimethyl } \\
\text { disulfide, and } 3 \text { others } \\
\text { TSP (quantitative): } 3 \\
\text { acids and } 2 \text { aldehydes }\end{array}$ & $\begin{array}{l}\text { Qualitative: } \\
\text { solvent } \\
\text { extraction, } \\
\text { SPME }^{2} \& \\
\text { P\&T, } \\
\text { followed by } \\
\text { GC-MS } \\
\text { Quantitative: } \\
\text { P\&T followed } \\
\text { by GC-MS }\end{array}$ & $\begin{array}{l}\text { Grower- } \\
\text { finisher; } \\
\mathrm{MV}\end{array}$ & Kansas & $\begin{array}{l}\text { Solvent extraction, SPME, } \\
\text { and P\& T yielded } \\
\text { different identification } \\
\text { results. Among the } \\
\text { quantitated odorants, } \\
\text { acetic acid was the most } \\
\text { abundant. }\end{array}$ \\
\hline $\begin{array}{l}\text { Cai et al. } \\
(2006)\end{array}$ & $\begin{array}{l}\text { TSP: } 4 \text { alkanes, } 4 \\
\text { alcohols, } 8 \text { aldehydes, } 7 \\
\text { ketones, } 8 \text { acids, } 6 \\
\text { amines and nitrogen } \\
\text { heterocycles, } 3 \text { sulfides }\end{array}$ & $\begin{array}{l}\text { Headspace } \\
\text { SPME } \\
\text { followed by } \\
\text { GC-MS for } \\
\text { odorants }\end{array}$ & $\begin{array}{l}\text { Grower- } \\
\text { finisher; } \\
\text { MV }\end{array}$ & Iowa & $\begin{array}{l}\mathrm{PM}_{1} \text { contained higher } \\
\text { odorant contents (by \%) } \\
\text { than } \mathrm{PM}_{10} \text { and then TSP; } \\
\text { Carbonxen/PDMS was the } \\
\text { most effective SPME } \\
\text { fiber; no quantitation was }\end{array}$ \\
\hline
\end{tabular}




\begin{tabular}{|c|c|c|c|c|c|}
\hline & $\begin{array}{l}\text { and thiols, } 7 \text { aromatics, } \\
\text { and 2-pentylfuran } \\
\text { PM }_{10}: 3 \text { alkanes, } 4 \\
\text { alcohols, } 8 \text { aldehydes, } 7 \\
\text { ketones, } 7 \text { acids, } 3 \\
\text { amines and nitrogen } \\
\text { heterocycles, } 3 \text { sulfides } \\
\text { and thiols, } 7 \text { aromatics, } \\
\text { and } 2 \text {-pentylfuran } \\
\text { PM } 2.5: 1 \text { alkanes, } 2 \\
\text { alcohols, } 6 \text { aldehydes, } 2 \\
\text { ketones, } 2 \text { acid, } 3 \text { amines } \\
\text { and nitrogen } \\
\text { heterocycles, } 2 \text { sulfides } \\
\text { and thiols } \& 7 \text { aromatics } \\
\text { PM } 1 \text { : } 3 \text { alkanes, } 2 \\
\text { alcohols, } 3 \text { aldehydes, } 3 \\
\text { ketones, } 8 \text { acids, } 3 \\
\text { amines and nitrogen } \\
\text { heterocycles, } 2 \text { sulfides } \\
\text { and thiols, \& } 7 \text { aromatics }\end{array}$ & & & & $\begin{array}{l}\text { done and odorant content } \\
\text { comparisons were based } \\
\text { on peak areas. }\end{array}$ \\
\hline $\begin{array}{l}\text { Lee and } \\
\text { Zhang } \\
(2008)^{2}\end{array}$ & $\begin{array}{l}\text { Settled dust: } \mathrm{NH}_{3} \& \\
\text { odor }\end{array}$ & $\begin{array}{l}\text { TD followed } \\
\text { by } \mathrm{NH}_{3} \\
\text { analyzer for } \\
\mathrm{NH}_{3} ; \mathrm{TD} \\
\text { followed by } \\
\text { olfactometry } \\
\text { for odor } \\
\end{array}$ & $\begin{array}{l}\text { Farrowing, } \\
\text { nursery, } \\
\text { grower, } \\
\text { finisher; } \\
\text { MV }\end{array}$ & Illinois & $\begin{array}{l}\text { An average odor emission } \\
\text { rate was } 1.43 \pm 0.37 \text { OU } \\
\text { min }^{-1} \mathrm{~g}^{-1} \text { dust; no } \\
\text { quantitative information } \\
\text { about } \mathrm{NH}_{3} \text { was available; } \\
\text { odor-carrying capacity } \\
\text { was related to barn type. }\end{array}$ \\
\hline $\begin{array}{l}\text { Andersen } \\
\text { et al. } \\
(2014)^{2}\end{array}$ & $\begin{array}{l}\text { PM of unknown size: } 8 \\
\text { acids, } 5 \text { phenols, } 2 \\
\text { ketones \& } 2 \text { sulfides }\end{array}$ & TD-GC-MS & $\begin{array}{l}\text { Boars, } \\
\text { gilts, } \\
\text { finisher; } \\
\text { n/a }\end{array}$ & Denmark & $\begin{array}{l}\text { A dual filter (front plus } \\
\text { backup filters) setup and } \\
\text { denuders were used to } \\
\text { study gas-particle } \\
\text { partitioning of odorants } \\
\text { and their adsorption on } \\
\text { filters. }\end{array}$ \\
\hline $\begin{array}{l}\text { Yang et } \\
\text { al. }(2014)^{2}\end{array}$ & $\begin{array}{l}\text { TSP: } 18 \text { aldehydes, } 1 \\
\text { ketone, } 8 \text { alcohols, } 20 \\
\text { acids, } 7 \text { phenols \& } 3 \\
\text { nitrogen-containing } \\
\text { compounds } \\
\text { PM } 10: 18 \text { aldehydes, } 1 \\
\text { ketone, } 8 \text { alcohols, } 20 \\
\text { acids, } 7 \text { phenols \& } 3 \\
\text { nitrogen-containing } \\
\text { compounds }\end{array}$ & $\begin{array}{l}\text { Solvent } \\
\text { extraction } \\
\text { followed by } \\
\text { stable isotope } \\
\text { dilution GC- } \\
\text { MS }\end{array}$ & $\begin{array}{l}\text { Farrowing, } \\
\text { gestation, } \\
\text { nursery, } \\
\text { finisher; } \\
\text { MV }\end{array}$ & Illinois & $\begin{array}{l}\mathrm{PM}_{10} \text { contained higher } \\
\text { odorant contents (by \%) } \\
\text { than TSP; For both TSP } \\
\text { and } \mathrm{PM}_{10} \text {, their odorant } \\
\text { composition varied } \\
\text { significantly with barn } \\
\text { types and seasons; Among } \\
\text { the odorant quantitated, } \\
\text { acetic acid is the most } \\
\text { abundant. }\end{array}$ \\
\hline $\begin{array}{l}\text { Walgraeve } \\
\text { et al. } \\
(2015)^{5}\end{array}$ & $\begin{array}{l}\mathrm{PM}_{10} \text { (qualitative): } 7 \\
\text { acids, } 7 \text { aldehydes, } 3 \\
\text { alcohols, } 2 \text { phenols, } 2 \\
\text { esters, } 4 \text { heterocycles, } 2 \\
\text { sulfur-containing }\end{array}$ & $\begin{array}{l}\text { SPME } \\
\text { followed by } \\
\text { GC-MS }\end{array}$ & $\mathrm{n} / \mathrm{a} ; \mathrm{n} / \mathrm{a}$ & Belgium & $\begin{array}{l}\text { A column packed with } \\
\text { PM was challenged with } \\
\text { acetic acid, butanoic acid, } \\
\text { phenol, and dimethyl }\end{array}$ \\
\hline
\end{tabular}




\begin{tabular}{|l|l|l|l|l|l|}
\hline $\begin{array}{l}\text { compounds, 1 amine, } \\
\text { ketone \& 1 terpene }\end{array}$ & & & $\begin{array}{l}\text { disulfide to study their } \\
\text { gas-particle partitioning } \\
\text { using SIFT-MS } \text { S }^{6} \text { these } \\
\text { odorants were } \\
\text { concentrated in PM but } \\
\text { occurred at much lower } \\
\text { fractions in the particle } \\
\text { than the gas phase. }\end{array}$ \\
\hline
\end{tabular}

Note:

${ }^{1}$ GC-FID - gas chromatography-flame ionization detector; GC-MS - gas chromatography-mass spectrometry; SPME - solid-phase micro-extraction; P\&T - purge and trap; TD - thermal desorption; TD-GC-MS - thermal desorption gas chromatography-mass spectrometry

${ }^{2}$ Quantitative information was available in the publication.

${ }^{3}$ The authors reported a similar if not the same effort on a conference (Razote et al., 2002). However, the sampling method was slightly different and involved the use of backup glass fiber filters.

${ }^{4}$ Odor concentrations were measured by olfactometry.

${ }^{5}$ Quantitative analysis was done for amino acids and triacylglycerols.

${ }^{6}$ SIFT-MS: selective ion flow tube mass spectrometry.

Numerous odorants have been detected in swine barn $\mathrm{PM}$, including $\mathrm{NH}_{3}, \mathrm{H}_{2} \mathrm{~S}$, organic acids, alcohols, aldehydes, alkanes, alkenes, ketones, phenols, nitrogen-containing organic compounds, and sulfurcontaining organic compounds. Table S1 lists all the detected odorants (159 in total) and the publications reporting their occurrence. Many of these odorants were also found in the air of swine barns and/or in swine manure (Ni et al., 2012).

Upon the analysis of the previous publications, the following observations are made:

- All but three measurement efforts (including those before 1990) were done in the U.S. The only three non-U.S. ones were from Europe. Several simulation papers were published by researchers from Taiwan but no experimental data were available. The existing publications covered a broad range of focus subjects, including testing of concepts or methodology development (Hammond et al., 1979, 1981; Hartung et al., 1985; Das et al., 2004; Cai et al., 2006; Lee and Zhang, 2008), regular field monitoring (Donham et al., 1986; Razote et al., 2004; Yang et al., 2014), gas-particle partitioning (Andersen et al., 2014; Walgraeve et al., 2016), transport and exposure modeling (Liao and Singh, 1998a, 1998b; Liao et al., 2001; Yeh et al., 2001), and mitigation technologies (Licht and Miner, 1979; Oehrl et al., 2001).

- Nearly a half of the publications, especially early ones, provide no quantitative data. Semiquantitative analysis was occasionally done based on the chromatography peak areas of individual odorants [e.g., Cai et al. (2006)]. Quantitative data were available from ten studies, including seven studies since 1990. However, most of the data were from one or a few farm visits and extensive field sampling is largely lacking. The only multi-farm, multi-season monitoring effort was done by Yang et al. (2014).

- $\quad$ PM samples of various size fractions, including TSP (Hammond et al, 1981; Razote et al., 2004; Cai et al., 2006; Yang et al., 2014), $\mathrm{PM}_{10}$ (Cai et al., 2006; Yang et al., 2014; Walgraeve et al., 2015), $\mathrm{PM}_{2.5}$ (Cai et al., 2006), and $\mathrm{PM}_{1}$ (Cai et al., 2006), were collected for odorant analysis. In many early studies, settled dust was selected as a surrogate for PM (Hammond et al., 1979; Hartung et al, 1985; Donham et al., 1986; Wang et al, 1998; Oehrl et al., 2001; Das et al., 2004; Lee and Zhang, 2008). However, settled dust and PM could differ in size and origins (Refer to Section 3.1.3). Thus, it is uncertain whether the findings derived from settled dust also apply to actual PM samples. No direct comparison between PM and settled dust has been reported. 
- Aldehydes, acids, phenols, and nitrogen-containing compounds were often detected in collected PM and settled dust samples. The most frequently detected odorants $(\geq 7$ out of 12 publications in Table S1) were hexanal, acetic acid, propanoic acid, butanoic acid, pentanoic acid, phenol, $p$ cresol, indole, and skatole. Among the odorants quantified, acetic acid was the most abundant one (Hammond et al., 1981; Hartung et al., 1985; Razote et al., 2004; Andersen et al., 2014; Yang et al., 2014). The second most abundant odorant differed among publications, including propanoic acid (Hammond et al., 1981; Razote et al., 2004), p-cresol (Hartung et al, 1985), nonanoic acid (Oehrl et al., 2001), pentanoic acid (Andersen et al., 2014), and ethanol (Yang et al., 2014). Known for their malodors, sulfur-containing compounds were found to occur at very low concentrations in PM. Many of these compounds are highly volatile and, thus, would exist predominantly in gaseous forms (Andersen et al., 2014; Yang et al., 2014).

- The detected PM-borne odorants vary considerably in their sensory characteristics and odor thresholds (Cai et al., 2006; Yang et al., 2014). It is noteworthy that the odor thresholds compiled in the literature are for gaseous (odor thresholds in the air [OTA]) or waterborne odorants (odor thresholds in water [OTW]) only. They may not apply to PM-borne odorants, for two reasons. First, the gas-particle partition coefficient $\left(\mathrm{K}_{\mathrm{p}}\right.$; defined as the ratio of the mass fraction of a compound in PM to its concentration in the gas phase) of an odorant governs the equilibrium concentration of the odorant in the gaseous form. A PM-borne odorant with a low OTA (meaning that it carries a strong smell as a gas) could have a high $\mathrm{K}_{\mathrm{p}}$ and therefore occur at low gaseous concentrations. Secondly, PM can be trapped and accumulated in the human's nasal cavity before being sensed by olfactory cells. Odor perception, in this case, could be substantially different from that for gaseous odor molecules (Hammond et al., 1981; Yang et al., 2014). Odor activity values (OAVs) were occasionally calculated in the literature by normalizing PM-borne odorant concentrations with OTAs (Cai et al., 2006; Yang et al., 2014). However, they do not represent actual PM-associated odor levels, for the reasons discussed above.

- The detected odorants vary substantially in their sources (Yang et al., 2014). For example, fatty acids can be generated from the bacterial conversion of simple carbohydrates; whereas phenols can be degraded from tyrosine (Spoelstra 1980; Mackie, 1998). Indole and skatole, two malodorants of great concern, were believed to be of fecal origins and produced from the degradation of tryptophan or indeol-3-carboxylic acid by gastrointestinal microbes (Spoelstra 1980; Mackie, 1998). Thus, their occurrence in swine barn PM suggests that PM could partly originate from swine feces, which is consistent with the findings from PM source studies (Refer to Section 3.4). Some of the PM-borne odorants were also found in swine feed but at lower mass fractions (Yang et al., 2018). However, it remains uncertain whether these odorants were of feed origins or came from other sources but becoming sorbed or deposited to feed particles.

- Little is known about the total concentrations or fractions of odorants in swine barn PM. This is primarily because of methodology constraints. Various methods have been adopted but none of them can detect and quantify all possible odorants. From the existing data - though they are incomplete as explained - it appears that odorants account for only a small fraction of PM mass. Hammond et al. (1981) reported that $2 \%$ of PM mass was attributed to the odorants quantified. Hartung (1985) analyzed 11 odorants and they accounted for $\sim 0.09 \%$ of settle dust by mass. The five odorants quantified by Razote et al. (2004) accounted for $\sim 0.01 \%$ of collected TSP samples. Yang et al. (2014) quantified 57 odorants in PM sampled from 12 swine barns. The total mass fractions of these odorants were on average $2.86 \%$ in farrowing TSP, $5.55 \%$ in farrowing $\mathrm{PM}_{10}$, $3.24 \%$ in gestation TSP, $6.24 \%$ in gestation $\mathrm{PM}_{10}, 2.53 \%$ in nursery TSP, $4.28 \%$ in nursery $\mathrm{PM}_{10}$, $2.65 \%$ in finisher TSP, and $6.58 \%$ in finisher $\mathrm{PM}_{10} . \mathrm{PM}_{10}$ contained significantly higher odorant fractions than TSP. A similar observation $\left(\mathrm{PM}_{1}>\mathrm{PM}_{10}>\mathrm{TSP}\right.$ ) was made by Cai et al. (2006) through a comparison of GC-MS peak areas. The finding is consistent with that smaller particles in swine barns were of more fecal origins, derived from PM source studies (Refer to Section 3.4). 
- Many odorants occurred at a lower concentration (e.g., $\mu$ g odorant per $\mathrm{m}^{3}$ of barn air) in PM than in gaseous forms. Direct comparisons of PM-borne with gaseous odorants showed that most detected odorants existed primarily in the gas phase (Andersen et al., 2014; Walgraeve et al., 2015). The comparison result was further assessed through thermodynamic simulation. Using experimentally determined particle-to-gas partition coefficients $\left(\mathrm{K}_{\mathrm{PM} / \mathrm{air}}\right.$; a dimensionless version of $\mathrm{K}_{\mathrm{p}}$ ), it was calculated that the total mass fraction of PM-sorbed acetic acid, butanoic acid, dimethyl disulfide, and phenol would not exceed $0.11 \%$ of PM mass at $1 \mathrm{mg} \mathrm{m}^{-3} \mathrm{PM}_{10}$ (Walgraeve et al., 2015). The calculated odorant fractions were lower than some field measurement results (Hammond et al., 1981; Yang et al., 2014). Both $\mathrm{K}_{\mathrm{p}}$ and $\mathrm{K}_{\mathrm{PM} / \text { air }}$ are equilibrium constants. For PM inside swine barns (which is freshly generated and close to its sources), it is unclear whether gas-particle partitioning would have reached equilibriums. According to Andersen et al. (2014), odorants with higher $\mathrm{K}_{\mathrm{p}}$ values (e.g., hexanoic acid) would be enriched in PM and those with lower $K_{p}$ values (e.g., 3-hydroxybutanone) would stay predominately in the gas phase. Indirect comparisons between PM-borne and gaseous odorants, in which part of the data was from the literature, also led to the same conclusion that many odorants occurred primarily in the gas phase rather than in PM (Hammond et al., 1981; Yang et al., 2004). For $\mathrm{NH}_{3}$, assuming a TSP concentration of $2 \mathrm{mg} \mathrm{m}^{-3}$, the $3.9 \mathrm{mg} \mathrm{NH}_{3} \mathrm{~g}^{-1}$ dust value reported by Donham et al. (1986) can be translated into a PM-borne $\mathrm{NH}_{3}$ concentration of $7.8 \times 10^{-3} \mathrm{mg} \mathrm{m}^{-3}$, which is $\sim 3$ orders of magnitude smaller than typical $\mathrm{NH}_{3}$ gas concentrations in swine barns.

- PM can concentrate and amplify odors. PM carried substantially larger amounts of odorants than the same volume of air (Hammond et al., 1981; Walgraeve et al., 2015). Thus, PM deposited on the olfactory region in the human's nasal cavity will trigger an odor perception equivalent to a much larger volume of air. The enrichment ratio of an odorant in PM can be experimentally determined (Hammond et al., 1981) or calculated from its gas-particle partition coefficient $\left[K_{p}\right.$ or $\mathrm{K}_{\mathrm{PM} / \mathrm{air}}$; Walgraeve et al. (2015)]. Furthermore, the nasal cavity serves as a physical barrier for PM. The turns and curves inside the cavity lead to the aerodynamic separation of PM from inhaled air and the deposition of PM in the olfactory region. Compared to gaseous odorants, PMborne odorants, especially those carried by large particles, are more likely perceived by olfactory cells, thereby amplifying swine odors (Hammond et al., 1981). However, no quantitative information about the deposition of PM-borne odors versus gaseous odors in the olfactory region has been available.

- Little is known about the effect of barn types and seasons. Only one publication investigated PMborne odorants sampled from multiple barn types and multiple seasons (Yang et al. 2014). Results showed a large influence of barn types on odorant composition. Specifically, TSP and PM 10 samples from nursery barns were significantly different from those from farrowing and gestation barns; while the samples from finisher barns sit somewhere in-midst. Overall, PM samples from swine barns differed significantly from those from turkey and layer hen barns. Seasons also exhibited a significant influence. The total mass odorant fraction in both TSP and $\mathrm{PM}_{10}$ increased as the weather warmed up. Summer PM samples contained more hexanal, heptanal, nonanal, ethanol, 1-octanol, and 2-ethyl-1-hexanol but lesser acetic acid, propanoic acid, and 3-methylbutanoic acid than winter samples. Similar seasonality was observed for odorants in swine feeds (Yang et al., 2018), a major PM source in swine barns.

- The modeling work has yet to be validated. As aforementioned, modeling papers were available regarding the sorption and transport of PM-borne odors in swine barns, as well as human exposure to the odors (Liao and Singh, 1998a, 1998b; Liao et al., 2001; Yeh et al., 2001). No calibration or validation has been done. An in-depth analysis of the models is beyond our expertise and the scope of this review effort. Various assumptions were taken during model development. For example, it was assumed that the occurrence of odorants in PM was attributed to gas adsorption only and that the adsorption equilibrium and kinetics could be described by the 
Freundlich isotherm and the Langmuir-Hinshelwood equation, respectively. A revisit to these assumptions might be necessary given the research advances in the past 20 years. How to effectively utilize the modeling framework and interface it with other management models or tools remains an immense challenge.

Odors are a top air quality challenge facing pork producers. PM-borne odors have intrigued academia and industry for decades. After 55 years' research [since the pioneering work by Day et al. (1965)], our understanding of PM-borne odors and odorants has substantially improved. But yet many fundamental questions remain unanswered, e.g., to what degree PM contributes to a downwind odor nuisance, how PM-borne odors are transported and decayed in the environment, and what is the most cost-effective way to de-odor the smelly PM that stick on cloth, vehicles, or walls? Answers to these questions will enable improved management of swine odors and therefore benefit pork producers in the long run.

\subsubsection{Ions and others}

Ambient PM composition is often broken down into elements (excluding $\mathrm{C}, \mathrm{O}$, and $\mathrm{H}$ ), soluble ions, and carbonaceous material (Wilson et al., 2002). The corresponding analyses are being done for ambient PM samples gathered from hundreds of air monitoring stations in the world. Carbonaceous material consists of organic carbon (OC) and elemental carbon (EC), where OC refers to carbon in organic matter and EC refers to carbon in elemental forms. No OC/EC analysis has been performed for swine barn PM. Since PM in swine barns primarily originates from feeds and animal feces (Refer to Section 3.4), a high OC content and a low EC content are anticipated.

\section{$\underline{\text { Soluble ions }}$}

Soluble ions include $\mathrm{Cl}^{-}, \mathrm{NO}_{3}{ }^{-}, \mathrm{SO}_{4}{ }^{2-}$, and $\mathrm{NH}_{4}{ }^{+}$. Other anions (e.g., $\mathrm{PO}_{4}{ }^{3-}$ ) and cations (e.g., $\mathrm{K}^{+}$and $\mathrm{Na}^{+}$) are often not analyzed because they can be quantified through elemental analysis. Only two studies analyzed the composition of soluble ions in swine barn PM (Yang et al., 2011; Xu et al., 2016). Yang et al. (2011) collected $\mathrm{PM}_{10}$ and $\mathrm{PM}_{2.5}$ samples from 12 swine barns in Illinois during multiple seasons and examined their $\mathrm{Cl}^{-}, \mathrm{NO}_{3}{ }^{-}, \mathrm{SO}_{4}{ }^{2-}$, and $\mathrm{NH}_{4}^{+}$concentrations using ion chromatography (IC). A significant effect of barn types was observed. These ions accounted for on average $3.02 \%$ of $\mathrm{PM}_{10}$ and $3.42 \%$ of $\mathrm{PM}_{2.5}$ in farrowing barns, $3.93 \%$ of $\mathrm{PM}_{10}$ and $4.94 \%$ of $\mathrm{PM}_{2.5}$ in gestation barns, $3.89 \%$ of $\mathrm{PM}_{10}$ and $4.90 \%$ of $\mathrm{PM}_{2.5}$ in nursery barns, and $3.46 \%$ of $\mathrm{PM}_{10}$ and $3.98 \%$ of $\mathrm{PM}_{2.5}$ in finisher barns by mass. No significant seasonality was found for $\mathrm{PM}_{10}$; while summer $\mathrm{PM}_{2.5}$ samples had overall higher ion contents than winter samples. Xu et al. (2016) analyzed $\mathrm{Cl}^{-}, \mathrm{NO}_{3}{ }^{-}, \mathrm{SO}_{4}{ }^{2-}$, and $\mathrm{NH}_{4}{ }^{+}$in $\mathrm{TSP}$ and $\mathrm{PM}_{10}$ samples from a finisher barn in China using IC. A significant seasonality was observed, with summer TSP and PM $_{10}$ samples containing substantially higher $\mathrm{NO}_{3}{ }^{-}, \mathrm{SO}_{4}{ }^{2-}$ and $\mathrm{NH}_{4}{ }^{+}$contents than fall and winter samples. The authors assigned the sum of $\mathrm{NO}_{3}{ }^{-}, \mathrm{SO}_{4}{ }^{2-}$ and $\mathrm{NH}_{4}{ }^{+}$as secondary inorganic aerosols (SIAs) and found that they accounted for on average $12.0 \%$ of TSP mass and $13.9 \%$ of $\mathrm{PM}_{10}$ mass - which are greater than those reported by Yang et al. (2011). Caution should be taken when discussing SIAs in swine barns. It is an important topic since $\mathrm{NH}_{3}$ emitted from animal barns is an essential precursor for SIA formation and SIAs account for a significant fraction of atmospheric $\mathrm{PM}_{2.5}$ (up to $80 \%$ ). However, the IC quantification data from both studies (Yang et al., 2011; Xu et al., 2016) showed that $\mathrm{NO}_{3}{ }^{-}$and $\mathrm{SO}_{4}{ }^{2-}$ were not fully neutralized by $\mathrm{NH}_{4}{ }^{+}$in $\mathrm{PM}$. Thus, part of $\mathrm{NO}_{3}{ }^{-}$and $\mathrm{SO}_{4}{ }^{2-}$ could originate from minerals or nitrification and should not be included in the calculation of SIA mass in swine barns.

The analysis of elements, soluble ions, and OC/EC in swine barns is important from the ambient air quality management standpoint. It will enable the inclusion of swine barns as a PM source in the EPA's SPECIATE database and PM receptor modeling as part of State Implementation Plans (SIPs). However, how to utilize the composition information for the benefit of pork production remains a question.

\section{Others}

Other swine barn PM components that were tested include moisture, ashes, lipids, proteins, and amino acids. Heber et al. (1988b) quantified ash contents (reported as inorganic contents) in TSP samples from 
11 swine barns in Kansas using AOAC method 7.009 and found an average ash content of 13.1\% (range: 7.3-18.2\%), slightly lower than that in settled dust (13.5\%, range: 8.7-33.2\%). Aarnink et al. (1999) reported that PM sampled from swine barns contained $7.90 \pm 0.35 \%$ of moisture and $14.95 \pm 0.35 \%$ of ash contents by mass; and their fractions were similar to those in settled dust, feces dust, and skin particle dust. No information about analytical methods was provided. Similar ash content levels (reported as minerals) were reported by Yang et al. (2011) by summating all quantified elements and soluble ions. Total protein contents in swine barn PM were also measured (Curtis et al., 1975; Donham et al., 1986), with the average content ranging from $23 \%$ to $28.7 \%$. Relevant information can be found in Section 3.2.5. The Kjeldahl method was selected for crude protein quantification by Curtis et al. (1975). Commercial assays, such as bicinchoninic acid assay, Bradford assay, Lowry assay, and NanoOrange protein quantification kit, have been used to analyze total proteins in ambient PM. They should also work for swine barn PM characterization. Kristiansen et al. (2012) conducted a series of analyses to determine the composition of swine barn TSP samples (drying at $105^{\circ} \mathrm{C}$ for moisture, ignition at $550^{\circ} \mathrm{C}$ for volatile organic solids, CBQCA protein quantification kit [similar to NanoOrange] for protein, anthrone carbonhyrate method for carbonhydrate, and GC-FID for fatty acids) and found an average moisture content of $14 \%$ and a volatile organic solid content of $83 \%$. The volatile organic solids consisted of $82 \%$ carbohydrate, $21 \%$ protein, and 1\% fatty acids. Walgraeve et al. (2015) analyzed lipids (triacylglycerols) in swine barn $\mathrm{PM}_{10}$ samples by saponifying the lipids and converting produced fatty acids into their corresponding methyl esters (fatty acid methyl esters [FAME]). Using GC-FID, nine saturated and 11 unsaturated fatty acids (C6 to C20) were quantified, together accounting for $4.5 \%$ of $\mathrm{PM}_{10}$ mass. The same study also hydrolyzed proteins in the $\mathrm{PM}_{10}$ samples into amino acids and quantified amino acid derivates using HPLC. Seventeen amino acids were quantified, attributing to $33.2 \%$ of $\mathrm{PM}_{10}$ mass. Considering mass gains of proteins during hydrolysis, the value was consistent with early reports by Curtis et al. (1975) and Donham et al. (1986).

\subsection{Sources}

PM in animal barns is highly complex in composition and originates from various sources including feed, feces, animal skin and hair (feathers for poultry), beddings, construction materials, insect fragments, and microorganisms (Zhang, 2005). PM can be classified into inorganic, organic, and biological particles according to their composition and origins. The biological ones are often referred to as bioaerosols. However, an individual particle can be a mixture of inorganic, organic, and biological components, or an agglomerate of small particles with inorganic, organic, and biological origins. In fact, many particles in animal barns are formed through the agglomeration of small particles possibly from different sources (Koon et al., 1963).

Source identification and apportionment constitute two consecutive steps for the research of particle origins. The former aims to identify the sources of particles while the latter aims to quantitate the respective contributions of identified sources. The results of source apportionment are often presented in the unit of particle number or mass percentage (\%). Both source identification and apportionment can be done on a bulk scale (i.e., a collection of particles) or individual particles. Although an individual particle can be of multiple origins, many previous studies examined the shape, size, and/or composition of individual particles with optical or electron microscopy (Donham et al., 1986; Heber et al., 1988a) and assigned their origins (e.g., as feed or fecal particles) accordingly.

Feed was found as a primary PM source in swine barns in early studies (Curtis et al., 1975a; Honey and McQuitty, 1978; Donham et al., 1986; Heber et al., 1988). Curtis et al. (1975a) compared the crudeprotein $(\mathrm{CP})$ contents in feed, settled dust, and PM under different swine diet conditions and found the CP contents in PM were consistently close to those in the feed and settled dust. Based on this bulk scale analysis, they concluded that the majority of PM in swine barns was feed particles. Honey and McQuitty (1978) collected PM samples from four pig pens in an experimental room and used an optical microscope to count and identify particles. They found that hair and skin accounted for a small portion of particles (by number) and assumed the remaining cubical or spherical particles to be of feed origins. Donham et al. 
(1986) studied the sources of PM in 21 swine barns in Iowa using an optical microscope. They reported that PM was primarily from feed (starch, grain meal, plant trichomes, and corn silk; by particle number) and fecal materials (microorganisms, animal cells, and undigested feed), and the feed content increased with the size of pigs. The existence of dander, molds, pollens, insect fragments, and minerals in PM was also observed. Heber et al. (1988a) collected PM samples from 11 swine barns in Kansas with eight visits to each barn and used an SEM and an optical microscope to identify and classify particles. They found that the majority of particles were from the feed. Around $65 \%$ (by number) of particles were grain meal particles and $13.5 \%$ were starch granules. Most of the starch granules were larger than $6.7 \mu \mathrm{m}$. Grain meal particles were on average smaller but most of them were still larger than $3.0 \mu \mathrm{m}$. The study also revealed that PM composition varied with particle size and, in particular, the feed contents were lower for small particles than large particles. Aarnink et al. (1999) collected PM, settled dust, feed dust, manure dust, and skin particle samples from a grower-finisher barn in the Netherlands and compared their contents of $\mathrm{N}, \mathrm{P}, \mathrm{K}, \mathrm{Cl}, \mathrm{Na}$, ash, and dry matter. Through the bulk scale analysis, they found that PM and settled dust shared nearly the same chemical composition and suggested that PM mass in swine barns primarily originated from feed and skin particles.

However, a later study in the Netherlands indicated that manure and skin could be greater PM sources than animal feeds in swine barns (Cambra-López et al., 2011a). Different from earlier similar studies, the study combined the morphology and the elemental composition of individual particles for source identification and apportionment. A high-resolution SEM coupled with energy-dispersive x-ray analysis (EDX) was used for morphology and composition analyses. It was found that by mass most particles in swine barns originated from the skin $\left(0-79 \%\right.$ in $\mathrm{PM}_{2.5}$ and $0-71 \%$ in $\left.\mathrm{PM}_{2.5-10}\right)$ and manure (14-95\% in $\mathrm{PM}_{2.5}$ and $23-92 \%$ in $\mathrm{PM}_{2.5-10}$ ). It should be noted that the findings derived from the study do not completely contradict those from the earlier studies. First, Cambra-López et al. (2011a) only investigated particles smaller than $10 \mu \mathrm{m}\left(\mathrm{PM}_{2.5}\right.$ and $\left.\mathrm{PM}_{2.5-10}\right)$ while many of the earlier studies considered particles of all sizes. According to Donham et al. (1986) and Heber et al. (1988a), feed particles are usually large, e.g., $>10 \mu \mathrm{m}$. Secondly, the source contributions were reported by Cambra-López et al. (2011a) in mass percentage while many of the earlier studies presented their results in number percentage (Honey and McQuitty, 1978; Donham et al., 1986; Heber et al., 1988a). Since PM regulations are based on mass concentrations, mass source apportionment results would be more useful for air quality management.

Source identification and apportionment provide valuable information for the development of control strategies. Once a major source of PM is determined, measures can be implemented to suppress the source's PM generation, thereby reducing in-barn PM concentrations. For example, adding fat to animal feed was found to be an effective way to reduce the aerosolization of feed particles (Chiba et al., 1985). From the emission control standpoint, future source studies should focus on small particles, because once released from swine barns, large particles will quickly settle down but the small particles will travel a relatively long distance in the atmosphere, reaching neighboring communities and creating potential air pollution problems.

It is noteworthy that different source apportionment methods are used for atmospheric PM. Microscopic morphology analysis of individual particles is used but less often than receptor models. Receptor models rely on PM characteristics (e.g., chemical composition, size, and morphology of atmospheric PM) and source profiles (e.g., chemical composition, size, and morphology of source-emitted PM) to identify the contributing sources and quantitate their PM mass contributions. The commonly used receptor models include chemical mass balance (CMB), positive matrix factorization (PMF), and UNMIX. They are all statistical models and require no meteorology input. Receptor models are potentially useful for the study of PM sources in swine barns (Cambra-López et al., 2010). A discussion of receptor models is beyond the scope of this review. Further information can be found in Watson et al. (2002) and Hopke (2016). 


\section{Measurement Methodology}

\subsection{Mass concentration determination}

PM is usually reported, discussed, and regulated based on mass concentrations. Others, such as number concentrations and surface area concentrations, are occasionally used but primarily for research purposes. For simplicity, only the methodology for mass concentration measurement is reviewed here.

In general, PM mass concentrations can be determined with two types of methods: gravimetric and realtime. The gravimetric method, also known as the time-average or integrated method, involves the collection of PM samples on a filter medium at a known sampling airflow rate over a known period (e.g., 24 hours), and the weighing of the filter before and after the sample collection. Thus, the measurement result represents the average PM mass concentration over the entire sampling period. The real-time method, also known as the online method, generates continuous or semi-continuous mass concentration readings by feeding PM-laden air instantly to a sensing element or elements. It is noteworthy that "realtime" is an inaccurate generalization. In reality, many PM monitors (e.g., beta attenuation monitor [BAM]) are not truly real-time because of the time latency required for PM sensing in these instruments.

\subsubsection{Gravimetric methods}

A variety of PM samplers were used for PM collection in swine barns (Table 17). Most of them are sizeselective, i.e., they collect PM of a certain size range (e.g., $\mathrm{PM}_{10}$ ). This is achieved by using aerodynamic size separators to remove undesired PM, i.e., PM beyond the target size range. Two types of aerodynamic size separators were commonly used: impactors and cyclones. Both separate particles of different sizes based on their inertia (which is size-dependent) (Zhang, 2005). The PM samplers varied greatly in portability, cost, and sampling airflow rate. Among them, personal samplers were developed for PM exposure assessment in occupational environments. They are battery-powered and run at a relatively low sampling airflow rate. They are the most portable and usually the least expensive units, and can be worn by farm workers to assess their average PM exposure during a work shift. Other samplers must be installed at a fixed location and many of them rely on AC power to run sampling pumps.

Table 17. Gravimetric PM samplers used in past swine barn PM studies.

\begin{tabular}{|l|l|l|l|l|l|}
\hline $\begin{array}{l}\text { Gravimetric PM } \\
\text { samplers }{ }^{1,2}\end{array}$ & $\begin{array}{l}\text { Size } \\
\text { separators }\end{array}$ & $\begin{array}{l}\text { Available PM } \\
\text { size }\end{array}$ & $\begin{array}{l}\text { Sampling } \\
\text { airflow rate } \\
\text { (LPM) }\end{array}$ & $\begin{array}{l}\text { Manufacturer, } \\
\text { Country }\end{array}$ & $\begin{array}{l}\text { Past studies using the } \\
\text { technology }\end{array}$ \\
\hline $\begin{array}{l}\text { Ambient air } \\
\text { particle sampler }\end{array}$ & $\begin{array}{l}\text { Impactor, } \\
\text { cyclone }\end{array}$ & $\mathrm{PM}_{10} \& \mathrm{PM}_{2.5}$ & 16.7 & $\begin{array}{l}\text { Dandong Baite } \\
\text { Instrument Co., } \\
\text { Ltd., China }\end{array}$ & Shen et al. (2019) \\
\hline $\begin{array}{l}\text { BGI personal } \\
\text { sampler }\end{array}$ & Cyclone & $\begin{array}{l}\mathrm{PM}_{10}, \mathrm{PM}_{2.5}, \\
\mathrm{PM}_{1}, \text { respirable, } \\
\mathrm{PM}_{4}, \& \mathrm{PM}_{0.8}\end{array}$ & Up to 5 & $\begin{array}{l}\text { Mesa Labs, } \\
\text { USA }\end{array}$ & $\begin{array}{l}\text { Maghirang et al. (1997); } \\
\text { Predicala et al. (2001) }\end{array}$ \\
\hline Cassette only & $\mathrm{n} / \mathrm{a}^{4}$ & $\mathrm{TSP}$ & $\mathrm{n} / \mathrm{a}$ & $\begin{array}{l}\text { Many vendors } \\
\text { have filter } \\
\text { cassettes } \\
\text { available }\end{array}$ & $\begin{array}{l}\text { Duchaine et al. (2000); } \\
\text { Wang et al. (2002); Kim et } \\
\text { al. (2007); Kim et al. } \\
\text { (2008); Lavoie et al. } \\
\text { (2009); Jerez et al. } \\
\text { (2011a); Pilote et al. } \\
\text { (2019) }\end{array}$ \\
\hline $\begin{array}{l}\text { Conical } \\
\text { inhalable } \\
\text { sampler }\end{array}$ & impactor & $\begin{array}{l}\mathrm{PM}_{10}, \mathrm{PM}_{2.5}, \\
\text { inhalable \& } \\
\text { respirable }\end{array}$ & 3.5 & $\begin{array}{l}\text { JS Holdings, } \\
\text { UK }\end{array}$ & Basinas et al. (2013) \\
\hline $\begin{array}{l}\text { Harvard } \\
\text { impactor } \\
\text { (discontinued) }\end{array}$ & Impactor & $\begin{array}{l}\mathrm{PM}_{10}, \mathrm{PM}_{2.5} \& \\
\mathrm{PM}_{1}\end{array}$ & $5-20$ & $\begin{array}{l}\text { Air Diagnostics } \\
\text { and } \\
\text { Engineering } \\
\text { Inc., USA }\end{array}$ & Yang et al. (2011) \\
\hline
\end{tabular}




\begin{tabular}{|c|c|c|c|c|c|}
\hline $\begin{array}{l}\text { Isokinetic } \\
\text { sampler }\end{array}$ & $\mathrm{n} / \mathrm{a}^{4}$ & TSP & $\mathrm{n} / \mathrm{a}^{5}$ & $\begin{array}{l}\text { University of } \\
\text { Illinois, USA }\end{array}$ & $\begin{array}{l}\text { Yang et al. (2013); Yang et } \\
\text { al. (2015) }\end{array}$ \\
\hline $\begin{array}{l}\text { Low-volume } \\
\mathrm{PM}_{10} \text { reference } \\
\text { sampler }^{6}\end{array}$ & Impactor & $\mathrm{PM}_{10}$ & 38.3 & $\mathrm{n} / \mathrm{a}$ & $\begin{array}{l}\text { Zhao et al. (2009); Winkel } \\
\text { et al. (2015) }\end{array}$ \\
\hline $\begin{array}{l}\text { Medium-volume } \\
\text { air sampler }\end{array}$ & $\begin{array}{l}\text { Impactor, } \\
\text { cyclone }\end{array}$ & $\mathrm{PM}_{10} \& \mathrm{PM}_{2.5}$ & 16.7 & $\begin{array}{l}\text { Tianhong Co., } \\
\text { China }\end{array}$ & Xu et al. (2016) \\
\hline $\begin{array}{l}\text { MiniVol PM } \\
\text { sampler }\end{array}$ & Impactor & $\begin{array}{l}\text { TSP, } \mathrm{PM}_{10} \& \\
\mathrm{PM}_{2.5}\end{array}$ & 5 & $\begin{array}{l}\text { Airmetrics, } \\
\text { USA }\end{array}$ & $\begin{array}{l}\text { Schmidt et al. (2002); } \\
\text { Hofer and Nicolai (2007) }\end{array}$ \\
\hline $\begin{array}{l}\text { SKC Personal } \\
\text { sampler }\end{array}$ & $\begin{array}{l}\text { Impactor, } \\
\text { cyclone }\end{array}$ & $\begin{array}{l}\text { TSP, } \mathrm{PM}_{10} \\
\mathrm{PM}_{2.5} \text {, inhalable } \\
\text { \& respirable }\end{array}$ & Up to 5 & SKC Ltd, UK & $\begin{array}{l}\text { Takai et al. (1998); } \\
\text { Gustafsson (1999); } \\
\text { Simpson et al. (1999); } \\
\text { Predicala et al. (2001); } \\
\text { Schmidt et al. (2002); } \\
\text { Nonnenmann et al. (2004); } \\
\text { Rule et al. (2005); Kim et } \\
\text { al. (2007); Kim et al. } \\
\text { (2008); Costa et al. (2009); } \\
\text { O'Shaughnessy et al. } \\
\text { (2009); Thorne et } \\
\text { al. (2009); Shin et al. } \\
(2019)\end{array}$ \\
\hline $\begin{array}{l}\text { URG cyclone } \\
\text { sampler }\end{array}$ & Cyclone & $\mathrm{PM}_{10} \& \mathrm{PM}_{2.5}$ & $3-92$ & $\begin{array}{l}\text { URG Corp., } \\
\text { USA }\end{array}$ & $\begin{array}{l}\text { Zhao et al. (2009); } \\
\text { Cambra-López et al. } \\
\text { (2015); Winkel et al. } \\
(2015)\end{array}$ \\
\hline $\begin{array}{l}\text { Virtual cascade } \\
\text { impactor }\end{array}$ & Impactor & $\mathrm{PM}_{10} \& \mathrm{PM}_{2.5-10^{7}}$ & 3.11 & $\begin{array}{l}\text { Helmut Und } \\
\text { GmbH, } \\
\text { Germany }\end{array}$ & $\begin{array}{l}\text { Cambra-López et al. } \\
\text { (2011a, 2011b) }\end{array}$ \\
\hline $\begin{array}{l}\text { Zefon personal } \\
\text { sampler }\end{array}$ & Cyclone & Respirable & $1.7-2.5$ & $\begin{array}{l}\text { Zefon } \\
\text { International, } \\
\text { USA }\end{array}$ & $\begin{array}{l}\text { Chang et al. (2001a); Kim } \\
\text { et al. (2005); Kim et al. } \\
(2008)\end{array}$ \\
\hline
\end{tabular}

Note:

${ }^{1}$ Some publications contain no sampler information. They might use different samplers than the listed.

${ }^{2}$ No federal reference method (FRM) gravimetric samplers were used in swine barns likely because of their poor portability and high equipment costs.

${ }^{3}$ No size separator is used. A closed-face or open-face filter cassette is connected to a timer-controlled vacuum pump for TSP sampling.

${ }^{4}$ No size separator is required for TSP (total particle) sampling.

${ }^{5}$ The sampling airflow rate is adjustable to achieve isokinetic TSP sampling. Refer to Zhang (2015).

${ }^{6} \mathrm{~A}$ reference $\mathrm{PM}_{10}$ size separator per European standards (EN 12341).

${ }^{7} \mathrm{PM}_{2.5-10}$ refers to particles with an aerodynamic diameter between 2.5 and $10 \mu \mathrm{m}$

Table 18 summarizes the types of filters selected for PM mass concentration measurement in swine barns. Among them, ringed Teflon filters (i.e., PTFE filters with a PMP supporting ring) are recommended by the U.S. EPA for ambient PM monitoring because of the filters' superior chemical stability, lightweight, and minimal gas and water adsorption (Chow, 1995). However, in swine barns, glass fiber filters were most frequently used, for two reasons. First, glass fiber filters are more affordable than Teflon filters. Secondly, PM concentrations in swine barns are normally much greater than those in the ambient air. Thus, even though the gas and water adsorption by glass fiber filters causes uncertainties to mass measurement, its influence would be relatively minor. To minimize measurement uncertainties, filters must be conditioned before mass measurement (including both pre-sampling and post-sampling weighing). In most swine barn PM studies, filters were conditioned in a desiccator at room temperature for 24-48 hours. No specific humidity and temperature values were given; however, a relative humidity 
(RH) level of $<20 \%$ and a temperature level of $20-25^{\circ} \mathrm{C}\left(68-77^{\circ} \mathrm{F}\right)$ could be assumed when the lab and the desiccator were managed properly. This is in contrast to $30-45 \% \mathrm{RH}$ and $20-22{ }^{\circ} \mathrm{C}$ that the U.S. EPA recommends for ambient PM monitoring (Wilson, 2002). The filter mass measurement was normally done on a microbalance with a readability of $1 \mu \mathrm{g}$ or $10 \mu \mathrm{g}$. The former $(1 \mu \mathrm{g})$ is preferred as the PM mass concentration can be as low as tens of $\mu \mathrm{g} \mathrm{m}^{-3}$ in swine barns.

Table 18. Filters used in past swine barn PM studies.

\begin{tabular}{|c|c|}
\hline Filter type & Past studies using the filter \\
\hline Ringed Teflon filter (e.g., Teflo ${ }^{\mathrm{TM}}$ ) & Rule et al. (2005); Yang et al. (2011); Xu et al. (2016) \\
\hline Teflon membrane filter (e.g., Zefluor ${ }^{\mathrm{TM}}$ ) & $\begin{array}{l}\text { Lee et al. (2008); Costa et al. (2009); Jerez et al. (2009); Jerez et al. } \\
\text { (2011) }\end{array}$ \\
\hline Cellulose filter & $\begin{array}{l}\text { Reynolds et al. (1996); Gustafsson (1999); Wang et al. (2002); } \\
\text { Godbout et al. (2005); Lavoie et al. (2009) }\end{array}$ \\
\hline Glass fiber filter & $\begin{array}{l}\text { Takai et al. (1995; 1996); Douwes et al. (1996); Maghirang et al. } \\
\text { (1997); Senthilselvan et al. (1997); Simpson et al., (1999); Predicala } \\
\text { et al. (2001); Radon et al. (2002); Nonnenmann et al. (2004); Spaan et } \\
\text { al. (2005); Zhu et al. (2005); Mc Donnell et al. (2008); Kim et al. } \\
\text { (2007); Kim et al. (2008); Jerez et al. (2009); Thorne et al. (2009); } \\
\text { Jerez et al. (2011); Siggers et al. (2011); Traversi et al. (2011); } \\
\text { Basinas et al. (2013); Cambra-López et al. (2015); Yang et al. (2015); } \\
\text { Shang et al. (2020) }\end{array}$ \\
\hline Quartz fiber filter & Shen et al. (2019) \\
\hline Polycarbonate filter & Chang et al. (2001a); Cambra-López et al. (2011a, 2011b) \\
\hline PVC filter & $\begin{array}{l}\text { Dutkiewicz et al. (1994); Duchaine et al. (2000); Nonnenmann et al. } \\
\text { (2004); Létourneau et al. (2009); O'Shaughnessy et al. (2009); Pilote } \\
\text { et al. (2019); Shin et al. (2019) }\end{array}$ \\
\hline
\end{tabular}

The mass concentration of a PM sample $\left(\mathrm{C}_{\mathrm{p}} ; \mathrm{mg} \mathrm{m}^{-3}\right)$ can be calculated with Eq. 3 . The volume of sampled air varies with temperature and pressure. For PM concentrations measured under different temperature or pressure conditions, a correction is required to convert the volume of sampled air to a standard volume, i.e., the volume of sampled air under a standard condition (Eq. 4). Different regulations may define different sets of standard conditions. For example, in the U.S. NAAQS, the standard condition refers to a temperature of $25^{\circ} \mathrm{C}$ and a pressure of $1 \mathrm{~atm}(101,325 \mathrm{~Pa})$; while in the U.S. Standards of Performance for New Sources (SPNS), the standard condition is defined as $20^{\circ} \mathrm{C}$ and $1 \mathrm{~atm}$. The relevant information, however, was often lacking in the previous swine barn PM studies, making it difficult to compare the measurement results from different studies and to compare them with air quality standards.

$$
C_{p}=\frac{M_{p}}{V_{a}}=\frac{M_{t}-M_{0}}{Q \times t}
$$

where, $\quad M_{p}=$ mass (weight) of collected particles (mg)

$\mathrm{V}_{\mathrm{a}}=$ volume of sampled air $\left(\mathrm{m}^{3}\right)$

$\mathrm{M}_{\mathrm{t}}=$ mass of a filter after sampling; with collected particles (mg)

$\mathrm{M}_{0}=$ mass of the filter before sampling (mg)

$\mathrm{Q}=$ volumetric sampling airflow rate $\left(\mathrm{m}^{3} \mathrm{~h}^{-1}\right)$

$\mathrm{t}=$ sampling period $(\mathrm{h})$

$$
C_{p, s t d}=C_{p} \times \frac{T_{s t d}+273.15}{T+273.15} \times \frac{P}{P_{s t d}}
$$

where, $\mathrm{C}_{\mathrm{p}, \mathrm{std}}=$ corrected PM mass concentration, under the standard condition $\left(\mathrm{mg} \mathrm{m}^{-3}\right)$

$\mathrm{T}_{\text {std }}=$ standard air temperature $\left({ }^{\circ} \mathrm{C}\right)$

$\mathrm{T}=$ actual air temperature during $\mathrm{PM}$ sampling $\left({ }^{\circ} \mathrm{C}\right)$

$\mathrm{P}=$ actual air pressure $(\mathrm{atm})$

$\mathrm{P}_{\text {std }}=$ standard air pressure $(\mathrm{atm})$ 
Many PM samplers and filters were developed for sampling in the ambient air where the PM mass concentrations are substantially lower and the PM is dominated by fine particles. However, these conditions do not stand for swine barns, causing potential issues or challenges. The most prevalent one is overloading (Zhao et al. 2009; Yang et al. 2015). Overloading could occur to size separators and filters. For size separators, overloading could shift a separator's penetration curve beyond its acceptable range and cause the reentry of captured large particles to the sampling airflow. Both could bias measurement results. For example, the reentry of large particles leads to overestimates of PM concentrations. For filters, overloading could dislodge captured particles off the filter surface, resulting in underestimates of PM concentrations. No systematic investigation has been done on the overloading issue in swine barns. When it occurs, a possible solution is to reduce the sampling period, e.g., using a digital timer to turn on and off a sampling pump periodically (Yang et al. 2011).

Given the challenges facing size-selective PM sampling, an indirect method was occasionally used in the literature. The method features the collection of TSP on a hydrophobic filter and the analysis of the weight and PSD of the TSP sample. The TSP mass concentration $\left(\mathrm{C}_{\mathrm{TSP}}\right)$ is determined with the regular gravimetric method (i.e., weighing a TSP filter before and after sampling). The mass fraction of $\mathrm{PM}_{10}$ or $\mathrm{PM}_{2.5}$ in the TSP $\left(\mathrm{C}_{\mathrm{PM} 10} / \mathrm{C}_{\mathrm{TSP}}\right.$ or $\left.\mathrm{C}_{\mathrm{PM} 2.5} / \mathrm{C}_{\mathrm{TSP}}\right)$ is determined from the TSP's PSD profile. The $\mathrm{PM}_{10}$ or $\mathrm{PM}_{2.5}$ mass concentration can, thus, be estimated (Jerez et al. 2011; Wang-Li et al. 2013; Yang et al. 2015). The indirect method is easy to implement and circumvents possible issues with size separators. However, it relies on multiple assumptions, e.g., particles of all sizes having the same density and refractive index (Yang et al., 2015). These assumptions have yet to be fully validated.

As a classic method for PM mass concentration measurement, the gravimetric method is widely used in various air environments, including swine barns. Even though real-time PM monitors are becoming increasingly available, the gravimetric method is anticipated to continue its popularity given its ease to operate and maintain. Compared to the real-time method, the gravimetric method is relatively simple but yet it involves many technical details or considerations (e.g., gas-particle partitioning). An in-depth discussion about the gravimetric method can be found in Chow (1995) and Hinds (1999).

\subsubsection{Real-time methods}

With the advancement in sensor technologies, real-time methods are becoming increasingly powerful, user-friendly, and prevalent. In the past decade, numerous new PM instruments have entered the market at an affordable price and many of them fall into the category of optical PM monitors. This section reviews only the instruments that have been used for PM monitoring in swine barns (Table 19).

Table 19. Real-time PM monitors used in past swine barn PM studies.

\begin{tabular}{|l|l|l|}
\hline Instrument & Manufacturer, Country & Past studies using the instrument \\
\hline TEOM & ThermoFisher Scientific, USA & $\begin{array}{l}\text { Heber et al. (2006); Jacobson et al. (2006); Winkel et } \\
\text { al. (2015); Shang et al. (2020) }\end{array}$ \\
\hline BAM & $\begin{array}{l}\text { ThermoFisher Scientific, USA; } \\
\text { Met One Instruments, Inc., } \\
\text { USA }\end{array}$ & Winkel et al. (2015) \\
\hline \multicolumn{2}{|c|}{ Optical PM monitors } \\
\hline DustTrak & TSI Inc., USA & $\begin{array}{l}\text { Galmann et al. (2002); Cambra-López et al. (2011a); } \\
\text { Huaitalla et al. (2011); Cambra-López et al. (2015); } \\
\text { Winkel et al. (2015); Jones et al. (2016); Shen et al. } \\
(2019)\end{array}$ \\
\hline DustTrak DRX & TSI Inc., USA & $\begin{array}{l}\text { Anthony et al. (2015); Wenke et al. (2018); Dai et al. } \\
\text { (2019); Pilote et al. (2019) }\end{array}$ \\
\hline Dylos DC1100 & Dylos Corp., USA & Jones et al. (2016) \\
\hline $\begin{array}{l}\text { EPAM 5000 } \\
\text { particulate monitor }\end{array}$ & SKC Ltd, UK & Haeussermann et al. (2008); Costa et al. (2009) \\
\hline
\end{tabular}




\begin{tabular}{|l|l|l|}
\hline $\begin{array}{l}\text { Grimm aerosol } \\
\text { spectrometer }\end{array}$ & $\begin{array}{l}\text { Grimm Aerosol Technik, } \\
\text { Germany }\end{array}$ & $\begin{array}{l}\text { Liao et al. (2001); Van Ransbeeck et al. (2012, 2013); } \\
\text { Ulens et al. (2014); Winkel et al. (2015); Mostafa et } \\
\text { al. (2016); Kwon et al. (2016); Mostafa et al. (2017); }\end{array}$ \\
\hline $\begin{array}{l}\text { GT-331 handheld } \\
\text { particle counter }\end{array}$ & $\begin{array}{l}\text { Met One Instruments, Inc., } \\
\text { USA }\end{array}$ & Yao et al. (2010) \\
\hline $\begin{array}{l}\text { Handheld 3016 } \\
\text { particle counter }\end{array}$ & $\begin{array}{l}\text { Lighthouse Worldwide } \\
\text { Solutions, USA }\end{array}$ & Viegas et al. (2013) \\
\hline pDR-1200 & ThermoFisher Scientific, USA & Jones et al. (2016) \\
\hline
\end{tabular}

Tapered element oscillating microbalance (TEOM)

TEOM uses a tapered element, which is a hollow quartz cantilever with a Teflon filter mounted on its tip, to measure a change in the mass of particles collected on the filter. The mass measurement is based on a simple physical principle that the resonant vibration frequency of a cantilever decreases when additional mass is added to the cantilever. The mass-frequency relationship can be presented as:

$$
\Delta m=K_{0}\left(\frac{1}{f_{1}^{2}}-\frac{1}{f_{0}^{2}}\right)
$$

where, $\Delta \mathrm{m}=$ change in the mass of a cantilever-filter assembly; solely attributed to

collected particles

$\mathrm{K}_{0}=$ spring constant; determined by the mechanical property of the cantilever

$\mathrm{f}_{1}=$ final resonant vibration frequency $(\mathrm{Hz})$

$\mathrm{f}_{0}=$ initial resonant vibration frequency $(\mathrm{Hz})$

Thus, TEOM by nature is a gravimetric method; but different from those summarized in Section 4.1.1, TEOM tracks the mass change of collected particles every 10 seconds, thereby enabling semi-continuous monitoring of PM mass concentrations.

TEOM can be configured for TSP, $\mathrm{PM}_{10}$, or $\mathrm{PM}_{2.5}$ monitoring. Each requires a different sampler inlet and/or size separator. For TSP monitoring, a TSP inlet is used. It is noteworthy that the TSP inlet for TEOM (and BAM) does not truly collect "total" particles of all sizes. The default inlet provided by the manufacturer has a $50 \%$ cut size between 25 and $40 \mu \mathrm{m}$, depending on wind speeds (Wilson et al., 2002); that is, only $50 \%$ of particles larger than $25-40 \mu \mathrm{m}$ would be measured. For $\mathrm{PM}_{10}$ monitoring, a lowvolume (16.67 LPM, i.e., $1 \mathrm{~m}^{3} \mathrm{~h}^{-1}$ ) $\mathrm{PM}_{10}$ inlet is used. The inlet has an impactor cup inside to remove particles larger than $10 \mu \mathrm{m}$. For $\mathrm{PM}_{2.5}$ monitoring, a $\mathrm{PM}_{2.5}$ size separator is mounted downstream of the $\mathrm{PM}_{10}$ inlet to further remove particles larger than $2.5 \mu \mathrm{m}$. The size separator can be a Well Impactor Ninety-Six (WINS) or a BGI PM 2.5 Very Sharp Cut Cyclone (VSCC). For $\mathrm{PM}_{2.5}$ monitoring in swine barns, the VSCC is a better option because of its superior performance under heavy PM loading conditions (Kenny et al. 2000). TEOM could also be coupled with other low-volume inlets and size separators, e.g., URG cyclones and dichotomous virtual impactors. The latter combination (TEOM 1405D) was used in a recent swine barn PM study (Shang et al., 2020).

TEOM requires a fixed sampling airflow rate (16.67 LPM) at the sampler inlet and/or size separator. Downstream of the size separator, only 3 LPM of the sampled air flows to the sensing element. The remaining 13.67 LPM serves as a bypass flow. Both flows are regulated using electronic mass flow controllers. The total airflow rate of 16.67 LPM is critical for ensuring that the measured particles are of the right size (e.g., $\mathrm{PM}_{2.5}$ or $\mathrm{PM}_{10}$ ) because the size-separation performance of sampler inlets and size separators is affected by volumetric airflow rates (Hinds, 1999).

To minimize the interference of varying air density and water vapor condensation with PM mass measurement, the cantilever-filter assembly of TEOM is maintained at an elevated temperature with a default value of $50^{\circ} \mathrm{C}$. However, this elevated temperature could cause the volatilization loss of volatile and semi-volatile substances from particles. As discussed in Section 3.4, a large portion of fine particles in swine barns originate from feces and they are rich in volatiles and semivolatiles. Thus, using TEOM for $\mathrm{PM}_{2.5}$ monitoring in swine barns could carry biases. Although no relevant studies were done in swine 
barns, the measurement biases were affirmed by Li et al. (2012) from the field assessment of TEOM in a layer hen house. TEOM is listed by the U.S. EPA as a Federal Equivalent Method (FEM) for PM 10 monitoring (USEPA, 2020). But it is not a FEM for $\mathrm{PM}_{2.5}$, for a similar reason (volatilization-induced biases). To apply TEOM for $\mathrm{PM}_{2.5}$ monitoring, one could decrease the temperature or add a filter dynamic measurement system (FDMS) to condition the PM-laden air before it being directed to the sensing element. TEOM-FDMS is a U.S. EPA-certified FEM for $\mathrm{PM}_{2.5}$ and $\mathrm{PM}_{2.5-10}$ (USEPA, 2020).

\section{Beta attenuation monitor (BAM)}

BAM, also known as a beta gauge or beta-radiation attenuation monitor, derives PM mass from the PM's attenuation (absorption) of beta-rays. The instrument collects particles on a moving glass fiber filter tape. Before a clean spot of the filter tape is subjected to PM collection, it is irradiated with beta-rays emitted from a carbon-14 $\left({ }^{14} \mathrm{C}\right)$ radiation source. A radiation counter on the other side of the filter determines the baseline beta radiation level, i.e., a zero reading. The clean spot then advances to a filter cassette where PM-laden air is pulled through the spot. After a certain period (e.g., 1 hour), the PM-laden spot moves back in-between the beta-ray source and the radiation counter to measure the beta radiation level after PM collection. According to Beer-Lambert's Law, the mass of PM on the filter spot can be calculated as:

where, $\quad m=$ particles mass on the filter spot $(\mu \mathrm{g})$

$$
\frac{m}{A}=\frac{1}{\mu} \ln \left(\frac{I_{0}}{I_{1}}\right)
$$

$\mathrm{A}=$ area of the filter spot $\left(\mathrm{cm}^{2}\right)$

$\mu=$ absorption cross-section of particles ${ }^{1}\left(\mathrm{~cm}^{2} \mu \mathrm{g}^{-1}\right)$; varying little with the composition of PM substances

$\mathrm{I}_{0}=$ beta radiation level before PM collection (i.e., of a clean filter spot)

$\mathrm{I}_{1}=$ beta radiation level after PM collection (i.e., of a PM-laden filter spot)

BAM is listed by the U.S. EPA as FEMs for $\mathrm{PM}_{2.5}$ and $\mathrm{PM}_{10}$ monitoring. It can be coupled with various low-volume (16.67 LPM) sampler inlets and/or size separators. In reality, many of these inlets and size separators can be interchangeably used on BAM and TEOM. The glass fiber filter used by BAM is more water-absorbing than the Teflon filter used by TEOM. Thus, for BAM, the relative humidity (RH) of the sampled air must be controlled before it reaches the filter spot. The RH control is done using a fixedtemperature inlet heater, or a smart inlet heater with its temperature adjusted based on the temperature and humidity of the sampled air. Similar to TEOM, BAM should be housed in an environmental enclosure during field deployment. The enclosure provides a relatively constant temperature and prevents the instrument from dust, water, and other hazards.

Both BAM and TEOM provide semi-continuous PM mass concentration readings and can be deployed in swine barns for months without substantial maintenance. The regular maintenance work includes replacing the filter or filter tape, cleaning the sampler inlet or size separator, and performing leak checks and flow audits (Heber et al., 2006). BAM by nature is an indirect method. Thus, a calibration against the gravimetric method is strongly recommended before using BAM for PM monitoring in swine barns. BAM offers limited choices in terms of sampling time intervals. The minimal time interval is 1 hour for BAM to update its PM concentration reading. In comparison, TEOM can offer an updated PM reading every 10 seconds and, thus, would be preferred when short-term PM concentration changes are of interest. However, as an FEM for $\mathrm{PM}_{10}$ and $\mathrm{PM}_{2.5}$, BAM is more versatile; and a recent BAM model (Thermo Scientific Model 5028i) has overcome the time-interval limitation and is capable of measuring PM $_{10}$ and $\mathrm{PM}_{2.5}$ simultaneously with a single instrument.

\section{Optical PM monitors}

Interactions between light and PM are complicated. When a light beam irradiates airborne particles, part of the light passes by, part of the light is absorbed by the particles, and part of light changes its direction due to processes such as refraction and reflection. In physics, these three interactions are defined as light 
transmission, absorption, and scattering, respectively. A summation of light absorbance and scattering is termed light extinction. According to Beer-Lambert's Law, PM mass concentrations can be derived from light extinction through PM-laden air. Examples of light extinction-based instruments include densitometer, transmissometer, aethalometer, etc. However, none of them have been deployed for PM studies in swine barns. To our knowledge, all of the optical PM monitors used in swine barns are based on light scattering. Thus, only light scattering PM monitors are reviewed here.

Light is an electromagnetic wave. Its interactions with PM are therefore described by Maxwell's equations. For PM within the micron size range, Maxwell's equations can be approximated by the Mie scattering theory. The theory assumes that all particles are spherical, solid, and homogenous. According to the theory, the size and accordingly the volume of particles are related to and can be computed from the angle and intensity of scattered light. By further assuming particle density, PM mass concentration can be derived. Differing in functionality, light scattering PM monitors can be grouped into two categories: light scattering photometer and Optical Particle Counter (OPC).

A light scattering photometer (e.g., EPAM 5000, DataRam pDR-1200, TSI DustTrak 8520 \& 8530) measures the mass concentration of a PM sample. It uses an optical detector to measure the intensity of scattered light at a single fixed angle. Based on the scattered angle $(\theta)$, i.e., the angle between the light beam and the optical detector, the instruments can be further classified into forward $\left(\theta>90^{\circ}\right)$, orthogonal $\left(\theta \approx 90^{\circ}\right)$, and backward $\left(\theta<90^{\circ}\right)$ light-scattering photometers. A photometer is usually coupled with a size-selective sampler inlet and/or separator to measure the PM of the desired size, e.g., $\mathrm{PM}_{2.5}$; and PM mass concentration $\left(\mathrm{C}_{\mathrm{p}}, \mathrm{g} \mathrm{m}^{-3}\right)$ can be computed as:

where,

$$
\begin{aligned}
& \qquad C_{p}=\frac{b_{s p}}{\alpha_{M}} \\
& \mathrm{~b}_{\mathrm{sp}}=\text { intensity of scattered light }\left(\mathrm{m}^{-1}\right) \\
& \alpha_{\mathrm{M}}=\text { mass scattering efficiency }\left(\mathrm{m}^{2} \mathrm{~g}^{-1}\right)
\end{aligned}
$$

The mass scattering efficiency $\alpha_{M}$ characterizes the light scattering per unit mass of particles and it varies with measured PM substances. For example, assuming that a PM sample follows the lognormal size distribution, for a given scattered angle, $\alpha_{M}$ can be calculated based on the Mie scattering theory:

where, $\quad \rho_{\mathrm{p}}=$ particle density $\left(\mathrm{g} \mathrm{m}^{-3}\right)$

$$
\alpha_{M}=\frac{1.5}{\rho_{p}} \int \frac{Q_{s c a t}(n, k, D, \lambda) f\left(D, D_{g}, \sigma_{g}\right)}{D} d D
$$

$\mathrm{D}=$ particle diameter $(\mathrm{m})$

$\mathrm{n}=$ real part of particle refractive index $(\mathrm{n} \pm i \mathrm{k})$

$\mathrm{k}=$ imaginary part of particle refractive index $(\mathrm{n} \pm i \mathrm{k})$

$\lambda=$ light beam wavelength $(\mathrm{m})$

$\mathrm{Q}_{\text {scat }}(\mathrm{n}, \mathrm{k}, \mathrm{D}, \lambda)=$ Mie scattering efficiency (dimensionless)

$\mathrm{D}_{\mathrm{g}}=$ mass median diameter of particles (MMD, m)

$\sigma_{\mathrm{g}}=$ geometric standard deviation (GSD, dimensionless)

$\mathrm{f}\left(\mathrm{D}, \mathrm{D}_{\mathrm{g}}, \sigma_{\mathrm{g}}\right)=$ density function of particle size distribution

Thus, light scattering photometers do not directly measure PM mass concentrations. As an indirect method, they must be calibrated with the measured PM to ensure their measurement accuracy. The calibration can be done through a field comparison of the photometer with a co-located gravimetric PM sampler or samplers (Winkel et al., 2015; Yang et al, 2018). It is noteworthy that some instrument vendors provide calibration services; however, their calibration standard could be substantially different from swine barn PM, resulting in an improper calibration factor. Taking TSI DustTrak 8520 as an example, the instrument uses a 780-nm light source and measures scattered light from $87^{\circ}$ to $90^{\circ}$. It has multiple options of sampler inlets and impactors available for size-selective PM monitoring. It is calibrated in the factory using Arizona road dust with different properties than PM in swine barns. As a 
result, TSI DustTrak was found to significantly underestimate TSP and $\mathrm{PM}_{10}$ mass concentrations in swine barns when a factory calibration factor was used (Winkel et al., 2015; Pilote et al., 2019).

An OPC measures the size distribution of a TSP sample and optionally derives size-segregated PM mass concentrations from the measured PSD profile. While a photometer measures the light intensity scattered by a cloud of particles, an OPC measures the pulse signal of scattered light created by individual particles. A light pulse is detected by an optical detector when a particle quickly passes through a light beam. Thus, the signal can be used for particle counting. According to the Mie scattering theory, the height of the pulse signal is proportional to the particle size. By compiling the sizing results of many individual particles over a time period (e.g., $5 \mathrm{~min}$ ), a PSD profile can therefore be generated. To achieve the desired function, an OPC has a specially designed airflow and optical system. As a result, an OPC is often more complicated and expensive than a light scattering photometer of similar measurement accuracy. The derivation of PM mass concentrations from PSD profiles involves several assumptions with such as particle morphology and density. In reality, these assumptions are often addressed by comparing an OPC with co-located gravimetric samplers or certified monitors (to derive PM-specific calibration factors). One of the most prevalent OPCs for swine barn PM studies is Grimm aerosol spectrometers (Models $1.100 \& 11-\mathrm{X}$ series). The instrument can classify particles into 31 size channels and provide the mass concentration readings of $\mathrm{PM}_{1}, \mathrm{PM}_{2.5}, \mathrm{PM}_{10}$, respirable, thoracic, and inhalable particles simultaneously. Other OPCs for real-time PM concentration measurement include GT-331 handheld particle counter, Lighthouse handheld 3016 particle counter, and Dylon DC1100 \& DC1700.

A unique design combining a light-scattering photometer with a simple OPC was proposed by Wang et al. (2009). The design has been implemented in TSI DustTrak DRX series products (Models 8533, 8533EP, and 8534). Although the instruments are branded as photometers, their OPC components enable them to simultaneously measure $\mathrm{PM}_{1}, \mathrm{PM}_{2.5}, \mathrm{PM}_{10}$, respirable, and total PM (TPM) mass concentrations.

\subsection{Size distribution measurement}

Various techniques/instruments have been used to determine the PSD of swine barn PM samples (Table 20). They can be classified into three categories: aerodynamic, light scattering, and microscopic methods. Different categories of methods target different diameters. An aerodynamic sizer measures aerodynamic diameters, a light scattering sizer measures optical diameters, and a microscope measures geometric diameters. These diameters can be converted to one another. A conversion often involves numerous assumptions. A detailed discussion about PM diameters and their inter-conversions is beyond the scope of this review and can be found in Zhang (2005).

Table 20. Measurement methods for PM size distribution in swine barns.

\begin{tabular}{|l|l|l|l|}
\hline Method category & PM sizer & Manufacturer, Country & $\begin{array}{l}\text { Past studies using the } \\
\text { technology }\end{array}$ \\
\hline $\begin{array}{l}\text { Aerodynamic, } \\
\text { gravimetric }\end{array}$ & $\begin{array}{l}\text { Berner low-pressure } \\
\text { impactor }\end{array}$ & Hauke-MP GmbH, Austria & Lammel et al. (2004) \\
\cline { 2 - 4 } & $\begin{array}{l}\text { Marple cascade } \\
\text { impactor }\end{array}$ & Thermo Scientific, USA & O'Shaughnessy et al. (2012) \\
\cline { 2 - 4 } & $\begin{array}{l}\text { Non-viable Andersen } \\
\text { cascade impactor } \\
\text { (eight stages) }\end{array}$ & $\begin{array}{l}\text { Westech Scientific } \\
\text { Instruments, UK; Tisch } \\
\text { Environmental, USA; Thermo } \\
\text { Scientific, USA (Graseby } \\
\text { Andersen Inc., USA until } \\
\text { 2005) }\end{array}$ & $\begin{array}{l}\text { Donham et al. (1986); } \\
\text { Maghirang et al. (1997); } \\
\text { Aarnink et al. (1999); Predicala } \\
\text { et al. (2001); Predicala and } \\
\text { Maghirang (2003; 2004); } \\
\text { Siggers et al. (2011); Alonso et } \\
\text { al. (2016) }\end{array}$ \\
\hline $\begin{array}{l}\text { Aerodynamic, real- } \\
\text { time }\end{array}$ & APS or UVAPS & TSI Inc., USA & $\begin{array}{l}\text { Barber et al. (1991); Welford et } \\
\text { al. (1992); Chen et al. (1995); } \\
\text { Agranovski et al. (2004) }\end{array}$ \\
\cline { 2 - 4 } & $\begin{array}{l}\text { Aerosizer DSP } \\
\text { particle sizer }\end{array}$ & TSI Inc., USA & $\begin{array}{l}\text { Lee et al. (2008); Yang et al. } \\
\text { (2012) }\end{array}$ \\
\hline
\end{tabular}




\begin{tabular}{|c|c|c|c|}
\hline \multirow[t]{6}{*}{$\begin{array}{l}\text { Light scattering, } \\
\text { real-time }\end{array}$} & $\begin{array}{l}\text { Aerosol Particle Size } \\
\text { Spectrometer }\end{array}$ & Topas GmbH, Germany & La et al. (2019) \\
\hline & $\begin{array}{l}\text { CLIMET laser } \\
\text { particle counter }\end{array}$ & $\begin{array}{l}\text { Climet Instrument Company, } \\
\text { USA }\end{array}$ & $\begin{array}{l}\text { Perkins and Feddes (1996); } \\
\text { Wang et al. (2002); Rule et al. } \\
(2005)\end{array}$ \\
\hline & DustTrak DRX & TSI Inc., USA & Dai et al. (2019) \\
\hline & $\begin{array}{l}\text { Grimm aerosol } \\
\text { spectrometer }\end{array}$ & $\begin{array}{l}\text { Grimm Aerosol Technik, } \\
\text { Germany }\end{array}$ & $\begin{array}{l}\text { Schneider et al. (2001); Van } \\
\text { Ransbeecck et al. (2013); Lai } \\
\text { et al. (2014); Ulens et al. } \\
\text { (2016) }\end{array}$ \\
\hline & $\begin{array}{l}\text { Lighthouse laser } \\
\text { particle counter }\end{array}$ & $\begin{array}{l}\text { Lighthouse Worldwide } \\
\text { Solutions, USA }\end{array}$ & $\begin{array}{l}\text { Viegas et al. (2013); De Jong } \\
\text { et al. (2014) }\end{array}$ \\
\hline & $\begin{array}{l}\text { Met One laser } \\
\text { particle counter }\end{array}$ & MetOne Instrument, USA & $\begin{array}{l}\text { Tanaka and Zhang (1996); } \\
\text { Zhang et al. (1996); } \\
\text { Senthilselvan et al. (1997) }\end{array}$ \\
\hline \multirow[t]{2}{*}{$\begin{array}{l}\text { Light scattering, } \\
\text { filter-based }\end{array}$} & $\begin{array}{l}\text { Horiba particle size } \\
\text { analyzer }\end{array}$ & Horiba Ltd., Japan & $\begin{array}{l}\text { Jerez et al. (2008; 2011a); Lee } \\
\text { et al. (2008); Yang et al. (2015) }\end{array}$ \\
\hline & Malvern Mastersizer & Malvern Panalytical Ltd., UK & Lee et al. (2008) \\
\hline $\begin{array}{l}\text { Electrical resistivity, } \\
\text { filter-based }\end{array}$ & Coulter counter & $\begin{array}{l}\text { Beckman Coulter Life } \\
\text { Sciences, USA }\end{array}$ & $\begin{array}{l}\text { Heber et al. (1988a); Jerez et } \\
\text { al. (2008; 2011a); Lee et al. } \\
(2008)\end{array}$ \\
\hline \multirow{2}{*}{$\begin{array}{l}\text { Microscopy, filter- } \\
\text { based }\end{array}$} & Optical microscopy & $\mathrm{n} / \mathrm{a}$ & Donham et al. (1986) \\
\hline & $\begin{array}{l}\text { Scanning electron } \\
\text { microscopy }\end{array}$ & $\mathrm{n} / \mathrm{a}$ & $\begin{array}{l}\text { Nilsson et al. (1982); Heber et } \\
\text { al. (1988); Cambra-López et al. } \\
\text { (2011a; 2011b) }\end{array}$ \\
\hline
\end{tabular}

Note:

${ }^{1}$ APS - Aerodynamic particle sizer

\subsubsection{Aerodynamic sizers}

Gravimetric methods

The concurrent concentration measurement of $\mathrm{PM}_{2.5}, \mathrm{PM}_{10}$, and $\mathrm{PM}$ of other size ranges can provide PSD information. The measurement can be done by co-locating multiple gravimetric samplers each equipped with a different aerodynamic inlet or size separator (differing in $50 \%$ cut size $\left[\mathrm{D}_{50}\right]$ ). However, this method is costly and labor-intensive. Because of the limited cut size options, the derived PSD profile is of low resolution. To address these limitations, cascade impactors are often used instead.

A cascade impactor, also called a multi-stage impactor, is a stack of impactors each holding a different cut size. From the inlet to the outlet of the stack, the cut size of a stage/impactor decreases. A stage collects particles larger than its cut size on a collection medium (e.g., a filter disc or an aluminum foil) and transfers particles smaller than the cut size to the next stage. The collection medium can be submitted for gravimetric analysis. With a known sampling period and a known sampling airflow rate, the PM mass concentration of each size stage can, thus, be determined. The greater the number of stages is, the better size resolution a cascade impactor could offer.

Among various impactors, non-viable Andersen cascade impactors have been most commonly selected for swine barn PM studies (Table 20). A non-viable Andersen cascade impactor consists of eight stages (0 to 7), with cut sizes of 9.0, 5.8, 4.7, 3.3, 2.1, 1.1, 0.7, and $0.4 \mu \mathrm{m}$. A pre-separator is installed before Stage 0 to remove particles larger than $10 \mu \mathrm{m}$. Therefore, the eight stages collect particles with aerodynamic diameters of 9.0-10, 5.8-9.0, 4.7-5.8, 3.3-4.7, 2.1-3.3, 1.1-2.1, 0.7-1.1, and 0.4-0.7 $\mu \mathrm{m}$. It is noteworthy that Andersen cascade impactors have viable versions. A viable Andersen cascade impactor is used to collect bioaerosol samples on agar plates. Due to its different design specifications, a viable Andersen cascade impactor is unsuitable for gravimetric PSD analysis. 
A Berner low-pressure impactor (BLPI) consists of six stages, with cut sizes of $0.25,0.43,0.86,1.73$, 3.42 , and $6.61 \mu \mathrm{m}$. BLPI is also available in eight or ten stages, with additional stages stacked to determine the size distribution of submicron particles (i.e., particles with diameter $<1 \mu \mathrm{m}$ ). A Maple cascade impactor is a personal sampler compact in size and can be carried by farm workers for occupational exposure assessment.

Other than the aforementioned cascade impactors, one may use a Micro-Orifice Uniform Deposit Impactor (MOUDI; TSI Inc., USA) or a Dekati Low-Pressure Impactor (DLPI; Dekati Ltd., Finland) for size distribution measurement. Both instruments have been extensively used for atmospheric and indoor (including livestock barns) PM studies and they are available in different size-stage configurations. For MOUDI, five configurations are available, including three-stage, six-stage, eight-stage, ten-stage, and thirteen-stage impactors. For DLPI, three size-stage configurations are offered (four, five, and fourteen).

Real-time methods

PM size distribution can be derived in real-time by continuously measuring the mass of particles collected on each stage of a cascade impactor. Examples of such instruments include Quartz Crystal Microbalance (QCM) MOUDI (TSI Inc., USA) and Electrical Low-Pressure Impactor (ELPI; Dekati Ltd., Finland). A QCM MOUDI uses QCM, a highly sensitive mass transducer, to measure the mass of particles deposited on each stage. An ELPI charges the sampled particles before feeding them into a cascade impactor and estimates the mass of particles collected on each impactor stage by quantifying the total charge carried by the stage. Neither QCM MOUDI nor ELPI has been used in swine barns. The ELPI was used in a poultry barn PM study in Iowa (Prueger et al., 2008).

Another real-time method is the use of time-of-flight particle sizers. In a time-of-flight particle sizer, a particle is accelerated by pulling a highly diluted PM-laden air sample through an orifice. Immediately after the orifice is two closely located, parallel laser beams. When the particle passes through the beams, it scattering of the laser light results in two pulses on an optical detector. The time difference between the two pulses, i.e., the time required for a particle to travel the small distance between the two laser beams, is related to the particle's aerodynamic diameter. Because of their greater inertia, larger particles have lower accelerating rates and, thus, take a longer time to travel a given distance; whereas, smaller particles accelerate faster and take a shorter time to travel the same distance. Based on the time-of-flight principle, the aerodynamic diameter of a particle can be determined. A PSD profile can, thus, be derived by summarizing the sizing results of many particles in the air sample.

Two time-of-flight particle sizers have been used in swine barn PM studies: Aerodynamic Particle Sizer (APS) and Aerosizer DSP. Both are patented products of TSI Inc. Aerosizer DSP was discontinued in 2002 but is still available in some research groups. It can classify particles from 0.3 to $700 \mu \mathrm{m}$ into 44 size channels. APS has undergone several upgrades since its invention in the 1980s. The current model is the APS model 3321 and it can classify particles from 0.5 to $20 \mu \mathrm{m}$ into 52 size channels based on their aerodynamic diameters. Different from previous models, the APS model 3321 is additionally equipped with an OPC that enables the classification of particles from 0.37 to $20 \mu \mathrm{m}$ into 16 size channels based on their optical diameters.

\subsubsection{Light scattering sizers}

\section{Real-time methods}

The size distribution of a PM sample can be analyzed in real-time using an OPC. As described in Section 4.1.2, an OPC estimates the size of a single particle from the pulse height of the scattered light that the particle creates when traveling through a light beam. By sizing numerous particles over a certain time interval, a PSD profile can be generated. In theory, a mathematical relation between particle size and pulse height is given by the Mie scattering theory. However, in reality, the relationship is experimentally determined by calibrating an OPC with monodispersed particle standards of different sizes (Note: 
Monodispersed particles refer to particles uniform in size). Instrument design and calibration affect the size classification resolution of an OPC.

Although some OPCs read real-time PM mass concentrations, the majority of OPCs measure PSD only and present their measurement results in the form of number PSD, i.e., the number (count) of particles within each size channel. Again, an OPC measures the optical diameter of particles. To convert a number PSD derived from an OPC to a volume PSD (i.e., the volume of particles within each size channel), two assumptions are required. First, particles are solid and spherical so that the optical of a particle would be equal to its geometric diameter. The geometric diameter can then be used to calculate a particle's volume. Second, all particles within a size channel share the same diameter (which is usually the geometric or arithmetic mean diameter of the channel). To further convert a volume PSD to a mass PSD (i.e., the mass of particles within each size channel), a density value must be assumed. For simplicity, particles of all sizes are often assumed to share the same density. It should be noted that the mass PSD here is based on geometric diameters (assumed to be equal to optical diameters); whereas, $\mathrm{PM}_{10}, \mathrm{PM}_{2.5}$, respirable $\mathrm{PM}$, and alike are defined based on aerodynamic diameters. Thus, to derive PM mass concentrations from the mass PSD, a further conversion from geometric diameters to aerodynamic diameters is required (Zhang, 2005).

\section{Filter-based methods}

In several previous studies, a TSP sample was collected on a hydrophobic filter medium (e.g., a Teflon membrane filter) and extracted into an aqueous solution for PSD analysis. Light scattering particle sizers for liquid samples were used, including Horiba LA-300, Malvern Mastersizer, Beckman LS 13 320, and LS230 (Wang-Li, 2013). These analyzers have a different optical system than OPCs. Instead of using a single optical detector to target individual particles, they use multiple detectors to measure the light scattered by a collection of particles over a broad angle. To enhance the extraction efficiency and preserve particles during extraction, chemical stabilizers such as sodium polymetaphosphate (NaPMP) and lithium chloride ( $\mathrm{LiCl}$ ) were often added to the aqueous solution (Lee, 2009; Yang et al., 2015). In addition to light scattering particle sizers, a Coulter counter (Beckman Coulter Life Sciences, USA) was also used to determine the size distribution of filter-collected PM samples (Jerez et al. 2008; Lee et al. 2008; Jerez et al., 2011a). The Coulter counter determines the size of particles based on their induced changes in the electrical resistance of sample extracts.

The filter-based methods exempt the field deployment of real-time particle sizers. They can be combined with gravimetric PM sampling and analysis, thereby simplifying the field monitoring setup. However, particles could change their size during PM collection, extraction, and size analysis. For example, the dissolution of soluble particles or soluble part of particles could significantly bias the size measurement results. The accuracy of the filter-based methods has yet to be fully assessed.

\subsubsection{Microscopic methods}

The size of individual particles can be determined using a microscope. This requires the field collection of a PM sample on a filter medium. Polycarbonate filters (e.g., Whatman Nuclepore) are recommended for sample collection because their smooth surface and round, uniformly-sized pores provide a good contrast for PM identification and size measurement (Mamane et al., 2001). However, other filter types (e.g., glass filter filters) were still occasionally used (Shen et al., 2019). Size measurement can be done manually, automatically, or semi-automatically. All of the previous studies in swine barns used the manual method, i.e., manually measuring the shape and size of individual particles on acquired images. The semiautomated method uses image analysis software programs (e.g., ImageJ) to automatically detect particles on a processed image and measure their PSD. The method, however, requires the manual adjustment of image processing parameters such as thresholds and backgrounds. The automated method uses an automated microscope (e.g., Phenom desktop SEM [ThermoFisher Scientific, USA]) for high-throughput, automatic measurement of particle size. To our knowledge, neither semi-automated nor automated methods have been employed for PSD measurement in swine barns. The semi-automated method was previously used for counting bioaerosols in a Danish swine barn (Kristiansen et al., 2012). 
Both optical microscopes and SEMs were used. Because electron beams (adopted by SEMs for object illumination) have smaller wavelengths than visible light, SEMs typically provide greater amplification than optical microscopes. Thus, SEMs are particularly suitable for the size measurement of fine particles. Some SEMs are equipped with additional detectors such as energy-dispersive X-ray spectroscopy (EDX or EDS). It enables the concurrent analysis of the chemical composition of individual particles and, thus, benefits the identification and classification of particles (Refer to Section 3.4).

\subsection{Morphology and density}

\subsubsection{Morphology}

PM morphology is determined through microscopic image analysis. Modern particle imaging systems can provide automated, high-throughput morphology measurement. Examples of such systems include Morphologi G4 (Malvern Instruments Ltd., Worcestershire, UK) and Horiba PSA300 (Horiba Group, Edison, New Jersey). However, they have not been used in the previous swine barn PM studies. A shape factor $(\chi)$ was usually not the primary purpose of PM morphology analysis. Rather, the acquired morphology information was used for PM classification, source identification, and the estimation of PM surface area, fractal dimension, and other properties (Wang et al., 2008).

Most previous studies used SEMs to visually measure the shape, size, and texture of PM samples from swine barns. These included a regular SEM (Stroik, 1987; Heber et al., 1988a), a field emission SEM (Shen et al., 2019), and a field emission high-resolution SEM (Cambra-López et al. (2011a), differing in electron sources and resolution. An SEM uses a focused electron beam (typically $0.2-40 \mathrm{k} \mathrm{eV}$ ) to scan the surface of a test sample. The interaction of the electron beam with the sample produces various signals such as secondary electrons and back-scattered electrons. Among them, the secondary electrons are commonly used for morphology analysis and they are generated from electron beam-induced ionization at the sample surface. In an SEM, these secondary electrons are detected by an Everhart-Thornley detector. The intensity of detected signals is related to material composition and surface morphology. A digital image can, thus, be created when the beam finishes the scanning of a sample. A major advantage of an SEM over an optical microscope [Note: Used by Mostafa et al. (2016)] lies in its superior magnification (SEM: up to 300,000x versus optical microscope: up to 1500x) and resolution. The magnification and resolution can be further improved with field emission or high-resolution SEMs. This allows one to easily identify and measure fine particles. The manual inspection and measurement of PM morphology are highly labor-intensive (Chow et al., 2015). Image analysis software programs [e.g., FETEX 2.0 (CambraLópez et al., 2011a)] were often used to facilitate the process. With advancements in machine learningassisted image analysis, it is expected that PM morphology will gain increasing attention. Many unresolved questions (e.g., the size and mixing state of airborne viral, bacterial, and fungal particles) will possibly be addressed through morphology analysis.

As aforementioned, an SEM requires a high vacuum in its testing chamber unless it is an environmental SEM. A high vacuum environment would result in the volatilization loss of volatiles and semivolatiles in PM. This, along with electron beam irradiation, could cause the deformation of particles (McDonald and Biswas, 2004). Therefore, the morphology (including PM size) observed from an SEM specimen does not necessarily represent actual PM morphology.

\subsubsection{Density}

PM density refers to the true density of PM materials. Particles in swine barns are highly variable in sources, composition, mixing states, hygroscopicity, etc. Accordingly, their density values vary greatly and the reported PM density is an average of a collection of particles. PM density measurement is a longstanding challenge for aerosol science (Ristimäki et al., 2002; Hu et al., 2012). For PM in swine barns, its density can be measured or estimated with two different methods:

- Gas pycnometry. A gas pycnometer is an instrument specifically for true density measurement. It utilizes a gas replacement principle to measure the net volume of a test sample (Note: Excluding 
the volume taken by external and internal pores). Along with precise mass measurement, the density of the test sample can be calculated. However, the instrument has several limitations when applied to PM. Taking the AccuPyc II 1340 pycnometer (Micromeritics Instrument Corp., Norcross, Georgia) as an example, the bulk volume of test samples must be greater than $0.5 \mathrm{~cm}^{3}$. This requires at least $\sim 200 \mathrm{mg}$ of PM samples to be collected, which is impossible in reality. To address this limitation, settled dust was selected as a surrogate for density measurement in the literature (Jerez, 2007; Lee and Zhang, 2008; Lee, 2009; Yang et al., 2015). The dust samples were usually collected from exhaust fans, pen dividers, and feed lines, and they were conditioned in desiccators before pycnometry analysis to prevent measurement biases induced by absorbed water. A detailed analysis procedure can be found from Lee (2009) and Yang (2010).

- Indirect method. PM density can be calculated from Eq. 3.5 when the PM's aerodynamic diameter, equivalent volume diameter, and shape factor are known (DeCarlo et al., 2004). However, this requires online, simultaneous measurement of both diameters (Refer to Section 4.2 for their measurement methods) and was rarely used because of the complexity of required measurement systems (Hering and Stolzenburg, 1995; Ristimäki et al., 2002). An alternative method was used by Mostafa et al. (2016) in which a sedimentation cylinder was built to measure the settling velocity of particles $\left(\mathrm{v}_{\mathrm{s}}\right)$ and the PM density was calculated as:

$$
\frac{\rho_{p}}{\chi}=18 \frac{v_{s} \eta}{g d_{e}^{2} C_{c e}}
$$

where, $\quad \eta=$ dynamic viscosity of air (Pa sec)

Specifically, a pulse release of PM was conducted at the top of the sedimentation cylinder. The time for particles of different sizes to arrive at the cylinder bottom, i.e., settling time was tracked using a Grimm aerosol spectrometer. A settling velocity was then calculated by dividing the cylinder height by the measured settling time.

Both methods involve many assumptions. Thus, the measurement results may carry large uncertainties. A discussion of the assumptions and associated uncertainties requires advanced knowledge of aerosol mechanics and instrumentation and it is beyond the scope of this review effort. Further information can be found from Hinds (1999) and Zhang (2005).

\subsection{Bioaerosol characterization}

\subsubsection{Bacterial and fungal counts}

\section{Culturable bacterial and fungal counts}

The measurement of culturable bacterial/fungal counts typically consists of three steps: sampling, cultivation, and enumeration. Sampling represents the collection of airborne microbes (more strictly speaking, microbe-laden particles), cultivation involves the growth of target microbes on a growth medium or media to form visible colonies, and enumeration refers to the counting of formed bacterial or fungal colonies (Ghosh et al., 2015). An optional step is identification, with aims to determine microbial species based on the appearance of the colonies formed (Dutkiewicz et al., 1994; Mackiewicz, 1998; Chang et al., 2001b; Predicala et al., 2002; Haas et al., 2021). Identification can also be done by taking individual colonies for further investigation including microscopic analysis, biochemical testing, DNA sequencing, and proteomic analysis (Radon et al., 2002; Yuan et al., 2010; Ferguson et al., 2016; Wenke et al., 2018; White et al., 2020).

Various sampling methods are available (Table 21). In general, they can be classified into two categories (dry and wet) based on collection media. The dry methods collect airborne microbes on filters or agar plates. For filter methods, the same setup for PM sampling can be used. However, it is noteworthy that filters pose stress to collected airborne microbes because of impaction and desiccation, thereby reducing the culturability of the microbes (Wang et al. 2001). After collection, the filter is extracted in a surfactant 
solution [e.g., Tween-20 (Godbout et al., 2005; Friese et al., 2012) and Tween-80 (Radon et al., 2002; Madsen et al., 2018)] and the extract is diluted and transferred to an agar plate or plates for cultivation.

Table 21. Sampling methods used in swine barn culturable airborne microbe studies since 1990.

\begin{tabular}{|c|c|c|}
\hline $\begin{array}{l}\text { Method } \\
\text { category }\end{array}$ & $\begin{array}{l}\text { Collection } \\
\text { Medium }\end{array}$ & Specific method and the studies adopting the method \\
\hline \multirow[t]{2}{*}{ Dry } & Filter & $\begin{array}{l}\text { Cellulose nitrate membrane filter: Predicala et al. (2002) } \\
\text { Glass fiber filter: Godbout et al. (2005) } \\
\text { Polycarbonate filter: Radon et al. (2002); Friese et al. (2012); Lee and Liao (2014) } \\
\text { Teflon filters: Madsen et al. (2018) }\end{array}$ \\
\hline & Agar plate & $\begin{array}{l}\text { Viable Andersen six-stage impactor: Cormier et al. (1990); Butera et al. (1992); } \\
\text { Thorne et al. (1992); Dutkiewicz et al. (1994); Duchaine et al. (2000); Chang et al. } \\
\text { (2001b); Predicala et al. (2002); Agranovski et al. (2004); Chinivasagam and Blackall } \\
\text { (2005); Banhazi et al. (2007); Lee et al. (2009); Létourneau et al. (2009); Yuan et al. } \\
\text { (2010); Ferguson et al. (2016); Madsen et al. (2018); Tao et al. (2019); Kim and Ko } \\
\text { (2019); White et al. (2020) } \\
\text { Viable Andersen two-stage impactor: Gibbs et al. (2004); Gibbs et al. (2006); Green } \\
\text { et al. (2006) } \\
\text { Viable Andersen single-stage impactor: Kim et al. (2006); Kim et al. (2008) } \\
\text { MB1 MICROBIO Air Sampler: Keessen et al. (2011) } \\
\text { Microbiological air sampler MAS-100: Vanhee et al. (2009); Yao et al. (2010); } \\
\text { Masclaux et al. (2013); Popescu et al. (2014) } \\
\text { RCS centrifugal air sampler: Lau et al. (1996) } \\
\text { Slit sampler: Dutkiewicz et al. (1994); Mackiewicz (1998); }\end{array}$ \\
\hline Wet & Liquid & $\begin{array}{l}\text { AGI impinger: Thorne et al. (1992); Duchaine et al. (2000); Chang et al. (2001b); } \\
\text { Agranovski et al. (2004); Chi and Li (2005); Chinivasagam and Blackall (2005); Kim } \\
\text { et al. (2007); Thorne et al. (2009); Ko et al., (2010); Létourneau et al. (2010); Friese } \\
\text { et al. (2012); Schulz et al. (2012); Hass et al. (2021) } \\
\text { Coriolis } ® \mu \text { sampler: Bonifait et al. (2014); Viegas et al. (2017); Wenke et al. (2018); } \\
\text { Eisenlöffe et al (2019); Lühken et al. (2019); Pilote et al. (2019) }\end{array}$ \\
\hline
\end{tabular}

For agar plate methods, airborne microbes are directly collected onto agar plates. Before they settle on the agar plate surface, airborne microbes are usually segregated into multiple size ranges using cascade impactors. Among various impactors, a viable Andersen six-stage impactor is most frequently used. The impactor was invented by Dr. Ariel Andersen in the 1950s (Andersen, 1958) and it quickly became one of the most prevalent bioaerosol samplers in industry and academia. The working principle of cascade impactors can be found in Section 4.2.1 or Zhang (2005). Again, Andersen cascade impactors have viable and non-viable versions. They should not be interchangeably used because of their different design specifications. A viable Andersen six-stage impactor separates airborne microbes into six size ranges: $>7$, 4.7-7, 3.3-4.7, 2.1-3.3, 1.1-2.1, and 0.65-1.1 $\mu \mathrm{m}$. An agar plate is placed in each impactor stage for bioaerosol collection. A viable Andersen six-stage impactor and its brother products (single- or two-stage) are commercially available from Thermo Fisher Scientific Inc. (Waltham, MA) or Tisch Environmental (Cleves, $\mathrm{OH})$.

The wet methods collect airborne microbes in a liquid medium, usually, a sterile phosphate-buffered saline (PBS) or peptone solution amended with a non-ionic surfactant [e.g., Tween-80 (Duchaine et al., 2000; Wenke et al., 2018) and TritonX-100 (Viegas et al., 2017)] and/or an antiform agent (Thorne et al., 1992; Agranovski et al. 2004). After sample collection, the medium is transferred to an agar plate or 
plates for cultivation. Two devices have been used for swine barn bioaerosol studies. A Coriolis ${ }^{\circledR} \mu$ sampler uses a wet cyclone design in which airborne microbes, driven by a centrifugal force, are separated from air streams and scrubbed into a liquid medium in the cyclone chamber. An AGI impinger is another prevalent bioaerosol sampling device besides the Andersen impactor. It utilizes an impaction mechanism, that is, airborne microbes, after accelerated at a nozzle, impact into a liquid medium because of their greater inertia than gas molecules. Particle diffusion is also believed to play a role in bioaerosol collection by the AGI impinger (Reponen et al., 2001). Other impingers include SKC Biosamplers (with 8 different models). Their applications in swine barn bioaerosol research can be found in Section 4.4.3.

Sampling methods affect the final counting results of culturable bacteria or fungi. Higher culturable counts from AGI impingers than Andersen six-stage impactors were observed in two previous swine barn studies (Thorne et al., 1992; Agranovski et al., 2004). Liquid media are considered to be less stressful (Note: desiccation stress) to airborne microbes than solid media including agar plates. Besides, Andersen six-stage impactors were designed for bioaerosol sampling in relatively clean environments. They can easily be overloaded in swine barns with typically high bioaerosol concentrations. Specifically, each impactor stage has 400 nozzles so in principle the number of colonies formed on an agar plate is no greater than 400. Overloading occurs when multiple microbe-laden particles deposit and form colonies beneath the same nozzle and nearly all nozzles are saturated in this manner. The overloading, if occurs, will result in an underestimate of culturable bacterial/fungal counts. To address this issue, Andersen sixstage impactors were often operated for only tens of seconds to a few minutes in swine barns and a positive-hole conversion was done to correct for the underestimation caused by the "carpooling" of multiple particles (Macher, 1989). For further information regarding sampler selection and sampling time determination, readers may refer to Roponen et al. (2001).

Nearly all the previous studies used agar plates to cultivate collected bacteria or fungi. Depending on target microbes and subsequent analyses, different cultivation media and cultivation conditions were selected (Table 22). For Andersen six-stage impactors and alike, the same agar plates were used for both sampling and cultivation. Thus, they are summarized in the same table.

Table 22. Cultivation media and conditions used in swine barn bioaerosol studies since 1990.

\begin{tabular}{|c|c|c|}
\hline Target microbe(s) & Cultivation medium & Cultivation condition \\
\hline Bacteria $^{1}$ & $\begin{array}{l}\text { Blood-based agar: Friese et al. (2012) } \\
\text { Brain heart infusion agar: Bonifait et al. (2014); } \\
\text { Pilote et al. (2019) } \\
\text { Columbia agar: Popescu et al. (2014); Wenke et al. } \\
\text { (2018) } \\
\text { Horse blood agar: Banhazi et al. (2007) } \\
\text { Nutrient agar: Sowiak et al. (2012); Tao et al. (2019) } \\
\text { R2A agar: Agranovski et al. (2004); Chinivasagam } \\
\text { and Blackall (2005); Thorne et al. (2009); Ko et al. } \\
\text { (2010) } \\
\text { Sheep blood agar: Dutkiewicz et al. (1994)² } \\
\text { Trypticase soy agar (TSA): Cormier et al. (1990); } \\
\text { Thorne et al. (1992); Lau et al. (1996); Duchaine et } \\
\text { al. (2000); Chang et al. (2001b); Gibbs et al. (2004); } \\
\text { Chi and Li (2005); Godbout et al. (2005); Gibbs et al. } \\
\text { (2006); Green et al. (2006); Kim et al. (2006); Kim et } \\
\text { al. (2007); Kim et al. (2008); Lee (2009); Thorne et } \\
\text { al. (2009); Vandee et al. (2009); Yao et al. (2010); }\end{array}$ & $\begin{array}{l}\text { Room temperature for 5-7 d: Ko et } \\
\text { al. }(2010) \\
20^{\circ} \mathrm{C} \text { for } 4 \mathrm{~d} \text { : Vanhee et al. (2009) } \\
25^{\circ} \mathrm{C} \text { for } 1-3 \mathrm{~d} \text { : Thorne et al. } \\
(2009)^{2} \\
25^{\circ} \mathrm{C} \text { for } 5 \mathrm{~d} \text { : Agranovski et al. } \\
(2004) \\
30^{\circ} \mathrm{C} \text { for } 2 \mathrm{~d} \text { : Chinivasagam and } \\
\text { Blackall }(2005) \text {; Sowiak et al. } \\
(2012) \\
30^{\circ} \mathrm{C} \text { for } 2-5 \mathrm{~d} \text { : Chang et al. } \\
(2001 \mathrm{~b}) \\
30^{\circ} \mathrm{C} \text { for } 5 \mathrm{~d} \text { : Duchaine et al. } \\
(1992) \\
30^{\circ} \mathrm{C} \text { for } 7 \mathrm{~d} \text { : Viegas et al. (2017) } \\
30^{\circ} \mathrm{C} \text { for } 5-7 \text { d: Thorne et al. } \\
(1992) \text {; Viegas et al. (2017) } \\
30-35^{\circ} \mathrm{C} \text { for } 2 \text { d: Lay et al. (1996) }\end{array}$ \\
\hline
\end{tabular}




\begin{tabular}{|c|c|c|}
\hline & $\begin{array}{l}\text { Viegas et al. (2017); Eisenlöffe et al (2019); Kim and } \\
\text { Ko (2019); Lühken et al. (2019); Haas et al. (2021) } \\
\text { Tryptone glucose extract agar: Radon et al. (2002) }\end{array}$ & 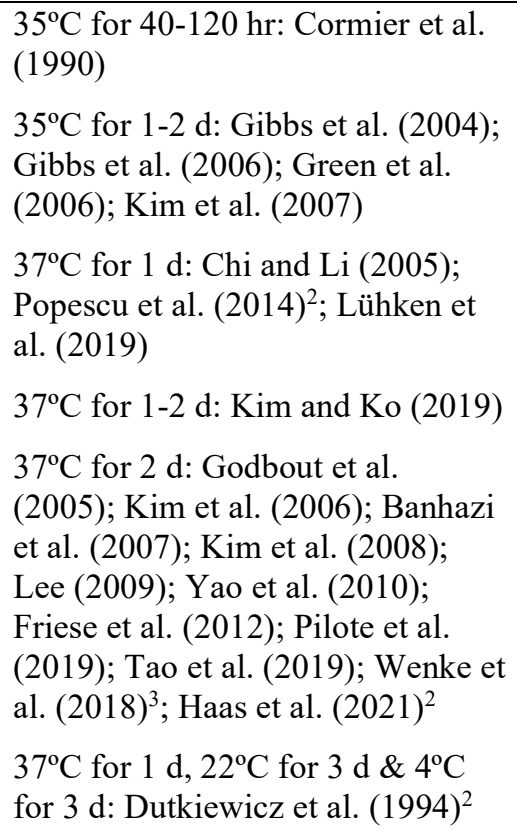 \\
\hline $\begin{array}{l}\text { Gram-negative } \\
\text { bacteria }\end{array}$ & $\begin{array}{l}\text { Endo agar: Popescu et al. (2014); Ferguson et al. } \\
\text { (2016) } \\
\text { Esosin methylene blue (EMB) agar: Dutkiewicz et al. } \\
\text { (1994) } \\
\text { MacConkey agar: Cormier et al. (1990); Chang et al. } \\
\text { (2001b); Yuan et al. (2010); Haas et al. (2021) } \\
\text { Modified Conradi agar: Kim et al. (2007) }\end{array}$ & $\begin{array}{l}30^{\circ} \mathrm{C} \text { for up to } 10 \mathrm{~d} \text { : Chang et al. } \\
(2001 \mathrm{~b}) \\
\left.35^{\circ} \mathrm{C} \text { for } 1-2 \mathrm{~d} \text { : Kim et al. ( } 2007\right) \text {; } \\
\text { Yuan et al. }(2010) \\
35^{\circ} \mathrm{C} \text { for } 40-120 \mathrm{hr} \text { : Cormier et al. } \\
(1990) \\
37^{\circ} \mathrm{C} \text { for } 1 \mathrm{~d} \text { : Popescu et al. }(2014) \\
37^{\circ} \mathrm{C} \text { for } 2 \mathrm{~d} \text { : Haas et al. }(2021) \\
37^{\circ} \mathrm{C} \text { for } 1 \mathrm{~d}, 22^{\circ} \mathrm{C} \text { for } 3 \mathrm{~d} \& 4^{\circ} \mathrm{C} \\
\text { for } 3 \mathrm{~d} \text { : Dutkiewicz et al. }(1994)\end{array}$ \\
\hline Coliform & $\begin{array}{l}\text { Brilliance Coliform selective agar: Wenke et al. } \\
\text { (2018) } \\
\text { Chromocult Coliform agar: Yao et al. (2010) } \\
\text { MacConkey agar: Lau et al. (1996) } \\
\text { Violet read bile agar: Viegas et al. (2017) }\end{array}$ & $\begin{array}{l}30-35^{\circ} \mathrm{C} \text { for } 2 \mathrm{~d} \text { : Lay et al. (1996) } \\
35^{\circ} \mathrm{C} \text { for } 5-7 \mathrm{~d} \text { : Viegas et al. (2017) } \\
37^{\circ} \mathrm{C} \text { for } 2 \mathrm{~d} \text { : Yao et al. (2010); } \\
\text { Wenke et al. (2018) }\end{array}$ \\
\hline E. coli & 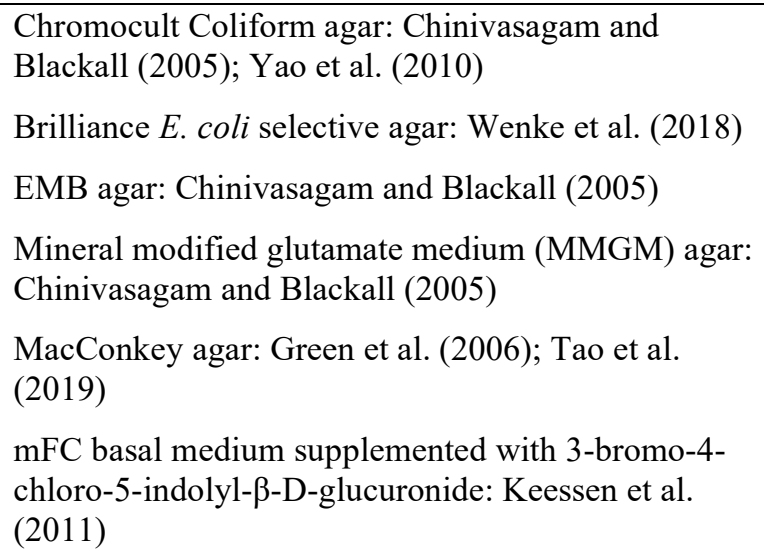 & $\begin{array}{l}35^{\circ} \mathrm{C} \text { for } 1 \mathrm{~d} \text { : Chinivasagam and } \\
\text { Blackall }(2005) \text { for Chromocult } \\
37^{\circ} \mathrm{C} \text { for } 1 \mathrm{~d} \text { : Chinivasagam and } \\
\text { Blackall }(2005) \text { for EMB } \& \\
\text { MMGM } \\
37^{\circ} \mathrm{C} \text { for } 2 \mathrm{~d} \text { : Yao et al. (2010); Tao } \\
\text { et al. (2019); Wenke et al. (2018) } \\
44.5^{\circ} \mathrm{C} \text { for } 18-24 \text { h: Létourneau et } \\
\text { al. }(2010)\end{array}$ \\
\hline
\end{tabular}




\begin{tabular}{|c|c|c|}
\hline Salmonella spp. & Bismuth sulfite agar: Pilote et al. (2019) & $37^{\circ} \mathrm{C}$ for $2 \mathrm{~d}$ : Pilote et al. (2019) \\
\hline $\begin{array}{l}\text { Clostridium } \\
\text { difficile }\end{array}$ & $\begin{array}{l}\text { CLO-agar: Keessen et al. (2011) } \\
\text { Clostridium difficile agar: Pilote et al. (2019) }\end{array}$ & $\begin{array}{l}37^{\circ} \mathrm{C} \text { for } 2 \mathrm{~d} w / \mathrm{o} \mathrm{O}_{2}: \text { Keessen et al. } \\
(2011) \text {; Pilote et al. (2019) }\end{array}$ \\
\hline $\begin{array}{l}\text { Clostridium } \\
\text { perfringens }\end{array}$ & mCP agar: Létourneau et al. (2010) & $\begin{array}{l}44.5^{\circ} \mathrm{C} \text { for } 1 \mathrm{~d} \text { : Létourneau et al. } \\
(2010)\end{array}$ \\
\hline $\begin{array}{l}\text { Staphylococcus } \\
\text { spp. }\end{array}$ & $\begin{array}{l}\text { Baird-Parker agar: Tao et al. (2019) } \\
\text { Chapman agar: Popescu et al. (2014) } \\
\text { Mannitol salt agar: Green et al. (2006); Friese et al. } \\
(2012)\end{array}$ & $\begin{array}{l}37^{\circ} \mathrm{C} \text { for } 1 \mathrm{~d} \text { : Popescu et al. (2014) } \\
37^{\circ} \mathrm{C} \text { for } 2 \mathrm{~d} \text { : Friese et al. (2012); } \\
\text { Tao et al. (2019) }\end{array}$ \\
\hline $\begin{array}{l}\text { Staphylococcus } \\
\text { aureus }\end{array}$ & $\begin{array}{l}\text { ChromoID Saureus agar: Masclaux et al. (2013); } \\
\text { Hass et al. (2021) } \\
\text { CHROMagar Staph aureus agar: Pilote et al. (2019) } \\
\text { S. aureus selective agar: Madsen et al. (2018) }\end{array}$ & $\begin{array}{l}37^{\circ} \mathrm{C} \text { for } 2 \mathrm{~d} \text { : Hass et al. (2021); } \\
\text { Pilote et al. (2019) } \\
37^{\circ} \mathrm{C} \text { for } 3 \mathrm{~d} \text { : Masclaux et al. } \\
(2013)\end{array}$ \\
\hline MRSA & $\begin{array}{l}\text { Brilliance MRSA agar: Madsen et al. (2018) } \\
\text { CHROMagar MRSA agar: Schulz et al. (2012); } \\
\text { Ferguson et al. (2016); Wenke et al. (2018); Pilote et } \\
\text { al. (2019) } \\
\text { MRSA chromogenic agar: Masclaux et al. (2013) } \\
\text { MRSA screen agar: Friese et al. (2012) } \\
\text { MRSA selective agar: Gongora et al. (2013) }\end{array}$ & $\begin{array}{l}37^{\circ} \mathrm{C} \text { for } 1 \mathrm{~d} \text { : Gongora et al. (2013) } \\
37^{\circ} \mathrm{C} \text { for }(24+17) \text { hr: Schulz et al. } \\
(2012) \\
37^{\circ} \mathrm{C} \text { for } 2 \mathrm{~d} \text { : Friese et al. }(2012) \text {; } \\
\text { Wenke et al. (2018); Pilote et al. } \\
(2019) \\
37^{\circ} \mathrm{C} \text { for } 3 \mathrm{~d} \text { : Masclaux et al. } \\
(2013)\end{array}$ \\
\hline $\begin{array}{l}\text { Streptococcus } \\
\text { aureus }\end{array}$ & Fresh blood agar: Tao et al. (2019) & $37^{\circ} \mathrm{C}$ for $2 \mathrm{~d}$ : Tao et al. (2019) \\
\hline $\begin{array}{l}\text { Haemolytic } \\
\text { streptococci } \\
\text { (Streptococcus } \\
\text { pyogenes) }\end{array}$ & Sheep blood azide agar: Lühken et al. (2019) & $\begin{array}{l}35^{\circ} \mathrm{C} \text { for } 1-2 \mathrm{~d} \text { with } 5 \% \mathrm{CO}_{2}: \\
\text { Lühken et al. (2019) }\end{array}$ \\
\hline Campylobacter & $\begin{array}{l}\text { Charcola ceforperazone desoxycholate agar: } \\
\text { Létourneau et al. (2010) }\end{array}$ & $\begin{array}{l}42^{\circ} \mathrm{C} \text { for } 2 \mathrm{~d} \mathrm{w} / \mathrm{o} \mathrm{O}_{2} \text { : Létourneau et } \\
\text { al. }(2010)\end{array}$ \\
\hline Enterococcus & mEnterococcus agar: Létourneau et al. (2010) & $\begin{array}{l}37^{\circ} \mathrm{C} \text { for } 2 \mathrm{~d} \text { : Létourneau et al. } \\
(2010)\end{array}$ \\
\hline $\begin{array}{l}\text { Listeria } \\
\text { monocytogenes }\end{array}$ & PALCAM agar: Pilote et al. (2019) & $\begin{array}{l}37^{\circ} \mathrm{C} \text { for } 2 \mathrm{~d} \mathrm{w} / 5 \% \mathrm{CO}_{2} \text { : Pilote et } \\
\text { al. }(2019)\end{array}$ \\
\hline $\begin{array}{l}\text { Mycobacterium } \\
\text { avium }\end{array}$ & $\begin{array}{l}\text { Middlebrook 7H10 Agar + OADC growth } \\
\text { supplement: Pilote et al. (2019) }\end{array}$ & $\begin{array}{l}37^{\circ} \mathrm{C} \text { for } 2 \mathrm{~d} \mathrm{w} / 5 \% \mathrm{CO}_{2} \text { : Pilote et } \\
\text { al. }(2019)\end{array}$ \\
\hline $\begin{array}{l}\text { Yersinia } \\
\text { enterocolitica }\end{array}$ & $\begin{array}{l}\text { Cefsulodin-Irgasan-Novobiocin agar: Létourneau et } \\
\text { al. (2010) }\end{array}$ & $\begin{array}{l}30^{\circ} \mathrm{C} \text { for } 18 \mathrm{~h} \text { : Létourneau et al. } \\
(2010)\end{array}$ \\
\hline $\begin{array}{l}\text { Thermophilic } \\
\text { Actinomycetes }\end{array}$ & $\begin{array}{l}\text { TSA: Dutkiewicz et al. (1994); Létourneau et al. } \\
\text { (2009) }\end{array}$ & $\begin{array}{l}52^{\circ} \mathrm{C} \text { for } 5 \mathrm{~d} \text { : Létourneau et al. } \\
(2009) \\
55^{\circ} \mathrm{C} \text { for } 5 \mathrm{~d} \text { : Dutkiewicz et al. } \\
(1994)\end{array}$ \\
\hline
\end{tabular}




\begin{tabular}{|c|c|c|}
\hline Fungi $^{4}$ & $\begin{array}{l}\text { DG-18 agar: Radon et al. (2002); Viegas et al. } \\
\text { (2017); Lühken et al. (2019); White et al. (2020) } \\
\text { Malt extract agar (MEA): Thorne et al. (1992); } \\
\text { Dutkiewicz et al. (1994); Chang et al. (2001b); } \\
\text { Radon et al. (2002); Chi and Li (2005); Kim et al. } \\
\text { (2006); Kim et al. (2007); Kim et al. (2008); Thorne } \\
\text { et al. (2009); Létourneau et al. (2009); Ko et al. } \\
\text { (2010); Sowiak et al. (2012); Lee and Liao (2014); } \\
\text { Viegas et al. (2017) } \\
\text { Rose Bengal agar: Duchaine et al. (2000); } \\
\text { Agranovski et al. (2004); Vanhee et al. (2009); } \\
\text { Létourneau et al. (2009); } \\
\text { Sabourand dextrose agar: Cormier et al. (1990); } \\
\text { Masclaux et al. (2013); Popescu et al. (2014) } \\
\text { Sterile water: Godbout et al. (2005) }\end{array}$ & 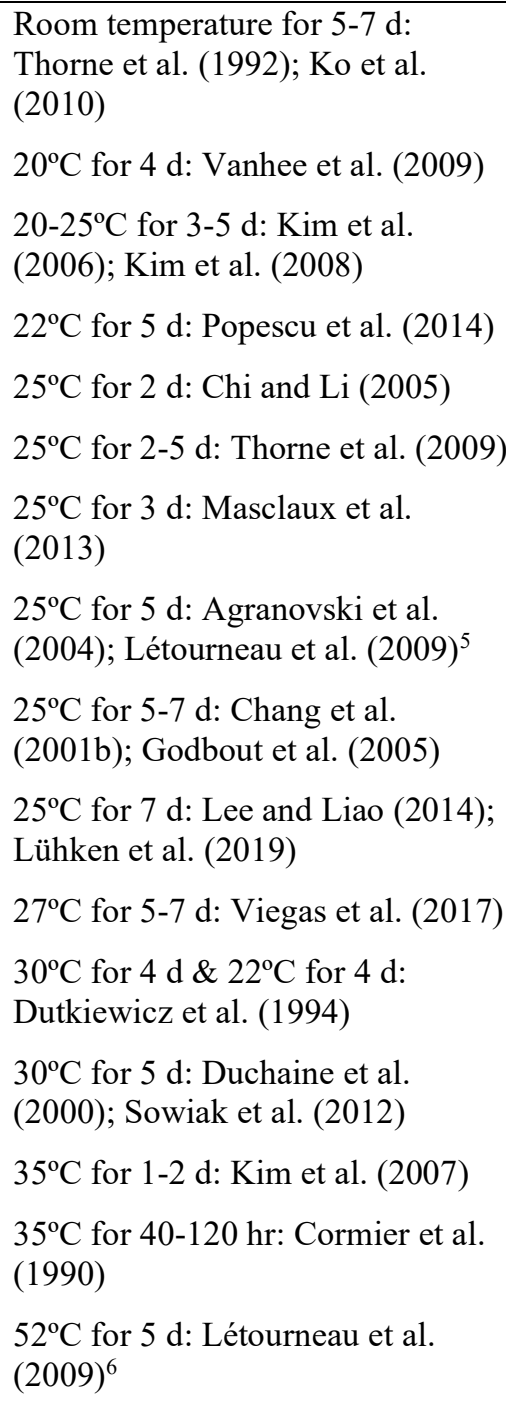 \\
\hline Aspergillus spp. & Czapek solution agar: Cormier et al. (1990) & $\begin{array}{l}35^{\circ} \mathrm{C} \text { for } 40-120 \mathrm{hr}: \text { Cormier et al. } \\
(1990)\end{array}$ \\
\hline
\end{tabular}

Note:

${ }^{1}$ Bacteria here refer to general bacteria, including mesophilic bacteria;

${ }^{2}$ Presented as mesophilic bacteria;

${ }^{3}$ Cultivated with $5 \% \mathrm{CO}_{2}$ on day 2 ;

${ }^{4}$ Fungi here refer to general fungi and are interchangeably termed with molds;

5 Presented as mesophilic molds;

6 Thermotolerant molds.

Various cultivation media and conditions were used. For general bacteria, trypticase soy agar (TSA) was the most frequently selected medium. To suppress fungal growth, bacterial agar was sometimes amended with cycloheximide, a natural fungicide (Duchaine et al., 2000; Kim et al., 2006; Haas et al, 2021). The cultivation temperature ranged from room temperature $\left(20-25^{\circ} \mathrm{C}\right)$ to $37^{\circ} \mathrm{C}$ and the cultivation time varied from 1 to 7 days. The most commonly selected cultivation condition is $37^{\circ} \mathrm{C}$ for 2 days, which applies to not only general bacteria but most individual bacterial species or groups. Several studies presented their results as mesophilic bacterial counts (Table 5). They should be considered the same as bacterial counts since there was no difference in cultivation media or conditions (Table 22). In principle, mesophilic 
bacteria are bacteria that grow between $20{ }^{\circ} \mathrm{C}$ and $45{ }^{\circ} \mathrm{C}$ (Schiraldi and De Rosa, 2014). All the reported cultivation temperatures for bacteria fall into this range.

For general fungi, malt extract agar (MEA) was most frequently selected. To inhibit bacterial growth, antibacterial agents such as chloramphenicol and streptomycin were usually added (Cormier et al., 1990; Agranovski et al, 2004; Létourneau et al., 2009; Viegas et al, 2017). The cultivation temperature ranged from room temperature to $35^{\circ} \mathrm{C}$ and the cultivation time varied from $1-7$ days. The only exception is Létourneau et al. (2009) in which agar plates were cultivated at $52^{\circ} \mathrm{C}$ to measure thermotolerant molds. The most prevalent cultivation temperature and time were $25^{\circ} \mathrm{C}$ and 5 days, respectively, for fungi. Cultivation time must be sufficient for bacteria or fungi to grow into colonies. But it cannot be too long to avoid the overgrowth of colonies causing difficulty in counting and isolating.

After cultivation, the colonies formed can be enumerated visually or with the aid of equipment [e.g., Quebec colony counters (Thorne et al., 1992; Lau et al., 1996; Agarnovski et al., 2004) or software (e.g., ImageJ). Again, for bacterial/fungal counts derived from Andersen impactors, a multi-jet impactor positive-hole correction is needed (Macher, 1992). Impingers are less prone to overloading. However, the liquid medium must be serially diluted (up to a dilution ratio of $10^{5}$ ) to ensure the number of colonies formed on an agar plate stays within a manageable range for visual enumeration (Duchaine et al., 2000; Kim et al., 2007; Thorne et al., 2009).

Total bacterial and fungal counts

Various methods are available for the measurement of total bacteria/fungi in indoor air environments (Ghosh et al., 2015). The methods that have been used for swine barns can be classified into two categories: (1) fluorochrome-assisted counting and (2) qPCR. They are discussed in separate paragraphs.

The fluorochrome-assisted counting methods involve the use of fluorescent cell stains (e.g., DAPI and $\mathrm{AO}$ ) or fluorescent nucleic acid hybridization probes (e.g., a fluorochrome-labeled DNA probe).

Fluorescent cell stains are normally coupled with EPM or flow cytometry for microbial enumeration. Fluorescent nucleic acid probes constitute a core part of FISH technology and cell enumeration is also normally done with EPM. Numerous fluorochromes are available (e.g., https://www.olympus-

lifescience.com/en/microscope-resource/primer/techniques/fluorescence/fluorotable2/). However, only a few have been used for staining airborne microbes sampled from swine barns, as listed below:

- $\mathrm{AO}$ is a nucleic acid stain with a maximum excitation wavelength at $502 \mathrm{~nm}$ and a maximum emission wavelength at $526 \mathrm{~nm}$ when binding to DNA and $460 \mathrm{~nm}$ when binding to RNA. It is cell-permeable, meaning that it can penetrate the cell membranes and organelles of both viable and non-viable microbes to interact with DNA or RNA.

- DAPI is also a nucleic acid stain and binds strongly to DNA regions rich in A (adenine) and T (thymine). It has a maximum excitation wavelength at $350 \mathrm{~nm}$ and a maximum emission wavelength at $470 \mathrm{~nm}$. Similar to AO, DAPI can pass through cell membranes and, thus, can stain both viable and non-viable microbes.

- PI is a nucleic acid stain with enhanced fluorescence after binding to DNA. It shows a maximum excitation wavelength of $536 \mathrm{~nm}$ and a maximum emission wavelength of $617 \mathrm{~nm}$. Different than DAPI and AO, PI is not cell-permeable and can only stain damaged cells. Thus, it is commonly used to study the viability of microbes.

- PAS is a staining method targeting polysaccharides such as glucans. It uses periodic acid to oxidize these sugars into aldehydes that then react with the Schiff reagent to create a purplemagenta color. PAS can be a regular or a fluorescent staining method. When conjugating the Schiff reagent with aniline blue, a fluorochrome, it becomes a fluorescent stain. PAS is often used to label fungal spores since fungal cell walls are abundant in glucans (Refer to Section 3.2.5). 
- ChemChrome V6 is an ester precursor of fluorescein (a prevalent nucleic acid stain) and it is converted to fluorescein in the presence of esterase. Fluorescein can penetrate cell membranes and bind to DNA or RNA and has a maximum excitation wavelength of $494 \mathrm{~nm}$ and a maximum emission wavelength of $518 \mathrm{~nm}$. ChemChrome V6 was used together with ChemSol B16 and B2 solutions (Vanhee et al., 2008) but no detailed information about these combinations is given.

For filter samples (Kristiansen et al., 2012; Radon et al., 2002; Lee and Liao, 2014), bioaerosols must be first extracted from a PM-laden filter, usually in a surfactant (e.g., Tween 80) amended PBS solution. For liquid samples from impingers (Lange et al., 1997; Chi and Li, 2005; Thorne et al., 2009), no extraction is needed but serial dilution may be necessary to adjust cell concentrations within a detectable range. The liquid acquired from extraction or dilution is then stained with a selected fluorochrome. When flow cytometry is used, the stained liquid is submitted for cell counting without further treatment. When EPM is used, the liquid is usually filtered with a black polycarbonate filter (offering a great contrast), and the cells retained on the filter are counted at a magnification of 400-1000x. EPM is typically equipped with a tungsten lamp and multiple excitation optical filters to achieve a desired excitation wavelength and multiple emission optical filters to selectively detect the target emission. Flow cytometry adopts a similar detection principle to EPM; however, it has a specially designed flow chamber to allow microbial cells to pass the excitation light beam on an individual basis and, thus, count the cells from emission light pulses. Microbial identification (e.g., distinguishing fungal spores from bacteria) can be done with EPM through the morphology analysis of observed microbes and/or combined use of other stains such as FISH probes (Chi and Li, 2005). Some flow cytometers can simultaneously measure the size of cells, which may also help with microbial identification or classification. Only one study adopted FISH (Chi and Li, 2005) and further information about the technology is available in Section 4.4.3.

The qPCR method quantifies the copy number of a target gene in a bioaerosol sample. It amplifies a target gene (or a segment of the gene) over multiple cycles and the amplification selectivity is achieved using a pair of primers. A primer is a short, single-strand DNA or RNA sequence that complements the starting or end sequence of a target gene. Thus, a primer pair defines the bacterial or fungal DNA region to be amplified. The gene region selected must serve as a fingerprint (indicator) of the microbes of interest, e.g., 16S rRNA for bacteria and ITS for fungi. 16S rRNA is a hypervariable region in bacterial DNA and it has been extensively used for bacterial identification (Yoo et al., 2017). Similarly, ITS genes are highly variable among fungal species. Different from regular PCR, qPCR uses fluorescent nucleic acid stains or fluorescent DNA probes to track the amplification efficiency of every cycle, thereby allowing one to back-calculate the number of gene copies in an original sample. Further information about qPCR can be found in Pepper et al. (2011) and Yates (2020). The total bacteria/fungi measurement with qPCR typically consists of three steps: bioaerosol sampling, DNA extraction, and qPCR.

- The following bioaerosol samplers were used in the literature: filter samplers (Masclaux et al., 2009; Kumari and Choi, 2004, 2015; Kumari et al., 2016), Coriolis ${ }^{\circledR} \mu$ wet cyclones (Bonifait et al., 2014; Kraemer et al., 2019; Pilote et al., 2019; Watt et al., 2020), impingers (Létourneau et al., 2009), and electrostatic dustfall collectors (Luiken, 2021). While solid samples were acquired from filter samplers and electrostatic dust fall collectors, liquid samples were derived from wet cyclones and impingers.

- Multiple DNA extraction kits were used, including QIAamp DNA Minikit (Létourneau et al., 2009; Bonifait et al., 2014), Fast Spin Kit (Masclaux et al., 2013), Power Soil Kit (Kumari and Choi, 2014, 2015; Kumari et al., 2016), Qiagen DNA Minikit (Kraemer et al., 2019), Ultra Clean GelSpin DNA Extraction Kit (Watt et al., 2020), and Nucleospin 8 Plant II Kit (Luiken, 2021).

- All existing studies performed qPCR with commercial qPCR systems. E. coli genomes (Létourneau et al., 2009; Bonifait et al., 2014; Pilote et al., 2019) or synthetic bacterial DNA (Luiken, 2021) with known 16S rRNA gene copies were diluted to build a calibration curve for the quantification of total bacteria. For fungi, synthetic fungal amplicons were used as the 
calibration standard (Kumari et al., 2016). For specific bacterial species, plasmid vectors ligated with species-specific genes were used to build calibration curves (Masclaux et al., 2013). Information about the selected primers can be found in corresponding publications.

A single microbial cell can have multiple gene copies and the number of gene copies per cell differs with microbial species. Therefore, for total bacteria or fungi, the qPCR results can hardly be translated into actual cell counts. But for a known species, the number of gene copies per cell is relatively constant, e.g., seven 16S rRNA gene copies per E. coli cell (Callahan et al., 2019). Bonifait et al. (2014) presented the counts of total bacteria and Streptococcus suis in cells $\mathrm{m}^{-3}$; however, no conversion factors were offered.

The first use of PCR and FISH for examining swine barn bioaerosols was reported by Lange (1996) (no quantitative data was given, though). Since then, molecular biology technologies have found increasing applications in swine barn bioaerosol research. They constitute a key component of culture-independent bioaerosol measurement. Other applications of these technologies can be found in the next few sections. Both culture-independent and dependent methods have their advantages and limitations. A comparison of different counting technologies is given in Thorne and Heederik (1999).

\subsubsection{Viruses}

It is important to recognize that the current measurement methods for airborne porcine viruses are largely exploratory and have yet to be well-established for large-scale field monitoring (Arruda et al., 2019). As an example, Stein et al. (2018) developed a method capable of detecting airborne PRRSV-1 under experimental conditions; however, the field deployment of the method in a PRRSV-infected farm was unsuccessful. This demonstrates the complexity and technical challenges associated with field viral measurement and the necessity for further methodology development.

All the publications in Table 7 used qPCR or real-time RT-PCR for viral detection. The two methods are very similar in that they both offer quantitative results (in the copy number of genes in a sample) by tracking the amplification efficiency of every PCR cycle. While qPCR works for DNA viruses, real-time RT-PCR is required for the detection of RNA viruses. Compared to qPCR, real-time RT-PCR includes an additional step, i.e., the creation of a complementary DNA (cDNA) sequence complementary to viral RNA through reverse transcription. The cDNA created is then quantified through regular qPCR.

For viral detection, qPCR and real-time RT-PCR are also used to determine if a sample is positive for a target virus based on a preset criterion or criteria of cycle threshold $(\mathrm{Ct})$. The $\mathrm{Ct}$ is defined as the number of PCR cycles needed to reach a fluorescence signal threshold level (due to the use of fluorochromes in qPCR). A low Ct value suggests a high abundance of target viral RNA or DNA genes in the sample. Several different $\mathrm{Ct}$ criteria were selected in the literature. A bioaerosol sample was considered positive when its Ct value was below 35 (Corzo et al., 2013; Neira et al., 2016; Vilalta et al., 2019; Alonso et al., 2017) or 36 (Bell, 2020); or suggestively positive when its Ct value was below 38.5 (Bell, 2020) or 40 (Corzo et al., 2013; Neira et al., 2016; Alonso et al., 2017). Bioaerosols generally contained a lesser amount of genomic material than pig nasal swab or oral fluid samples (Stein et al., 2018). Accordingly, different Ct criteria may be applied for positive sample determination.

The measurement procedure for airborne porcine viruses consists of three steps: bioaerosol sampling, RNA or DNA extraction, and PCR (qPCR or real-time RT-PCR).

- Wet cyclones were the most prevalent bioaerosol samplers in the literature (Corzo et al., 2013; Brito et al., 2014; Priebe et al., 2015; Neira et al., 2016; Naide et al., 2018; Stein et al., 2018; Wenke et al., 2018; Bell, 2020), followed by filter samplers (Verreault et al., 2010; O'Brien and Nonnenmann, 2016; Stein et al., 2018; Bell, 2020; López-Lorenzo et al., 2021) and impingers (Rodríguez de Evgrafov et al., 2013; Anderson et al., 2016). The selected filters include gelatin filters (Verreault et al., 2010; López-Lorenzo et al., 2021) and PTFE filters (O’Brien and Nonnenmann, 2016; Bell, 2020). Non-viable cascade impactors were used to study the size distribution of viral particles, with samples collected on aluminum plates (Alonso et al., 2017). 
One study collected deposited dust samples for viral measurement (Vilata et al., 2019). Despite the prevalence of wet cyclones, no studies have yet demonstrated or affirmed their superiority to other samplers. A lower IAV detection rate was derived from Coriolis ${ }^{\circledR} \mu$ (a wet cyclone) than filter samplers (Bell, 2020).

- Limited information is available about RNA or DNA extraction from collected samples. For liquid samples acquired from wet cyclones and impingers, they can be directly submitted for DNA or RNA extraction. For solid samples derived from filter samplers or sedimentation plates, they can be extracted into a liquid solution and optionally further pelleted before extraction (Verreault et al., 2010; O’Brien and Nonnenmann, 2016; López-Lorenzo et al., 2021). No extraction kit information is available for DNA viruses. In principle, many commercial DNA extraction kits should work. For RNA viruses, the selected extraction kits include QIAamp Viral RNA Mini Kit (O’Brien and Nonnenmann, 2016; Naide et al., 2018) and MagMAX 96 Viral RNA Isolation Kit (Corzo et al., 2013).

- Real-time RT-PCR and qPCR were often done with commercial kits, e.g., Takara one-step qRTPCR Kit (Anderson et al., 2016) and Superscript III Platinum one-step qRT-PCR Kit (Bell, 2020). Information about the selected PCR primers can be found in corresponding publications. The establishment of a calibration curve often involves several steps (Bell, 2020). First, the genes of a target virus were inserted into plasmid vectors. The vectors were then cloned in host bacterial cells (e.g., E. coli.). For RNA viruses, the next step was to transcribe the inserted genes. Finally, the transcripts or cell extracts were serially diluted and analyzed to build the calibration curve.

Special attention should be paid to the selection of bioaerosol samplers. Most commercial bioaerosol or PM samplers are not designed for the collection of airborne viruses (Anderson et al., 2017), especially when the viruses occur in the air as individual particles. AGI-30 impingers have a $50 \%$ cut size of $0.3 \mu \mathrm{m}$ (Lin et al., 2020) and Coriolis ${ }^{\circledR} \mu$ samplers are stated to effectively collect PM larger than $0.5 \mu \mathrm{m}$. Both are larger than the size of individual viruses $(0.02-0.5 \mu \mathrm{m})$ and that of the minor viral PSD peak $(0.4 \mu \mathrm{m})$ reported by Alonso et al. (2017). PM filters generally perform better than wet cyclones and impingers in collecting submicron particles. However, little is known about their performance for particles $<0.1 \mu \mathrm{m}$ or the viability of viruses on the filter surface. To make measurement results comparable, a standard sampling protocol needs to be developed.

\subsubsection{Microbial composition}

This section provides a brief overview of relevant methods that have been adopted for swine barn PM research. Readers should bear in mind that numerous methods are available for microbial composition analysis and that new methods continue to emerge. A detailed discussion of the methods is beyond the scope of the review and can be found in Pepper et al. (2011), Yoo et al. (2017), and Yates (2016),

\section{Culture-dependent methods}

In culture-dependent methods, after airborne microbes are collected on or transferred to an agar plate, they are cultivated to form visible colonies. A colony can be identified for its microbial species or group based on its appearance (Chang et al., 2001b; Predicala et al., 2002) including the size, shape, color, surface texture, elevation, and margin (i.e., edge) of the colony. The identification work usually involves a comparison of formed colonies with a reference library or colonies prepared from pure cultures. A microscope may be used to assist the visual observation and/or comparison of colony characteristics (Chang et al., 2001b; Radon et al., 2002).

A formed colony can be isolated and cultivated in a selective or differential medium or a set of such media for species identification or categorization (Murray et al., 2020). For example, Predicala et al. (2002) grew colony isolates (from R2A agar plates) with five selective/differential agars. Seven bacterial genera were, thus, identified. Identification can also be done through biochemical testing. For example, Gram staining can distinguish Gram-negative bacteria from Gram-positive bacteria (Dutkiewicz et al., 
1994; Kim et al., 2007). Hydrogen peroxide can be used to detect the occurrence of catalase, thereby distinguishing Streptococcus from Staphylococcus (Regev-Yochay et al., 2006). Many of these biochemical tests have been incorporated as part of selective or differential media (Popescu et al. 2014).

A recent development is to identify colonies or affirm identification results (from the above tests) through genomic or proteomic analysis. To do it, colony isolates were subjected to PCR (Ferguson et al., 2016; Wenke et al., 2018; Haas et al., 2021) or matrix-assisted laser desorption ionization-time of flight mass spectrometry (MALDI-TOF MS) analysis (Madsen et al., 2018; White et al., 2019, 2020; Hass et al., 2021). Both PCR and MALDI-TOF MS are molecular biology methods: PCR for genomic analysis and MALDI-TOF MS for proteomic analysis. Since they were used for the analysis of individual colonies, they should be considered as part of culture-dependent methods. However, they can also be part of culture-independent methods. A review of these analytical methods is given in the following section.

\section{Culture-independent methods}

A fundamental difference between culture-independent and culture-dependent methods is that the former methods require no cultivation steps. Instead, biological molecules characteristic of a species or a group of species are extracted from bioaerosol samples and subjected to molecular biology analysis. For cultureindependent methods, a measurement procedure typically consists of three steps: sampling, extraction (including purification and/or amplification), and molecular biology analysis.

Various devices and media were selected for swine barn PM sampling. The selected samplers include IOM or SKC personal PM samplers (Nehme et al., 2008, 2009; Hong et al., 2021), isokinetic TSP sampler (Hong et al., 2012), filter cassettes (Kristiansen et al., 2012; Kumari and Choi, 2014, 2015; Arfken et al., 2015; Kumari et al., 2016; Yan et al., 2019, 2021), BTPM-H1 ambient air PM samplers (Tang et al., 2020), TH-150F PM samplers (Song et al., 2021), Andersen multistage non-viable cascade impactors (White et al., 2020), AGI or SKC impingers (Rodríguez de Evgrafov et al., 2013; Drukenmüller et al., 2017; Liu, 2020), Coriolis ${ }^{\circledR} \mu$ samplers (Kraemer et al., 2019), ESP samplers (Vestergaard et al., 2018; White et al., 2019; Luiken et al., 2020), and Andersen multistage viable cascade impactors and alike (White et al., 2020; Tang et al., 2021). Many of them (devices listed before impingers) are filter samplers. The selected filters include gelatin filters (Nehme et al., 2008, 2009), glass fiber filters (Hong et al., 2012; Yan et al., 2019, 2021; White et al., 2020; Song et al., 2021), cellulose nitrate filters (Kumari and Choi, 2014, 2015; Kumari et al., 2016), and Teflon filters (Tang et al., 2020). To prevent microbial contamination, these filters were often autoclaved or baked before use (Hong et al., 2012; Kumari and Choi et al., 2014, 2015; Tang et al., 2020; Song et al., 2021). An ESP collects bioaerosols on a collecting electrode or electrodes and the collected bioaerosols can later be dislodged from the collecting electrode. An Andersen viable cascade impactor collects bioaerosols to agar plates. An impinger and a Coriolis ${ }^{\circledR} \mu$ sampler collect bioaerosols into a liquid medium. The selection of sampling devices and media has a large influence on bioaerosol extraction.

The culture-independent methods can be classified into two categories: proteomics and genomics. Their sample extraction and analysis are presented separately here. For proteomic analysis, MALDI-TOF MS is the only analytical tool that has been applied to swine barn bioaerosols. Two studies (White et al., 2019, 2020) used MALDI-TOF MS to identify microbial species in colony isolates, i.e., colonies formed on agar plates. Thus, their measurement would fall into the category of culture-dependent methods. The only study using MALDI-TOF MS for culture-independent microbial detection was Drukenmüller et al. (2017) in which bioaerosols were collected into a PBS solution using an impinger. The liquid was then filtered sequentially with two cell strainers of different pore sizes $(70 \mu \mathrm{m}$ and $40 \mu \mathrm{m})$. The sequential (cascade) filtration, coupled with ultra-high-speed centrifuging, led to the separation of microbes into two size fractions: $20 \mu \mathrm{m}$ and $5 \mu \mathrm{m}$. The bioaerosol samples were pelleted (upon centrifuging) and re-suspended in a matrix solution before being submitted for MALDI-TOF MS analysis. The analysis generated highresolution mass spectra of bioaerosols. By comparing the generated mass spectra with reference spectra derived from pure cultures, bacteria were identified at the genus or species level. Collections of microbial 
reference mass spectra have been available, e.g., BDAL standard library and Filamentous fungi library. They, along with special software (MALDI Biotype, Bruker Corp., Billerica, MA), were used to aid the identification of airborne microbes in swine barns (White et al., 2019, 2020). Detailed information about MALDI-TOF MS and its application to microbial analysis can be found in Singhal et al. (2015).

Several genomic methods (also known as nucleic acid-based methods) were selected to study microbial composition in swine barn bioaerosols: DGGE, FISH, Clone library, NGS, and shotgun metagenomic sequencing (Table 9). A comprehensive review of these methods is available in Yoo et al. (2017) and Yates (2020). Among these methods, FISH is the only method that requires no PCR products and, thus, it is discussed separately. Others are discussed after a review of PCR steps in the literature.

As an in-situ technology, FISH can be directly applied to environmental bioaerosol samples, without extraction or purification. It uses a DNA or RNA strand conjugated with fluorescent molecules (i.e., fluorochromes) as a probe to selectively hybridize and bond with a target gene in the microbes of interest, thereby enabling the detection of specific microbes. FISH can also be used to determine the presence of specific functional genes. The detection/identification is usually done with a fluorescence microscope (that excites the fluorochromes and visualizes the cells or cell organelles carrying the target genes). Only one study used FISH to study the composition of swine barn bioaerosols (Kristiansen et al., 2012), with one general bacterial fluorescent probe and ten specific probes selected for microbial identification. The hybridization was done on gelatin-coated glass slides and the visualization was performed with an Axioscope II epifluorescence microscope (Carl Zeiss, Germany).

PCR is fundamental to many nucleic acid-based methods. It selectively amplifies a target DNA or RNA gene or gene segment, which occurs at trace amounts in a sample, to such an extent that molecular analysis of the gene becomes feasible. Section 4.4.1 discusses a special type of PCR known as qPCR that can quantify the copies of a target gene in a bioaerosol sample. Similar to qPCR, PCR uses a pair of primers to define and delimit the region of genes to be amplified. The selection of primers depends on the microbes of interest and the subsequent analysis. Relevant information is given when discussing specific analytical methods. Similar to qPCR, PCR is usually done through thermal cycling - DNA strands are synthesized at low temperatures (from free nucleic acids) and denatured at high temperatures (deconjugated as free single strands) repeatedly over multiple cycles.

Before PCR, the genetic material (usually DNA) of microbes must be extracted and purified. Many swine barn bioaerosol studies used a soil DNA extraction kit (e.g., Power Soil Kit) for this purpose (Kristiansen et al., 2012; Kumari and Choi, 2014, 2015; Arfken et al., 2015; Kumari et al., 2016; Mbareche et al., 2019; Yan et al., 2019, 2021; White et al., 2019, 2020; Tang et al., 2020, 2021). Other extraction kits selected include QIAamp DNA Mini Kit (Nehme et al., 2008, 2009), Fast DNA SPIN Kit (Kristiansen et al., 2012; Song et al., 2021), GenElute Plant Genomic DNA Miniprep Kit (Drukenmüller et al., 2017), Qiagen DNA Minikit (Kraemer et al., 2019), NucliSens Magnetic Extract Kit (Liu, 2020), and Nucleospin 8 Plant II Kit (Luiken et al., 2020). Two studies used a customized extraction protocol (Hong et al., 2012; Rodríguez de Evgrafov et al., 2013). For filter samples, a PM-laden filter can be sliced and then subjected to DNA extraction (Hong et al., 2012; Kumari and Choi, 2014, 2015; Arfken et al., 2015; Kumari et al., 2016; Tang et al., 2020; Hong et al., 2021; Song et al., 2021), or PM can be washed off the filter and pelleted (through centrifuging) for DNA extraction (Nehme et al., 2008, 2009; Yan et al., 2019, 2021). For bioaerosols sampled with ESP, a mixed solution of $\mathrm{NaCl}$ and Tween 80 was used to extract bioaerosols from ESP (White et al., 2019). A similar procedure was adopted by Vestergaard et al. (2018). After DNA extraction and PCR, the following analyses were carried out:

- DGGE. Three early studies adopted this technology (Nehme et al., 2008, 2009; Hong et al., 2012). DGGE was extensively used in microbial community studies but has been largely replaced by sequencing in recent years. DGGE separates a mixture of amplified DNA sequences (PCR products) into multiple bands through electrophoresis, based on their differences in melting in a denaturing agent. The number, location, and intensity of the bands can be used to characterize and 
compare the richness and diversity of microbial communities. The bands can be excised for sequencing to further identify associated microbial species. In the literature, the V3 (Nehme et al., 2008, 2009) and V4-V5 regions (Hong et al., 2012) of 16S rRNA gene sequences were PCR'ed before the DGGE analysis. The $16 \mathrm{~S}$ rRNA gene refers to the DNA sequence that codes $16 \mathrm{~S}$ ribosomal RNA in a prokaryotic cell; and it is the most prevalent fingerprint for bacterial/archaeal identification and phylogenetic analysis (Yates, 2020).

- Clone library. Five studies adopted this technology. Among them, two excised DGGE bands (Nehme et al., 2008, 2009) and three collected purified PCR products (amplicons) (Kristiansen et al., 2012; Rodríguez de Evgrafov et al., 2013; Drukenmüller et al., 2017) for clone library construction. The construction is usually done using a TOPO TA cloning kit. Specifically, the purified PCR products are ligated into plasmid vectors in host bacterial cells (e.g., E. coli) and cloned by cultivating the cells. The recombinant plasmids from clone colonies are then sequenced for microbial identification. An advantage of the clone library method is that it enables long reads (typically $>1000$ base pairs [bps]) from sequencing and, thus, allows for microbial identification (taxonomic/phylogenetic assignment) at high resolutions, e.g., at species or strain levels. The clone library method is often coupled with Sanger sequencing, a traditional low-throughput DNA sequencing technology but capable of generating long reads. Because of the long reads, the PCR primers selected for clone library construction are usually different than those for other sequencing technologies. The primer pairs selected include $63 \mathrm{f} / 1387 \mathrm{r}$ (Nehme et al., 2008), 8f/1492r (Kristiansen et al., 2012), 515f/1391r (Rodríguez de Evgrafov et al., 2013), and 27f/1492r (Drukenmüller et al., 2017) for bacteria, Ar3f/Ar1492r for archaea (Nehme et al., 2009), ARC8f/ARC1492r for archaea and fungi (Kristiansen et al., 2012), and nu-SSU0817f/nuSSU-1536r for fungal phyla Ascomycota and Basidiomycota (Kristiansen et al., 2012).

- NGS. Compared with clone library sequencing, NGS is a high-throughput sequencing technology and can offer millions of reads in a single run. However, the reads are relatively short (a few hundred bps). Thus, NGS generally cannot provide the same taxonomic resolution as clone library sequencing. NGS is the most prevalent sequencing method in the literature for its massive data output and affordability. Two NGS techniques were used: (1) barcoded 454 pyrosequencing (454 Life Sciences, Branford, CT) and (2) Illumina sequencing (Illumina Inc., San Diego, CA). The former technique, now discontinued, was used by Hong et al. (2012) and Arfken et al. (2015); while the latter was used in all other NGS studies (Table 9). Illumina sequencing provides more reads in a single run but the reads are generally shorter than 454 pyrosequencing ( $150 \mathrm{bps}$ vs $500 \mathrm{bps}$ ). A technical review of Illumina sequencing and 454 pyrosequencing is beyond our expertise. Additional information can be found from the companies' websites or Cao et al. (2017). The PCR primers selected for NGS include 519f/926r (Hong et al., 2012), 338f $/ 533 \mathrm{r}$ (Kumari and Choi, 2014), 338f/519r (Kumari and Choi, 2015), 27f/338r (Arfken et al., 2015), 341f/805r (Vestergaard et al., 2018; Hong et al., 2021), 515f/806r (Kraemer et al., 2019; Yan et al., 2021), 515f/805r (White et al., 2019), 515f/813r (Liu, 2020), and 338f/806r (Tang et al., 2020, 2021; Song et al., 2021) for bacteria; and ITS1FI2f/ITS2r (Kumari et al., 2016), ITS1f/ITS1r (White et al., 2019, 2020), ITS3f/ITS4r (Liu, 2020), and ITS1f/ITS2r (Tang et al., 2020) for fungi. Similar to $16 \mathrm{~S}$ rDNA for bacteria, the ITS region is the most prevalent fingerprint for fungal identification since it is highly variable among fungal species.

- Shotgun metagenomic sequencing. Only two studies adopted this technology (Yan et al. 2019; Luiken et al., 2020). Instead of using PCR primers to target fingerprint DNAs, shotgun metagenomic sequencing, in principle, sequences all genomic DNAs in a bioaerosol sample. To do it, DNA molecules extracted from the sample are broken down into short fragments [e.g., 350 bps (Yan et al., 2019)], (optionally) barcoded, and submitted for NGS sequencing. The acquired sequence reads are processed and assembled (based on their overlaps) into long sequences for taxonomic assignment and classification. Compared with PCR-based sequencing, shotgun 
metagenomic sequencing requires no PCR, provides superior taxonomic resolution, identifies prokaryotes and eukaryotes concurrently, and is capable of profiling functional genes (e.g., ARGs). However, it has limited coverage of bacterial species, requires a greater amount of DNA input, and is prone to interference from host (e.g., swine) DNA. In Yan et al. (2019), $\sim 5 \mu \mathrm{g}$ of DNA per sample was gathered for shotgun metagenomic analysis on an Illumina HiSeq 2000 platform. Functional annotations and antibiotic resistance genes were also reported. To overcome the issue of limited DNA material in bioaerosols, a Kapa Hyper Prep Kit was used by Luiken et al. (2020) to selectively amplify certain genes and prepare a library for metagenomic sequencing.

For sequencing-based microbial identification, bioinformatic analysis and reference databases are critical. Numerous bioinformatics tools (for purposes such as alignment, trimming, error correction, and taxonomic annotation) were used in the literature and a review of these tools is beyond the scope of this review effort. Regarding reference databases, the databases for bacterial identification include the National Center for Biotechnology Information (NCBI) BLAST (Nehme et al., 2008, 2009; Rodríguez de Evgrafov et al., 2013), Ribosomal Database Project (RDP) (Hong et al., 2012; Drukenmüller et al., 2017), Silva 16S rRNA (Kristiansen et al., 2012; Kumari and Choi, 2015; Vestergaard et al., 2018; Mbareche et al., 2019; White et al., 2019; Yan et al, 2019, 2021; Liu, 2020; Tang et al., 2021), EzTaxon-e (Kumari and Choi, 2014), Greengenes (Arfken et al., 2015), and Genbank (Drukenmüller et al., 2017); and the ones for fungi include Silva 18S rRNA (Kristiansen et al., 2012), NCBI BLAST (Kumari et al., 2016), UNITE (White et al., 2019, 2020), and GenBank (Liu, 2020).

\subsubsection{ARB and ARGs}

\section{ARB measurement}

ARB are often detected with culture-dependent methods and the detection involves the use of selective or differential cultivation media. A selective medium is used to isolate a target group of bacteria by inhibiting the growth of other microbes. A differential medium is used to distinguish a target group or species from closely resembled groups. Various selective/differential media are commercially available (Table 22). These media must be incubated under appropriate conditions (temperature, time duration, and atmosphere) to ensure the reliability of measurement results.

In addition to commercial media, self-prepared media can be used for ARB detection. These media are often prepared by amending a general-purpose bacterial cultivation medium (e.g., TSA or R2A) with antibiotics or antimicrobials. For example, Chen et al. (2019) added tetracycline and erythromycin each to an LB nutrient agar and used the self-prepared selective media to detect airborne tetracycline- and erythromycin-resistant bacteria in swine barns. Arfken et al. (2015) used kanamycine-amended LuriaBertani agar plates for the detection of kanamycin-resistant bacteria.

Selective/differential media can be loaded in an agar plate-based impactor for direct ARB measurement (Gongara et al., 2013; Masclaux et al., 2013; Ferguson et al., 2016; Madsen et al., 2018) or used as a screening tool to identify ARB in samples from other types of bioaerosol samplers. For PM-laden filters from filter samplers, bioaerosols are first extracted into liquids. Liquid samples from PM extraction, wet cyclones, or impingers are diluted and then plated on selective/differential agar plates (Friese et al., 2012; Schulz et al., 2012; Wenke et al., 2018). The liquids can also be filtered and the filters are then pressed on the agar plates for ARB cultivation and identification (Friese et al., 2012; Angen et al., 2021).

Antimicrobial susceptibility testing (AMT) is a prevalent approach to identifying ARB colonies formed on a cultivation medium, either general-purpose or selective. Gibbs et al. $(2004,2006)$ adopted a threestep procedure for airborne ARB detection. In the first step, bioaerosols were collected and grown on TSA agar plates. In the second step, selective agars were used to identify the bacteria of interest (e.g., $S$. aureus) with the replica plate method. In the final step, the colony isolates of known bacteria were subjected to AMT by challenging these isolates (on Mueller-Hinton agar and TSA plates) with antibiotics. The final step followed the Kirby-Bauer diffusion disk method. The same method was adopted by Wu et 
al. (2019); however, the study used a selective medium for E. coli collection and growth and, thus, had no separate identification step (i.e., the second step). Chapin et al. (2005) employed a three-step procedure similar to Gibbs et al. (2004, 2006) but with two differences: (1) an impinger was selected for bioaerosol collection and the acquired liquid was diluted and cultivated on a selective medium for Enterococcus identification, and (2) in the final step, the MIC agar dilution method was selected for AMT analysis.

The ARB isolates can be further analyzed for ARGs (Friese et al., 2012; Schulz et al., 2012; Ferguson et al., 2016; Wenke et al., 2018), resistance to other antibiotics (Ferguson et al., 2016; Davis et al., 2018), and microbial composition (Masclaux et al., 2013; Arfken et al., 2015; Chen et al., 2019). For MRSA, $m e c(A)$ genes are often analyzed through PCR to confirm the isolates' methicillin resistance, and PantonValentine leucocidin or $n u c$ genes can be PCR'ed to confirm the presence of $S$. aureus. Other postanalysis of MRSA isolates include spa typing (PCR detection of spa gene subtypes) and coagulase reactions (positive for $S$. aureus).

Regarding sampling methods, filter samplers, agar plates-based impactors (e.g., viable Andersen cascade impactors), impingers, and wet cyclones have all been reported in the literature. Among them, viable Andersen cascade impactors were most commonly selected. As aforementioned, these impactors are prone to overloading when measuring airborne culturable bacterial counts in swine barns. Accordingly, the seleted sampling time typically ranged from tens of seconds to a few minutes. This issue could be slightly relaxed for ARB sampling, especially when selective media are used for ARB collection and the target ARB account for only a small portion of total culturable bacteria.

\section{$\underline{\text { ARG measurement }}$}

Two types of nucleic acid-based methods were used for ARG detection: PCR (including qPCR) and metagenomic sequencing (Table 11). Both PCR and qPCR use the same ARG primers. While regular PCR can identify the presence of target ARGs, qPCR can quantify the copies of target ARGs in a DNA extract. For each ARG subtype [e.g., mec(A) and tet(H)], the sequence information of primers can be found in corresponding publications.

Metagenomic sequencing can be classified into (1) amplicon and (2) shotgun metagenomic sequencing. Amplicons refer to PCR products containing selectively amplified DNA sequences or genes. Several types of amplicons are frequently used for the analysis of microbial communities in bioaerosol samples: 16S rRNA amplicons for bacteria and archaea, ITS amplicons for fungi, and 18S rRNA amplicons for fungi and other eukaryotes. None of them can detect ARGs. Comparatively, shotgun metagenomic sequencing requires no amplicons, i.e., PCR products. A brief description of this technology is given in Section 4.4.3. Since it is whole-genome sequencing, the DNA sequences generated from shotgun sequencing can be compared against ARG sequence databases to identify the presence of ARGs. The ARG databases selected include the Antibiotic Resistance Database (ARDB) (Yan et al., 2019) and the Comprehensive Antibiotic Resistance Database (CARD) (Yan et al., 2021).

Various sampling devices have been used for ARG measurement, including Andersen viable impactors (Sapkota et al., 2006; Wu et al., 2019), impingers (Létourneau et al., 2010), wet cyclone (e.g. Coriolis ${ }^{\circledR} \mu$ ) samplers (Pilote et al., 2019), ESP samplers (Luiken et al., 2020), and filter samplers (Hong et al., 2012; Kumari and Choi, 2014, 2015; Yan et al., 2019, 2021; Song et al., 2021). For filter samplers, glass fiber filters were most commonly used, followed by cellulose nitrate filters. Various kits have been used for DNA extraction from collected samples, including QIAamp DNA Mini Kit, Power Soil Kit, Fast DNA Spin Kit, and Nucleospin 8 Plant II Kit. Additional information regarding DNA extraction can be found in Section 4.4.3.

\subsubsection{Bioaerosol markers}

\section{Endotoxin}


Endotoxins can be analyzed with GC-MS or LAL assays. The GC-MS method quantifies 3-hydroxylated fatty acids (3-OH FAs) in lipid A, a major component of endotoxin molecules (Mielniczuk et al., 1993). The typical chain lengths of 3-OH FAs are $\mathrm{C}_{10}, \mathrm{C}_{12}, \mathrm{C}_{14}, \mathrm{C}_{16}$, and $\mathrm{C}_{18}$ (Liu et al., 2000). The analysis consists of three steps. First, endotoxins are extracted from a filter sample in a hot methanolic $\mathrm{HCl}$ solution. Secondly, the extracts are subjected to trimethylsilyl derivatization. Finally, the trimethylsilyl derivatives are analyzed using GC-MS or GC-MS-MS (Saraf et al., 1999). The measured concentrations are presented in the unit of ng 3-OH FAs $\mathrm{m}^{-3}$. Since the GC-MS method measures specific chemicals with a well-refined wet chemistry procedure, the analysis results are highly replicable - an advantage over the LAL assay method (Reynolds et al., 2005). However, 3-OH FAs concentrations are not a direct measure of toxicity. Only one endotoxin study in swine barns used the GC-MS method (Wang et al., 1996). PM sampling lasted for only 3 hours in the study and, thus, the measurement results can hardly be compared with those from other studies.

The LAL assay is the de facto standard method for endotoxin analysis. LAL is an aqueous extract from the blood of Limulus Polyphemus, a horseshoe crab. The animal is highly sensitive to infection by Gramnegative bacteria, and once infected, blood clotting quickly occurs (Williams, 2007). Five types of LAL assays are commercially available: gel clot, endpoint fluorescent, endpoint chromogenic, kinetic chromogenic, and kinetic turbidimetric. Different types of LAL assays could produce different quantification results (Reynolds et al., 2002; Thorne et al., 1997). Most swine barn studies used the kinetic chromogenic LAL assay (Table 13) for its great sensitivity and wide detection range.

A chromogenic LAL assay is made up of a colorless substrate and a proenzyme extracted from amoebocyte cells in the blood of Limulus polyphemus. The proenzyme becomes an active enzyme in the presence of endotoxins. The enzyme then dissociates the colorless substrate into a short peptide segment and a p-nitroaniline (pNA; a yellow organic compound). The pNA can be photometrically quantified at $405 \mathrm{~nm}$. In the kinetic assay, the pNA-associated color development is semi-continuously monitored at $37^{\circ} \mathrm{C}$ with an incubating microplate reader. The onset time of a test sample (i.e., the reaction time needed to reach a pre-set absorbance level at $405 \mathrm{~nm}$ ) is compared with the onset time of endotoxin standards to calculate the endotoxin concentration in the test sample.

The LAL assay analysis results are highly dependent on experimental procedures. For airborne endotoxin measurement, endotoxins are first extracted from collected PM samples and the extracts are then diluted to ensure that the diluted concentration stays within the detection range of a selected assay. Many factors can affect the potency of endotoxins and accordingly the analysis results, including PM sampling media, solvents for extraction, containers, extraction methods, solvents for dilution, and dilution ratios (Douwes et al., 1995; Spaan et al., 2007, 2008). Therefore, caution should be taken when comparing the measurement results from different studies. Efforts have been made to develop a standard protocol (Douwes et al., 1995; Thorne et al., 2003; Spaan et al., 2007; 2008). However, no such protocol has been established. According to Reynolds et al. (2005), LAL assays would be suitable for comparing endotoxin contamination in similar environments; and when environmental conditions are substantially different, the GC-MS method could be a better choice.

Because the LAL assay method is based on enzyme reactions, factors that promote or inhibit enzyme activation and activity can interfere with the analysis results (Williams, 2007). To identify possible inhibition or enhancement, positive product control (PPC) samples are often analyzed, along with test samples and endotoxin standards. When significant inhibition or enhancement is observed, the test samples should be re-extracted or diluted to another ratio. To address the interference issue, a special kinetic chromogenic LAL assay named the kinetic Limulus assay with resistant-parallel-line estimation (KLARE) was developed by Milton et al. (1992). Two previous studies used the KLARE assay for airborne endotoxin measurement in swine barns (Thorne et al., 1997; Chang et al., 2001a). However, according to Thorne et al. (1997), the KLARE assay could underestimate endotoxin concentrations when glass fiber filters were used for PM sample collection. 
Because of the ubiquitous presence of Gram-negative bacteria, caution must be taken to prevent possible contamination of PM samplers and filters before, during, and after field sampling. Prevention measures may include sterilizing samplers and filters (through UV radiation, ozonation, or baking [for glass or quartz fiber filters only]), keeping filters in sterile containers, storing filters in an ultralow temperature freezer, and sterilizing filter handling tools using lab micro-incinerators (Yang, 2010; Chow et al., 2015).

$(1 \rightarrow 3)-\beta$-D-glucan

Two methods are available for $(1 \rightarrow 3)$ - $\beta$-D-glucan analysis: inhibition enzyme immunoassay (EIA) and LAL assay (Rylander, 1999). They both have been used for PM studies in swine barns. Similar to the case of endotoxins, no SOP has been available for airborne $(1 \rightarrow 3)-\beta$-D-glucan measurement.

The EIA method was developed by Douwes et al. (1996). It is a competitive enzyme-linked immunosorbent assay (ELISA) with $(1 \rightarrow 3)-\beta$-D-glucans as the antigen. In this method, a glucan conjugate solution is injected into animals, e.g., rabbits, to create anti- $\beta(1 \rightarrow 3)$-glucan antibodies in the blood, and the antibodies are then extracted and purified for detection purposes. As an ELISA method, the EIA requires a primary and a secondary antibody, prepared with different animals. A downside of the method is its limited sensitivity. To ensure that the $(1 \rightarrow 3)-\beta$-D-glucan concentration in a PM extract is greater than the detection limit, preparing a 1-mL extract requires $25 \mathrm{mg}$ PM (Iossifova, 2006). A revised EIA named monoclonal antibody-based two-site enzyme immunoassay (mAb-EIA) was developed with improved selectivity and it was used for bioaerosol measurement in swine barns (Sander et al., 2008).

The LAL assays for $(1 \rightarrow 3)-\beta$-D-glucan analysis are similar to those for endotoxins. The only difference lies in activating factors. While activating factor $\mathrm{C}$ is used in endotoxin LAL assays, activating factor $\mathrm{G}$ is used in $(1 \rightarrow 3)-\beta$-D-glucan assays. Only $(1 \rightarrow 3)-\beta$-D-glucans can activate factor $G$, thereby initiating an enzyme-catalyzed color- or turbidity-yielding process (Douwes, 2005). Among various assays, a kinetic chromogenic LAL assay was often selected (Table 14) because of its large detection range and superior sensitivity. The experimental procedure is similar to that for airborne endotoxin analysis. However, an alkaline solution is advised to use for PM extraction to release $(1 \rightarrow 3)-\beta$-D-glucans from fungal cell walls while destroying endotoxins. Compared to the EIA, the kinetic chromogenic LAL assay is more sensitive, accurate, and specific; and it requires less lab equipment (Iossifova, 2006). The kinetic chromogenic LAL assay with activating factor $\mathrm{G}$ has been extensively used for airborne $(1 \rightarrow 3)-\beta$-D-glucan assessment in various environments, including swine barns. The assay requires a nearly neutral $\mathrm{pH}$ condition. A pH adjustment must be done to the alkaline extract before submitting it for analysis (Yang, 2010).

\subsection{Chemical analysis}

\subsubsection{Elemental composition}

Individual particles

SEM-EDX is the most prevalent method for elemental composition analysis of individual particles, including swine barn PM. To do it, PM must be first collected on filters (Cambra-López et al., 2011a, 2011b; Shen et al., 2019) or microscopy grids (Schneider et al., 2001). Both polycarbonate filters (Cambra-López et al., 2011a, 2011b) and quartz fiber filters (Shen et al., 2019) were used. However, a quartz fiber filter is not recommended because of its rough surface (providing a poor background). The sampling time should be carefully regulated to avoid the overlapping of particles on the filter surface.

In an SEM-EDX system, SEM is used to identify and magnify a target particle or particles, thus enabling the subsequent EDX analysis. As an add-on module to SEM, EDX energizes a particle with an X-ray or electron beam and detects the X-rays emitted from the particle. X-rays are emitted when electrons in the particle's atoms restore from excited (energized) to ground states. Because the energy of emitted X-ray photons is element-specific, EDX can identify chemical elements in the particle and further enable quantitative analysis based on photon counts. However, the quantitative analysis using SEM-EDX is known to carry large uncertainties. For example, the lack of calibration standards with X-ray generation 
and propagation manners similar to actual PM samples can compromise the accuracy of quantitative analysis (Newbury and Ritchie, 2013). Thus, SEM-EDX may better serve as a particle classifier - as in Cambra-López et al. (2011a, 2011b) - than a quantitative tool.

\section{$\underline{\text { Bulk PM }}$}

No method information is available in Aarnink et al. (1999). Yang et al. (2011) used X-ray fluorescence (XRF) and ICP-AES to determine the elemental composition of $\mathrm{PM}_{2.5}$ and $\mathrm{PM}_{10}$ samples from swine barns. Both XRF and ICP-AES are listed by the U.S. Environmental Protection Agency (EPA) as standard methods [Method IO-3.3 (USEPA, 1999a) and Method IO-3.4 (USEPA, 1999b)] for ambient PM analysis and have been extensively used worldwide. Examples of their applications include the CSN and IMPROVE networks in the U.S. Another EPA standard method is Method IO-3.5 that uses inductively coupled plasma-mass spectrometry (ICP-MS) (USEPA, 1999c). However, its application to swine barn PM has not been reported.

The detection principle of ICP-AES can be found in USEPA (1999b). In brief, the instrument nebulizes a test solution or suspension and injects formed droplets into a test chamber where an argon plasma (also known as argon torch) bombards off the water and breaks down molecules into their respective atoms. In the plasma, the atoms are ionized (lose electrons) and quenched (regain electrons) repeatedly, emitting light with wavelengths characteristic of the elements contained. For ICP-AES analysis, PM samples are first collected on a filter. Teflon filters and acid-washed quartz fiber filters are normally used because of their low impurity contents. Next, PM is extracted with hot acids or microwave extraction. A hot acid extraction method (a mixture of hydrochloric acid and nitric acid, heated at $160^{\circ} \mathrm{C}$ ) was used by Yang et al. (2011). The extract can then be submitted for ICP-AES analysis. A similar sampling and extraction protocol applies to ICP-MS analysis. ICP-MS is selected when exceptional sensitivity is required.

The detection principle of XRF is similar to that of EDX (USEPA, 1999a). For XRF analysis, PM is usually sampled on a ringed Teflon filter (e.g., Teflo ${ }^{\mathrm{TM}}$ from Pall Corp., Port Washington, NY). The filter is exceptionally thin and light and contains a very low impurity level. These features are critical for XRF analysis. However, XRF may be unsuitable for swine barn PM analysis, especially the quantification of light elements (Yang et al., 2011). Because of high PM concentrations in swine barns, the PM deposited on a filter surface can easily exceed $0.1 \mathrm{mg} \mathrm{cm}^{-2}$ filter area, causing significant attenuation of low-energy fluorescence X-rays emitted from light elements. The XRF analysis of PM samples also involves several other assumptions (e.g., PM size and composition) and restrictions. A detailed discussion about the issues can be found in Yang et al. (2011). Compared to ICP-AES, XRF is a non-destructive method. Thus, the samples after XRF analysis can be submitted for other physical and chemical tests (USEPA, 1999a).

\subsubsection{PM-borne odors}

The measurement of PM-borne odors typically consists of three steps: (1) sampling, (2) sample extraction or preparation, and (3) odor or odorant analysis. Since many PM-borne odorants in swine barns are volatile organic compounds (VOCs), the measurement protocols developed for indoor PM or ambient PM-borne VOCs were usually followed. However, a unique environment condition in swine barns (e.g., exceptionally high VOC concentrations in the gas phase) poses a challenge to odorant measurement. A discussion of the challenge and possible solutions is attempted in this section.

\section{Settled dust sampling}

Few technical details are available in the literature regarding the collection of settled dust. Hartung (1985) placed aluminum foil-covered sedimentation plates $2 \mathrm{~m}$ above the floor to collect settled dust. Oehrl et al. (2001) collected settled dust from exhaust fans and kept it in 10-mL glass vials. Das et al. (2004) used a vacuum sampler to collect dust into sample bags. Lee and Zhang (2008) scraped dust from exhaust fans, pen dividers, and pipelines using a stainless-steel knife and kept the samples in Petri dishes at $4^{\circ} \mathrm{C}$. The collected settled dust samples were directly submitted for sample extraction/preparation (Hartung, 1985; 
Oehrl et al., 2001; Lee and Zhang, 2008) or resuspended in the lab for PM sampling (Hammond et al., 1979) or size separation (Das et al., 2004) before moving to the next experimental step.

PM sampling

PM sampling setup has a large influence on the accuracy of odorants measurement. Relevant information, however, is limited in the literature. Regarding samplers, an ESP was used by Hammond et al. (1981) for TSP collection, in which particles were attracted onto a collecting electrode. All other studies used filter samplers; however, the specific setup differed among publications.

- Filters. Several studies used a single glass fiber filter for PM sampling (Day et al., 1965; Razote et al., 2004; Yang et al., 2014). Glass fiber filters are inexpensive and easy to clean (via baking). However, they are known to absorb significant amounts of VOCs from the air, thereby leading to an overestimate of PM-borne odorant concentrations (Andersen et al., 2014). The same sampling artifact also occurs to quartz fiber filters (Walgraeve et al. 2015). To address the issue, Yang et al. (2014) and Walgraeve et al. (2015) dislodged particles from filters for odorant analysis. However, it only works when PM loadings are high on filters. Another solution is to use dual glass or quartz fiber filters: a front filter and a backup filter. With a long enough sampling time, both filters would have been saturated by VOCs from the air. By subtracting an odorant's concentration on the backup filter from that on the front filter, the odorant concentration in collected PM can be calculated. Dual filters were attempted by Hammond et al. (1981) and later adopted by Razote et al. (2002) and Andersen et al. (2014) in their studies of swine barn PM-borne odors. According to Andersen et al. (2014), a backup filter should also be installed when sampling PM with a Tefloncoated filter. Teflon-coated filters absorb lesser but still significant amounts of odorants from the air. Cai et al. (2006) collected PM on Teflon filters.

- Denuders. A denuder is a non-obstructive scrubber that can remove certain VOCs from the air (depending on coatings). Only one study included denuders in its sampling setup (Andersen et al., 2014). However, the purpose was to capture VOCs in the air for odorant analysis. In a classic setup for PM-borne VOCs sampling, a denuder is installed before filter holders to pre-remove gaseous VOCs in the air. Dual filters may also be used; but in this case, the concentration of a PM-borne odorant would be equal to the sum of its concentration on the front filter and that on the backup filter (Wilson et al., 2002). The backup filter can be replaced by a sorption column to capture all the VOCs bypassing or released from the front filter.

- Filter samplers. Various filter samplers were used, including isokinetic TSP samplers (Yang et al., 2014), Harvard impactors (Yang et al., 2014), open cassettes (Razote et al., 2002, 2004), high volume $\mathrm{PM}_{10}$ sampler (Walgraeve et al., 2015), and tapered element oscillating microbalance (TEOM) (Cai et al., 2006). In theory, VOC sorption and desorption on a PM-laden filter or a denuder can be affected by linear velocity (which is equal to a sampling airflow rate divided by an effective filter area) (Forbes et al., 2012). Thus, the specifications of a PM sampler can also affect odorant sampling. However, no relevant information is available in the literature. Teflon filters in a TEOM are usually kept at $50^{\circ} \mathrm{C}$ to prevent condensation. This may cause the volatilization loss of volatile odorants (Cai et al., 2006).

Upon the analysis of the sampling protocols in the literature, we recommend the use of dual filters for high or middle-volume PM sampling (e.g., 16.7 LPM for $24 \mathrm{hrs)} \mathrm{and} \mathrm{the} \mathrm{use} \mathrm{of} \mathrm{a} \mathrm{denuder} \mathrm{plus} \mathrm{a} \mathrm{filter}$ plus a sorption column for low-volume PM sampling (e.g., 5 LPM for $2 \mathrm{hrs).} \mathrm{In} \mathrm{the} \mathrm{latter} \mathrm{setup,} \mathrm{glass} \mathrm{or}$ quartz fiber filters can be used because of their large VOCs adsorption capacity. An ESP sampler may also be selected for its exemption from filter-induced sampling artifacts. The PM samples collected should be immediately extracted (Razote et al., 2004) or stored in an ultra-low temperature freezer ($80^{\circ} \mathrm{C}$ ) to minimize volatilization loss (Yang et al., 2014).

Sampling extraction/preparation 
Various sampling extraction or preparation methods were used in the literature, including solvent extraction, headspace SPME, P\&T, and thermal desorption. Among them, solvent extraction was the most prevalent method. The solvents selected include a water-ether mixture (Hammond et al., 1979), diethyl ether (Hammond et al., 1981; Yang et al., 2014), ethanol (Hartung, 1985), methanol (Oehrl et al., 2001), dichloromethane (Razote et al., 2002, 2004), and acetone (Das et al., 2004). These solvents differ in their properties (e.g., polarity) and, thus, extract an odorant at different efficiencies. An extraction efficiency (EE) can further be affected by factors such as filter material, extraction temperature and time, and agitation strength. EE is especially important for quantitative analysis. To assess and address EE, dust samples or PM filters can be spiked with internal standards with known concentrations before extraction (Yang et al., 2014). The acquired extract was usually concentrated in a pure $\mathrm{N}_{2}$ stream (Hammond et al., 1981; Razote et al., 2002, 2004; Das et al., 2004; Yang et al., 2014) before odorant analysis. Solvent extraction is a classic method for the measurement of PM-borne VOCs. It offers accurate quantitative results when properly operated. However, solvent extraction is time-consuming and labor-intensive compared to methods such as headspace SPME and P\&T.

PM extracts can be further processed through adsorption, derivation, extraction, evaporation, etc. These post-solvent extraction steps were common in early studies but not seen in the publications since 1990 . Hammond et al. (1979) used a cold trap to condense PM extract vapors and then concentrated acquired liquids on a water bath. Hammond et al. (1981) carried out a series of wet chemistry experiments to further separate and purify acids, phenols, and carbonyls from PM extracts. Hartung (1985) alkalinized a PM extract and then acidified it to separate phenolic/indolic compounds from fatty acids.

Headspace SPME is a technology developed by Dr. Pawliszyn and his colleagues at the University of Waterloo, Canada in the early 1990s (Zhang and Pawliszyn, 1993). It features the use of coated silica fibers to sorb (absorb and/or adsorb) and enrich VOCs from the air in a headspace. The technology was initially designed for the measurement of VOCs in water samples but quickly found applications for other environmental samples, including PM (Vaz, 2003). For PM-borne VOCs measurement, a PM sample is placed in an enclosed vial and the VOCs released from the sample are sorbed onto a pre-conditioned SPME fiber or fibers. Headspace SPME was employed by three studies (Razote et al., 2002, 2004; Cai et al., 2006; Walgraeve et al., 2015) to extract odorants from swine barn PM; however, no quantitative analysis was conducted. The SPME filters tested include polydimethylsiloxane (PDMS), Carbowax/divinylbenzene, and Carboxen/PDMS. Headspace SPME can be used for quantitative VOC analysis; but in general, it is less prevalent than solvent extraction. When using SPME, the GC must be equipped with an SPME injector or injector liner.

Purge-and-trap (P\&T) is a popular technology to analyze VOCs in water and soil samples. It uses an inert gas stream to purge a liquid or solid sample and a cold or sorbent trap to capture (and enrich) the VOCs purged off the sample. At elevated temperatures, the captured VOCs are released from the trap and transferred to GC for analysis. Only one study used P\&T for swine barn PM samples (Razote et al., 2002, 2004) and it was limited to qualitative analysis.

Thermal deposition (TD) features the desorption of PM-borne odors (odorants) at increased temperatures. The method was adopted by two previous studies but in different fashions. Lee and Zhang (2008) built a temperature-controllable convective chamber, inside which a settled dust sample was purged with pure air and heated to $105^{\circ} \mathrm{C}$. The air effluent from the chamber was collected for $\mathrm{NH}_{3}$ and odor analysis.

Andersen et al. (2014) placed a PM filter in an empty steel tube and heated the tube to $100{ }^{\circ} \mathrm{C}, 200{ }^{\circ} \mathrm{C}$, and $290^{\circ} \mathrm{C}$ with a TD module. The module was part of a TD-GC-MS system. The gas desorbed from the PM filter was immediately analyzed by GC-MS. Quantitative results were available from both studies.

Odor/odorant analysis

Most of the previous studies used GC to analyze odorants, especially organic odorants in swine barn PM samples. In GC, a packed or capillary column separates multiple gas analytes based on their different affinities to the column packings or coatings and accordingly different mobilities in the column. Capillary 
columns were usually selected for their superior separation performance. Packed columns were only used in early studies (Hammond et al., 1979, 1981; Hartung, 1985). The capillary columns selected in the literature included weakly polar columns (DB-5 and alike) (Razote et al., 2002, 2004; Das et al., 2004; Walgraeve et al., 2015) and polar columns (DB-wax and alike) (Oehrl et al., 2001; Cai et al., 2006; Andersen et al., 2014; Yang et al., 2014). During capillary GC analysis, a column oven was programmed to raise its temperature from $40-80{ }^{\circ} \mathrm{C}$ to $150-260^{\circ} \mathrm{C}$ at a rate of $4-10^{\circ} \mathrm{C} \mathrm{min}-1$. The temperature of GC injectors was typically maintained at $250^{\circ} \mathrm{C}$. A variable injector temperature program $\left(-50\right.$ to $250^{\circ} \mathrm{C}$ at 12 ${ }^{\circ} \mathrm{C} \mathrm{min}^{-1}$ ) was adopted by Yang et al. (2014). For injection of PM extracts, both splitless (Yang et al., 2014) and split modes (Oehrl et al., 2001) were reported.

Two types of GC detectors were commonly selected for odorant analysis: FID (Hammond et al., 1979; Hartung et al., 1985; Wang et al., 1998; Oehrl et al., 2001) and mass selective detector (MSD or MS) (Hammond et al., 1979; Das et al., 2004; Razote et al., 2004; Cai et al., 2006; Anderson et al., 2014; Yang et al., 2014; Walgraeve et al., 2015). An FID uses a hydrogen flame to ionize organic molecules and detects induced currents. An MSD breaks down a molecule into ionized fragments and measures the mass-to-charge ratios of produced fragments - known as a mass spectrum. Because a mass spectrum is molecule specific, it enables the quick identification of an odorant. Comparatively, an FID relies on a comparison of retention time with standards for odorant identification. The temperatures of FID and MSD (Note: MSD transfer lines) were typically set at $280^{\circ} \mathrm{C}$ to avoid the condensation of semi-volatiles. A higher MSD transfer line temperature $\left(320^{\circ} \mathrm{C}\right)$ was adopted by Walgraeve et al. (2015). For both GC-FID and GC-MS, the quantification of odorants requires calibration standards. They can be external or internal standards. A unique calibration method known as stable isotope dilution was employed by Yang et al. (2014) which featured the spiking of PM filter samples with stable isotope internal standards. However, this method only works for GC-MS. Other GC systems include a GC with a sulfur chemiluminescence detector for $\mathrm{H}_{2} \mathrm{~S}$ detection and quantification (Das et al., 2004).

Selected ion flow tube mass spectrometry (SIFT-MS) was used for odorant analysis (Walgraeve et al., 2015). SIFT-MS is a real-time chemical ionization MS technology and can measure multiple gases simultaneously. Additional information about this technology can be found in Smith and Śpaněl (2005). It is noteworthy that Walgraeve et al. (2015) used SIFT-MS to study the sorption of four odorants on swine barn PM but still used GC-MS to detect odorants in actual PM samples.

A few studies analyzed $\mathrm{NH}_{3}$ and odor emission potency in swine barn PM (Louis and Licht, 1979; Donham et al., 1986; Lee and Zhang, 2008). However, only one study entailed analytical methods (Lee and Zhang, 2008). For odor, the gas sample from thermal desorption was transferred into a gas sampling bag and then shipped to an olfactometry lab for odor concentration measurement. In the lab, an olfactometer serially diluted the sample until odor panelists were unable to detect the odor in the diluted sample. The dilution ratio was taken as the odor threshold concentration. For $\mathrm{NH}_{3}$, the gas sample from thermal desorption was immediately transferred into a chemiluminescence $\mathrm{NH}_{3}$ analyzer. $\mathrm{NH}_{3} / \mathrm{NH}_{4}{ }^{+}$in swine barn PM can also be quantified by ion chromatography or colorimetry after being extracted in water (Yang et al., 2011).

In summary, various methods have been adopted to detect and quantify PM-borne odors or odorants in swine barns. For qualitative analysis, a three-step procedure is recommended: (1) ESP sampling, (2) headspace SPME, and (3) GC-MS analysis. A dual-filter setup is not recommended because a correction of sampling artifacts requires quantitative information. For quantitative analysis, the three steps are (1) ESP or dual-filter sampling, (2) solvent extraction, and (3) GC-MS analysis. We suggest spiking PM samples with internal standards before solvent extraction so that the recovery efficiency of an odorant during sample extraction and analysis can be accurately assessed and considered.

\section{Mitigation Technologies}

PM could exert adverse health effects on pigs and farm workers and compromise equipment and materials inside swine barns. Upon being emitted into the atmosphere, PM could spread odors, pathogens, and other 
hazardous substances to nearby livestock farms and communities. PM mitigation, thus, benefits both pig production and environmental stewardship.

According to their installation locations, PM mitigation technologies can be generalized into two categories: in-barn and end-of-pipe. In-barn mitigation occurs inside a swine barn, with the primary goal of reducing indoor PM concentrations. End-of-pipe mitigation occurs at the exhaust of a barn to reduce PM emissions into the atmosphere. Only in-barn mitigation technologies are reviewed (Table 23) since this report focuses on PM in swine barns. A review of end-of-pipe PM mitigation technologies, such as cyclones and wet scrubbers, can be found in Li (1997) and Tan and Zhang (2004).

Table 23. In-barn PM mitigation technologies tested in swine barns since 1990.

\begin{tabular}{|c|c|c|c|c|c|}
\hline Reference & Technology & $\begin{array}{l}\text { Reduction } \\
\text { effectiveness }\end{array}$ & $\begin{array}{l}\text { Barn \& } \\
\text { ventilation type }\end{array}$ & Location & Main findings \\
\hline \multicolumn{6}{|c|}{ Oil/water sprinkling } \\
\hline $\begin{array}{l}\text { Zhang et al. } \\
\text { (1994) }\end{array}$ & $\begin{array}{l}\text { Sprinkling a mineral } \\
\text { oil }\left(\sim 15 \mathrm{~mL} \text { oil } \mathrm{m}^{-2}\right. \\
\left.\text { day }^{-1}\right) \text { to barn floors }\end{array}$ & $\begin{array}{l}75 \% \text { for } \\
\text { respirable } \\
76 \% \text { for } \\
\text { inhalable }\end{array}$ & $\begin{array}{l}\text { Grower-finisher; } \\
\text { MV }\end{array}$ & $\begin{array}{l}\text { Saskatchewan, } \\
\text { Canada }\end{array}$ & $\begin{array}{l}\text { Right after oil } \\
\text { sprinkling, PM } \\
\text { concentrations } \\
\text { were close to } \\
\text { those in a nearby } \\
\text { office }\end{array}$ \\
\hline \multirow[t]{3}{*}{$\begin{array}{l}\text { Takai et al. } \\
\text { (1995) }\end{array}$} & \multirow{3}{*}{$\begin{array}{l}\text { Sprinkling a rapeseed } \\
\text { oil-water mixture }(5- \\
\left.10 \mathrm{~mL} \text { oil pig } \text { day }^{-1}\right)\end{array}$} & $\begin{array}{l}76 \% \text { for } \\
\text { respirable }\end{array}$ & Nursery; n/a & \multirow[t]{3}{*}{ Demark } & \multirow{3}{*}{$\begin{array}{l}\text { No improved pig } \\
\text { performance } \\
\text { was observed }\end{array}$} \\
\hline & & $\begin{array}{l}54 \% \text { for } \\
\text { respirable }\end{array}$ & Grower; n/a & & \\
\hline & & $\begin{array}{l}52 \% \text { for } \\
\text { respirable }\end{array}$ & Finisher; n/a & & \\
\hline $\begin{array}{l}\text { Perkins and } \\
\text { Feddes } \\
(1996)\end{array}$ & $\begin{array}{l}\text { Spraying } 24-60 \mathrm{~mL} \\
\mathrm{~m}^{-2} \text { to barn floors }\end{array}$ & $\begin{array}{l}\text { Up to } 73 \% \text { for } \\
\text { respirable }\end{array}$ & Farrowing; MV & $\begin{array}{l}\text { Alberta, } \\
\text { Canada }\end{array}$ & $\mathrm{n} / \mathrm{a}$ \\
\hline $\begin{array}{l}\text { Zhang et al. } \\
\text { (1996) }\end{array}$ & $\begin{array}{l}\text { Sprinkling canola oil } \\
\text { at various rates }\end{array}$ & $\begin{array}{l}37-89 \% \text { for } \\
\text { TSP }\end{array}$ & $\begin{array}{l}\text { Grower-finisher; } \\
\text { MV }\end{array}$ & $\begin{array}{l}\text { Saskatchewan, } \\
\text { Canada }\end{array}$ & $\begin{array}{l}\text { At the same total } \\
\text { volume of oil } \\
\text { applied, PM } \\
\text { reduction } \\
\text { increased with } \\
\text { oil sprinkling } \\
\text { frequency }\end{array}$ \\
\hline $\begin{array}{l}\text { Senthilselvan } \\
\text { et al. (1997) }\end{array}$ & 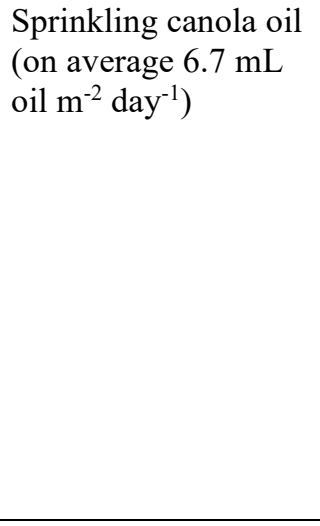 & $\sim 84 \%$ for TSP & $\begin{array}{l}\text { Grower-finisher; } \\
\text { MV }\end{array}$ & $\begin{array}{l}\text { Saskatchewan, } \\
\text { Canada }\end{array}$ & $\begin{array}{l}\text { Other benefits } \\
\text { included a } 94 \% \\
\text { reduction in } \\
\text { personal PM } \\
\text { exposure, a 92\% } \\
\text { reduction in } \\
\text { airborne } \\
\text { endotoxins, and } \\
\text { an } 89 \% \\
\text { reduction in } \\
\text { personal } \\
\text { endotoxin } \\
\text { exposure }\end{array}$ \\
\hline $\begin{array}{l}\text { Lemay et al. } \\
(2000)\end{array}$ & 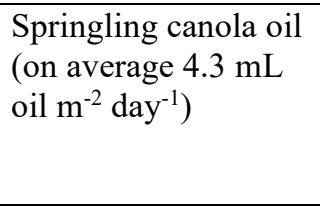 & $\begin{array}{l}87 \% \text { for TSP } \\
90 \% \text { for } \\
\text { inhalable } \\
86 \% \text { for } \\
\text { respirable }\end{array}$ & $\begin{array}{l}\text { Grower-finisher; } \\
\text { MV }\end{array}$ & $\begin{array}{l}\text { Saskatchewan, } \\
\text { Canada }\end{array}$ & $\begin{array}{l}\text { A specially } \\
\text { designed oil } \\
\text { sprinkling } \\
\text { system was } \\
\text { developed } \\
\end{array}$ \\
\hline
\end{tabular}




\begin{tabular}{|c|c|c|c|c|c|}
\hline $\begin{array}{l}\text { Takai and } \\
\text { Pedersen } \\
\text { (2000) }\end{array}$ & $\begin{array}{l}\text { Spraying a rapeseed } \\
\text { oil-water mixture } \\
\left(3.1-3.9 \mathrm{~g} \text { oil } \mathrm{m}^{-2} \text { day }\right. \\
\left.{ }^{1}\right) \text {, coupled with } \\
\text { adding } 4 \% \text { of fat to } \\
\text { the feed }\end{array}$ & $\begin{array}{l}80 \% \text { (35- } \\
95 \%) \text { for TSP }\end{array}$ & $\begin{array}{l}\text { Finisher; MV } \\
\text { (chimney) }\end{array}$ & Denmark & $\begin{array}{l}\text { Animal activity } \\
\text { controlled } \\
\text { spraying } \\
\text { reduced oil- } \\
\text { water usage }\end{array}$ \\
\hline $\begin{array}{l}\text { Godbout et } \\
\text { al. }(2001)\end{array}$ & Sprinkling canola oil & 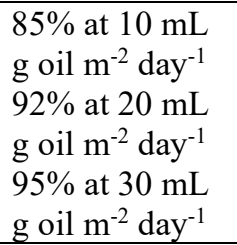 & $\begin{array}{l}\text { Finisher; lab } \\
\text { chambers }\end{array}$ & $\begin{array}{l}\text { Quebec, } \\
\text { Canada }\end{array}$ & $\mathrm{n} / \mathrm{a}$ \\
\hline $\begin{array}{l}\text { Paszek et al. } \\
(2001)\end{array}$ & $\begin{array}{l}\text { Sprinkling vegetable } \\
\text { oil (on average } 6.7 \\
\mathrm{~mL} \text { oil } \mathrm{m}^{-2} \text { day }^{-1} \text { ) }\end{array}$ & $\begin{array}{l}59 \% \text { for TSP } \\
65 \% \text { for } \\
\text { respirable } \\
79 \% \text { for } \\
\text { inhalable } \\
\end{array}$ & $\begin{array}{l}\text { Finisher; side- } \\
\text { curtain }\end{array}$ & Minnesota & $\begin{array}{l}\text { The operating } \\
\text { cost was } \$ 0.58 \\
\text { per pig }\end{array}$ \\
\hline $\begin{array}{l}\text { Wang et al. } \\
(2002)\end{array}$ & 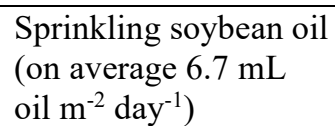 & $\begin{array}{l}70 \% \text { for all } \\
\text { sizes of } \\
\text { particles }\end{array}$ & Finisher; MV & Illinois & $\mathrm{n} / \mathrm{a}$ \\
\hline $\begin{array}{l}\text { Nonnenmann } \\
\text { et al. (2004) }\end{array}$ & $\begin{array}{l}\text { Spraying an oil-water } \\
\text { mixture }(7 \mathrm{~g} \text { soybean } \\
\text { oil pig } \text { day }^{-1} \text { or } 8 \mathrm{~g} \\
\left.\text { canola oil pig } \text { pay }^{-1}\right)\end{array}$ & $\begin{array}{l}\sim 52 \% \text { for } \\
\text { respirable }\end{array}$ & Finisher; $\mathrm{n} / \mathrm{a}$ & Iowa & $\begin{array}{l}\text { No difference } \\
\text { between } \\
\text { soybean and } \\
\text { canola oils }\end{array}$ \\
\hline $\begin{array}{l}\text { Rule et al. } \\
(2005)\end{array}$ & $\begin{array}{l}\text { Atomizing an acid- } \\
\text { oil-alcohol mixture } \\
\left(45 \mathrm{~mL} \text { oil } \mathrm{m}^{-2} \text { day }^{-1}\right)\end{array}$ & $\begin{array}{l}75-90 \% \text { for } \\
\text { TSP, } \mathrm{PM}_{10} \text {, and } \\
\mathrm{PM}_{2.5}\end{array}$ & $\begin{array}{l}\text { Finisher; MV } \\
\text { (tunnel) }\end{array}$ & $\begin{array}{l}\text { Mid-Atlantic } \\
\text { region, USA }\end{array}$ & $\begin{array}{l}>90 \% \text { reduction } \\
\text { in the levels of } \\
\text { total viable } \\
\text { bacteria, Gram- } \\
\text { negative bacilli, } \\
\text { and } \\
\text { Enterococcus } \\
\text { spp. was also } \\
\text { achieved }\end{array}$ \\
\hline $\begin{array}{l}\text { Heber et al. } \\
(2006)\end{array}$ & Sprinkling soybean oil & $67 \%$ for TSP & Finisher; MV & US Midwest & $\mathrm{n} / \mathrm{a}$ \\
\hline $\begin{array}{l}\text { Kim et al. } \\
(2006)\end{array}$ & $\begin{array}{l}\text { Spraying seven } \\
\text { different liquids }\end{array}$ & $\begin{array}{l}\sim 70 \% \text { for TSP } \\
\text { when spraying } \\
\text { soybean oil }\end{array}$ & Grower; MV & Korea & $\begin{array}{l}\text { Except for } \\
\text { soybean oil, dust } \\
\text { reduction by } \\
\text { other liquids } \\
\text { diminished after } \\
3 \text { hours }\end{array}$ \\
\hline $\begin{array}{l}\text { Ouellette et } \\
\text { al. (2006) }\end{array}$ & $\begin{array}{l}\text { Sprinkling canola, } \\
\text { soybean, or sunflower } \\
\text { oil }\left(10 \mathrm{~mL} \text { oil } \mathrm{m}^{-2} \text { day }\right. \\
\left.{ }^{1}\right)\end{array}$ & $\begin{array}{l}68-72 \% \text { for } \\
\text { TSP }\end{array}$ & $\begin{array}{l}\text { Finisher; lab } \\
\text { chambers }\end{array}$ & $\begin{array}{l}\text { Quebec, } \\
\text { Canada }\end{array}$ & $\mathrm{n} / \mathrm{a}$ \\
\hline \multirow[t]{2}{*}{$\begin{array}{l}\text { Banhazi } \\
(2007)\end{array}$} & \multirow[t]{2}{*}{$\begin{array}{l}\text { Sprinkling a canola } \\
\text { oil-water mixture ( } 3 \mathrm{~g} \\
\text { oil pig-1 day-1) }\end{array}$} & $\begin{array}{l}28 \% \text { for } \\
\text { respirable } \\
43 \% \text { for } \\
\text { inhalable } \\
42 \% \text { for total } \\
\text { culturable } \\
\text { bacteria }\end{array}$ & Nursery; n/a & \multirow[t]{2}{*}{ Australia } & $\mathrm{n} / \mathrm{a}$ \\
\hline & & $\begin{array}{l}17 \% \text { for } \\
\text { respirable }\end{array}$ & Grower; n/a & & $\begin{array}{l}\text { Total viable } \\
\text { bacterial levels }\end{array}$ \\
\hline
\end{tabular}




\begin{tabular}{|c|c|c|c|c|c|}
\hline & & $\begin{array}{l}46 \% \text { for } \\
\text { inhalable }\end{array}$ & & & $\begin{array}{l}\text { increased after } \\
\text { treatment }\end{array}$ \\
\hline $\begin{array}{l}\text { Jin and } \\
\text { Predicala } \\
\text { (2011) }\end{array}$ & 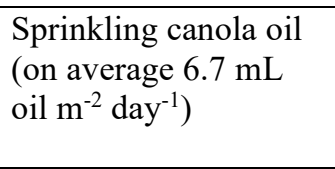 & $\begin{array}{l}\sim 57 \% \text { for } \\
\text { respirable }\end{array}$ & $\begin{array}{l}\text { Grower-finisher; } \\
\text { MV }\end{array}$ & $\begin{array}{l}\text { Saskatchewan, } \\
\text { Canada }\end{array}$ & $\begin{array}{l}\sim 32 \% \text { reduction } \\
\text { in personal } \\
\text { exposure to } \\
\text { respirable PM }\end{array}$ \\
\hline $\begin{array}{l}\text { Siggers et al. } \\
\text { (2011) }\end{array}$ & 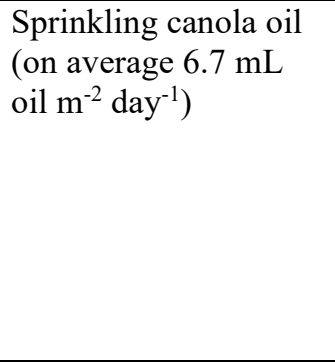 & $\begin{array}{l}86 \% \text { for TSP } \\
82.5 \% \text { for } \\
\text { endotoxins } \\
32 \% \text { for total } \\
\text { culturable } \\
\text { bacteria } \\
52 \% \text { for total } \\
\text { culturable } \\
\text { fungi }\end{array}$ & $\begin{array}{l}\text { Grower-finisher; } \\
\text { MV }\end{array}$ & $\begin{array}{l}\text { Saskatchewan, } \\
\text { Canada }\end{array}$ & $\begin{array}{l}\text { The reduction } \\
\text { was greater for } \\
\text { larger than } \\
\text { smaller particles }\end{array}$ \\
\hline \multirow[t]{2}{*}{$\begin{array}{l}\text { Banhazi } \\
\text { (2013) }\end{array}$} & \multirow[t]{2}{*}{ 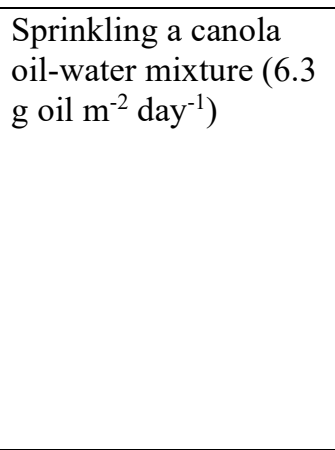 } & $\begin{array}{l}35 \% \text { for } \\
\text { respirable } \\
51 \% \text { for } \\
\text { inhalable } \\
55 \% \text { for total } \\
\text { culturable } \\
\text { bacteria }\end{array}$ & Nursery; MV & \multirow[t]{2}{*}{ Australia } & $\mathrm{n} / \mathrm{a}$ \\
\hline & & $\begin{array}{l}13 \% \text { for } \\
\text { respirable } \\
53 \% \text { for } \\
\text { inhalable }\end{array}$ & Grower; NV & & $\begin{array}{l}\text { Total viable } \\
\text { bacterial levels } \\
\text { increased after } \\
\text { treatment }\end{array}$ \\
\hline $\begin{array}{l}\text { Mostafa et } \\
\text { al. (2017) }\end{array}$ & $\begin{array}{l}\text { Sprinkling an oil- } \\
\text { water mixture }(3-6 \\
\left.\mathrm{mL} \text { oil } \text { pig }^{-1} \text { day }^{-1}\right)\end{array}$ & $\begin{array}{l}29-83 \% \text { for } \\
\text { TSP } \\
20-80 \% \text { for } \\
\mathrm{PM}_{10}\end{array}$ & Finisher; MV & Germany & $\begin{array}{l}\text { The sprinkling } \\
\text { system with } \\
\text { smaller nozzles } \\
\text { delivered better } \\
\text { reduction than } \\
\text { that with larger } \\
\text { nozzles }\end{array}$ \\
\hline \multicolumn{6}{|c|}{ Ionization } \\
\hline $\begin{array}{l}\text { Tanaka and } \\
\text { Zhang } \\
\text { (1996) }\end{array}$ & $\begin{array}{l}\text { Commercial negative } \\
\text { ionization systems }(- \\
9,300 \text { and }-16,500 \mathrm{~V})\end{array}$ & $\begin{array}{l}\text { Up to } 46 \% \text { at } \\
\text { low ventilation } \\
\text { rates } \\
\text { As low as } 3 \% \\
\text { at high } \\
\text { ventilation } \\
\text { rates }\end{array}$ & $\begin{array}{l}\text { Grower-finisher; } \\
\text { MV }\end{array}$ & $\begin{array}{l}\text { Saskatchewan, } \\
\text { Canada }\end{array}$ & $\begin{array}{l}\text { Reduction } \\
\text { efficiency } \\
\text { decreased with } \\
\text { PM } \\
\text { accumulation of } \\
\text { on electrode } \\
\text { surface led to } \\
\text { decreased }\end{array}$ \\
\hline \multirow[t]{2}{*}{$\begin{array}{l}\text { Rosentrater } \\
(2003)\end{array}$} & \multirow{2}{*}{$\begin{array}{l}\text { Self-customized } \\
\text { electrostatic } \\
\text { precipitators made } \\
\text { from charging wires } \\
\text { and collection pipes (- } \\
24 \mathrm{kV} \text { ) }\end{array}$} & $\begin{array}{l}36 \% \text { for } \\
\text { respirable } \\
58 \% \text { for TSP }\end{array}$ & Nursery; MV & Iowa & \multirow{2}{*}{$\begin{array}{l}\text { Better removal } \\
\text { performance } \\
\text { was observed for } \\
\text { larger particles }\end{array}$} \\
\hline & & $\begin{array}{l}50 \% \text { for } \\
\text { respirable } \\
45 \% \text { for TSP }\end{array}$ & Farrowing; MV & Iowa & \\
\hline $\begin{array}{l}\text { Hofer and } \\
\text { Nicolai } \\
\text { (2007) }\end{array}$ & $\begin{array}{l}\text { Electrostatic space } \\
\text { discharge systems } \\
\text { (ESDS) }\end{array}$ & $\begin{array}{l}40-46 \% \text { for } \\
\mathrm{PM}_{2.5} \\
32-58 \% \text { for } \\
\mathrm{PM}_{10} \\
45-83 \% \text { for } \\
\text { TSP }\end{array}$ & Finisher; MV & $\begin{array}{l}\text { n/a, likely } \\
\text { U.S. Midwest }\end{array}$ & $\mathrm{n} / \mathrm{a}$ \\
\hline
\end{tabular}




\begin{tabular}{|c|c|c|c|c|c|}
\hline $\begin{array}{l}\text { Cho et al. } \\
(2012)\end{array}$ & $\begin{array}{l}\text { Air cleaners (plasma- } \\
\text { based ionization) }\end{array}$ & $\begin{array}{l}78 \% \text { for } \mathrm{PM}_{1} \\
79 \% \text { for } \mathrm{PM}_{2.5} \\
22 \% \text { for total } \\
\text { culturable } \\
25 \% \text { for total } \\
\text { culturable } \\
\text { fungi }\end{array}$ & $\begin{array}{l}\text { n/a; MV (cross- } \\
\text { flow) }\end{array}$ & Korea & $\begin{array}{l}\text { No reduction in } \\
\mathrm{PM}_{10} \text { or TSP } \\
\text { was seen }\end{array}$ \\
\hline $\begin{array}{l}\text { Rademacher } \\
\text { et al. (2012) }\end{array}$ & $\begin{array}{l}\text { Commercial } \\
\text { electrostatic particle } \\
\text { ionization }(\mathrm{EPI}) \\
\text { systems }(-30 \mathrm{kV})\end{array}$ & $\begin{array}{l}47 \% \text { for } \mathrm{PM}_{2.5} \\
58 \% \text { for } \mathrm{PM}_{10}\end{array}$ & Nursery; n/a & $\begin{array}{l}\text { n/a, likely } \\
\text { U.S. Midwest }\end{array}$ & $\mathrm{n} / \mathrm{a}$ \\
\hline \multirow[t]{2}{*}{$\begin{array}{l}\text { Winkel et al. } \\
\text { (2014) }\end{array}$} & $\begin{array}{l}\text { Commercial negative } \\
\text { corona ionization } \\
(\mathrm{NCI}) \text { systems }(-30 \\
\mathrm{kV})\end{array}$ & $36 \%$ for $\mathrm{PM}_{10}$ & \multirow[t]{2}{*}{ Finisher; MV } & \multirow[t]{2}{*}{$\begin{array}{l}\text { The } \\
\text { Netherlands }\end{array}$} & \multirow[t]{2}{*}{$\mathrm{n} / \mathrm{a}$} \\
\hline & $\begin{array}{l}\text { Commercial } \\
\text { electrostatic filtration } \\
\text { unit (EFU) systems }\end{array}$ & $28 \%$ for $\mathrm{PM}_{10}$ & & & \\
\hline $\begin{array}{l}\text { De Jong et } \\
\text { al. (2014) }\end{array}$ & $\begin{array}{l}\text { Commercial EPI } \\
\text { systems }(-30 \mathrm{kV})\end{array}$ & $\begin{array}{l}\text { By particle } \\
\text { counts: } \\
46 \% \text { for } \mathrm{PM}_{10} \\
44 \% \text { for } \mathrm{PM}_{2.5}\end{array}$ & Nursery; n/a & Kansas & $\mathrm{n} / \mathrm{a}$ \\
\hline $\begin{array}{l}\text { Alonso et al. } \\
(2016)\end{array}$ & $\begin{array}{l}\text { Commercial EPI } \\
\text { systems }(-30 \mathrm{kV})\end{array}$ & $\begin{array}{l}76-82 \% \text { for } \\
\mathrm{PM} \geq 1 \mu \mathrm{m} \\
52-56 \% \text { for } \\
\mathrm{PM}<1 \mu \mathrm{m}\end{array}$ & $\begin{array}{l}\text { Nursery; } \\
\text { environment- } \\
\text { controlled } \\
\text { chambers } \\
\end{array}$ & Minnesota & $\begin{array}{l}\text { Reduction in } \\
\text { viable PRRSV } \\
\text { and IAV was } \\
\text { observed }\end{array}$ \\
\hline $\begin{array}{l}\text { La et al. } \\
(2019)\end{array}$ & $\begin{array}{l}\text { Commercial EPI } \\
\text { systems }(-30 \mathrm{kV})\end{array}$ & $\begin{array}{l}>94 \% \text { for } \mathrm{PM} \\
\geq 0.6 \mu \mathrm{m} \\
100 \% \text { for } \mathrm{PM} \geq \\
6 \mu \mathrm{m} \\
68-96 \% \text { for } \\
\text { PPRSV }\end{array}$ & $\begin{array}{l}\text { No pigs; test } \\
\text { chambers }\end{array}$ & $\begin{array}{l}\text { Manitoba, } \\
\text { Canada }\end{array}$ & $\begin{array}{l}\text { PM reduction } \\
\text { performance } \\
\text { decreased with } \\
\text { an increased } \\
\text { ventilation rate }\end{array}$ \\
\hline \multicolumn{6}{|c|}{ Alternation of feed and feeders } \\
\hline $\begin{array}{l}\text { Welford et } \\
\text { al. (1992) }\end{array}$ & $\begin{array}{l}\text { Adding } 2 \% \text { canola oil } \\
\text { to feed }\end{array}$ & $\begin{array}{l}32 \% \text { for } \\
\text { inhalable }\end{array}$ & $\begin{array}{l}\text { Grower-finisher; } \\
\text { MV }\end{array}$ & $\begin{array}{l}\text { Saskatchewan, } \\
\text { Canada }\end{array}$ & $\begin{array}{l}\text { Increases in } \\
\text { respirable } \\
\text { particle count } \\
\text { and bacterial } \\
\text { count were } \\
\text { observed } \\
\end{array}$ \\
\hline \multirow[t]{3}{*}{$\begin{array}{l}\text { Li et al. } \\
\text { (1993) }\end{array}$} & $\begin{array}{l}\text { Pelletizing feed into } \\
\text { 3-mm pellets }\end{array}$ & $\begin{array}{l}40 \% \text { for } \\
\text { respirable }\end{array}$ & \multirow[t]{3}{*}{$\mathrm{n} / \mathrm{a}$; lab chamber } & \multirow[t]{3}{*}{$\begin{array}{l}\text { United } \\
\text { Kingdom }\end{array}$} & \multirow[t]{3}{*}{$\mathrm{n} / \mathrm{a}$} \\
\hline & $\begin{array}{l}\text { Coating feed pellets } \\
\text { with } 2 \% \text { lignin }\end{array}$ & $\begin{array}{l}33 \% \text { for } \\
\text { respirable }\end{array}$ & & & \\
\hline & $\begin{array}{l}\text { Coating feed pellets } \\
\text { with } 2 \% \text { fat }\end{array}$ & $\begin{array}{l}25 \% \text { for } \\
\text { respirable }\end{array}$ & & & \\
\hline \multirow[t]{2}{*}{$\begin{array}{l}\text { Takai et al. } \\
\text { (1996) }\end{array}$} & \multirow[t]{2}{*}{$\begin{array}{l}\text { Adding } 4 \% \text { animal fat } \\
\text { to feed }\end{array}$} & $\begin{array}{l}37 \% \text { for TSP } \\
57 \% \text { for } \\
\text { respirable } \\
\end{array}$ & $\begin{array}{l}\text { Nursery; MV } \\
\text { (chimney) }\end{array}$ & \multirow[t]{2}{*}{ Demark } & $\begin{array}{l}\text { A } 47 \% \text { reduction } \\
\text { in TSP exposure } \\
\text { was observed }\end{array}$ \\
\hline & & $\begin{array}{l}42 \% \text { for TSP } \\
39 \% \text { for } \\
\text { respirable }\end{array}$ & $\begin{array}{l}\text { Finisher; MV } \\
\text { (chimney) }\end{array}$ & & $\begin{array}{l}\text { A } 67 \% \text { reduction } \\
\text { in TSP exposure } \\
\text { was observed }\end{array}$ \\
\hline $\begin{array}{l}\text { Thaler et al. } \\
\text { (1999) }\end{array}$ & $\begin{array}{l}\text { Adding } 3 \% \text { corn oil to } \\
\text { feed }\end{array}$ & $40 \%$ for TSP & $\begin{array}{l}\text { Grower-finisher; } \\
\text { MV }\end{array}$ & South Dakota & $\mathrm{n} / \mathrm{a}$ \\
\hline
\end{tabular}




\begin{tabular}{|c|c|c|c|c|c|}
\hline $\begin{array}{l}\text { Jin and } \\
\text { Predicala } \\
(2011)\end{array}$ & $\begin{array}{l}\text { Reducing crude } \\
\text { proteins in feed diet } \\
\text { (19.5\% down to } 15 \% \\
\text { during growing; } \\
18.2 \% \text { down to } 12 \% \\
\text { during finishing) }\end{array}$ & $\begin{array}{l}\sim 23 \% \text { for } \\
\text { respirable }\end{array}$ & $\begin{array}{l}\text { Grower-finisher; } \\
\text { MV }\end{array}$ & $\begin{array}{l}\text { Saskatchewan, } \\
\text { Canada }\end{array}$ & $\mathrm{n} / \mathrm{a}$ \\
\hline \multicolumn{6}{|c|}{ Recirculating air filtration } \\
\hline $\begin{array}{l}\text { Carpenter } \\
\text { and Fryer } \\
(1990)\end{array}$ & Recirculating air filter & $\begin{array}{l}50-60 \% \text { for } \\
\text { TSP and total } \\
\text { culturable } \\
\text { bacteria }\end{array}$ & Nursery; MV & $\begin{array}{l}\text { United } \\
\text { Kingdom }\end{array}$ & $\begin{array}{l}\text { Sedimentation } \\
\text { was even more } \\
\text { impactful on } \\
\text { dust removal }\end{array}$ \\
\hline \multirow[t]{2}{*}{$\begin{array}{l}\text { Lau et al. } \\
(1996)\end{array}$} & $\begin{array}{l}\text { Recirculating air with } \\
\text { 3-stage fabric filters }\end{array}$ & $\begin{array}{l}18-64 \% \text { for } \\
\text { inhalable } \\
10-50 \% \text { for } \\
\text { total culturable } \\
\text { bacteria }\end{array}$ & Grower; MV & \multirow[t]{2}{*}{$\begin{array}{l}\text { British } \\
\text { Columbia, } \\
\text { Canada }\end{array}$} & \multirow{2}{*}{$\begin{array}{l}\text { Electrostatic } \\
\text { filters had higher } \\
\text { dust removal } \\
\text { efficiency only } \\
\text { in spring and } \\
\text { winter }\end{array}$} \\
\hline & $\begin{array}{l}\text { Recirculating air with } \\
\text { electrostatic } \\
\text { precipitators }\end{array}$ & $\begin{array}{l}20-66 \% \text { for } \\
\text { inhalable } \\
20-52 \% \text { for } \\
\text { total culturable } \\
\text { bacteria }\end{array}$ & Finisher; MV & & \\
\hline $\begin{array}{l}\text { Anthony et } \\
\text { al. (2015) }\end{array}$ & $\begin{array}{l}\text { Recirculating air with } \\
\text { Shaker dust collectors }\end{array}$ & $\begin{array}{l}33 \% \text { for } \\
\text { inhalable } \\
41 \% \text { for } \\
\text { respirable }\end{array}$ & Farrowing; MV & Iowa & $\begin{array}{l}\text { The system had } \\
\text { no significant } \\
\text { effects on } \mathrm{NH}_{3} \\
\text { or } \mathrm{CO}_{2}\end{array}$ \\
\hline $\begin{array}{l}\text { Mostafa et } \\
\text { al. }(2017)\end{array}$ & $\begin{array}{l}\text { Recirculating air with } \\
\text { wet scrubbers (using } \\
\text { water or acid) for dust } \\
\& \text { gas removal }\end{array}$ & $\begin{array}{l}52-72 \% \text { for } \\
\text { TSP } \\
52-67 \% \text { for } \\
\mathrm{PM}_{10}\end{array}$ & Finisher; MV & Germany & $\begin{array}{l}\text { Reduction } \\
\text { efficiency was } \\
\text { greater for larger } \\
\text { particles than } \\
\text { smaller particles }\end{array}$ \\
\hline $\begin{array}{l}\text { Wenke et al. } \\
(2018)\end{array}$ & $\begin{array}{l}\text { Recirculating air filter } \\
\text { (MERV 5-6 pocket } \\
\text { filter) })^{2}\end{array}$ & $\begin{array}{l}8 \% \text { for TSP } \\
\text { compared to a } \\
\text { barn w/o filter }\end{array}$ & Finisher; MV & Germany & $\begin{array}{l}\text { Airborne } \\
\text { culturable } \\
\text { bacteria were } \\
\text { also reduced }\end{array}$ \\
\hline $\begin{array}{l}\text { Eisenlöffe et } \\
\text { al. (2019) }\end{array}$ & $\begin{array}{l}\text { Recirculating air filter } \\
\text { (ISO } 50 \% \text { coarse) }^{3} \\
\text { with UVC light }\end{array}$ & $\begin{array}{l}78 \% \text { for TSP } \\
\text { compared to a } \\
\text { barn w/o filter } \\
37 \% \text { for total } \\
\text { culturable } \\
\text { bacteria } \\
\end{array}$ & Nursery; MV & Germany & $\mathrm{n} / \mathrm{a}$ \\
\hline
\end{tabular}

Note:

${ }^{1}$ The reduction effectiveness in bioaerosol is also summarized. It is noteworthy that bioaerosol reduction results from (1) physical removal of dust and (2) inactivation of biological agents. Although a mitigation technology could act on both, these two factors were not assessed separately in most previous studies.

${ }^{2} \mathrm{MERV}$ - Minimum efficiency reporting value

${ }^{3}$ ISO - International Organization for Standardization

Ventilation is not covered in this review. Ventilation can be considered as an in-barn PM mitigation technology (Tan and Zhang, 2004). A higher ventilation rate brings in more fresh air, resulting in a usually lower indoor PM concentration. Ventilation system design and operation, thus, can impact PM concentrations and emissions. However, the primary function of a swine barn's ventilation system is to ensure an appropriate thermal environment for pigs. In most barns, ventilation rates are regulated based on indoor temperatures only. Furthermore, the effect of ventilation rates on indoor PM concentrations has yet to be fully understood. Although an increased ventilation rate promotes dilution, the elevated air 
velocity it creates could enhance the suspension and re-suspension of dust particles (Yang et al., 2015). Ventilation also affects indoor PM concentrations via its regulation of humidity. High air humidity levels could suppress PM suspension inside animal barns (Pearson and Sharples, 1995).

It is also noteworthy that the PM reduction effectiveness derived from stationary samplers (i.e., samplers installed at a fixed location) was usually different than that of personal (exposure) samplers (Table 23). As mentioned in Section 4.1, personal samplers are carried by caretakers or other staff to assess their PM exposure during a work shift or shifts. Due to large spatial and temporal variability in PM generation inside swine barns, personal and stationary samplers usually read different concentrations.

\subsection{Oil/water sprinkling}

To our knowledge, the first attempt at sprinkling oil/water for swine barn PM control was reported by Dr. Hisamitsu Takai at Aarhus University in Denmark (Takai, 1987). It quickly attracted great interest from academia, especially in the 1990s and 2000s. To date, oil/water sprinkling has been the most studied inbarn PM mitigation method for swine and poultry barns. Oil/water sprinkling for dust control is not a new idea and it has been extensively used to reduce the emissions of fugitive dust such as road dust and mine tailings dust. The working principle of the method is straightforward. Liquid droplets sprayed in the room air can wash out airborne particles - a process similar to the wet deposition of atmospheric PM. When the liquid reaches the floors or other room surfaces, it bonds small particles together, thereby reducing the suspension and resuspension of particles (Guo et al., 2011).

Pure water was usually not used (Takai and Pedersen, 2000; Kim et al., 2006). No specific explanation was given in the literature but it is likely for several reasons. First, water has a higher vapor pressure so it evaporates out faster than oils. Thus, the dust suppression effect of water sprinkling does not persist long. Secondly, the viscosity of water is around 2-fold lower than those of plant oils (Diamante and Lan, 2014), meaning that water applied on the floor or other room surfaces is more prone to aerosolization (i.e., becoming particles) than oils. Thirdly, a very high moisture environment in swine barns, resulting from frequent water applications, could facilitate the growth and reproduction of microorganisms, causing animal health and odor concerns (Xie et al., 2017). Fourthly, some organic particles are hydrophobic, with poor wettability in pure water. Wettability is a key parameter affecting the bonding (coagulation) of particles and accordingly particle suspension (Copeland and Kawatra, 2005). Because of the aforementioned reasons, oils or oil-water mixtures were commonly used.

All but one study selected plant oils (e.g., canola and soybean oils) possibly because of the oils' biological benignness and availability to pork producers. When blended with water, the percentage of oils varied greatly among studies, ranging from 5\% (Nonmenmann et al., 2003) to 40\% (Banhazi 2007; 2013). Surfactants (e.g., Tween 80 and Span 80) were often added to the oil-water mixture to promote emulsions and accordingly the formation of a stable, uniform mixture of water and oils (Takai, 1987; Paszek et al., 2001; Nonmenmann et al., 2003; Banhazi, 2007; 2013). However, the high material cost of surfactants could impede their use in commercial barns.

The sprinkling rate was typically measured as the mass or volume of oils applied per pig (or per $\mathrm{m}^{2}$ of

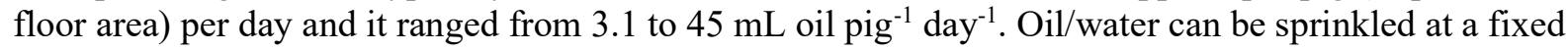
rate or variable rates. Zhang et al. (1996) compared 6 oil sprinkling treatments in grower-finisher barns and recommended a variable-rate treatment upon considering a trade-off between effectiveness and economics: $40 \mathrm{~mL}$ oil m $\mathrm{m}^{-2}$ day $^{-1}$ in the first two days, $20 \mathrm{~mL}_{\text {oil m}}^{-2}$ day $^{-1}$ in the next two days, and $5 \mathrm{~mL}$ oil $\mathrm{m}^{-2}$ day $^{-1}$ in the remain days (an average sprinkling rate of $6.7 \mathrm{~mL}$ oil m $\mathrm{m}^{-2} \mathrm{day}^{-1}$ ). This treatment plan was adopted by many later studies (Senthilselvan et al., 1997; Paszek et al., 2001; Jin and Predicala, 2011; Seggers et al., 2011; Banhazi, 2013). A larger sprinkling rate and a higher application frequency were found to improve dust control efficiency. However, a daily oil application rate (dosage) approaching or exceeding $20 \mathrm{~mL} \mathrm{~m}^{-2}$ would result in slippery walkways (Zhang et al., 1996). A feasible way to reduce the oil application dosage while keeping dust control effective is sprinkling oil/water when pigs are 
active. This could be achieved by wiring a sprinkling system controller to animal activity sensors (Takai and Pedersen, 2000).

Oil/water can be sprinkled with low-pressure sprayers (Zhang et al., 1994; 1996; Perkins and Feddes, 1996) or high-pressure pipe systems (Takai et al., 1995; Takai and Pederson, 2000; Nonmenmann et al., 2003; Banhazi, 2007; Jin and Predicala, 2011). The former method is affordable, installation-free, and easy to implement. However, the application height was typically $<1 \mathrm{~m}$ to the floor, limiting the floor area radius that each spray could cover. Because of their low operating pressures, the low-pressure sprayers were less capable of generating small, uniformly-sized droplets than high-pressure pipe systems. Several customized high-pressure pipe systems were tested in previous oil/water sprinkling studies (Takai et al., 1995; Lemay et al., 2000; Paszek et al., 2001; Nonmenmann et al., 2003). These systems each included an oil reservoir, a high-pressure pump, pipes, and nozzles. The nozzles were typically installed near the ceiling of a swine barn (at a height of 2.0-3.5 m above the floor) to maximize the coverage area of each nozzle. Only a few studies provided specific design information. Among the limited reports, the operating pressure of these high-pressure systems ranged from $241 \mathrm{kPa}$ (Nonmenmann et al., 2003) to $5 \mathrm{MPa}$ (Taikai, et al. 2000), and the median/mean diameter of droplets was 110-600 $\mu \mathrm{m}$ (Takai et al., 1995; Takai and Pederson, 2000). However, with no design and operation details available, it is impossible to conduct a systematic comparison of those sprinkling systems.

Oil/water sprinkling was also tested without pigs in lab chambers for suppression of PM generation from feeds, a primary source of PM in swine barns (Heber and Martin, 1991; Mankell, et al., 1995; Guarino et al., 2007). These studies, however, are excluded in this review as it is difficult to directly translate their findings to real-world swine barn PM control efforts.

\subsection{Ionization}

Ionization aims to charge airborne particles inside a swine barn. Because of electrostatic forces, charged particles are attracted to the barn's room surfaces or specialized collectors. Charged particles also tend to clump together, thereby precipitating out faster than uncharged particles. The use of ionization in animal barns can date back to the 1960s (Brown and Stone, 1965; Dobie et al., 1966). These early studies focused on the possible influence of air ions on animal production performance. To our knowledge, the first attempt at using ionization for PM control in swine barns was reported by Dr. Dwaine Bundy at Iowa State University (Bundy, 1974). Since then, a variety of ionization techniques have been tested inside swine barns to reduce indoor PM concentrations (Table 23) or at the barns' air exhaust to mitigate PM emissions (which is beyond the scope of this review).

Technically, ionization-based PM control is based on the same principle as electrostatic precipitation (ESP). The latter has been used to control PM emissions from industrial sources (e.g., coal-fired power plants) for over a century. In reality, some researchers used the terms ionization and ESP interchangeably (Veenhuizen, 1989). However, it is noteworthy that although a few studies used industrial ESP designs (Fournier, 1992; George and Feddes, 1995a), most ionization systems tested in swine barns employed a simpler design than commercial ESP systems.

In an ionization system, a high DC voltage is applied across two electrodes: a charging electrode and a collection electrode. The charging electrode can be a wire, a barbed wire, a metal bar with teeth (or other types of tapered sections), etc., sharing a common feature of a small surface area and a large curvature. The purpose of this feature is to create an electric field near the electrode surface which is strong enough to ionize air molecules and/or particles. The collection electrode can be a plate, a tube, a cup, etc., with an extended surface area for particle collection. The charging and collection electrodes are often placed in parallel with small spacing in between. Particle removal by an ionization system is a four-step process: air ionization, charging, migration, and collection.

- Air ionization. The extremely strong electric field adjacent to the charging electrode surface dissociates air molecules into electrons and positive ions. Based on the polarity of the charging 
electrode, there are two types of ionization systems: positive and negative. In a positive system (Note: It is also called a positive corona system; a corona is formed due to the recombination of positive ions and electrons), the positive charging electrode attracts and scavenges electrons while repelling positive ions to space. The positive ions gain additional energy when migrating in the electric field. When the gained energy exceeds a certain level, the collision of the positive ions with other air molecules would create more positive ions. In a negative system (also known as a negative corona system), a similar process occurs but the cascade ionization process is primarily caused by electrons in the space. Most previous ionization systems in swine barns were negative systems (Table 23), likely because of their better voltage/current characteristics than positive systems (Cooper and Alley, 2010). However, positive systems produce less ozone than negative systems and, thus, could be a better option from the animal health perspective.

- Charging. Particles gain electric charges when collided by randomly moving electrons or positive ions in the space - a mechanism termed diffusion charging or diffusional charging. Particles can also become charged via field charging in which the collision is driven by the electromigration of electrons or ions in the electric field. The charging process can occur repeatedly until the charges on a particle become saturated. Particles would eventually carry positive charges in a positive ionization system and negative charges in a negative system.

- Migration. The electric field drives charged particles to migrate towards an electrode with the opposite polarity. In both positive and negative ionization systems, particles migrate towards the collection electrode. The final migration velocity of a charged particle, which is often referred to as a drift velocity, is determined by a balance between the electrostatic force and the air friction exerted on the particle. The drift velocity (similar to the terminal settling velocity for gravitational settling) is a key design parameter for ionization systems (Cooper and Alley, 2010).

- Collection. Once a particle reaches a collection electrode, it transfers part of the charges it carries to the electrode. The remaining charges make the particle attach to the electrode surface because of an electrostatic force. Particles accumulated on the surface of collection electrodes can be mechanically removed after a certain period.

Most previous swine barn PM studies used commercial ionization systems, with no design specifications available. Thus, it is difficult to make a comprehensive comparison of different systems. In general, these ionization systems use only a single section of paired electrodes (Note: Commercial ESP systems have multiple sections in the direction of airflow to achieve an exceptionally high PM removal efficiency), with larger spacing between electrodes than that in commercial ESP systems. As a result, those systems have a generally lower PM mitigation efficiency than ESP systems; and particle deposition occurs on the surfaces of not only collection electrodes but also other objects inside a swine barn.

An ionization system consumes no water, oil, or chemicals during operation. Another possible advantage is its low power consumption - because of the high resistivity of air, the current in an ionization system is expected to be very low (milliamps). Only a few previous studies reported current consumption data (Rosentrater, 2003; Winkel et al., 2014). However, no further normalization of the data with such as the number/weight of pigs or barn areas was reported, making it difficult to compare energy consumption between different systems.

As aforementioned, drift velocity is a key parameter for ionization system design. It is related to not only electric field strength but also particle characteristics such as particle size and dielectric constant. George and Feddes (1995b) measured the properties of organic and respirable particles in swine barns, including particle size and resistivity. The acquired data, however, has yet to be effectively utilized.

\subsection{Alternation of feed and feeders}

Feed is a primary source of PM in swine barns. Thus, any measures that suppress the suspension of feed particles can help reduce indoor PM concentrations. These measures include pelletization of feed, the use 
of wet feeders, and the modification of feed diet. An early review of those measures can be found in Pearson and Shaples (1995).

Pelleted feed was reported to result in lower PM concentrations than meal (mash or ground) feed (Bundy and Hazen, 1975; Robertson, 1992; Li et al., 1993), for two possible reasons. First, because of its large granular size and physical integrity, pelleted feed is less likely to disaggregate and suspend as airborne particles. Secondly, the pelleted feed was found to increase feed efficiency and cause less feed spillage in feeders (Han et al., 2001), which in turn could reduce the suspension of feed particles. Although early studies all indicated the benefit of pelleted feed, a recent study in nursery barns found that pelleted feed resulted in higher indoor PM concentrations than coarsely ground meal (Ulens et al., 2015). The authors ascribed this to the formation of small particles during feed pelleting.

Wet feeders amend dry feed (either in the form of pellets or powders) with water. The high moisture content of feed in theory would suppress the suspension of feed particles (Bundy, 1974). The benefit of wet feeders for swine barn PM management was first identified by several independent studies in Europe (Pearson and Shaples, 1995) where wet feeders remain prevalent as of today. A similar benefit was observed by Yang et al. (2015) from a multi-farm monitoring project in the U.S. Midwest; however, according to the authors, swine barn types could confound the observed difference between dry and wet feeders. The effectiveness of wet feeders for PM mitigation was challenged by Robertson (1992) who found that the barns with wet feeders were among the dustiest of surveyed confined swine farms. In two independent studies, no significant difference in PM concentrations was noted between dry and wet feeders (Guingand, 1999; Takai and Pederson, 2000). Such inconsistency in the literature could be related to changes in dry feeder designs (Aarnink and Ellen, 2007).

Modification of feed diet aims to increase the physical integrity of feed particles while maintaining (if not improving) pig performance. The most studied diet modification is adding fat or oil to swine feed. Although adding fat as an energy source to swine feed has been practiced for $>60$ years, the first study of its mitigation of swine barn PM was reported by Chiba et al. (1985). Dietary fat was thought to serve as a binder agent to bind small particles together during feed storage, delivery, and feeding, thereby reducing the potency of dust suspension. By adding $2.5 \%, 5.0 \%$, and $7.5 \%$ of tallow (an animal fat) to the diet of grower-finisher pigs, the average indoor PM concentrations were reduced by $21 \%, 50 \%$, and $56 \%$, respectively (Chiba et al., 1985; 1987). Vegetable oils were found to function similarly to animal fats. Gore et al. (1986) added 5\% soybean oil to nursery swine diets and found a reduction in settled dust by $45-47 \%$ and a reduction in total viable bacteria by $27 \%$. Similar observations were made by Gast and Bundy (1986) and Clark and McQuitty (1988). Since 1990, a few follow-up studies have been done, with a consistent reduction in TSP or inhalable particles observed (Table 23). For respirable particles, not every effort was successful. Welford et al. (1992) reported a 46\% increase in respirable particle counts after oil treatment. They suggested that the interception and scavenging of fine particles (e.g., respirable) by coarse particles (e.g., inhalable) could play a role in the settling removal of fine particles and, thus, a decreased inhalable particle concentration upon oil treatment could discourage respirable particle removal. Other than oil and fat, the feed additives tested include lecithin (Gast and Bundy, 1986) and lignin (Li et al., 1993), both resulting in a significant PM reduction. Molasses was proposed by Pearson and Shaples (1995) as a feed additive for in-barn PM mitigation; however, it has yet to be tested.

The purpose of feed diet modification is multifaceted. For air quality management, most previous studies focused on odor mitigation. PM mitigation was often investigated as a side-benefit. A comprehensive review of the effect of feed diets on odor is given by Le et al. (2007). In principle, any diet modification can be tested for PM concentrations. In addition to feed additives, reducing the dietary crude protein content was reported to reduce PM concentrations inside grower-finisher barns (Jin and Predicala, 2011). The reason is unknown. Reduced crude proteins were believed to decrease total nitrogen excretion from pigs, thereby reducing the generation and emissions of ammonia and odors (Hayes et al., 2004). 
In summary, although most previous studies offered positive results, no agreement has been reached regarding the effectiveness of pelleted feed or wet feeders for PM mitigation. Adding fat/oil to feed was effective, particularly for large particles. Compared to oil/water sprinkling and ionization, feed and feeder alternation receives fewer research interests, especially in recent years. This is likely because any alternation of feed and/or feeders could significantly impact pig performance. Swine nutrition carries greater weight than air quality when it comes to feeds and feeders.

\subsection{Recirculating air filtration}

Recirculating air filtration, also known as internal air filtration or indoor air purification or air cleaning, features a recirculated air loop that feeds PM-laden air inside a built environment to an air cleaner and releases clean air back to the environment. The concept of recirculating air filtration can date back to the early $20^{\text {th }}$ century (Janssen, 1999) when multiple studies examined its effectiveness in temperature and odor control. To our knowledge, the idea of using recirculating air filtration for animal environmental control was first proposed by Littmann (1965) and the first study of its effectiveness in swine barn PM reduction was reported by Carpenter et al. (1986). Since 1990, six relevant studies have been reported. Five of them used fabric filters, one used ESP systems, and one used wet scrubbers for in-barn PM removal (Table 23).

PM removal by fabric filters is governed by three mechanisms: impaction, interception, and diffusion. Impaction occurs when a particle strikes a filter fiber in a face-to-face "direct hit" fashion. In comparison, interception can be considered as a "side slam" - the moving trajectory of a particle stays off a fiber but because of the definite size of the particle, it still strikes the fiber. Diffusion occurs when a small particle would miss the fiber but strikes it because of Brownian motion. It is noteworthy that the high efficiency of fabric filters is largely ascribed to dust layers built up on the fabric which fill interstitial holes. The three mechanisms apply to the "dirty" fabric filters as well.

PM removal by wet scrubbers is primarily contributed by the impaction of particles onto liquid droplets. In a wet scrubber, a liquid (usually water) is pressurized to form fine liquid droplets using nozzles, venturi, or venturi jets so as to increase the contact of particles with the liquid. Various wet scrubbers designs are available, including spray-chamber, cyclone spray-chamber, wet-impingement, and venturi scrubbers. The one adopted by Mostafa et al. (2017) is a typical horizontal spray-chamber scrubber, with a entrainment eliminator installed downstream to remove liquid droplets; and a sulfuric acid solution was selected as the liquid for simultaneous $\mathrm{PM}$ and $\mathrm{NH}_{3}$ removal.

Detailed information about fabric filters, ESP systems (Refer to Section 5.2), and wet scrubbers can be found from Cooper and Alley (2010). In general, fabric filters offer a greater PM removal efficiency but create a higher pressure drop than ESP systems and wet scrubbers. A higher pressure drop means that additional energy is needed to recirculate and clean a given volume of barn air.

In reality, several fabric filters tested in swine barns held only a moderate filtration efficiency. No reason was given regarding filter selection and it was likely because of energy consideration. For example, an ISO 50\% coarse filter (Eisenlöffe et al., 2019) is $<50 \%$ effective in $\mathrm{PM}_{10}$ removal; and an MERV 5-6 pocket filter (Wenke et al., 2018) has a removal efficiency of 20-49\% for particles with diameters of 3-10 $\mu \mathrm{m}$. High-efficiency fabric filters or filter sets were also tested. Lau et al. (1996) used a 3-stage filter set, with 2 coarse filters for pre-filtration and a high-efficiency particulate air (HEPA) filter as the final stage. A commercial shaker dust collector (Model: SDC-140) was tested by Anthony et al. (2015). The collector consisted of high-efficiency fabric bags, with $>99 \%$ efficiency for general industrial dust.

It is important to note that filtration or scrubbing efficiency is different from overall in-barn PM reduction. The latter is related to not only the efficiency of recirculating air filters but also barn volume, recirculating airflow, in-barn PM generation, PM sedimentation, ventilation, infiltration, exfiltration, etc. A classic indoor air quality box model considering recirculated air can be found from de Nevers (2010). The model is based on material balance and can be used to determine the recirculating airflow required 
for target PM reduction. However, many of the model parameters (e.g., ventilation rates) were unavailable in the previous swine barn studies, making it difficult to conduct a thorough analysis of system performance and a comparison among different filtration systems.

\section{Knowledge Gaps and Future Research Needs}

Decades of research has profoundly advanced our knowledge of PM in swine barns, including sources, characteristics, measurement, and mitigation. However, PM continues to be an environmental challenge facing pork producers. Some fundamental questions remain unanswered, calling for future research input. Detailed information can be found in the previous sections. This section list several major knowledge gaps identified from the review effort.

- Little is known about the concentration and size distribution of submicron particles (i.e., PM with diameters $<1 \mu \mathrm{m}$ ) in swine barns. These particles are of growing concern, as exemplified by the $\mathrm{PM}_{1}$ standard being rigorously discussed by the U.S. EPA and the European Union. Because of their ultra-small size, submicron particles can enter alveoli and be directly absorbed into pulmonary cells. No PM sources in swine barns have been known to emit a significant amount of submicron particles. However, this may be ascribed to the lack of monitoring data. Furthermore, submicron particles can be associated with airborne porcine viruses. As mentioned in Section 3.2.2, some porcine viruses could occur as individual airborne particles, with diameters $<1 \mu \mathrm{m}$. This size fraction of viruses is hard to remove with regular PM mitigation technologies. Thus, the measurement of submicron PM in swine barns can improve our understanding of airborne viral transmission in and around infected barns and aid the development of mitigation technologies.

- An updated model to simulate in-barn PM concentrations is lacking. Previous studies have investigated the effect of various environmental and operational factors such as barn type, ventilation, outdoor temperature, and stock density. Based on the investigation results, semimechanistic or statistical models were developed to predict in-barn PM concentrations from these easily measurable factors (Pedersen et al., 2000; Yang, 2010). However, no further modeling effort was seen in the past decade. In the meantime, the increasing use of farm information systems and real-time PM monitors have generated massive data. A thorough analysis of the big data is needed to further assess the effect of individual factors. A more robust, accurate, and comprehensive model is anticipated, with the data and advanced data analytics tools (e.g., deep learning). Knowledge of PM concentrations is critical as many air hazards (e.g., odor levels and pathogen concentrations) in swine barns can correlate with PM concentrations.

- Additional research is needed to further investigate the spatial distribution of PM in swine barns to better assess PM exposure risks for human and pigs. Previous investigations predominantly focused on PM concentrations. Little is known about the distribution of other PM characteristics such as PSD, bacterial/fungal counts, viruses, and microbial composition. Microbial composition may be a good subject to start with for its strong implications for human and animal health. The investigation can share the same filters as PM concentration monitoring and relevant analysis (e.g., PCR and DNA sequencing) is becoming increasingly affordable. In addition to grid sampling (adopted by most of the previous investigations), future research may consider sampling $\mathrm{PM}$ in different function or risk zones inside swine barns.

- Limited information is available about the size distribution of some key bioaerosols. These include ARGs, viruses, and size-segregated microbial composition. Special attention should be paid to zoonotic pathogens, including their concentrations and viability in different size fractions. Size is a critical factor affecting the transport and fate of bioaerosols. Pathogens and allergens can bind to large particles or occur as individual particles in the air. Knowledge of their size distribution is essential for the development of cost-effective mitigation or prevention strategies. Another factor related to size is the mixing state of bioaerosols, i.e., the way of microbes mixed with abiotic components in a particle; and it remains largely unexplored. The mixing state is 
expected to have a substantial influence on the viability and infectivity of bioaerosols. Bioaerosol size and mixing state can be measured using microscopy coupled with microbial identification technologies and/or size segregated sampling.

- For the U.S. pork industry, updated information is needed regarding bioaerosols in swine barns, especially culturable bacterial/fungal counts, total bacterial/fungal counts, microbial composition, and ARGs. Most field research projects were done over ten years ago. Their results may not represent the current status because of the continual consolidation of pork production and changes in swine nutrition and veterinary practices. The past ten years also witnessed the rapid development and deployment of molecular biology technologies. These technologies are becoming increasingly powerful, accessible, and affordable. A revisit to swine barn bioaerosols with the new technologies can profound our understandings of bioaerosols in various aspects: concentration, composition, viability, health impacts, transport, mitigation, etc. Furthermore, advances in bioinformatics have made it possible to unravel the interrelations between different bioaerosols (e.g., ARGs and bacterial composition) and between bioaerosols and abiotic PM components (e.g., PM-borne odorants). All these advancements together provide an unprecedented opportunity to address pork production-associated bioaerosol issues.

- Mathematical modeling is needed to understand and assess the role of PM in causing community odor nuisances. Odor is a top air quality challenge facing pork producers. The previous studies have identified and qualified numerous odorants in PM. The data, however, have yet to be effectively utilized for odor assessment. A conceptual exposure model is needed to describe the pathways for PM-borne odors to transport from swine barns to a neighboring community. For each pathway, environmental transport modeling (e.g., air dispersion modeling) needs to be done to predict the occurrence and concentration of odors at the neighboring community. Odor exposure routes (via inhalation) should also be modeled, thereby completing the modeling framework. It is noteworthy that the previous modeling work on PM-borne odors focused on inbarn transport and exposure, and requires significant revisions for community odor nuisance simulation.

- Additional research is needed for source apportionment of PM and bioaerosols. Most PM source apportionment research projects were done over ten years ago. In the U.S., no relevant studies have been reported since 1990. PM source apportionment is critical as it enables cost-effective control of in-barn PM by addressing major sources. As mentioned in Section 3.4, PM source apportionment can be done through microscopic analysis of individual particles or receptor modeling. The latter requires the measurement of PM chemical composition (which has been done by several studies). The source information of bioaerosols is equally important but remains largely unexplored. Similarly, both microscopic analysis and receptor modeling can be useful for bioaerosol source apportionment. The latter may be conducted with the microbial composition information derived from high-throughput DNA sequencing.

- The performance of low-cost PM sensors has yet to be assessed in swine barns. Numerous lowcost PM sensors have become available in the past few years. They constitute a central component of affordable handheld or wearable air quality meters. Although their extensive use in swine barns has yet to come, these sensors may create numerous challenges and opportunities. Regarding challenges, the meters may be used by non-farm groups to survey air quality around swine farms. Regarding opportunities, the meters may offer a less expensive and more convenient approach for in-barn air quality monitoring and personal exposure assessment. The low-cost sensors may also help to achieve the precision management of in-barn PM - mitigation (e.g., oil sprinkling) is more cost-efficient when PM concentrations are available as a control input. Efforts should be made to test whether the sensors perform properly for swine barn PM and to identify the best-performing sensors if possible. 
- Innovative in-barn PM mitigation solutions are needed. Nearly all existing mitigation solutions fall into four technological categories, as summarized in Section 5. Their history can all date back to the 1970 s or 1980s. Decades of research has generated massive data. However, none of them have been widely used in commercial barns. Further development of these conventional technologies is necessary. Meanwhile, efforts should be encouraged to develop innovative mitigation technologies or solutions. PM mitigation is anticipated to be part of an integrated precision swine farming system, thereby enabling the "smart" control of PM generation, concentrations, and emissions in and from swine barns. The effectiveness of conventional and innovative technologies in bioaerosol (e.g., PRRSV and S. aureus) reduction should receive particular attention because of the health implications of bioaerosols.

\section{Acknowledgments}

This study was sponsored by the National Pork Board (Grant No. 20-140). The authors also wish to thank the support of the USDA NIFA Hatch (SD00H709-20) and Multistate Hatch Projects (SD00R690-20) through the South Dakota Agricultural Experimental Station. The discussion and statements made in the report only represent the authors' opinions and should not be taken as the viewpoints of the National Pork Board or South Dakota State University.

\section{References}

Aarnink, A. J. A., \& Ellen, H. H. (2007). Processes and factors affecting dust emissions from livestock production. In International Conference DustConf 2007 - How to Improve Air Quality, Maastricht, The Netherlands.

Aarnink, A. J. A., Roelofs, P. F. M. M., Ellen, H., \& Gunnink, H. (1999) Dust sources in animal houses. In Proceedings of International Symposium on Dust Control in Animal Production Facilities (pp. 34-40). Scandinavian Congress Center, Aarhus, Denmark.

ACGIH (1985). Particle Size-Selective Sampling in the Workplace: Report of the ACGIH Technical Committee on Air Sampling Procedure. Publication No. 830. American Conference of Governmental and Industrial Hygienists, Cincinnati, $\mathrm{OH}$.

ACGIH (1989). Guidelines for the Assessment of Bioaerosols in the Indoor Environment. American Conference of Industrial Hygienists, Cincinnati, $\mathrm{OH}$.

Agranovski, V., Ristovski, Z., Blackall, P. J., \& Morawska, L. (2004). Size-selective assessment of airborne particles in swine confinement building with the UVAPS. Atmospheric Environment, 38(23), 3893-3901.

Albina, E. (1997). Epidemiology of porcine reproductive and respiratory syndrome (PRRS): an overview. Veterinary Microbiology, 55(1-4), 309-316.

Almuhanna, E. A. 2007. Dust control in livestock buildings with electrostatically-charged water spray. Ph.D. dissertation, Kansas State University, Manhattan, KS.

Alonso, C., Murtaugh, M. P., Dee, S. A., \& Davies, P. R. (2013). Epidemiological study of air filtration systems for preventing PRRSV infection in large sow herds. Preventive Veterinary Medicine, 112(1-2), 109-117.

Alonso, C., Raynor, P. C., Davies, P. R., \& Torremorell, M. (2015). Concentration, size distribution, and infectivity of airborne particles carrying swine viruses. PloS One, 10(8), e0135675.

Alonso, C., Raynor, P. C., Davies, P. R., Morrison, R. B., \& Torremorell, M. (2016). Evaluation of an electrostatic particle ionization technology for decreasing airborne pathogens in pigs. Aerobiologia, 32(3), 405-419.

Alonso, C., Raynor, P. C., Goyal, S., Olson, B. A., Alba, A., Davies, P. R., \& Torremorell, M. (2017). Assessment of air sampling methods and size distribution of virus-laden aerosols in outbreaks in swine and poultry farms. Journal of Veterinary Diagnostic Investigation, 29(3), 298-304.

Aminov, R. I., \& Mackie, R. I. (2007). Evolution and ecology of antibiotic resistance genes. FEMS Microbiology Letters, 271(2), 147-161. 
Aminov, R. I., Garrigues-Jeanjean, N., \& Mackie, R. (2001). Molecular ecology of tetracycline resistance: development and validation of primers for detection of tetracycline resistance genes encoding ribosomal protection proteins. Applied and Environmental Microbiology, 67(1), 22-32.

Andersen, A. A. (1958). New sampler for the collection, sizing, and enumeration of viable airborne particles. Journal of Bacteriology, 76(5), 471-484.

Andersen, K. B., Glasius, M., \& Feilberg, A. (2014). Gas-particle partitioning of odorants in a pig house measured by thermal desorption GC/MS. Environmental Science: Processes \& Impacts, 16(5), 1059-1068.

Anderson, B. D., Lednicky, J. A., Torremorell, M., \& Gray, G. C. (2017). The use of bioaerosol sampling for airborne virus surveillance in swine production facilities: a mini review. Frontiers in Veterinary Science, 4, 121.

Anderson, B. D., Ma, M., Xia, Y., Wang, T., Shu, B., Lednicky, J. A., Ma, M. J., Lu, J. \& Gray, G. C. (2016). Bioaerosol sampling in modern agriculture: a novel approach for emerging pathogen surveillance? The Journal of Infectious Diseases, 214(4), 537-545.

Anderson, W. B., Slawson, R. M., \& Mayfield, C. I. (2002). A review of drinking-water-associated endotoxin, including potential routes of human exposure. Canadian Journal of Microbiology, 48(7), 567-587.

Angen, Ø., Nielsen, M. W., Løfstrøm, P., Larsen, A. R., \& Hendriksen, N. B. (2021). Airborne spread of methicillin resistant Staphylococcus aureus from a swine farm. Frontiers in Veterinary Science, 8,601 .

Anthony, T. R., Altmaier, R., Jones, S., Gassman, R., Park, J. H., \& Peters, T. M. (2015). Use of recirculating ventilation with dust filtration to improve wintertime air quality in a swine farrowing room. Journal of Occupational and Environmental Hygiene, 12(9), 635-646.

Arfken, A. M., Song, B., \& Sung, J. S. (2015). Comparison of airborne bacterial communities from a hog farm and spray field. Journal of Microbiology and Biotechnology, 25(5), 709-717.

Arruda, A. G., Tousignant, S., Sanhueza, J., Vilalta, C., Poljak, Z., Torremorell, M., Alonso, C., \& Corzo, C. A. (2019). Aerosol detection and transmission of porcine reproductive and respiratory syndrome virus (PRRSV): What is the evidence, and what are the knowledge gaps? Viruses, 11(8), 712.

Attwood, P., Brouwer, R., Ruigewaard, P., Versloot, P., Dewit, R., Heederik, D., \& Boleij J. S. (1987). A study of the relationship between airborne contaminants and environmental-factors in Dutch swine confinement buildings. American Industrial Hygiene Association Journal, 48(8), 745-751.

Attwood, P., Versloot, P., Heederik, D., Dewit, R., \& Boleij, J. S. (1986). Assessment of dust and endotoxin levels in the working environment of Dutch pig farmers: a preliminary study. Annals of Occupational Hygiene, 30(2), 201-208.

Banhazi, T. (2007). Improving air quality in piggery buildings. In XIII International Congress on Animal Hygiene (pp. 237-241), Estonian University of Life Sciences, Tartu, Estonia.

Banhazi, T. (2013). Controlling the concentrations of airborne pollutants in three different livestock facilities. In Livestock housing: Modern Management to Ensure Optimal Health and Welfare of Farm Animals (pp. 281-295), Wageningen Academic Publishers, The Netherlands.

Barber, E. M., Dawson, J. R., Battams, V. A., \& Nicol, R. A. C. (1991). Spatial variability of airborne and settled dust in a piggery. Journal of Agricultural Engineering Research, 50, 107-127.

Basinas, I., Schlünssen, V., Takai, H., Heederik, D., Omland, Ø., Wouters, I. M., Sigsgaard, T., \& Kromhout, H. (2013). Exposure to inhalable dust and endotoxin among Danish pig farmers affected by work tasks and stable characteristics. Annals of Occupational Hygiene, 57(8), 10051019.

Bell, N. G. (2020). Environmental sampling and next-generation sequencing as a novel approach for the detection and characterization of influenza A virus (IAV) in swine. M.S. thesis, University of Toronto, Ontario, Canada. 
Boissy, R. J., Romberger, D. J., Roughead, W. A., Weissenburger-Moser, L., Poole, J. A., \& LeVan, T. D. (2014). Shotgun pyrosequencing metagenomic analyses of dusts from swine confinement and grain facilities. PloS One, 9(4), e95578.

Bonifait, L., Veillette, M., Létourneau, V., Grenier, D., \& Duchaine, C. (2014). Detection of Streptococcus suis in bioaerosols of swine confinement buildings. Applied and Environmental Microbiology, 80(11), 3296-3304.

Bonlokke, J. H., Mériaux, A., Duchaine, C., Godbout, S., \& Cormier, Y. (2009). Seasonal variations in work-related health effects in swine farm workers. Annals of Agricultural and Environmental Medicine, 16(1), 43-52.

Bottcher, R. W. (2001). An environmental nuisance: odor concentrated and transported by dust. Chemical Senses, 26(3), 327-331.

Brito, B., Dee, S., Wayne, S., Alvarez, J., \& Perez, A. (2014). Genetic diversity of PRRS virus collected from air samples in four different regions of concentrated swine production during a high incidence season. Viruses, 6(11), 4424-4436.

Brown, R. H., \& Stone, B. J. (1965). Air ionization in the environment of farm animals. Transactions of the ASAE, 8(1), 15-0017.

Bundy, D. S. (1974). Ionization control and particle size distribution of dust in swine buildings. Ph.D. dissertation, Iowa State University, Ames, IA.

Bundy, D. S., \& Hazen, T. E. (1975). Dust levels in swine confinement systems associated with different feeding methods. Transactions of the ASAE, 18(1), 137-0139.

Burshtein, N., Lang-Yona, N., \& Rudich, Y. (2011). Ergosterol, arabitol and mannitol as tracers for biogenic aerosols in the eastern Mediterranean. Atmospheric Chemistry and Physics, 11(2), 829839.

Butera, M., Smith, J. H., Morrison, W. D., Hacker, R. R., Kains, F. A., \& Ogilvie, J. R. (1991). Concentration of respirable dust and bioaerosols and identification of certain microbial types in a hog-growing facility. Canadian Journal of Animal Science, 71(2), 271-277.

Cai, L., Koziel, J. A., Lo, Y. C., \& Hoff, S. J. (2006). Characterization of volatile organic compounds and odorants associated with swine barn particulate matter using solid-phase microextraction and gas chromatography-mass spectrometry-olfactometry. Journal of Chromatography A, 1102(1-2), 6072.

Callahan, B. J., Wong, J., Heiner, C., Oh, S., Theriot, C. M., Gulati, A. S., McGill, S. K., \& Dougherty, M. K. (2019). High-throughput amplicon sequencing of the full-length 16S rRNA gene with single-nucleotide resolution. Nucleic Acids Research, 47(18), e103-e103.

Cambra-López, M., Aarnink, A. J., Zhao, Y., Calvet, S., \& Torres, A. G. (2010). Airborne particulate matter from livestock production systems: A review of an air pollution problem. Environmental Pollution, 158(1), 1-17.

Cambra-López, M., Hermosilla, T., Lai, H. T., Aarnink, A. J. A., \& Ogink, N. W. M. (2011a). Particulate matter emitted from poultry and pig houses: source identification and quantification. Transactions of the ASABE, 54(2), 629-642.

Cambra-López, M., Torres, A. G., Aarnink, A. J. A., \& Ogink, N. W. (2011b). Source analysis of fine and coarse particulate matter from livestock houses. Atmospheric Environment, 45(3), 694-707.

Cambra-López, M., Winkel, A., Mosquera, J., Ogink, N. W., \& Aarnink, A. J. (2015). Comparison between light scattering and gravimetric samplers for $\mathrm{PM}_{10}$ mass concentration in poultry and pig houses. Atmospheric Environment, 111, 20-27.

Cao, Y., Fanning, S., Proos, S., Jordan, K., \& Srikumar, S. (2017). A review on the applications of next generation sequencing technologies as applied to food-related microbiome studies. Frontiers in Microbiology, 8, 1829.

Carpenter, G. A. (1986). Dust in livestock buildings - review of some aspects. Journal of Agricultural Engineering Research, 33(4), 227-241.

Carpenter, G. A., \& Fryer, J. T. (1990). Air filtration in a piggery: filter design and dust mass balance. Journal of Agricultural Engineering Research, 46, 171-186. 
Carpenter, G. A., Cooper, A. W., \& Wheeler, G. E. (1986). The effect of air filtration on air hygiene and pig performance in early-weaner accommodation. Animal Science, 43(3), 505-515.

Chang, C. W., Chung, H., Huang, C. F., \& Su, H. J. J. (2001a). Exposure assessment to airborne endotoxin, dust, ammonia, hydrogen sulfide and carbon dioxide in open style swine houses. Annals of Occupational Hygiene, 45(6), 457-465.

Chang, C. W., Chung, H., Huang, C. F., \& Su, H. J. J. (2001b). Exposure of workers to airborne microorganisms in open-air swine houses. Applied and Environmental Microbiology, 67(1), 155161.

Chang, C. W., Hung, N. T., \& Chen, N. T. (2017). Optimization and application of propidium monoazide-quantitative PCR method for viable bacterial bioaerosols. Journal of Aerosol Science, 104, 90-99.

Chapelle, F. H., O'Neill, K., Bradley, P. M., Methé, B. A., Ciufo, S. A., Knobel, L. L., \& Lovley, D. R. (2002). A hydrogen-based subsurface microbial community dominated by methanogens. Nature, 415(6869), 312-315.

Chapin, A., Rule, A., Gibson, K., Buckley, T., \& Schwab, K. (2005). Airborne multidrug-resistant bacteria isolated from a concentrated swine feeding operation. Environmental Health Perspectives, 113(2), 137-142.

Chen, M., Qiu, T., Sun, Y., Song, Y., Wang, X., \& Gao, M. (2019). Diversity of tetracycline-and erythromycin-resistant bacteria in aerosols and manures from four types of animal farms in China. Environmental Science and Pollution Research, 26(23), 24213-24222.

Chen, Y., Zhang, Y., \& Barber, E. M. (1995). New mathematical model of particle size distribution for swine building dust. ASHRAE Transactions, 101(Pt 2), 1169-1178.

Chi, M. C., \& Li, C. S. (2005). Fluorochrome and fluorescent in situ hybridization to monitor bioaerosols in swine buildings. Aerosol Science and Technology, 39(11), 1101-1110.

Chiba, L. I., Pec, E. R., \& Lewis, A. J. (1987). Use of dietary fat to reduce dust, aerial ammonia and bacterial colony forming particle concentrations in swine confinement buildings. Transactions of the ASAE, 30(2), 464-0468.

Chiba, L. I., Peo Jr, E. R., Lewis, A. J., Brumm, M. C., Fritschen, R. D., \& Crenshaw, J. D. (1985). Effect of dietary fat on pig performance and dust levels in modified-open-front and environmentally regulated confinement buildings. Journal of Animal Science, 61(4), 763-781.

Chinivasagam, H. N., \& Blackall, P. J. (2005). Investigation and application of methods for enumerating heterotrophs and Escherichia coli in the air within piggery sheds. Journal of Applied Microbiology, 98(5), 1137-1145.

Cho, M. S., Ko, H. J., Kim, D., \& Kim, K. Y. (2012). On-site application of air cleaner emitting plasma ion to reduce airborne contaminants in pig building. Atmospheric Environment, 63, 276-281.

Chow, J. C. (1995). Measurement methods to determine compliance with ambient air quality standards for suspended particles. Journal of the Air \& Waste Management Association, 45(5), 320-382.

Chow, J. C., Yang, X., Wang, X., Kohl, S. D., Hurbain, P. R., Chen, L. A., \& Watson, J. G. (2015). Characterization of ambient PM10 bioaerosols in a California agricultural town. Aerosol and Air Quality Research, 15(4), 1433-1447.

Christensen, H., Vinzents, P., Nielsen, B. H., Finsen, L., Pedersen, M. B., \& Sjøgaard, G. (1992). Occupational exposures and health among Danish farmers working in swine confinement buildings. International Journal of Industrial Ergonomics, 10(4), 265-273.

Clark, P. C., \& McQuitty, J. B. (1988). Air quality in farrowing barns. Canadian Agricultural Engineering, 30(1), 173-8.

Clark, S., Rylander, R., \& Larsson, L. (1983). Airborne bacteria, endotoxin and fungi in dust in poultry and swine confinement buildings. American Industrial Hygiene Association Journal, 44(7), 537541.

Clauß, M., Springorum, A. C., \& Hartung, J. (2012). Comparison of different fluorescence and nonfluorescence staining techniques for rapid detection of airborne micro-organisms collected on 
room temperature vulcanizing (RTV) silicones from generated aerosols and from ambient air. Aerosol Science and Technology, 46(7), 818-827.

Cooper, C. D., \& Alley, F. C. (2010). Air Pollution Control: A Design Approach (Fourth Edition). Waveland Press, Long Grove, IL.

Copeland, C. R., \& Kawatra, S. K. (2005). Dust suppression in iron ore processing plants. Mining, Metallurgy \& Exploration, 22(4), 177-191.

Cormier, Y., Tremblay, G. U. Y., Meriaux, A., Brochu, G., \& Lavoie, J. (1990). Airborne microbial contents in two types of swine confinement buildings in Quebec. American Industrial Hygiene Association Journal, 51(6), 304-309.

Corzo, C. A., Culhane, M., Dee, S., Morrison, R. B., \& Torremorell, M. (2013). Airborne detection and quantification of swine influenza a virus in air samples collected inside, outside and downwind from swine barns. PloS one, 8(8), e71444.

Costa, A., Borgonovo, F., Leroy, T., Berckmans, D., \& Guarino, M. (2009). Dust concentration variation in relation to animal activity in a pig barn. Biosystems Engineering, 104(1), 118-124.

Cox, C. S. (1989). Airborne bacteria and viruses. Science Progress Oxford, 73(4), 469-499.

Cox, C. S., \& Wathes, C. M. (1995). Bioaerosols Handbook. Lewis Publishers/ CRC Press, Boca Raton, FL.

Crook, B., \& Sherwood-Higham, J. L. (1997). Sampling and assay of bioaerosols in the work environment. Journal of Aerosol Science, 28(3), 417-426.

Crook, B., Robertson, J. F., Glass, S. T., Botheroyd, E. M., Lacey, J., \& Topping, M. D. (1991). Airborne dust, ammonia, microorganisms, and antigens in pig confinement houses and the respiratory health of exposed farm workers. American Industrial Hygiene Association Journal, 52(7), 271279.

Crowe, C. K., Harris, D. H., Elliott, L. P., Wilson, E. R., \& Wiseman, B. S. (1996). A possible relationship between low facility dust and endotoxin levels and improved growth rates in pigs reared by Isowean ${ }^{\mathrm{SM}}$. Swine Health and Production, 4(5), 231-236.

Curtis, S. E., Anderson, C. R., Simon, J., Jensen, A. H., Day, D. L., \& Kelley, K. W. (1975c). Effects of aerial ammonia, hydrogen sulfide and swine-house dust on rate of gain and respiratory-tract structure in swine. Journal of Animal Science, 41(3), 735-739.

Curtis, S. E., Balsbaugh, R. K., \& Drummond, J. G. (1978). Comparison of Andersen eight-stage and two-stage viable air samplers. Applied and Environmental Microbiology, 35(1), 208-209.

Curtis, S. E., Drummond, J. G., Grunloh, D. J., Lynch, P. B., \& Jensen, A. H. (1975a). Relative and qualitative aspects of aerial bacteria and dust in swine houses. Journal of Animal Science, 41(5), 1512-1520.

Curtis, S. E., Drummond, J. G., Kelley, K. W., Grunloh, D. J., Meares, V. J., Norton, H. W., \& Jensen, A. H. (1975b). Diurnal and annual fluctuations of aerial bacterial and dust levels in enclosed swine houses. Journal of Animal Science, 41(5), 1502-1511.

Cyprowski, M., Buczyńska, A., Kozajda, A., Sowiak, M., Bródka, K., \& Szadkowska-Stańczyk, I. (2012). Exposure to $(1 \rightarrow 3)-\beta$-D-glucans in swine farms. Aerobiologia, 28(2), 161-168.

Dai, C., Huang, S., Zhou, Y., Xu, B., Peng, H., Qin, P., \& Wu, G. (2019). Concentrations and emissions of particulate matter and ammonia from extensive livestock farm in South China. Environmental Science and Pollution Research, 26(2), 1871-1879.

Das, K. C., Kastner, J. R., \& Hassan, S. M. (2004). Potential of particulate matter as a pathway for odor dispersion. In 2004 ASAE Annual Meeting (Paper no. 04-4125). American Society of Agricultural and Biological Engineers, St. Joseph, MI.

Davidson, C. I., Phalen, R. F., \& Solomon, P. A. (2005). Airborne particulate matter and human health: a review. Aerosol Science and Technology, 39(8), 737-749.

Davis, M. F., Pisanic, N., Rhodes, S. M., Brown, A., Keller, H., Nadimpalli, M., Christ, A., Ludwig, S., Ordak, C., Spicer, K., Love, D.C., Larsen, J., Wright, A., Blacklin, A., Flower, B., Stewart, J., Sexton, K. G., Rule, A. M., \& Heaney, C. D. (2018). Occurrence of Staphylococcus aureus in 
swine and swine workplace environments on industrial and antibiotic-free hog operations in North Carolina, USA: A One Health pilot study. Environmental Research, 163, 88-96.

Day, D. L., Hansen, E. L., \& Anderson, S. (1965). Gases and odors in confinement swine buildings. Transactions of the ASAE, 8(1), 118-0121.

de Felippe Junior, J., da Rocha e Silva Júnior, M., Maciel, F. M., \& Mendes, N. F. (1993). Infection prevention in patients with severe multiple trauma with the immunomodulator beta 1-3 polyglucose (glucan). Surgery, Gynecology \& Obstetrics, 177(4), 383-388.

de Groot, G. A., Geisen, S., Wubs, E. J., Meulenbroek, L., Laros, I., Snoek, L. B., Lammertsma, D.R., Hansen, L.H., \& Slim, P. A. (2021). The aerobiome uncovered: Multi-marker metabarcoding reveals potential drivers of turn-over in the full microbial community in the air. Environment International, 154, 106551.

De Jong, J. A., Card, K. N., DeRouchey, J. M., Baumgartner, M., \& Tomlinson, P. J. (2014). Effects of electrostatic particle ionization on air quality, emissions, and growth performance of pigs housed in a thermo-regulated facility. Accessed at: https://krex.kstate.edu/dspace/bitstream/handle/2097/19140/swine14pg310-314.pdf?sequence=1

de Nevers, N. (2010). Air Pollution Control Engineering, $2^{\text {nd }}$ Edition. Waveland press, Long Grove, IL.

DeCarlo, P. F., Slowik, J. G., Worsnop, D. R., Davidovits, P., \& Jimenez, J. L. (2004). Particle morphology and density characterization by combined mobility and aerodynamic diameter measurements. Part 1: Theory. Aerosol Science and Technology, 38(12), 1185-1205.

Dee, S., Batista, L., Deen, J., \& Pijoan, C. (2005). Evaluation of an air-filtration system for preventing aerosol transmission of porcine reproductive and respiratory syndrome virus. Canadian Journal of Veterinary Research, 69(4), 293.

Dee, S., Otake, S., Oliveira, S., \& Deen, J. (2009). Evidence of long distance airborne transport of porcine reproductive and respiratory syndrome virus and Mycoplasma hyopneumoniae. Veterinary Research, 40(4), 1-13.

Dewey, C. E., Cox, B. D., Straw, B. E., Bush, E. J., \& Hurd, S. (1999). Use of antimicrobials in swine feeds in the United States. Journal of Swine Health and Production, 7(1), 19-25.

Diamante, L. M., \& Lan, T. (2014). Absolute viscosities of vegetable oils at different temperatures and shear rate range of 64.5 to $4835 \mathrm{~s}^{-1}$. Journal of Food Processing, 234583.

Dobie, J. B., Bond, T. E., Givens, R. L., Heitman, H., Jacob, F. C., Kelly, C. F., Sprock, C.M., \& Wilson, W. O. (1966). Effect of Air Ions on Swine and Poultry. Transactions of the ASAE, 9(6), 8830886.

Doig, P. A., \& Willoughby, R. A. (1971). Response of swine to atmospheric ammonia and organic dust. Journal of the American Veterinary Medical Association, 159(11), 1353-1361.

Donaldson, A. I., \& Ferris, N. P. (1976). The survival of some air-borne animal viruses in relation to relative humidity. Veterinary Microbiology, 1(4), 413-420.

Donham, K. J. (1990). Health effects from work in swine confinement buildings. American Journal of Industrial Medicine, 17(1), 17-25.

Donham, K. J., Cumro, D., Reynolds, S. J., \& Merchant, J. A. (2000). Dose-response relationships between occupational aerosol exposures and cross-shift declines of lung function in poultry workers: Recommendations for exposure limits. Journal of Occupational and Environmental Medicine, 42(3), 260-269.

Donham, K. J., Reynolds, S. J., Whitten, P., Merchant, J. A., Burmeister, L., \& Popendorf, W. J. (1995). Respiratory dysfunction in swine production facility workers: Dose-response relationships of environmental exposures and pulmonary function. American Journal of Industrial Medicine, 27(3), 405-418.

Donham, K. J., Scallon, L. J., Popendorf, W., Treuhaft, M. W., \& Roberts, R. C. (1986). Characterization of dusts collected from swine confinement buildings. American Industrial Hygiene Association Journal, 47(7), 404-410. 
Donham, K. J., Zavala, D. C., \& Merchant, J. (1984a). Acute effects of the work environment on pulmonary functions of swine confinement workers. American Journal of Industrial Medicine, 5(5), 367-375.

Donham, K. J., Zavala, D. C., \& Merchant, J. A. (1984b). Respiratory symptoms and lung function among workers in swine confinement buildings: a cross-sectional epidemiological study. Archives of Environmental Health: An International Journal, 39(2), 96-101.

Donham, K., Haglind, P., Peterson, Y., Rylander, R., \& Belin, L. (1989). Environmental and health studies of farm workers in Swedish swine confinement buildings. Occupational and Environmental Medicine, 46(1), 31-37.

Dosman, J. A., Senthilselvan, A., Kirychuk, S. P., Lemay, S., Barber, E. M., Willson, P., Cormier, Y., \& Hurst, T. S. (2000). Positive human health effects of wearing a respirator in a swine barn. Chest, $118(3), 852-860$.

Douwes, J. (2005). (1--> 3)-Beta-D-glucans and respiratory health: a review of the scientific evidence. Indoor Air, 15(3), 160-169.

Douwes, J., Doekes, G., Montijn, R. O. Y., Heederik, D., \& Brunekreef, B. (1996). Measurement of beta $(1 \rightarrow 3)$-glucans in occupational and home environments with an inhibition enzyme immunoassay. Applied and Environmental Microbiology, 62(9), 3176-3182.

Douwes, J., Thorne, P., Pearce, N., \& Heederik, D. (2003). Bioaerosol health effects and exposure assessment: progress and prospects. Annals of Occupational Hygiene, 47(3), 187-200.

Douwes, J., van der Sluis, B., Doekes, G., van Leusden, F., Wijnands, L., van Strien, R., Verhoeff, A., \& Brunekreef, B. (1999). Fungal extracellular polysaccharides in house dust as a marker for exposure to fungi: relations with culturable fungi, reported home dampness, and respiratory symptoms. Journal of Allergy and Clinical Immunology, 103(3), 494-500.

Douwes, J., Versloot, P., Hollander, A., Heederik, D., \& Doekes, G. (1995). Influence of various dust sampling and extraction methods on the measurement of airborne endotoxin. Applied and Environmental Microbiology, 61(5), 1763-1769.

Druckenmueller, K., Gärtner, A., Jaeckel, U., Klug, K., Schiffels, J., Guenther, K., \& Elbers, G. (2017). Development of a methodological approach for the characterization of bioaerosols in exhaust air from pig fattening farms with MALDI-TOF mass spectrometry. International Journal of Hygiene and Environmental Health, 220(6), 974-983.

Duchaine, C., Grimard, Y., \& Cormier, Y. (2000). Influence of building maintenance, environmental factors, and seasons on airborne contaminants of swine confinement buildings. AIHAJ-American Industrial Hygiene Association, 61(1), 56-63.

Dutkiewicz, J., Pomorski, Z. J., Sitkowska, J., Krysińska-Traczyk, E., Skórska, C., Prażmo, Z., Cholewa, G., \& Wójtowicz, H. (1994). Airborne microorganisms and endotoxin in animal houses. Grana, 33(2), 85-90.

Eduard, W., Lacey, J., Karlsson, K., Palmgren, U., Ström, G., \& Blomquist, G. (1990). Evaluation of methods for enumerating microorganisms in filter samples from highly contaminated occupational environments. American Industrial Hygiene Association Journal, 51(8), 427-436.

Eisenlöffel, L., Reutter, T., Horn, M., Schlegel, S., Truyen, U., \& Speck, S. (2019). Impact of UVCsustained recirculating air filtration on airborne bacteria and dust in a pig facility. PloS One, 14(11), e0225047.

Elliott, L. F., McCalla, T. M., \& Deshazer, J. A. (1976). Bacteria in the air of housed swine units. Applied and Environmental Microbiology, 32(2), 270-273.

Engstad, C. S., Engstad, R. E., Olsen, J. O., \& Østerud, B. (2002). The effect of soluble $\beta-1$, 3-glucan and lipopolysaccharide on cytokine production and coagulation activation in whole blood.

International Immunopharmacology, 2(11), 1585-1597.

Ferguson, D. D., Smith, T. C., Hanson, B. M., Wardyn, S. E., \& Donham, K. J. (2016). Detection of airborne methicillin-resistant Staphylococcus aureus inside and downwind of a swine building, and in animal feed: potential occupational, animal health, and environmental implications. Journal of Agromedicine, 21(2), 149-153. 
Fiser, A. (1969). The bacterial content of air in a fattening house for pigs with a dry feed technology. Acta Veterinaria Brno, 38, 273-286.

Fiser, A. (1970). Microbiological picture of air in large-scale farrowing house and pre-feeding piggery. Acta Veterinaria Brno, 39, 89-100.

Forbes, P. B., Karg, E. W., Zimmermann, R., \& Rohwer, E. R. (2012). The use of multi-channel silicone rubber traps as denuders for polycyclic aromatic hydrocarbons. Analytica Chimica Acta, 730, 7179.

Fournier, S. (1992). The removal of airborne dust from swine housing by electrostatic precipitation. M.S. thesis, University of Alberta, Edmonton, Alberta, Canada.

Friese, A., Schulz, J., Hoehle, L., Fetsch, A., Tenhagen, B. A., Hartung, J., \& Roesler, U. (2012). Occurrence of MRSA in air and housing environment of pig barns. Veterinary Microbiology, 158(1-2), 129-135.

Gallmann, E., Hartung, E., \& Jungbluth, T. (2002). Comparison of the indoor dust concentration between two different housing and ventilation systems for fattening pigs. Aus dem Institut für Technologie und Biosystemtechnik, 145-154.

Gast, R. M., \& Bundy, D. S. (1986). Control of feed dusts by adding oils. In 1986 ASAE Annual Meeting (Paper No. 86-4039), American Society of Agricultural Engineers, St. Joseph, MI.

George, S. S., \& Feddes, J. J. R. (1995a). Removal of airborne swine dust by electrostatic precipitation. Canadian Agricultural Engineering, 37(2), 103-107.

George, S. S., \& Feddes, J. J. R. (1995b). Electrical properties of organic and respirable swine dust. Canadian Agricultural Engineering, 37(2), 97-102.

Ghosh, B., Lal, H., \& Srivastava, A. (2015). Review of bioaerosols in indoor environment with special reference to sampling, analysis and control mechanisms. Environment International, 85, 254-272.

Gibbs, S. G., Green, C. F., Tarwater, P. M., \& Scarpino, P. V. (2004). Airborne antibiotic resistant and nonresistant bacteria and fungi recovered from two swine herd confined animal feeding operations. Journal of Occupational and Environmental Hygiene, 1(11), 699-706.

Gibbs, S. G., Green, C. F., Tarwater, P. M., Mota, L. C., Mena, K. D., \& Scarpino, P. V. (2006). Isolation of antibiotic-resistant bacteria from the air plume downwind of a swine confined or concentrated animal feeding operation. Environmental Health Perspectives, 114(7), 1032-1037.

Godbout, S., Lavoie, J., Lemay, S. P., Lachance, I., Pouliot, F., \& Belzile, M. (2005). Impact of in-barn manure separation on the biological air quality of swine buildings. In 2005 ASAE Annual Meeting (Paper No. 055018). American Society of Agricultural and Biological Engineers, St. Joseph, MI.

Godbout, S., Lemay, S. P., Joncas, R., Larouche, J. P., Martin, D. Y., Bernier, J. F., Zijlstra, R.T., Chénard, L., Marquis, A., Barber, E.M., \& Massé, D. (2001). Oil sprinkling and dietary manipulation to reduce odour and gas emissions from swine buildings-laboratory scale experiment. In Livestock Environment VI, Proceedings of the 6th International Symposium 2001 (p. 671-678), Louisville, KY.

Gongora, C. E., Damborg, P. P., Nielsen, S. S., Gibbs, S., \& Guardabassi, L. (2013). Effect of a disinfectant powder on methicillin-resistant Staphylococcus aureus in pigs, bedding and air samples under simulated farm conditions. The Pig Journal, 68, 13-18.

Góra, A., Mackiewicz, B., Krawczyk, P., Golec, M., Skórska, C., Sitkowska, J., Cholewa, G., Larsson, L., Jarosz, M., Wójcik-Fatla, A., \& Dutkiewicz, J. (2009). Occupational exposure to organic dust, microorganisms, endotoxin and peptidoglycan among plants processing workers in Poland. Annals of Agricultural and Environmental Medicine, 16(1), 143-150.

Gore, A. M., Kornegay, E. T., \& Veit, H. P. (1986). The effects of soybean oil on nursery air quality and performance of weanling pigs. Journal of Animal Science, 63(1), 1-7.

Grantz, D. A., Garner, J. H. B., \& Johnson, D. W. (2003). Ecological effects of particulate matter. Environment International, 29(2-3), 213-239. 
Green, C. F., Gibbs, S. G., Tarwater, P. M., Mota, L. C., \& Scarpino, P. V. (2006). Bacterial plume emanating from the air surrounding swine confinement operations. Journal of Occupational and Environmental Hygiene, 3(1), 9-15.

Guarino, M., Jacobson, L. D., \& Janni, K. A. (2007). Dust reduction from oil-based feed additives. Applied Engineering in Agriculture, 23(3), 329-332.

Guingand, N. (1999). Dust concentrations in piggeries: influence of season, age of pigs, type of floor and feed presentation in farrowing, post-weaning and finishing rooms. In Dust Control in Animal Production Facilities (pp. 69-75), Aarhus University, Aarhus, Denmark.

Guo, L., Maghirang, R. G., Razote, E. B., Trabue, S. L., \& McConnell, L. L. (2011). Concentrations of particulate matter emitted from large cattle feedlots in Kansas. Journal of the Air \& Waste Management Association, 61(10), 1026-1035.

Gustafsson, G. (1999). Factors affecting the release and concentration of dust in pig houses. Journal of Agricultural Engineering Research, 74, 379-390.

Haas, D., Köck, S., Fritz, T., Galler, H., Habib, J., Kropsch, M., \& Reinthaler, F. F. (2021). Bioaerosol measurements over a fattening period in a pig barn focused on the presence of Staphylococcus spp. Aerobiologia, 37, 1-12.

Haeussermann, A., Costa, A., Aerts, J. M., Hartung, E., Jungbluth, T., Guarino, M., \& Berckmans, D. (2008). Development of a dynamic model to predict $\mathrm{PM}_{10}$ emissions from swine houses. Journal of Environmental Quality, 37, 557-564.

Haglind, P., \& Rylander, R. (1987). Occupational exposure and lung function measurements among workers in swine confinement buildings. Journal of Occupational Medicine, 29(11), 904-907.

Hammond, E. G., Fedler, C., \& Junk, G. (1979). Identification of dust-borne odors in swine confinement facilities. Transactions of the ASAE, 22(5), 1186-1189.

Hammond, E. G., Fedler, C., \& Smith, R. J. (1981). Analysis of particle-borne swine house odors. Agriculture and Environment, 6(4), 395-401.

Hamscher, G., \& Hartung, J. (2008). Veterinary antibiotics in dust: sources, environmental concentrations, and possible health hazards. In K. Kümmerer (Eds.) Pharmaceuticals in the Environment (pp. 95-102). Springer, Berlin, Heidelberg, Germany.

Hamscher, G., Pawelzick, H. T., Sczesny, S., Nau, H., \& Hartung, J. (2003). Antibiotics in dust originating from a pig-fattening farm: a new source of health hazard for farmers? Environmental Health Perspectives, 111(13), 1590-1594.

Han, I. K., Lee, J. H., Piao, X. S., \& Li, D. (2001). Feeding and management system to reduce environmental pollution in swine production-review. Asian-Australasian Journal of Animal Sciences, 14(3), 432-444.

Harting, J. R., Gleason, A., Romberger, D. J., Von Essen, S. G., Qiu, F., Alexis, N., \& Poole, J. A. (2012). Chronic obstructive pulmonary disease patients have greater systemic responsiveness to ex vivo stimulation with swine dust extract and its components versus healthy volunteers. Journal of Toxicology and Environmental Health, Part A, 75(24), 1456-1470.

Hartung, J. (1985). Gas chromatographic analysis of volatile fatty acids and phenolic/indolic compounds in pig house dust after ethanolic extraction. Environmental Technology Letters, 6(1-11), 21-30.

Hartung, J. (1986). Dust in livestock buildings as a carrier of odours. In V.C. Nielsen, J.H. Voorburg, \& P. L'Hermite (Eds.) Odour Prevention and Control of Organic Sludge and Livestock Farming, Elsevier Applied Science Publishers, London, United Kingdom.

Hayes, E. T., Leek, A. B. G., Curran, T. P., Dodd, V. A., Carton, O. T., Beattie, V. E., \& O’Doherty, J. V. (2004). The influence of diet crude protein level on odour and ammonia emissions from finishing pig houses. Bioresource Technology, 91(3), 309-315.

He, Y., Yuan, Q., Mathieu, J., Stadler, L., Senehi, N., Sun, R., \& Alvarez, P. J. (2020). Antibiotic resistance genes from livestock waste: Occurrence, dissemination, and treatment. NPJ Clean Water, 3(1), 1-11.

Heber, A. J., \& Martin, C. R. (1991). Effect of additives on aerodynamic segregation of dust from swine feed. Transactions of the ASAE, 31(2), 558-0563. 
Heber, A. J., Lim, T. T., Ni, J. Q., Tao, P. C., Schmidt, A. M., Koziel, J. A., Hoff, S.J., Jacobson, L.D, Zhang, Y., \& Baughman, G. B. (2006). Quality-assured measurements of animal building emissions: Particulate matter concentrations. Journal of the Air \& Waste Management Association, 56(12), 1642-1648.

Heber, A. J., Stroik, M., Faubion, J. M., \& Willard, L. H. (1988a). Size distribution and identification of aerial dust particles in swine finishing buildings. Transactions of the ASAE, 31(3), 882-0887.

Heber, A. J., Stroik, M., Nelssen, J. L., \& Nichols, D. A. (1988b). Influence of environmental factors on concentrations and inorganic content of aerial dust in swine finishing buildings. Transactions of the ASAE, 31(3), 875-0881.

Heederik, D., Brouwer, R., Biersteker, K., \& Boleij, J. S. (1991). Relationship of airborne endotoxin and bacteria levels in pig farms with the lung function and respiratory symptoms of farmers. International Archives of Occupational and Environmental Health, 62(8), 595-601.

Heederik, D., Sigsgaard, T., Thorne, P. S., Kline, J. N., Avery, R., Bønløkke, J. H., Chrischilles, E. A., Dosman, J. A., Duchaine, C., Kirkhorn, S. R., \& Merchant, J. A. (2007). Health effects of airborne exposures from concentrated animal feeding operations. Environmental Health Perspectives, 115(2), 298-302.

Helander, I., Saxen, H., Salkinoja-Salonen, M., \& Rylander, R. (1982). Pulmonary toxicity of endotoxins: comparison of lipopolysaccharides from various bacterial species. Infection and Immunity, 35(2), 528-532.

Heldal, K., Skogstad, A., \& Eduard, W. (1996). Improvements in the quantification of airborne microorganisms in the farm environment by epifluorescence microscopy. The Annals of Occupational Hygiene, 40(4), 437-447.

Hering, S. V., \& Stolzenburg, M. R. (1995). On-line determination of particle size and density in the nanometer size range. Aerosol Science and Technology, 23(2), 155-173.

Hinds, W. C. (1999). Aerosol Technology: Properties, Behavior, and Measurement of Airborne Particles. John Wiley \& Sons, New York.

Hinz, T., \& Linke, S. (1998). A comprehensive experimental study of aerial pollutants in and emissions from livestock buildings. Part 2: Results. Journal of Agricultural Engineering Research, 70, 119129.

Hofer, B. J., \& Nicolai, D. E. (2007). Electrostatic space charge system for reducing dust in a swine finishing barn. In 2007 ASABE/CSBE North Central Intersectional Conference, American Society of Agricultural and Biological Engineers, Fargo, ND.

Holness, D. L., O'Blenis, E. L., Sass-Kortsak, A., Pilger, C., \& Nethercott, J. R. (1987). Respiratory effects and dust exposures in hog confinement farming. American Journal of Industrial Medicine, 11(5), 571-580.

Honey, L. F., \& McQuitty, J. B. (1979). Some physical factors affecting dust concentrations in a pig facility. Canadian Agricultural Engineering, 21(1), 9-14.

Hong, P. Y., Li, X., Yang, X., Shinkai, T., Zhang, Y., Wang, X., \& Mackie, R. I. (2012). Monitoring airborne biotic contaminants in the indoor environment of pig and poultry confinement buildings. Environmental Microbiology, 14(6), 1420-1431.

Hong, S. W., Park, J., Jeong, H., \& Kim, M. (2021). Evaluation of the microbiome composition in particulate matter inside and outside of pig houses. Journal of Animal Science and Technology. DOI: https://doi.org/10.5187/jast.2021.e52

Hopke, P. K. (2016). Review of receptor modeling methods for source apportionment. Journal of the Air \& Waste Management Association, 66(3), 237-259.

Hu, M., Peng, J., Sun, K., Yue, D., Guo, S., Wiedensohler, A., \& Wu, Z. (2012). Estimation of sizeresolved ambient particle density based on the measurement of aerosol number, mass, and chemical size distributions in the winter in Beijing. Environmental Science \& Technology, 46(18), 9941-9947. 
Huaitalla, R. M., Gallmann, E., \& Liu, X. (2011). Particulate Matter emitted from a Pig Farm in Beijing: A Preliminary Study. In $2^{\text {nd }}$ International Conference on Environmental Science and Development (pp. 45 - 47), Singapore.

Ijaz, M. K. (1985). Studies on the airborne survival of rotaviruses and a human coronavirus. Ph.D. dissertation, University of Ottawa, Ottawa, Ontario, Canada.

Ijaz, M. K., Karim, Y. G., Sattar, S. A., \& Johnson-Lussenburg, C. M. (1987). Development of methods to study the survival of airborne viruses. Journal of Virological Methods, 18(2-3), 87-106.

Iossifova, Y. Y. (2006). (1-3)- $\beta-D-G l u c a n s$ in Indoor Environments-Laboratory Analysis and Wheeze in Infants, Ph.D. dissertation, University of Cincinnati, Cincinnati, $\mathrm{OH}$.

Iversen, M., Kirychuk, S., Drost, H., \& Jacobson, L. (2000). Human health effects of dust exposure in animal confinement buildings. Journal of Agricultural Safety and Health, 6(4), 283.

Jacobson, L. D., Heber, A. J., Hoff, S. J., Zhang, Y., Beasley, D. B., Koziel, J. A., \& Hetchler, B. P. (2006). Aerial pollutants emissions from confined animal buildings. In Workshop on Agricultural Air Quality (pp. 775-874), Washington, DC.

Janni, K. A., Torremorell, M., Jacobson, L. D., Alonso, C., \& Hetchler, B. P. (2018). Modeling airborne virus concentrations in filtered swine barns with negative-pressure ventilating systems. Transactions of the ASABE, 61(3), 1089-1099.

Janssen, J. E. (1999). The history of ventilation and temperature control: The first century of air conditioning. ASHRAE Journal, 41(10), 47-52.

Jargot, D., \& Melin, S. (2013). Characterization and validation of sampling and analytical methods for mycotoxins in workplace air. Environmental Science: Processes \& Impacts, 15(3), 633-644.

Jerez, S. B. (2007). Airborne pollutant spatial distribution, emission, and ventilation effectiveness for mechanically ventilated livestock buildings. Ph.D. dissertation, University of Illinois at UrbanaChampaign, Urbana, IL.

Jerez, S. B., Zhang, Y., \& Wang, X. (2008). Spatial distribution measurement and simulation of particulate matter concentration in a tunnel ventilated swine building. In Livestock Environment VIII - Proceedings of the $8^{\text {th }}$ International Symposium (pp. 85-94), Iguassu Falls, Brazil.

Jerez, S. B., Zhang, Y., \& Wang, X. (2009). Spatial distribution measurement and simulation of particulate matter concentration in a tunnel ventilated swine building. In Livestock Environment VIII (pp. 85- 94), American Society of Agricultural and Biological Engineers, Iguassu Falls, Brazil.

Jerez, S. B., Zhang, Y., \& Wang, X. (2011a). Measurement of particle size distribution in a swine building. Transactions of the ASABE, 54(3), 1103-1117.

Jerez, S. B., Zhang, Y., \& Wang, X. (2011b). Spatial and temporal distributions of dust and ammonia concentrations in a swine building. Transactions of the ASABE, 54(5), 1873-1891.

Jin, Y., \& Predicala, B. (2011). Evaluation of engineering and management control measures for improving air quality in swine production. In CSBE/SCGAB 2011 Annual Conference (Paper No. CSBE11-300). Canadian Society for Bioengineering, Winnipeg, Manitoba, Canada.

Jin, Y., Lim, T. T., Ni, J. Q., Ha, J. H., \& Heber, A. J. (2012). Emissions monitoring at a deep-pit swine finishing facility: Research methods and system performance. Journal of the Air \& Waste Management Association, 62(11), 1264-1276.

Jones, S., Anthony, T. R., Sousan, S., Altmaier, R., Park, J. H., \& Peters, T. M. (2016). Evaluation of a low-cost aerosol sensor to assess dust concentrations in a swine building. Annals of Occupational Hygiene, 60(5), 597-607.

Karlsson, K., \& Malmberg, P. (1989). Characterization of exposure to molds and actinomycetes in agricultural dusts by scanning electron microscopy, fluorescence microscopy and the culture method. Scandinavian Journal of Work, Environment \& Health, 353-359.

Keessen, E. C., Donswijk, C. J., Hol, S. P., Hermanus, C., Kuijper, E. J., \& Lipman, L. J. A. (2011). Aerial dissemination of Clostridium difficile on a pig farm and its environment. Environmental Research, 111(8), 1027-1032. 
Kelly, J. T., Avise, J., Cai, C., \& Kaduwela, A. P. (2011). Simulating particle size distributions over California and impact on lung deposition fraction. Aerosol Science and Technology, 45(2), 148162.

Kenny, L. C., R. Gussmann, and M. Meyer. 2000. Development of a sharp-cut cyclone for ambient aerosol monitoring applications. Aerosol Science and Technology. 32(4): 338-358.

Kiekhaefer, M. S., Donham, K. J., Whitten, P., \& Thorne, P. S. (1995). Cross seasonal studies of airborne microbial populations and environment in swine buildings: implications for worker and animal health. Annals of Agricultural and Environmental Medicine, 2(1), 37-44.

Kim, K. H., Kabir, E., \& Kabir, S. (2015). A review on the human health impact of airborne particulate matter. Environment International, 74, 136-143.

Kim, K. Y., \& Ko, H. J. (2019). Indoor distribution characteristics of airborne bacteria in pig buildings as influenced by season and housing type. Asian-Australasian Journal of Animal Sciences, 32(5), 742.

Kim, K. Y., Ko, H. J., Kim, H. T., \& Kim, C. N. (2006). Effect of spraying biological additives for reduction of dust and bioaerosol in a confinement swine house. Annals of Agricultural and Environmental Medicine, 13(1), 133-138.

Kim, K. Y., Ko, H. J., Kim, H. T., Kim, C. N., \& Kim, Y. S. (2008). Assessment of airborne bacteria and fungi in pig buildings in Korea. Biosystems Engineering, 99(4), 565-572.

Kim, K. Y., Ko, H. J., Kim, H. T., Kim, Y. S., Roh, Y. M., Lee, C. M., \& Kim, C. N. (2007). Influence of extreme seasons on airborne pollutant levels in a pig-confinement building. Archives of Environmental \& Occupational Health, 62(1), 27-32.

Kim, K. Y., Ko, H. J., Kim, Y. S., \& Kim, C. N. (2008). Assessment of Korean farmer's exposure level to dust in pig buildings. Annals of Agricultural and Environmental Medicine, 15(1), 51-58.

Kim, K. Y., Ko, H. J., Lee, K. J., Park, J. B., \& Kim, C. N. (2005). Temporal and spatial distributions of aerial contaminants in an enclosed pig building in winter. Environmental Research, 99(2), 150157.

Kirkhorn, S. R., \& Garry, V. F. (2000). Agricultural lung diseases. Environmental Health Perspectives, 108(S4), 705-712.

Ko, G., Simmons, III, O. D., Likirdopulos, C. A., Worley-Davis, L., Williams, C. M., \& Sobsey, M. D. (2010). Endotoxin levels at swine farms using different waste treatment and management technologies. Environmental Science \& Technology, 44(9), 3442-3448.

Koon, J., Howes, J. R., Grub, W., \& Rollo, C. A. (1963). Poultry dust: Origin and composition. Agricultural Engineering, 44(11), 608-609.

Kosová, M., Dolejš̌, J., Toufar, O., Knížek, J., \& Adamec, T. (2009). Analysis of dust fractiones at piggery. Research in Pig Breeding, 3(2), 7-10.

Kraemer, J. G., Aebi, S., Oppliger, A., \& Hilty, M. (2019). The indoor-air microbiota of pig farms drives the composition of the pig farmers' nasal microbiota in a season-dependent and farm-specific manner. Applied and Environmental Microbiology, 85(9), e3038-18.

Kraemer, J. G., Ramette, A., Aebi, S., Oppliger, A., \& Hilty, M. (2018). Influence of pig farming on the human nasal microbiota: key role of airborne microbial communities. Applied and Environmental Microbiology, 84(6), e02470-17.

Kristiansen, A., Saunders, A. M., Hansen, A. A., Nielsen, P. H., \& Nielsen, J. L. (2012). Community structure of bacteria and fungi in aerosols of a pig confinement building. FEMS Microbiology Ecology, 80(2), 390-401.

Kumari, P., \& Choi, H. L. (2014). Seasonal variability in airborne biotic contaminants in swine confinement buildings. PLoS One, 9(11), e112897.

Kumari, P., \& Choi, H. L. (2015). Manure removal system influences the abundance and composition of airborne biotic contaminants in swine confinement buildings. Environmental Monitoring and Assessment, 187(8), 1-10. 
Kumari, P., Woo, C., Yamamoto, N., \& Choi, H. L. (2016). Variations in abundance, diversity and community composition of airborne fungi in swine houses across seasons. Scientific Reports, $6(1), 1-11$.

Kwon, K. S., Lee, I. B., \& Ha, T. (2016). Identification of key factors for dust generation in a nursery pig house and evaluation of dust reduction efficiency using a CFD technique. Biosystems Engineering, 151, 28-52.

La, A., Zhang, Q., Levin, D. B., \& Coombs, K. M. (2019). The effectiveness of air ionization in reducing bioaerosols and airborne PRRS virus in a ventilated space. Transactions of the ASABE, 62(5), 1299-1314.

Lai, H. T. L., Aarnink, A. J. A., Cambra-López, M., Huynh, T. T. T., Parmentier, H. K., \& Koerkamp, P. G. (2014). Size distribution of airborne particles in animal houses. Agricultural Engineering International: CIGR Journal, 16(3), 28-42.

Lai, J., Wang, H. H., Ortega, D. L., \& Widmar, N. J. O. (2018). Factoring Chinese consumers' risk perceptions into their willingness to pay for pork safety, environmental stewardship, and animal welfare. Food Control, 85, 423-431.

Lammel, G., Schneider, F., Brüggemann, E., Gnauk, T., Röhrl, A., \& Wieser, P. (2004). Aerosols emitted from a livestock farm in southern Germany. Water, Air, and Soil Pollution, 154(1-4), 313-330.

Lange, J. L. (1996). Bioaerosols: Molecular techniques for assessment and determinants of exposure in agriculture. Ph.D. dissertation, The University of Iowa, Iowa City, IA.

Lange, J. L., Thorne, P. S., \& Lynch, N. (1997). Application of flow cytometry and fluorescent in situ hybridization for assessment of exposures to airborne bacteria. Applied and Environmental Microbiology, 63(4), 1557-1563.

Larsson, K., Eklund, A., Malmberg, P., \& Belin, L. (1992). Alterations in bronchoalveolar lavage fluid but not in lung function and bronchial responsiveness in swine confinement workers. Chest, 101(3), 767-774.

Lau, A. K., Vizcarra, A. T., Lo, K. V., \& Luymes, J. (1996). Recirculation of filtered air in pig barns. Canadian Agricultural Engineering, 38, 297-304.

Lavoie, J., Godbout, S., Lemay, S. P., \& Belzile, M. (2009). Impact of in-barn manure separation on biological air quality in an experimental setup identical to that in swine buildings. Journal of Agricultural Safety and Health, 15(3), 225-240.

Le, P. D., Aarnink, A. J., Ogink, N. W., Becker, P. M., \& Verstegen, M. W. (2005). Odour from animal production facilities: its relationship to diet. Nutrition Research Reviews, 18(1), 3-30.

Lee, J. (2009). Characterization and concentrations of particulate matters emitted from confinement animal buildings. Ph.D. dissertation. University of Illinois at Urbana-Champaign, Urbana, IL.

Lee, J., \& Zhang, Y. (2008). Evaluation of gas emissions from animal building dusts using a cylindrical convective chamber. Biosystems Engineering, 99(3), 403-411.

Lee, J., Zhang, Y., Wang, X., Yang, X., Su, J., Faulkner, B., Shaw, B., \& Riskowski, G. L. (2008). Measurement of particle size distributions in swine buildings. In Livestock Environment VIIIProceedings of the $8^{\text {th }}$ International Symposium (pp. 95-100), Iguassu Falls, Brazil.

Lee, S. A., \& Liao, C. H. (2014). Size-selective assessment of agricultural workers' personal exposure to airborne fungi and fungal fragments. Science of the Total Environment, 466, 725-732.

Lemay, S. P., Chenard, L., Barber, E. M., \& Fengler, R. (2000). Optimization of a sprinkling system using undiluted canola oil for dust control in pig buildings. In Air Pollution from Agricultural Operations - Proceedings of the Second International Conference (pp. 337-344), American Society of Agricultural Engineers, Des Moines, IA.

Létourneau, V., Duchaine, C., Belzile, M., Girard, M., Lemay, S. P., \& Godbout, S. (2020). Bench-scale pig buildings: Validation of a model for studying airborne contaminants of concern for human and animal health. Transactions of the ASABE, 63(2), 541-548.

Létourneau, V., Néhme, B., Mériaux, A., Massé, D., \& Duchaine, C. (2009). Impact of production systems on swine confinement buildings bioaerosols. Journal of Occupational and Environmental Hygiene, 7(2), 94-102. 
Létourneau, V., Nehmé, B., Mériaux, A., Massé, D., Cormier, Y., \& Duchaine, C. (2010). Human pathogens and tetracycline-resistant bacteria in bioaerosols of swine confinement buildings and in nasal flora of hog producers. International Journal of Hygiene and Environmental Health, 213(6), 444-449.

Levy, J., \& Wilmott, R. W. (1993). Defense Mechanisms of the Respiratory Tract. In Z. Spirer, C.M. Roifman, D. Branski (Eds), Pediatric Immunology. Karger Publishers, Basel, Switzerland.

Li, Q. F., Wang-Li, L., Liu, Z., \& Heber, A. J. (2012). Field evaluation of particulate matter measurements using tapered element oscillating microbalance in a layer house. Journal of the Air \& Waste Management Association, 62(3), 322-335.

Li, X. W. (1997). Effects of dust and contaminants in animal buildings on human health and control strategies. Journal of Environmental Science \& Health Part A, 32(9-10), 2449-2469.

Li, X., Own, J.E., \& Pearson, C. C. (1993) Respirable dust from animal feeds. In Proceedings of International Livestock Environment Symposium IV, Warwick, England.

Liao, C. M., \& Singh, S. (1998). Characterizing odor adsorption on dust surface based on age and size distributions of airborne dust in a ventilated airspace. Journal of Environmental Science \& Health Part A, 33(6), 1091-1117.

Liao, C. M., \& Singh, S. (1998). Modeling dust-borne odor dynamics in swine housing based on age and size distributions of airborne dust. Applied Mathematical Modelling, 22(9), 671-685.

Liao, C. M., Chen, J. W., Huang, M. Y., Chen, J. S., \& Chang, T. J. (2001). An inhalation dose model for assessing dust-borne VOC-odor exposure from feeding in swine buildings. Transactions of the ASAE, 44(6), 1813-1824.

Licht, L. A., \& Miner, J. R. (1979). A scrubber to reduce livestock confinement building odors. Transactions of the ASAE, 22(5), 1152-1156.

Lillie, R. J. (1949). Air Pollutants Affecting the Performance of Domestic Animals: a Literature Review. Agricultural Handbook No. 380. U.S. Department of Agriculture - Agricultural Research Service, Washington, DC.

Lin, X., Reponen, T., Willeke, K., Wang, Z., Grinshpun, S. A., \& Trunov, M. (2000). Survival of airborne microorganisms during swirling aerosol collection. Aerosol Science \& Technology, 32(3), 184196.

Littmann, S. A. (1965). Fitting air-tempering and filtering equipment to animal-environment control. Transactions of the ASAE, 8(3), 349-0351.

Liu, D. (2020). Microorganisms and their components present in livestock ambient air in relation to respiratory symptoms. Ph.D. dissertation, Utrecht University, Utrecht, The Netherlands.

Liu, L. J. S., Krahmer, M., Fox, A., Feigley, C. E., Featherstone, A., Saraf, A., \& Larsson, L. (2000). Investigation of the concentration of bacteria and their cell envelope components in indoor air in two elementary schools. Journal of the Air \& Waste Management Association, 50(11), 19571967.

López-Lorenzo, G., López-Novo, C., Prieto, A., Díaz, P., Panadero, R., Rodríguez-Vega, V., Morrondo, P., Fernández, G., \& Díaz-Cao, J. M. (2021). Monitoring of porcine circovirus type 2 infection through air and surface samples in vaccinated and unvaccinated fattening farms. Transboundary and Emerging Diseases. (In press) https://doi.org/10.1111/tbed.14069.

Lühken, E., Nicolaisen, T., Stracke, J., Schulz, J., \& Kemper, N. (2019). Microbiological air quality in free-farrowing housing systems for sows. Veterinary and Animal Science, 8, 100065.

Luiken, E. (2021). Antimicrobial resistance in the farm environment: determinants of the resistome of animal feces and airborne dust. Ph.D. dissertation, Utrecht University, Utrecht, The Netherlands.

Luiken, R. E., Van Gompel, L., Bossers, A., Munk, P., Joosten, P., Hansen, R. B., Knudsen, B.E., GarcíaCobos, S., Dewulf, J., Aarestrup, F.M. and Wagenaar, J.A, Smit, L. A .M., Mevius, D. J., Heedrik, D. J. J., \& Schmitt, H. (2020). Farm dust resistomes and bacterial microbiomes in European poultry and pig farms. Environment International, 143, 105971.

Macher, J. M. (1989). Positive-hole correction of multiple-jet impactors for collecting viable microorganisms. American Industrial Hygiene Association Journal, 50(11), 561-568. 
Mackie, R.I., Stroot, P.G., \& Varel, V.H. (1998). Biochemical identification and biological origin of key odor components in livestock waste. Journal of Animal Science, 76, 1331-1342.

Mackiewicz, B. (1998). Study on exposure of pig farm workers to bioaerosols, immunologic reactivity and health effects. Annals of Agricultural and Environmental Medicine, 5, 169-176.

Madsen, A. M., Kurdi, I., Feld, L., \& Tendal, K. (2018). Airborne MRSA and total Staphylococcus aureus as associated with particles of different sizes on pig farms. Annals of Work Exposures and Health, 62(8), 966-977.

Maghirang, R. G., Puma, M. C., Liu, Y., \& Clark, P. (1997). Dust concentrations and particle size distribution in an enclosed swine nursery. Transactions of the ASAE, 40(3), 749-754.

Malmberg, P., \& Larsson, K. (1993). Acute exposure to swine dust causes bronchial hyperresponsiveness in healthy subjects. European Respiratory Journal, 6(3), 400-404.

Mamane, Y., Willis, R., \& Conner, T. (2001). Evaluation of computer-controlled scanning electron microscopy applied to an ambient urban aerosol sample. Aerosol Science \& Technology, 34(1), 97-107.

Mankell, K. O., Janni, K. A., Walker, R. D., Wilson, M. E., Pettigrew, J. E., Jacobson, L. D., \& Wilcke, W. F. (1995). Dust suppression in swine feed using soybean oil. Journal of Animal Science, 73(4), 981-985.

Martin, M. J., Thottathil, S. E., \& Newman, T. B. (2015). Antibiotics overuse in animal agriculture: a call to action for health care providers. American Journal of Public Health, 105(12), 2409-2410.

Martin, R. S., Silva, P. J., Moore, K., Erupe, M., \& Doshi, V. S. (2008). Particle composition and size distributions in and around a deep-pit swine operation, Ames, IA. Journal of Atmospheric Chemistry, 59(2), 135-150.

Martin, S. W., \& Willoughby, R. A. (1972). Organic dusts, sulfur dioxide, and the respiratory tract of swine. Archives of Environmental Health: An International Journal, 25(3), 158-165.

Martin, W. T., Zhang, Y., Willson, P., Archer, T. P., Kinahan, C., \& Barber, E. M. (1996). Bacterial and fungal flora of dust deposits in a pig building. Occupational and Environmental Medicine, 53(7), 484-487.

Masclaux, F. G., Sakwinska, O., Charrière, N., Semaani, E., \& Oppliger, A. (2013). Concentration of airborne Staphylococcus aureus (MRSA and MSSA), total bacteria, and endotoxins in pig farms. Annals of Occupational Hygiene, 57(5), 550-557.

May, S., Romberger, D. J., \& Poole, J. A. (2012). Respiratory health effects of large animal farming environments. Journal of Toxicology and Environmental Health, Part B, 15(8), 524-541.

Mbareche, H., Veillette, M., Pilote, J., Létourneau, V., \& Duchaine, C. (2019). Bioaerosols play a major role in the nasopharyngeal microbiota content in agricultural environment. International Journal of Environmental Research and Public Health, 16(8), 1375.

Mc Donnell. P., Coggins, M. A., Hogan, V. J., \& Fleming, G. T. (2008). Exposure assessment of airborne contaminants in the indoor environment of Irish swine farms. Annals of Agricultural and Environmental Medicine, 15(2), 323-326.

McDonald, R., \& Biswas, P. (2004). A methodology to establish the morphology of ambient aerosols. Journal of the Air \& Waste Management Association, 54(9), 1069-1078.

McGlone, J. J. (2013). The future of pork production in the world: towards sustainable, welfare-positive systems. Animals, 3(2), 401-415.

Menetrez, M. Y., Foarde, K. K., Dean, T. R., Betancourt, D. A., \& Moore, S. A. (2007). An evaluation of the protein mass of particulate matter. Atmospheric Environment, 41(37), 8264-8274.

Michel, O., Nagy, A. M., Schroeven, M., Duchateau, J., Neve, J., Fondu, P., \& Sergysels, R. (1997). Dose-response relationship to inhaled endotoxin in normal subjects. American Journal of Respiratory and Critical Care Medicine, 156(4), 1157-1164.

Mielniczuk, Z., Mielniczuk, E., \& Larsson, L. (1993). Gas chromatography-mass spectrometry methods for analysis of 2-and 3-hydroxylated fatty acids: Application for endotoxin measurement. Journal of Microbiological Methods, 17(2), 91-102. 
Mielniczuk, Z., Mielniczuk, E., \& Larsson, L. (1995). Determination of muramic acid in organic dust by gas chromatography-mass spectrometry. Journal of Chromatography B: Biomedical Sciences and Applications, 670(1), 167-172.

Miller, J. D., \& Young, J. C. (1997). The use of ergosterol to measure exposure to fungal propagules in indoor air. American Industrial Hygiene Association Journal, 58(1), 39-43.

Milton, D. K., Feldman, H. A., Neuberg, D. S., Bruckner, R. J., \& Greaves, I. A. (1992). Environmental endotoxin measurement: the kinetic Limulus assay with resistant-parallel-line estimation. Environmental Research, 57(2), 212-230.

Milton, D. K., Gere, R. J., Feldman, H. A., \& Greaves, I. A. (1990). Endotoxin measurement: aerosol sampling and application of a new Limulus method. American Industrial Hygiene Association Journal, 51(6), 331-337.

Molenar, J. V. (2000). Theoretical analysis of $\mathrm{PM}_{2.5}$ mass measurements by nephelometry. In Proceeding of the Air and Waste Management Association Specialty Conference: PM2000: Particulate Matter and Health (Paper No. 110). Air and Waste Management Association, Pittsburgh, PA.

Mostafa, E., Hoelscher, R., Diekmann, B., Ghaly, A. E., \& Buescher, W. (2017). Evaluation of two indoor air pollution abatement techniques in forced-ventilation fattening pig barns. Atmospheric Pollution Research, 8(3), 428-438.

Mostafa, E., Nannen, C., Henseler, J., Diekmann, B., Gates, R., \& Buescher, W. (2016). Physical properties of particulate matter from animal houses-empirical studies to improve emission modelling. Environmental Science and Pollution Research, 23(12), 12253-12263.

Murray, P. R., Rosenthal, K. S., \& Pfaller, M. A. (2020). Medical Microbiology, Ninth Edition. Elsevier Health Sciences, New York.

Naide, T., Ikeguchi, A., Islam, M. A., Katsuda, K., Kawashima, K., Nakakubo, R., \& Miyazaki, A. (2018). Relationship between aerosol concentration and airborne microbe including porcine sapelovirus concentration in Japanese weaning swine houses. In 10th International Livestock Environment Symposium (ILES X) (Paper No. ILES18-118). American Society of Agricultural and Biological Engineers, St. Joseph, MI.

Naide, T., Ikeguchi, A., Miyazaki, A., \& Katsuda, K. (2015). Effect of reducing concentration of picornaviridae, sapelo virus, porcine epidemic diarrhea virus and escherichia coli with spraying functional water. In 2015 ASABE Annual International Meeting (Paper No. 152188871). American Society of Agricultural and Biological Engineers, St. Joseph, MI.

NASS (2021). Quarterly Hogs and Pigs. National Agricultural Satistics Service (NASS). Accessed at: https://downloads.usda.library.cornell.edu/usdaesmis/files/rj430453j/7p88db205/mw22w1890/hgpg0321.pdf

Nayak, G., Andrews, A. J., Marabella, I., Aboubakr, H. A., Goyal, S. M., Olson, B. A., Torremorell, M., \& Bruggeman, P. J. (2020). Rapid inactivation of airborne porcine reproductive and respiratory syndrome virus using an atmospheric pressure air plasma. Plasma Processes and Polymers, 17(10), 1900269.

Nehmé, B., Gilbert, Y., Létourneau, V., Forster, R. J., Veillette, M., Villemur, R., \& Duchaine, C. (2009). Culture-independent characterization of archaeal biodiversity in swine confinement building bioaerosols. Applied and Environmental Microbiology, 75(17), 5445-5450.

Nehme, B., Létourneau, V., Forster, R. J., Veillette, M., \& Duchaine, C. (2008). Culture-independent approach of the bacterial bioaerosol diversity in the standard swine confinement buildings, and assessment of the seasonal effect. Environmental Microbiology, 10(3), 665-675.

Neira, V., Rabinowitz, P., Rendahl, A., Paccha, B., Gibbs, S. G., \& Torremorell, M. (2016). Characterization of viral load, viability and persistence of influenza A virus in air and on surfaces of swine production facilities. PloS One, 11(1), e0146616.

Newbury, D. E., \& Ritchie, N. W. (2013). Is scanning electron microscopy/energy dispersive X-ray spectrometry (SEM/EDS) quantitative? Scanning, 35(3), 141-168.

Ni, J. Q., Robarge, W. P., Xiao, C., \& Heber, A. J. (2012). Volatile organic compounds at swine facilities: A critical review. Chemosphere, 89(7), 769-788. 
Nilsson, C. (1982). Dust investigations in pig houses. Report 25. Department of Farm Buildings, Swedish University of Agricultural Sciences, Lund, Sweden.

NIOSH. (2021). Occupational Exposure Limits. National Institute for Occupational Safety and Health, Cincinatti, OH. Accessed at: https://www.cdc.gov/niosh/topics/flavorings/limits.html

Noble, W. C., Lidwell, O. M., \& Kingston, D. (1963). The size distribution of airborne particles carrying micro-organisms. Epidemiology \& Infection, 61(4), 385-391.

Nonnenmann, M. W., Donham, K. J., Rautiainen, R. H., O’Shaughnessy, P. T., Burmeister, L. F., \& Reynolds, S. J. (2004). Vegetable oil sprinkling as a dust reduction method in swine confinement. Journal of Agricultural Safety and Health, 10(1), 7-15.

O'Shaughnessy, P. T., Achutan, C., \& Karsten, A. W. (2002). Temporal variation of indoor air quality in an enclosed swine confinement building. Journal of Agricultural Safety and Health, 8(4), 349.

O’Shaughnessy, P. T., Donham, K. J., Peters, T. M., Taylor, C., Altmaier, R., \& Kelly, K. M. (2009). A task-specific assessment of swine worker exposure to airborne dust. Journal of Occupational and Environmental Hygiene, 7(1), 7-13.

O’Shaughnessy, P., Peters, T., Donham, K., Taylor, C., Altmaier, R., \& Kelly, K. (2012). Assessment of swine worker exposures to dust and endotoxin during hog load-out and power washing. Annals of Occupational Hygiene, 56(7), 843-851.

Oehrl, L. L., Keener, K. M., Bottcher, R. W., Munilla, R. D., \& Connelly, K. M. (2001). Characterization of odor components from swine housing dust using gas chromatography. Applied Engineering in Agriculture, 17(5), 659.

Oliver, J. D. (2005). The viable but nonculturable state in bacteria. Journal of Microbiology, 43(S1), 93100.

Olson, N. C., Brown Jr, T. T., \& Anderson, D. L. (1985). Dexamethasone and indomethacin modify endotoxin-induced respiratory failure in pigs. Journal of Applied Physiology, 58(1), 274-284.

Otake, S., Dee, S. A., Jacobson, L., Pijoan, C., \& Torremorell, M. (2002). Evaluation of aerosol transmission of porcine reproductive and respiratory syndrome virus under controlled field conditions. Veterinary Record, 150(26), 804-808.

Ouellette, C., Lemay, S., Godbout, S., \& Edeogu, I. (2006). Oil application to reduce dust and odour emissions from swine buildings. In CSBE/SCGAB 2006 Annual Conference (Paper No. 06-147). Canadian Society for Bioengineering, Edmonton, Alberta, Canada.

Palmgren, U., Ström, G., Blomquist, G., \& Malmberg, P. (1986b). Collection of airborne microorganisms on Nuclepore filters, estimation and analysis - CAMNEA method. Journal of Applied Bacteriology, 61(5), 401-406.

Palmgren, U., Ström, G., Malmberg, P., \& Blomquist, G. (1986a). The Nuclepore filter method: a technique for enumeration of viable and nonviable airborne microorganisms. American Journal of Industrial Medicine, 10(3), 325-327.

Paszek, D. A., Jacobson, L. D., Johnson, V. J., \& Nicolai, R. E. (1998). Design and management of an oil sprinkling system to control dust, odor, and gases in and from a curtain-sided pig finishing barn. In 2001 ASAE Annual Meeting (Paper No. 014076). American Society of Agricultural and Biological Engineers, Sacramento, CA.

Pearson, C. C., \& Sharples, T. J. (1995). Airborne dust concentrations in livestock buildings and the effect of feed. Journal of Agricultural Engineering Research, 60(3), 145-154.

Pedersen, S., Jørgensen, H., \& Theil, P. K. (2015). The influence of diurnal variation in animal activity and digestion on animal heat production. Agricultural Engineering International: CIGR Journal, special issue, 18-29.

Pedersen, S., Nonnenmann, M., Rautiainen, R., Demmers, T. G. M., Banhazi, T., \& Lyngbye, M. (2000). Dust in pig buildings. Journal of Agricultural Safety and Health, 6(4), 261.

Pepper, I. L., Gerba, C. P., Gentry, T. J., \& Maier, R. M. (2011). Environmental Microbiology, Second Edition. Academic Press, New York.

Perkins, S. L., \& Feddes, J. J. R. (1996). The effect of timing of floor-application of mineral oil on dust concentrations in a swine farrowing unit. Canadian Agricultural Engineering, 38(2), 123-127. 
Peters, T. M., Anthony, T. R., Taylor, C., Altmaier, R., Anderson, K., \& O’shaughnessy, P. T. (2012). Distribution of particle and gas concentrations in swine gestation confined animal feeding operations. Annals of Occupational Hygiene, 56(9), 1080-1090.

Pilote, J., Létourneau, V., Girard, M., \& Duchaine, C. (2019). Quantification of airborne dust, endotoxins, human pathogens and antibiotic and metal resistance genes in Eastern Canadian swine confinement buildings. Aerobiologia, 35(2), 283-296.

Pöhlker, C., Huffman, J. A., \& Pöschl, U. (2012). Autofluorescence of atmospheric bioaerosolsfluorescent biomolecules and potential interferences. Atmospheric Measurement Techniques, 5(1), 37-71.

Poole, J. A., Dooley, G. P., Saito, R., Burrell, A. M., Bailey, K. L., Romberger, D. J., Mehaffy, J., \& Reynolds, S. J. (2010). Muramic acid, endotoxin, 3-hydroxy fatty acids, and ergosterol content explain monocyte and epithelial cell inflammatory responses to agricultural dusts. Journal of Toxicology and Environmental Health, Part A, 73(10), 684-700.

Poole, J. A., Thiele, G. M., Alexis, N. E., Burrell, A. M., Parks, C., \& Romberger, D. J. (2009). Organic dust exposure alters monocyte-derived dendritic cell differentiation and maturation. American Journal of Physiology-Lung Cellular and Molecular Physiology, 297(4), L767-L776.

Popescu, S., Borda, C., Diugan, E. A., \& Oros, D. (2014). Microbial air contamination in indoor and outdoor environment of pig farms. Scientific Papers Animal Science and Biotechnologies, 47(1), 182-187.

Poruthoor, S. K., Dasgupta, P. K., \& Genfa, Z. (1998). Indoor air pollution and sick building syndrome. Monitoring aerosol protein as a measure of bioaerosols. Environmental Science \& Technology, 32(8), 1147-1152.

Predicala, B. Z., \& Maghirang, R. G. (2003). Field comparison of inhalable and total dust samplers for assessing airborne dust in swine confinement barns. Applied Occupational and Environmental Hygiene, 18(9), 694-701.

Predicala, B. Z., \& Maghirang, R. G. (2004). Measurement of particulate matter emission rates from mechanically ventilated swine barns. Transactions of the ASAE, 47(2), 557.

Predicala, B. Z., Maghirang, R. G., Jerez, S. B., Urban, J. E., \& Goodband, R. D. (2001). Dust and bioaerosol concentrations in two swine Finisher buildings in Kansas. Transactions of the ASAE, 44(5), 1291-1298.

Predicala, B. Z., Urban, J. E., Maghirang, R. G., Jerez, S. B., \& Goodband, R. D. (2002). Assessment of bioaerosols in swine barns by filtration and impaction. Current Microbiology, 44(2), 136-140.

Preller, L., Heederik, D., Kromhout, H., Boleij, J. S., \& Tielen, M. J. (1995). Determinants of dust and endotoxin exposure of pig farmers: development of a control strategy using empirical modelling. Annals of Occupational Hygiene, 39(5), 545-557.

Priebe, A., Kvisgaard, L. K., Rathkjen, P. H., Hjulsager, C. K., Havn, K., \& Larsen, L. E. (2015, June). Detection of PRRSV in air sampled inside and outside PRRSV-positive herds in Denmark. In Proceedings of the International Porcine Reproductive and Respiratory Syndrome Congress (pp. 3-5), Ghent, Belgium.

Prueger, J. H., Eichinger, W. E., Barnhardt, B., Lewandowski, P., Pfeiffer, R. L., \& Hatfield, J. L. (2008). Particulate and Ammonia Concentration Measurements from a Poultry Facility in Central Iowa. Accessed at: https://www.iihr.uiowa.edu/wp-content/uploads/2013/06/TR-468.pdf

Puma, M. C., Maghirang, R. G., Hosni, M. H., \& Hagen, L. (1999). Modeling of dust concentration distribution in a simulated swine room under non-isothermal conditions. Transactions of the ASAE, 42(6), 1823-1832.

Rademacher, C., Bradley, G., Pollmann, S., Coffelt, B., Baumgartner, M., \& Baumgartner, J. (2012). Electrostatic particle ionization (EPI) improves nursery pig performance and air quality. In 2012 AASV Annual Meeting: Integrating Science, Welfare, and Economics in Practice (pp. 257-258), American Association of Swine Veterinarians, Perry, IA. 
Radon, K., Danuser, B., Iversen, M., Monso, E., Weber, C., Hartung, J., Donham, K., Palmgren, U., \& Nowak, D. (2002). Air contaminants in different European farming environments. Annals of Agricultural and Environmental Medicine, 9(1), 41-48.

Razote, E. B., Maghirang, R. G., Seitz, L. M., \& Jeon, I. J. (2004). Characterization of volatile organic compounds on airborne dust in a swine finishing barn. Transactions of the ASAE, 47(4), 1231.

Razote, E. B., Maghirang, R. G., Seitz, L. M., \& Jeon, I. J. (2002). Characterization of volatile organic compounds in airborne dust. In 2002 ASAE Annual Meeting (Paper no. 02-4162). American Society of Agricultural and Biological Engineers, St Joseph, MI.

Reeve, K. A., Peters, T. M., \& Anthony, T. R. (2013). Wintertime factors affecting contaminant distribution in a swine farrowing room. Journal of Occupational and Environmental Hygiene, 10(6), 287-296.

Regev-Yochay, G., Trzcinski, K., Thompson, C. M., Malley, R., \& Lipsitch, M. (2006). Interference between Streptococcus pneumoniae and Staphylococcus aureus: in vitro hydrogen peroxidemediated killing by Streptococcus pneumoniae. Journal of Bacteriology, 188(13), 4996-5001.

Reponen, T., Willeke, K., Grinshpun, S., \& Nevalainen, A. (2001). Biological particle sampling. In: P.A. Baron \& K. Willeke (Eds), Aerosol Measurement: Principles, Techniques, and Applications (pp. 549-570). John Wiley and Sons, New York.

Reynolds, S. J., Donham, K. J., Whitten, P., Merchant, J. A., Burmeister, L. F., \& Popendorf, W. J. (1996). Longitudinal evaluation of dose-response relationships for environmental exposures and pulmonary function in swine production workers. American Journal of Industrial Medicine, 29(1), 33-40.

Reynolds, S. J., Milton, D. K., Heederik, D., Thorne, P. S., Donham, K. J., Croteau, E. A., ... \& Larsson, L. (2005). Interlaboratory evaluation of endotoxin analyses in agricultural dusts - comparison of LAL assay and mass spectrometry. Journal of Environmental Monitoring, 7(12), 1371-1377.

Reynolds, S.J., Thorne, P.S., Donham, K.J., Croteau, E.A., Kelly, K.M., Lewis, D., Whitmer, M., Heederik, D.J.J., Douwes, J., Connaughton, I., Koch, S., Malmberg, P., Larsson, B.M., \& Milton, D.K. (2002). Comparison of endotoxin assays using agricultural dusts. American Industrial Hygiene Association Journal, 63, 430-438.

Ristimäki, J., Virtanen, A., Marjamäki, M., Rostedt, A., \& Keskinen, J. (2002). On-line measurement of size distribution and effective density of submicron aerosol particles. Journal of Aerosol Science, $33(11), 1541-1557$.

Robertson, J. F. (1992). Dust and ammonia in pig buildings. Farm Buillding Progress, 1992, 110, 19-24.

Rodríguez de Evgrafov, M., Kõll, P., Frank, D. N., Baumgartner, L. K., Robertson, C. E., Hernández, M. T., \& Pace, N. R. (2013). Molecular analysis of bacterial and circovirus bioaerosols in concentrated animal feeding operations. Aerosol Science and Technology, 47(7), 755-766.

Rosentrater, K. A. (2003). Performance of an electrostatic dust collection system in swine facilities. Agricultural Engineering International: CIGR Journal, 1-10.

Rule, A. M., Chapin, A. R., McCarthy, S. A., Gibson, K. E., Schwab, K. J., \& Buckley, T. J. (2005). Assessment of an aerosol treatment to improve air quality in a swine concentrated animal feeding operation (CAFO). Environmental Science \& Technology, 39(24), 9649-9655.

Rylander, R. (1999). Indoor air-related effects and airborne (1--> 3)-beta-D-glucan. Environmental Health Perspectives, 107(S3), 501-503.

Rylander, R., \& Etzel, R. (1999). Introduction and summary: workshop on children's health and indoor mold exposure. Environmental Health Perspectives, 107(S3), 465-468.

Rylander, R., Donham, K. J., Hjort, C., Brouwer, R., \& Heederik, D. (1989). Effects of exposure to dust in swine confinement buildings - a working group report. Scandinavian Journal of Work, Environment \& Health, 309-312.

Rylander, R., Persson, K., Goto, H., Yuasa, K., \& Tanaka, S. (1992). Airborne beta-1, 3-glucan may be related to symptoms in sick buildings. Indoor Environment, 1(5), 263-267. 
Salazar-Cerezo, S., Martinez-Montiel, N., Cruz-Lopez, M. D. C., \& Martinez-Contreras, R. D. (2018). Fungal diversity and community composition of culturable fungi in Stanhopea trigrina cast gibberellin producers. Frontiers in Microbiology, 9, 612.

Sander, I., Fleischer, C., Borowitzki, G., Brüning, T., \& Raulf-Heimsoth, M. (2008). Development of a two-site enzyme immunoassay based on monoclonal antibodies to measure airborne exposure to $(1 \rightarrow 3)-\beta-D-g l u c a n$. Journal of Immunological Methods, 337(1), 55-62.

Sapkota, A. R., Ojo, K. K., Roberts, M. C., \& Schwab, K. J. (2006). Antibiotic resistance genes in multidrug-resistant Enterococcus spp. and Streptococcus spp. recovered from the indoor air of a large-scale swine-feeding operation. Letters in Applied Microbiology, 43(5), 534-540.

Saraf, A., Larsson, L., Burge, H., \& Milton, D. (1997). Quantification of ergosterol and 3-hydroxy fatty acids in settled house dust by gas chromatography-mass spectrometry: comparison with fungal culture and determination of endotoxin by a Limulus amebocyte lysate assay. Applied and Environmental Microbiology, 63(7), 2554-2559.

Saraf, A., Park, J. H., Milton, D. K., \& Larsson, L. (1999). Use of quadrupole GC-MS and ion trap GCMS-MS for determining 3-hydroxy fatty acids in settled house dust: relation to endotoxin activity. Journal of Environmental Monitoring, 1(2), 163-168.

Sattar, S. A., Ijaz, M. K., \& Gerba, C. P. (1987). Spread of viral infections by aerosols. Critical Reviews in Environmental Control, 17(2), 89-131.

Sauvé, J. F., Locke, S. J., Josse, P. R., Stapleton, E. M., Metwali, N., Altmaier, R. W., Andreotti, G., Thorne, P.S., Hofmann, J. N., Freeman, L.E. B, \& Friesen, M. C. (2020). Characterization of inhalable endotoxin, glucan, and dust exposures in Iowa farmers. International Journal of Hygiene and Environmental Health, 228, 113525.

Schenker, M. B., Christiani, D., Cormier, Y., Dimich-Ward, H., Doekes, G., Dosman, J., Douwes, J., Dowling, K., Enarson, D., Green, F., Heederik, D., Husman, K., Kennedy, S., Kullman, G., Lacasse, Y., Lawson, B., Malmberg, P., May, J., McCurdy, S., Merchant, J., Myers, J., Nieuwenhuijsen, M., Olenchock, S., Saiki, C., Schwartz, D., Seiber, J., Thorne, P., Wagner, G., White, N., Xu, X. P., \& Chan-Yeung, M. (1998). Respiratory health hazards in agriculture. American Journal of Respiratory and Critical Care Medicine, 158(5), S1-S76.

Schierl, R., Heise, A., Egger, U., Schneider, F., Eichelser, R., Neser, S., \& Nowak, D. (2007). Endotoxin concentration in modern animal houses in southern Bavaria. Annals of Agricultural and Environmental Medicine, 14(1).

Schiraldi C., De Rosa M. (2014) Mesophilic organisms. In: E. Drioli \& L. Giorno (Eds), Encyclopedia of Membranes. Springer, Berlin, Heidelberg, Germany.

Schmidt, D. R., Jacobson, L. D., \& Janni, K. A. (2002). Continuous monitoring of ammonia, hydrogen sulfide and dust emissions from swine, dairy and poultry barns. In 2002 ASAE Annual Meeting / CIGR XVth World Congress (Paper Number: 024060), American Society of Agricultural Engineers and Commission Internationale du Genie Rural, Chicago, IL.

Schneider, F. E., Engelhardt, T., \& Wieser, P. H. (2001). Characterization of aerosol particles from animal husbandry with single particle analytic techniques. In 2001 ASAE Annual Meeting (Paper No. 014010). American Society of Agricultural and Biological Engineers, Sacramento, CA.

Schulz, J., Friese, A., Klees, S., Tenhagen, B. A., Fetsch, A., Rösler, U., \& Hartung, J. (2012). Longitudinal study of the contamination of air and of soil surfaces in the vicinity of pig barns by livestock-associated methicillin-resistant Staphylococcus aureus. Applied and Environmental Microbiology, 78(16), 5666-5671.

Schulz, J., Kemper, N., Hartung, J., Janusch, F., Mohring, S. A., \& Hamscher, G. (2019). Analysis of fluoroquinolones in dusts from intensive livestock farming and the co-occurrence of fluoroquinolone-resistant Escherichia coli. Scientific Reports, 9(1), 1-7.

Schwartz, D. A., Thorne, P. S., Yagla, S. J., Burmeister, L. F., Olenchock, S. A., Watt, J. L., \& Quinn, T. J. (1995). The role of endotoxin in grain dust-induced lung disease. American Journal of Respiratory and Critical Care Medicine, 152(2), 603-608. 
Seedorf, J., Hartung, J., Schröder, M., Linkert, K. H., Phillips, V. R., Holden, M. R., Sneath, R.W., Short, J.L., White, R. P., Pedersen, S., Takai, H., Johnsen., J. O., Metz, J. H. M., Groot Koerkamp., P. W. G., Uenk, G. H., \& Wathes, C. M. (1998). Concentrations and emissions of airborne endotoxins and microorganisms in livestock buildings in Northern Europe. Journal of Agricultural Engineering Research, 70(1), 97-109.

Sender, R., Fuchs, S., \& Milo, R. (2016). Revised estimates for the number of human and bacteria cells in the body. PLoS biology, 14(8), e1002533.

Senthilselvan, A., Zhang, Y., Dosman, J. A., Barber, E. M., Holfeld, L. E., Kirychuk, S. P., Cormier, Y., Hurst, T.S., \& Rhodes, C. S. (1997). Positive human health effects of dust suppression with canola oil in swine barns. American Journal of Respiratory and Critical Care Medicine, 156, 410-417.

Shang, B., Liu, Y., Dong, H., Tao, X., \& Yao, H. (2020). Particulate matter concentrations and emissions of a fattening pig facility in northern China. Atmospheric Pollution Research, 11(11), 1902-1911.

Shen, D., Wu, S., Li, Z., Tang, Q., Dai, P., Li, Y., \& Li, C. (2019). Distribution and physicochemical properties of particulate matter in swine confinement barns. Environmental Pollution, 250, 746753.

Shin, S. J., Song, E. S., Kim, J. W., Lee, J. H., Gautam, R., Kim, H. J., Kim, Y.G., Cho, A.R., Yang, S.J., Acharya, M., Kim, C.Y., Lee, B.C., Kim, C.H., Oh, H.G., Kwag, J.H., Yoon, D.H., Kim, H.A., \& Heo, Y. (2019). Major environmental characteristics of swine husbandry that affect exposure to dust and airborne endotoxins. Journal of Toxicology and Environmental Health, Part A, 82(4), 233-243.

Shirley, G. L. (1905). Farm Hygiene. Kansas State University, Manhattan, KS.

Siggers, J. L., Kirychuk, S. P., Lemay, S. P., \& Willson, P. J. (2011). Size distribution of particulate and associated endotoxin and bacteria in traditional swine barn rooms and rooms sprinkled with oil. Journal of Agromedicine, 16(4), 271-279.

Sigsgaard, T., Malmros, P., Nersting, L., \& Petersen, C. (1994). Respiratory disorders and atopy in Danish refuse workers. American Journal of Respiratory and Critical Care Medicine, 149(6), 1407-1412.

Simpson, J. C. G., Niven, R. M., Pickering, C. A. C., Oldham, L. A., Fletcher, A. M., \& Francis, H. C. (1999). Comparative personal exposures to organic dusts and endotoxin. Annals of Occupational Hygiene, 43(2), 107-115.

Singhal, N., Kumar, M., Kanaujia, P. K., \& Virdi, J. S. (2015). MALDI-TOF mass spectrometry: an emerging technology for microbial identification and diagnosis. Frontiers in Microbiology, 6 , 791.

Smit, L. A., Heederik, D., Doekes, G., Blom, C., van Zweden, I., \& Wouters, I. M. (2008). Exposureresponse analysis of allergy and respiratory symptoms in endotoxin-exposed adults. European Respiratory Journal, 31(6), 1241-1248.

Smith, D., \& Španěl, P. (2005). Selected ion flow tube mass spectrometry (SIFT-MS) for on-line trace gas analysis. Mass Spectrometry Reviews, 24(5), 661-700.

Song, L., Wang, C., Jiang, G., Ma, J., Li, Y., Chen, H., \& Guo, J. (2021). Bioaerosol is an important transmission route of antibiotic resistance genes in pig farms. Environment International, 154, 106559.

Sowiak, M., Bródka, K., Buczyńska, A., Cyprowski, M., Kozajda, A., Sobala, W., \& SzadkowskaStańczyk, I. (2012). An assessment of potential exposure to bioaerosols among swine farm workers with particular reference to airborne microorganisms in the respirable fraction under various breeding conditions. Aerobiologia, 28(2), 121-133.

Spaan, S., Doekes, G., Heederik, D., Thorne, P.S., \& Wouters, I.A. (2008). Effect of extraction and assay media on analysis of airborne endotoxin. Applied and Environmental Microbiology, 74, 38043811 . 
Spaan, S., Heederik, D.J.J., Thorne, P.S., \& Wouters, I.M. (2007). Optimization of airborne endotoxin exposure assessment: Effects of filter type, transport conditions, extraction solutions, and storage of samples and extracts. Applied and Environmental Microbiology, 73, 6134-6143.

Spaan, S., Wouters, I. M., Oosting, I., Doekes, G., \& Heederik, D. (2005). Exposure to inhalable dust and endotoxins in agricultural industries. Journal of Environmental Monitoring, 8(1), 63-72.

Spoelstra, S.F., 1980. Origin of objectionable odorous components in piggery wastes and the possibility of applying indicator components for studying odor development. Agricultural Environment, 5, 241-260.

Stein, H., Schulz, J., Morgenstern, R., Voglmayr, T., Freymüller, G., Sinn, L., Rümenapf, T., HennigPauka, I., \& Ladinig, A. (2018). Use of Three Air Samplers for the Detection of PRRSV-1 under Experimental and Field Conditions. Animals, 8(12), 233.

Stroik, M. (1987). A quantitative and qualitative analysis of swine finishing house dust with scanning electron and light microscopy. M.S. thesis, Kansas State University, Manhattan, KS.

Takai, H. (1987): Minimise dust by spraying oil emulsion. Pig-Misset, 3, 1-13.

Takai, H., \& Pedersen, S. (2000). A comparison study of different dust control methods in pig buildings. Applied Engineering in Agriculture, 16(3), 269-277.

Takai, H., Jacobson, L. D., \& Pedersen, S. (1996). Reduction of dust concentration and exposure in pig buildings by adding animal fat in feed. Journal of Agricultural Engineering Research, 63(2), 113120.

Takai, H., Møller, F., Iversen, M., Jorsal, S. E., \& Bille-Hansen, V. (1995). Dust control in pig houses by spraying rapeseed oil. Transactions of the ASAE, 38(5), 1513-1518.

Takai, H., Pedersen, S., Johnsen, J. O., Metz, J. H. M., Koerkamp, P. G., Uenk, G. H., Phillips, V. R., Holden, M.R., Sneath, R.W., Short, J. L., White, R. P., Hartung, J., Seedorf, J., Schröder, M., Linkert, K.H., \& Wathes, C.M. (1998). Concentrations and emissions of airborne dust in livestock buildings in Northern Europe. Journal of Agricultural Engineering Research, 70, 59-77.

Tan, Z., \& Zhang, Y. (2004). A review of effects and control methods of particulate matter in animal indoor environments. Journal of the Air \& Waste Management Association, 54(7), 845-854.

Tanaka, A., \& Zhang, Y. (1996). Dust settling efficiency and electrostatic effect of a negative ionization system. Journal of Agricultural Safety and Health, 2(1): 39-47.

Tang, Q., Huang, K., Liu, J., Jin, X., \& Li, C. (2021). Distribution characteristics of bioaerosols inside pig houses and the respiratory tract of pigs. Ecotoxicology and Environmental Safety, 212, 112006.

Tang, Q., Huang, K., Liu, J., Shen, D., Dai, P., Li, Y., \& Li, C. (2020). Seasonal variations of microbial assemblage in fine particulate matter from a nursery pig house. Science of the Total Environment, $708,134921$.

Tao, X., Shang, B., Dong, H., Chen, Y., \& Xin, H. (2019). Concentrations and distributions of airborne bacteria inside and downwind of a growing swine building in China. Transactions of the ASABE, 62(3), 731-736.

Thaler, R. C., Rops, B.D., \& Pohl, S. H. (1999). Comparison of normal corn and high oil corn (hoc) for growth performance, carcass characteristics, and dust control in swine grow-finish barns (Animal Science 9920 No. 1999), South Dakota State University, Brookings, SD.

Thedell, T. D., Mull, J. C., \& Olenchock, S. A. (1980). A brief report of gram-negative bacterial endotoxin levels in airborne and settled dusts in animal confinement buildings. American Journal of Industrial Medicine, 1(1), 3-7.

Thorn, J., Beijer, L., \& Rylander, R. (1998). Airways inflammation and glucan exposure among household waste collectors. American Journal of Industrial Medicine, 33(5), 463-470.

Thorne, P. S., \& Heederik, D. (2008). Assessment Methods for Bioaerosols. In T. Salthammer (Eds), Organic Indoor Air Pollutants: Occurrence, Measurement, Evaluation. Wiley-Vch, New York.

Thorne, P. S., Ansley, A. C., \& Perry, S. S. (2009). Concentrations of bioaerosols, odors, and hydrogen sulfide inside and downwind from two types of swine livestock operations. Journal of Occupational and Environmental Hygiene, 6(4), 211-220. 
Thorne, P. S., Bartlett, K. H., Phipps, J., \& Kulhankova, K. (2003). Evaluation of five extraction protocols for quantification of endotoxin in metalworking fluid aerosol. Annals of Occupational Hygiene, 47(1), 31-36.

Thorne, P. S., Kiekhaefer, M. S., Whitten, P., \& Donham, K. J. (1992). Comparison of bioaerosol sampling methods in barns housing swine. Applied and Environmental Microbiology, 58(8), 2543-2551.

Thorne, P. S., Reynolds, S. J., Milton, D. K., Bloebaum, P. D., Zhang, X., Whitten, P., \& Burmeister, L. F. (1997). Field evaluation of endotoxin air sampling assay methods. American Industrial Hygiene Association Journal, 58(11), 792-799.

Todar, K. (2020). Todar's Online Textbook of Bacteriology: Bacterial Endotoxin. Accessed at: http://textbookofbacteriology.net/endotoxin.html

Torremorell, M., Pijoan, C., Janni, K., Walker, R., \& Joo, H. S. (1997). Airborne transmission of Actinobacillus pleuropneumoniae and porcine reproductive and respiratory syndrome virus in nursery pigs. American Journal of Veterinary Research, 58(8), 828-832.

Traversi, D., Alessandria, L., Schilirò, T., \& Gilli, G. (2011). Size-fractionated $\mathrm{PM}_{10}$ monitoring in relation to the contribution of endotoxins in different polluted areas. Atmospheric Environment, 45(21), 3515-3521.

Ulens, T., Demeyer, P., Ampe, B., Van Langenhove, H., \& Millet, S. (2015). Effect of grinding intensity and pelleting of the diet on indoor particulate matter concentrations and growth performance of weanling pigs. Journal of Animal Science, 93(2), 627-636.

Ulens, T., Millet, S., Van Ransbeeck, N., Van Weyenberg, S., Van Langenhove, H., \& Demeyer, P. (2014). The effect of different pen cleaning techniques and housing systems on indoor concentrations of particulate matter, ammonia and greenhouse gases $\left(\mathrm{CO}_{2}, \mathrm{CH}_{4}, \mathrm{~N}_{2} \mathrm{O}\right)$. Livestock Science, 159, 123-132.

Ulens, T., Millet, S., Van Weyenberg, S., Van Der Meeren, P., Van Langenhove, H., \& Demeyer, P. (2016). Results of measurements of particulate matter concentrations inside a pig fattening facility. Biotechnologie, Agronomie, Société et Environnement, 20(1), 13-16.

Underdahl, N. R., Rhodes, M. B., Socha, T. E., \& Shulte, D. D. (1982). A study of air quality and respiratory infections in pigs raised in confinement. Livestock Production Science, 9(4), 521-529.

Urbain, B., Prouvost, J. F., Beerens, D., Ansay, M., \& Gustin, P. (1996). Acute effects of endotoxin inhalation on the respiratory tract in pigs: interaction with ammonia. Inhalation Toxicology, $8(9)$, 947-968.

USEPA (1999a).Compendium Method IO-3.3: Determination of metals in ambient particulate matter using X-ray fluorescence (XRF) spectroscopy. United States Environmental Protection Agency, Cincinnati, OH. Assessed at: https://www.epa.gov/sites/default/files/2019-11/documents/mthd-33.pdf

USEPA (1999b).Compendium Method IO-3.4: Determination of metals in ambient particulate matter using inductively coupled plasma (ICP) spectroscopy. United States Environmental Protection Agency, Cincinnati, OH. Assessed at: https://www.epa.gov/sites/default/files/201507/documents/epa-io-3.4.pdf

USEPA (1999c).Compendium Method IO-3.5: Determination of metals in ambient particulate matter using inductively coupled plasma/mass spectrometry (ICP/MS). United States Environmental Protection Agency, Cincinnati, OH. Assessed at: https://www.epa.gov/sites/default/files/201911/documents/mthd-3-5.pdf

USEPA (2020). List of designated reference and equivalent methods. United States Environmental Protection Agency, Research Triangle Park, NC. Assessed at: https://www.epa.gov/sites/production/files/2019-08/documents/designated reference andequivalent methods.pdf

USEPA. (2018). Particulate Matter Emissions. U.S. Environmental Protection Agency, Washington DC. Accessed at: https://cfpub.epa.gov/roe/indicator.cfm?i=19 
USEPA. (2021). NAAQS Table. U.S. Environmental Protection Agency, Washington DC. Accessed at: https://www.epa.gov/criteria-air-pollutants/naaqs-table

van Hoek, A. H., Mevius, D., Guerra, B., Mullany, P., Roberts, A. P., \& Aarts, H. J. (2011). Acquired antibiotic resistance genes: an overview. Frontiers in Microbiology, 2, 203.

Van Ransbeeck, N., Van Langenhove, H., \& Demeyer, P. (2013). Indoor concentrations and emissions factors of particulate matter, ammonia and greenhouse gases for pig fattening facilities. Biosystems Engineering, 116(4), 518-528.

Van Ransbeeck, N., Van Langenhove, H., Van Weyenberg, S., Maes, D., \& Demeyer, P. (2012). Typical indoor concentrations and emission rates of particulate matter at building level: a case study to setup a measuring strategy for pig fattening facilities. Biosystems Engineering, 111(3), 280-289.

Vanhee, L. M., Nelis, H. J., \& Coenye, T. (2008). Enumeration of airborne bacteria and fungi using solid phase cytometry. Journal of Microbiological Methods, 72(1), 12-19.

Vaz, J. M. (2003). Screening direct analysis of PAHS in atmospheric particulate matter with SPME. Talanta, 60(4), 687-693.

Veenhuizen, M. A. (1989). Development and evaluation of an atmospheric dust removal system for swine housing using electrostatic precipitation techniques. Ph.D. dissertation, Iowa State University, Ames, IA.

Verreault, D., Létourneau, V., Gendron, L., Massé, D., Gagnon, C. A., \& Duchaine, C. (2010). Airborne porcine circovirus in Canadian swine confinement buildings. Veterinary Microbiology, 141(3-4), 224-230.

Vestergaard, D. V., Holst, G. J., Basinas, I., Elholm, G., Schlünssen, V., Linneberg, A., Šantl-Temkiv, T., Finster, K., Sigsgaard, T., \& Marshall, I. P. (2018). Pig farmers' homes harbor more diverse airborne bacterial communities than pig stables or suburban homes. Frontiers in Microbiology, 9 , 870.

Viegas, C., Faria, T., Monteiro, A., Caetano, L. A., Carolino, E., Quintal Gomes, A., \& Viegas, S. (2017). A novel multi-approach protocol for the characterization of occupational exposure to organic dust-Swine production case study. Toxics, 6(1), 5.

Viegas, S., Mateus, V., Almeida-Silva, M., Carolino, E., \& Viegas, C. (2013). Occupational exposure to particulate matter and respiratory symptoms in Portuguese swine barn workers. Journal of Toxicology and Environmental Health, Part A, 76(17), 1007-1014.

Vieira, F. C. S., \& Nahas, E. (2005). Comparison of microbial numbers in soils by using various culture media and temperatures. Microbiological Research, 160(2), 197-202.

Vilalta, C., Sanhueza, J., Garrido, J., Murray, D., Morrison, R., Corzo, C. A., \& Torremorell, M. (2019). Indirect assessment of porcine reproductive and respiratory syndrome virus status in pigs prior to weaning by sampling sows and the environment. Veterinary Microbiology, 237, 108406.

Vinzents, P., \& Nielsen, B. H. (1992). Variations in exposures to dust and endotoxin in Danish piggeries. American Industrial Hygiene Association Journal, 53(4), 237-241.

von Ah, S., Stephan, R., Zurfluh, K., Sidler, X., \& Kümmerlen, D. (2019). Occurrence of quinoloneresistant Escherichia coli in environmental samples from a sow pool system in Switzerland. Schweizer Archiv für Tierheilkunde, 161(6), 387-394.

Vu, T. V., Delgado-Saborit, J. M., \& Harrison, R. M. (2015). Particle number size distributions from seven major sources and implications for source apportionment studies. Atmospheric Environment, 122, 114-132.

Walgraeve, C., Bruneel, J., Van Huffel, K., Demeestere, K., Vincze, L., De Meulenaer, B., \& Van Langenhove, H. (2015). Sorption behaviour of targeted volatile organic compounds on airborne particulate matter using selected ion flow tube mass spectrometry. Biosystems Engineering, 131, 84-94.

Wan, G. H., \& Li, C. S. (1999). Indoor endotoxin and glucan in association with airway inflammation and systemic symptoms. Archives of Environmental Health: An International Journal, 54(3), 172179. 
Wang, X., Chancellor, G., Evenstad, J., Farnsworth, J. E., Hase, A., Olson, G. M., Screenath, A., \& Agarwal, J. K. (2009). A novel optical instrument for estimating size segregated aerosol mass concentration in real time. Aerosol Science and Technology, 43(9), 939-950.

Wang, X., Stroot, P.G., Zhang, Y., \& Riskowski, G.L. (1998) Odor carrying characteristics of dust from swine facilities. In 1998 ASAE Annual Meeting (Paper no. 98-4068), American Society of Agricultural Engineers, St. Joseph, MI.

Wang, X., Zhang, Y., Riskowski, G. L., \& Ellis, M. (2002). Measurement and analysis of dust spatial distribution in a mechanically ventilated pig building. Biosystems Engineering, 81(2), 225-236.

Wang, X., Zhang, Y., Zhao, L. Y., \& Christianson, L. L. (2005). Numerical modeling of dust spatial distribution in a mechanically ventilated airspace. Transactions of the ASAE, 48(2), 729-737.

Wang, X., Zhang, Y., Zhao, L. Y., \& Riskowski, G. L. (2000). Effect of ventilation rate on dust spatial distribution in a mechanically ventilated airspace. Transactions of the ASAE, 43(6), 1877.

Wang, X., Zhang, Y., Zhao, L., \& Riskowski, G. L. (1999). Development of a multipoint aerosol sampler using critical flow control devices. Transactions of ASHRAE, 105(2), 1108-1113.

Wang, Z. H., Zhang, L. Z., Zhang, Y. L., Zhao, Z., \& Zhang, S. M. (2008). Morphology of single inhalable particle in the air polluted city of Shijiazhuang, China. Journal of Environmental Sciences-China, 20(4), 429-435.

Wang, Z., Malmberg, P., Larsson, B. M., Larsson, K., Larsson, L., \& Saraf, A. (1996). Exposure to bacteria in swine-house dust and acute inflammatory reactions in humans. American Journal of Respiratory and Critical Care Medicine, 154(5), 1261-1266.

Wang, Z., Reponen, T., Grinshpun, S. A., Górny, R. L., \& Willeke, K. (2001). Effect of sampling time and air humidity on the bioefficiency of filter samplers for bioaerosol collection. Journal of Aerosol Science, 32(5), 661-674.

Wang-Li, L., Cao, Z., Buser, M., Whitelock, D., Parnell, C. B., \& Zhang, Y. (2013). Techniques for measuring particle size distribution of particulate matter emitted from animal feeding operations. Atmospheric Environment, 66, 25-32.

Watson, J. G., Zhu, T., Chow, J. C., Engelbrecht, J., Fujita, E. M., \& Wilson, W. E. (2002). Receptor modeling application framework for particle source apportionment. Chemosphere, 49(9), 1093 1136.

Watt, A. E., Browning, G. F., Markham, P. F., \& Marenda, M. S. (2020). Detection of naturally aerosolized Actinobacillus pleuropneumoniae on pig farms by cyclonic air sampling and qPCR. Veterinary Microbiology, 250, 108856.

Welford, R. A., Feddes, J. J. R., \& Barber, E. M. (1992). Pig building dustiness as affected by canola. Canadian Agricultural Engineering, 34(2), 365.

Welshans, K. (2021). Pork Exports Shatter Previous Records in 2020. National Pork Farmer. Access at: https://www.nationalhogfarmer.com/agenda/pork-exports-shatter-previous-records-2020

Wenke, C., Pospiech, J., Reutter, T., Altmann, B., Truyen, U., \& Speck, S. (2018). Impact of different supply air and recirculating air filtration systems on stable climate, animal health, and performance of fattening pigs in a commercial pig farm. PloS One, 13(3), e0194641.

White, J. K., Nielsen, J. L., \& Madsen, A. M. (2019). Microbial species and biodiversity in settling dust within and between pig farms. Environmental Research, 171, 558-567.

White, J. K., Nielsen, J. L., \& Madsen, A. M. (2020). Potential respiratory deposition and species composition of airborne culturable, viable, and non-viable fungi during occupancy in a pig farm. Atmosphere, 11(6), 639.

Williams, K.L. (2007). Endotoxins: Pyrogens, LAL testing and Depyrogenation, 3rd Edition. CRC Press, Baco Raton, FL.

Wilson, W. E., Chow, J. C., Claiborn, C., Fusheng, W., Engelbrecht, J., \& Watson, J. G. (2002). Monitoring of particulate matter outdoors. Chemosphere, 49(9), 1009-1043.

Winkel, A., Rubio, J. L., Vonk, J., \& Ogink, N. W. (2015). Equivalence testing of filter-based, betaattenuation, TEOM, and light-scattering devices for measurement of PM10 concentration in animal houses. Journal of Aerosol Science, 80, 11-26. 
Winkel, A., Vermeij, I., \& Ellen, H. H. (2014). Testing of various techniques for dust reduction in an experimental pig house. In Proceedings of the International Conference of Agricultural Engineering (Paper No. C0416), European Society of Agricultural Engineers, Zurich, Switzerland.

Wu, B., Qi, Q., Zhang, X., Cai, Y., Yu, G., Lv, J., Gao, L., Wei, L., \& Chai, T. (2019). Dissemination of Escherichia coli carrying plasmid-mediated quinolone resistance (PMQR) genes from swine farms to surroundings. Science of the Total Environment, 665, 33-40.

Xie, Q., Ni, J. Q., \& Su, Z. (2017). Fuzzy comprehensive evaluation of multiple environmental factors for swine building assessment and control. Journal of Hazardous Materials, 340, 463-471.

Xu, W., Zheng, K., Meng, L., Liu, X., Hartung, E., Roelcke, M., \& Zhang, F. (2016). Concentrations and emissions of particulate matter from intensive pig production at a large farm in north China. Aerosol and Air Quality Research, 16(1), 79-90.

Yan, H., Li, Y., Zhang, Y., Zhang, H., Guo, Z., \& Liu, J. (2021). Deciphering of microbial diversity and antibiotic resistome of bioaerosols in swine confinement buildings. Science of the Total Environment, 781, 147056.

Yan, H., Zhang, L., Guo, Z., Zhang, H., \& Liu, J. (2019). Production phase affects the bioaerosol microbial composition and functional potential in swine confinement buildings. Animals, 9(3), 90.

Yang, X. (2010). Physical, chemical and biological properties of airborne particles emitted from animal confinement buildings. Ph.D. dissertation, University of Illinois at Urbana-Champaign, Urbana, IL.

Yang, X., Lee, J., Barker, D. E., Wang, X., \& Zhang, Y. (2012). Comparison of six particle size distribution models on the goodness-of-fit to particulate matter sampled from animal buildings. Journal of the Air \& Waste Management Association, 62(6), 725-735.

Yang, X., Lee, J., Zhang, Y., Wang, X., \& Yang, L. (2015). Concentration, size, and density of total suspended particulates at the air exhaust of concentrated animal feeding operations. Journal of the Air \& Waste Management Association, 65(8), 903-911.

Yang, X., Lorjaroenphon, Y., Cadwallader, K. R., Wang, X., Zhang, Y., \& Lee, J. (2014). Analysis of particle-borne odorants emitted from concentrated animal feeding operations. Science of the Total Environment, 490, 322-333.

Yang, X., Lorjaroenphon, Y., Li, H., Cadwallader, K. R., Wang, X., \& Zhang, Y. (2018). Quantification of Odorants in Animal Feeds at Commercial Swine and Poultry Operations. Transactions of the ASABE, 61(2), 693-698.

Yang, X., Wang, X., \& Zhang, Y. (2014). Assessment of Airborne Endotoxin at the Air Exhaust of Swine and Poultry Confinement Buildings. ASHRAE Transactions, 120(1), 316-325.

Yang, X., Wang, X., Zhang, Y., Lee, J., Su, J., \& Gates, R. S. (2011). Characterization of trace elements and ions in PM10 and PM2.5 emitted from animal confinement buildings. Atmospheric Environment, 45(39), 7096-7104.

Yang, X., Wang, X., Zhang, Y., Lee, J., Su, J., \& Gates, R. S. (2013). Monitoring total endotoxin and $(1 \rightarrow 3)-\beta$-d-glucan at the air exhaust of concentrated animal feeding operations. Journal of the Air \& Waste Management Association, 63(10), 1190-1198.

Yang, X., Zhang, C., \& Li, H. (2018). Field comparison of TSI dusttrak versus TEOM in two poultry houses. Transactions of the ASABE, 61(2), 653-660.

Yao, H. Q., Choi, H. L., Lee, J. H., Suresh, A., \& Zhu, K. (2010). Effect of microclimate on particulate matter, airborne bacteria, and odorous compounds in swine nursery houses. Journal of Animal Science, 88(11), 3707-3714.

Yates, M. V. (2020). Manual of Environmental Microbiology, Fourth Edition. ASM Press, Washington DC.

Yeh, Y. L., Liao, C. M., Chen, J. S., \& Chen, J. W. (2001). Modelling lumped-parameter sorption kinetics and diffusion dynamics of odour-causing VOCs to dust particles. Applied Mathematical Modelling, 25(7), 593-611. 
Yoo, K., Lee, T. K., Choi, E. J., Yang, J., Shukla, S. K., Hwang, S. I., \& Park, J. (2017). Molecular approaches for the detection and monitoring of microbial communities in bioaerosols: A review. Journal of Environmental Sciences, 51, 234-247.

Yuan, W., Chai, T. J., \& Miao, Z. M. (2010). ERIC-PCR identification of the spread of airborne Escherichia coli in pig houses. Science of the Total Environment, 408(6), 1446-1450.

Yue, W., Stölzel, M., Cyrys, J., Pitz, M., Heinrich, J., Kreyling, W. G., Wichmann, H. E., Peters, A., Wang, S., \& Hopke, P. K. (2008). Source apportionment of ambient fine particle size distribution using positive matrix factorization in Erfurt, Germany. Science of the Total Environment, 398(13), 133-144.

Zahn, J. A., Anhalt, J., \& Boyd, E. (2001). Evidence for transfer of tylosin and tylosin-resistant bacteria in air from swine production facilities using sub-therapeutic concentrations of tylan in feed. Journal of Animal Science, 79(S1), 189.

Zhang, Y. (2005). Indoor Air Quality Engineering. CRC Press, Boca Raton, FL.

Zhang, Y., Nijssen, L., Barber, E. M., Feddes, J. J., \& Sheridan, M. (1994). Sprinkling mineral oil to reduce dust concentration in swine buildings. ASHRAE Transactions, 100(2), 1043-1050.

Zhang, Y., Tanaka, A., Barber, E. M., \& Feddes, J. J. R. (1996). Effects of frequency and quantity of sprinkling canola oil on dust reduction in swine buildings. Transactions of the ASAE, 39(3), 1077-1081.

Zhang, Z., \& Pawliszyn, J. (1993). Headspace solid-phase microextraction. Analytical Chemistry, 65(14), $1843-1852$.

Zhao, Y., Aarnink, A. J., Hofschreuder, P., \& Koerkamp, P. W. G. (2009). Evaluation of an impaction and a cyclone pre-separator for sampling high PM10 and PM2. 5 concentrations in livestock houses. Journal of Aerosol Science, 40(10), 868-878.

Zhu, Y. G., Johnson, T. A., Su, J. Q., Qiao, M., Guo, G. X., Stedtfeld, R. D., Stedtfeld, R.D., \& Tiedje, J. M. (2013). Diverse and abundant antibiotic resistance genes in Chinese swine farms. Proceedings of the National Academy of Sciences, 110(9), 3435-3440.

Zhu, Z., Dong, H., Tao, X., \& Xin, H. (2005). Evaluation of airborne dust concentration and effectiveness of cooling fan with spraying misting systems in swine gestation houses. In Livestock Environment VII, Proceedings of the Seventh International Symposium (pp. 224-229), American Society of Agricultural Engineers, Beijing, China. 


\section{Appendix}

Table S1. List of odorants identified in swine barn PM (1979-Present).

\begin{tabular}{|c|c|c|c|c|c|c|c|c|c|c|c|c|}
\hline \multirow{2}{*}{ Odorants } & \multicolumn{12}{|c|}{ References $^{1}$} \\
\hline & $\mathrm{i}$ & ii & iii & iv & $\mathrm{v}$ & vi & vii & viii & ix & $\mathrm{x}$ & $\mathrm{xi}$ & xii \\
\hline \multicolumn{13}{|c|}{ Aldehydes } \\
\hline$(E)$-2-decenal & & & & & & & $*$ & & & & $*$ & \\
\hline (E)-2-heptenal & & & & & & & $*$ & & & & $*$ & \\
\hline (E)-2-hexenal & & $*$ & & & & & $*$ & & & & $*$ & \\
\hline (E)-2-nonenal & * & & & & & & $*$ & & & & $*$ & \\
\hline (E)-2-octenal & & & & & & & $*$ & & & & $*$ & \\
\hline$(E, E)$-2,4-decadienal & * & $*$ & & & & & & & & & $*$ & \\
\hline$(E, E)$-2,4-nonadienal & & $*$ & & & & & $*$ & $*$ & & & $*$ & \\
\hline$(E, Z)-2,6$-nonadienal & & & & & & & & & & & $*$ & \\
\hline (Z)-4-heptenal & $*$ & & & & & & & & & & & \\
\hline 2-butanal & & $*$ & & & & & & & & & & \\
\hline 2-butyl-2-octenal & & & & & & & $*$ & & & & & \\
\hline 2-heptenal & & $*$ & & & & & & & & & & \\
\hline 2-methyl-2-pentenal & & & & & & & & & & & $*$ & \\
\hline 2-methylbutanal & & & & & & & & & & & & $*$ \\
\hline 2-methylpropanal & & & & & & & $*$ & & & & & \\
\hline 2-methyl-2-propenal & & & & & & & & & & & & $*$ \\
\hline 2-pentanal & & $*$ & & & & & & & & & & \\
\hline 2-undecenal & & & & & & & & & & & $*$ & \\
\hline 2,4-heptadienal & $*$ & $*$ & & & & & & & & & & \\
\hline 2,4-nonadienal & $*$ & & & & & & $*$ & & & & & \\
\hline 3-methylbutanal & & . & & & & & $*$ & $*$ & & & & $*$ \\
\hline benzaldehyde & & $*$ & & & & & $*$ & & & & $*$ & $*$ \\
\hline butanal & & $*$ & & & & & & $*$ & & & & \\
\hline decanal & & $*$ & & & & $*$ & * & & & & $*$ & \\
\hline heptanal & $*$ & & & & & $*$ & $*$ & $*$ & & & $*$ & $*$ \\
\hline hexanal & $*$ & $*$ & & & & $*$ & $*$ & $*$ & & & $*$ & $*$ \\
\hline nonanal & $*$ & & & & & $*$ & $*$ & $*$ & & & $*$ & \\
\hline octanal & & & & & & $*$ & $*$ & $*$ & & & $*$ & \\
\hline pentanal & & $*$ & & & & & $*$ & $*$ & & & & $*$ \\
\hline trans-4,5-epoxy-(E)-2-decenal & & & & & & & & & & & $*$ & \\
\hline vanillin & $*$ & & & & & & & & & & $*$ & \\
\hline \multicolumn{13}{|c|}{ Ketones } \\
\hline 1-(1-cyclohexen-1-yl) ethanon & & & & & & & & $*$ & & & & \\
\hline 1-octen-3-one & $*$ & $*$ & & & & & & & & & $*$ & \\
\hline 2-heptanone & & & & & & & $*$ & & & & & $*$ \\
\hline 2-octanone & & $*$ & & & & & $*$ & & & & & \\
\hline
\end{tabular}




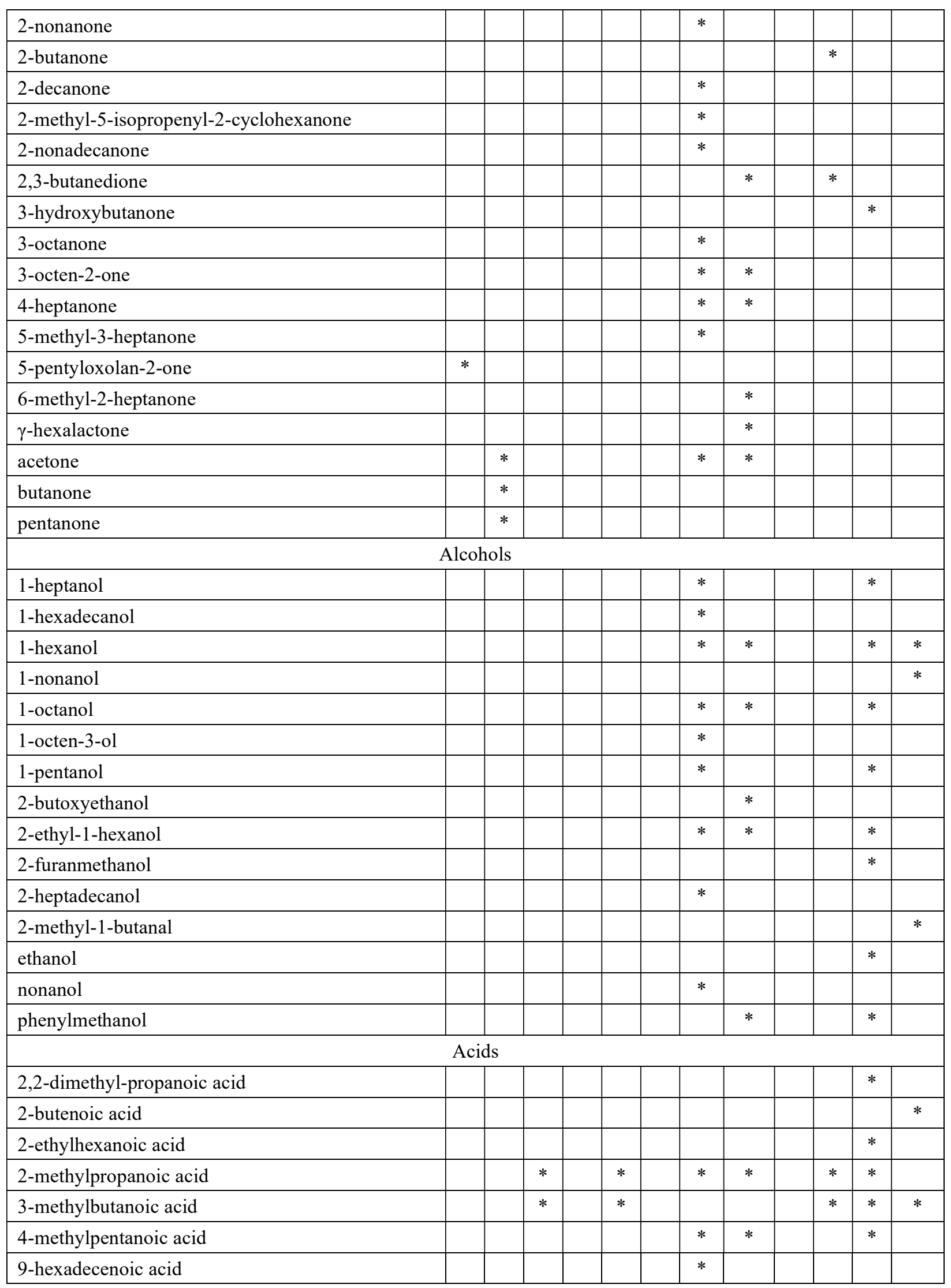




\begin{tabular}{|c|c|c|c|c|c|c|c|c|c|}
\hline 9-octadecenoic acid & & & & & $*$ & & & & \\
\hline 9,12-octadecenoic acid & & & & & $*$ & & & & \\
\hline acetic acid & & * & $*$ & $*$ & $*$ & $*$ & $*$ & * & * \\
\hline benzoic acid & & $*$ & & & $*$ & & & $*$ & \\
\hline butanoic acid & & $*$ & $*$ & $*$ & $*$ & $*$ & $*$ & $*$ & * \\
\hline decanoic acid & & $*$ & & & & & & $*$ & \\
\hline dodecanoic acid & $*$ & $*$ & & & & & & $*$ & \\
\hline heptanoic acid & & $*$ & & $*$ & & $*$ & $*$ & $*$ & \\
\hline hexadecanoic acid & & & & & $*$ & & & & \\
\hline hexanoic acid & & $*$ & & $*$ & & $*$ & $*$ & * & $*$ \\
\hline nonanoic acid & & $*$ & & $*$ & & & & $*$ & \\
\hline octadecenoic acid & & & & & $*$ & & & & \\
\hline octanoic acid & & $*$ & & $*$ & & & & $*$ & \\
\hline pentanoic acid & & $*$ & $*$ & $*$ & $*$ & $*$ & $*$ & $*$ & * \\
\hline phenylacetic acid & $*$ & $*$ & & & & & & $*$ & \\
\hline phenylpropanoic acid & $*$ & $*$ & & & & & & $*$ & \\
\hline propanoic acid & & * & $*$ & $*$ & $*$ & $*$ & $*$ & * & * \\
\hline tetradecanoic acid & & $*$ & & & & & & & \\
\hline tridecanoic acid & & $*$ & & & & & & $*$ & \\
\hline undecanoic acid & & $*$ & & & & & & $*$ & \\
\hline \multicolumn{10}{|c|}{ Phenols } \\
\hline guaiacol & & & & & & & & $*$ & \\
\hline 2,6-di-tert-butyl-4-ethylphenol & & & & & & $*$ & & & \\
\hline 4-ethylphenol & $*$ & & & & $*$ & $*$ & $*$ & $*$ & \\
\hline$m$-cresol & & & & & & & & $*$ & \\
\hline$m$-ethylphenol & & & & & $*$ & & & & \\
\hline$O$-cresol & & & & & & & & $*$ & \\
\hline$o$-ethylphenol & & & & & $*$ & & & & \\
\hline$p$-cresol & $*$ & $*$ & $*$ & $*$ & $*$ & $*$ & $*$ & * & $*$ \\
\hline$p$-ethylphenol & & & $*$ & & & & & & \\
\hline phenol & & & $*$ & $*$ & $*$ & $*$ & $*$ & $*$ & $*$ \\
\hline$p$-vinylguaiacol & & & & & & & & $*$ & \\
\hline \multicolumn{10}{|c|}{ Esters } \\
\hline 2-ethylhexyl butyrate & & & & & $*$ & & & & \\
\hline 2-ethylhexyl acetate & & & & & $*$ & & & & \\
\hline dibutyl phthalate & & & & & $*$ & & & & \\
\hline diethyl phthalate & & & & & $*$ & & & & \\
\hline diisobutyl phthalate & & & & & $*$ & & & & \\
\hline hexylacetate & & & & & & & & & * \\
\hline methyl butyrate & & & & & $*$ & & & & $*$ \\
\hline
\end{tabular}




\begin{tabular}{|c|c|c|c|c|c|c|c|c|c|c|c|}
\hline 2-methylfuran & & & & & & $*$ & & & & & \\
\hline 2-pentylfuran & $*$ & & & & & * & $*$ & & & $*$ & \\
\hline diethyl ether & & & & & & $*$ & & & & & \\
\hline \multicolumn{12}{|c|}{ Hydrocarbons } \\
\hline 1-methyl-2-isopropylbenzene & & & & & & $*$ & & & & & \\
\hline 1-methyl-4-isopropylbenzene & & & & & & $*$ & & & & & \\
\hline 1,1-dichloro-1-fluoroethane & & & & & & & $*$ & & & & \\
\hline 2,6,10,14-tetramethyl-hexadecane & & & & & & * & & & & & \\
\hline dodecane & & & & & & $*$ & $*$ & & & & \\
\hline eicosane & & & & & & $*$ & & & & & \\
\hline heptadecane & & & & & & $*$ & & & & & \\
\hline heptane & & & & & & $*$ & $*$ & & & & \\
\hline hexadecane & & & & & & $*$ & & & & & \\
\hline hexamethylcyclotrisiloxane & & & & & & $*$ & & & & & \\
\hline nonadecane & & & & & & $*$ & & & & & \\
\hline octadecane & & & & & & $*$ & & & & & \\
\hline octamethylcycloterasiloxane & & & & & & $*$ & & & & & \\
\hline octane & & & & & $*$ & & & & & & \\
\hline pentane & & & & & & & * & & & & \\
\hline pentadecane & & & & & & $*$ & & & & & \\
\hline styrene & & & & & & & $*$ & & & & \\
\hline tetradecane & & & & & & $*$ & & & & & \\
\hline tridecane & & & & & & $*$ & & & & & \\
\hline limonene & & & & & & $*$ & & & & & * \\
\hline \multicolumn{12}{|c|}{ Nitrogen-containing compounds } \\
\hline 2'-aminoacetophenone & & & & & & & * & & & & \\
\hline 2-methyl-1H-pyrrole & & & & & & $*$ & & & & & \\
\hline 2-methylpyrimidine & & & & & & & & & & & * \\
\hline 2-piperidinone & & & & & & & $*$ & & & & \\
\hline 2,5-dimethylpyrazine & & & & & & & & & & & $*$ \\
\hline 3-pentanamin & & & & & & & $*$ & & & & \\
\hline 4-methyl indole & & & & & & $*$ & & & & & \\
\hline 5-acethyl-2-methylpyridine & & & & & & & $*$ & & & & \\
\hline acetamide & & & & & & & $*$ & & & & \\
\hline ammonia $\left(\mathrm{NH}_{3}\right)$ & & & $*$ & & & & & $*$ & & & \\
\hline benzothiazole & & & & & & $*$ & & & & & \\
\hline indole & & $*$ & & $*$ & & $*$ & $*$ & & $*$ & $*$ & $*$ \\
\hline$N, N$-dimethyl-formamide & & & & & & & $*$ & & & & \\
\hline$o$-aminoacetophenone & & & & & & & & & & $*$ & \\
\hline skatole & $*$ & $*$ & & $*$ & & $*$ & $*$ & & $*$ & $*$ & * \\
\hline trimethylamine & & & & & & & * & & & & $*$ \\
\hline
\end{tabular}




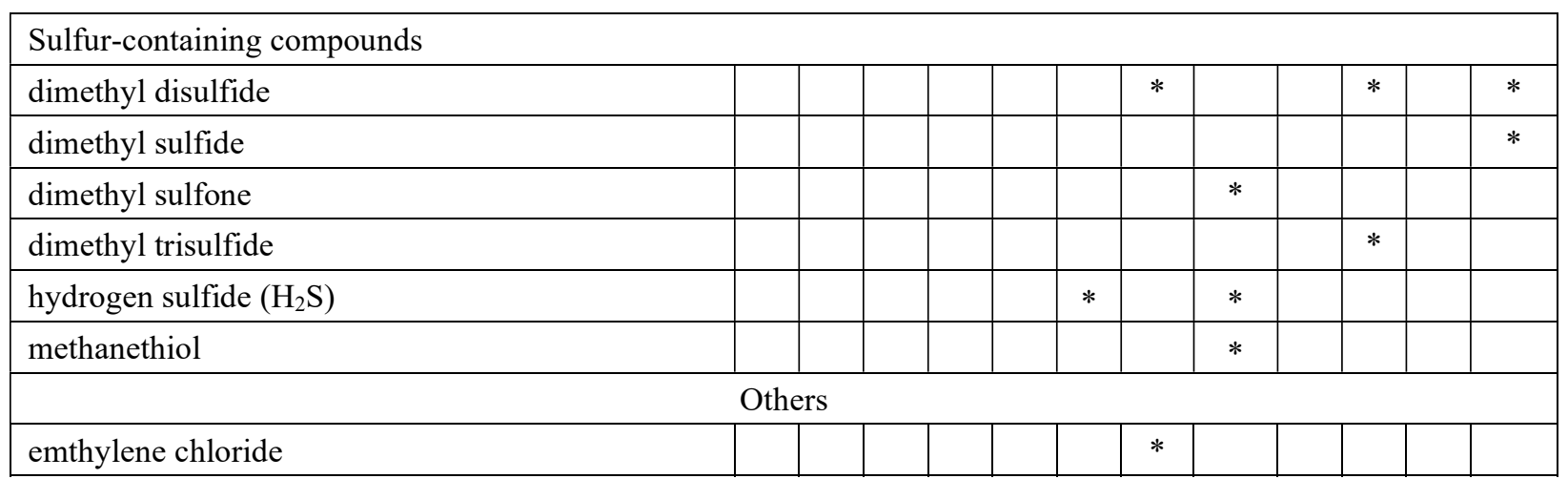

Note:

${ }^{1}$ i: Hammond et al. (1979); ii: Hammond et al. (1981); iii: Hartung et al. (1985); iv: Donham et al. (1986); v: Oehrl et al. (2001); vi: Das et al. (2004); vii: Razote et al. (2004); viii: Cai et al. (2006); ix: Lee and Zhang (2008); x: Andersen et al. (2014); xi: Yang et al. (2014); xii: Walgraeve et al. (2015). 